\title{
Rates, Trends, Causes, and Consequences of Urban Land-Use Change in the United States
}

\section{Professional Paper 1726}

U.S. Department of the Interior

U.S. Geological Survey 


\section{Rates, Trends, Causes, and Consequences of Urban Land-Use Change in the United States}

Edited by William Acevedo, Janis L. Taylor, Dave J. Hester, Carol S. Mladinich, and Sonya Glavac

Professional Paper 1726 


\title{
U.S. Department of the Interior DIRK KEMPTHORNE, Acting Secretary
}

\author{
U.S. Geological Survey \\ P. Patrick Leahy, Acting Director
}

\section{U.S. Geological Survey, Reston, Virginia: 2006}

This report and any updates to it are available online at:

http://pubs.usgs.gov/pp/1726/

For product and ordering information:

World Wide Web: http://www.usgs.gov/pubprod

Telephone: 1-888-ASK-USGS

For more information on the USGS - the Federal source for science about the Earth, its natural and living resources, natural hazards, and the environment:

World Wide Web: http://www.usgs.gov

Telephone: 1-888-ASK-USGS

Any use of trade, product, or firm names in this publication is for descriptive purposes only and does not imply endorsement by the U.S. Government.

Although this report is in the public domain, permission must be secured from the individual copyright owners to reproduce any copyrighted materials contained within this report.

Cataloging-in-Publication data are on file with the Library of Congress (URL http://www.loc.gov/).

Produced in the Western Region, Menlo Park, California

Manuscript approved for publication, June 2, 2006

Text edited by James W. Hendley II

Layout and design by Stephen L. Scott

COVER - This aerial photograph of part of Santa Clara County, California, typifies the urbanization that has occurred throughout much of the United States since World War II. Before the war, this area was mostly agricultural land. 


\section{Contents}

Introduction

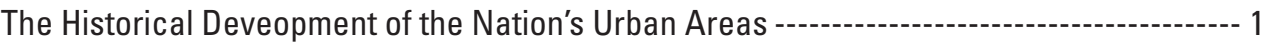

Roger F. Auch, William Acevedo, and Janis L.. Taylor

Factors Affecting Urban Land-Use Change

Cultural and Demographic Factors in Urban Decentralization in the United States-

A Historical Overview --- 13

Alexander von Hoffman and John Felkner

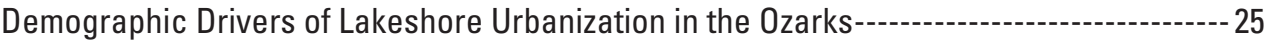
Sonya Glavac

Economic Aspects of Urban Decentralization in Historical Perspective --------------- 33

Alexander von Hoffman and John Felkner

General Trends Regarding Aggregate Materials for Urban Development,

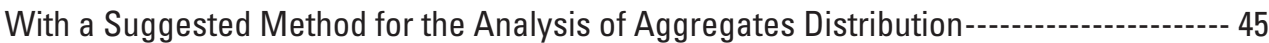
Dalia Varanka

Quantifying Landscape Change

Wrestling Sprawl to the Ground-Defining and Measuring an Elusive Concept ------------ 55 George Galster, Royce Hanson, Michael R. Ratcliffe, Harold Wolman, Stephen Coleman, and Jason Freihage

Measuring Urban Sprawl and Extent Through Multitemporal Imperviousness

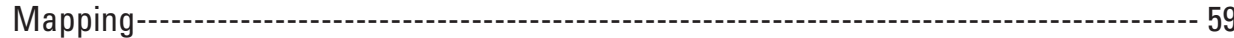

George Xian, Limin Yang, Jacqueline M. Klaver, and Nazmul Hossain

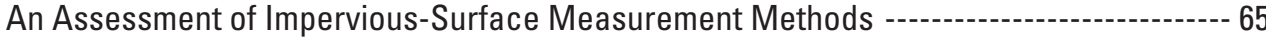
E. Terrence Slonecker and Janet S. Tilley

Comparing Impervious-Cover Densities on the Basis of Land-Use Types Between

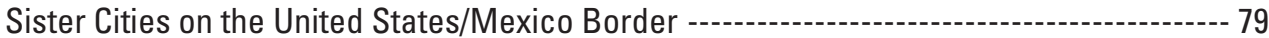
Jean Parcher

The Use of Spatial Analytical Techniques to Identify Potential Brownfields Sites----------- 87 Janet S. Tilley, Robin Paul, Terrance Slonecker, and Ellen Walkowiak

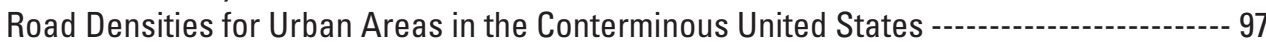
Raymond D. Watts, John McCammon, Roger Compton, Carl Rich, and Tom Owens

Quantifying Urban Intensity in Drainage Basins for Assessing Stream Ecological

Conditions 101

Gerard McMahon and Thomas F. Cuffney

Regional Trends in Urban Land-Use Change

Analyzing Albuquerque's Landscape Evolution in the 20th and 21st Centuries-------------- 113 David J. Hester

Change to Urban, Agricultural, and Forested Land in Central and Southern Maryland

From 1850-1990

Janis L. Taylor and William Acevedo

Regional Landscape Change in the Northern Colorado Front Range -------------------139 Carol S. Mladinich

A 30-Year Study of Urban Dynamics for the Municipality of Anchorage, Alaska, 1970-2000 -

Carl J. Markon

Consequences and Impacts of Urbanization

The Effects of Urbanization on Discharge and Suspended-Sediment Concentrations

in a Southern California River

Jonathan A. Warrick and Kevin M. Orzech 
Changes in Anthropogenic Impervious Surfaces, Precipitation, and Daily

Streamflow Discharge-A Historical Perspective in a Mid-Atlantic Subwatershed------- 171 David B. Jennings, and S. Taylor Jarnagin

Urban Growth and Seagrass Distribution Trends in Tampa Bay, Florida --------------------- 185 Mike Crane and George Xian

An Overview of the Stressors and Ecological Impacts Associated with Regional and Global Patterns of Population, Land-Use, and Land-Cover Change S. Taylor Jarnagin 


\title{
The Historical Development of the Nation's Urban Areas
}

\author{
By Roger F. Auch'1, William Acevedo², and Janis L. Taylor ${ }^{1}$
}

\section{Introduction}

Over the past 200 years, changes to the Nation's urban areas have been dramatic. Changes that have occurred relate both to the location of urban centers, as well as to the spatial extent of land dedicated to urban uses. Urban areas at the beginning of the 19th century were located primarily along major rivers or bodies of water, as waterways provided the most efficient means for transporting goods and people. As railroads became prominent, urban areas were able to expand or develop away from the water's edge.

Geographic features such as steep slopes, wetlands, and lack of freshwater impeded settlement. In 1902, the National Reclamation Act was passed and with it came funding for the construction of water storage and transportation systems. This encouraged urban expansion in the arid west. After World War II, the Nation's urban areas continued to expand outward away from the city center as populations migrated to the margins of urban areas, where land was less expensive and the environment was less polluted. In 1956, the Federal Highway Act and the building of Interstate highways further facilitated urban expansion across the United States. Rural towns, small industrial centers, and farmland were engulfed by expanding urban centers.

Over the past 200 years, numerous social, cultural, economic, and political incentives have encouraged urban expansion. In the 1800 s, the industrial revolution influenced where people lived and worked. Many people shifted from agricultural production in rural areas to factory work in urban centers.

Advances in transportation systems, such as rail transport in the 19th and early 20th centuries, followed by the mass production of the automobile and convenient air travel, facilitated a mobile society and a national economy. Economic growth and a population boom after World War II spurred increased suburbanization - the shifting of residential areas to the outlying section of a city or to a separate municipality—on the fringe of urban areas. Other economic and political incentives that shaped the urban

${ }^{1}$ SAIC TSSC, work performed under U.S. Geological Survey contract 03CRN001 at U.S. Geological Survey, Center for Earth Resources Observation and Science, Sioux Falls, SD 57198.

${ }^{2}$ U.S. Geological Survey, Center for Earth Observations and Science, Sioux Falls, SD 57198. environment included Federally backed home loans, credit and tax mechanisms that encouraged new development, and less restrictive municipal ordinances regarding building codes, environmental laws, and zoning regulations.

Throughout the past two centuries land use changes associated with increasing urbanization have had impacts that resonate at local, regional, and even national scales. Landscape changes resulting from urbanization can be mapped and studied over time. Understanding these changes requires a study of the causes of change as related to social, economic, and political influences. Understanding these changes also requires analysis of how urbanization physically spreads across the landscape. The knowledge gained from studying urban land-use change can be helpful when it flows into local, regional, and national decisionmaking that relates to land-use decisions that impact the people, the economy, and the environment. Deriving a correlation between physical change and the explanations of the causes of change can help anticipate and mitigate the impacts of future change.

Throughout the past two centuries changes to the Nation's urban areas are inextricably linked to population changes. The Nation's population started growing slowly along the eastern seaboard during the 17th and 18th centuries, accelerated in the second half of the 19th century, and then continued steadily spreading westward throughout the next hundred years ${ }^{3}$ (fig. 1). Currently, nearly 80 percent of the U.S. population resides in urban areas (fig. 2). Land area dedicated to urban use continues to expand, although differently than it has in the past. Most newly urbanized areas are much less densely populated and less intensively developed than they were 50 to 100 years ago (Lopez and Hynes, 2003; Platt, 1996).

\section{Historical Perspective}

American cities grew steadily throughout the first 75 years of nationhood but remained relatively small in geographic area

\footnotetext{
${ }^{3}$ We recognize that during the 17 th and 18 th centuries settled populations resided throughout the territory that became the United States, with concentrations in particular locations, some of which are pointed out elsewhere in the paper.
} 


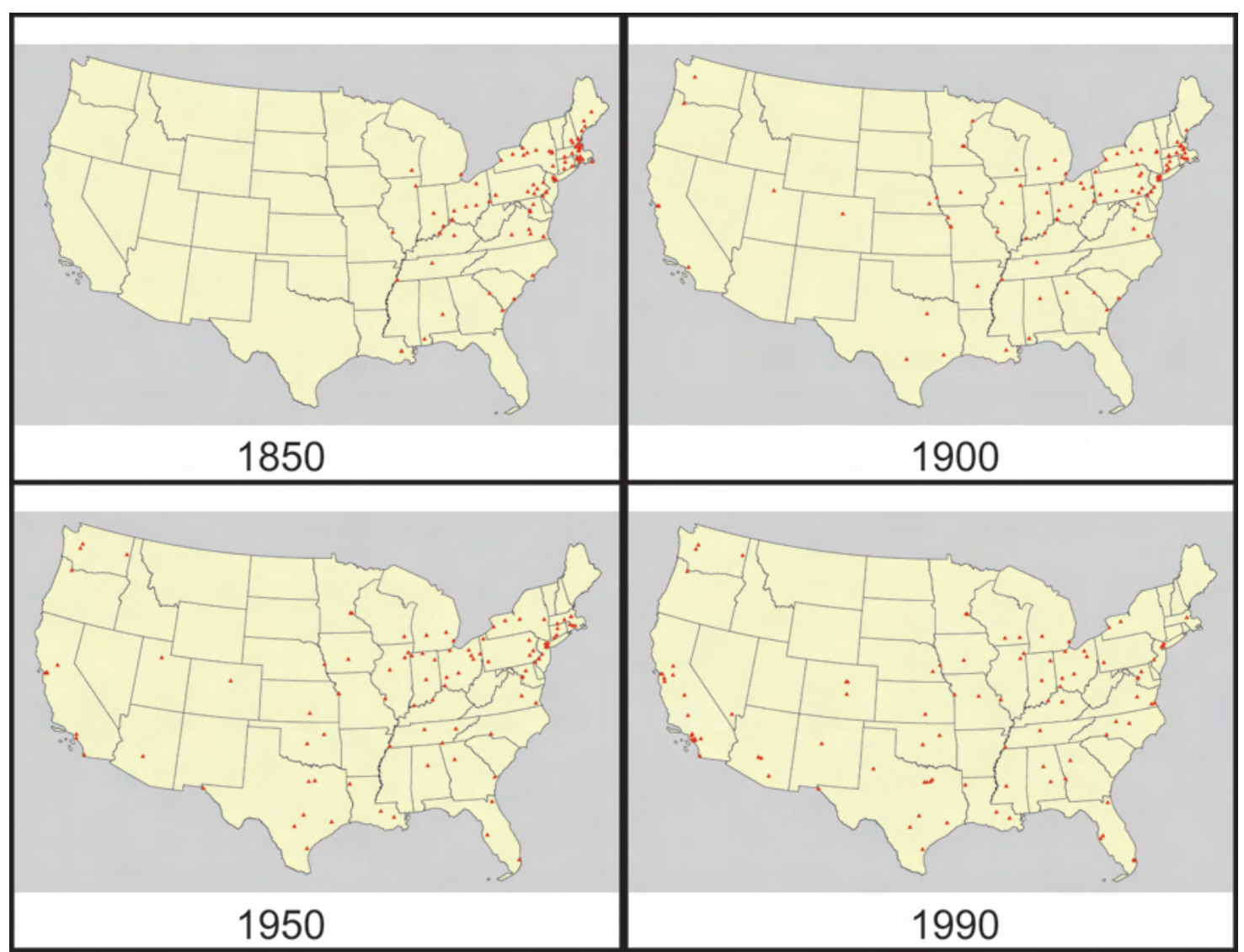

Figure 1. Time-series of the Nation's 50 largest cities (red triangles) in 1850, 1900, 1950, and 1990. In 1850, most of the largest cities in the United States were east of the Mississippi River. Transportation systems, such as railroads and major ports, helped push some of the largest cities into the western half of the Nation by 1900 . The growth of cities in Florida, Texas, and Arizona can be seen on the 1950 map. The movement to the Southwest is even more pronounced by 1990, as California, Nevada, Arizona, Colorado, and Texas have nearly 50 percent of the largest cities.

\section{Urban Population as a Percentage of U.S. Total}

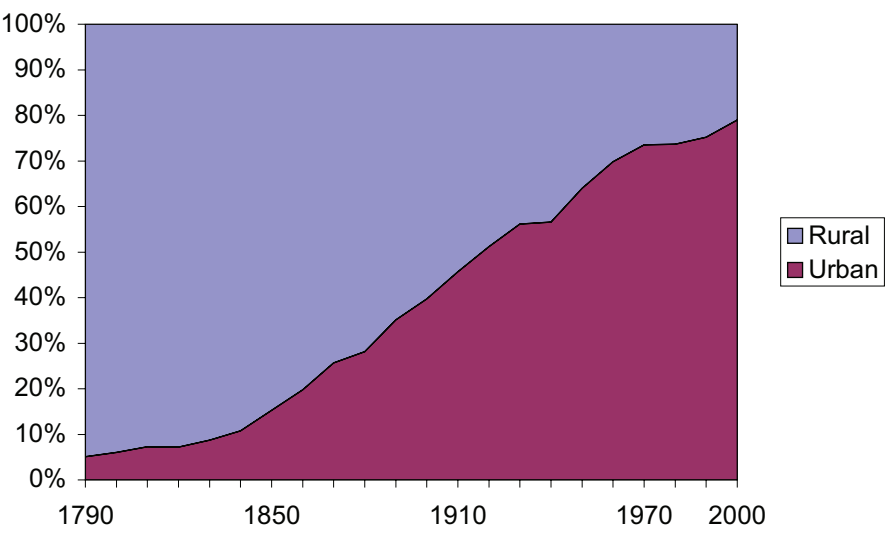

Figure 2. Graph of percent U.S. population living in urban areas versus rural areas. (Sources: U.S. Bureau of the Census, 2003, American FactFinder, P2 Urban and Rural-(6) Universe -Total Population ( http://factfinder.census. gov]); U.S. Bureau of the Census, 2000, Statistical abstract of the United States-2000: Washington, D.C., U.S. Government Printing Office, p. 38; U.S. Bureau of the Census, 1976, Historical statistics of the United States-colonial times to 1970, part 1: Washington, D.C., U.S. Government Publishing Office, p. 11-12.)

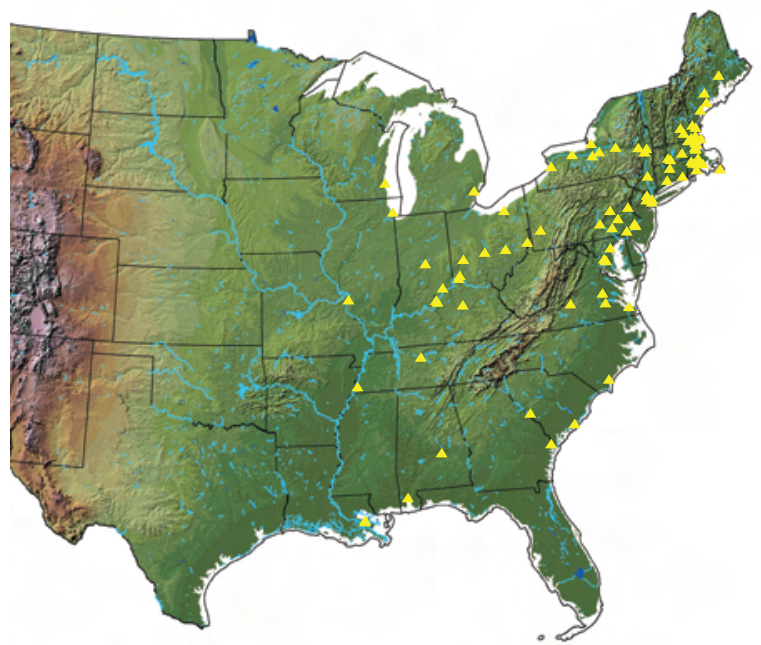

Figure 3. Map showing the major rivers (blue lines) in the eastern United States and the locations of the 50 largest cities (yellow triangles) in 1850. American cities grew steadily throughout the first 75 years of nationhood but remained relatively small in geographic area and population. Most were located along transportation access points - at seaports, along navigable tidal and major inland rivers, along canals, and around the Great Lakes. 
and population. Most were located along transportation access points - at seaports, along navigable tidal and major inland rivers, along canals, and around the Great Lakes (fig. 3). At this time, the regional hinterlands beyond the cities produced raw commodities as a part of rural-based economies. Those commodities were then processed into durable and nondurable goods in urban centers and redistributed in the area or transported to other regions where they were refined or even exported (Borchert, 1967).

By the eve of the Civil War, however, the nature of urban development had begun to change. Cities were becoming greater centers of industry, as access to local and regional natural resources improved and these resources were exploited. In addition, European social unrest led to a steady stream of immigrants arriving in the United States. These conditions were especially marked in New England and the Mid-Atlantic States. The South and Midwest, by contrast, remained predominantly rural, although regional economies were linked to urban markets (Goldfield and Brownell, 1990). A few western cities also appeared at this time, although few were significant on the national scene. San Francisco and Sacramento were the only western cities to place in the top 100 largest urban areas in 1860, with San Francisco ranking in the top 25 cities (Gibson, 1998). In general, the economies of these western cities tended to be based either on localized mineral wealth or agriculture. In the Southwest, a handful of these urban areas were Hispanic cultural centers (Starrs, 1995) (fig. 4).

The pace of urbanization quickened following the Civil War. Trains became the dominant transportation mode throughout the country, especially after 1870 , when an economical way to mass produce steel was introduced, allowing for the construction of a vast rail network (fig 5). Many cities were created as a result of railroad expansion, whereas others grew in size after becoming rail hubs (fig. 6). By 1890 , industrialization gained prominence and a national economy was becoming established (Borchert, 1967). Natural resources from all parts of the country were used to fuel a rapidly expanding industrial nation. (Meyer, 1987, 321345). Immigration, mostly from Europe, continued to bolster the burgeoning population. Drawn by factory jobs, many immigrants settled in cities. At this time, the majority of the Nation's urban population was located in the Northeast and the Midwest (Goldfield and Brownell, 1990, 185-212). Cities in the South and West continued to grow, but remained smaller in comparison. For example, in 1896, Miami had a mere 500registered voters (Proctor, 1996).

By 1900, changes in agricultural production increased the flow of people to the cities. Regional specialization of specific commodities as a result of environmental conditions gave agricultural producers in some places an advantage over producers elsewhere. Farmers in areas where land was of marginal quality many times had to abandon agriculture and seek out other sources of employment (Meyer, 1987; Borchert, 1987). In the South, many African Americans migrated to northern industrial cities to escape the growing failure of the post-slavery sharecropping system that relied on monoculture cotton pro- duction (Clark, 1984; Spinney, 2000). Hispanic workers came to California and other Western States in increasing numbers as new irrigation projects made it possible to raise high-value, but labor-intensive, fruits and vegetables. Migrant field workers and their families often ended up living in the small, but growing, urban areas throughout the region (Haverluk, 2000).

The old "downtown" city in America reached its zenith by the end of the World War I. The inner core of the city was the center of industrial management, production, and distribution. Such cities were predominantly densely populated, as most workers lived in multifamily dwellings near their sites of employment. Downtown landscapes were also being transformed as rising land prices and new technologies fostered the construction of high-rise buildings, or "skyscrapers." Suburbanization was initially limited to neighboring communities linked by railroads and electric streetcars to the city centers. Paved, multilane highways were just making their first appearance (Muller, 1986). The U.S. Census of 1920 revealed that, for the first time, more Americans lived in urban, rather than rural settings ${ }^{4}$ (Platt, 1996).

Between 1930 and 1945, the United States experienced both the Great Depression and the World War II. These events ultimately formed a watershed that marked a new era in urban development, one that has evolved over the past 50 years. Some of the seeds of this change had already been sown, however, during the previous few decades. These included the rapid increase in automobile ownership in the 1920s and the creation of the modern mortgage loan in the 1930s. The Depression and then rationing during World War II limited consumer spending, first due to hardship and then by forced austerity. This way of life eventually led to a build-up of personal savings that helped create the Nation's booming post-war economy and into which the "baby boom" generation was born. Another factor that played a role in urban development was the involvement by the Federal Government, in both the national economy and those of local communities, in committing massive amounts of money to fight the Depression and later, the war. One noteworthy aspect of this involvement was longterm home mortgage loan insurance offered by several agencies, such as the Federal Housing Administration and then the Veterans Administration, following the war. Most of the housing units financed in this manner were built on the edge of the existing cities (Jackson, 1985). In time, the selective funding of major public works and the creation of a "military-industrial complex" would come to favor some urban areas over others (Goldfield and Brownell, 1990; Markusen and others, 1991). A third significant influence on urban growth in the post-war era was the exposure that millions of Americans gained to other parts of the country. During the 1930s, many people abandoned regions fraught with economic and environmental problems for new places that

\footnotetext{
${ }^{4}$ In 1910, the U.S. Census Bureau changed the definition of urban places so that the minimum population threshold for an urban place went from 4,000 to 2,500. Had the threshold remained at 4,000, the United States would not have reached the 50 percent threshold, where more Americans lived in urban rather than rural settings, until 1940.
} 


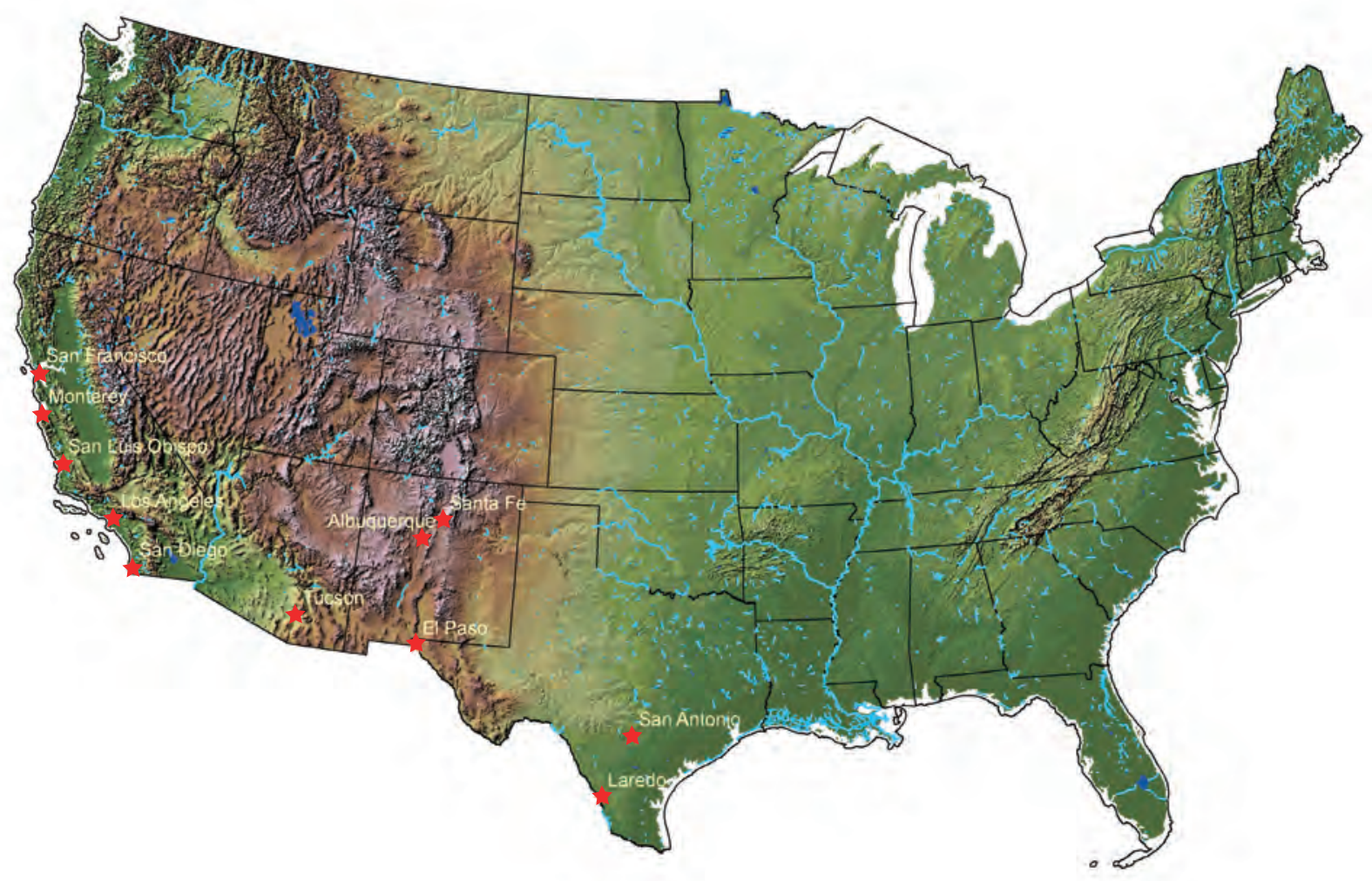

Figure 4. Hispanic settlements (red stars) across the Southwest in the 1850s. Rivers are shown in blue.

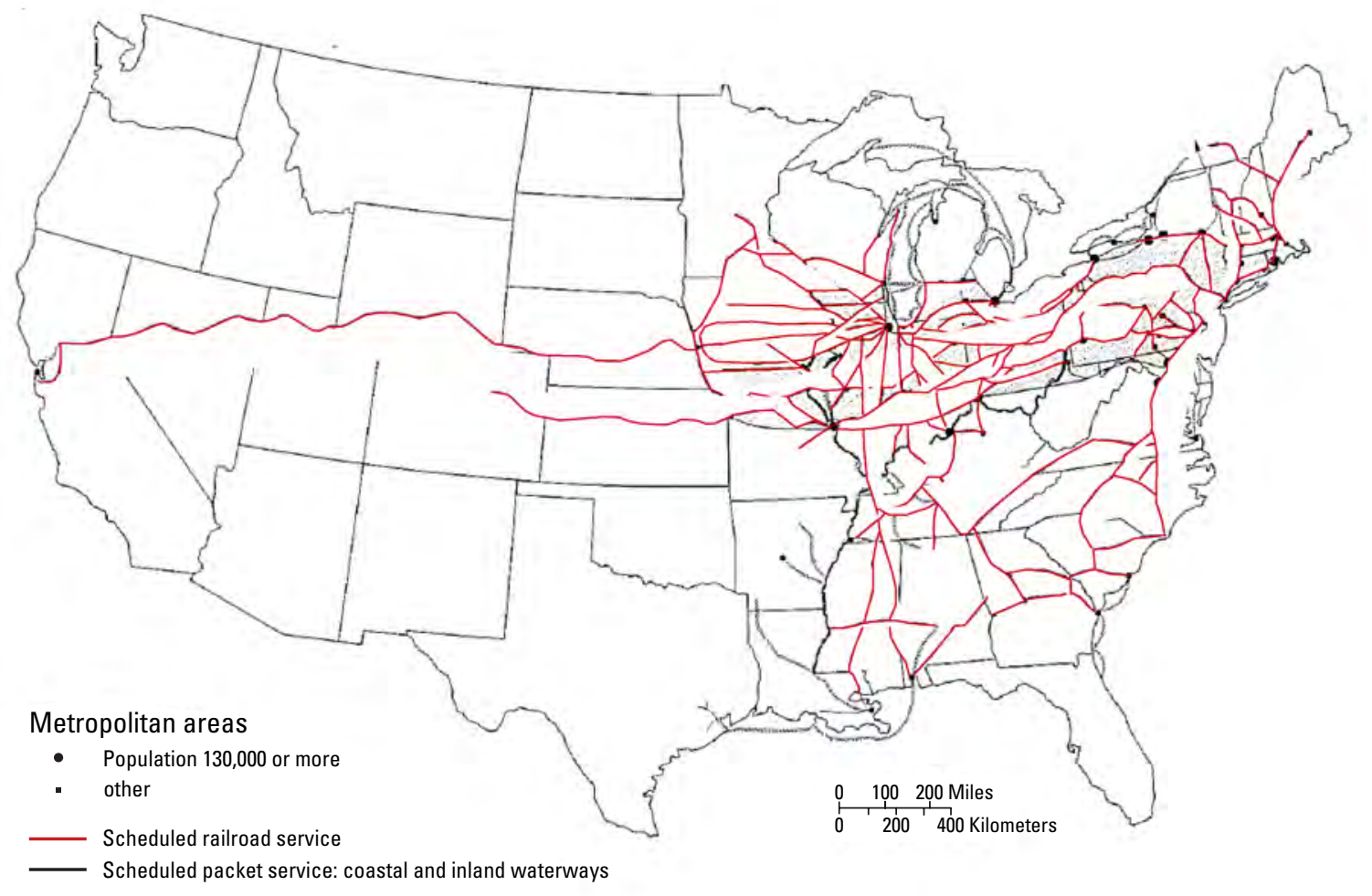

Figure 5. Major railroad lines across the United States in 1869. 
were thought to offer better opportunities and living conditions (Gregory, 1989; Lewis, 1987). Others who had been involved in military service were exposed to parts of the country that to many had greater potential appeal as future places of residence than their former communities (Mohl and Mormino, 1996; Lewis, 1987; Abbott, 1981).

A new form of urban growth gained prominence after World War II—mass suburbanization around the older cities. Suburbanization had been occurring for more than a century, but the trend exploded during the post-war era. Several factors fostered the increased growth of suburbanization. First, the development of an improved highway system allowed people to use automobiles to commute to their jobs in the cities from outside municipal boundaries. This trend began in the 1920s, but accelerated greatly after the 1940s. The passage of the Federal Interstate Highway Act in the 1950s set the stage for large-scale, multi-lane roads that became a reality over the next 20 years. Other driving forces behind suburbanization were subtler. The Nation's growing middle class now had financial resources and with the aid of Federal home loan programs could afford to buy single-family residences away from the high-density city center and maintain their suburban lifestyle by commuting (Jackson, 1985). Suburbs also repre- sented a "refuge" for a growing number of white Americans who wished to remove themselves from the increasingly nonwhite population of the cities and the desegregation of schools (Bickford, 1997; Boustan, 2005). Many other Americans fled from the congestion, pollution, multifamily residences, and high land prices typically found in the heart of the city. Many of the Nation's citizens were only a generation or two removed from farm or small-town living; the suburbs offered a means of bridging small-town and city life (Herbers, 1986, 91-101).

The Cold War era spurred the development of technology aimed at keeping the United States ahead of its perceived adversaries. Federal funding was channeled into research centers and defense industries. Communities that were home to major universities, aerospace and electronics industries, or defense installations benefited and grew as a result of these expenditures. Examples include Boston, Los Angeles, Washington, D.C., and Colorado Springs (Markusen and others, 1991). Civic leaders sometimes pressured state officials to restructure existing universities - or to establish new ones - in attempts to attract new industries to an area (Moehring, 2000). Technological advancements, such as the growth of civil aviation, increasingly inexpensive and plentiful electricity, and the widespread use of air conditioning encouraged the growth

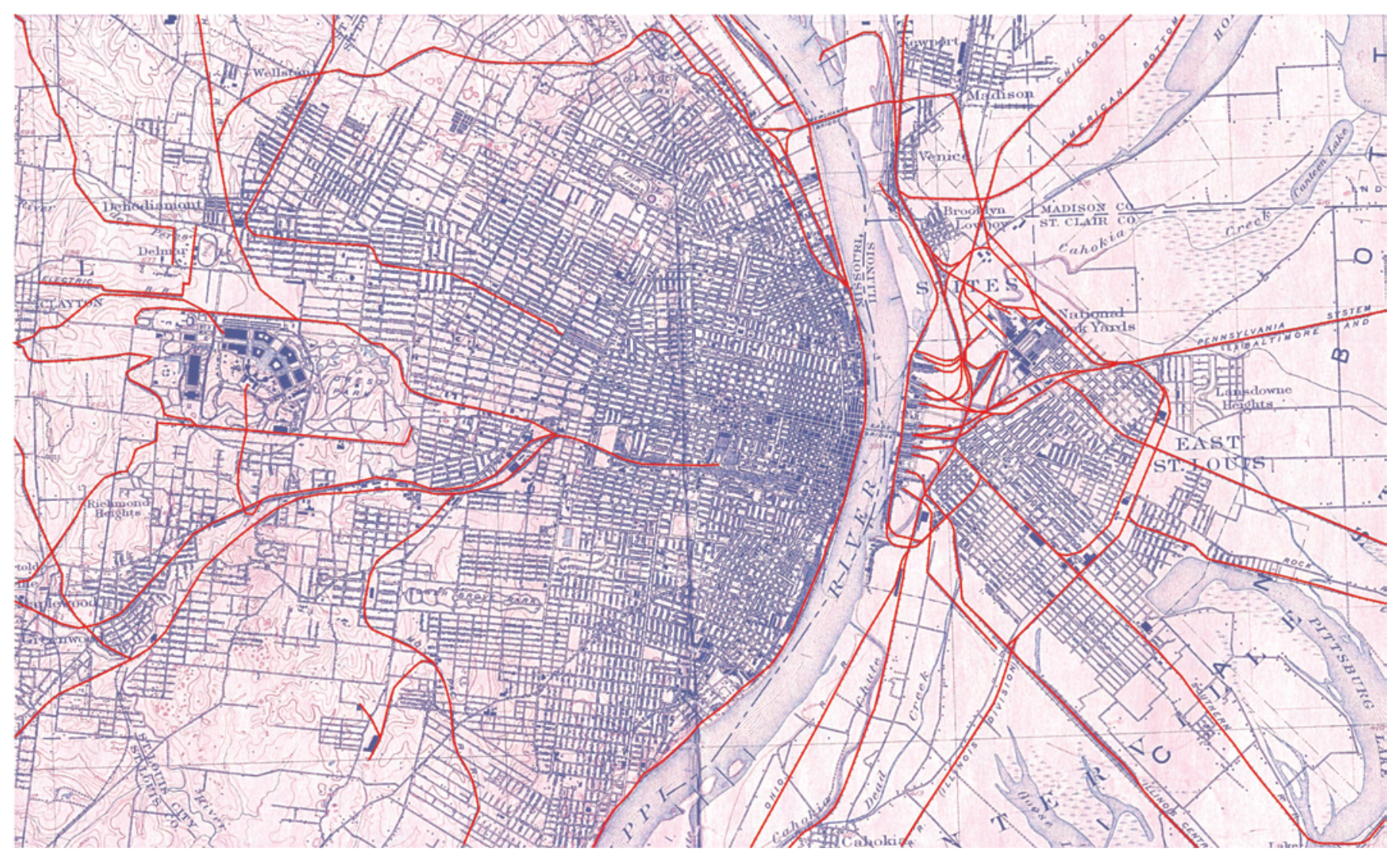

Figure 6. Railroad development in Saint Louis as seen on this U.S. Geological Survey topographic map of Saint Louis, Missouri, in 1912. Railroad lines are highlighted in red. On the east side of the Mississippi River there is a major railroad hub. 
The Historical Development of the Nation's Urban Areas

of cities in many parts of the country. Air conditioning, in particular, helped overcome environmental conditions in the Southeast and Southwest that were perceived drawbacks of year-round living in these regions (Mohl and Mormino, 1996; Moehring, 2000).

The 1970 census revealed that, by this time, more of the Nation's urban population lived in the suburbs than in central cities. The suburbs had continued to grow during the 1960s, but by the end of the decade their relationship to the city centers had changed. The suburbs were no longer simply "bedroom communities" for commuting city workers. They had emerged as focal points for the retail and service sectors of the urban economy, a trend that had been growing during the previous decades (Abbott, 1981; von Hoffman and Felkner, 2001).

Through the 1970s, city centers remained strongholds of finance and corporate management. Manufacturing, on the other hand - one of the leading segments of urban employment - was beginning to suffer major losses in the central cities. This was especially true for manufacturing's "heavy" industries. A number of factors contributed to this decline, but perhaps the most influential was the fact that the city centers had lost their real or perceived competitive advantage.

Although economic restructuring had a detrimental effect, changes in transportation and changes in industrial architecture, as well as the need for more space, also led employers to move outside central cities to suburban locations. More space was needed as warehouses were now being built horizontally, rather than vertically, which required more land than in the past. A horizontal layout improved access by trucks that hauled the goods. Both truck access to the warehouse and convenient locations near highways were now a rising priority and led employers to move outside central cities.

Deindustrialization of city centers accelerated throughout the next decade and continued into the 1980s. It left a changed urban landscape, both physically and functionally (Bluestone and Harrison, 1982; Jakle and Wilson, 1992). Cities such as Pittsburgh, Pennsylvania, and Youngstown, Ohio were prominent examples of this type of change.

The desire for new housing and lower costs also encouraged the spread of development around metropolitan regions. Land costs for new housing construction tended to be less expensive on the periphery of a metropolitan region. The increasing suburbanization of employment also allowed people who desired new housing to live further out from the urban core, while maintaining a similar commuting pattern to that so prevalent several decades earlier. From about 1970, land-use regulations became strict in many of the post- World War II suburban counties, which affected the cost of new housing by limiting the area available for development and driving individual unit costs higher. Adjacent counties that lacked such restrictive zoning in many instances absorbed the "spillover" of new development from more densely settled places (Morrill, 1992; Levinson, 1997a, 1997b).

Expansion of the elderly middle-class segment of society helped change the geographic patterns of urban areas in the post-World War II era. These "retirees" were living longer and enjoying greater geographic mobility because they could take "transfer payments", such as Social Security, company pensions, and rental or investment money, away from their home communities and spend it elsewhere (Mohl and Mormino, 1996). Cities that grew because of inmigration of retirees include the Orlando, Tampa and St. Petersburg, Phoenix, and Las Vegas areas among others (fig. 7).

A second group, people with transferable skills primarily in the service sector of the economy, also enjoyed the freedom to move to regions that were perceived to be more desirable places to live. Areas with natural amenities, such as mild winters, scenic vistas, and opportunities for waterrelated recreational activities, attracted many people from both of these relatively mobile groups ("retirees" and people with transferable skills) (Herbers, 1986; Power, 1996). As a result, the "Sunbelt" of the South and West gained in population. Many small- and medium-sized cities in the former regions were transformed by the influx of people and grew into major urban areas of national significance.

The growth of many Sunbelt cities also benefited from laissez-faire attitudes of local governments in regard to urban planning. Civic boosterism had always been a means through which individual cities could gain status within regional and national urban hierarchies. But the explosive growth in the major Sunbelt metropolitan areas was greatly aided by "probusiness" and "pro-growth" policies that were characterized by few regulations. The "boom" atmosphere that ensued resulted in the perception of both positive and negative externalities that usually accompany rapid urbanization (Kirby and Lynch, 1987; Luckingham, 1989; Payne, 1994; Goodstein, 1999, 2000). Prominent examples include Houston, Phoenix, and Denver (fig. 8).

The spatial distribution of employment also changed over recent decades. As suburbs became retail and service centers over time, manufacturing - both in terms of production and management - had also become a growing presence in suburban and exurban areas (von Hoffman and Felkner, 2001). Most industries in these areas are typically described as being "light" or "high-tech," and are much less site specific than their older, "heavy" industrial counterparts. Light industries are often located near transportation or information-based access points, such as along interstate highway "corridors" or near research facilities and (or) major universities (Fulton, 1986) (fig. 9).

Many high-tech industries often cater to the needs and desires of their specialized workforce and are located in places with abundant natural amenities. To a certain extent, industry management has also left the city center in favor of "corporate campuses" located near interstate highway interchanges or major airports (Garreau, 1991). Even small or medium sized cities have seen an increase in industrial activities as the result of being within a day's drive of larger manufacturing centers that can supply the new "just-intime," inventory-limited production systems (Rubenstein, 1990). An example is the Toyota car assembly plant, located near Lexington, Kentucky, that was built in the 1980s and is 


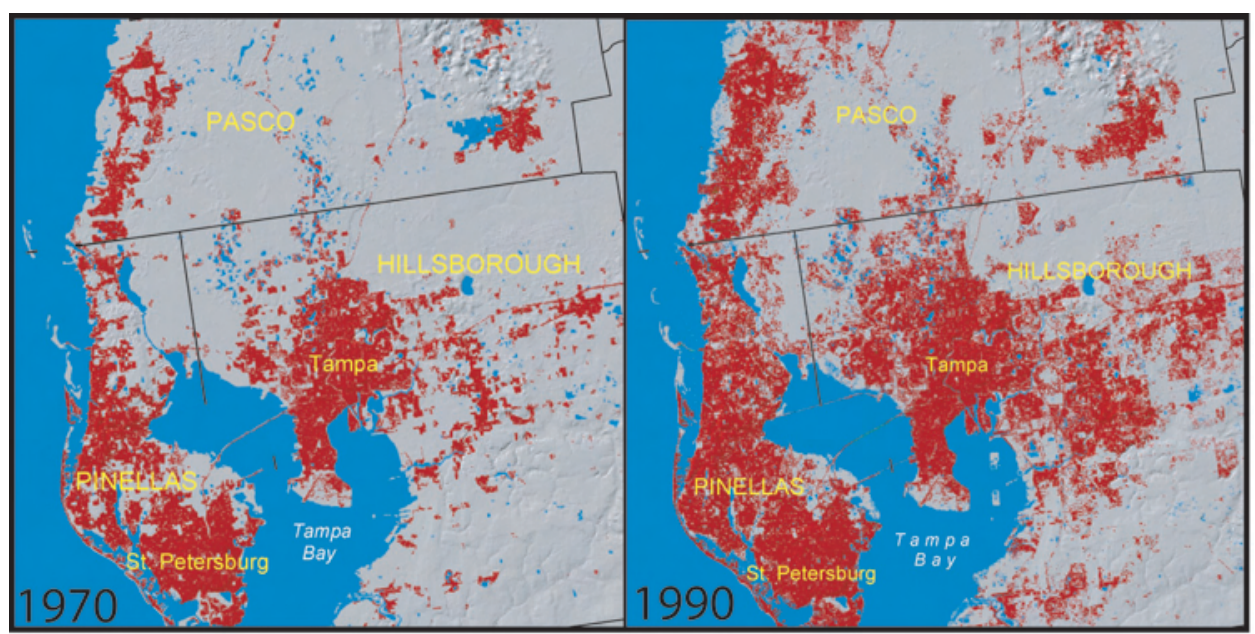

Figure 7. Urban areas (red) in the Tampa Bay, Florida, region in 1970 and 1990. Retirees, many of them migrating from other places, have played a role in the urban growth of areas within the Tampa Bay region. Senior citizens (age 65 and over) constituted nearly 30 percent of the combined population of Pasco and Pinellas Counties in 1970. The percentage of residents of retirement age had dropped slightly by 1990 , but an additional 134,000 seniors were living in these two counties (U.S. Census Bureau, 1973).

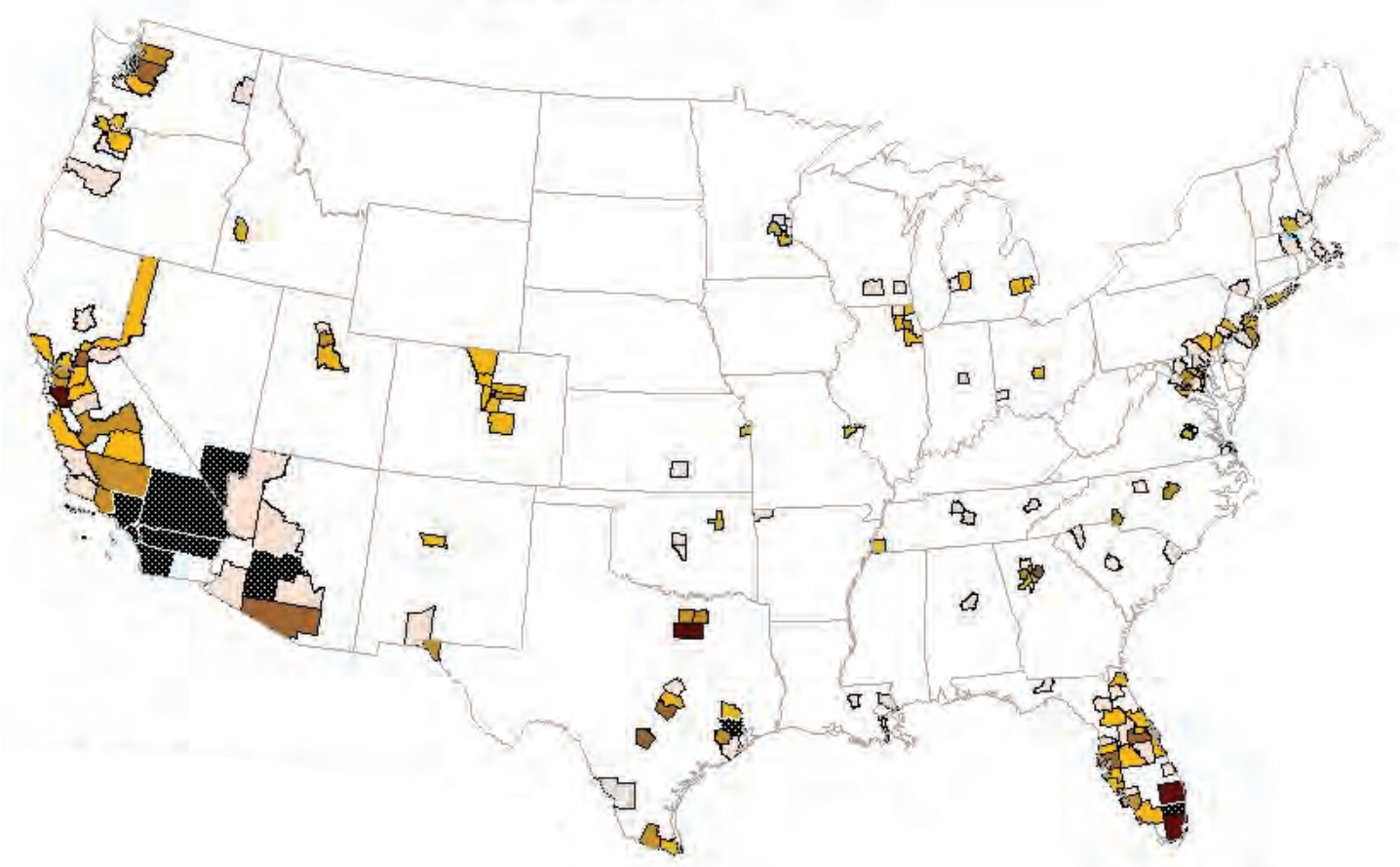

State boundaries

Counties gaining over 100,000 in population

$100,000-150,000$

$150,001-300,000$

$300,001-450,000$

$450,001-600,000$

$600,001-1,000,000$

$1,000,001-2,477,358$

Figure 8. Counties in the United States gaining more than 100,000 in population between 1970 and 2000. 

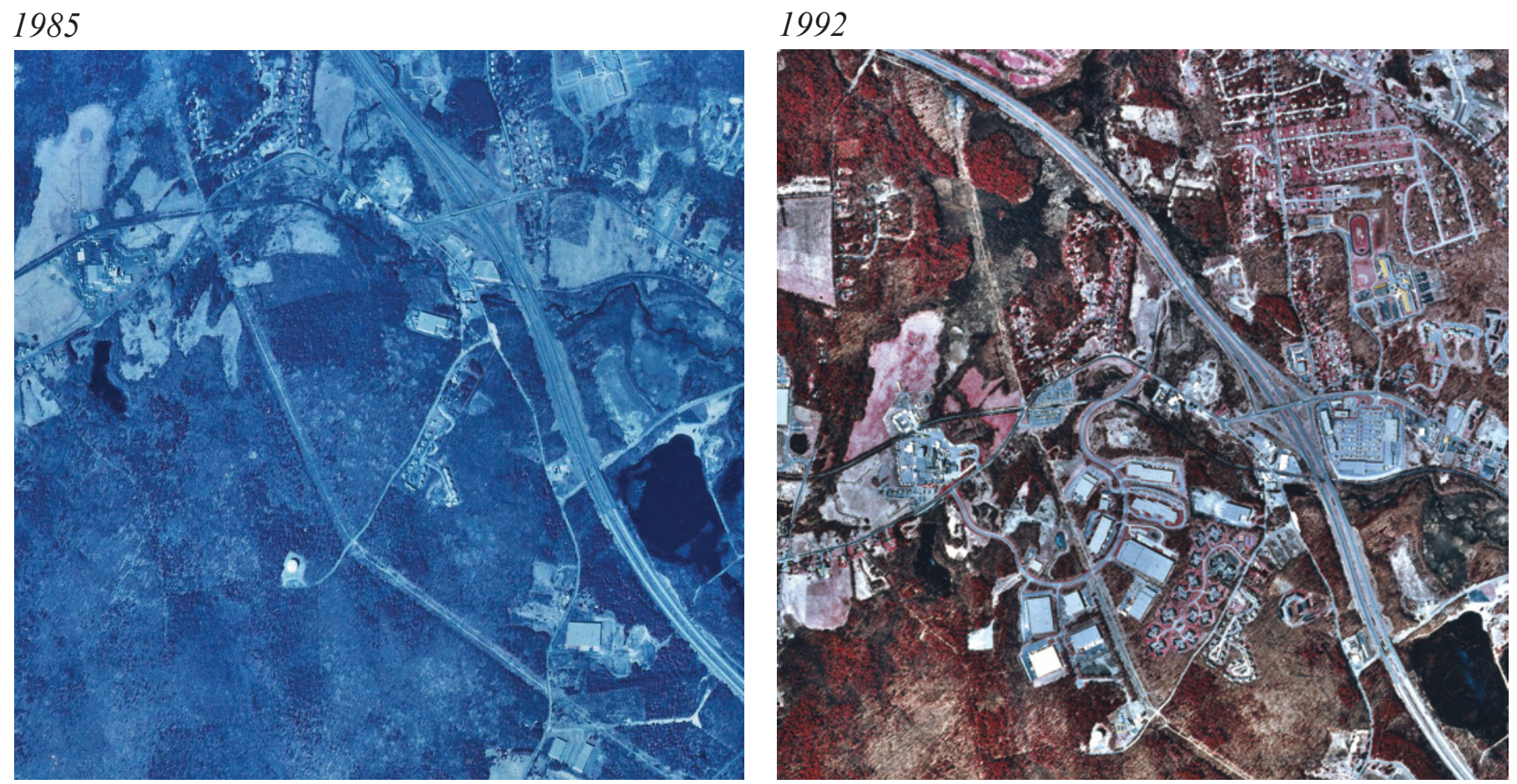

Figure 9. Images of Franklin, Massachusetts, approximately 30 miles southwest of downtown Boston, in 1985 and 1992 . Modern manufacturing is often located near the edge of a city and with convenient interstate highway access. Interstate 495 is located in the right side of the photographs. In 1985, the area to the south and west of I-495 is mostly wooded. The scene dramatically changes by 1992 as an industrial park and other development replaces the forest land. (Images from U.S. Geological Survey aerial photography from the National High Altitude and the National Aerial Photography programs.)

within a day's drive of the traditional core region of U.S. automobile manufacturing (fig.10).

The retail and wholesale of goods has also followed the pattern of locating in areas outside of the city center. Big

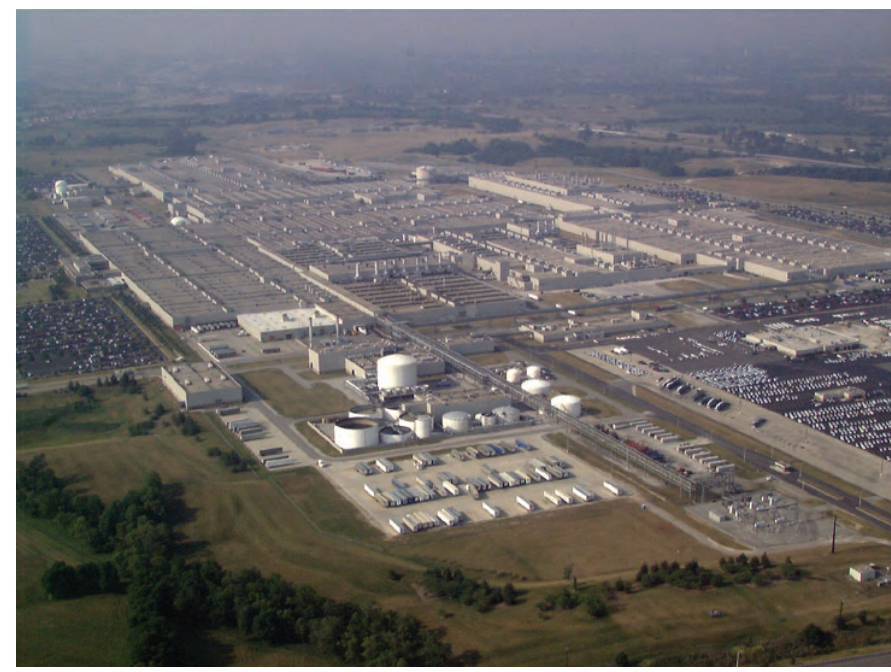

Figure 10. The Toyota car assembly plant, located near Lexington, Kentucky, and built in the 1980s, is within a day's drive of the traditional core region of U.S. automobile manufacturing. (Source: Toyota Motor Manufacturing, Kentucky, Inc.) box stores, such as Walmart, are now frequently found more conveniently located near highway interchanges and at large intersections in suburban areas. Also found in convenient transportation locations are wholesale distribution warehouses that are built horizontally across large areas and have good ingress and egress for trucks that deliver the goods.

Suburbanization did not strictly take the form of everwidening concentric circles around a central city. Suburbs often developed along main highways in a linear fashion, linking pre-existing, outlying communities with the main city. In other cases, suburbanization progressed in leapfrog fashion, bypassing certain areas because of environmental conditions, ownership status, or zoning ordinances (fig. 11).

Changes in land cover and land use that resulted from suburbanization differed across the Nation, depending on local conditions (Stansfield, 1998). In some places, agricultural land offered the best possibilities for development (Matlack, 1997) (fig. 12). Alternatively or in other areas, marginal or nonagricultural land was the preferred choice for development, especially as time passed and other options became limited (Abler, Adams and Borchert, 1976). Development around lakes and other natural amenities are examples of this type of growth. As a result, the periphery of most metropolitan areas became a jumbled mosaic of different land covers and uses (Hart, 1991).

The 1970s witnessed the spread of another form of urban growth, exurban living, although this trend had also been 

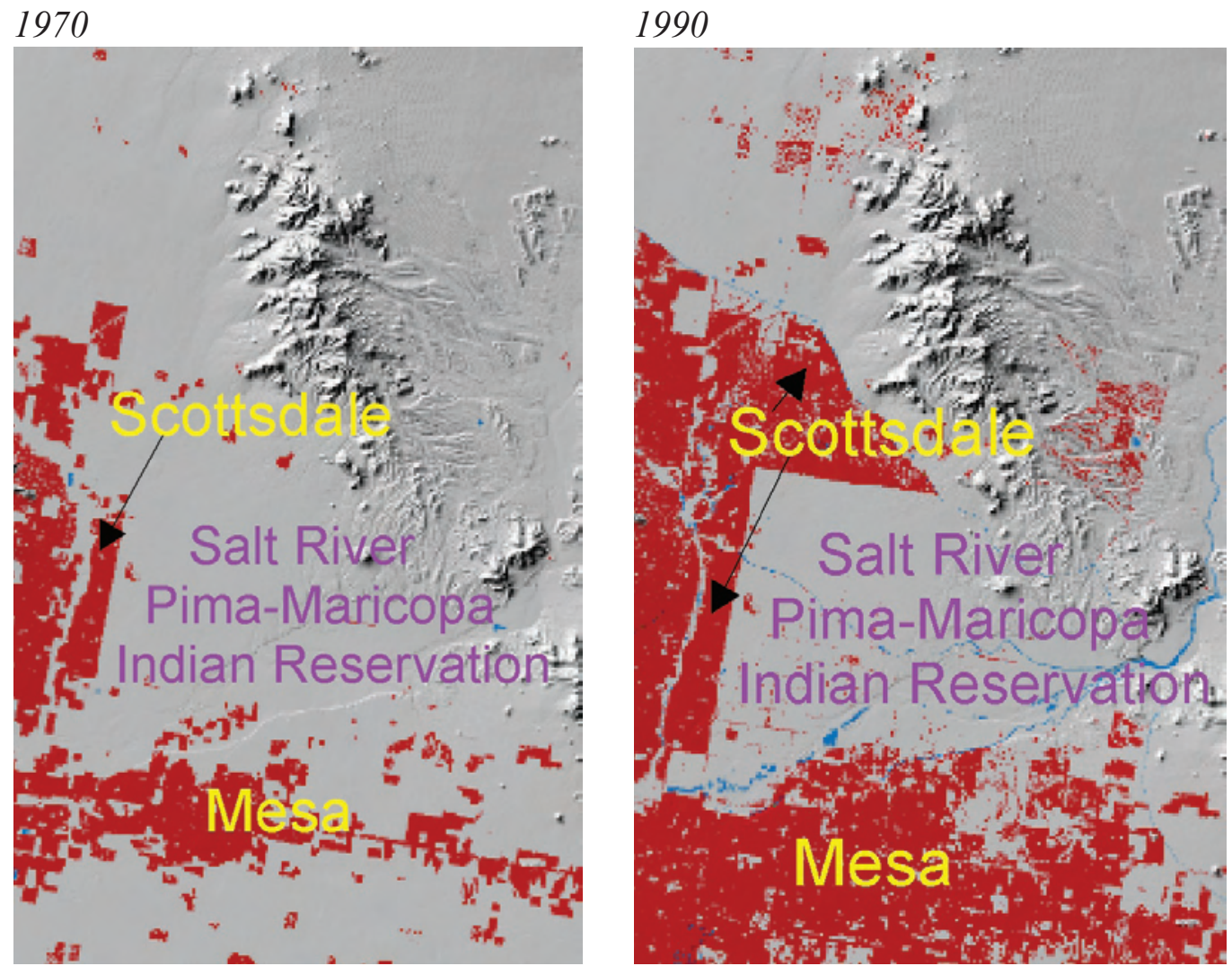

Figures 11. Different land ownership and its impact on urban growth are clearly seen in the Scottsdale/Mesa region of the Phoenix, Arizona, metropolitan area between 1970 and 1990. Urban land use shown in red. The urbanized land of Scottsdale stopped at the western and northwest boundaries of the Salt River Pima-Maricopa Indian Reservation. Mesa was also growing adjacent to the reservation's southern boundary by 1990 .

ongoing to a much lesser extent for decades (Gottmann, 1961, 1969). In the minds of many, the suburbs had become havens of conformity, the site of nearly identical, ranch-style subdivisions and strip malls. The suburbs also started to manifest the same negative urban aspects of the older cities, especially in those closest to them. Those people who wanted some of the urban advantages sought something other than the typical suburb. Many moved to large lots in surrounding rural areas and built single-family residences. These "ranchettes"

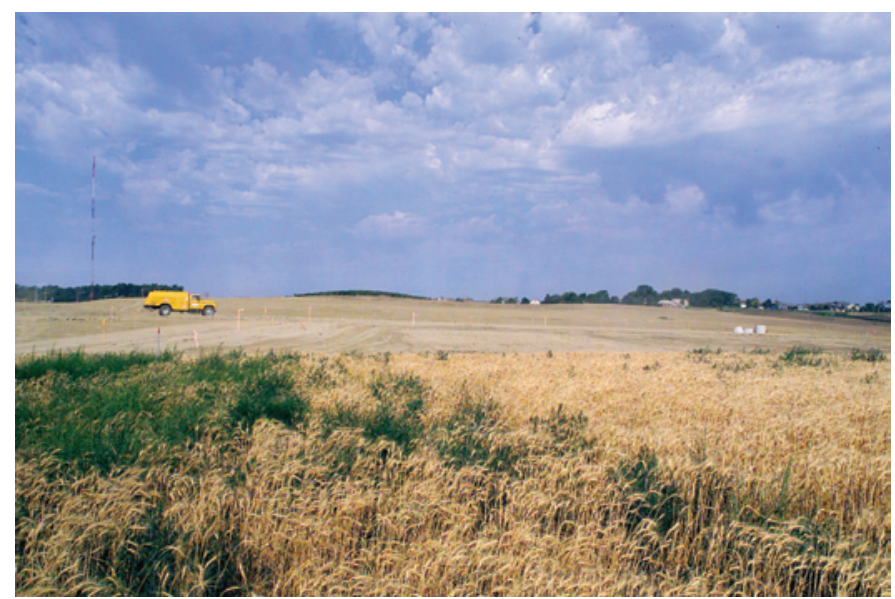

Figure 12. Former cropland, now residential "blanks," ready for new development, Sioux Falls, South Dakota.
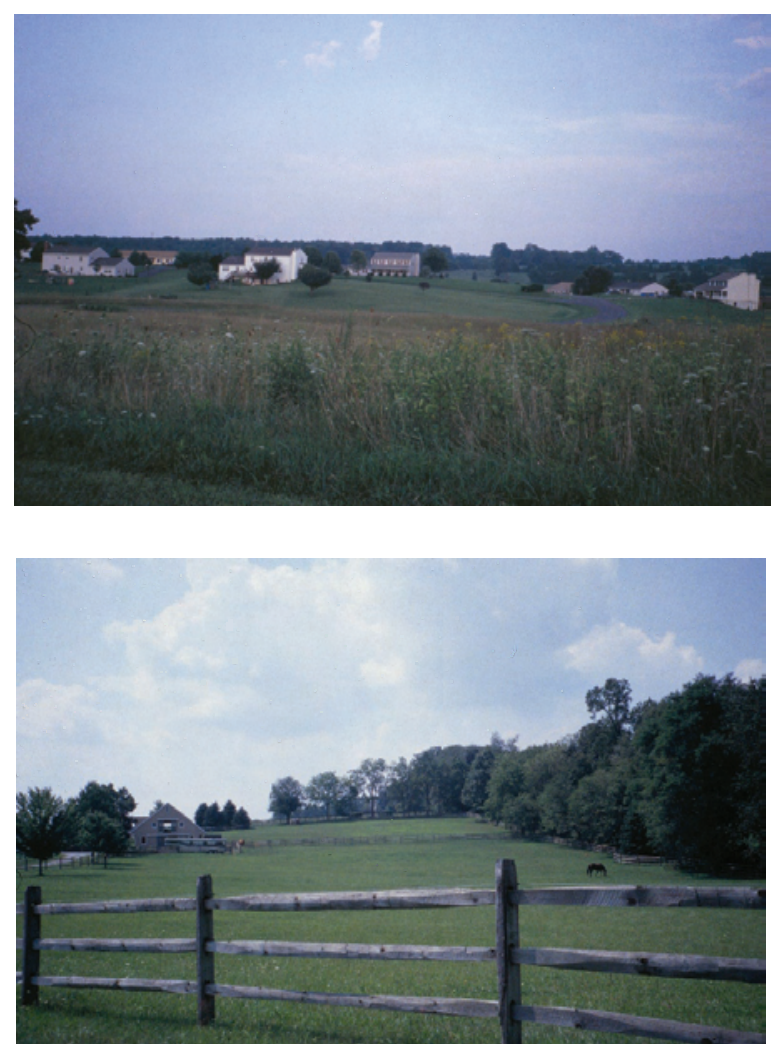

Figure 13. Exurban residences: (top) a rural sub-division in Culpeper County, Virginia, and (bottom) a "hobby farm" in Chester County, Pennsylvania. 


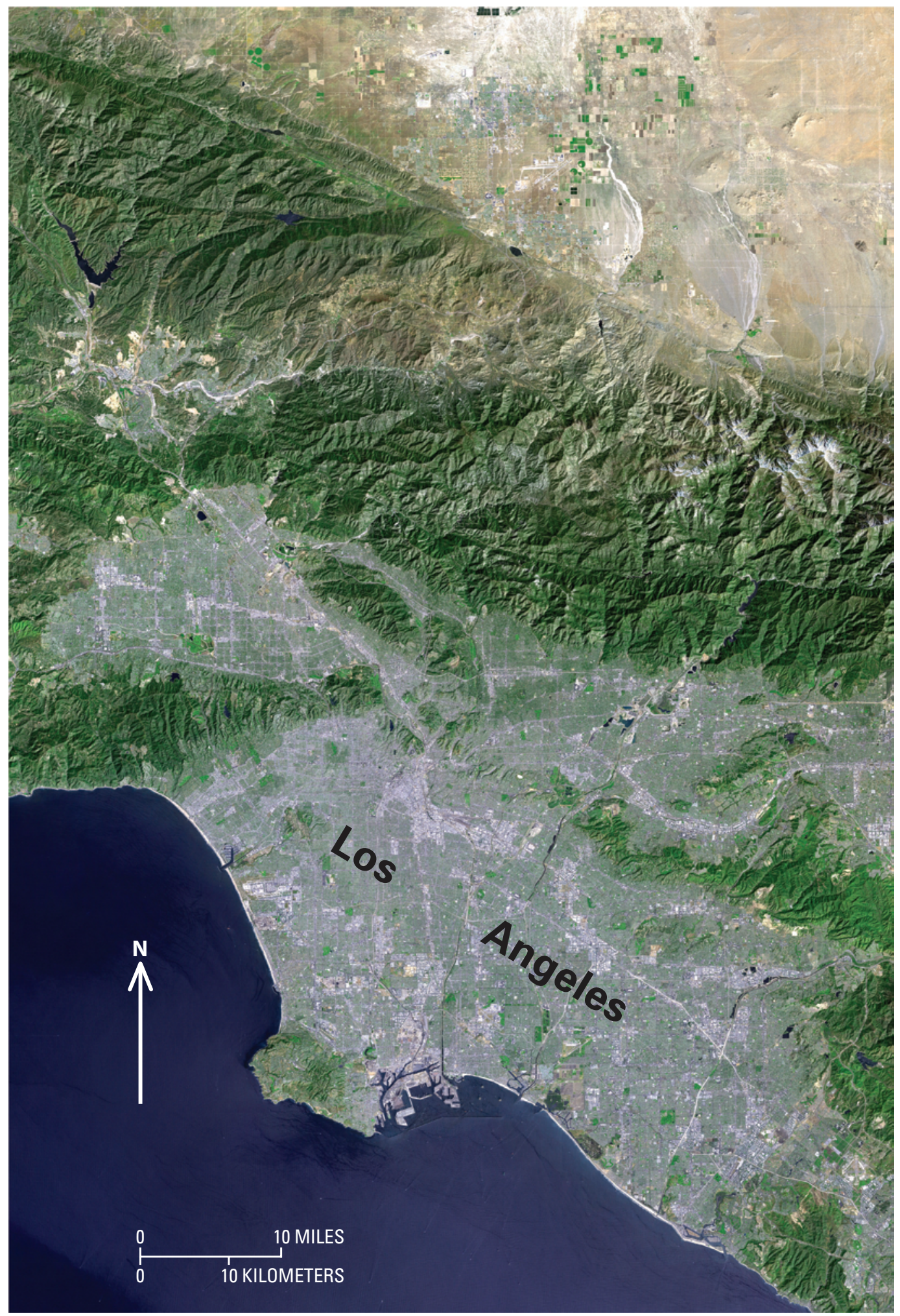

Figure 14. Los Angeles, California, and vicinity seen from space, as viewed by the Landsat 7 satellite from an altitude of 437 miles on May 4, 2001. Topographic shading has been enhanced using an elevation data set acquired by the Space Shuttle Endeavour in February 2000. By the early 1990s, the development in the Los Angeles Basin extended from the edge of the ocean to the base of all the mountain ranges. This perspective view is Shuttle Radar Topography Mission (SRTM) combined with Landsat. Image is courtesy of Courtesy NASA/JPL-Caltech (http://photojournal.jpl.nasa.gov/jpeg/PIA03376.jpg). 
or "acreages" typically ranged in size from 1 to 20 acres of land. The smaller ones were usually maintained as more traditional suburban house/yard/garden residence, while larger ones might have horses, ponds, woodlots, and even a few cattle (fig. 13). The latter did not function as farms, however, and actually fragmented surrounding land types, agricultural or otherwise. These "exurban" areas often had no recognized center, such as a major town, but instead were tied loosely to the region's primary metropolitan center (Herbers, 1986; Theobald, Gossnell, and Riebsame, 1996).

Many of the processes described in the last few pages are still ongoing within urban areas. Some cities continue to grow significantly, whereas various factors have slowed the growth of others. One reason that some portions of metropolitan areas have appeared to stop growing is that they have reached certain physical limits of their geography. In the last several decades, many cities in the United States have experienced "infilling" of areas that were initially bypassed during past periods of urbanization. Many metropolitan regions, such as the Los Angeles basin or San Francisco Bay area, have little remaining land available for development within what has been perceived as their traditional urban base (fig. 14) (Fishman, 1987).

The nonurbanized portions of these cities are preserved or restricted lands, such as regional parks, conservation or farmland trust areas, and military installations. Other nonurbanized lands either are prohibitively expensive or are unsuitable for development, such as those with steep terrain or extensive wetlands. Suprametropolitan regions continue to expand; for example, greater Los Angeles spills out onto the Mojave Desert beyond the San Gabriel Mountains and San Francisco Bay area urbanization pushes down numerous valleys in Contra Costa, Alameda, and Santa Clara Counties.

\section{Conclusion}

There is little doubt that urban areas will continue to change and grow in size. Population growth, a driver of many of the changes, is not likely to cease or decrease in the near future. Associated with increasing population is an increase in the amount of land dedicated to urban uses. The fashion in which the land is to be used, including density and intensity of development, is yet to be determined. However, analyzing the dynamic land-use changes that have occurred up to the present time will lead to a better understanding of the impacts that can be anticipated from future urbanization.

\section{References}

Abbott, C., 1981, the new urban America growth and politics in the sunbelt cities: Chapel Hill, N.C., University of North Carolina Press, $317 \mathrm{p}$.

Abler, R., Adams, J.S., and Borchert, J. R., 1976, the twin cities of St. Paul and Minneapolis: Cambridge, Mass.,
Ballinger Publishing Co., 69 p.

Bickford, E., 1997, White Flight-The Effect of Minority Presence on Post-World War II Suburbanization: University of California-Berkeley, Cliometric Society, accessed March 15, 2006 [http://www.eh.net/Clio/Publications/].

Bluestone, B., and Harrison, B., 1982, The deindustrialization of America —Plant closings, community abandonment, and the dismantling of basic industry: New York, Basic Books, $323 \mathrm{p}$.

Borchert, J.R., 1987, America's northern heartland: Minneapolis, University of Minnesota Press, $250 \mathrm{p}$.

Borchert, J.R., 1967, American metropolitan evolution: Geographical Review, v. 57, p. 301-332.

Boustan, L.P., 2005, Postwar suburbanization "white flight"? Evidence from the black migration, Harvard University Department of Economics, Ph.D. candidate manuscript, accessed March 15, 2006 [http://www.people.fas.harvard. edu/ platt/papers/blackbox.pdf].

Clark, T.D., 1984, the greening of the South the recovery of land and forest: Lexington, Ky., University of Kentucky Press, $168 \mathrm{p}$.

Fishman, R., 1987, Bourgeois utopias - The rise and fall of suburbia: New York, Basic Books, 241 p.

Fulton, W., 1986, Silicon strips: Planning (APA), v. 52, no. 5, p. 7-12.

Garreau, J., 1991, Edge city life on the new frontier: New York, Doubleday, 546 p.

Gibson, C., 1998, Population of the 100 largest cities and other urban places in the United States-1790 to 1990: U.S. Census Bureau, Population Division, Working Paper No. 27, accessed Oct. 13, 2003 [http:www.census.gov/ population/www/documentation/twps0027.html].

Goldfield, D.R., and Brownell, B.A., 1990, Urban America a history: Boston, Houghton Mifflin, 493 p.

Goodstein, P., 2000, Denver in our time a people's history of the modern mile high city volume two-DIA and other scams: Denver, New Social Publications, 552 p.

Goodstein, P., 1999, Denver in our time a people's history of the modern mile high city volume one: big money in the big city: Denver, New Social Publications, 496 p.

Goodstein, P., 1969, Virginia in our century: Charlottesville, Va., University of Virginia Press, $656 \mathrm{p}$.

Gottmann, J., 1961, Megalopolis the urbanized northeastern seaboard of the United States: New York, The Twentieth Century Fund, $810 \mathrm{p}$.

Gregory, J.N., 1989, American exodus the dust bowl migration and Okie culture in California: New York, Oxford University Press, $338 \mathrm{p}$.

Hart, J.F., 1991, the perimetropolitan bow wave: Geographical Review, v. 81, no. 1, p. 35-51.

Haverluk, T.W., 2000, American metropolitan revolutioneast meets west: 31 st annual South Dakota state geography convention, Brookings, S. Dak., Mar. 16-18, 2000.

Herbers, J., 1986, the new heartland: America's flight beyond the suburbs and how it's changing our future: New York, Times Books, $228 \mathrm{p}$. 
Jackson, K.T., 1985, Crabgrass frontier the suburbanization of the United States: New York, Oxford University Press, 396 p.

Jakle, J.A., and Wilson, D., 1992, Derelict landscapes the wasting of America's built environment: Savage, Md., Rowman \& Littlefield Publishers, Inc., 342 p.

Kirby, A., and Lynch, A.K., 1987, A ghost in the growth machine - The aftermath of rapid population growth in Houston: Urban Studies, v. 24, no. 587, p. 587-596.

Levinson, D.M., 1997, Job and housing tenure and the journey to work: The Annals of Regional Science, v. 31, p. 451-471.

Levinson, D.M., 1997, The limits to growth managementDevelopment regulation in Montgomery County, Maryland: Environment and Planning B, Planning and Design, v. 24, p. 689-707.

Lewis, P., 1987, America between the wars-The engineering of a new geography, in Mitchell, R.D., and Groves, P.A., eds., North America the historical geography of a changing continent: Totowa, N. J., Rowman \& Littlefield, Inc., p. 410-437.

Lopez, R., and Hynes, P.H., 2003, Sprawl in the 1990sMeasurement, distribution and trends: SAGE Publications, Urban Affairs Review, v. 38, no. 3, p. 325-355.

Luckingham, B., 1989, Phoenix the history of a southwestern metropolis: Tucson, Ariz., University of Arizona Press, 316 p.

Markusen, A., Hall, P., Campbell, S., and others, 1991, The rise of the gunbelt-The military remapping of industrial America: New York, Oxford University Press, 341 p.

Matlack, G.R., 1997, Land use and forest habitat distribution in the hinterland of a large city: Journal of Biogeography, v. 24, p. 297-307.

Meyer, D.R., 1987, The national integration of regional economies, 1860-1920, in Mitchell, R. D., and Groves, P. A., eds., North America the historical geography of a changing continent: Totowa, N. J., Rowman \& Littlefield, Inc., p. 321-343.

Moehring, E.P., 2000, Resort city in the sunbelt Las Vegas 1930-2000: Reno, Nev., University of Nevada Press, 359 p.

Mohl, R.A., and Mormino, G. R., 1996, the big change in the sunshine state - A social history of modern Florida, in Gannon, M., ed., the new history of Florida: Gainesville, Fla., University of Florida Press, p. 418-447.

Morrill, R., 1992, Population redistribution within metropolitan regions in the 1980s - Core, satellite, and exurban growth: Growth and Change, v. 23, no. 3, p. 277 302.
Muller, P.O., 1986, Transportation and urban growth the shaping of the American metropolis: Focus, v. 36, no. 2, p. 8-17.

Payne, D., 1994, Big D triumphs and troubles of an American supercity in the 20th century: Dallas, Three Forks Press, 497 p.

Platt, R.H., 1996, Land use and society geography, law, and public policy: Washington, D.C., Island Press, 507 p.

Power, T.M., 1996, Lost landscapes and failed economiesthe search for a value of place: Washington, D.C., Island Press, $304 \mathrm{p}$.

Proctor, S., 1996, Prelude to the new Florida, 1877-1919, in Gannon, M., ed., The new history of Florida: Gainesville, Fla., University of Florida Press, p. 266-286.

Rubenstein, J.M., 1990, Japanese motor vehicle production in the USA-Where and why: Focus, v. 40, no. 2, p. 7-11.

Spinney, R.G., 2000, City of big shoulders a history of Chicago: DeKalb, Ill., Northern Illinois University Press, $300 \mathrm{p}$.

Stansfield, C.A., Jr., 1998, A geography of New Jersey the city in the garden: New Brunswick, N. J., Rutgers University Press, $313 \mathrm{p}$.

Starrs, P.F., 1995, Conflict and change on the landscapes of the arid American west, in Castle, E.N., ed., The changing American countryside: Lawrence, Kan., University Press of Kansas, p. 271-285.

Theobald, D.M., Gosnell, H., and Riebsame, W.E., 1996, Land use and landscape change in the Colorado mountains II- a case study of the East River: Mountain Research and Development, v. 16, no. 4, p. 407-418.

U.S. Bureau of the Census, 2003, American FactFinder, P2 Urban and Rural-(6) Universe -Total Population (http:// factfinder.census.gov] (Use "search" option, select subject "urban and rural", select above table option, August 29, 2003).

U.S. Bureau of the Census, 2000, Statistical abstract of the United States-2000: Washington, D.C., U.S. Government Printing Office, p. 38.

U.S. Bureau of the Census, 1976, Historical statistics of the United States - Colonial times to 1970, part 1: Washington, D.C., U.S. Government Publishing Office, p. 11-12.

von Hoffman, A., and Flekner, J., 2001, The historical origins and causes of urban decentralization in the United States: Cambridge, Mass., Joint Center for Housing Studies, Harvard University, 35 p. 


\title{
Cultural and Demographic Factors in Urban Decentralization in the United States-A Historical Overview
}

\author{
By Alexander von Hoffman' and John Felkner ${ }^{1}$
}

\section{Introduction}

Over the past three decades the phenomenon known as urban or suburban sprawl has become the subject of enormous controversy. Critics have charged that sprawl destroys the natural environment, causes traffic congestion, undermines a sense of community, and contributes to decay and concentration of poverty in innercity neighborhoods.

Despite its notoriety, there is no commonly accepted definition of "sprawl." Since it first appeared in the 1940s (Soanes, 2001), the term sprawl has been a pejorative term used to describe forms of urban development in suburban or rural locales, deemed undesirable for a variety of reasons (Galster and others, 2001). Whatever definition of sprawl they adopt, all commentators on the subject implicitly or explicitly conceive of sprawl as a decentralized pattern of urban growth, the opposite of compact development, whether in a single urban core or in dense nodes.

The dispersion of settlements outside an urban center is hardly new-Geoffrey Chaucer wrote of "suburbs" in The Canterbury Tales - but it is in the United States that a decentralized arrangement of residences, businesses, commercial enterprises, and institutions emerged as the dominant form of urban development. Decentralized patterns of urban growth first appeared in the United States in the early 1800s, creating, as it were, early forms of sprawl. By 1970 the majority of Americans lived in suburbs rather than in cities or rural areas. In the United States suburban areas have become "the dominant American cultural landscape" (Hayden, 2000). American metropolitan areas are less dense and more "suburbanized" than metropolitan areas in other highincome countries (Mieszkowski and Mills, 1993). ${ }^{2}$

\footnotetext{
${ }^{1}$ Joint Center for Housing Studies, Harvard University, Boston, MA.

${ }^{2}$ A note on terminology: Whereas the term "suburb" in the United Kingdom and Australia generally refers to a defined neighborhood outside the central business district of a city, in the United States the term can mean either an outlying part of a city or a separate jurisdiction adjacent to or within commuting distance of a central city. Although its characteristics are not codified, most Americans would consider the characteristics of a suburb to be a significant proportion of resident wage-earners who commute to work out of the community (until relatively recently to the downtown area) and (or) housing built at lower densities than housing in the inner city. As historians such as Jackson (1987) and Binford (1985) have noted, however, the character and function of suburbs have evolved since the nineteenth century.
}

Throughout the nineteenth and twentieth centuries, a complex of forces encouraged dispersion of urban land uses and population in the United States. For almost two centuries, among the most powerful forces encouraging urban decentralization have been demographic and cultural. On the demographic side, the dramatic increase in population, primarily through immigration, has led Americans to search for homes on the urban periphery, sometimes to place distance between themselves and other Americans. In the cultural sphere, reformers and policy makers have proclaimed the superiority of suburban living and the single-family home.

Based on extensive review of the scholarly literature, the following essay traces the demographic and cultural causes of decentralized urban growth in the United States over the past two hundred years. It shows that the growth of population groups, including immigrants, racial minorities, and, more recently, the baby-boom generation, supplied the people to conquer the ever-expanding suburban realm. Deeply held cultural beliefs, the essay further demonstrates, provided an incentive for Americans to move to the outskirts of town.

\section{Demographic Factors in Urban Decentralization}

\section{An Urban, then Suburban People}

Over the past two centuries, the number of inhabitants of the United States mushroomed, and most of that growth took place in metropolitan areas, whose territory in turn has expanded. In 1800, the Nation contained about 5 million people; by 1900 the number of inhabitants had grown to 76 million. A hundred years later the United States was home to 281 million.

Most of the Nation's population growth occurred in urban areas, first in central cities and later suburbs. During the three decades prior to the Civil War, urban population grew at rates never yet equaled in American history-the number of city dwellers grew by 64 percent from 1830 to 1840 and by 92 percent from 1840 to 1850 . After the war, the number of cities and the number of people living in them continued to grow dramatically. For example, between 1800 and 1850, New York City's population ballooned from 61,000 to more than half a 
million, and by 1880 it had surpassed the million mark. During the first half of the nineteenth century, Baltimore's population increased six-fold to 169,000 , Boston's population more than quintupled to 137,000, and Philadelphia's tripled to 121,000 (Gibson, 1998). Between 1860 and 1920, the population in cities of more than 8,000 residents skyrocketed from 6.2 to 54.3 million (Chudacoff, 1975).

During the twentieth century, urban areas continued to attract people, but over time increasing numbers flowed to communities outside the old neighborhoods. The populations of most central cities grew until about 1950; thereafter, the numbers living in western cities such as Los Angeles and Phoenix continued to climb, while those in the large cities of East and Midwest began to decline ${ }^{3}$ (Gibson, 1998; U.S. Bureau of the Census, 1975; Teaford, 1986). Yet almost everywhere throughout the twentieth century, the growth in suburban populations accelerated. In 1910, 21 percent of all Americans lived in central cities, three times as many as lived in suburbs, but by 1970, 38 percent of the Nation's population lived in suburbs, more than those in either cities or rural areas, which held 31 percent each. Outer areas have continued to gain people, so that by 2000 , remarkably, half of the entire U.S. population lived in the suburbs (Hobbs and Stoops, 2002).

\section{The Urban Migration of the Foreign-Born and Racial Minority Groups}

Natural increase accounted for some of the dramatic growth in urban population during the nineteenth and early twentieth centuries, but massive migrations - especially from foreign lands - provided most of it (Chudacoff, 1975; Nash, 1988; Palm, 1981; Ward, 1971). Great waves of immigrants came in the 1850s (when more than two million entered the United States), 1880s, 1900s, and 1920s, after which immigration subsided until the latter twentieth century. By 1910 the number of foreign-born in the United States reached 13.5 million and constituted 15 percent of the American population. During the nineteenth century, most immigrants hailed from western Europe - primarily Ireland and Germany — but by the early twentieth century, the newcomers came primarily from southern and eastern Europe, Asia, and other parts of the western hemisphere (Gibson and Lennon, 1999; Easterlin, 1980).

Most immigrants poured into America's growing cities to take advantage of the economic opportunities. When the Civil War broke out in 1861, half the inhabitants of Chicago, Milwaukee, and St. Louis were immigrants. In 1890, 61 percent of the foreign-born lived in cities where they made up a

\footnotetext{
${ }^{3}$ New York's population, for example, more than doubled from 1900 to 1950 from 3.4 million to 7.9 million, which was about the same population it had in 1970. Chicago's population increased from 1.6 million in 1900 to 3.6 million in 1950 and then decreased to 3.4 million in 1970. The population of Philadelphia, Detroit, Baltimore, and many other large cities followed similar patterns, increasing until 1950 and decreasing thereafter.
}

full quarter of the population. In some cities, the immigrants far exceeded that proportion. By the early twentieth century, for example, three-quarters of the populations of New York, Chicago, Cleveland, Detroit, and Boston were immigrants and their children (Gibson and Lennon, 1999; Higham, 1984).

After the Federal Government passed the rigorously restrictive Immigration Act of 1924 - the climax to decades of antiimmigration campaigns - the number of immigrants declined sharply. For the rest of the twentieth century, European immigrants and their descendants assimilated into American society, living in ethnic neighborhoods or, increasingly, the suburbs.

Instead of immigrants from across the oceans, migrants from the rural south and south of the border now flowed into the cities of the United States. Attracted by the industrial and defense jobs created during the World Wars, southern whites and blacks moved to the Nation's urban regions. Mexicans, Puerto Ricans, Cubans, and other Hispanics also went north to the cities in significant numbers. An overwhelmingly large share of the African-Americans who fled the rural south to escape racial segregation and oppression went to northern and western cities, where they found better economic and political opportunities but continued to suffer discrimination, which declined following civil rights victories in the late twentieth century. The impact of black migrants on certain northern cities was enormous. By 1960, African Americans made up more than a quarter of the populations of Philadelphia, Detroit, Baltimore, Cleveland, Washington, and St. Louis (Thernstrom and Thernstrom, 1999), where, for the most part, they lived in ghettos.

After a new Federal law passed in 1965 opened the doors of the United States to immigrants, foreign immigration resumed on a massive scale (Frey, 2001; Frey and Alden Speare, 1988). Approximately 10 million legal and illegal immigrants entered the United States between 1980 and 1990 (Frey, 1995), perhaps the largest volume of any decade of the century, and more than 8 million more foreigners settled here in the 1990s (Mulder, and others, 2002). Most of the new wave of immigrants came from Central America-more than a third of the foreign-born population in 2000 hailed from Mexico or other Central American countries-Asia, and eastern Europe, and many, although not all, were unskilled workers. The overwhelming majority of newcomers settled in and around large cities. In 2000, the U.S. Census Bureau reported, 95 percent of the foreign-born lived in urban areas. Furthermore, the newcomers tended to concentrate in a handful of large metropoli$\tan$ areas. More than half of the foreign-born lived in the nine largest metropolitan areas. The metropolitan regions of Los Angeles, New York, San Francisco, Miami, and Chicago each contained more than a million immigrants and together almost half of the total foreign-born population (Schmidley, 2001).

\section{The Impact of Immigrants and Racial Minority Groups on Suburbia}

The flow of immigrants and members of racial minority groups into urban areas encouraged decentralization of those 
regions indirectly and directly. They promoted decentralization indirectly by provoking better-off city dwellers to retreat to communities located further away from the city. When the first sizable waves of immigrants landed in the early nineteenth century, many native-born middle-class and wellto-do Protestant Americans disdained the Irish and Germans immigrants' reputation for drunkenness and violence and adherence to the Roman Catholic faith. In the latter nineteenth century, immigrants' alien languages and dress marked them apart from the native-born population. Many were poor and lived in scandalously crowded innercity slums, which the middle-class considered breeders of disease, crime, and potential revolution (Riis, 1890). Even as reformers urged that the slums be broken up and replaced, the specter of the slums and antiimmigrant feelings caused many middle- and upper-class urban residents to withdraw to quieter, greener, and more sparsely settled regions (Higham, 1984). Similarly, in the late twentieth century, white working- and middle-class families fled their neighborhoods rather than live next to minority households escaping the ghettos and barrios. Indeed, middle- and working-class African Americans also broke away from the inner city, where lower-class residents continued to struggle (Wilson, 1987).

At the same time whites fled cities for the urban periphery, immigrants and racial minority groups also directly fostered urban decentralization by moving to suburbia themselves. During the nineteenth century, African-Americans and the foreign-born tended to concentrate mainly in innercity industrial areas near the waterfronts and rail lines, but blacks, particularly in the South, and first and second generation immigrants settled on the outskirts of cities as well (von Hoffman, 1994; Goldfield, 1989).

Although innercity racial and ethnic ghettos grew during the twentieth century, suburban areas also contained a wide range of racial and ethnic groups. Douglass (1925) discovered suburbs with heavy concentrations of African-Americans and immigrants in the 1920s. In the early twentieth century, the best-known immigrant suburbs were the predominantly Polish community of Hamtramck, outside Detroit, Michigan, and the Italian immigrant town of Cicero, Illinois, which Al Capone made his base of operations (Nelli, 1970; Zunz, 1982).

In the last decades of the twentieth century, the pace of African-American suburbanization increased markedly (Weise, 1992; Pendleton, 1973; Thernstrom and Thernstrom, 1999; Frey, 2000). Aided by newfound prosperity and the lowering of discriminatory barriers, more than seven million African-Americans have relocated to the suburbs since 1970, a movement of historic proportions (Thernstrom and Thernstrom, 1999). The black population of Prince George's County, outside Washington, D.C., for example, jumped from 14 to 63 percent between 1970 and 2000 (Frey, 2000). Suburban black settlements range from the classic enclaves for upwardly mobile city dwellers to extensions of segregated innercity ghettos, leading Muller (1981) to categorize them as either "colonized" or "ghettoized" (Massey and Denton, 1993).
Similarly, immigrants during the last 30 years have become a major feature of the contemporary suburban landscape. By 2000, half of the foreign-born lived outside central cities, slightly more than the share living within them. Asians were more likely to live in suburbs than in cities, and almost half of Hispanics lived in suburban areas. As a result, the recent wave of immigration produced, seemingly overnight, large foreign-born suburban communities, such as the Chinese suburb of Monterey Park, California (Frey, 2000; Frey, 2003; Fong, 1995). Indeed, by 2000, racial and ethnic minorities made up 27 percent of suburban populations, up from 19 percent in 1990 (Frey, 2000).

As suburbia expanded, it became home to a range of income groups. The spread of factories to the suburbs encouraged the growth of communities of blue-collar workers. During the early twentieth century, thriving working-class communities grew on the outskirts of Toronto-where many built their own houses - and oil workers made communities in the industrial zones outside Los Angeles (Harris, 1996; Nicolaides, 2002). After World War II ended, according to Muller (1981) suburban blue-collar communities proliferated, both in newly built housing subdivisions and in the older inner-ring towns near central cities. In fact, by the end of the century, suburban areas had become home not only to the working class, but also increasingly to the poor, leading concerned policymakers and urban planners to seek solutions to the problem of suburban decline (Lucy and Phillips, 2000).

\section{Effects of the Baby Boom}

The United States experienced another significant demographic event in the postwar period that is worth noting for its contribution to suburban growth. For most of the twentieth century, marriage and birth rates for native-born Americans declined, but for two decades starting in the mid-1940s, the rates surged, and the result became known as the "baby boom." Spurred by the return of soldiers from World War II and the long-suppressed desires for a higher standard of living, unprecedented numbers of Americans formed new households, creating a pressing need for new housing. The resulting construction boom pushed suburban development as never before-housing starts between 1946 and 1955 doubled over the preceding 15 years, and between 1950 and 1960 suburban areas grew by 46 percent (Zukin, 1991).

The coming of age of the baby-boom generation in the years after 1970 again spurred not only suburban but also exurban growth. Many baby-boomers purchased homes during the 1970s and 1980s, fueling a home-buying surge, much of which further helped expand metropolitan areas (Dunphy, 1997). By the 1990s some baby-boomers had attained sufficient affluence to purchase second or retirement homes in exurbia. This was part of a related movement (described below in "To the Wilderness"), in which a growing number of affluent or elderly people moved in recent years to communities with amenities such as golf courses or pleasant views (Frey and Alden Speare, 1992). 


\section{Cultural Forces for Urban Decentralization}

The dispersion of the urban population in the United States, however, was not simply the result of increasing numbers of people searching for comfortable living space. From the early days of the Republic, deep currents in American culture propelled its citizens out of cities into an ever-expanding suburban realm. Beliefs in an inexhaustible supply of land, the value of owning a single-family house, the uplifting role of nature in domestic life, the suburban community as an engine of reform, consumption as a way of life, romanticist notions of untamed nature, and the importance of rural recreation have all dug their way deep into the American psyche. Once lodged in the minds and hearts of Americans, these notions worked as powerful forces for the decentralization of urban settlements.

Fundamental to the American attitude toward the land, perhaps, is the "prairie philosophy," the perception that the land needs to be tamed and is available in unlimited supply for development - a" notion of boundless space" (Moe, 1995). Some observers linked the nineteenth-century belief in American's "manifest destiny" to conquer the frontier to the sense that urban dwellers are entitled to settle where they wish in the hinterlands (Burchell and Listokin, 1995; Downs, Linneman, and Richmond, 1995). The link may be tenuous, but certainly a sense of the abundance of land and belief in the inalienable right to claim it has enabled cities to encroach on the countryside.

\section{Social Change, Reform, and the Moral Home}

Just as essential, if not more so, to the expansion of cities was the critical value placed on the independently owned single-family residence - a hallmark of the suburban realm. In the colonial period, most townsfolk, even wealthy merchants, both worked and lived in the same building, often sharing the space with servants and apprentices. Such domestic arrangements changed in the late eighteenth and early nineteenth centuries when city dwellers - including even artisans who could afford it - moved to homes apart from their workplaces (Blackmar, 1989). Until the luxury apartment building came into vogue, the shared dwelling, especially the boarding house, seemed declassé or a sign of immaturity. The question for many became not whether but how they could purchase a single-family house, and the search for an answer led to the creation of building and loan associations - known as building cooperatives in the late nineteenth century and, ultimately, the creation of the financial system that supports homeownership today.

The dissemination of the cult of domesticity, which celebrated the home as the center of a moral middle-class life, also provided a powerful stimulus to settlement on the urban periphery. From the 1830s onwards, a flood of books, articles, and pamphlets insisted that family and home were key to a moral Christian life. In the domestic division of labor, nineteenth-century reformers argued, men should serve as public figures and breadwinners while women superintended domestic affairs (Cott, 1977; Ryan, 1981; Clark, 1986). In advice books to women, such as The American Woman's Home, Catharine Beecher, a popular nineteenth-century writer, urged women to design and organize their houses and gardens in such a way as to nurture the spiritual life and moral character of their families (Beecher, 1841, Beecher and Stowe, 1869; Jackson, 1987; Hayden, 2000).

The moral reformers argued that the American family should live with and amidst the beneficent influence of nature, in contrast to the baleful effects of crowded and unhealthy city life. Inevitably, some reformers, notably architect and writer Andrew Jackson Downing, urged Americans to take up residence in homes set in a properly domesticated landscape in the country or the suburbs. Expressing romanticist beliefs in the influence of the external environment on the individual, they asserted that pastoral settings were aesthetically, morally, and physically healthful places that would counteract the ills of urban existence, such as pollution, congestion, and psychological stress (Hayden, 2000; Schuyler, 1996; von Hoffman, 1994; Schuyler, 1986). The reformers felt that homes in natural environments would bring together the best of the city and the country, elevating the benefits of "aesthetic and moral nature" and linking the "life contemplative with the life practical" (Fishman, 1987). Such places, they concluded, were ideal for educated middle- and upper-class men and women to raise their families. Thus emerged in the mid-nineteenth century the belief in the superiority of suburban living that by the late twentieth century many Americans accepted without question (Lewis, 1996; Clark, 1986).

\section{Suburban Design in American Culture}

Innovations in the design of the moral suburb helped make decentralized urban settlements - with a particular physical form - popular in North America. Fishman (1987) traced the roots of modern American suburbia to late-eighteenth-century English suburban villas and their landscaped grounds. In their park and community plans, nineteenth-century American landscape architects drew heavily from the English pastoral or romantic school of landscape gardening, whose naturalistic elements contrasted with formal French and Italian garden designs. Inspired by suburban housing developments, such as Park Village in London and Victoria Park in Manchester, and urged on by Andrew Jackson Downing, Americans in the 1850s began to incorporate serpentine roads, parklands, and lawns into subdivisions and towns. Projects designed by Downing's collaborator, Alexander Jackson Davis, and by Frederick Law Olmsted and Calvert Vaux-New Jersey's Llewellyn Park in 1853 and Riverside, Illinois in 1869, respectively - became influential prototypes of the new suburb. From the mid-nineteenth century onwards, plantings and curvilinear roads in the English (and by now also American) landscape 
tradition appeared in railroad commuter towns-strung out, for example, along routes the Main Line outside Philadelphia and near the Chicago and Milwaukee line on Chicago's North Shore - and in subdivisions sprouting up on the ever-expanding circumference of cities (Fishman, 1987; Jackson, 1987; Schuyler, 1986; Archer, 1983; von Hoffman, 1996; Ebner, 1988).

European and American planners, designers, and reformers in the twentieth century continued to try to create new communities that improved upon crowded city neighborhoods and disorderly or unaesthetic areas outside cities. The Garden City movement, which originated in England at the turn of the century, aimed at combining the virtues of city and countrysuch as urban economic opportunities and rural greenbelts. (At the first Garden City, Letchworth, and later Hampstead Garden Suburb, British architects Unwin and Parker experimented with grouping houses around communal greenspaces and shared walkways.) During the 1910s and 20s the Garden City movement in the United States inspired the design of industrial towns such as Kohler, Wisconsin, and suburbs such as Mariemont, Ohio (near Cincinnati). An offshoot of the movement, the Regional Planning Association of America (RPAA), evolved into diverse efforts to plan urban and rural areas in a comprehensive way. At the height of its influence, two RPAA architects, Clarence Stein and Henry Wright, designed Radburn, New Jersey, billed as a new kind of community for the motor age, with innovative features as superblocks free of automobile traffic, houses placed along cul-de-sacs, and separate circulation systems for pedestrians and vehicles, as well as parks and lawns throughout (Buder, 1990; Spann, 1996; Schaffer, 1982).

From the 1930s onwards, government and private developers of new communities adopted many of the signature planning features of the Garden City and regional planning movements. Several Federal Government agencies in the New Deal administration of Franklin D. Roosevelt developed housing and new towns in suburban and rural areas. Three Federally sponsored Greenbelt Towns in Wisconsin, Ohio, and Maryland, for example, were intended to offer both employment and residences were short-lived experiments that in any case evolved into suburbs. To carry out such projects, agency officials hired Garden City and RPAA designers as either advisers or planners. At the same time, the government planning agencies - including the Federal Housing Administration and the Regional Planning Commission of Los Angeles County - recommended that subdivision developers abandon straight grid plans in favor of such features as curvilinear streets, superblocks, cul-de-sacs, and greenbelts. As a result, the large-scale developers, such as Kaiser Community Homes, that built out the Los Angeles region in the 1940s produced an entire territory that reflected the traditions and innovations of suburban and new town design (Hise, 1997; Crawford, 1995; Rowe, 1991; Schaffer, 1982).

By bestowing recognizable forms on new development on the urban periphery, landscape and town planning efforts had a tremendous impact on suburban design in the post-World War
II era. True, late twentieth-century suburban development took many shapes. It ranged from watered down versions - such as the first Levittown in Long Island - to the revival of the Garden City style in the plans of New Urbanism designers (Kelly, 1993; Calthorpe, 1993; Rowe, 1991). Nonetheless, the landscape and planning traditions produced the images that became the hallmark of modern American suburbia, and their popularity was yet one more cultural impetus to decentralized urban settlements.

Some (Harris and Lewis, 2001; Wunsch, 1995) have criticized the work of historians of American suburbia for emphasizing the role of the elite and ignoring the workingclass and industrial areas in their work. Granted, as we have seen above, from early days America's metropolitan areas contained a diversity of peoples, yet the elite suburban ideal and its realization on the ground stimulated the decentralization of American cities in two fundamental ways. First, it provided an incentive for the urban wealthy and upper-middle class to move to outlying areas, which in turn redefined these communities as "suburban." Second, it set an example — even the mold - of suburban living that was copied and made available in one form or another to households across a spectrum of income groups (Sies, 2001).

Strikingly, the idea and the form of suburban living spread to those lower on the economic ladder even though planned suburbs and subdivisions - including some inspired by the Garden City movement - usually prevented racial and religious minorities from living in them or relegated racial minorities to inferior living conditions. Such exclusive developments as Palos Verdes, California, the Country Club District, Missouri, and even Forest Hills Gardens - a progressively planned philanthropic development in Queens, New York-barred Jews and African Americans from purchasing homes. The planned industrial towns by definition usually included a range of workers, but as a rule separated residences by income group or by work status (management, skilled employees, and unskilled workers) and some segregated members of racial or ethnic minorities in houses significantly more humble than those for other residents. Yet as the persistent and increasing diversity of suburban areas shows, Americans of minority or low-income backgrounds have aspired to rather than reject suburban life.

\section{The Suburban Home as a Commodity}

Although the ideal of the suburban home as a place of uplift, first devised in the nineteenth century, persisted in one form or another through the twentieth century, Americans increasingly came to see - and lust for - the suburban house as a commodity that reflected social status and purchasing power.

Technological innovations helped bring the suburban home across the cultural bridge from a site of domestic reform to a good for domestic consumption. In the early twentieth century, popular magazines and newspapers - picking up where nineteenth-century reformers such as Beecher left 
off-trumpeted progressive reform theories of sanitation and efficiency in domestic life. Periodicals - including Good Housekeeping, Cosmopolitan, and Hearth and Home - campaigned in the 1920s for healthful houses and championed the bungalow, preferably with its open-air sleeping porch, as the best choice for a new suburban house. The healthy house crusaders paid particular attention to kitchens and bathrooms, and applauded the combination of sanitation with the latest in household appliance technology (Teaford, 1986). In the same years, however, the novelist Sinclair Lewis would depict the healthy suburban house as a status symbol for the acquisitive upper-middle class (Lewis, 1922).

After World War II, sales of consumer goods and suburban houses surged. Even before the war ended, newspaper and magazine advertisements for all sorts of merchandise whetted the consumer appetite of Americans weary of depression conditions and wartime restrictions. After the war, suburban subdivisions proliferated - spurred by a short but severe housing shortage - and sales of domestic appliances and automobiles spiked. Real estate marketers emphasized efficient mass production techniques and the low-density, automobile friendly suburban plans, which included - in contrast to crowded city living - the detached single-family house, yard, and surrounding greenery. Nor did they neglect to point out the reasonable price for a suburban home - made more reasonable by Veterans Administration loans. In the process, a new vision of the ideal home - the "dream house of the future"- emerged that differed substantially from its bungalow and neocolonial predecessors. Magazines glowingly hailed the new "ranch" or "contemporary modern" homes that filled suburban tracts (Jackson, 1987; Clark, 1986).

Despite intellectuals' critiques of the Levittowns and Lake Forests as unaesthetic and conformist, industry thrived by focusing on the desires of the consumer family in the suburbs. Marketing campaigns for suburban homes proclaimed design features conducive to raising children, such as "family rooms," "play rooms," and large backyard patios with barbeques. Manufacturers of appliances and cleaning products appealed to women consumers by projecting images of housework as "easy and fun." Technological innovation, they claimed, would free women from the hard work of the old "domestic economy" (Clark, 1986; Hayden, 2000). The suburban home became big business, something to market and sell on a massbasis. As a growing number of products became more available in postwar America, the single-family home became, more than ever, a reflection of personal taste, income, and status. Not surprisingly, the suburban shopping mall became the chief headquarters of the new consumer society (Cohen, 1996).

\section{To the Wilderness}

Americans' long-standing affinity for nature in wilderness and rural areas - as opposed to the tamed landscapes of the suburbs - is yet one more important cultural ingredient in the persistent decentralization of their urban settlements. Americans' attitudes toward nature are a large subject about which much has been written, far more than can be stated here. Suffice it to say that by the eighteenth century educated Europeans came to appreciate wilderness areas - once shunned as places of desolation - which they cataloged into types of landscapes, most notably the picturesque and sublime (Bate, 1961; Monk, 1960; Huth, 1957).

By the nineteenth century, an ascendant romanticism fostered appreciation for nature, in both tame and wild forms, on both sides of the Atlantic. Under its influence, as we have seen, landscape architects such as Olmsted promoted pastoral park and suburban landscapes for their benign influences on individuals. Following similar romanticist principles, however, advocates of untamed nature argued that contemplation of picturesque and sublime landscapes also produced salutary moral, psychological, physical effects (von Hoffman, 1988). In such works as "Rip Van Winkle," "The Scarlet Letter," and "The Song of Hiawatha," nineteenth-century writers Washington Irving, Nathaniel Hawthorne, and Henry Wadsworth Longfellow used the imagery of wild nature to produce a mythic history for America. Artists Frederic Church and Albert Bierstadt glorified the wilderness for its grandeur and sublimity (Novak, 1995; Crandell, 1993). Others followed in their wake and helped popularize romanticist thinking about America's untamed natural environment and the people who inhabited it. Nothing demonstrates the power of these constructed myths better than the romantic image of the American West and its celebration in literature and popular culture-from Wild West shows to cowboy films (Smith, 1978; May, 1997; Cawelti, 1984).

Hence, as they conquered the frontier and ever since, Americans relished their continent's natural areas as stirring scenery. During the nineteenth century, tourists began to explore the outback while well-to-do vacationers frequented resorts in the mountains and on the seashore (Sears, 1998; Sternglass, 2001). To exploit the enthusiasm for wild and picturesque scenery, the railroad companies published guides and offered special routes into the remote countryside. At the same time, naturalist John Muir among others led a successful movement to establish national wilderness parks and helped make the preservation of wilderness areas a national policy (Turner, 1985; Runte, 1997; Magoc, 1999). In the twentieth century, the automobile gave the public greater access to wilderness and resort areas. At the same time, automobile clubs championed car touring and lobbied for better roads on which to get to the countryside (Flink, 1988; Jakle, 1985), and recent superhighway construction has made it even easier to travel to rural America.

Americans also have a long tradition of active recreation in natural settings - from urban sports such as baseball to spelunking. From the mid-nineteenth century leaders of the Muscular Christianity movement to today's physical fitness advocates, active recreation has been promoted as virtuous to mind and body alike — often in similar terms as the arguments for passive contemplation of natural scenery (von Hoffman, 
1988). From the early twentieth century, outdoorsmen and women took to wilderness and rural areas to camp, fish, hike, and ski. In recent decades masses of Americans have flocked enthusiastically to the outback to ski, hike, climb mountains, ride horses, and raft on white-water rivers, to name a few of the popular recreational activities. In the process, the rustic lodges of yore have given way to large recreational developments, and in some places the entire countryside economy has turned from traditional pursuits, such as agriculture, to become primarily places of recreation (Braden, 1988).

The popularity of natural environments - as scenery or setting for active sports and recreation - directly contributed to the dispersion of urban dwellers into an ever-expanding area away from cities. Inevitably, journeys into the outback lead some to settle there permanently - to enjoy activities in nature all year, to service those who come to such places, or both. At the same time, some urban dwellers - more frequently suburban dwellers - have sought to escape the expanding and increasingly populated suburbs by moving to rural environments where they can bask in the glory of the countryside.

Urbanites trickled into the countryside for much of the twentieth century, but the settlement of what became known as "exurbia" began in earnest about mid-century. Since the 1970s, affluence and the coming-of-age of the baby boom generation brought an influx of hobby farmers, second-home owners, retirees, and long-distance commuters into rural America. After slowing down in the 1980s, the movement of people into the backcountry accelerated in the 1990s. In the last decade, counties that offered natural amenities and outdoor recreational activities attracted disproportionate numbers of people, some of whom were of retirement age but others of whom were 30 years of age or older and with children (Johnson, 2002).

In some places, the arrival of city folk augurs the arrival of the city itself - in the form of subdivisions and shopping centers (Spectorsky, 1955; Audirac, 1999; Hart, 1995). There along the rural-urban fringe, once-wild nature - championed for its wholesome effects on its beholders - is transformed into tamed suburban nature, whose apologists also argued for its uplifting influence.

\section{Political Localism Versus Coordination of Suburban Interests}

The outward movement of peoples of diverse racial, ethnic, and income groups and the cultural imperatives of moral reform, modern suburban design, the house as a commodity, and romance of rural and wild landscapes created a patchwork quilt of population groups and types of communities on the urban periphery. The political autonomy of local jurisdictions in the United States aided and abetted not only this geographic expansion of urban development, but also the expression of the diverse interests of the diverse population groups. As a result, political localism has hindered - if not prevented - coordinated planning in metropolitan areas that would centralize or at least concentrate new growth.

The independence of local political entities took root during the colonial period and grew stronger thereafter. Provincial assemblies originally and state legislatures after the American Revolution granted corporate charters to local jurisdictions. Although occasionally legislatures abrogated some measure of home rule from large cities as part of reform movements, they have usually not interfered with the prerogatives of towns, and today there is widespread support for small, local governments as opposed to regional government entities (Baldassare, 1992).

Whether their leaders liked it or not, however, towns located near cities generally were incorporated into the economic and social networks of the growing metropolis. As the towns grew and changed, conflicts emerged over whether to limit services and taxes or to spend to provide new schools, sewers, utilities, and police and fire assistance to the growing populace (von Hoffman, 1994; Binford, 1985; Warner Jr., 1972). At the same time, urban business and political leaders wanted to extend the domain of their cities to increase the tax base and enhance their sense of local prestige.

There were four different possible approaches to these problems: (1) cities could expand their boundaries by annexing adjacent communities into the municipal corporation; (2) increased powers of old communities or create new municipalities within the suburban ring; (3) special taxing districts could be established to provide for one or more important functions; and (4) county governments could expand their powers by becoming more like cities themselves (Jackson, 1987).

From the nineteenth century onwards, powerful fastgrowing cities adopted the first alternative, annexing neighboring territory. Between 1850 and 1910 a dozen major U.S. cities expanded their boundaries by more than 500 percent through the addition of more than 800 square miles of land (Jackson, 1987). The largest cities annexed the most land. In 1898, for example, New York City annexed Brooklyn, Queens, Staten Island, and the Bronx to increase its size from 44 to 300 square miles (and take in almost two million more residents), and between 1890 and 1920, Los Angeles added more than 330 square miles. Large booming cities continued to annex territory in the twentieth century. Houston, Texas, captured the most land between 1948 and 1967 when it ballooned from 76 to 446 square miles, but numerous other Sunbelt citiesincluding San Antonio, Texas, Phoenix, Arizona, and San Jose, California - added more than 100 square miles to their domains between 1950 and 1975.

As peripheral communities grew wealthier and stronger, however, they were able to assert their independence from central cities. An early turning point came in 1874 when, 6 years after Boston had annexed five neighboring communities, the town of Brookline spurned Boston. Thereafter, a number of suburban communities, including Oak Park and Evanston outside Chicago and parts of Alameda County adjacent to Oakland, California, rebuffed efforts at consolidation (Palm, 1981). In the 1920s, movie stars rallied to preserve 
the posh suburb of Beverly Hills from becoming part of Los Angeles (Teaford, 1986). In the postwar era, even dynamic cities encountered fierce resistance to annexation from outlying towns. In the 1950s and 1960s suburban cities, Tempe and Scottsdale, Arizona, fought off Phoenix's plans for aggrandizement, and in the 1970s Aurora, Colorado, held back Denver (Abbott, 1981).

The leaders of the resistance to joining central cities were usually upper-middle class suburbanites. In general, they feared low-income immigrants and, in the twentieth century, blacks, were hostile to urban political machines, which they saw as corrupt and dependent on lower-class voters, or wanted to preserve political prerogatives for people like themselves.

Local leaders who held these kinds of sentiments found a powerful tool in zoning, a land use planning device introduced in 1916 in New York where it was used to protect residential areas from the encroachments of the garment district. A 1926 U.S. Supreme Court decision ensured the right of local governments to pass zoning laws in order to separate land uses. In the following decades suburban towns used zoning rules to exclude multifamily housing from single-family neighborhoods, establish minimum lot sizes for areas of new residential development, and prohibit particular kinds of commercial or industrial development. In many suburban communities, these sorts of regulations have been used to enforce or reinforce the exclusion of low-income groups from the towns (Burchell, 1998; Cervero, 1991; Downs, 1999; GAO, 1999; Orfield, 1997; Sierra Club, 1999). By stipulating that single-family houses be on large lots and in effect forcing moderate- and low-income families to live elsewhere, zoning and like tools encourage extensive low-density development of urban areas (Baldassare, 1992; Doyle, 2001).

The autonomy of local jurisdictions also allowed them to pursue diverse agendas, including enabling individuals to develop properties freely, without coordinating with other communities or working under metropolitan plans that might channel growth to use land efficiently. Numerous authors have blamed the fragmented political authority of metropolitan areas for a host of ills. These include not only scattered and disorganized land uses and uneven aesthetic qualities, but also traffic congestion, lack of affordable housing in suburbs, inefficient local service delivery, and racial and income segregation (Rusk, 1995; Baldassare, 1992; Bollens, 1988; Kasarda, 1980; Schneider, 1980; Schneider and Logan, 1981; Black and Henderson, 1999; Burchell, 1998; Calthorpe, 2000a; Calthorpe, 2000b; Downs, 1999; Lessard, 2001; Moskowitz and Lindbloom, 1993; Orfield, 1997). The chief problem, the critics complain, is a lack of a clear regional planning vision - or at least one coordinated vision shared by multiple municipalities (Sanchez, 2000; Chen, 2000).

In fact, some urban regions have tried to adopt various metropolitan solutions to solve their problems. County governments in some places - Dade County, Florida, for exampleexpanded their powers to rule over a large territory - although this was often a way of achieving political control over the central city. In counties such as Montgomery County, Mary- land, however, county-wide planning has managed growth and saved land (von Hoffman and Harrigan, 2002). Several metropolitan areas established agencies to provide for one or more important functions. For example, both Denver and Atlanta established regional transportation agencies to develop mass transit systems in the 1970s, and the latter area set up the Atlanta Regional Commission to coordinate planning (Abbott, 1981). Perhaps the greatest exception to the lack of regional planning is the Portland Metropolitan Council, a board that controls the urban growth boundary outside the city of Portland. Also, States such as Florida, New Jersey, Georgia, and Oregon have established statewide agencies to supervise urban growth or conserve forests, fields, and wetlands (DeGrove and Miness, 1992; Cullingworth, 1993).

Yet all in all, such regional solutions were temporary or partial, or in the case of Portland, exceptional. The chief reason regional planning has been extremely limited in the United States is that most Americans approve of fragmented political authority. Voters have turned down regional government proposals frequently (Campbell and Dollenmeyer, 1975) and, when surveyed, strongly opposed intracounty regional government and single purpose agencies to address metropolitan-wide problems, such as environmental pollution (Baldassare, 1989). These suburban attitudes express distrust of large, urban government bureaucracies, a preference for decentralized public services, and a strong desire for local rule of homogeneous communities (Baldassare, 1989; Fischer, 1984; Popenoe, 1985).

Altshuler (1999) described the conflict between the idea of a coordinated political approach across communities and the beliefs in individual property rights and local prerogatives as the expression of competing "ideo-logics." On one hand, an American communal instinct highlights values such as equality, integration, and democracy and provides a rationale for government intervention to prevent market failures; on the other, the primacy of individual rights stresses personal property ownership, the freedom to choose one's associates, the efficiency of market allocation, and the perverse effects of big government (Altshuler, 1999). The result is that within any given metropolitan area, efforts at coordination of metropolitan development are only partially successful. In general, some communities exclude new development while others encourage it or fail to resist it, and the urbanized area extends ever-outwards in piecemeal fashion.

\section{Conclusion}

Urban decentralization has been a powerful trend in American history over the past two hundred years. The United States today boasts great metropolitan areas whose number and size continue to grow. The outer parts of these urban regions are, contrary to the image of the homogeneous suburb, diverse and ever-changing patchworks of land uses and neighborhoods - like their nineteenth-century predecessors but ever more vast. 
The growth of the national population, including immigrants, racial minorities, and the baby-boom generation, supplied the people who pressed inexorably outwards from the urban core. Yet beneath the reasons that Americans today choose to live in suburban and exurban locales - such as consumer taste, status anxieties, and desire for high-quality schools - lies a moral imperative inherited from the past. Deep in the American consciousness is a belief that seminatural suburban or rural environments are better for us. The autonomy and power of local government in the United States has compounded the problem of coordinating the diverse interests of the communities within metropolitan regions and managing future growth in a rational way.

This overview, however brief, demonstrates the deepseated hindrances that face those who would control urban development in order to balance the needs of the natural environment with the desires of the humans who inhabit it.

\section{References}

Abbott, Carl, 1981, The new urban America-growth and politics in sunbelt cities: Chapel Hill, NC, University of North Carolina Press.

Altshuler, A.A., 1999, The ideo-logics of urban landuse politics, in Derthick, M. ed., Dilemmas of Scale in America's Federal Democracy: Cambridge, MA, Cambridge University Press.

Archer, J., 1983, Country and city in the American romantic suburb: Journal of the Society of Architectural Historians, v. 42, n. 2, p. 139-156.

Audirac, I., 1999, Unsettled views about the fringe: Ruralurban or urban-rural frontiers, in Furuseth, O.J. and Lapping, M.B., eds., Contested countryside-The rural urban fringe in north America: Brookfield, VT, Ashgate Press., p. 7-32.

Baldassare, M., 1989, Citizen support for regional government in the new suburbia: Urban Affairs Quarterly, v. 24, p. 460469.

Baldassare, M., 1992, Suburban communities: Annual Review of Sociology, v. 18, p. 475-494.

Bate, W.J., 1961, From classic to romantic_-Premises of taste in eighteenth-century england: New York, NY, Harper.

Beecher, C.E., 1841, 1977, A treatise on domestic economy: New York, NY, Schocken Books, Inc., Reprint, ed.

Beecher, C.E. and Stowe, H.B., 1869, 1975, The American woman's home or principles of domestic science: Hartford, CT, Stowe-Day Foundation.

Binford, H., 1985, The first suburbs: Chicago, IL, University of Chicago Press.

Black, D. and Henderson, V. 1999, A theory of urban growth: Journal of Political Economy, v. 107, n. 2, p. 252-284.

Blackmar, E., 1989, Manhattan for rent: Ithaca, NY, Cornell University Press.

Bollens, S.A., 1988, Municipal decline and inequality in American suburban rings, 1960-1980: Regional Studies, v.
22, n. 4, p. 277-285.

Braden, D.R., 1988, Leisure and entertainment in America: Dearborn, MI, Henry Ford Museum and Greenfield Village.

Buder, S., 1990, Visionaries and planners - The garden city movement and the modern community: New York, NY, Oxford Univ. Press.

Burchell, R.W., 1998, Cost of sprawl-revisited: Washington, D.C., National Academy Press.

Burchell, R.W., and Listokin, D., 1995, Land, infrastructure, housing costs and fiscal impacts associated with growthThe literature on the impacts of sprawl versus managed growth: Cambridge, MA, The Lincoln Institute, Working Paper Lincoln Institute Product Code, WP95RB1.

Calthorpe, P., 2000a, New urbanism and the apologists for sprawl: Places-a Forum of Environmental Design, v. 13, n. 2, p. 67-69.

Calthorpe, P., 2000b, The Regional City-planning for the end of sprawl: Washington, D.C., Island Press.

Calthorpe, P., 1993, The Next American metropolis-Ecology, community, and the American dream: Princeton, NJ, Princeton Architectural Press.

Campbell, A., and Dollenmeyer, J., 1975, Governance in a metropolitan society, in A. Hawley and Rock, V., eds., Metropolitan American in contemporary society: New York, NY, John Wiley, p. 355-396.

Cawelti. J., 1984, The six-gun mystique: Bowling Green, OH, Bowling Green State University Popular Press.

Cervero, R., 1991, Land use and travel at suburban activity centers: Transportation Quarterly, v. 45, n. 4, p. 479-491.

Chen, D.D.T., 2000, The science of smart growth: Scientific American, v. 12, p. 84-91.

Chudacoff, H.P., 1975, The evolution of American urban society: Englewood Cliffs, NJ, Prentice-Hall, Inc.

Clark, C.E., 1986, The American family home-1800 -1960: Chapel Hill, NC, The University of North Carolina Press.

Cohen, L., 1996, From town center to shopping center-The reconfiguration of community marketplaces in postwar America: American Historical Review, v. 101, n. 4, p. 10501081 .

Cott, N.F., 1977, The bonds of womanhood-Woman's sphere in New England-1780 -1835: New Haven, CT, Yale University Press.

Crandell, G., 1993, Nature pictorialized-The View in landscape history: Baltimore, MD, Johns Hopkins University Press.

Crawford, M., 1995, Building the workingman's paradiseThe design of American company towns: New York, NY, Verso.

Cullingworth, J.B., 1993, The political culture of planningAmerican land use planning in comparative perspective: New York, NY, Routledge.

DeGrove, J.M., and Miness, D.A., eds., 1992, The new frontier for land policy_planning and growth management in the States: Cambridge, MA, Lincoln Land Institute.

Douglass, H.P., 1925, The suburban trend: New York, NY, The Century Co. 
Downs, A., 1999, Some realities about sprawl and urban decline: Housing Policy Debate, v. 10, n. 4, p. 955-974.

Downs, A., Linneman, P., and Richmond, H.R., 1995, Alternatives to sprawl: Paper presented at the Alternatives to Sprawl conference, Washington, D.C. March 22, 1995.

Doyle, R., 2001, Sprawling into the third millenium: Scientific American, March.

Dunphy, R.T., 1997, Moving beyond gridlock-Traffic and development: Washington, D.C., The Urban Land Institute.

Easterlin, R.A., 1980, Economic and social characteristics of the immigrants - Harvard Encyclopedia of American Ethnic Groups: Cambridge, MA, Harvard University Press.

Ebner, M., 1988, Creating Chicago's north shore: Chicago, IL, University of Chicago Press.

Fischer, C.S., 1984, The urban experience: New York, NY, Harcourt, Brace, Jovanovich.

Fishman, R., 1987, Bourgeois utopias: the rise and fall of suburbia: New York, NY, Basic Books.

Flink, J.J., 1988, The automobile age: Cambridge, MA, MIT Press.

Fong, T., 1995, The first suburban Chinatown-The remaking of Monterey Park, California: Philadelphia, PA, Temple University Press.

Frey, W.H., 2003, Melting pot suburbs-A study of suburban diversity, in Katz, B. and Lang, R.E., eds., Redefining urban and suburban America: Washington, D.C., The Brookings Institution.

Frey, W.H., 2001, The Census 2000 Series-A new look at a changing urban America: Washington, D.C., The Brookings Institution.

Frey, W.H., 2000, The new urban demographics: The Brookings Review, v. 18, n. 3, p. 20-23.

Frey, W.H., 1995, Immigration and internal migration 'flight' from U.S. metropolitan areas-Toward a new demographic Balkanisation: Urban Studies, v. 32, n. 4/5.

Frey, W.H., and Alden Speare, J., 1988, Regional and metropolitan growth and decline in the United States: New York, NY, Russell Sage Foundation.

Frey, W.H., and Alden Speare, J., 1992, The revival of metropolitan population growth in the United States-An assessment of findings from the 1990 Census: Population and Development Review, v. 18, n. 1, p. 129-146.

Galster, G., Hanson, R., Ratcliffe, M.R., Wolman, H., Coleman, S., and Freihage, J., 2001, Wrestling sprawl to the ground-Defining and measuring an elusive concept: Housing Policy Debate, v. 12, n. 4.

Gibson, C.J., 1998, Population of the 100 largest cities and other urban places in the United States-1790 to 1990: Washington, D.C., U.S. Bureau of the Census, Population Division Working Paper 27.

Gibson, C.J. and Lennon., E., 1999, Historical census statistics on the foreign-born population of the United States-18501990: Washington, D.C., U.S. Bureau of the Census, Population Division Working Paper 29.

Goldfield, D.R., 1989, Cotton fields and skyscrapersSouthern city and region: Baltimore, MD, Johns Hopkins
University Press.

Harris, R., 1996, Unplanned suburbs-Toronto's American tragedy, 1901-1951: Baltimore, MD, Johns Hopkins University Press.

Harris, R. and Lewis, R., 2001, The geography of North American cities and suburbs, 1900-1950: Journal of Urban History, v. 27, n. 3, p. 262-292.

Hart, J.F., 1995, "Rural" and "farm" no longer mean the same, in Castle, E.N., ed., The changing American countrysiderural people and places: Lawrence, KS, University Press of Kansas.

Hayden, D., 2000, Model Houses for the Millions: The Making of the American Suburban Landscape, 1820-2000, Working Paper Lincoln Institute Product Code: WP00DH2, Boston, MA, The Lincoln Institute.

Higham, J., 1984, Send These To Me-immigrants in Urban America: Baltimore, MD, Johns Hopkins University Press.

Hise, G., 1997, Magnetic Los Angeles: Planning the twentiethcentury metropolis: Baltimore, MD, Johns Hopkins University Press.

Hobbs, F. and Stoops, N., 2002, Demographic trends in the 20th century: U.S. Census Bureau, Washington, D.C., U.S. Government Printing Office, Census 2000 Special Reports, Series CENSR-4.

Huth, H., 1957, Nature and the American-Three centuries of changing attitude: Berkeley, CA, University of California Press.

Jackson, K., 1987, Crabgrass frontier: New York, NY, Oxford University Press.

Jakle, J. A., 1985, The Tourist-Travel in twentieth-century North America: Lincoln, NE, University of Nebraska Press.

Johnson, K.M., 2002, The rural rebound of the 1990s and beyond, in Levitt, J.N., ed., Conservation in the internet age: Washington, D.C., Island Press.

Kasarda, J.D., 1980, The implications of contemporary redistribution trends for national urban policy: Social Science Quarterly, v. 61, n. 3/4, p. 373-400.

Kelly, B.M., 1993, Expanding the American dream-Building and rebuilding Levittown: New York, NY, State University of New York.

Lessard, S., 2001, A different kind of urb: The New York Times Book Review, February 18, 2001.

Lewis, P.G., 1996, Shaping Suburbia-How political institutions organize urban development: Pittsburgh, PA, University of Pittsburgh Press.

Lewis, S., 1922, Babbitt: New York, NY, Harcourt, Brace and Co.

Lucy, W.H. and Phillips, D.L., 2000, Confronting suburban decline-Strategic planning for metropolitan renewal: Washington, D.C., Island Press.

Magoc, C.J., 1999, Yellowstone-The creation and selling of an American landscape, 1870-1903: Albuquerque, NM, U. of New Mexico Press and Helena, MT, Montana Historical Society Press.

Massey, D.S. and Denton, N.A., 1993, American apartheidSegregation and the making of the underclass: Cambridge, 
MA, Harvard University Press.

May, S.J., 1997, Zane Grey-Romancing the West: Athens, $\mathrm{OH}$, Ohio University Press.

Mieszkowski, P. and Mills, E.S., 1993, The causes of metropolitan suburbanization: The Journal of Economic Perspectives, v. 7, n. 3, p. 135-147.

Moe, R., 1995, Growing wiser, finding alternatives to sprawl: Design Quarterly v. 164, p. 4-5.

Monk, S.H., 1960, The Sublime-A study of critical theories in XVIII-century England: Ann Arbor, MI, University of Michigan Press.

Moskowitz, H.S. and Lindbloom, C.G., 1993, The new illustrated book of development definitions: New Brunswick, NJ, Rutgers University Center for Urban Policy Research.

Mulder, T.; Hollmann, F.; Lollock, L.; Cassidy, R.; Costanzo, J.; and Baker, J., 2002, Measurement of net international migration to the United States-1990 to 2000: Washington, D.C., U.S. Bureau of the Census, Population Division Working Paper 51.

Muller, P.O., 1981, Contemporary suburban America: Englewood Cliffs, N.J., Prentice-Hall.

Nash, G.B., 1988, The social evolution of preindustrial American cities, 1700-1820, in. Mohl, R.A, ed., The making of urban America: Wilmington, DE, Scholarly Resources Inc.

Nelli, H.S., 1970, Italians in Chicago, 1880-1930: New York, NY, Oxford University Press.

Nicolaides, B.M., 2002, My blue heaven - Life and politics in the working-class suburbs of Los Angeles, 1920-1965: Chicago, IL, University of Chicago Press.

Novak, B., 1995, Nature and culture-American landscape and painting, 1825-1875: New York, NY, Oxford University Press.

Orfield, M., 1997, Metropolitics-A regional agenda for community and stability: Cambridge, MA, Lincoln Institute of Land Policy.

Palm, R., 1981, The geography of American cities: New York, NY, Oxford University Press.

Pendleton, W.H., 1973, Blacks in suburbs, in Masotti, L.H. and Hadden, J.K. eds., The urbanization of the suburbs: Urban Affairs Annual Reviews 7, Beverly Hills, CA, Sage Publications.

Popenoe, D., 1985, Private pleasure, public plight-American metropolitan community life: New Brunswick, NY, Transaction Press.

Riis, J.A., 1890, reprint ed. 1971, How the other half lives: New York, NY, Johnson Reprint Corporation.

Rowe, P.G., 1991, Making a middle landscape: Cambridge, MA, MIT Press.

Runte, A., 1997, National parks-The American experience: Lincoln, NE, University of Nebraska Press.

Rusk, D., 1995, Cities without suburbs: Washington, D.C., Woodrow Wilson Center Press.

Ryan, M.P., 1981, Cradle of the middle class-The family in Oneida County, New York, NY, 1790-1865: Cambridge,
MA, Cambridge University Press.

Sanchez, L., 2000, Keeping the individual in sight-The Federal role in supporting historic communities, in Rowe, P. ed., Sprawl-Beyond the rhetoric: Cambridge, MA, McGraw-Hill Construction Information Group.

Schaffer, D., 1982, Garden cities for America-The Radburn experience: Philadelphia, PA, Temple University Press.

Schmidley, A.D., 2001, Profile of the foreign-born population in the United States-2000,: Washington, D.C., U.S. Census Bureau, Current population report Series P23206.

Schneider, M., 1980, Resource reallocation, population movement and the fiscal condition of metropolitan communities: Social Science Quarterly.

Schneider, M. and Logan, J.R., 1981, Fiscal implications of class segregation-Inequalities in the distribution of public goods and services in suburban municipalities: Urban Affairs Quarterly v. 17, p. 23-36.

Schuyler, D., 1996, Apostle of taste-Andrew Jackson Downing, 1815-1852: Baltimore, MD, Johns Hopkins University Press.

Schuyler, D., 1986, The new urban landscape--The redefinition of city form in nineteenth-century America: Baltimore, MD, Johns Hopkins University Press.

Sears, J.F., 1998, Sacred places-American tourist attractions in the nineteenth-century: Amherst, MA, University of Massachusetts Press.

Sierra Club, 1999, What is sprawl?: [www.sierraclub.org/ sprawl/report98/what.html].

Sies, M.C., 2001, North American suburbs, 1880-1950: Journal of Urban History, v. 27, n. 3, p. 314-346.

Smith, H.N., 1978, Virgin land-The American west as symbol and myth: Cambridge, MA, Harvard University Press.

Soanes, Catherine, ed., 2001, Oxford dictionary of current English (3rd ed.): Oxford University Press, USA.

Spann, E.K., 1996, Designing modern America-The Regional Planning Association of America and its members: Columbus, IL, Ohio State U. Press.

Spectorsky, A.C., 1955, The exurbanites: Philadelphia, PA, Lippincott.

Sternglass, J., 2001, First resorts-Pursuing pleasure at Saratoga Springs, Newport, and Coney Island: Baltimore, MD, Johns Hopkins University Press.

Teaford, J., 1986, The twentieth-century American city: Baltimore, MD, The Johns Hopkins University Press.

Thernstrom, S., and Thernstrom, A., 1999, America in black and white-One Nation indivisible: New York, NY, Simon and Schuster.

Turner, F.W., 1985, Rediscovering America—John Muir in his time and ours: New York, NY, Viking, 1985.

U.S. Bureau of the Census, 1975, Historical statistics of the United States - Colonial times to 1970: Washington, D.C., Series C-89-119.

U.S. Government Accounting Office, 1999, Community development-Extent of Federal influence on "urban 
sprawl" is unclear: [http://www.gao.gov/archive/1999/ rc99087.pdf].

von Hoffman, A., 1988, 'Of greater lasting consequence,' Frederick Law Olmsted and the fate of Franklin Park, Boston: Journal of the Society of Architectural Historians, v. 47, n. 4, p. 339-350.

von Hoffman, A., 1994, Local attachments, The making of an American urban neighborhood, 1850 to 1920: Baltimore, MD, The Johns Hopkins University Press.

von Hoffman, A., 1996, Weaving the urban fabric-Nineteenthcentury patterns of residential real estate development in outer Boston: Journal of Urban History, v. 22, n. 2, p. 191230.

von Hoffman, A., and Harrigan, L., 2002, Forty years of fighting sprawl-Montgomery County, Maryland, and growth control planning in the metropolitan region of Washington, D.C.:, Boston, MA, Joint Center for Housing Studies, Harvard University, Working Paper Series, W02-6.
Warner, S.B., Jr., 1972, The urban wilderness, A history of the American city: New York, NY, Harper and Row.

Ward, D., 1971, Cities and immigrants - A geography of change in nineteenth-century America: New York, NY, Oxford University Press.

Weise, A., 1992, Places of our own-Suburban black towns before 1960: Journal of Urban History, v. 19, p. 30-54.

Wilson, W.J., 1987, The truly disadvantaged, the inner city, the underclass, and public policy: Chicago, IL, U. of Chicago Press.

Wunsch, J.L., 1995, The surburban cliché: Journal of Social History, v. 28, n. 3, p. 643.

Zukin, S., 1991, The hollow center-U.S. cities in the global era, in Wolfe, A., ed., America at century's end: Berkeley, CA, University of California Press.

Zunz, O., 1982, The changing face of inequality-Urbanization, industrial development, and immigrants in Detroit, 18801920: Chicago, IL, University of Chicago Press. 


\title{
Demographic Drivers of Lakeshore Urbanization in the Ozarks
}

\author{
By Sonya M. Glavac ${ }^{1}$
}

\section{Introduction}

The rapid expansion of recreation and retirement at the many manmade lakes in the Ozarks has created many large and small communities along the shorelines of these lakes. In many cases these are equivalent to small towns and in some cases, such as the Lake of the Ozarks, the lakeshore communities are equivalent to medium sized cities, at least in the summertime with 300,000 persons on or near the lake. The transient nature of the "dwellers" of these communities, which vary by seasons, days of the week and even time of the day change the nature of the urbanization process. The problems of these communities may be classified as social, economic or environmental, but in fact all are intricately related. Most of these communities are consumption rather than production based economies and thus their existence and futures are closely tied to maintenance of those environmental qualities that enticed people there in the first place.

In this paper the urbanization around the lakeshores in the Ozarks is examined. More specifically the paper explores how urbanization has evolved around the lakes and examines what is causing this rapid growth in urban land uses around these once small rural communities. These urban communities are quite distinguishable from other urban forms due to their demographic compositions and their temporal occupancy. Between 10 and 85 percent of the homes in these communities are seasonal holiday homes, often only occupied for a few months of the year. Therefore the physical structure of these urban areas is very different as a result of the temporary nature of these populations. The seasonal nature of the population also makes traditional measures of urbanization, such as population density, inappropriate because they are based on census data that is only collected at one point each decade and does not represent the changing seasonal nature of these populations. In this paper the change in the extent of urbanization is calculated through the use of remote sensing. This data is then used in a regression model along with 2000 and 1990 census data to test what is driving urbanization around the shores of Ozark lakes.

'NRC Post Doctoral Associate, United States Geological Survey, 1400 Independence Road, MS 706, Rolla, MO 65401-2602.

\section{Missouri Lakeshore Communities}

Throughout mid-America there are numerous large lakes that have been created by dams constructed by the U.S. Army Corps of Engineers (USACE) and other governmental and private organizations. The primary purposes for the construction of these dams have been flood control, power generation and navigation. However, many of the lakes have become major recreation areas for nearby populations and in some cases the lakes draw visitors and potential residents from great distances. The summer vacation homes on the lakes of southern Missouri are an immediately recognizable element of the rural-recreational landscape. Vacation homes have become the dominant land use along the lakes and waterways. Intensification of lakefront development can be seen across the region, but is mostly clustered adjacent to the lakes. Accessibility to the water is the key attractive feature of these properties. Another important feature of the urban patterns around the lakes is the roadway structure, which now provides year-round access, whereas along more rural roads access during winter is more limited. Many of the townships surrounding the lakes are a result of residential-development spillover. The growth pressure has resulted in cottages turning into year-round homes.

This paper will concentrate on two reservoirs in the Ozark mountain region-Table Rock Lake and Pomme de Terre Lake. These two lakes were chosen because both are USACE lakes and therefore must abide by similar controls, but also because these two lakes are very different in their location, their size, the populations they attract, and the form of urbanization developing around the lakes.

Table Rock Lake is located on the main stem of the White River at river mile 528.8 adjacent to the city limits of Branson, Missouri. However, Branson is located on Lake Taneycomo and therefore is not included in this study. Construction of Table Rock was completed in 1958 and is one of the largest lakes in Missouri with a surface area of 52,300 acres. Although the lake was originally designed for flood control and hydroelectric power generation, over the years the lake has been used as much for recreation as for its original purposes. This initially led to small resorts and second home communities being built around the lake that have more recently turned into a combination of permanent retirement communities and resort communities.

The second study area is Pomme de Terre Lake, which is located in the Missouri River Basin on the Pomme de Terre River. Pomme de Terre Lake was completed in 1961 and 
covers 7,820 acres and can expand to as much as 16,100 acres during periods of heavy rain as excess runoff is impounded to prevent downstream flooding. Many recreational and retirement communities now reside adjacent to this lake. The Pomme de Terre area gives residents a sense of "sought isolation"- the isolation of the lake itself, as well as how the individual properties have developed around the lake. The area is low density and rural residential, unlike the development around Table Rock Lake. The physical form of the urban property is also very different in the two study areas. Along Pomme de Terre Lake are all single row cottage properties along the margins of the USACE lake, giving the area a more rural atmosphere. This is unlike the properties around Table Rock Lake, where there is primarily medium-density developments or clusters. These areas are also somewhat unique in that there is no planning in the rural counties of Missouri; building permits are not even required. This results in unregulated development around Pomme de Terre Lake and limited zoning around Table Rock Lake.

\section{A Conceptual Model of Urbanization of Lakeshore Communities}

Urban theories and models examining urbanization abound, but most are not valid in the study of lakeshore communities in their current state as these theories typically model metropolitan areas and only address a rather narrow spectrum of issues. The particular problems of modeling lakeshore recreation-retirement communities are exacerbated by the extreme "seasonality" of the populations of these areas. This study emerges from the fundamental contention that the dynamics of population change over time are intimately linked to changing urban structure of lakeshore communities. That is, a changing urban structure is reflected by the characteristics of the population that evolves as the population changes over time. In general, the importance of the lake within tourist areas has been responsible for a common pattern of linear development along the lake frontage itself, with pronounced gradients of decline in land values and associated changes in land uses with increasing distance from the lake.

The migration literature often alludes to tourism leading to permanent migration and urban change. However, there is some contradiction in the findings. For example, Stallman and Espinoza (1996) found that tourism in earlier life is not a sufficient causal factor for migration. This is similar to the findings of the earlier study by Wiseman and Rosemont (1979) who found that although some retirees considered vacation areas as potential retirement destinations the majority did not. Martine and others (1987) found that of the seasonal residents they interviewed only 23 percent were considering moving to their vacation home. Contradicting these findings are the studies by Halseth (1998), who found that there is strong link between owning a vacation home and permanent migration and Marcooiler and others (1996), who found that tourism led to buying second homes and later seasonal residence after retirement.

In addition, there are many other factors that influence the act of migration and in the development of an urban community. Tourism can act as a pull factor by providing information about the existence of amenities elsewhere, as well as providing social networks. Many persons considering retirement consider only those locations where they have vacationed for many years and to which they have developed strong attachments (Wiseman and Roseman, 1979). Other factors quoted in the literature (Wiseman and Roseman, 1979) that influence destination choices include amenities, ecological conditions, warmer climates, similar cultures, health care, scenic importance, recreational opportunities, low cost of living, and modest tax rates. More specifically, features that attract retirees to communities include business/employment opportunities, mild climates, low cost of living, being close to family, being close to friends, low cost of housing, adult educational opportunities, low medical costs, retirement communities, recreational opportunities, and modest tax rates.

The role of the second home development often associated with early stages of resort or tourism development is common in the lake districts in middle America. These second homes often attract retired migrants who reside there during the summer months only. These people adopt different uses of the landscape and require somewhat different amenities than the community as a whole, thereby having a different impact on the urban morphology and how it changes over time.

In figure 1 the process of lakeshore development is summarized. The rural residential countryside surrounding the lakes in Missouri is a geographically and socially divided landscape. The conversion of vacation homes from seasonal to year-round homes is a dynamic responsible for new in-migration. Initially these Missouri lakeshore communities had limited tourist and recreational activities, along the lakeshores themselves and the rivers. There were resort hotels that also catered for the more elite who could afford the time and expense of hunting and fishing in these newly accessible areas. Increased accessibility over time through better quality road networks has opened up these areas to a much wider public.

The original population was drawn to the lakes for their natural and recreational amenities. Visitors were more likely to be from local urban regions within driving distance. Over time these visitors purchased second homes around the lake. Due to the lack of development land was inexpensive and there was little or no planning regulations (which is still the case in most rural areas today). This led to low-density development with little infrastructure and limited commercial and industrial activities. As time progresses the age of the second homeowners has increased. Many of the second homeowners retire to these areas, converting their vacation homes into permanent homes. This resulted in the need for more government and community infrastructure, such as all season roads, hospitals, restaurants and shops. This additional infrastructure combined with the natural amenities of the lakes attracted a new popu- 
lation to the lakes. As the population grew so did the cost of housing as well as the socioeconomic status of the community, leading to a segmented population and distinct urban structure around the lake.

Three population types can be found to live in these communities - original inhabitants, converters (people who turn their vacation home into a permanent residence), and migrants (people who move to the area without previously owning a home there). When comparing original inhabitants, seasonal inhabitants, and permanent migrants Halseth (1998) found that 54 percent of converters had at least a university education and 55 percent of original inhabitants had at least a high school education, as compared to 73 percent of seasonal migrants having at least a university education.

The costs of purchase, mortgage, insurance, maintenance, travel to and from the home, and property taxes situate vacation home ownership within a particular economic framework, making ownership selective. This causes separation in geographic and social space of the original permanent residents of the small towns and rural countryside and the vacation homeowners. The costs of owning cottage property may not only act to limit access to ownership but may also work to generate a significant push factor behind the conversion of cottages into year-round or retirement homes.
Around the lakes of southern Missouri three types of communities can be seen:

(1) Small communities located at principal crossroads or historic transshipment areas.

(2) Individual residences dispersed along the local road networks. Some farms and rural residences associated with local employment, local retirees, and more recently exurban hobby farmers.

(3) Settlements along vacation home areas. These areas contain seasonal homes, permanent residences, and recreational and commercial businesses, which form a distinctive linear pattern along the margins of the lakes and waterways. There is also an element of dispersion as the pattern is broken due to roads and other natural features. The most heavily used area is the area directly on or around the lake in what is labeled the consumer consumption district core and periphery areas in figure 1 . The core and periphery is not unlike the core and periphery in traditional central business districts, with the primary difference being that nothing is being produced, but rather it is the area itself that is being consumed or used as a recreational district. Development closest to the lake consists of resorts and high-density housing due to the high cost of land. As value decreased with distance from the lake so does housing density.

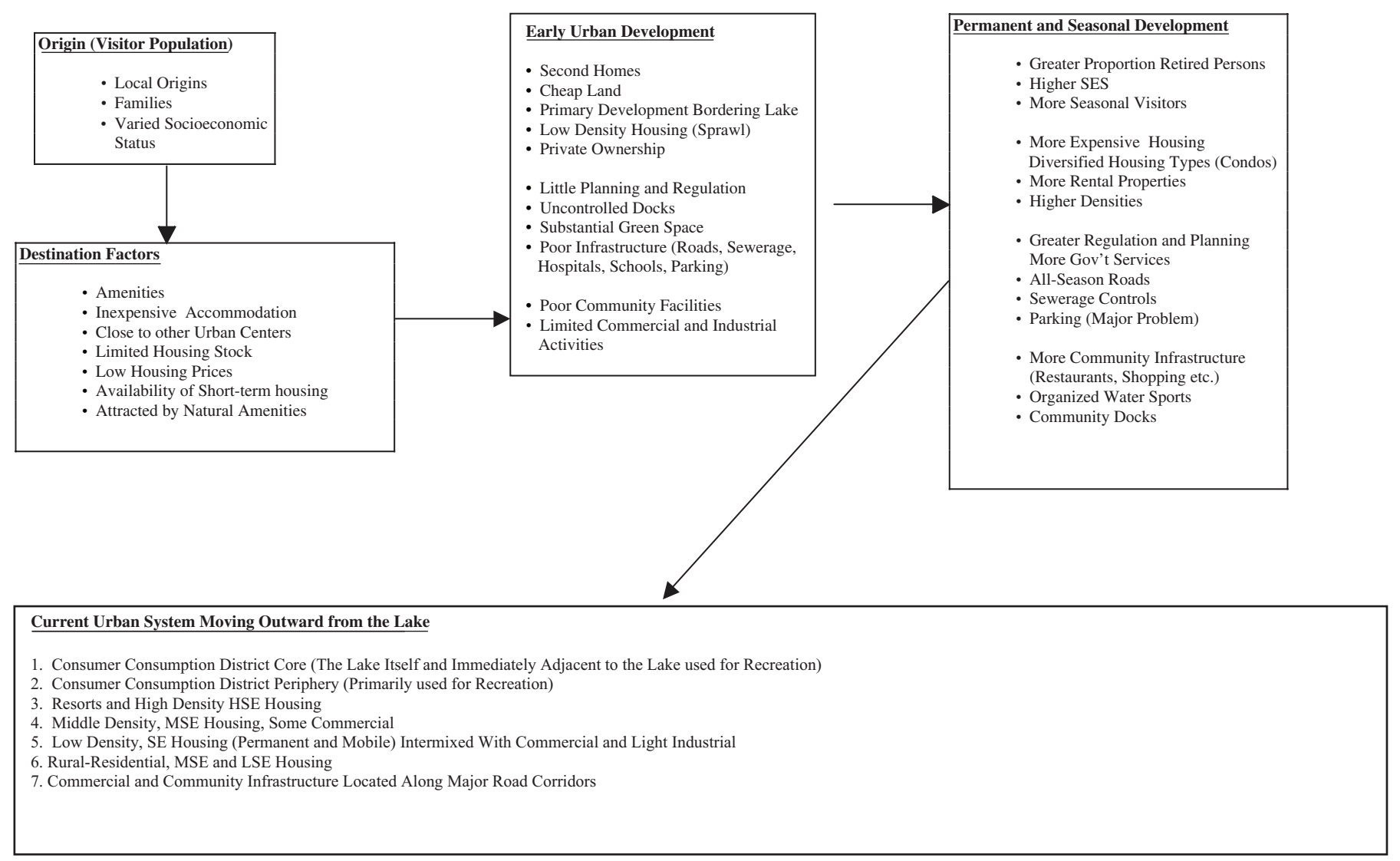

Figure 1. Conceptual model of lakeshore urbanization. SES, socioeconomic status; SE, socioeconomic; HSE, high socioeconomic; MSE, middle socioeconomic; LSE, low socioeconomic. 


\section{Realization of the Conceptual Model}

In the sections that follow the model developed in figure 1 will be tested through the use of remote sensing to uncover land-use change and by a linear regression model for each lake. The first stage of the analysis involved uncovering land-use change from 1990 to 2000. Using population densities and similar measures to uncover urban change is not appropriate when examining seasonal communities as the population from the summer season to other seasons varies dramatically. Typically census data is used. As the census is typically taken in April each ten years, it does not give an appropriate picture of the true urban extent. To calculate the urban change around the lakes Landsat Thematic Mapper (TM) imagery was used. Four Landsat TM winter scenes (from Path 25, Row 34, and Path 25, Row 35) for the years 1990 and 2000 were used (see figs. 2 through 5). Imagery from 1990 was used as the reference year as census data was also available for that year. Although higher-density urban areas were readily identifiable, low density housing outside the towns located in agricultural landscapes were problematic due to the large amounts of tree cover. There are limitations when examining small communities due to the large amount of vegetation cover, thereby limiting the amount of detail that is available from Landsat data. Aerial photography, such as digital orthoquads (DOQs) and other aerial photography were used to test the accuracy of the classification. Ground truthing for the 2000 image was also performed to verify that the images were correctly classified. The red in figures 2 through 5 show urban areas. As can be seen on the images of both lakes, there has been a tremendous amount of urban growth over the past decade. Image differencing in ARCView was then performed to identify the change from nonurban pixels to urban pixels. Census block boundaries were then applied to the 30 -meter by 30-meter pixels.

Remotely sensed data can only provide information on changes in the physical environment, rather than the dynamics behind the urban growth. Data on the dynamics of urban change came from Census data. It should be noted that there are also problems with using census data as it does not include data on the human occupancy but collects information on permanent residence only and at only one point in time. As much of the population in this region is likely to be seasonal, either retirees or persons using the area for recreational purposes,

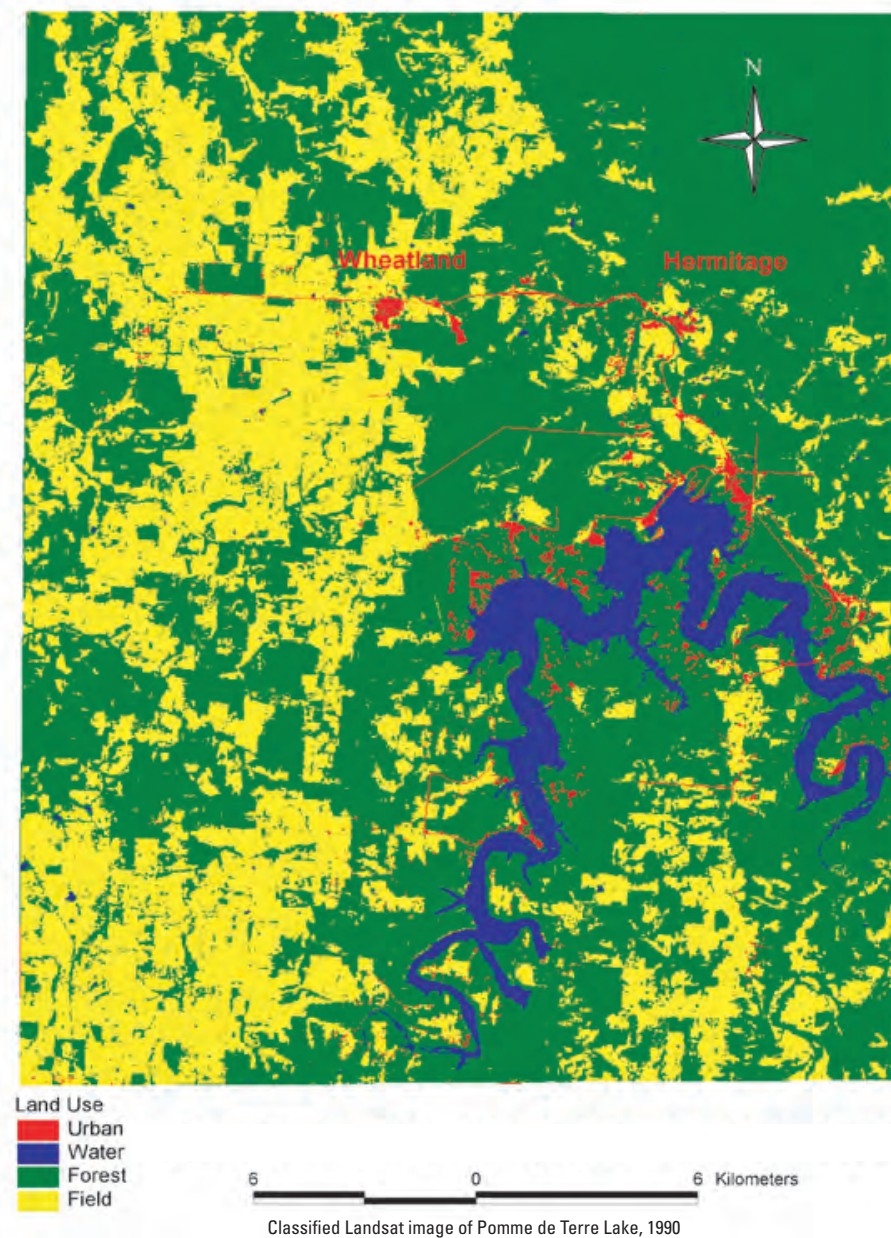

Figure 2. Classified Landsat image of Pomme de Terre Lake, 1990.

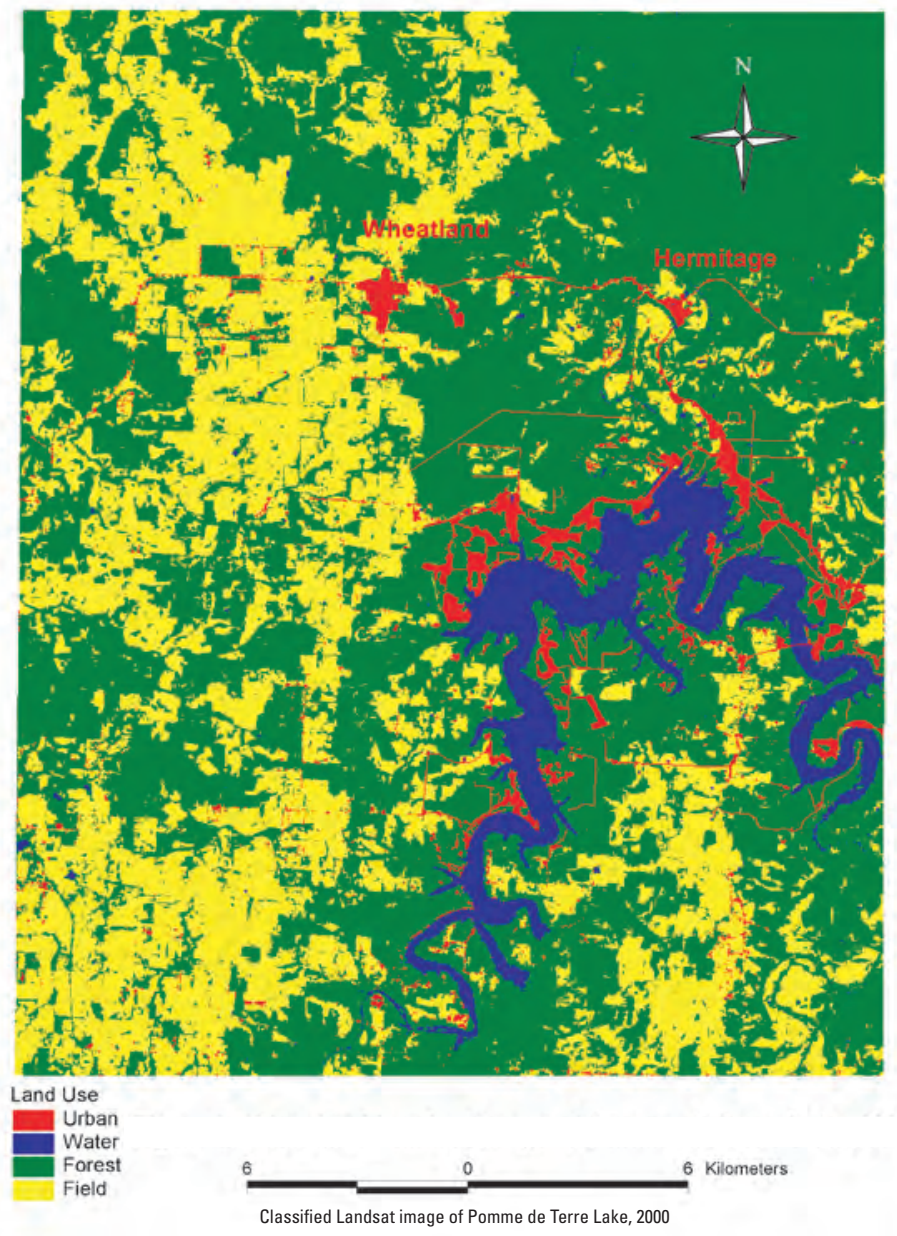

Figure 3. Classified Landsat image of Pomme de Terre Lake, 2000. 
Table 1. Descriptive statistics for Pomme de Terre Lake.

\begin{tabular}{|l|l|l|}
\hline Variable & Mean & $\begin{array}{l}\text { Std. } \\
\text { Deviation }\end{array}$ \\
\hline NEW URBAN (acres) & 5.191 & 4.046 \\
\hline ORIG URBAN (acres) & 2.2456 & 7.3494 \\
\hline DISTANCE (km) & 4.00 & 3.94 \\
\hline POPULATION 1990 & 13.14 & 177.20 \\
\hline POPULATION CHANGE & 2.33 & 20.42 \\
\hline AGE<18 YEARS & 1.59 & 3.16 \\
\hline RETIRED & 2.36 & 5.09 \\
\hline HOUSEHOLDS & 3.81 & 5.98 \\
\hline HOUSING UNITS & 6.33 & 9.93 \\
\hline MEDIAN NO. ROOMS & 4.98 & .16 \\
\hline MEDIAN YEAR MOVED & 1993 & .60 \\
\hline MEDIAN VALUE (\$) & 64,827 & 83,770 \\
\hline RENTER OCCUPIED & .53 & 1.70 \\
\hline SEASONAL HOUSING 90 & 69.10 & 34.61 \\
\hline $\begin{array}{l}\text { CHANGE IN SEASONAL } \\
\text { PROPORTION/ TOTAL } \\
\text { HOUSING }\end{array}$ & .13 & .29 \\
\hline N & & \\
\hline
\end{tabular}

they are missed in the census taken in April every ten years. However, to gather that information purpose-built surveys must be undertaken, which is cost prohibitive. However, as the aim of this paper is to examine urban change and not permanent migration the use of census data is appropriate.

The drivers of urban change are calculated through the use of a linear regression model where the dependent variable is the number of acres in a block that were urban in 2000 that were not urban in 1990. The conversion from nonurban to urban is seen as a function of several factors identified in figure 1, including the amount of block that is already urban, distance from the lake and demographic and socioeconomic variables such population in earlier period (1990), popula-

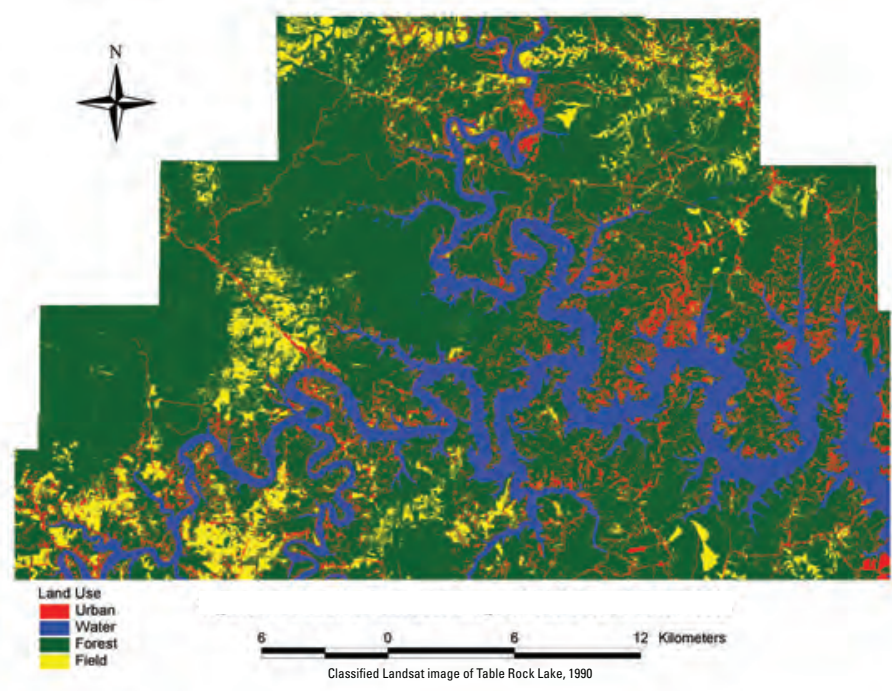

Figure 4. Classified Landsat image of Table Rock Lake, 1990.
Table 2. Descriptive statistics for Table Rock Lake.

\begin{tabular}{|l|l|l|}
\hline Variable & Mean & $\begin{array}{l}\text { Std. } \\
\text { Deviation }\end{array}$ \\
\hline NEW URBAN (acres) & 5.810 & 16.813 \\
\hline ORIG URBAN (acres) & 9.600 & 22.012 \\
\hline DISTANCE (km) & 1.98 & 1.83 \\
\hline POPULATION 1990 & 8.06 & 23.40 \\
\hline POPULATION CHANGE & 4.37 & 21.97 \\
\hline AGE<18 YEARS & 2.35 & 6.80 \\
\hline RETIRED & 2.54 & 7.18 \\
\hline HOUSEHOLDS & 5.29 & 13.24 \\
\hline HOUSING UNITS & 7.64 & 19.62 \\
\hline MEDIAN NO. ROOMS & 5.07 & .381 \\
\hline MEDIAN YEAR MOVED & 1995 & 1.62 \\
\hline MEDIAN VALUE (\$) & 95,475 & 22,684 \\
\hline RENTER OCCUPIED & 1.14 & 5.02 \\
\hline SEASONAL HOUSING 90 & 128.74 & 79.98 \\
\hline $\begin{array}{l}\text { CHANGE IN SEASONAL } \\
\text { PROPORTION/ TOTAL HOUSING }\end{array}$ & -.13 & .24 \\
\hline N & 2,806 & \\
\hline
\end{tabular}

tion change, age of the population, retired population, number of households, number of housing units, median number of rooms, median value of housing units, housing that is occupied by renters, and the amount of seasonal housing in 1990 and the change in the proportion of seasonal housing of all housing between 1990 and 2000. Although multicollinearity would be an expected problem between several of these variables, the correlations between them were not either very high or very low and therefore do not violate the assumptions of regression analysis. One reason for this is because the housing stock does not truly represent the population, as much of the

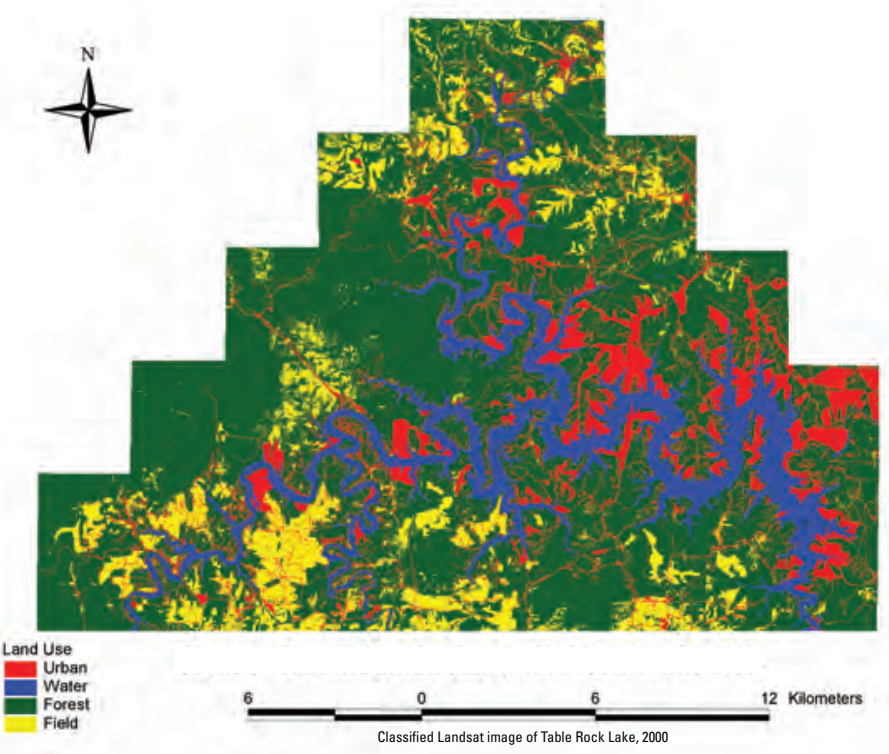

Figure 5. Classified Landsat image of Table Rock Lake, 2000. 
Table 3. Overview of lake statistics.

\begin{tabular}{|l|l|l|l|l|}
\hline & $\begin{array}{l}\text { Pomme de } \\
\text { Terre }\end{array}$ & & Table Rock & \\
\hline & $\mathbf{1 9 9 0}$ & $\mathbf{2 0 0 0}$ & $\mathbf{1 9 9 0}$ & $\mathbf{2 0 0 0}$ \\
\hline URBAN (Acres) & 2180 & 11139 & 26,938 & 43,247 \\
\hline$\%$ URBAN/TOTAL & $0.57 \%$ & $2.91 \%$ & $7.57 \%$ & $12.6 \%$ \\
\hline DISTANCE & & $4.00 \mathrm{~km}$ & & $1.83 \mathrm{~km}$ \\
\hline TOT POPULATION & 7,752 & 9,689 & 22,050 & 34,387 \\
\hline RETIRED & & 2,033 & & 7,121 \\
\hline$<18$ YEARS & & 1,366 & & 6,599 \\
\hline MOVED & & 1,993 & & 1,994 \\
\hline HOUSEHOLDS & & 4,232 & & 14,837 \\
\hline OCCUPIED RENTING & & 453 & & 3,186 \\
\hline HOUSING UNITS & & 5,454 & & 21,448 \\
\hline MEDIAN ROOMS & & 4.98 & & 5.07 \\
\hline MEDIAN VALUE & $\$ 31,543$ & $\$ 85,924$ & $\$ 50,538$ & $\$ 95,474$ \\
\hline SEASONAL VAC & & 1,768 & & 4,739 \\
\hline $\begin{array}{l}\text { PROPORTION } \\
\text { SEASONAL/TOTAL } \\
\text { UNITS }\end{array}$ & $39.51 \%$ & $32.42 \%$ & $12.17 \%$ & $22.10 \%$ \\
\hline
\end{tabular}

housing is for seasonal use only. The means and standard deviations for these variables can be seen in tables 1 and 2 below.

\section{Results}

The first aim of this study was in investigate the spatial patterns of urban development around Pomme de Terre Lake and Table Rock Lake. Figures 2 through 5 reveal that there are in fact three types of urban communities surrounding the lakes in Missouri. The first type includes those located at crossroads, such as in the case of Hermitage and Wheatland. The amount of land dedicated to urban purposes is expanding outward in these communities, along with some infill of land within the already urbanized areas. These communities continue to serve the communities located closer to the lakes, where there is still a lack of services, especially in the case of Pomme de Terre Lake.

It is also evident that people are continuing to locate along major local roads as well as along major transportation routes. However, the largest amount of change occurred within three kilometers from the shoreline of the lakes. Again, by examining figures 2 through 5 it can see that urbanization is not only moving outward from the lakes as people settle for properties without direct lake access but that there is a significant amount of redevelopment occurring around the lakes in addition to more infill, resulting in higher-density development, especially around Table Rock Lake. Overall the amount of land that has become urban in the Pomme de Terre area rose from 0.57 percent to 2.91 percent, which is not a huge increase in percentage terms but in total numbers increased by 8,959 acres, as seen in table 3 . This indicates that it is a case of urban sprawl rather than redevelopment or infill. Conversely, the amount of land classified as urban around Table Rock Lake grew by 16,309 acres, but this is much smaller as the amount of land that was already urban abound Table Rock Lake was much larger proportionally ( 7.57 percent to 12.6 percent).

The population at Pomme de Terre Lake grew by nearly 25 percent, compared to that of Table Rock Lake, which grew
Table 4. Regression results for Pomme de Terre Lake.

\begin{tabular}{|l|r|r|}
\hline Variable & Coefficient & \multicolumn{1}{l}{ Std. Error } \\
\hline Constant) & $2,126.860$ & $1,980.390$ \\
\hline ORIG URBAN & .353 & $.057 * * *$ \\
\hline DISTANCE & -.107 & .126 \\
\hline POP1990 & $-8.5 \mathrm{E}-04$ & .005 \\
\hline POP CHANGE & $1.8 \mathrm{E}-02$ & .046 \\
\hline RETIRED & -.219 & $.110^{* *}$ \\
\hline AGE<18 & -.750 & $.174 * * *$ \\
\hline HOUSEHOLDS & .384 & .246 \\
\hline HOUSING UNITS & .917 & $.119 * * *$ \\
\hline MEDIAN ROOMS & -6.029 & 3.951 \\
\hline MEDIAN YEAR MOVED & -1.052 & .988 \\
\hline MEDIAN VALUE & $3.473 \mathrm{E}-05$ & .000 \\
\hline RENTER OCC & -.919 & $.249 * * *$ \\
\hline SEASONAL HOUSING 90 & $-3.639 \mathrm{E}-02$ & $.015 * *$ \\
\hline CHANGE IN SEASONAL PROPORTION & -5.418 & $1.524 * * *$ \\
\hline Adjusted R & $.497 * * *$ & \\
\hline$* * *$ Significant .01; ** Significant .05; * Significant .1 & & \\
\hline
\end{tabular}

by nearly 60 percent. Pomme de Terre Lake has a higher proportion of retired migrants, and a smaller proportion of persons less than 18 years compared to Table Rock Lake. Table Rock Lake, on the other hand, is of higher socioeconomic status, as indicated by higher median housing prices and larger houses (median number of rooms). This is indicative of residents converting their vacation cottages into permanent residences. There are also differences between the two lakes in the change in the proportion of housing that is seasonally occupied of all housing. In the case of Table Rock Lake, the proportion of vacation/seasonal homes rose from only 12.17 percent to 22.10 percent of all housing over the ten-year period, whereas for Pomme de Terre there was a decline in the proportion of housing that is seasonally occupied.

To investigate the influence of these variables on urban development two multiple regressions $(\underline{r})$ were performed at the census-block level. Land cover change to urban was the dependent variable (number of acres that was not urban in 1990 but was 2000). The results of these regression models can be seen in tables 4 and 5. Although the adjusted $\mathrm{r}^{2}$ values are less than expected for both models, the models are of a reasonable fit and statistically significant, with an Adjusted $\mathrm{r}^{2}$ of 0.497 for Pomme de Terre Lake and 0.423 for Table Rock Lake. An examination of the blocks with large residuals did not reveal any obvious spatial pattern to the residuals.

Although there are some similarities between the variables that are significant in the two lake models there are also several differences. The variable that accounted for the most variation in both models is the amount of land that was already urban in 1990. The more urban a block was in 1990 the more likely there was additional urban development between 1990 and 2000.

The variables, Retired and Population under 18 Years, are both statistically significant and negative in both lake models. For the variable Retired, the coefficients are not of the expected sign $(+)$ as it was expected that the greater the number of retirees the greater the urban development. The variable of Number of Persons under 18 Years is also negative. This suggests that the increase in population and urban- 
Table 5. Regression results for Table Rock Lake.

\begin{tabular}{|l|r|r|}
\hline Variable & Coefficient & Std. Error \\
\hline (Constant) & $-1,373.418$ & $368.645^{* * *}$ \\
\hline ORIG URBAN & .338 & $.016^{* * *}$ \\
\hline DISTANCE & -.503 & $.154^{* * *}$ \\
\hline POP1990 & .410 & $.089^{* * *}$ \\
\hline POP CHANGE & .415 & .089 \\
\hline RETIRED & -.239 & $.086^{* * *}$ \\
\hline AGE<18 & -.575 & $.158^{* * *}$ \\
\hline HOUSEHOLDS & -.206 & .172 \\
\hline HOUSING UNITS & $2.605 \mathrm{E}-02$ & .051 \\
\hline MEDIAN ROOMS & 1.835 & $.770^{* *}$ \\
\hline MEDIAN YEAR MOVED & .682 & $.184^{* * *}$ \\
\hline MEDIAN VALUE & $5.658 \mathrm{E}-05$ & $.000^{* * *}$ \\
\hline RENTER OCC & -.426 & $.093^{* * *}$ \\
\hline SEASONAL HOUSING 90 & $-2.19 \mathrm{E}-02$ & $.005^{* * *}$ \\
\hline CHANGE IN SEASONAL PROPORTION & -.467 & 1.134 \\
\hline Adjusted R & $.423 * * *$ & \\
\hline$* * *$ Significant .01; ** Significant .05; * Significant .1 & & \\
\hline
\end{tabular}

ized land around the lakes is by persons of working age, most likely of preretirement age.

The Renter Occupier variable is also negative and statistically significant in both models, indicating that the growth in urban development is negatively related to an increase in rental properties, or in other words, the more rental occupiers the less likely there is to be urban growth.

The only other variable that is statistical significant in both models is the variable Seasonal Housing Units in 1990. In both models the coefficient is negative but very small. This is not surprising given the size of the unit of observation. For each additional seasonal housing unit in 1990 there is a decline in the number of acres of new urban land. This is the opposition of what was expected. What is also surprising is that the variable Change in the Proportion of Seasonal Housing Units to All Housing Units from 1990 to 2000 is not statistically significant in both models. This variable is only statistically significant in the Pomme de Terre model and of the expected sign (-). The decline in the proportion of seasonal housing between 1990 and 2000 led to an increase in the number of acres that is new urban. This would imply that a greater proportion of land is being occupied by permanent residents, rather than just for seasonal use, as suggested in figure 1.

Two variables that are not significant in either model are the Number of Households and Population Change. This is surprising as it was expected that an increase in permanent population would result in an increase in the number of acres that are urban. However, this could lead to the conclusion that urban growth is due to seasonal rather than permanent migration to the lakeshore.

The only other variable that is statistically significant in the Pomme de Terre model is the Number of Housing Units. This coefficient is of the expected sign (+). For each additional housing unit there is an additional 0.917 acres of urban land. This would indicate urban sprawl rather than infill or redevelopment.
There are several other variables that are statistically significant and of the correct sign for Table Rock Lake. These include Distance from the Lake, Median Number of Rooms, Median Value of the Housing Units and Median Year of Migration to the area. The coefficient of the variable Distance is negative, suggesting that urban expansion is occurring close to the lakeshore rather than in a pattern of sprawl away from the lake. This pattern can also be seen in figure 5 .

Also as expected, an increase in the Median Number of Rooms leads to an increase in the number of additional acres of urban land. The coefficient for Median Value of Housing Units is also positive - the higher the housing price the more land that has become urban. The results of these two variables indicate that there is an increase in socioeconomic status around Table Rock Lake, as indicated in figure 1.

The only other statistically significant variable is Year of Migration. As expect the later people moved to Table Rock Lake the greater the urban expansion.

\section{Conclusions}

The objectives of this paper were to first analyze recent patterns of urban expansion around the two lake areas of Missouri and second to explain what has been driving growth around the lakes over the past decade. The first objective was accomplished through the use of remotely sensed data. Urbanization around both Pomme de Terre Lake and Table Rock Lake has been extensive over the past decade. The most active urban growth areas are located on the northern sides of both lakes. The majority of the urban development is taking place adjacent to the lakes and along major arterial roads. However, in the case of Pomme de Terre Lake there is also a significant amount of urban sprawl.

Multiple regression models were then used to test how great an influence the factors identified in figure 1 had on urbanization around the two lakes. The overall model performances are adequate, but not as high as expected. The variables that have the greatest influence on the increase on Original Urban (the amount of urban land that was originally classified as being urban) are age structure of the population (it is not the retired population that is causing growth) and Seasonal Housing. For Pomme de Terre Lake the Number of Housing Units and the Change in the Proportion of Seasonal Housing Units to All Housing Units from 1990 to 2000 are also significant, indicating that owning a vacation home can lead to permanent migration to the amenity rich lakeshore communities. Socioeconomic variables in the Table Rock model also indicate that there is positive relationship with urban expansion.

There are a number of implications of the rapid urban growth around these communities, which is why it is important to understand how and why these lakeshore communities are growing. Population and urban growth can bring new jobs, economic prosperity, add new industries, improve regional infrastructure, enhance educational opportunities, and increase 
tax revenue in the form of sales tax, occupancy taxes, and property taxes. Services that would other wise not be possible in such small communities are becoming more common. Seasonal migrants, tourists and local residents, especially more recent ones expect a high quality of life that the natural amenities of these lakeshore communities can provide along with the benefits of larger urban areas. However, there are number negative impacts of this growth that should also be mentioned. These include the increase in solid-waste production, higher volumes of urban nonpoint runoff, loss of green space, decline in water quality, and traffic. There is also the problem of increased economic costs for local governments, such as providing all weather roads and hospitals. Whether or not growth of lakeshore communities is a good or a bad thing, depends upon one's viewpoint, but either way it warrants further investigation.

\section{References}

Beale, Calvin L, 1988, Americans heading for the cities, once again: Rural Development Perspectives, v. 4, no. 3, p. 2-6.

Espinoza, Maria C., and Stallmann, Judith I., 1996, Seasonal migration of retirees - a review of the literature: Department of Agricultural Economics, Texas A\&M University, College Station, Texas, Faculty Paper Series FP97-2.

Halseth, Greg, 1998, Cottage country in transition-A social geography of change and contention in the rural-recreation countryside: Montreal, Canada, McGill-Queens University Press, $304 \mathrm{p}$.

Marcouiller, David W., Green, Gary P., Deller, Steven C., Sumathi, N.R. and Erkkila, Daniel L., 1996, Recreational homes and regional development - a case study from the Upper Great Lakes States: University of Wisconsin Extension, Madison, WI.

Martin, Harry W., Hoope, Sue K., Larson, C. Lynn, and Leon, Robert L., 1987, Texas snowbirds - seasonal migration to the Rio Grande Valley: Research on Aging, v. 9, no. 1, p. 134-147.

McHugh, Kevin E., 1990, Seasonal migration as a substitute for, or precursor to, permanent migration: Research on Aging, v. 12, no. 2, p. 229- 245.

Stallman, Judith I., and Espinoza, Maria C., 1996, Tourism and retirement migration:

Department of Agricultural Economics, Texas A\&M University, College Station, Texas, Faculty Paper Series FP97-3.

Stallmann, Judith I., and Siegel, Paul, 1995, Attracting retirees as an economic development strategy-looking into the future: Economic Development Quarterly, v. 9, no. 4, p. 372-383.

Wiseman, Robert F., and Roseman, Curtis C., 1979, A typology of elderly migration based on the decision making process: Economic Geography, v. 55, no. 4. p. 324-337. 


\title{
Economic Aspects of Urban Decentralization in Historical Perspective
}

\author{
By Alexander von Hoffman ${ }^{1}$ and John Felkner ${ }^{1}$
}

\section{Introduction}

Economic forces have been crucial to the geographic expansion of metropolitan areas of American cities. The increasing production of goods and services across a metropolitan territory, the demand for labor at workplaces within the metropolitan area, and the creation of new land devoted to urban uses are among the many economic factors that have contributed to the territorial expansion of the metropolis. Indeed, throughout the history of the United States, numerous economic factors have helped decentralize urban places. In the limited space available here, however, we are able to consider only a few.

The following pages consider the growth of national economy, decentralization of economic activity, transportation and communications, the process of land development, factors influencing development on the rural fringe, and the Federal Government's role in financing suburban expansion. They demonstrate that the economic dimensions of urban decentralization are complex and deeply rooted in American history, and will not be easily reversed.

\section{The Growth of the National Economy}

Like the growth of the national population, the growth of the national economy enabled and contributed to the expansion of urban areas. A nation with small and stagnant production of goods and services would have little reason or ability to de-concentrate its few economic activities. In contrast, the United States over the past two centuries experienced tremendous economic growth. The commercial expansion of the eighteenth and early nineteenth centuries, the industrial revolution of the nineteenth and twentieth centuries, and the technological advances of the twentieth century, along with the creation of national communications and transportation networks, made the United States into a global economic superpower and gave its people an unprecedented standard of living.

Over the Nation's history, America's cities acted as control centers and switchboards for the Nation's economic

\footnotetext{
'Joint Center for Housing Studies, Harvard University, Boston University, Boston, Mass.
}

growth. As regional economies exploded in the nineteenth century, urban capital and entrepreneurs pushed increasing production of hinterland farms, mines, and eventually factories, and the number of commercial transactions in city business districts multiplied exponentially. American cities became immense clearinghouses of wholesale and retail goods for regional, national, and international markets; headquarters for the national and international corporate businesses and banks; and great manufacturing centers in their own right as well. When the American economy shifted to producing services rather than goods in the late twentieth century, cities led in the provision of business-related services, such as legal work, and administrative and health services.

\section{Transportation and Communication Innovations}

Many students of urban development attributed the decentralized growth pattern of American cities to improvements in transportation and communications (Lewis, 1996; Warner, 1987; Borchert, 1967). According to economic theory, the dense clusters of people and goods found in traditional cities facilitated economic transactions through the "agglomeration economies" achieved by efficient transfer of goods and information in close physical proximity. Technological innovations in the means of transport and communication, however, reduce the costs and increase the speed and efficiency of transporting goods and people (LeRoy and Sonstelie, 1983; Mieszkowski and Mills, 1993). These gains in ability to move merchandise and information mitigate the loss of agglomeration economies and therefore encourage urban decentralization (Beeson, 1992; Burchell and Listokin, 1995; Duranton, 1999).

Technological improvements in urban transportation and communications, however, were as much a result as a cause of urban expansion. Improvements in transportation often arose in response to demands from individuals or groups who had an interest in those improvements. Entrepreneurs, suburban residents, and automobile clubs, for example, at one time or another called for and received commuting services, rail connections, and better roads. Once efficient methods of transportation and communications were created, however, they acted as powerful stimuli to further development and expansion of the urban periphery. 


\section{Early Urban Transportation}

Although a fundamental condition of the United States has been an abundance of land ${ }^{2}$, until the 1850 s the settled areas of even the largest cities - including New York, NY, Boston and Philadelphia - rarely extended beyond 2 miles from the city-center, the average distance a person could walk in half an hour. Thus, historians labeled this early configuration "the walking city" because of its size and mode of conveyance (Binford, 1985; Chudacoff, 1975; Jackson, 1987; Vance, 1991). The limitations of walking largely contributed to the compactness of the early-nineteenth-century cities. The fastest method of travel or freight was by water, but in the years following the American Revolution, a nation intent on exploiting the hinterland and expanding its commerce worked assiduously to improve transportation by building new roads - especially the straight-line turnpikes - bridges, and canals.

During the nineteenth century, the growth of the population of cities and consequent pressure for expansion rendered the walking city obsolete and led to a series of systems of urban transportation based on different technologies (Jackson, 1987). The first successful means of mechanized transportation for urban residents was the steam-powered ferry. The introduction of regular ferry service between Brooklyn and New York, NY, in 1814 attracted to Brooklyn large numbers of Manhattan commuters who sought refuge from the congestion and high housing costs of Manhattan (Jackson, 1987), as they still do today.

In the following decades, American cities adopted various forms of mass transit that made access to peripheral communities possible for commuters. First came the omnibus (a horse-drawn coach), then steam commuter railroads, the horse railway, the cable car, and finally in the early twentieth century, the electric powered subway and elevated rail cars. The lines of transportation systems generally followed extant major roads and encouraged further building along them. As a result, spokes of relatively dense development radiated from the inner city to clusters of residences and stores, which had served previously as inland village centers. As these networks enhanced property values along these networks, they encouraged further growth (Jackson, 1987; Adams, 1970; Lewis, 1996; von Hoffman, 1994; Warner, 1973, 1987, Vance, 1991).

Meanwhile, starting in the 1830 s, railroads began offering short-distance passenger service in response to requests from businessmen living on the urban fringe. As the new system of discounted or "commutation" fares became popular, train companies catered to the growing number of commuters to travel to work. In time the railroad became an essential part of life for prosperous suburban commuters living in elite railroad suburbs, such as those built up along the Main Line outside Philadelphia and through Westchester County outside New York, NY, City (von Hoffman, 1994; Fishman, 1987).

\footnotetext{
${ }^{2}$ Much of this land, of course, was expropriated from the indigenous peoples of North America so that citizens of the United States could exploit it.
}

\section{Industrial Decentralization Begins}

At the same time that urban people were moving to the outlying neighborhoods and suburbs, the rapidly increasing urban economic activities were spilling out of the inner cities as well. In the first decades of nineteenth century, entrepreneurs on the urban periphery processed hinterland materials for city buyers in cattle yards, slaughterhouses, and grain mills or, taking advantage of inexpensive land for large-scale operations, operated factories, such as foundries and brickyards, to fabricate goods for the urban economy (Binford, 1985; von Hoffman, 1994). The railroad contributed to further industrial deconcentration by carrying freight to and from factories located in the suburban borderlands and connected to trunk lines by short spurs. These factories in turn attracted workers who moved to nearby neighborhoods. During the late nineteenth century the number and size of suburban manufacturing complexes grew. By the early twentieth century, sociologists made note of industrial suburban towns, such as the "satellite cities," devoted to railcar and steel manufacturing that appeared outside Chicago and St. Louis (Taylor, 1915).

As railroad and streetcar service became more frequent in the late nineteenth century, increasing numbers of people traveled in and out of outer city and suburban neighborhoods for work, recreation, and even worship. As the urban areas expanded, secondary business centers developed at the larger intersections, and some even grew to resemble small downtowns. In addition to factories and workshops, suburban areas sprouted retail stores, tradesmen, personal servicessuch as barbershops - professional services of doctors and lawyers, local newspapers, real estate firms, and insurance companies. As a result, from at least as early as the $1860 \mathrm{~s}$ (long before the automobile highway era), residents began to practice cross-town commuting, traveling between homes and jobs in outer neighborhoods and suburbs, rather than to and from the central business district (von Hoffman, 1994).

The centers of cities became crowded with residents and businesses during the late nineteenth century, and the urban periphery as a result also increased population and economic activities. The peripheral areas developed diverse communities, ranging from satellite cities to bedroom communities that provided jobs as well as homes. A study of 10 major cities and 57 suburbs in their metropolitan areas showed that in 1920 the percentage of industrial wage earners in industrial and mixed residential and industrial suburbs frequently equaled or exceeded the percentage of industrial wage earners in central cities (Douglass, 1925, p. 87-89) (table 1).

\section{An Automotive Society}

In the twentieth century, the creation of a transport system based on the automobile and the truck further expanded the territory and the scope of economic activities in outlying areas. 
Table 1. Distribution of Industrial Wage Earners by Location, 1920.

\begin{tabular}{|l|l|l|}
\hline Types of Communities & Number & $\begin{array}{l}\text { Median Percentage of } \\
\text { Industrial Wage Earners }\end{array}$ \\
\hline Central Cities & 10 & 12.4 \\
\hline Mixed Suburbs & 10 & 11.9 \\
\hline Industrial Suburbs & 28 & 25.5 \\
\hline Residential Suburbs & 17 & 2.6 \\
\hline
\end{tabular}

Data from the 1920 census. Source: Douglass, (1925 p. 88).

The invention and mass-production of the automobile was a breakthrough in the search for a flexible and convenient means of urban transportation. In the early twentieth century, American automobile manufacturing was subject to the upheavals of a rapid growing industry, but it produced a font of innovations, among the most important of which was assembly-line production. Entrepreneurs such as Henry Ford brought the price of automobiles within reach of the average family, and as a result car ownership in the United States skyrocketed. In 1920, there were 13 Americans for every registered car; by 1960, this number had dropped to three (Mitchell, 2001).

The automobile provided Americans with unprecedented mobility. As automobile clubs lobbied successfully for better roads, real-estate developers began to take heed of the car's potential. Among the first was Jesse Clyde Nichols who developed the exclusive Country Club District in Kansas City with prosperous automobile owners in mind. Other developers built up hitherto overlooked suburban areas. No longer restricted to areas next to fixed rail transport and the cable-car tracks, realestate developers filled in interstices between rail routes and extended the boundaries of the urban region outwards (Flink, 1988; Worley, 1990; Jackson, 1987).

Since the automobile became readily available, urban Americans have embraced it. This embrace could be deadly to the traditional city with its central business district and a densely settled inner core. In Los Angeles, for example, voters in the 1920s and 1930s encouraged unrestricted use of cars on city streets, embraced general fees for freeway construction, and resisted subsidies for mass transit, which contributed to the demise of one of the most complete regional streetcar systems in the country (Bottles, 1987).

In addition, the automobile and the highways that served it contributed to suburban competition for downtown retail and office activities, which took new design forms. The introduction of the automobile-oriented shopping center in Kansas City's exclusive Country Club District in the 1920s heralded a new physical plan for retail shopping which would in time overtake the old ribbon-shaped commercial strip (Worley, 1990) and steal business from downtown department stores. From the shopping center eventually evolved the indoor regional mall (Rowe, 1991), which in some places supplanted early shopping centers. Meanwhile, elegant corporate head- quarters and clusters of office buildings - also once the exclusive province of downtowns - appeared far from the city near major highway exchanges, further undermining the importance of traditional central business districts (Rowe, 1991; Garreau, 1991).

In the late twentieth century, the love affair with the automobile continued unabated. Since 1970, the number of cars and trucks in the United States has grown twice as fast as the population. The number of vehicle miles traveled jumped by an astounding 41 percent, while the population grew by only four percent. By 1990, the number of vehicles per household exceeded the number of eligible drivers per household, and yet the total number of cars and the number of cars per person and per eligible driver continued to climb in the 1990s. Low fuel costs encourage greater use of the car and in turn undermined the use of public transportation or carpooling, which might encourage more concentrated development patterns (Dunphy, 1997).

\section{Trucking}

Concurrent with the growth of automobile ownership was the increase in the use of trucks for the movement of supplies and goods. The ratio of trucks to cars grew from 1 to 55 in 1905, to 1 to 6 by 1935 (U.S. Bureau of the Census, 1975). The availability of trucks gave executives of companies the choice of locating in areas outside central and industrial cities. By the 1940s, enough firms were relocating that the National Industrial Conference Board sponsored a survey of 148 companies to understand the trend toward "decentralization in industry." Although many had decentralized by acquiring geographically dispersed companies and war plants, about one in four had adopted a policy of decentralization. Interestingly, none of the reasons that executives gave for decentralizing their plant facilities had to do with technology or efficient factory design. The most frequently mentioned reasons were proximity to important new markets, the ability to tap new reservoirs of labor, and a preference for a small city or town location - in other words, the companies were pursuing the residents of suburbs and country towns as either consumers or workers (Dickson, 1948). 
With the construction of the interstate highways in the postwar years, trucking increased to a massive scale. The ability to move goods enabled the establishment of wholesale distribution centers and manufacturing plants near highway interchanges deep in the hinterland of metropolitan areas (Baldassare, 1992; Warner, 1987). In the 1930s, for example, rail and truck transport helped turn the Los Angeles region into an industrial giant, with such industries as oil drilling, airplane, automobile, and rubber in suburban towns such as El Segundo, San Pedro and Long Beach, California. After the war, the aerospace industry boosted industrial suburbs in Los Angeles and Orange Counties. In the latter twentieth century, manufacturing in metropolitan areas increasingly located in suburbs and exurban or nonmetropolitan areas beyond the suburbs, even as the manufacturing sector declined (Stanback and Knight, 1976; Stanback, 1991; Till, 1981).

Having taken up an automobile driving way of life, Americans helped to create sprawling urban regions by seeking to reduce their time commuting in their cars. The cycle began when an employer moves an industrial, service, or other employment center to a suburban location, perhaps to obtain a more pleasant environment for directors or employees or (as mentioned above) to be close to a large base of customers, workers, distributors, or suppliers. The employees who lived close to city centers then followed their employer to the suburbs in order to shorten the length and time of their journeys to work (Pivo, 1990). Such decisions caused commuting from suburbs to central cites to decline noticeably as early as the 1960s (Berry, 1977), and their full decentralizing effect became apparent in the 1980s when journeys to work from one suburb to another became more common than either central-city-to-central-city or suburb-to-central-city commuting (Pisarki, 1987).

\section{The Stimuli of Highway Construction and Airports}

The explosion of automobile and truck use would not have been possible without a simultaneous enormous investment in road construction. Early in the century, special interest groups lobbied for new streets, as the automobile quickly became an integral part of the entire economy. Soon most major cities built "parkways" and "expressways," new circulation routes dedicated to motor vehicular traffic, to avoid congestion of the city streets (Jackson, 1987). The Federal Interstate Highway Act of 1956 created a new generation of high-speed automobile roads, many of which connected the central cities with far-flung suburban locales. The newly built Federal interstate highways encouraged the development of new suburban homes and businesses within easy access of the roads - a situation which stranded businesses on the old routes without customers, as Alfred Hitchcock humorously depicted the Bates Motel in his 1960 movie, Psycho. Federal and state governments continue to pay out large sums to build, expand, and maintain the nation's highways not only for automobiles but also for increasingly large and heavy freight trucks.

In the late twentieth century, air travel emerged as another principal form of transportation, especially for many kinds of business interactions, which interlocks with the systems of automobile and truck conveyance of people and freight. As economic transactions became increasingly national and global, they involved an ever-expanding network of clients and customers (Lessard, 2001). According to one theory, as more and global economic trade is carried out by air, airports are replacing seaports as primary economic hubs (Kotkin and DeVol, 2001). Certainly airports have become new nodes of development. The areas around them now have developed not only ancillary services to the airline industry, but also urban complexes of offices, hotels, and other businesses (Muller, 1981). The success of these airport nodes of development rests not only on the airline traffic, but also on their locations near major highways and convenient connections to the metropolitan road system.

\section{Improvements in Communications}

Improvements in communication allowed people within the widening business and social networks to coordinate their activities and thus reinforced the effects of advances in transportation. In the nineteenth and twentieth centuries, the introduction of mass production techniques to publishing and applied to trade and popular publications vastly expanded the information available to business people and to their customers. At the same time, the creation of first telegraph and then telephone networks facilitated the expansion of metropolitan areas even as they made national and international communication possible. The telegraph allowed the national railroad companies to synchronize the movement of trains and at the same time enabled businessmen to place orders and ship goods across the country and the world. By the early twentieth century, a rapidly expanding telephone network "gave stock traders such as Edward Harriman, managers of mammoth retail stores such as Macy's and the city's burgeoning population the ability to communicate instantaneously by voice from one end of the metropolis to the other" (Levitt, 2002, p. 29-30).

The widespread dissemination of radio and television communication connected a disparate population by providing instant access to national news and entertainment. In the first half of the twentieth century, residents of metropolitan areas, sharing in mass culture and connecting to one another through electronic telephony, were able to spread out further than they had in the past.

In recent years, telecommunications systems - especially the growth of computer networks and now the Internet-have allowed firms to do business at greater geographic distances than previously possible. Telecommunications allow access to remote customers, suppliers, and subsidiary offices or employees. Although businesses and activities still tend to cluster in certain locations or regions, telecommunications systems 
Table 2. Average annual rates of growth of employment in retailing and manufacturing in the central cities and suburbs of eight large metropolitan areas, 1940-1970.

\begin{tabular}{|l|l|l|l|l|l|l|}
\hline Decade & $\begin{array}{l}\text { Central } \\
\text { Cities } \\
\text { Population }\end{array}$ & $\begin{array}{l}\text { Manufacturing } \\
\text { employment }\end{array}$ & $\begin{array}{l}\text { Retail } \\
\text { employment }\end{array}$ & $\begin{array}{l}\text { Suburbs } \\
\text { Population }\end{array}$ & $\begin{array}{l}\text { Manufacturing } \\
\text { employment }\end{array}$ & $\begin{array}{l}\text { Retail } \\
\text { employment }\end{array}$ \\
\hline $1940 \mathrm{~s}$ & 0.8 & 10.4 & 4.7 & 4.2 & 12.2 & 8.4 \\
\hline $1950 \mathrm{~s}$ & -0.2 & -1.1 & -0.5 & 6.8 & 5.0 & 7.7 \\
\hline $1960 \mathrm{~s}$ & -0.5 & -1.3 & -1.3 & 3.4 & 4.2 & 7.5 \\
\hline
\end{tabular}

Notes: Metropolitan areas are Baltimore, Boston, Cleveland, Denver, New Orleans, New York, NY, Philadelphia, and St. Louis. Unweighted modified average of average annual rates of employment in the eight metropolitan areas. Decades for retail figures run from 1939 to 1948,1948 to 1958, and 1958 to 1967; for manufacturing, years decades run from 1939 to 1947,1947 to 1958 , and 1958 to 1967.

Source: Stanback, and Knight (1976 p. 97).

reduce the cost and inconvenience of distance and thus those clusters occur in ever-more decentralized nodes in evergrowing urban realms (Berry, 1981; Clark, 2000; Duranton, 1999; Kain, 1975; Kotkin and DeVol, 2001; McArdle, 1999; Townsend, 2001).

\section{The Decentralization of Economic Activity}

By the middle decades of the twentieth century, if not before, business firms in many metropolitan areas in the United States were creating more new jobs in the suburbs than in the cities. Moreover, as Stanback and Knight showed, by the 1940 s the suburbs were generating employment more rapidly than they were attracting people, which foreshadowed further future population growth (Stanback and Knight, 1976) (table 2).

The increase in suburban employment ran across the board of job categories. A study of 101 metropolitan areas found that between 1960 and 1970 suburbs gained blue-collar employment by 29 percent as opposed to a 13 percent loss in central cities and suburbs increased white-collar jobs by 67 percent while central cities gained only by 7 percent (Berry and Kasarda, 1977, p. 236). The suburbs were usurping the traditional role of the big city downtown as an employment center.

Hence, by the late twentieth century, the entire range of economic activities could be found as easily outside the cities as within. In 1970, suburbs were the principle places of employment in nine of the 15 largest metropolitan areas (Jackson, 1987; Warner, 1987). In the previous 20 years, manufacturing especially dispersed, with many enterprises relocating to suburban industrial parks or from the Northeast and Midwest to the South and West. Yet at the same time, insurance companies, branch banks, regional sales staffs, and doctors offices reduced their costs and increased their accessibility by moving to suburban locations (Baldassare, 1992). Suburban areas became as economically diverse as the cities and in time duplicated or supplanted the core's economic activities — such as the shift of large-scale retail trade carried on in department stores from downtown to shopping malls.

The long-term increase in the share of total employment located outside of central cities has persisted in recent decades. Five of every six jobs added to the economy since 1960 were located beyond central city limits. Of the 18.5 million people added to the work force during the 1980s, 7.2 million (39 percent) found work in suburbs, 6.5 million (35 percent) found work in central cities, while the remainder found work in nearby metropolitan regions or outside metropolitan boundaries. As jobs in industry, retail, services, and offices increasingly moved outside cities in the late twentieth century (Dunphy, 1997), scholars discovered, the sort of agglomeration economies that had given rise to the central cities now accrued to the office, mixed-use, and retail nodes of the outer parts of metropolitan areas (Dunphy, 1997; Stanback, 1991).

Furthermore, scholars argue, the shift in employment from manufacturing to information and producer services pushed the decentralization of employment centers (Baldassare, 1992; Frey and Alden Speare, 1988; Riebsame, Gosnell, and Theobald, 1996). Services in such areas as finance, insurance, real estate, and accounting are said to be less dependent than manufacturing on access to water and inland shipping routes and thus have a greater freedom of mobility. The freedom of mobility combined with dramatic improvements in telecommunication networks has brought, according to some analysts, has had a dramatic impact on the distribution of jobs in metropolitan areas by dramatically increasing office space in suburban locales (Armstrong, 1979; Clark, 1982; Fulton, 1986; Glaeser, 2000; Pivo, 1990; Sassen, 1990).

By the end of the twentieth century, the phenomenon of "job sprawl" had become as conspicuous as population sprawl. A survey of jobs in the 100 largest primary metropolitan statistical areas (which for the larger metropolitan areas are smaller entities than the Consolidated Metropolitan Statistical Areas) found that in 1996 on average only 22 percent of the employed workers had jobs located within three miles of the central city center while 35 percent worked at sites more than 10 miles from the city center. Metropolitan areas varied in their distribution of employment, 
of course. About two-thirds of the metropolitan areas had relatively concentrated employment - either 25 percent or more jobs within 3 miles of the central business district or 60 percent or more jobs within 10 miles of the center. Yet a third of the metropolitan areas were highly decentralized in employment, with 40 percent or more of the jobs outside the ten-mile ring (Glaeser, Kahn, and Chu, 2001). A number of researcher have found that decentralized employment has been increasing, with the number of urban-type jobs growing not only in inner-ring suburbs, but also in outer-ring suburbs and exurbia (Muller, 1981; Harris, 1991; Lang and LeFurgy, 2003, Roepke, 1983; von Hoffman and DeNormandie, 2004). This trend has its critics, who assert that "job sprawl" is inefficient and penalizes low-income workers and central city residents (Persky and Wiewel, 2000).

\section{The Land Development Process Versus Planned Growth}

The outward expansion of the urban complex-its people and activities - into the territory surrounding cities ultimately relies on the transferal and development of real estate for urban uses. Active land markets and professional real-estate development operations emerged gradually in American cities, but they did so in a way that hindered metropolitan planning or managed growth. The following discussion concerns the development of urban residential land in the previously nonurban places, but similar processes occur in the development of urban commercial and industrial areas.

In the Nation's early years, the market in land outside the urban core was slow. Except for areas near fast-growing New York, NY, farmers and country estate owners in the early nineteenth century held most exurban land in large tracts for their own purposes, seldom thinking of their properties as a speculative investment. When the possibility of suburban development came to outer city neighborhoods, landholders thought of their property in terms of longterm investment, selling off a few lots when their values rose. So slow was the process and so modest the pay-off that people who developed the exurban lands did it as a part-time occupation (Blackmar, 1989; von Hoffman, 1996).

From about the 1860s onward, a long-term boom in the population in America's large cities transformed the outerareas land market, which became increasingly organized and specialized. Land subdividers targeted specific segments of the housing market more precisely by lot size and landscape. Full-time neighborhood real-estate agents appeared, acquiring capital and credit for real estate projects became easier, and occasionally developers sometimes built houses instead of passing the job on to others. Some developers increased the scale of their developments and worked in more than one town (von Hoffman, 1996; Keating, 1988). By the late nineteenth century it was clear that suburban land markets could be profitable, and, as a study of Chicago land values showed, upswings in real estate cycles lured ordinary citizens and small operators to speculate in neighborhood properties (Hoyt, 1933).

The trends toward organizing the market for and development of suburban lands continued in the twentieth century. Professional developers subdivided large tracts of land, tapped banks and insurance companies for financing, and sometimes built and marketed their own structures. Real estate developers targeted their projects to different income groups. For upperand middle-class consumers, who were concerned about maintaining prestige and property values, developers - such as Kansas City's J.C. Nichols - used deed restrictions and other techniques to exclude unwanted income and ethnic groups. Other developers such as B.E. Taylor in outer Detroit laid out subdivisions with modestly built and priced houses for the working class (Worley, 1990; Loeb, 2001; Jackson, 1987).

Since World War II, large land developers known as community builders have attracted much attention by acquiring large tracts of land, designing comprehensive plans, and overseeing the entire development process, even including the building of homes. From the first Levittown to the giant Irvine Ranch, the community builders achieved economies of scale much greater than their competitors and produced dramatic results: creating entire towns and cities where there had been nothing. The developers of Kaiser Community Homes in southern California or Sharpsville in Texas - not to mention new towns such as Reston, Virginia, and Columbia, Maryland, implemented sophisticated community plans based on the Garden City and community planning tradition. Even the Levitt company, although ambivalent about community planning, incorporated some of its principles in their Levittown developments (Hise, 1997; Rowe, 1991; Kelly, 1993; Weiss, 1987; Gans 1967). If left to the community builders, then, the expansion of urban areas would likely take place in a more orderly and planned fashion than it would in other hands.

For the most part, however, the economics of suburban real estate have brought about a fragmented, parochial approach to land development, with little regard for metropolitan planning. In the nineteenth century, small-scale local actors developed real estate in suburban neighborhoods and towns because only they knew what land was available and the likelihood of attracting purchasers (von Hoffman, 1996). Despite the increasing organization of the industry, most suburban real-estate development in the twentieth century continued to be a local affair (Loeb, 2001). Even the postwar developers who developed new subdivisions for the towns outside Boston and in Chicago's "technoburb" of Naperville, Illinois, resided in the general area in which they worked, had long-standing ties to their communities and, importantly, local bankers and political leaders (Charles and Keating, 1993; Rowe, 1991).

True, some homebuilding and shopping center developers began operating on a national scale from the 1960s, and simi-

\footnotetext{
${ }^{3}$ Robert Fishman coined the term, "technoburb," in his history of suburbia (Fishman, 1978).
} 
lar national office developers, such as Trammell Crow, came to prominence starting in the 1980 s, but most builders still worked at a relatively small scale. As before, however, successful suburban real estate development depended on knowledge of local conditions, both economic and political. In General, developers specialized in a particular territory and local officials imposed any planning regulations. As a result, development projects tended to be unrelated to other developments or regional growth schemes and contributed to the kind of scattered, leap-frog development often labeled sprawl.

\section{Land Markets and Urban Development}

The conversion of rural or vacant lands for urban uses became a widespread phenomenon during the twentieth century. Until relatively recently, most students of land markets reported that the value of urban land - as well as population density - fell as distance from the city center increased (Clark, 1968; Hoyt, 1933). If all factors were equal, Clawson (1971) noted, this generalization would hold for suburbs and the rural fringe, but all factors are not equal in such areas. The growth of employment and shopping nodes in the urban periphery has created new locational preferences that exert an influence on land values and density. And, as always, the presence of a particular social class of resident or of amenities - such as lakes or mountains that might provide views or recreation — raises or lowers the prices buyers are willing to pay.

The expectation of intensive development, moreover, boosts land prices in areas of potential new urban development. Studies of the development of suburban areas outside Sacramento, California and Philadelphia, Pennsylvania, in the 1950s and 1960s showed that nearby construction of a freeway, sewers, and shopping centers increased the value of developable land, and that tracts zoned for dense housing types such as row houses - potentially more profitable - were priced twice as high as single-family housing (Clawson, 1971). In case studies of six communities scattered about the San Francisco Bay Area in the 1970s, Dowall (1984) discovered that perceived conditions in surrounding land markets played a large part in determining land and housing prices. Even in a town that had little developable land, prices did not soar because of the supply of vacant land in nearby communities, which gave developers the choice to go elsewhere rather than pay dearly for property. In contrast, expectations of future growth in towns that were near communities with high demand or in the path of housing development encouraged by the county's urban corridor raised land and housing values. ment may have been planted even though the transition may lie far in the future. The conventional perception is that such areas are arenas for conflict between farming and urban land uses, in which urban land uses always prevail (Nelson, 1999). Such views rarely take into account the longterm restructuring of agriculture that in effect reduced profitability in farming, especially small-scale farming, in many parts of North America (Hart, 1995). Increased productivity and specialization in agriculture - based on among other factors technological improvements in equipment and increased reliance on chemical fertilizers - over the course of the twentieth century has led to geographic specialization of production, large-scale farming and raising of animal stock, and high capital costs. Many agricultural areas and small-scale family farms became marginally profitable at best, causing young farmers and the youth of farm regions to have increasingly turned away from farming to other pursuits.

The decline of agriculture invited the development of the rural fringe. The fall in agricultural profits and the number of people in agriculture living on the land led inevitably to a decline in farmland prices in rural areas in many regions. As old farmhouses become vacant and fields went unplanted, city folk found it relatively inexpensive to set up either part-time or full-time residence in the country. The well-to-do city dweller who finds his dream house in an old abandoned farmhouse situated deep in the countryside became something of a stock figure in American twentieth-century literature (Kaufman and Hart, 1940; Hodgins, 1946; Spectorsky, 1955). In an empirical study, Clawson (1971) reported abandoned farms provided a significant portion of rural land developed for urban purposes outside Wilmington, Delaware, between 1937 and 1964.

More frequently, however, farmland passed out of production and the hands of farmers well before it became urban. In an interim stage, which can last decades depending on the pace and direction of suburban development, other owners - including hobby farmers, vacation homeowners, large and small capital investors, and wealthy syndicates - retain the land. Only when approaching development raises land prices and taxes sufficiently will individual owners - if they wish to - decide to sell. The diversity and number of owners of rural lands causes land to become available for development in relatively small tracts and at different times (Clawson, 1971; Brown, Phillips, and Roberts, 1981; Brown and Roberts, 1978). Hence, the patterns of land ownership on the rural fringe - like the patterns of urban real-estate development - allow the decentralization of urban land uses and activities but at the same time create obstacles to planned growth.

\section{Conversion of the Rural Fringe to Urban Outskirts}

Beyond the areas of potentially intense suburban development is the rural fringe or exurbia, where the seeds of develop-

\section{The Economic Role of the Federal Government in Suburban Development}

In the twentieth century, the United States Government helped to shape, encourage, and - most importantly-finance 
urban decentralization, especially through single-family home ownership. Prior to the Great Depression of the 1930s, the Federal Government was reluctant to intervene in the production or purchase of homes. Although some housing reformers felt differently, the prevailing ideology of the time held that the purchase of a home was an individual's responsibility, thrift was important, and subsidizing the rent or purchase of homes smacked of socialism (Chudacoff, 1975). However, the Great Depression brought soaring mortgage foreclosures at the rate of one thousand per day, a collapse in the housing industry, and attitudes about government intervention in the housing field soon changed. The government now experimented with directly providing housing - such as in the greenbelt towns and the public housing program enacted in 1937. However, the government actions that had the most profound effect on the housing industry and consequently the building out of suburbia were taken to shore up the private housing industry.

The important measures the New Deal took on behalf of the housing industry were aimed at its financiers. To save the financially stressed savings and loan associations, the Home Owners Loan Corporation (HOLC) was established in 1933 with the power to exchange government bonds for defaulted home mortgages. The HOLC refinanced tens of thousands of mortgages in danger of foreclosure and even granted lowinterest loans so owners could recover homes lost through forced sales. The Federal Housing Administration (FHA) established by the Housing Act of 1934, helped mortgage lenders by insuring home mortgages. As a result, mortgage lenders gained the confidence to lower down-payments and extend loan repayment periods to twenty-five or thirty years, thus making home purchase affordable to a wider group of potential buyers.

The new Federal programs, HOLC and FHA, helped housing production almost immediately. The amount of new housing climbed rapidly from 93,000 in 1933 to 332,000 in 1937. By the end of 1972, FHA had helped nearly 11 million families to buy houses (Jackson, 1987).

After World War II, new programs helped to raise housing numbers even more dramatically. The Veterans' Administration offered to guarantee longterm, low-interest loans to returning soldiers, bringing the price of a home in new developments such as Levittown well within reach of the middleclass buyers. It was not until the postwar period that the 1934 act's provisions took full effect by allowing the establishment of entities for conducting a national secondary market for mortgages. Once established, however, the agencies-Federal National Mortgage Association (known as Fannie Mae) started in 1938, the Government National Mortgage Association (Ginnie Mae) in 1968, and the Federal Home Loan Mortgage Corporation (Freddie Mac) in 1970 - attracted a flood of investment money into the real-estate market and further fueled the market in houses. They also helped made it possible to funnel funds to the fast-growing areas of the country in the South and West.

The Federal programs that aided the market for singlefamily houses contributed heavily to the expansion of met- ropolitan areas. From the beginning, the FHA - through its standards for the structure and style of the houses whose mortgages it would insure - primarily aided the purchase (and therefore production) of single-family, rather than multipleunit structures, which were instead produced by the chronically under-funded public housing program. Furthermore, the FHA and HOLC shied away from insuring sales in innercity and racial-minority neighborhoods, which both helped undermine property values in those places and boosted sales in suburban locales. It is a remarkable fact that Federal mortgage instruments financed more than 50 percent of suburban houses constructed after World War II (Kleinberg, 1997).

Other Federal policies also promoted extensive decentralization of urban areas. Since World War II, U.S. tax codes allowed homeowners a deduction for their mortgage payments and provided favorable conditions for the treatment of capital gains from home sales, which provided incentives for both home ownership and purchase of new homes (Bereuter, 2000; Doyle, 2001; Hanchett, 2001; Hayden, 2000). Also, Federal subsidies for infrastructure and transportation networksespecially the landmark Interstate Highway Act of 1956 and later highway appropriation legislation - alleviated the cost of suburban development for local governments, as well as the individuals who used them and facilitated rapid urban decentralization (Cashin, 2000; Government Accounting Office, 1999; Katz, 2000).

In the past decade, the finance policies of the Federal Government and government-sponsored enterprises further encouraged urban decentralization. Through its policies, the Federal Reserve Board delivered historically low mortgage interest rates, while Fannie Mae and Freddie Mac pursued the aggressive mortgage purchase policies. These policies have brought single-family homeownership rates up to an unprecedented 68 percent of American households (Joint Center for Housing Studies, 2003). The promotion of construction and purchase of single-family homes, which are disproportionately located in suburban and exurban areas, thus contributes directly to the sprawling expansion of metropolitan areas.

Finally, the Federal Government has played a direct role in decentralizing urban development within metropolitan areas. The decisions to build and expand Federal facilities, such as military bases, promote employment and therefore increase settlement in the areas where they are located. In the Washington, D.C., metropolitan area, the Federal Government's long-standing policy to move government agencies to Virginia and Maryland has helped create one of the most sprawling urban regions in the Nation (von Hoffman and Harrigan, 2002; von Hoffman and Harrigan, 2003).

\section{Conclusion}

However brief and limited it is, this survey of the economic history of urban decentralization in the United States underscores how complex and deeply rooted is the tendency to expand urban activities into ever-increasing metropolitan areas. 
The growth of the American economy, propelled by technological innovations not only in industry but also in transportation and communications, set the stage for two related developments. As business and industry expanded in volume, some urban workers began moving to homes further away from the crowded centers of the early towns. At the same time, entrepreneurs also moved their enterprises to the urban periphery. The movement of people and firms to the outskirts encouraged improvements in transportation, which in turn encouraged more people and firms to move to the growing suburbs. After a series of different technologies of intra- and interurban transport, the invention of the automobile and the truck ushered in the era of the modern sprawling metropolitan area.

To incorporate heretofore rural or idle lands for urban uses, specialists in real-estate development worked out planning and development techniques, as well as devising new suburban building types such as the shopping mall and the office park. The fragmented nature of holdings and investment on the urban-rural fringe facilitated urban development but hindered rational planning.

Finally, the Federal Government has played a large role in the ongoing development of suburbia, particularly through financing mechanisms that make the purchase of single-family homes relatively inexpensive and low risk.

In conclusion, any successful management of sprawling urban growth will have to involve many economic aspects of urban development. Efforts to succeed in managing growth may depend upon incentives for workers and entrepreneurs to centralize their activities, new transportation guidelines or even technologies, policies to encourage real-estate developers to use land efficiently, and new Federal transportation and home financing programs. The strategies may have to be diverse and complex, but, as this review suggests, so too are the economic factors in the ongoing expansion of metropolitan areas.

\section{References}

Adams, J.S., 1970, Residential structure of midwestern cities: Annals of the Association of American Geographers, January, p. 37-62.

Armstrong, R.B., 1979, National trends in office construction, employment and headquarter location in U.S. metropolitan areas, in Daniels, P.W. ed., Spatial patterns of office growth and location: New York, NY, John Wiley.

Baldassare, M., 1992, Suburban communities: Annual Review of Sociology, v. 18, p. 475-494.

Beeson, P.E., 1992, Agglomeration economies and productivity growth, in Mills, E.S. and McDonald, J.F., eds., Sources of metropolitan growth: New Brunswick, NJ, Center for Urban Policy Research.

Bereuter, D., 2000, Livable communities through American federalism, in Rowe, P. ed., Sprawl-Beyond the rhetoric: Cambridge, MA, McGraw-Hill Construction Information Group.

Berry, B.J.L., and Kasarda, J.D., 1977, Contemporary urban ecology: New York, NY, Macmillan Pub. Co.

Berry, B.J.L., 1977, The changing shape of metropolitan America-Commuting patterns, urban fields and decentralization processes, 1960-1970: Cambridge, MA, Ballinger Publishing Co.

Berry, B.J.L., 1981, Comparative urbanization, divergent paths in the twentieth century: New York, NY, St. Martin's Press.

Binford, H., 1985, The first suburbs: Chicago, IL, University of Chicago Press.

Blackmar, E., 1989, Manhattan for rent: Ithaca, NY, Cornell University Press.

Bottles, S., 1987, Los Angeles and the automobile-The making of the modern city: Berkeley, CA, University of California Press.

Brown, H.J., Phillips, R.S., and Roberts, N.A., 1981, Land markets at the urban fringe-New insights for policy makers: American Planning Association Journal, v. 47, n. 2, p. 131-144.

Brown, H.J., and Roberts, N.A., 1978, Land owners at the urban fringe: Discussion Paper D78-10, Department of City and Regional Planning, Harvard University.

Burchell, R.W. and Listokin, D., 1995, Land, infrastructure, housing costs and fiscal impacts associated with growthThe literature on the impacts of sprawl versus managed growth: Cambridge, MA, The Lincoln Institute, Working Paper Lincoln Institute Product Code: WP95RB1.

Cashin, S.D., 2000, Public Subsidies and the role of suburbanization in urban economic development-A reply to Timothy Bates: Economic Development Quarterly, v. 14, n. 3, p. 242-247.

Charles, J. and Keating, A.D., 1993, Postwar residential developers and suburban planning: Paper delivered at the Fifth National Conference on American Planning History, Chicago, IL, November 19.

Chudacoff, H.P., 1975, The evolution of American urban society: Englewood Cliffs, NJ, Prentice-Hall, Inc.

Clark, C., 1968, Population growth and land use: New York, NY, St. Martin's Press.

Clark, D., 2000, World urban development_-Processes and patterns at the end of the twentieth century: Geography, v. 85, p. $15-23$.

Clark, D., 1982, Urban geography: Baltimore, MD, Johns Hopkins University Press.

Clawson, M., 1971, Suburban land conversion in the United States: Baltimore, MD, The Johns Hopkins Press for Resources for the Future, Inc.

Dickson, P.W., 1948, Decentralization in industry-Studies in business policy: New York, NY, National Industrial Conference Board, Inc, no. 30.

Douglass, H.P., 1925, The suburban trend: New York, NY, The Century Co.

Dowall, D.E., 1984, The suburban squeeze-Land conversion and regulation in the San Francisco Bay Area: Berkeley, CA, University of California Press.

Doyle, R., 2001, Sprawling into the third millennium: Scientific American, March. 
Dunphy, R.T., 1997, Moving beyond gridlock-Traffic and development: Washington, D.C., The Urban Land Institute.

Duranton, G., 1999, Distance, land, and proximity-Economic analysis and the evolution of cities: Environment and Planning, v. 31, n. 12, p. 2169-2188.

Fishman, R., 1987, Bourgeois Utopias-The rise and fall of suburbia: New York, NY, Basic Books.

Flink, J.J., 1988, The automobile age: Cambridge, MA, MIT Press.

Frey, W.H., and Alden Speare, J., 1988, Regional and metropolitan growth and decline in the United States: New York, NY, Russell Sage Foundation.

Fulton, W., 1986, Offices in the Dell: Planning, v. 52, n. 7, p. 13-17.

Gans, H.J., 1967, The Levittowners-Ways of life and politics in a new suburban community: New York, NY, Vintage Books.

Garreau, J., 1991, Edge city: New York, NY, Academic Press.

Glaeser, E.L., 2000, Demand for density?: The Brookings Review, v. 13, n. 3, p. 12-14.

Glaeser, E.L.; Kahn, M.; and Chu, C., 2001, Job sprawlEmployment location in U.S. metropolitan areas: The Brookings Institution Center on Urban and Metropolitan Policy, Survey Series.

Hanchett, T.W., 2001, The other "subsidized housing": Journal of Housing and Community Development, v. 58, n. 1, p. 18-22.

Harris, R., 1991, The geography of employment and residence in New York, NY, since 1950, in Mollenkopf, J.H. and Castells, M., eds., Dual city—Restructuring New York: New York, NY, Russell Sage Foundation.

Hart, J.F., 1995, "Rural" and "farm" no longer mean the same, in Castle, E.N., ed., The changing American countrysideRural people and places: Lawrence, KS, University Press of Kansas.

Hayden, D., 2000, Model houses for the millions - The making of the American suburban landscape, 1820-2000:

Boston, MA, Lincoln Institute, Working Paper Lincoln Institute Product Code: WP00DH2.

Hise, G., 1997, Magnetic Los Angeles-Planning the twentieth-century metropolis: Baltimore, MD, Johns Hopkins University Press.

Hodgins, E., 1946, Mr. Blandings builds his dream house: New York, NY, Simon and Schuster.

Hoyt, H., 1933, One hundred years of land values in Chicago: Chicago, IL, University of Chicago Press.

Jackson, K., 1987, Crabgrass frontier: New York, NY, Oxford University Press.

Joint Center for Housing Studies, 2000, The state of the Nation's housing: Cambridge, MA, Harvard University.

Kain, J.F., 1975, The distribution and movement of jobs and industry, in Kain, J.F. ed., Essays on urban spatial structure: Cambridge, MA, Ballinger.

Katz, B., 2000, The Federal role in curbing sprawl: Annals of the American Academy of Political and Social Science, v. 572, p. 66-77.
Kaufman, G.S., and Hart, M., 1940, George Washington slept here: New York, NY, Random House.

Keating, A.D., 1988, Building Chicago-Suburban developers and the creation of a divided metropolis: Columbus, $\mathrm{OH}$, Ohio State University Press.

Kelly, B.M., 1993, Expanding the American dream-Building and rebuilding Levittown: New York, NY, State University of New York.

Kleinberg, B., 1997, Urban America in transformationPerspectives on urban policy and development: Thousand Oaks, CA, Sage Publications.

Kotkin, J., and DeVol, R.C., 2001, Knowledge-value cities in the digital age: Santa Monica, CA, The Milken Institute.

Lang, R.E., and LeFurgy, J., 2003, Edgeless citiesExamining the non-centered metropolis: Housing Policy Debate, v. 14, n. 3, p. 427-460.

Levitt, J.N., 2002, Networks and nature in the American experience, in Levitt, J.N., ed., Conservation in the internet age: Washington, D. C., Island Press.

LeRoy, S., and Sonstelie, J., 1983, Paradise lost and regained-Transportation innovation, income and residential location: Journal of Urban Economics, v. 13, n. 1, p. 67-89.

Lessard, S., 2001, A different kind of urb: The New York Times Book Review.

Lewis, P.G., 1996, Shaping suburbia-How political institutions organize urban development: Pittsburgh, PA, University of Pittsburgh Press.

Lewis, S., 1922, Babbitt: New York, NY, Harcourt, Brace and Co.

Loeb, C.S., 2001, Entrepreneurial vernacular-Developers' subdivisions in the 1920s: Baltimore, MD, Johns Hopkins University Press.

McArdle, N., 1999, Outward bound-The decentralization of population and employment: Cambridge, MA, Joint Center for Housing Studies, Harvard University, Working Paper Series W99-5.

Mieszkowski, P., and Mills, E.S., 1993, The causes of metropolitan suburbanization: The Journal of Economic Perspectives, v. 7, n. 3, p. 135-147.

Mitchell, J.G., 2001, Urban sprawl: National Geographic, July.

Muller, P.O., 1981, Contemporary suburban America: Englewood Cliffs, N.J., Prentice-Hall.

Nelson, A.C., 1999, The exurban battleground, in Furuseth, O.J. and Lapping, M.B. eds., Contested countryside-The rural urban fringe in North America: Brookfield, Vt., Ashgate Press, p. 137-150.

Persky, J. and Wiewel, W., 2000, When corporations leave town - the costs and benefits of metropolitan job sprawl: Detroit, MI, Wayne State University Press.

Pisarski, A.E., 1987, Commuting in America-A National report on commuting patterns and trends: Washington D.C., Eno Foundation for Transportation.

Pivo, G., 1990, The net of mixed beads-Suburban office development in six metropolitan regions: Autumn, p. 457469. 
Riebsame, W.E., Gosnell, H., and Theobald, D.M., 1996, Land use and landscape change in the Colorado MountainsTheory, scale, and pattern: Mountain Research and Development, v. 16, n. 4, p. 395-405.

Roepke, H.G., 1983, Industry in nonmetropolitan Areas, in Platt, R.H. and Macinko, G., eds., Beyond the urban fringe - Land use issues of nonmetropolitan America: Minneapolis, University of Minnesota Press, p. 149-158.

Rowe, P.G., 1991, Making a middle landscape: Cambridge, MA, MIT Press.

Sassen, S., 1990, Economic restructuring and the American city: Annual Review of Sociology, v. 16, p. 465-490.

Spectorsky, A.C., 1955, The exurbanites: Philadelphia, PA, Lippincott.

Stanback, T.M. and Knight, R.V., 1976, Suburbanization and the city: Montclair, N.J., Allanheld, Osmun, and Co. and Universe Books.

Stanback, T.M., 1991, The new suburbanization-Challenge to the central city: Boulder, CO, Westview Press.

Taylor, G.R., 1915, Satellite cities - a study of industrial suburbs: New York, NY and London, D. Appleton and company.

Till, T.E., 1981, Manufacturing industry-Trends and impacts. in Hawley, A.H. and Mazie, S.M., eds., Nonmetropolitan America in transition: Chapel Hill, NC, University of North Carolina Press.

Townsend, A.M., 2001, The Internet and the rise of the new network cities, 1969-1999: Environment and Planning BPlanning and Design, v. 28, n. 1, p. 39-58.

U.S. Bureau of the Census 1975, Historical statistics of the United States, colonial times to 1970: Washington, D.C., U.S. Bureau of the Census, Series C-89-119.

U. S. Government Accounting Office, 1999, Community development-Extent of Federal influence on "urban sprawl” is unclear: [http:/www.gao.gov/archive/1999/ rc99087.pdf].
Vance, J.E., 1991, Human mobility and the shaping of cities, in Hart, J.F., Our changing cities: Baltimore, MD, Johns Hopkins University Press.

von Hoffman, A., 1996, Weaving the urban fabricNineteenth-century patterns of residential real estate development in outer Boston: Journal of Urban History, v. 22, n. 2, p. 191-230.

von Hoffman, A., 1994, Local attachments - The making of an American urban neighborhood, 1850 to 1920: Baltimore, MD, Johns Hopkins University Press.

von Hoffman, A., and DeNormandie, J., 2004, County population and employment patterns in metropolitan areas_-Patterns and Process of Sprawl: Joint Center for Housing Studies/United States Geological Survey, Unpublished paper.

von Hoffman, A., and Harrigan, L., 2003, Happy to growDevelopment and planning in Fairfax County, Virginia: Joint Center for Housing Studies, Harvard University, Working Paper Series, W04-2.

von Hoffman, A., and Harrigan, L., 2002, Forty years of fighting sprawl-Montgomery County, Maryland, and growth control planning in the metropolitan region of Washington, D. C.: Joint Center for Housing Studies, Harvard University, Working Paper Series, W02-6.

Warner, S.B., Jr., 1973, Streetcar suburbs: New York, NY, Atheneum.

Warner, S.B., Jr., 1987, The private city-Philadelphia in three periods of its growth: Philadelphia, PA, University of Pennsylvania Press.

Weiss, M.A., 1987, The rise of the community builders - The American real estate industry and urban land planning: New York, NY, Columbia University Press.

Worley, William S., 1990, J.C. Nichols and the shaping of Kansas City-Innovation in planned residential communities: Columbia, MO, University of Missouri Press. 



\title{
General Trends Regarding Aggregate Materials for Urban Development, With a Suggested Method for the Analysis of Aggregates Distribution
}

\author{
By Dalia Varanka ${ }^{1}$
}

\section{Introduction}

Urban infrastructure development is highly dependent on aggregates industrial minerals - sand, gravel, and crushed stone - as the primary materials for concrete and other types of construction. The trend for inland urban areas is, however, that obtaining adequate amounts of aggregates is becoming an increasing challenge. Aggregates are a mineral commodity that because of its low unit value and the large quantities used is prohibitively expensive to transport overland for long distances. As these urbanized areas expand, the availability of aggregates becomes increasingly limited, primarily because communities being built over the mineral deposits are in conflict with the industry about land use priorities. The impacts caused by quarries have led to the establishment of environmental standards in the permitting process for resource extraction that set terms for the aggregates industry to meet. This paper is written in two parts; the first provides the background to problems involved in aggregates resource extraction for construction where the operations come in conflict with quality of life standards of suburban residential communities. The second part presents a method for analyzing the flow of aggregates between quarries and urban infrastructure job sites that can show potential impacts of expanding the infrastructure or permitting new quarrying near communities.

\section{Background}

The rapid decentralization of cities, industry, and population in the United States has brought to the forefront a national dialogue on the balancing of the expanding urban and industrial infrastructure and the consumption of economic and natural resources. Concurrently, the extensive urban and regional infrastructure built during the twentieth century is in great need of repair or replacement. One of the key resources central to these issues is aggregates-crushed

${ }^{1}$ U.S. Geological Survey, 1400 Independence Road, Rolla, MO 65401, 573-308-3897. stone, sand, and gravel - for both new construction and to maintain or replace earlier structures. The extraction of aggregates, however, requires setting priorities between beneficial and detrimental effects. A problem foreseen by the aggregates industry is whether or not the availability of these resources will be sufficient to meet future urbanization demands and the expansion of infrastructure. Suburban development on top of geologic deposits of aggregates restricts the development of new quarries. Suburban municipalities have enacted land-use restrictions on subsurface resource extraction to mitigate the environmental effects of these intensive industries.

The objective of this paper is to provide background on national trends on the material flow of aggregates in terms of the relation between industrial production of aggregates, the urban built environment, and social concerns of municipal residents. This paper will outline the spatial patterns in the diffusion of these mineral resources, and will clarify the geographical context of their production and use. The availability of aggregates is central to transportation and urban development, yet is under represented in both traditional land use and emerging sustainable development discussions. The main sources of information are government reports and industry publications. One objective of this paper is to help link these two spheres of the study of aggregates resources. Specific questions that this paper is intended to address include:

(1) What are the factors presently affecting the mining and consumption of aggregates?

(2) What is the general pattern of proximity and accessibility of aggregates for urban development?

(3) What volume of supply and demand of aggregates may be expected in the future?

(4) How may the expected urban growth cause the pattern of aggregates distribution to shift?

(5) What is the capacity of the transportation network to affordably transport aggregates, given the expected patterns?

(6) What impact would opening new quarries have on competitive market supply, or the impact of new development-residential, commercial, or industrial —on aggregates demand?

Other regional studies on this topic used analytical approaches, such as the correlation of population and aggregates within proximity to each other, comparison of popula- 
tion and urban size relative to aggregate consumption, and the analysis of counties producing or not producing aggregates (Robinson, 2002; Wilburn and Langer, 2004). This study focuses on the analytical potential of applying a quantitative method called spatial accessibility and interaction modeling to the problem of aggregates distribution in urban areas. The quantitative patterns of past aggregates production and consumption are analyzed using a historical database and mapping technology. However, the environmental and social contexts of supply and consumption of aggregates in the past are equally important in understanding how land-use policies and future decisions will affect resource and urban development.

Chicago was chosen as a study site because of its tremendous demand for aggregates and its prominent position as a global harbor city, yet one linked to most of the mid-western region of the United States. Situated on the Great Lakes, Chicago is a starting and ending point in international trade shipping and serves as an intermediary point for expanding cities on the Mississippi River Basin network (fig. 1). In addition to its position on the river network (of key importance because waterborne transport is the cheapest way to move the massive weight of aggregates), Chicago is a locus on the continental railway network, enabling the movement of the aggregates to and from inland points of consumption. A study of Chicago potentially could yield regional, national, and international implications.

This paper will present some background on the use of aggregates in urban areas, including the problems involved in the extraction, use, and disposal. That section will be followed by a presentation on the geographic concepts of spatial accessibility and interaction, and the urban Chicago context. The paper ends with a report on the status of a geographic research project on the quantitative study of aggregates flow in the Chicago area.

\section{The Context of the Aggregates Industry}

\section{Aggregate Products and Industrial Production}

Aggregates in general may consist of limestone and dolomite, with varying amounts of shale, and some types of chert. The proper rock is necessary for the specific surface conditions and for the preferred chemical characteristics, but product characteristics do not differ significantly between residential or industrial use. Rock absorption (permeability) is a key factor in some products, such as asphalt. Techniques have been researched for producing an acceptable product with aggregates that previously were not useable.

The main aggregate products (sand, gravel, and crushed stone) constitute as much as 60 to 70 percent of the volume of concrete and are also in high demand for materials such as asphaltic concrete ("asphalt") and road-base fill. The processing of aggregates for concrete production and road construction begins with crushing the rock into gravel, which causes extensive dust. Sizing and washing the stone follows the crushing. These three steps are the extent of aggregates processing prior to their use in construction. Crushed stone is also the principle raw material for portland cement, but undergoes extensive processing in the making of cement.

Recycling to help replace shortages of aggregates is not considered to be economical. Recycled aggregates are not as strong as virgin aggregate products so cannot be used in all applications. Various additives are being tested to improve the recycled product, but results are poor. Recycled products fill only a small percentage of the total demand for aggregates, except for asphalt paving (Wilburn and Goonan, 1998). Recycling is most likely in large urban areas where there is a shortage of natural aggregates, and disposal of deteriorated structures is expensive or not permitted; however, the potential benefits of recycling are substantial. Recycling can slow the rate and depletion of natural aggregates, which will slow the rate of surface disturbance.

The economy of aggregates is closely tied to the construction sector of the national economy and especially to the public spending on roads and bridges. The profitability of specific companies also depends on two other factors. The first is having a large relative share of the market and a low relative share of the costs. The lowest delivered cost includes the combined costs of service, equipment, freight, and products. Second is the extraction of a high-quality product, that is materials that meet users' needs. This factor depends at least in part on the geological exploration of aggregates deposits (new technology, for example microgravity tests, are making exploration cheaper and more effective). The viability of aggregate extraction is constrained mostly by the thickness of the geologic overburden and the thickness of aggregate deposits of particular qualities.

\section{Consumption}

The demand for aggregates products is huge. In addition to the demand for new construction, existing infrastructure needs to be replaced cyclically. Complete replacement of asphalt roads is needed within about 7 years, though potholes appear much sooner than that. Concrete is estimated to last about 30 years or less. Federally funded highway construction requires the use of SUPERPAVE (Superior Performing Asphalt Pavements, a rigorous standard for asphalt concrete developed in the 1980s) that is estimated to last approximately 20 years.

The demand for aggregates for new construction is difficult to quantify. Measures of estimated consumption often are offered in per capita averages, but this method does not allow the spatial analysis of consumption. Urban growth history can be estimated from various statistics, for example housing starts and other building permits, such as for overpasses, high rises, parking garages, and airport terminals. Development, used as a variable or measure of urban growth can be monitored but not projected quantitatively (Northeastern Illinois Planning Commission, 2004). 


\section{Transportation}

Aggregates are a high-volume/low-unit-value material, entailing high transportation costs. Part of the valuation of aggregates is considered to be "place" value; supplies closer to the delivery site are more desirable than supplies further away. Historically, most aggregates were consumed locally, but this is less true today. Because fewer quarries are opening, the existing quarries are serving larger surrounding areas. Extremely extensive mining operations are serving areas as much as 80 miles away. However, most concrete is manufactured close to the consumer. The path of aggregates shipping network is pretty much direct between the quarry, the concrete plant, and the job site.

Transportation costs can double for distances more than 50 miles away. Trucking costs are increasing because of congested traffic - charged not by distance, but by the hour. Since most construction is done from late spring through early fall, inventories of aggregates often are built during the winter and shipped through the summer, just when traffic is most congested. Rail may also help ease costs, but heavy regulation and limited tracks and terminal facilities limit this. Each transport mode has economic and physical risks involved in terms of flexibility of movement, timeliness, labor intensity, and cost. Risk is inversely proportional to cost (for example, trucking is most convenient but most expensive.) Each transport mode has its required infrastructure and schedule, capacity, and distance constraints.

Anticipated future transportation trends in the aggregates industry include greater deregulation, using transportation brokers, and more product distribution centers, including appropriate terminals for increased rail, barge, and ship use. Challenges include a growing emphasis on just-in-time delivery practices that are best served by trucking. A movement away from sand and gravel and toward crushed stone is occurring, as sand and gravel become less available. Future trends in the industry may include importing crushed stone by barge from distant locations, though fewer ports can accommodate
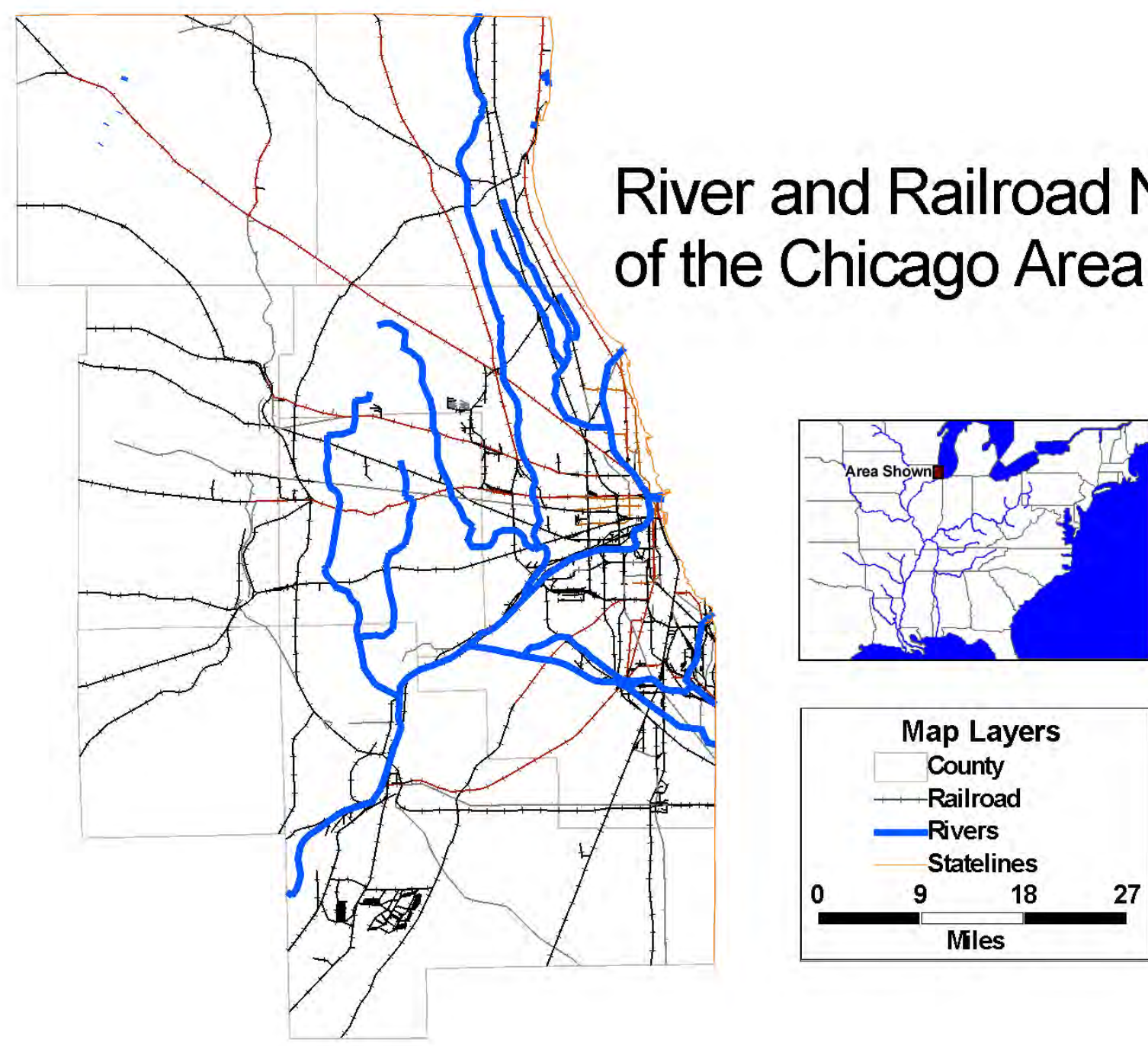

Figure 1. Map showing Chicago as the hub of transportation for the Midwest.

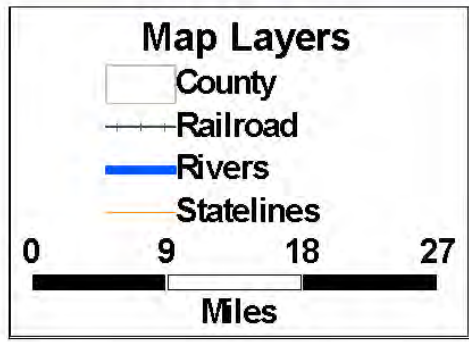


the larger ships. Imports travel by barge to specific harbors, or often directly to specific construction projects. Sometimes shipping costs can be reduced if the carrier can back haul another commodity.

\section{Land Use and Environmental Impact}

\section{Issues Surrounding Land Use and Impacts}

Land-use policy and planning rarely include a mineral component. If aggregates resources are not considered in current land-use plans, they will, either be restricted from development despite the community's need for them or inefficiently considered in growth management. Obtaining permits to extract aggregates requires time, money, and work and often involves negotiations for approval. Proposed sites for quarries may fall within more than one regulatory jurisdiction or specially designated areas. The specific impacts of quarrying include problems related to water-table fluctuation, risks related to dangerous land surfaces (sharp edges and drop offs), and postmining land use. Production impacts such as dust, ground vibration, risks related to industrial machinery, falling debris, noise, the affected viewscape, and heavy truck traffic are all concerns. In mixed land-use areas, blasting is blamed when structural deterioration appears in nearby buildings and other structures. A problem at the end of the aggregates life cycle is that deteriorated products must be disposed of. Suitable land-use planning can minimize or mitigate these anticipated scenarios.

Quarries may affect the local water table. By removing the upper layers of the surface, ground water infiltrates faster and the water table drops, most of which would be due to dewatering the quarry. Shallow ground water may be vulnerable to depletion if a water supply is nearby and pumping the resource along side a sand or gravel pit that is dewatering. Quarrying without dewatering or near a large water source such as a river would probably have minimal real impact on the water table. This impact would probably be restricted spatially; flooded quarries would help recharge deeper aquifer systems, which are more in need of recharge. Sand and gravel operations, however, are typically in unconfined aquifers, and often are within recharge areas for confined aquifers. They are also quite extensive in some places (Warner, Kelly, oral communication, 2002). The interaction of quarries, groundwater, and aquifers comes into focus again when considering landuse plans for spent quarries as water holding facilities. Lately, ground-water contamination from past mining operations is a topic for increased public concern when using these quarries for wastewater holding and disposal.

Environmental regulation, particularly of air quality, can also be an issue where limestone quarries are located close to cement manufacturing plants. Crushed stone for cement production use the most common elements and compounds found in Earth's crust — calcium, alumina, silica, and iron-and are processed at extremely high temperatures, which creates both very high energy demands and results in carbon dioxide deposition into the atmosphere. Wastes from the intermediate product (called clinker) may also have to be deposited in the environment. These pollutants are sometimes the reason for limits on the permitting of new production, and thus perhaps the available commodity as well. Alternative fuels and materials sources are being investigated and developed.

The public may be even more greatly opposed to aggregates operations than other urban infrastructure development, because people are generally unaware of the cost of the aggregates they use each month. Land-use plans are highly influenced by economic considerations that are applicable to the permitting of quarries as well. Like many industries, aggregates companies require an experienced labor force. Economically depressed communities need infusions of jobs. Though quarries do not generally create a lot of employment, employment does rise in the construction and transportation economic sectors, and the local economy benefits indirectly. Communities may chose to sell their aggregates resources; however, the likely costs of mitigation and remediation measures must be considered as well. A variety of postmining land uses may be considered, but some, like waste storage or nuclear shelters, may be considered undesirable. When possible, the conversion of abandoned quarries to recreational lakes and parks can be a positive reclamation land use.

Pushing mining further away causes the unit price of delivered aggregates to increase. By maintaining adequate local supplies, the cost in local demand markets could be controlled. Local planners should be encouraged to inventory the aggregates supplies and create protection zones so that they can be mined under appropriate permitting processes. Underground mining may be an option in developed areas; in addition to extracting materials, mining leaves space for underground land use. Good community planning can minimize short and long-term environmental impacts of quarrying in multiple land use areas.

\section{Principles of Spatial Accessibility and Interaction Modeling}

A technique to effectively organize and study the problems of the aggregates industry and market as discussed in the first section of this paper, as well as analyzing and testing specific elements or influences in their supply and demand, is a quantitative technique called spatial accessibility and interaction modeling. Spatial interaction modeling analyzes trends, as a result of decisionmaking, in the flow of goods between origins and destinations, and over various types of impediments in the spatial separation between them. Certain conditions must be in place for the modeling of interaction to occur:

(1) There must be a market of product supply and consumer demand that complement each other; there 
must be mutual interests in the commodities to transport,

(2) There are no intervening opportunities along the net work to interfere with the measure of the flow of commodities between origins and destinations, and

(3) The product must be transferable along a network.

Three fundamental assumptions of spatial interaction theory include:

- Favorable conditions for the suppliers at the origins to generate shipments and market conditions at the destination to attract products. The factors involved may be simple, such as aggregate volume, or complex factors, such as economic feasibility.

- Spatial interaction theory assumes a positive relation between volume of flow and population size of origin and destination areas.

- Between the origins and destinations, impedance along a network diminishes the volume and rate of flow. Appropriate measure of impedance may be distance, cost, availability of transport, or time and may be calculated with an equation. The theoretical assumption is that interaction decreases with or is inversely proportional to increasing distance; this is sometimes called distance decay.

These concepts are summarized in the mathematical expression:

production of origin $\times$ attractiveness of destination $(\text { distance })^{2}$

The exponent of the distance represents the average trip length.

A destination point has many attributes that attract the flow of materials or create consumption demand. For aggregates, some of these would be market value, land use, or low risk shipping. An effective way to express destination attractiveness is as an index value that combines all of the factors that make the destination attractive. Shipments result from the properties of the origin to generate the transport of a particular product. Commercial production is sometimes controlled by the expected demand at the market (the destination); the production and flow of aggregates is assumed to be the ability of the industry to produce an affordable product to satisfy consumer demand.

For conventional retailing studies, where consumers travel to make purchases, origins are the points where transportation starts and destinations are the market place where a trip ends, but for aggregates, the quarry will be considered the origin. Demand is the need for a particular type of service or goods; in the case of delivered goods, as for aggregates, it would be calculated at the destination. In this study of aggregates, the point of consumption is the concrete plant or the job site. Supply is the availability of services or goods. For aggregates, this will be calculated at the place of production (fig. 2).

The analysis of the flow of materials takes the form of a network of points of aggregate origin, transportation linkages and nodes connecting to points of development locations. Our perception of the distance of a destination may not match Euclidean distance, because humans tend to view distance with deterrents to movement. Deterrents can be used as a parameter to exaggerate the geometric distance to destinations. That parameter is called the distance decay factor. The impedance of transport is calculated in this study in terms of distance and volume of flow. The chemical or geological qualities of a product can be considered an intervening factor from the distance decay curve of transport cost. Another intervening variable along the relatively simple curve is recycling, although the amount of recycled materials is only a fraction of the total demand.

The equivalency between geographical features, spatial interaction theory, and the Geographical Information System (GIS) data model (ESRI, 2004) is described in table 1.

The selected factors explain much of the variability in the data and could serve as predictive factors. Other variables have an impact on this process, but their incorporation, though important for explanatory purposes, wasn't taken into account for reasons of generalization. This study of aggregates in Chicago is a macro spatial interaction model focusing not on the choices of individuals, but on general trends. The model, as it is outlined in this paper, provides the major measurable, explanatory factors, but not any predictive functions.

\section{Data About Aggregate Diffusion Processes}

Specific attributes of origin attributes for geographical analysis include the prioritization of resources for development according to physical and chemical qualities of aggregates or the desirability for extraction (due to depth or thickness, for example), the economical feasibility of extraction and expected amount of production of aggregates, and societal regulation of extraction activity. The data needed to reflect attributes of origins in the spatial interaction of the aggregates and urbanization include annual production figures, quarry locations, landuse, and geological maps.

The volume of natural aggregates shipping is relative to the required timing, risk factors, cost of transport, labor needs, and transfer points. The assumption of this study is that the Chicago area quarries ship their entire output to the Chicago area (Bhagwat, 2000; Mikulic, Donald, Oral Communication). Concrete plants (and to a lesser degree, cement plants) are considered intervening factors of the diffusion pattern, but ultimately, all aggregates are delivered to the construction site. Local sites that can economically consider recycling of aggregates near the building location are intervening variables as well.

For aggregates, the transportation network in the Chicago area is composed of three modes of transportation - ship/ barge, railroad, and truck. A single mode of transportation, truck, is assumed for the short distances found in the Chicago area. The impedance of transport is calculated in this study simply in terms of distance and volume of flow. The chemical or geological qualities of a product can be considered an 
Table 1. Equivalencies of features in theoretical, geographical, and representational concepts of aggregates studies.

\begin{tabular}{|l|l|l|}
\hline GEOGRAPHY FEATURE & THEORETICAL CONCEPT & GIS DATA MODEL \\
\hline Quarries & Origin & Node \\
\hline Delivery point & Destination & Centers \\
\hline Construction & Demand & Demand \\
\hline Aggregate volume & Supply & Supply \\
\hline Profit & Flow impulse or generation & Production index \\
\hline Development expansion & Flow attraction & Attractiveness index \\
\hline Transportation costs & Distance decay & Impedance \\
\hline
\end{tabular}
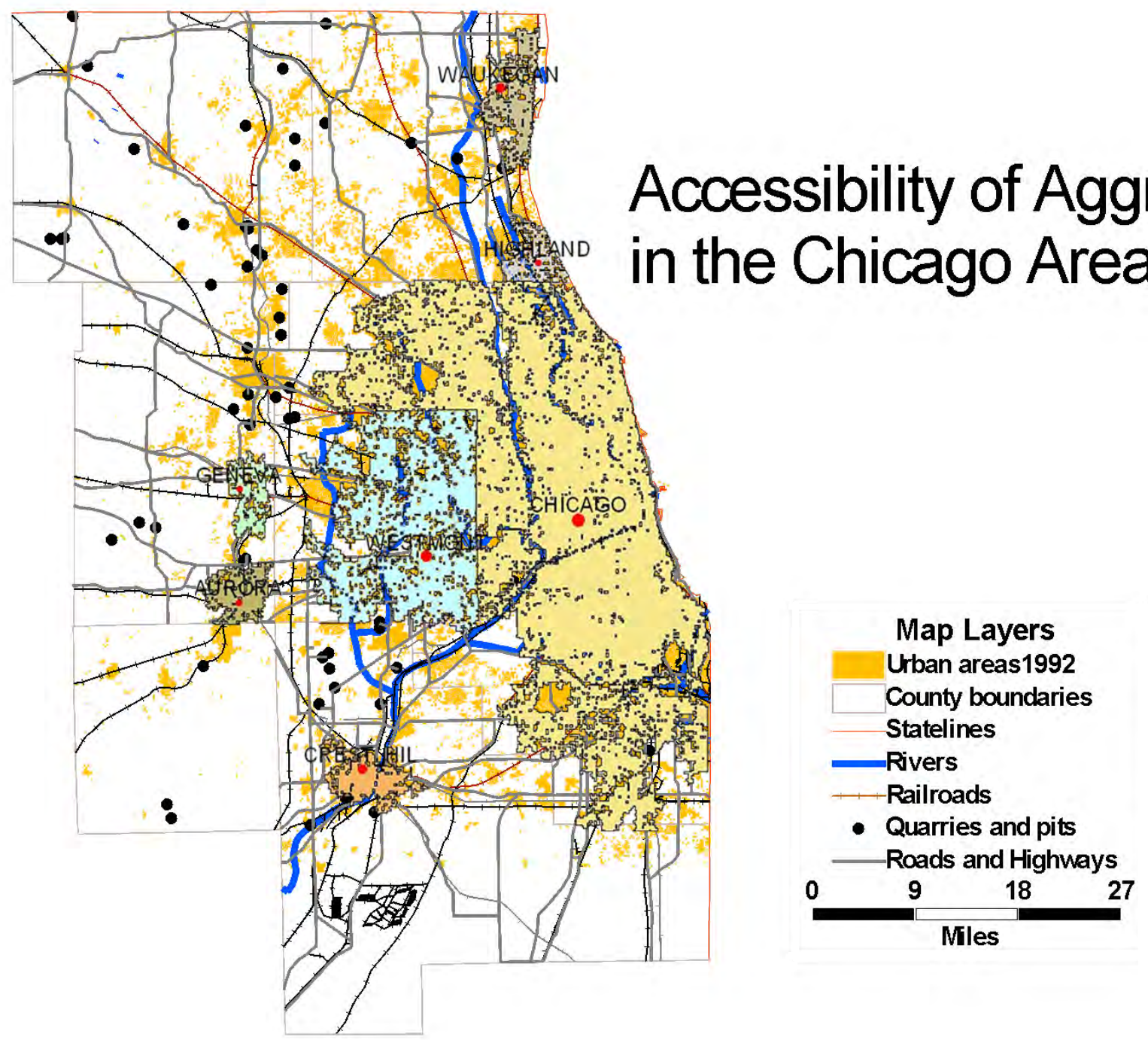

Figure 2. Locations of quarries, pit mines, and centers of urbanization in the Chicago area examined in this study. 
intervening factor from the distance decay curve of transport cost. However, to our advantage, few intervening variables are known that would interrupt the simple curve.

Deciding on data to adequately reflect aggregate demand, or destination points, is more complicated.

Destination attributes include:

- Projection of amounts required for new development and infrastructure maintenance,

- Quantity and type of material demanded,

- Accessibility - past development and future develop ment plans may be curtailing availability by removing surface production, and

- Acceptable economic cost of product.

Destination points were selected to represent urban centers as defined by the U.S. Census Bureau (2004). According to the Census Bureau, an area is urbanized if the population is greater than 50,000 or the population density is greater than 1,000 per square mile. These destination points within the Chicago urban-land-cover polygons were calculated by overlaying population distribution by county on urban-land-cover polygons (U.S. Geological Survey, 2000) and calculating percent population density. The resulting set of points represents a combination of areas of new urban expansion and older areas of the city that would require maintenance of earlier built urban structures. Demographic data can be further refined by incorporating urban social data, including growth plans, employment and travel to work data, household analyses, and building permits, at multiple scales. Measures such as development databases or accounting of Federal funding of urbaninfrastructure projects are strongly related to both demand or consumption quantities and impervious surface. The advantage of using urban-land-cover polygons is that it ties a third variable, area of impervious surface, to urban analysis, which fits better in systematic environmental studies.

\section{The Supply and Demand of Aggregates in the Chicago Area}

The local stone industry has affected the extent and quality of building in Chicago since the inception of the city's settlement, first as building stone and later as crushed stone for concrete in the twentieth century. The historical development of the Chicago infrastructure system can be traced to the transportation of rock outcrops along the Chicago River and the Illinois and Michigan Canal, to supply building materials and the opportunities for employment (Mikulic, 1989).

As the third largest city in the United States, Chicago has massive demand for aggregates. In addition to new construction, freeze/thaw conditions make concrete and asphalt infrastructure short-lived. The distribution of growth for population and employment is estimated by the Northeastern Illinois Planning Commission by requesting growth plans from local municipalities and shows growth to be most likely in Chicago's inner core and older suburbs and in the outer fringe of concentric rings around Chicago. The middle belt, where growth occurred from 1980 to 2000, is expected to have minimal expansion, but growth occurring in the room left between the axial lines of the railroad system (Northeastern Illinois Planning Commission, 1997).

There are two main geologic sources for aggregates in the Chicago area. One is the bedrock that underlies most of the entire Chicago metropolitan region except for the very western edge. Less prominently, the unconsolidated Quaternary glacial overburden produces aggregates as well. The average overburden is about 100 feet thick, but is thickest at the terminal moraines that the glaciers pushed to the western and southern edge of the region. Outcrops of bedrock occur in areas of deep erosion and in places associated with reef deposits. Many quarries are located on these outcrops (Mikulic and Goodwin, 1985).

The fringe area of expected metropolitan expansion and that of the terminal moraines suitable for aggregates extraction would roughly coincide within the time period of the regional growth plan. Existing quarries in the Chicago area have either exhausted their reserves or are limited in potential expansion by urban development. Two possibilities for alleviating this problem have been proposed. First is the recognition that most of the aggregates will have to be imported from further away at a higher cost than was the case in the past. Second, is the potential to exploit existing mines further by extending the mining underground. Additional rock suitable for aggregate exists below geologic layers of other surface land use. Underground mining has proven successful at some quarries and other companies are presently considering this option (Mikulic, 1990).

\section{Interaction Modeling of Aggregates for the Year 1990}

To date, a version of the spatial interaction model has been written as an ESRI-ArcInfo script and used successfully with data about aggregates production volumes in six Chicago area metropolitan counties. The U.S. Bureau of Mines collected aggregates production data until those data functions were transferred to the U.S. Geological Survey (USGS) at the end of 1995 (U.S. Geological Survey, 2004). Yearly production figures and quarry locations data are matched to points of aggregate origin on a transportation network of distribution linkages that connect to centroid points of urbanized areas identified by city name (fig. 3.; particular quarries remain identified by number only). The destination values that are used in computing the potential interactions associated with each of those destinations are derived by creating the population density values of the urban area they represent.

The output from spatial interaction modeling gives us an index of all possible potential interactions between known pairs of origins and destinations, but the numbers are more meaningful if constrained to the known production and destination values. Making the model "production constrained" means that predicted values of interaction starting at the origins equals the production volume (in tons) at the origins. 
Table 2. Spatial interaction output for quarries and urban subcenters in the Chicago metropolitan area.

[City numbers correspond to the urban polygons on the map in figure 2: (1) Waukegan, (2) Highland, (3) Geneva, (4) Chicago, (5) Westmont, (6) Aurora, (7) Crest Hill]

\begin{tabular}{|c|c|c|c|c|c|c|}
\hline \multicolumn{7}{|c|}{ Urbanized Areas } \\
\hline & 1 & 2 & 3 & 4 & 5 & 7 \\
\hline Quarry 1 & 11571, & 4960 & 2986, & 387189, & 47968 & 3720 \\
\hline Quarry 2 & 701 & 496 & 712 & 196827 & 39375,2866, & 78066 \\
\hline Quarry 3 & 12000 & 8774, & 51806, & 1583220 & 298262,33634, & 17888 \\
\hline Quarry 4 & 4311 & 3511, & 4610 & 315763 & 42435,4477 & 2686 \\
\hline Quarry 5 & 128 & 91 & 122 & 36088 & $7248, \quad 481$ & 15182 \\
\hline Quarry 6 & 184 & 133 & 240 & 60075, & 15211,1115 & 5887 \\
\hline Quarry 7 & 160 & 114 & 198 & 49837 & 12058,879 & 4148 \\
\hline Quarry 8 & 51052, & 32445 & 18138 & 2015909, & 251436,22563 & 16985 \\
\hline Quarry 9 & 22479 & 14286 & 7986 & 887625 & 110710, 9935, & 7479 \\
\hline Quarry 10 & 16631 & 8824 & 6426, & 669166, & 87178,8230 & 6387 \\
\hline Quarry 11 & 811 & 615 & 1343 & 75290 & 10805, 1177, & 679 \\
\hline Quarry 12 & 17667 & 13931 & 24254 & 1433937, & 205806,22412 , & 12935 \\
\hline Quarry 13 & 52034 & 17936, & 6314 & 949670 & 104477,8892, & 7595 \\
\hline Quarry 14 & 11759, & 3825 & 941 & 176537, & 18772,1335 & 1152 \\
\hline Quarry 15 & 475 & 320 & 1691, & 103144 & 34189,24535 & 3989 \\
\hline
\end{tabular}
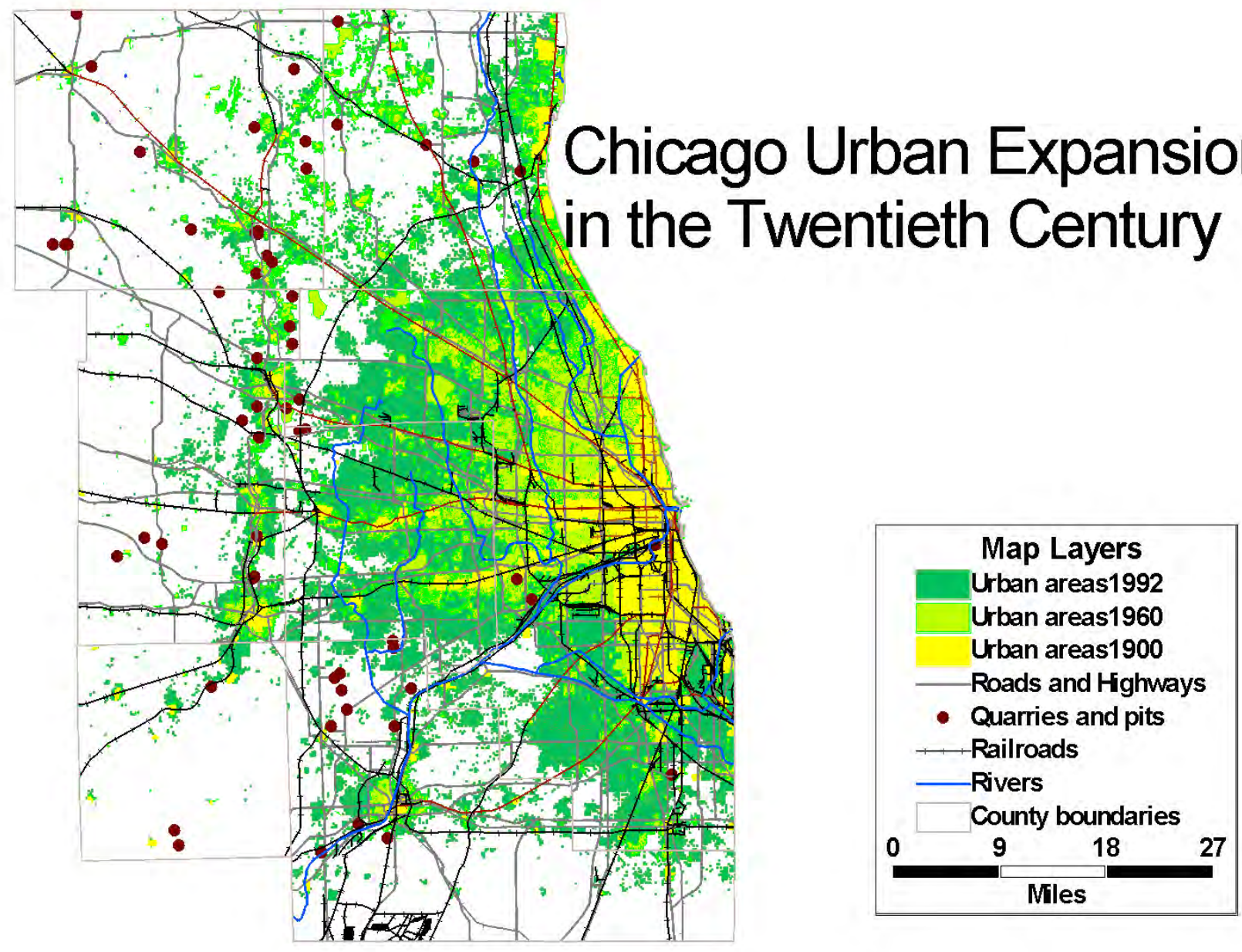

Figure 3. Map showing Chicago as an interaction network of aggregates producers and urban consumption in the 20th century. 
"Demand constrained" means that the predicted index of interactions ending at the destination equals the demand at the destinations, in this case, the demand represented by population density. Either one alone will produce unacceptable outcomes for the other, so we try to balance the interactions to match production and demand values or to be doubly constrained. "Doubly constrained" means that separate variables are selected for both origin and destination, providing they match the same number of flows as observed. When doubly constrained, the volume of interactions will equal the relative volume of production and demand. The spatial interaction model was run, doubly constrained, on total annual production data for 15 quarries and population densities of 7 urban centers (table 2).

The table represents the relative amount of potential or expected interactions in the commercial relationship between each quarry and city pairs. The numbers in the table are a combination of production (origins), population density (destinations), and distance (impedance, or cost). They are not raw values for any geographical feature, but are available for further mathematical calculations, such as averages, percentages, or regression analysis. The table would alter if a new quarry and its expected production were added to the area, increasing the supply of aggregates, or if new urban development and its expected population were considered, making demands for more aggregates that must be supplied from the local market.

\section{Conclusion}

Nationally, the suppliers of aggregates for urban expansion face economic and environmental complexities in extracting and moving the aggregates to the urban market. The aggregates industry and the people involved in urban expansion have mutual interests in planning for the supply of aggregates resources in the future. The problems facing the supply of aggregates for urban expansion can be organized and analyzed using the spatial interaction concept. Tools based on this concept provide both industry and local communities with a quantitative measure for selecting sites for the most effective use of natural aggregates. The USGS has produced such a tool for ESRI ArcInfo software users (Miller, 2004; Tiefelsdorf, 2003). Findings and visualization (adequate tools for the visual presentation of findings) will be completed in future stages of the project.

\section{Acknowledgments}

The technical organization of this research owes a particular debt to the USGS Minerals Information Team, particularly Lucy McCartan, Hendrik van Oss, and V.V. Tepordei. Byron Stone and James O'Neal of the Great Lakes Geological Mapping Coalition offered valuable comments and research support. Thomas Beard, Scott Whittaker, and George C. Miller compiled and analyzed data for mapping and geographic analysis, with data from George Xian and comments from E. Lynn Usery and Jeffrey D. Spooner, all researchers of the Geography Discipline, USGS. This project also benefited from my attendance at the Center for Spatially Integrated Social Science (CSISS), Spatial Accessibility and Interaction Workshop at the Geography Department of Ohio State University in 2003.

\section{References}

Bhagwat, Subhash, 2000, Industrial minerals in illinois-A key to growth: Illinois State Geological Survey, Champaign, Ill.

Drew, Lawrence, 1999, The Megaquarry, A Conversation on the state of the aggregate industry: Geotimes, August 1999, p. 17-22.

ESRI, 2004, Interaction; Arc/Info Help: Redlands, Calif.

Fotheringham, A.S., and O'Kelly, M.E., 1989, Spatial interaction models - Formulations and applications: Amsterdam, Kluwer Academic, 244 p.

Martin, Nathan, Worrell, Ernst, and Price, Lynn, 1999, Energy efficiency and carbon dioxide emissions reduction opportunities in the U.S. cement industry: Ernest Orlando Lawrence Berkeley National Laboratory, University of California, LBNL-44182.

Mikulic, Donald G., 1989, The Chicago stone industry-A historical perspective, in R.E. Hughes and J.C. Bradbury, eds., Proceedings of the $23^{\text {rd }}$ Forum on the Geology of Industrial Minerals: Illinois State Geological Survey Illinois Mineral Note 102, p. 93-99.

Mikulic, Donald G., 1990, Cross section of the Paleozoic rocks of northeastern Illinois - Implications for Subsurface Aggregate Mining: Illinois State Geological Survey, Illinois Minerals 106.

Mikulic, Donald G., The future of urban underground aggregate mining - Examples from Chicago, Indianapolis, and Milwaukee [abs.]: $40^{\text {th }}$ Forum on the Geology of Industrial Minerals Program with Abstracts, Bloomington, Ind., May 2-7, 2004, p. 55-56.

Mikulic, Donald G., and Goodwin, Jonathan H., 1985, Urban encroachment on dolomite resources of the Chicago area, Illinois: Illinois Department of Energy and Natural Resources, State Geological Survey Division Reprint 1986L, reprinted from Glaser, J.D., and Edwards J., eds., Proceedings of the Twentieth Forum on the Geology of Industrial Minerals - Industrial Minerals of the MidAtlantic States. (May 15-18, 1984): 1985, Maryland Geological Survey Special Publication No. 2. p. 125-131.

Northeastern Illinois Planning Commission, 2004, Research and forecast group development database: [http://www.nipc. cog.il.us/dataserv.htm].

Northeastern Illinois Planning Commission, 1997, Population, household and employment forecasts for northeastern Illinios 1990-2020: Chicago, Ill. [http://www.nipc.cog.il.us]. Robinson, Jr., Gilpin R., and Brown, William M., 2002, 
Sociocultural dimensions of supply and demand for natural aggregates - examples from the Mid-Atlantic region, United States: U.S. Geological Survey Open File Report 02-350 [http://pubs.usgs.gov/of/2002/of02-350/].

U.S. Bureau of the Census, 2004, Urban and Rural Definitions: [http://www.census.gov/population/censusdata/urdef.txt].

U.S. Geological Survey, 2004, Minerals resources on-line spatial data: [http://mrdata.usgs.gov/].

U.S. Geological Survey, 2002, Regional assessment of land use change - Land use change in the Chicago/Milwaukee region: [http://landcover.usgs.gov/urban/chicago/intro.php]. Wilburn, David R., and Goonan, Thomas G., 1998, Aggregates from natural and recycled resources, economic assessments for construction applications - A materials flow analysis: U.S. Geological Survey Circular 1176, p. 2 [http://pubs. usgs.gov/circ/1998/c1176/c1176.html].

Wilburn, David R., and Langer, William H., 2000, Preliminary report on aggregate use and permitting along the Colorado Front Range: U.S. Geological Survey Open File Report 00258 [http://pubs.usgs.gov/of/2000/ofr-00-0258/]. 


\title{
Wrestling Sprawl to the Ground-Defining and Measuring an Elusive Concept ${ }^{1}$
}

\author{
By George Galster ${ }^{2}$, Royce Hanson ${ }^{3}$, Michael R. Ratcliffe ${ }^{4}$, Harold Wolman ${ }^{5}$, Stephen Coleman ${ }^{6}$, and \\ Jason Freihage ${ }^{6}$
}

\section{Introduction}

The literature on urban sprawl confuses causes, consequences, and conditions. This article presents a conceptual definition of sprawl based on eight distinct dimensions of land use patterns: density, continuity, concentration, clustering, centrality, nuclearity, mixed uses, and proximity. Sprawl is defined as a condition of land use that is represented by low values on one or more of these dimensions.

\section{A Metaphor Rich in Ambiguity}

Urban sprawl is one name for many conditions. It has been attached to patterns of residential and nonresidential land use, to the process of extending the reach of urbanized areas (UAs), to the causes of particular practices of land use, and to the consequences of those practices. Sprawl has been denounced on aesthetic, efficiency, equity, and environmental grounds and defended on choice, equality, and economic grounds. Sprawl has become the metaphor of choice for the shortcomings of the suburbs and the frustrations of central cities. It explains everything and nothing.

Much of the confusion about sprawl stems from the conflation of ideology, experience, and effects. A term so widely used cannot be easily dismissed as too vague for serious discussion. Many policy makers claim to know it when they see it and make important policy judgments based on what they see or think they see. As a first step

\footnotetext{
${ }^{1}$ Reprinted from George Galster, Royce Hanson, Michael R. Ratcliffe, Harold Wolman, Stephen Coleman, and Jason Freihage, "Wrestling Sprawl to the Ground: Defining and Measuring an Elusive Concept," Housing Policy Debate v. 12, n. 4, p. 681-717. (C2001 Fannie Mae Foundation, Washington, D.C. Used with permission. The remainder of the original article elaborated on the conceptual definitions and was able to operationalize six of the eight dimensions for 13 urbanized areas.

${ }^{2}$ Wayne State University, Detroit, Mich.

${ }^{3}$ University of Maryland, Baltimore County, Baltimore, Md.

${ }^{4}$ U.S. Bureau of the Census.

${ }^{5}$ George Washington University, Washington, D.C.

${ }^{6}$ University of Maryland, Baltimore County, Baltimore, Md.
}

toward developing policies to deal with the causes or consequences of sprawl, it would help both critics and apologists if agreement could be reached on what sprawl is and how to measure it empirically and compare its occurrence across a large number of urban areas.

\section{Sprawling Literature: Lost in a Semantic Wilderness}

Consistent with the findings of others (Burchell and others, 1998), our survey of the literature yielded no common definition of sprawl and relatively few attempts to operationally define it in a manner that would lead to useful comparisons of areas to determine which had experienced greater or less degrees of sprawl. There are two notable recent exceptions: First, Torrens and Alberti (2000) offer sophisticated indices for measuring multiple aspects of sprawl, such as density, scatter, leapfrogging, interspersion, and accessibility, but provide no empirical prototypes. Second, Malpezzi (1999) has undertaken an ambitious effort to develop some precise definitions of several dimensions of sprawl such as density and lack of continuity. Moreover, he has quantified them for a sample of metropolitan areas and related them statistically to determinants of sprawl such as the length of average daily commutes.

Our analysis of the social science and planning literature suggests that definitions of sprawl can be grouped into six general categories:

(1) Sprawl is defined by an example, which is seen to embody the characteristics of sprawl, such as Los Angeles.

(2) Sprawl is used as an aesthetic judgment about a general urban development pattern.

(3) Sprawl is a cause of an externality, such as high dependence on the automobile, isolation of the poor in the inner city, the spatial mismatch between jobs and housing, or loss of environmental qualities.

(4) Sprawl is the consequence or effect of some independent variable, such as fragmented local government, poor planning, or exclusionary zoning.

(5) Sprawl is defined as one or more existing patterns of development. Those most frequently mentioned are low density, leapfrogging, distance to central facilities, dispersion of employment and residential development, and continuous strip development. 
(6) Sprawl is defined as a process of development that occurs over some period of time as an urban area expands.

\section{Definition by Example}

In both the popular and scholarly literature, sprawl is frequently defined by one or more examples of scattered or low-density patterns of urban development. Los Angeles is often given a place of honor in exemplary definitions. Robert Geddes (1997) asserted, "Its key words are fragmented, incomplete, ad hoc, uncentered" (p. 3). Unfortunately, while it is big and spread over a large area, Los Angeles is more densely settled than most large areas in the United States. Atlanta has come to replace it as an example of sprawl, but with the possible exception of Portland, OR, any area is a potential nominee. The flexibility of definition by example makes it possible to include all sorts of development patterns, from planned communities with clustered housing and mixed uses to exurban rural estates. A Wells Fargo Bank report, Preserving the American Dream, concluded that sprawl "receives blame for seemingly every bad aspect of contemporary urban life" (quoted in Myers and Kitsuse 1999, p. 6).

\section{Aesthetic Definition}

Ad hoc examples at least imply and often express an aesthetic judgment: Sprawl is ugly development. In The Language of Cities (1971) Charles Abrams defined sprawl as follows: "The awkward spreading out of limbs of either a man or a community. The first is a product of bad manners, the second of bad planning" (p. 293-94). Even so careful a land economist as Marion Clawson (1962) could not resist judgmental adjectives and adverbs in his definition: "[the] rapid spread of suburbs across the previously rural landscape, tendency to discontinuity, large closely settled areas intermingled haphazardly with unused areas" (p. 94).

\section{The Cause of an Unwanted Externality}

Traffic congestion (Black, 1996; Downs, 1999; Vermont Forum on Sprawl, 1999), environmental contamination (Sierra Club, 1998), income and racial segregation of neighborhoods (Downs, 1998), the mismatch between jobs and housing (Orfield, 1997), local fiscal disparities (Burchell and others, 1998), conversion of farmland to urban uses (U.S. General Accounting Office, 1999), and civic alienation (Popenoe, 1979), among other maladies of contemporary urban life, have been attributed to sprawl. Here the definitions segue from judgments about the appearance of sprawl to assertions of causal links between sprawling land use patterns and environmental, social, and economic costs. But these definitions basically describe what sprawl does (or is supposed to do) rather than what it is.

\section{A Consequence}

Sprawl is also frequently defined as the consequence of something else. Downs (1998), among others (Black, 1996; Burchell and others, 1998; Moskowitz and Lindbloom, 1993; Orfield, 1997), argues that sprawl occurs as a consequence of the fragmentation of control over land use in metropolitan areas. It is unclear whether sprawl is an intentional, necessary, or inadvertent consequence of fragmented governance of growth. In light of development patterns in areas with unified governments, such as Houston and Lexington, KY, it seems a doubtful proposition. In any event, understanding the policies that induce specific development patterns could lead to their correction if there were a clearer specification of what those patterns are.

\section{Selected Patterns of Land Development}

Altshuler and Gomez-Ibanez (1993) edge toward a clearer definition of sprawl by identifying the types of development patterns associated with it: Continuous low density residential development on the metropolitan fringe, ribbon low density development along major suburban highways, and development that leapfrogs past undeveloped land to leave a patchwork of developed and undeveloped tracts. (p. 67)

The inconsistency of continuous and leapfrog development aside, this definition at least characterizes land use conditions, and it is conceivable that continuous development, ribbon development along corridors, and leapfrog development are different forms of sprawl (Harvey and Clark, 1965). Other development patterns frequently characterized as sprawl include low density (Lockwood, 1999), random (GAO, 1999), large-lot single-family residential (Popenoe, 1979), radial discontinuity (Mills, 1980), single land use or physical separation of land uses (Burchell and others, 1998; Cervero, 1991), widespread commercial development (Downs, 1998), strip commercial (Black, 1996; Burchell and others, 1998), and non-compact (Gordon and Richardson, 1997).

\section{A Process of Development}

Finally, some commentators (Ewing, 1997; Harvey and Clark, 1965) suggest that sprawl represents a stage in the development process rather than a static condition. This definition suggests that some parts of an urban area may pass through a sprawl stage before eventually thickening and diversifying so they can no longer be characterized as sprawl, at least by those authors. When used to signify a stage or process of development, sprawl is a verb, rather than a noun connoting a condition. But little is gained by changing the part of speech, for there is little in the literature to indicate when sprawl metamorphoses into nonsprawl. It does, however, suggest that sprawl may represent some range on a development pattern continuum. 
These descriptions of sprawl leave one grasping for something more solid. How far does the development frog have to leap and how light and broad must its footprint be for sprawl to be present? When do land uses thin sufficiently from being compact, centered, or concentrated before they degrade into sprawl? An empirical definition is needed if the discussion is to move from polemics to a common understanding and useful analysis of urban form. Once that is achieved, it should be possible to conduct a better-informed discussion of the forces and factors that cause certain patterns of development and to address the consequences that flow from certain urban forms for different population groups, such as a region's poor.

Conceptually, a thing cannot simultaneously be what it is and what causes it or what it causes. If sprawl is to be a useful concept for describing something important that occurs in urban areas, it must first be reduced to some objective conditions or traits. Some of the characterizations drawn from the literature are too impressionistic for empirical measurement. Others identify conditions, dimensions, or attributes of sprawl that can be operationally defined, among them discontinuous, widespread, or random development; low-density residential or nonresidential development; continuous low-density or strip development; spatially segregated land uses; and dispersed employment centers.

\section{A Conceptual Definition}

As a noun, sprawl implies a condition characterizing an urban area, or part of it, at a particular time. If sprawl is to be measured as a condition of land use, it must be distinguished from other conditions that may well be related to it. On the basis of the descriptions of conditions characterizing it in the literature and amplified by observation and experience, the following conceptual definition is suggested:

Sprawl (n.) is a pattern of land use in a UA that exhibits low levels of some combination of eight distinct dimensions: density, continuity, concentration, clustering, centrality, nuclearity, mixed uses, and proximity.

This definition suggests the possibility that there can be different types of sprawl, consisting of different combinations of these dimensions ${ }^{7}$. It also suggests the possibility of defining sprawl as a process of development by looking at changes in patterns of land use over time, particularly at the periphery.

Emphasizing the pattern of land use distinguishes the condition from its causes or effects. The pattern of land use refers to the arrangement of the built environment for residential and employment activities. Other uses, such as passive or active open space, agriculture, and public facilities and networks, will affect that pattern along some of its dimensions.

${ }^{7}$ In our conceptualization that sprawl is a multidimensional phenomenon, we are consistent with the work of Malpezzi (1999) and Torrens and Alberti (2000).
The UA is a more appropriate unit of analysis than the metropolitan area (MA), which is composed of contiguous counties, some of which may contain large outlying rural areas with population densities far below the minimum UA threshold of 1,000 people per square mile. Including such rural areas can result in exaggeration of some dimensions of sprawl, such as density. Using the census-defined UA alone, however, may exclude semirural development at the urban fringe that some consider the epitome of sprawl. Whatever its limitations, the UA is a well-established construct that captures settlements averaging as few as 2.4 units per acre and the vast majority of all development of the MA. It may ultimately be useful to add to the UA subdivisions that are integrally associated with it, as distinct from established rural homesites and outlying communities located in metropolitan counties. Using the UA alone, however, should provide a reasonable test of the ability of the eight dimensions to characterize the extent of sprawl within it. And if they can, they can also be applied to a carefully delineated larger area.

Despite its disagreements and contradictions, the literature agrees that all development is not sprawl; simply because a UA is larger does not mean that it is more sprawled. Moreover, all sprawl does not have the same characteristics or dimensions. Excluding terms that cannot be easily quantified, such as ugly or excessive, there appear to be several objective dimensions of land use, that, if present at low levels in a UA, can fairly be called sprawl. Therefore, if each dimension of land use pattern is placed on a continuum, the lower the level, the greater the extent of sprawl on that dimension. It would seem fair to characterize UAs with development patterns that score low on all dimensions as experiencing more sprawl than others. Further, the dimensions may be present in different degrees and combinations across many urban areas, making it possible to distinguish different types of sprawl.

Note: Following the publication of this article in 2001, the research team, with assistance from the Urban Dynamics Program of the U.S. Geologic Survey, has engaged in a multiphased project to:

(1) Determine the relative accuracy and economy of using Census and National Land Cover Data Base data in measuring the dimensions of sprawl that were initially operationalized using census data alone,

(2) Improve the definition of the area over which sprawl should be measured,

(3) Develop a typology of sprawl and estimate the effects of each type on environmental, economic and social outcomes such as environmental pollution, traffic congestion, housing prices, income disparities, and racial segregation.

Results of this later research are reported in the following three publications:

Acevedo, W.; Galster, G.; Hanson, R.; Ratcliffe, M.R.; and

Wolman, H., 2002, Patterns and process of sprawl-Phase 1, Final Report to U.S. Geological Survey. 
Wolman, H.; Galster, G.; Hanson, R.; Ratcliffe, M.R.; Furdell, K.; and Sarzynski, A., 2005, The Fundamental Challenge in Measuring Sprawl-Which Land Should be Considered? Professional Geographer.

Cutsinger, J.; Galster, G.; Hanson, R.; and Wolman, H., 2004, Developing Typologies of Urban Sprawl, Unpublished paper delivered at Urban Affairs Association Annual Conference, April 2004.

\section{References}

Abrams, C., 1971, The Language of Cities: N.Y., Viking.

Altshuler, A., and Gomez-Ibanez, J.A., 1993, Regulation for Revenue: The Political Economy of Land Use Exactions, Washington, D.C., Brookings Institution.

Black, T.J., 1996, The Economics of Sprawl, Urban Land, v. 55 , no. 3, p. 6-52.

Burchell, R.W., Shad, N.A., Listokin, D., Phillips, H., Downs, A., Siskin, S., Davis, J.S., Moore, T., Helton, D., Gall, M., and ECONorthwest, 1998, Costs of Sprawl-Revisited: Washington, D.C., National Academy Press.

Cervero, R., 1991, Land use and travel at suburban activity centers: Transportation Quarterly, v. 45, n. 4, p. 479-91.

Clawson, M., 1962, urban sprawl and speculation in suburban land: Land Economics, v. 38, n. 2, p. 94-111.

Downs, A., 1998, How America's cities are growing-The big picture: Brookings Review, v. 16, n. 4, p. 8-12.

Downs, A., 1999, Some realities about sprawl and urban decline: Housing Policy Debate, v. 10, n. 4, p. 955-74.

Ewing, R., 1997, Is Los Angeles-style sprawl desirable?: Journal of the American Planning Association, v. 63, n. 1, p. 107-26.

Geddes, R., 1997, Metropolis unbound-The sprawling American city and the search for alternatives: American Prospect, v. 8, n. 35, p. 40 [accessed September 2001, http://www. prospect.org/v8/35/geddes-r.html].

Gordon, P., and Richardson, H.W., 1997, Are compact cities a desirable planning goal?, Journal of the American Planning Association, v. 63, n. 1, p. 89-106.

Harvey, R.O. and Clark, W.A.V., 1965, The nature and economics of sprawl: Land Economics, v. 41,n. 1, p. 1-9.

Lockwood, C., 1999, Sprawl: Hemispheres, September, p. 82-91.

Malpezzi, S., 1999, Estimates of the measurement and determinants of urban sprawl in U.S. metropolitan areas: University of Wisconsin, Madison, WI, Center for Urban Land Economics Research, unpub. paper.

Mills, D.E., 1980, Growth, speculation, and sprawl in a monocentric city, Journal of Urban Economics, v. 10, p. 201-26.

Moskowitz, H.S., and Lindbloom, C.G., 1993, the new illustrated book of development definitions: New Brunswick, NJ, Rutgers University, Center for Urban Policy Research.

Myers, D, and Kitsuse, A., 1999, The Debate over the Future Density of Development: Lincoln, NE, Lincoln Institute of Land Policy, working paper.

Orfield, M., 1997, Metropolitics_-A regional agenda for community and stability: Washington, DC, Brookings Institution, and Cambridge, MA, Lincoln Institute of Land Policy.

Popenoe, D., 1979, Urban sprawl—Some neglected sociology: Sociology and Social Research, v. 31, n. 2, p. 181-88.

Sierra Club, 1998, Sprawl-The dark Side of the American dream: [accessed September 2001, http://www.sierraclub. org/sprawl/report98/].

Torrens, P.M., and Alberti, M., 2000, Measuring sprawl: University College, London, Center for Advanced Spatial Analysis, unpub. Paper No. 27.

U.S. General Accounting Office, 1999, Community development - Extent of Federal influence on "urban sprawl" is unclear: Letter Report, April 30, GAO/RCED 99-87. Washington, DC.

Vermont Forum on Sprawl, 1999, Sprawl defined: [accessed September 2001, http://www. vtsprawl.org/sprawldef.htm]. 


\title{
Measuring Urban Sprawl and Extent through Multitemporal Imperviousness Mapping
}

\author{
By George Xian' ${ }^{1}$ Limin Yang ${ }^{2}$, Jacqueline M. Klaver ${ }^{1}$, and Nazmul Hossain ${ }^{1}$
}

\section{Introduction}

Urbanization and urban sprawl continues to spread through the United States. This land consumptive pattern of suburban growth has dominated the American landscape since Word War II. Urban land cover and land use (LCLU) have many significant impacts on the urban environment (Kirtland and others, 1994). Accurate and updated information on the status and trends of urban ecosystems is needed to develop strategies for sustainable development and to improve the livebility of cities. The ability to monitor urban LCLU changes is highly desirable by local communities and by policy decision makers alike. With increased availability and improved quality of multispatial and multitemporal remote sensing data, as well as new analytical techniques, it is now possible to monitor urban LCLU changes and urban sprawl in a timely and cost-effective fashion.

Many efforts have been made to develop of change detection methods using remote sensing data (see for example, Singh 1989; Kam, 1995; Ridd and Liu 1998; Sohl, 1999; Jensen, 1996; Seto and Liu, 2003). The most commonly used change detection methods are spectrally based (image to image) and classification based (map to map) (see for example, Green and others, 1994: Yang and Lo, 2002; Loveland and others, 2002). Urban change studies using Landsat Multispectral Scanner (MSS) or Landsat Thematic Mapper (TM) data have been conducted either at regional scales encompassing several urban areas (Todd, 1977; Royer and others, 1988) or a single metropolitan area (Gomarasca and others, 1993; Johnston and Watters, 1996). Recently, long term urban LCLU changes (over two decades or longer) have been studied using the methodology of post-classification comparison using the Landsat archive as a baseline data source (Chen and others, 2002; Yang and Lo, 2002; Loveland and others, 2002).

Detection of land-cover change in urban and suburban areas using remote sensing technique faces great challenges. Urban areas are heterogeneous and most pixels of urban images consist of a mixture of different surfaces. For instance, pixels that were classified as residential might vary between 20 percent and 100 percent in their impervious surface, and they might vary between 0 percent and 60 percent in their 57198

SAIC, U.S. Geological Survey, Center for EROS, Sioux Falls, SD

${ }^{2}$ Joint Laboratory for GeoInformation Science, The Chinese University of Hong Kong, Shatin, N.T. Hong Kong. tree canopy coverage (Clapham, 2003). Only recently, urban change studies using remotely sensed data have begun to explicitly account for non homogeneity at the sub-pixel level, providing quantifiable measurements for detecting changes ( $\mathrm{Ji}$ and others, 1999; Ward and others, 2000; Flanagan and Civco, 2001, Yang and others., 2003a; Goetz and others, 2004)

We have recently developed a change detection methodSub-pixel Imperviousness Change Detection (SICD) (Yang and others, 2003b) - to spatially quantify urban LCLU changes using remote sensing data in an objective and repeatable way. The method uses high-spatial-resolution imagery as training data in representing urban land-cover heterogeneity and medium resolution Landsat images to extrapolate imperviousness over large spatial areas. The research work presented in this paper describes further applications of the SICD method in urban change detection of two metropolitan areas in the United States.

\section{Study Areas and Landsat Data}

Urban land-cover change of two study areas were tested using the SICD method. The first area covers the western portion of the state of Georgia, extending southwest from the Atlanta metropolitan area to the cities of Columbus and Albany. The other area is in northern and central Florida. Major cities in this area include Tampa and St. Petersburg. For each study area, Landsat-5 TM and Landsat-7 Enhanced Thematic Mapper Plus (ETM+) data of two path/rows ( 180 $\mathrm{km}$ from east to west and $\sim 350 \mathrm{~km}$ from north to south) were obtained, including two dates acquired for Atlanta and four dates for Florida during the 1990 to 2002 time period (table 1).

All images were preprocessed by the U.S. Geological Survey (USGS), Center for Earth Resources Observation and Science (EROS) using standard methods (Irish, 2000), including (1) radiometric and geometric calibration and terrain correction, (2) conversion from digital number to at-satellite reflectance in order to correct for changing illumination geometry (for six reflective bands), (3) reprojection to Albers Equal Area, and (4) resampling to 30-meter resolution using cubic convolution. After initial preprocessing, tasseled-cap brightness, greenness, and wetness were derived using at-satellite reflectance-based coefficients according to Huang and others (2002).

Another important preprocessing step for change detection analysis is the radiometric normalization among images 
Table 1. Study areas and selected Landsat TM/ETM+ images used for this study.

\begin{tabular}{lcccccc}
\hline Location & Path & Row & Date 1 & Date 2 & Date 3 & Date 4 \\
\hline Atlanta, Ga. & 19 & 36 & $3 / 9 / 1993$ & $3 / 11 / 2001$ & & \\
& 19 & 37 & $3 / 9 / 1993$ & $3 / 11 / 2001$ & & \\
Tampa, Fla. & 17 & 40 & $10 / 2 / 1990$ & $5 / 22 / 1994$ & $10 / 21 / 2000$ & $5 / 4 / 2002$ \\
& 17 & 41 & $10 / 2 / 1990$ & $5 / 22 / 1994$ & $10 / 21 / 2000$ & $5 / 4 / 2002$ \\
\hline
\end{tabular}

acquired from different dates. Although we were able to obtain cloud-free images near an anniversary date, which greatly reduces the phenology differences and changes related to sunsensor-target geometry, some of the changes between each image pair could arise from changes in atmospheric conditions and slightly different sensor characteristics between TM and $\mathrm{ETM}+$ arising from longterm degrading of the TM sensor. To correct the potential bias caused by the sensor differences and their calibration, we first converted the digital number of Landsat 5 TM (DN5) to a pseudo Landsat 7 ETM+ DN (DN7) using calibration coefficients developed by Vogelmann and others (2001). The coefficients were derived using an analysis of tandem data sets of the Landsat 7 and Landsat 5 collected over the central United States. This conversion was made to take advantage of the superior radiometric calibration of the $\mathrm{ETM}+$. The conversion equation is DN7 $=\mathrm{DN} 5 *$ slope + intercept. The slope and intercept values are shown in table 2 for all six spectral bands.

After Landsat-5 data were converted to pseudo ETM+ DN (DN7), the remaining processing steps were the same as those applied to ETM+ data. Correction of atmospheric effects using absolute radiometric normalization was not possible for this study due to the lack of in-situ measurements needed for characterizing the atmospheric conditions of optical depth, water vapor content, and aerosols.

\section{Method}

A physical parameter, "anthropogenic impervious surface" defined as the impenetrable surfaces, such as rooftops, roads, and parking lots, was used as an indicator to identify the spatial extent and intensity of urban development. This parameter was chosen because the amount and change of impervious surfaces are likely linked to the major urban land-cover types and their changes. Indeed, imperviousness can be used as a key environmental indicator for urbanization and urban sprawl (see for example, Arnold and Gibbons, 1996; Clapham, 2003). The spatial extent and changes of impervious surfaces impact urban climate by altering sensible and latent heat fluxes within the urban surface and boundary layers. Development of impervious surfaces within a drainage basin increases the frequency and intensity of downstream runoff and decreases water quality (Schueler, 1994).
Table 2. Coefficients for conversion of Landsat 5 TM DN to Landsat 7 $\mathrm{ETM}+\mathrm{DN}$.

\begin{tabular}{c|cc}
\hline Band & Slope & Intercept \\
\hline 1 & 0.9398 & 4.2934 \\
2 & 1.7731 & 4.7289 \\
3 & 1.5348 & 3.9796 \\
4 & 1.4239 & 7.032 \\
5 & 0.9828 & 7.0185 \\
7 & 1.3017 & 7.6568 \\
\hline
\end{tabular}

The SICD is an objective and simple method to quantify urban LCLU changes through mapping imperviousness at different points in time. The methodology as it is illustrated in figure 1 includes several components: (1) training/validation data development, (2) predictive variable selection, and initial regression tree modeling and assessment, (3) spatial modeling and mapping, and (4) imperviousness change detection and interpretations.

\section{Reference Data Development for Sub-Pixel Imperviousness Mapping}

It is important to select a reference data source in order to derive an accurate training dataset for tree models. The Digital Orthrophoto Quarter Quadrangles (DOQQs) of the late 1990s produced by the USGS were utilized to derive training data and testing for imperviousness mapping. The DOQQs were scanned from the color infrared photographs acquired from the National Aerial Photography Program. Each DOQQ has three bands - green, red and near infrared — with a nominal spatial resolution of 1-meter.

For the western Georgia study area, three DOQQ images were selected for deriving the training/reference data, one within southern Atlanta, Georgia and two within Columbus, Georgia. Four DOQQs - central St. Petersburg, northern St. Petersburg, Tampa, and southern part of Tampa-were used for the Tampa Bay, Florida, area. These DOQQs were selected to capture the spectral and spatial variability of impermeable surfaces due to differences in building materials, ages, surface colors, and spatial orientation in and around the urban areas. Areas where observed land-cover changes occurred between the acquisition of the DOQQs and the TM/ETM+ images were excluded from the training dataset. All DOQQ images were reprojected to Albers Equal Area projection to register to the Landsat imagery. Visual inspection showed that the co-registration uncertainty between the DOQQ and the TM/ETM+ images were within 10 meters.

Six broad land cover classes - impervious surface, trees, grass, water, barren, and shadow-were differentiated on all DOQQ images. The classification was made through an unsu- 
pervised method. The preliminary classification was further refined by screen digitizing and recoding to achieve specified classification accuracy (greater than 85 percent). The shadow class was excluded from the following calculation of imperviousness because the class could not be unambiguously merged with any single land-cover class.

Pixels classified as impervious surface in 1-meter grids from the DOQQ were utilized to calculate the impervious surface percentage for each Landsat pixel. The result was a 30-m resolution raster image of imperviousness.

\section{Regression-Tree Modeling}

A regression tree algorithm was utilized to model subpixel percent imperviousness. The regression tree conducts a binary recursive partitioning and produces a set of rules and regression models to predict a target variable (percent imperviousness) based on training data. Each rule set defines the conditions under which a multivariate linear regression model is established for prediction (Breiman and others, 1984). In the partitioning process, each split is made such that the model's combined residual error for the two subsets is significantly lower than the residual error of the single best model (Huang and Townshend, 2003). The main advantage of the regression

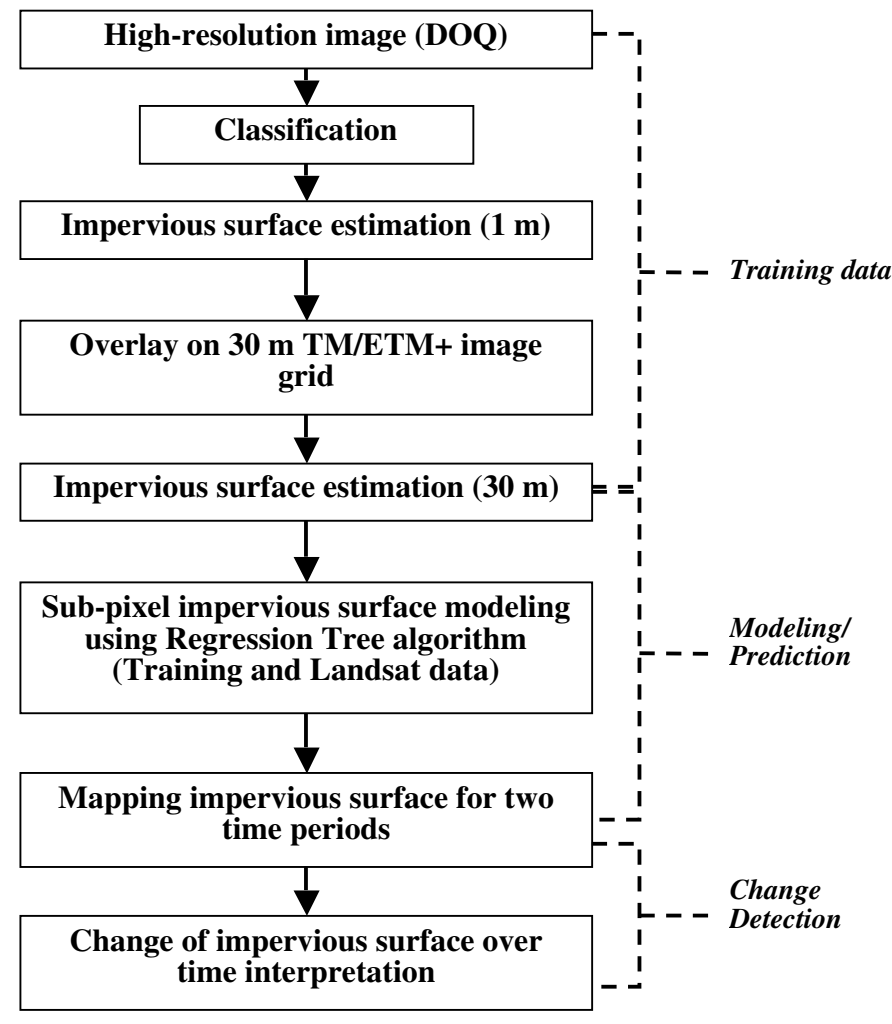

Figure 1. The procedure for impervious-surface mapping and change detection using remote-sensing data and a regression-tree model. tree algorithm is that it can account for a non-linear relationship between predictive and target variables, and allows both continuous and discrete variables to be used as input (predictive) data. Cubist (http://www.rulequest.com) is the regression tree program used in this study. This program has some advanced features, including pruning, committee models, and instance models.

The predicted percent impervious surface attributed to each pixel was evaluated using independent test data. Ideally, the test data should be collected from fieldwork based on a statistical sampling design. Due to time and resource constraints, 1-meter spatial resolution DOQQ was selected as the best option for providing the spatial resolution necessary to accurately determine impervious surfaces in our study areas. Impervious estimates derived from the 1-meter DOQQ were used for model evaluation. To ensure the validity of the assessment, all test data (pixels) were selected randomly and independently from the training dataset.

\section{Results}

Final products generated using the SICD include (1) spatial estimates of subpixel percent imperviousness at 30-meter resolution for western Georgia and Tampa Bay, as well as the impervious surface change over several points in time, and (2) error estimates of regression tree predicted imperviousness through validation. Over western Georgia, the average absolute error of the 1993 impervious prediction (by comparing model prediction against "true" values from the test data derived from $1 \mathrm{~m}$ DOQQs) was 16.4 per cent, and the correlation coefficient $(r)$ was 0.73 . For the 2001 impervious prediction, the average absolute error was 15.3 percent and $r$ was 0.78. For Florida implementation, the average absolute error of the impervious prediction ranges from 10 to 12 percent, and the correlation coefficient $(r)$ ranges from $0.70-0.80$ for $1991-2002$ prediction. The absolute accuracy of the change products can be affected by several factors, including relative image normalization among all images of different years, presence of small cloud/cloud shadow patches, use of a single date image for predicting imperviousness, and the uncertainty/error in the training data. The accuracy estimates reported here were based on evaluation of imperviousness prediction for each individual time period. No direct assessment was made to evaluate the quality of the change product due to the lack of ground-truth data for each time period from 1990 to 2002.

\section{Western Georgia}

The spatial patterns of the predicted percentage of imperviousness over western Georgia were reasonable. As was expected, all urban centers and the immediate surroundings located in and around the Atlanta metropolitan area were identified as the medium-to-high imperviousness. The rate of 
urban land cover change over metropolitan Atlanta (areas with an increase of percent imperviousness greater than 10 per cent from 1993 to 2001) was 7.5 percent. This estimate may be a little aggressive by including all areas with 10 per cent increase or higher, considering that the uncertainty of the regressiontree prediction was within the same order of magnitude $(\sim 10$ percent). By restricting changed areas to at least a 20 per cent increase, the change rate became 4.0 percent. This is similar to a 3.5 percent increase reported by Yang and Lo (2002) based on area of increased low and high-intensity urban land use derived from 1992 and 1997/98 Landsat data within an area that is slightly different from our study coverage.

Another area of interest is in the Fort Benning military training base and the adjacent city, Columbus, Georgia. The military installation is located in the lower Piedmont Region in western-central Georgia. Its immediate neighbors include Columbus, Georgia, and Phoenix City, and Alabama. Over time, urban development in those areas has influenced the military community's ability to maintain their mission focus. Conversely, the military installations affected the local community by alteration of land cover/use and other training activities. The SICD method identified LCLU changes in 1990s due

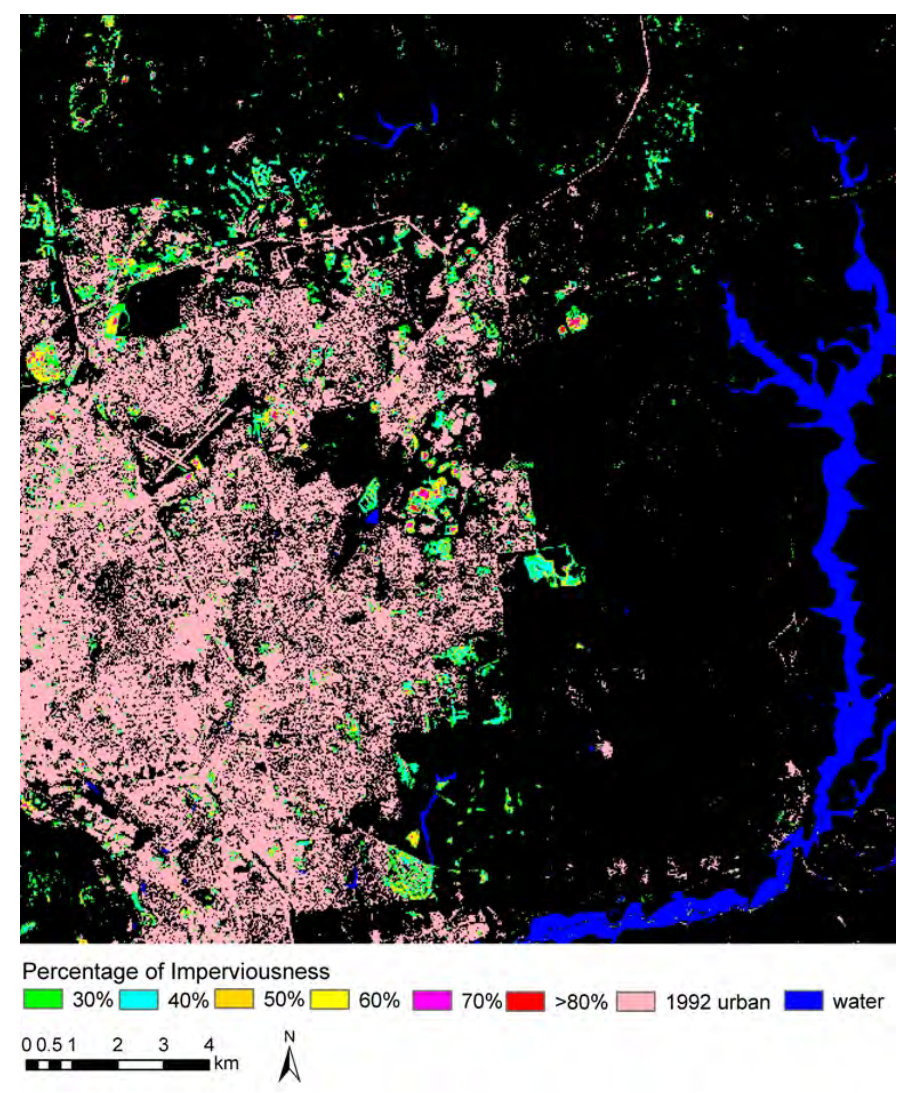

Figure 2. Imperviousness variations from 1993 to 2001 near Columbus, Georgia. The urban extent in 1992 was extracted from U.S. Geological Survey National Land Cover Dataset 1992. Most new development occurred on the fringe of the city. to continued urban development, as well as land cover changes within and around the military installation.

Figure 2 presents the difference of sub-pixel imperviousness between 1993 and 2001 with the background of urban extent obtained from the 1992 USGS National Land Cover Dataset. The map illustrates many LCLU changes in this area including some residential growth near the fringe of Columbus. Most of the noticeable change (change greater than 30 percent) occurred in the eastern and northern edges of the city. Several change patches on the eastern side showed greater than 70 percent change. New urban developments after 1992 were also detected. The spatial extent and the magnitude of changes of the impervious surface provide useful information to assess the interactions between the military installation and nearby cities.

\section{North and Central Florida}

Florida has experienced a rapid rate of population growth since 1945. Its eastern and western coasts have attracted many people to live in the area. More than 2 million people now live within the Tampa Bay watershed, and the population continues to grow. The urban extent indicated by zoning information in the Tampa Bay watershed area increased about 117 percent from 19,617 to 42,623 hectares (ha) from the 1940 s to 1960 s. Most of the growth occurred in Pinellas and Hillsborough Counties where population increased about 148 percent and 158 percent, respectively, from 1960 to 2001 . Recent census data show that population starts to increase in the north Florida area between 1990 and 2000. Increased development has resulted in high pressure for demand of more fresh water and better air quality. The continued anthropogenic alterations in the area have changed land cover and land use over the past 50 years. The mapped imperviousness over several points in time provides a unique dimension showing changes of land cover and land use from 1990 to early 2000 in the Tampa Bay and its surrounding areas. An interesting example of such change is seen in Hillsborough County and City of Tampa, Florida. Significant development of residential and recreational areas along major roads from 1991 to 2002 was reflected by the detected increase of imperviousness on the northern side of Tampa (fig. 3). The significant growth has received much attention by the local communities. According to the Hillsborough County Planning Agency, Hillsborough County is facing pressures from accelerated growth that threatens established areas, constrains public facilities and services and impacts natural resources. Overall, this impervious surface change highlights new urban developments in the area. The urban sprawl is highly aggregated around many cities.

\section{Discussion and Conclusions}

Studies presented in this paper demonstrate that use of the SICD can detect urban land-cover changes by quantifying 
subpixel percent imperviousness over time using Landsat and high-resolution imagery. The SICD provides necessary spatial details to detect changes of urban land cover. Compared to conventional urban change detection methods (band differencing, ratioing, change vector, post-classification and others), change detection through sub-pixel percent imperviousness mapping provides more information on the spatial extent and the intensity of urban LCLU change. This approach is more flexible and captures heterogeneity of urban land cover characteristics. In addition, the SICD is repeatable once training data are developed.

The information on intensity of urban land-cover change provided by percent imperviousness may help to infer the type of land use changes. For instance, where the imperviousness change over two time periods exceeds 80 percent, it is likely that the area has undergone a significant land-use change from rural land-use (for example, forest, agricultural, grassland) to a high-intensity urban land use (for example, commercial and industrial development), whereas a much lower amount of change (less than 20 percent) near an urban rural fringe is likely related to newly developed residential land use. A conceptual framework presented in Yang and others. (2003b) illustrates that the magnitude of change in percent imperviousness over time could be correlated to type and intensity of urban rural LCLU changes. In addition, the change product generated by this approach allows users to define and interpret land cover/use changes based on their own definition (e.g. change above certain percentage). It should be noted that the change product generated by this method has some limitations. Due to the uncertainty of the predicted imperviousness (around 10 to 15 percent), a 15 percent or less increase in imperviousness may or may not reflect actual changes within the study areas. This uncertainty poses a detail limit to the product generated using this method. With regard to potential applications of the impervious surface products other than urban land-use change detection, timely and spatially explicit imperviousness change data can help urban-land managers in their decision making and implementation of strategies for today's complex urban growth issues. Another application is in field of urban ecological modeling. Geospatial data of impervious surfaces and its change can be used not only as an indicator for water quality but also as a critical input data set for urban hydrological modeling. The data can also be used to quantify the land atmosphere interaction within urban climate system. Finally, quantification of urban development through mapping change of impervious surface provides useful data for urban dynamic simulation through model calibration and validation (Jantz and others, 2003).

\section{Acknowledgments}

This research was made possible in part by SAIC under USGS contract 03CRCN0001. Part of the work was funded by the Strategic Environmental Research and Development Program (SERDP) through project number 1257. We wish to thank Zheng Zhang, Joyce Fry, and Mark Driscoll for preprocessing Landsat data used in this study.

\section{References}

Arnold, C.A., Jr., and Gibbons, C.J., 1996, Impervious surface coverage - the emergence of a key urban environmental

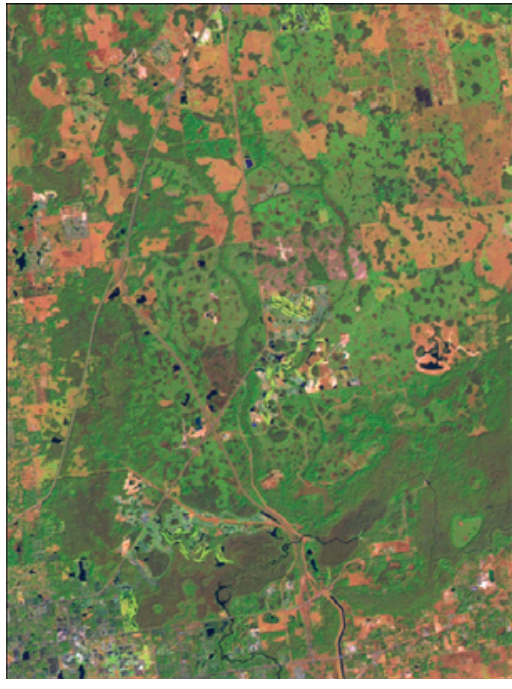

1991

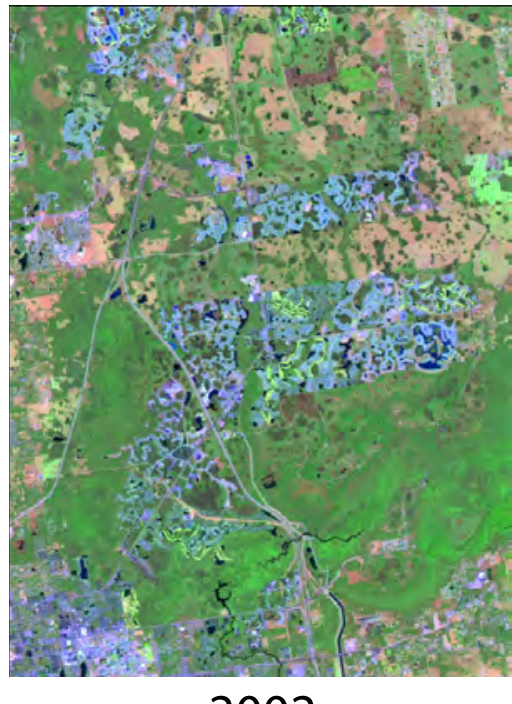

2002

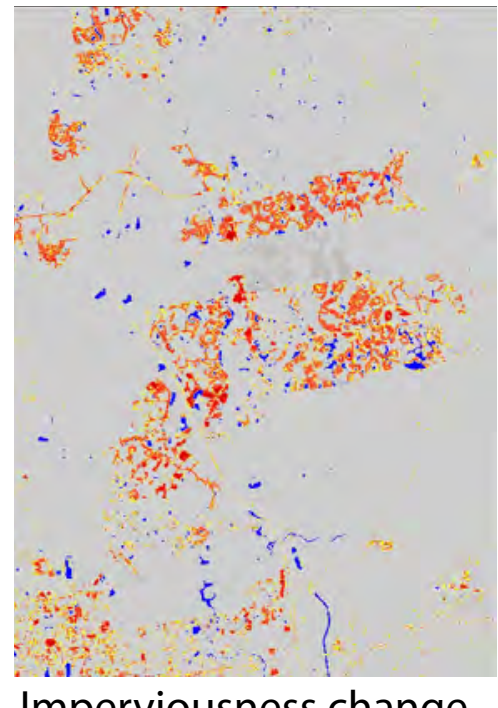

Imperviousness change

(1991-2002)

Figure 3. Comparison of Landsat imagery and mapped impervious surface change near Tampa, Florida (2002 prediction subtracts 1991 prediction). Landsat images in 1991 and 2001 are on the left and middle, respectively. The right image is the imperviousness change from 1991 to 2002. 
indicator: Journal of the American Planning Association, v. 62, no. 2, p. 243-258.

Breiman, L., Friedman, J., Olshen, R and Stone, C, 1984, Classification and Regression Trees: New York, Chapman and Hall, $358 \mathrm{p}$.

Chen, J., Gong, P., He, C., Luo, W., Tamural, M., and Shi, P., 2002, Assessment of the urban development plan of Beijing by using a CA-based urban growth model: Photogrammetric Engineering and Remote Sensing, v. 68, no. 10, p. 1063-1071.

Clapham, W.B., Jr., 2003, Continuum-based classification of remotely sensed imagery to describe urban sprawl on a watershed scale: Remote Sensing of Environment, no. 86, p. 322-340.

Flanagan, M., and Civco, D.L, 2001, Subpixel Impervious Surface Mapping: Proceedings, 2001 ASPRS Annual Convention, St. Louis, Mo., April 23-27, CD-ROM.

Goetz, S.J., Schaub, E., Wright, R.K., Smith, A.J., Zinecker, E., 2004, IKONOS imagery for resource management-Tree cover, impervious surfaces, and riparian buffer analyses in the mid-Atlantic region: Remote Sensing of Environment, v. 88, no. 1-2, p. 195-208.

Gomarasca, M. A., Brivio, P. A., Pagnoni, F., and Galli, A., 1993, One century of land use changes in the metropolitan area of Milan ( Italy): International Journal of Remote Sensing, no. 14, p. 211-223.

Green, K., Kempka, D., and Lackey, L., 1994, Using remote sensing to detect and monitor land-cover and land-use change: Photogrammetric Engineering and Remote Sensing, no. 60, p. 331-337.

Huang, C., and Townshend, J.R.G., 2003, A stepwise regression tree for nonlinear approximation-Applications to estimating subpixel land cover: International Journal of Remote Sensing, no. 1, p. 75-90.

Huang, C., Wylie, B., Yang. L., Homer, C. and Zylstra, G., 2002, Derivation of a tasseled cap transformation based on Landsat 7 at-satellite reflectance: International Journal of Remote Sensing, no. 23, p. 1741-1748.

Irish, R.R., 2000, Landsat 7 science data user's handbook: National Aeronautics and Space Administration Report 43015-01-003-0, [http://tpwww.gsfc.nasa.gov/IAS/handbook/ handbook_toc.html].

Jantz, C.J, Goetz, S.J., and Shelly, M., 2003, Using the SLEUTH Urban growth model to simulate the impacts of future policy scenarios on land use in the Baltimore-Washington metropolitan area: Environment and Planning (B), no. 30, p. 251-271.

Jensen, J. R., 1995, Introductory Digital Image Processing - a remote sensing perspective New Jersey: Prentice-Hall, p. 316.

Ji, M.H., and Jensen, J.R. 1999, Effectiveness of Subpixel Analysis in Detecting and Quantifying Urban Imperviousness from Landsat Thematic Mapper Imagery: Geocarto International, v. 14, no. 4, p. 31-39.

Johnston, A., and Watters, T. R., 1996, Assessing spatial growth of the Washington metropolitan area using Thematic Mapper data: [http://www.nasm.edu:2020/CEPSDOCS/wash/washdc1. html].
Kam, T. S., 1995, Integrating GIS and remote sensing techniques for urban land-cover and land-use analysis: Geocarto International, no. 10, p. 39-49.

Kirtland, D., Gaydos, L., Clarke, K, DeCola, L., Acevedo, W., and Bell, C., 1994, An analysis of human-induced land transformations in the San Francisco Bay/Sacramento area: World Resources Review, v. 6, no. 2, p. 206-217.

Loveland, T.R., Sohl, T.L., Stehman, S.V., Gallant, A.L., Sayler, K.L., and Napton, D.E., 2002, A strategy for estimating the rates of recent United States land-cover changes: Photogrammetric Engineering and Remote Sensing, v. 68, no. 10, p. 1091-1099.

Ridd, M. K., and Liu, J. J., 1998, A comparison of four algorithms for change detection in an urban environment: Remote Sensing of Environment, no.63, p.95-100.

Royer, A., Charbonneau, L., and Bonn, F., 1988, Urbanization and Landsat MSS albedo change in the Windsor-Que' bec corridor since 1972: International Journal of Remote Sensing, no. 9, p. 555-566.

Schueler, T.R., 1994, The importance of imperviousness: Watershed Protection Techniques, v. 1, no. 3, p. 100-111.

Seto, K., and Liu, W., 2003, Comparing ARTMAP neural network with the maximum-likelihood classifier for detecting urban change: Photogrammetric Engineering and Remote Sensing, v. 69, no. 9, p. 981-990.

Singh, A., 1989, Review article - digital change detection techniques using remotely-sensed data: International Journal of Remote Sensing, no. 10, p. 989-1003.

Sohl, T.L., 1999, Change analysis in the United Arab EmiratesAn investigation of techniques: Photogrammetric Engineering and Remote Sensing, v. 65, no. 4, p. 475-484.

Todd, W. J., 1977, Urban and regional land use change detected by using Landsat data: U.S. Geological Survey Journal of Research, no. 5, p. 527-534.

Vogelmann, J.E., Helder, D., Morfitt, R., Choate, M.J., Merchant, J.W., and Bulley, H., 2001, Effects of Landsat 5 Thematic Mapper and Landsat 7 Enhanced Thematic Mapper Plus radiometric and geometric calibrations and corrections on landscape characterization: Remote Sensing of Environment, no. 78 , p. $55-70$.

Ward, D., Phinn, S.R., and Murry, A.T., 2000, Monitoring Growth in Rapidly Urbanized Areas using Remotely Sensed Data: Professional Geographer, v. 52, no. 3, p. 371-386.

Yang, L., Huang, C., Homer, C.G., Wylie, B.K., and Coan, M.J., 2003a, An approach for mapping large-area impervious surfaces - Synergistic use of Landsat 7 ETM+ and high spatial resolution imagery: Canadian Journal of Remote Sensing, v. 29, no. 2, p. 230-240.

Yang, L., Xian, G., Klaver, J.M., and Deal, B., 2003b, Urban land-cover change detection through sub-pixel imperviousness mapping using remotely sensed data: Photogrammetric Engineering and Remote Sensing, v. 69, no. 9, p. 1003-1010.

Yang, X., and Lo, C.P., 2002, Using a time series of satellite imagery to detect land use and land cover changes in Atlanta, Georgia metropolitan area: International Journal of Remote Sensing, no .9, p. 1775-1798. 


\title{
An Assessment of Impervious-Surface Measurement Methods
}

\author{
By E. Terrence Slonecker ${ }^{1}$ and Janet S. Tilley ${ }^{2}$
}

\section{Introduction}

Over the past decade, impervious-surface coverage has emerged as one of the most important factors in the assessment of environmental condition. The amount of impervious-surface cover in a watershed has been established as an important indicator of water quality and aquatic ecosystem health (Arnold and Gibbons, 1996; Schueler, 1994; and Center for Watershed Protection, 2003). The study of impervious surfaces has become one of the growing areas of scientific interest in the characterization and control of non-point source (NPS) pollution, and the imperviousness issue has even been suggested as a unifying theme for overall study of watershed protection (Schueler, 1994) and as part of an urban ecosystems analytical model (Ridd, 1995). The effects of impervious surfaces have been tied to global carbon sequestration, and the total impervious surface area of the United States has recently been shown to be approaching the size of the State of Ohio (Elvidge and others, 2004).

However, even with the increased attention to impervious cover (IC), there is no predominant or widely accepted method for determining impervious area. Further, there are a wide variety of techniques that include statistical models, roadway and population correlations, cartographic products, digital image processing, photographic interpretation, and other methods that are all commonly utilized to determine one factor; the amount of impervious cover in a particular geographical area at a particular point in time (Slonecker and others, 2001). Unfortunately, very little research has been performed to determine the accuracy of the various methods, even though the total impervious area (TIA) indicator is strongly correlated with negative aquatic conditions in only a very small range (10 to 15 percent) of imperviousness of the total watershed area (Schueler, 1994).

Although our understanding of the effects of impervious cover is maturing, our understanding of effective planning and mitigation efforts for reducing the ecological effects of anthropogenic activity is still in its infancy. A logical first step in this process is to determine the components, or classes, of man-made structures that as a whole make up TIA. In this, it

${ }^{1}$ U.S. Environmental Protection Agency, 12201 Sunrise Valley Drive, Mail Stop 521, Reston, VA 20192.

${ }^{2}$ U.S. Geological Survey, 12201 Sunrise Valley Drive, Mail Stop 521, Reston, VA 20192. is critical to understand the accuracy and variability of other commonly used methods of deriving impervious-area measurement.

With the relatively recent availability of very high spatial resolution, georeferenced digital imagery, we now have the data necessary to address some of these issues of the components of imperviousness and the accuracy of some of the methods that we use to compute this parameter. In cooperation with the United States Geological Survey (USGS), Geographic Analysis and Monitoring (GAM) Program and The National Map, and the United States Environmental Protection Agency's (USEPA) Landscape Ecology Program, this collaborative research seeks to utilize very high spatial resolution imagery to map the individual components of impervious surfaces in six different watersheds in the United States in order to (1) identify the relative contribution on the individual components of IC and (2) utilize these high-accuracy GIS databases as "truth" to assess the accuracy other common methods of determining impervious cover.

\section{Background}

In the USEPA's Draft Report on the Environment, impervious surfaces and the extent of urban and suburban development are mentioned prominently as potential key indicators of ecological condition of both water and terrestrial ecosystems (USEPA, 2003a; USEPA, 2003b). The environmental protection of water quality has generally evolved away from end-of-pipe regulation to a more comprehensive watershed management approach in which the interface between human and ecological systems is better understood. Storm water runoff has always been of concern to planners and civil engineers, but until recently, the emphasis was on human safety as opposed to ecological consequences. However, comprehensive watershed management techniques are now being widely implemented that seek to understand and balance ecological factors, classic storm water management, and local land-use policy. Several researchers have shown the direct effect of impervious surfaces on the water quality of receiving streams (Klein, 1979; Todd, 1989; Booth and Reinfelt, 1993; and Schueler, 1994). Numerous cities have adopted comprehensive water quality planning efforts that integrate control of impervious surfaces as a central planning theme (Monday and others, 1994; Kienegger, 1992; and Plunk and others, 1990). There are numerous examples 
of impervious surfaces as a prime consideration in local planning processes.

In watershed planning and engineering, the relationship between impervious cover and runoff is viewed as a direct and quantitative relationship in which impervious cover systematically changes an aquatic ecosystem (Schueler, 1994; and Arnold and Gibbons, 1996). This process assumes many forms in both the in-stream and riparian zones. Schueler (1994) showed the relatively direct relationship between the percentage of watershed imperviousness and runoff coefficients and also showed that discharge rate and runoff volume can increase by orders of magnitude between natural and impervious areas. Several researchers have shown that a threshold for urban stream stability and habitat quality exists at approximately 10 to 15 percent watershed imperviousness (Schueler, 1994; Klein, 1979; Booth and Reinelt, 1993; Arnold and Gibbons, 1996; and May and others, 1997). Studies observing greater than 15 percent imperviousness have invariably registered the urban stream habitat as poor.

The immediate and direct ecological consequence of imperviousness of a watershed is the effect on stream morphology. With increased flow rate and volume comes destabilization of streams due to widening and incision accompanied by the onset of stream bank erosion and related habitat degradation. Channel instability is correlated with sub-bank full floods (Anderson, 1968; Leopold, 1968; Hammer, 1972; Hollis, 1975; and Booth, 1990) and is characterized as a loss of critical, in-stream and riparian ecostructures such as pool and riffle networks and vegetative cover as well as an increase in the cross-sectional zone of a channel during rates of high flow (Schueler, 1994).

Impervious surfaces have proven very efficient at conveying urban pollution to receiving streams and directly impacting stream water quality. Urban effluent transports sediment an order of magnitude greater than the sediment transported by comparably sized rural watersheds. Sediment transport from a hectare of urban development and highway construction activity can yield 20,000 to 40,000 times the sediment of a comparably sized agricultural or woodland area (Wolman and Schick, 1967; Burton and others, 1977; and Klein, 1979). Monitoring studies in Wisconsin (Bannerman and others, 1993) revealed specific relationships between pollutants and types of impervious surfaces (for example $E$. coli with residential streets, phosphorous with residential lawns, metals with industrial zones and so forth). The runoff from impervious surfaces of hydrocarbons (Whipple and Hunter, 1979), metals and road salt runoff (Crowther and Hynes, 1977), and their related effects on stream water quality has also been addressed. The hydrologic community has consistently utilized the parameter of imperviousness to model pollutant runoff and as a general measure of stream water quality (Schueler, 1994).

The effect of imperviousness on thermal properties of a stream is two-fold. Impervious surfaces hold and retain more heat than the natural features they replace. The heat from these surfaces is transferred down slope (via runoff) and warms the receiving stream. Schueler (1994) notes that impervious surface areas may be 10 to 12 degrees warmer than the fields and forests that they replace. Galli (1991) compared urban related streams in Maryland with a forested reference stream and found a correlation between urban imperviousness and higher relative stream temperatures. The other trending factor for in-stream warming is related to the reduction of streamside vegetative cover that shades the stream. This loss of riparian stream buffer is often due to urban encroachment as well as to erosion of stream banks from flooding. This is pointed out by Klein (1979), who notes a $6^{\circ} \mathrm{C}$ to $11^{\circ} \mathrm{C}$ variation in shaded and nonshaded areas on the same Maryland stream.

Perhaps the strongest environmental indicator of in-stream health is stream biodiversity. A change of in-stream characteristics due to watershed development (that is, increased flow volume, pollutant runoff, change in thermal characteristics) plays a systematic role in altering an aquatic ecosystem. Schueler (1994) cites 18 studies associated with the effects of imperviousness on stream biodiversity. The focus of these studies is aquatic insect and fish surveys, and results provide an overall characterization of ecosystem change as related to imperviousness of a watershed at the 10 to 15 percent level. Schueler (1994) and Arnold and Gibbons (1996) both observe that research over the past 20 years has consistently reported a correlation between watershed imperviousness and health of the receiving stream ecosystem. Schueler proposes and Arnold and Gibbons concur on a three-tiered threshold classification scheme of urban stream-quality potential based on watershed imperviousness levels:

- $\quad$ Stressed $=1$ to 10 percent imperviousness

- Impacted $=11$ to 25 percent imperviousness

- Degraded $=>26$ percent imperviousness

\section{Study Areas}

Six urban/suburban watersheds were chosen for this study based on their geographic distribution, urban setting, and imagery and data availability. The six watersheds are listed below and shown geographically on figure 1 (a more complete description of the test watersheds, methods, and procedures can be found in Tilley and Slonecker, 2005):

(1) Black River, Seattle, Washington.

(2) Difficult Run, Fairfax, Virginia.

(3) North Walnut Creek, Des Moines, Iowa.

(4) Oak Creek, Lincoln, Nebraska.

(5) Tuscarora Creek, Leesburg, Virginia.

(6) Wares Creek, Bradenton, Florida.

\section{Task 1-Obtain Detailed Impervious-Surface Data to Serve as Ground Reference Information}

In the first phase of this research, the primary task involved developing very high (sub-meter) spatial resolution GIS databases of the major component classes of impervious 
cover. Six classes were selected based on functional characteristics including:

Roads - Long, narrow areas of gravel, paved, or other hard surfaces that are utilized primarily for public transportation by automobile and are maintained and regulated by Federal, State, or local government.

Driveways - Hard paved surface or gravel areas that connect a house, garage, or other structure to a road surface for the purpose of automobile access and storage.

Buildings - All roofed structures including storage sheds and trailers (with the assumption that trailer's foundations were concrete pads).

Sidewalks - Very narrow hard surface areas that are generally found parallel to roadways and exist primary for pedestrian traffic. Recreational trails, such as bike trails, park and golf course cart paths are included in this category.

Parking lots-Hard surfaced areas that exist primarily for the temporary storage of automobiles, other vehicles, equipment and materials.

Other-Hard surface recreation areas such as basketball or tennis courts, patios, swimming pools-to include surround- ing patio, any other impervious surfaces that do not fit in any of the above categories.

Preliminary research was performed for each watershed to identify sources of both high-resolution imagery and GIS data from public or private sources. In some cases, aerial photographs were acquired, scanned, georegistered and (or) orthorectified using ENVI 3.6 (RSI Boulder, Colorado) image processing software. After all GIS data were acquired, local data were reviewed for consistency and accuracy, and were updated (by heads-up digitizing/editing) to temporally match the highresolution imagery source using ARCVIEW 3.x software (ESRI, Redlands, California). When no existing GIS data could be found, themes were digitized as polygons from a high spatial resolution imagery source. Figure 2 shows a graphic example of the data collection process. All datasets were subjected to a three-phase review and quality assurance process. This process is described in more detail in Tilley and Slonecker (2003).

\section{Task 2-Perform Intermediate Scale Calcula- tion of Impervious Surface Using Subpixel and Land-Use Coefficient Processing}

Two separate techniques were used to calculate impervious area at an intermediate scale. These two techniques were selected for their efficiency and common utilization in the literature. The first, subpixel processing, is a relatively recent

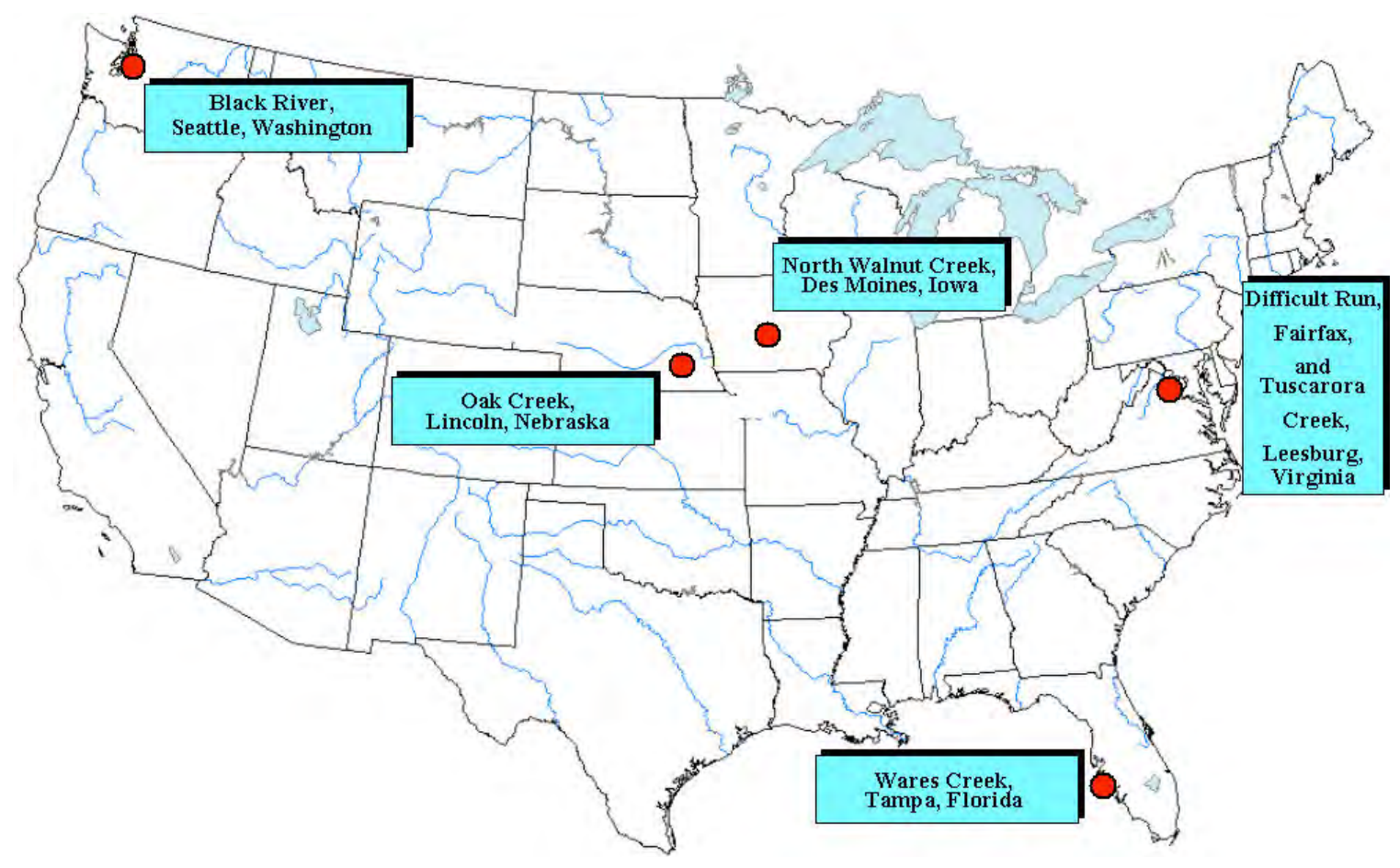

Figure 1. Locations of the six watersheds used in the study. 
advance in spectral analysis that utilizes a combination of spectral processing and statistical tools to derive information on the component makeup of an individual pixel. The second technique makes use of land-use coefficients that are com-

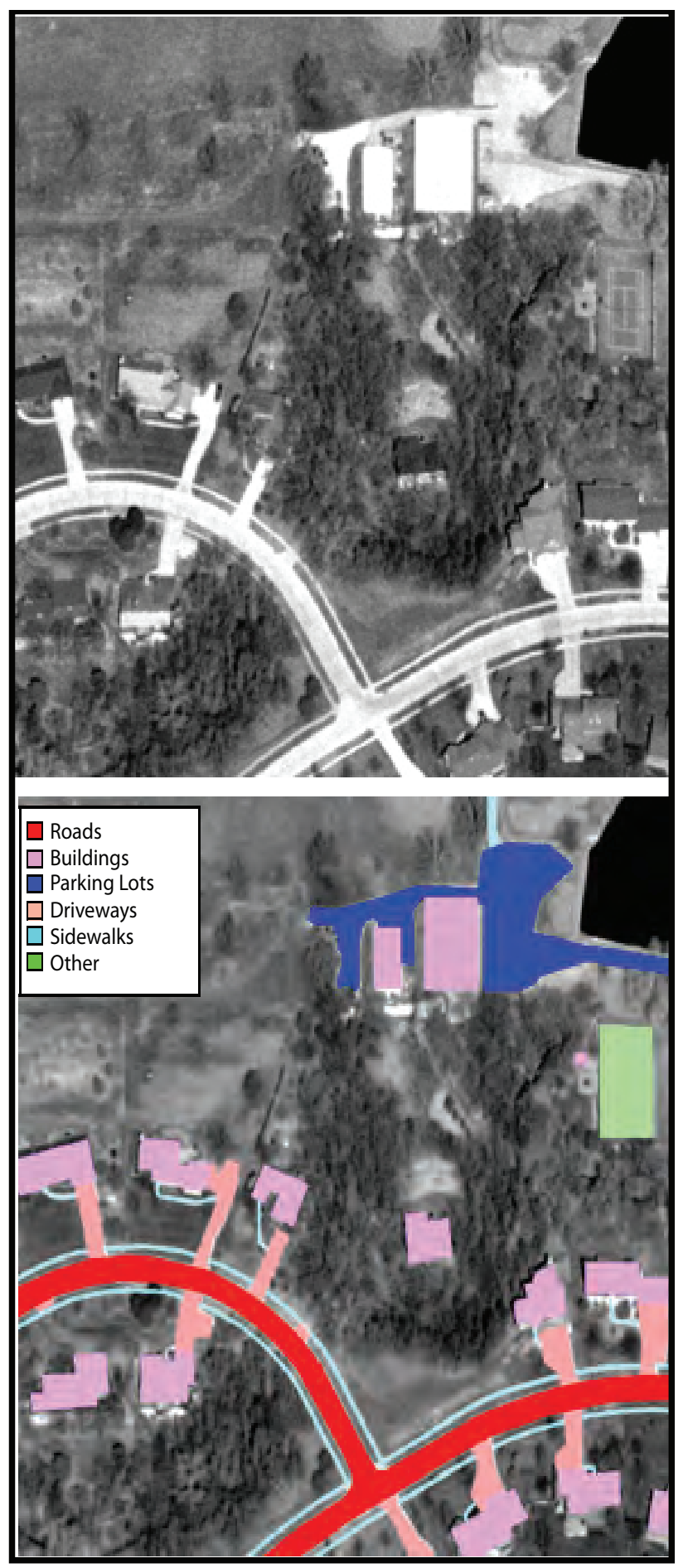

Figure 2. An example of heads-up digitizing of six classes of impervious-surface from rectified high-spatial-resolution imagery. monly used by hydrologists and watershed protection specialists working in the impervious surfaces research area.

\section{Task 2a-Subpixel Processing Techniques}

For many years, satellite remote sensing and image processing techniques were limited by the spatial resolution, or ground sample distance of the picture element (pixel). Typical systems such as the Landsat Thematic Mapper, with 30-meter pixel size, exhibited significant limitations on minimum mapping units, spatial accuracy, and general detail of derived products. However, a relatively new class of image processing techniques has been developed in the last decade that can be used to decompose the pixel into relative abundance of materials within it based on statistical analysis and spectral unmixing.

Spectral unmixing techniques strive to find proportions of end-members, spectrally "pure" pixels, within a pixel from the observed mixed pixel spectrum and a number of pure endmember spectra of known composition (Ji and Jensen, 1999; and Ward and others, 2000). The unmixing approach has been shown to be very successful when applied to high spectral resolution imaging or nonimaging data where subtle diagnostic absorption features largely determine the spectral characteristics of the data. These techniques have been also been extended to the mapping of impervious surfaces from Landsat imagery by utilizing samples of very high resolution imagery in conjunction with classification and regression tree (CART) statistical analyses. These subpixel mapping techniques can return data that is more accurate and at a finer spatial detail, than traditional classification techniques (Yang and others, 2003; Huang and Townshend, 2003).

The reflectance characteristics of impervious-surfaces lend themselves well to delineation via spectral remote sensing. Concrete, macadam, and other substances that are utilized in human construction efforts, generally have much different spectral profiles than do natural surfaces. With the ability to potentially acquire and provide classification data that are more accurate measures of the composition of the basic pixel, subpixel processing of widely available satellite imagery could become an important new source of impervious-surface data.

Further, several organizations now regularly process subpixel impervious-surface data, such as the Mid Atlantic Regional Earth Science Applications Center (RESAC) at the University of Maryland. The USGS Eros Data Center (EDC) plans to release a national subpixel data set as part of the year 2000 National Land Cover Dataset (NLCD) product. The potential accuracy and national availability of this data source made it an excellent candidate for testing in this study.

Subpixel image processing for impervious-surfaces is generally released in the form of an Arc/Info GRID file in which the cell value is the percentage of imperviousness calculated for that pixel. The GRID file is assigned color values by some percentage class of imperviousness.

The computation of total impervious cover from this type of data source is simple. After clipping the extent of the area 
of interest, such as a watershed, from the large grid, the values from the value attribute table (.vat), which are the "value" and "count", can be easily input into a spreadsheet for calculation of total imperviousness. Value represents the percentage of imperviousness and count represents the total number of occurrences in the data set. For example, the watershed boundary of
Tuscarora Creek was used to clip out its extent from the larger impervious surface grid. The vat table of the grid file lists the impervious percentage and the number of pixels that contain that percentage in the grid. The .vat can be directly input into a spreadsheet where TIA can easily be calculated using standard spreadsheet functions (see fig. 3).

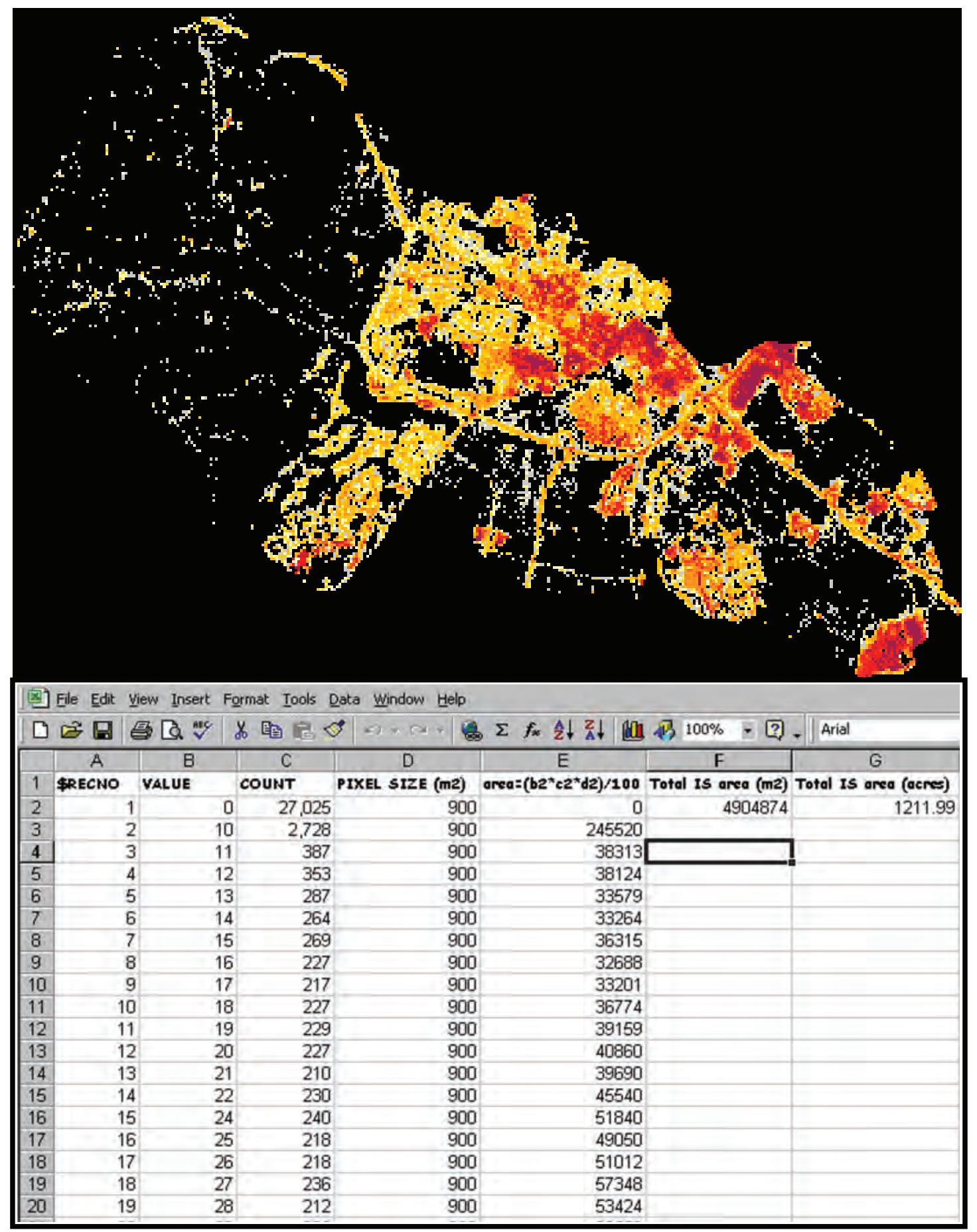

Figure 3. An impervious-surface map of Tuscarora Creek, Virginia, derived using subpixel digital-image processing. The value attribute table from the impervious-surface grid is input directly into a spreadsheet where the total impervious area can be calculated. 


\section{Task $2 \mathrm{~b}$-The Land-Use Coefficient Methodology}

The Land-Use Coefficient method may be used to determine the impervious surface area of a watershed (Capiella and Brown, 2001). Land-use generally differs from land-cover in two important aspects. First, land-use classification is based on the anthropogenic utilization of the land, not the ecological or biological function. Second, land-use is generally mapped in a vector, polygon form, as opposed to the raster-based model of most land-cover mapping. Determining land-use from remote sensing data has been a popular form of geographic analysis for many years, especially since the seminal paper by Anderson and others in 1976. This form of mapping involves the extraction of polygons of similar land-use from an image or cartographic base map. Impervious area of each land-use polygon is determined by multiplying the area of the polygon by a specific, previously determined coefficient that represents the average fractional percentage of impervious cover for a particular landuse (that is, industrial, low density residential). The sum of these areas for all the different land-use polygons is the impervious cover for the watershed. For example, table 1 lists the land-use classes and coefficients that were developed for the Chesapeake Bay Watershed (Capiella and Brown, 2001).

\section{Task 3-Calculation of Impervious Surface Area From Regional/National Synoptic Land-Cover Data Sources}

The third task in this research is the determination of impervious area from a synoptic data source that incorporated the land-use coefficient methodology previously discussed. In this case, the National Land Cover Database (NLCD) was selected. Synoptic, national NLCD data is currently available for the 1990 time frame and is being produced for the 2000 time frame. A complete description of the NLCD process and dataset can be found in Vogelmann and others (2001) and at the NLCD Web site. The computation of impervious area from land-cover offers two distinct advantages. First, land-cover can be developed from spectral satellite data and computed mostly from automated digital classification routines. Second, the availability of a nationally consistent land-cover data source allows for the rapid and efficient analysis of any watershed or area of the country, conserving valuable resources that would be expended on data acquisition and processing steps if the other methods were used.

The use of coefficients for impervious-surfaces in this context implies that there are similarities in landscape structure that would make this method of computing impervious surfaces feasible. Deriving the coefficients is accomplished by some type of sampling technique, where samples of higher resolution data are used to determine an average amount of imperviousness in each land-cover category. This average is then used to compute a coefficient for a "per pixel" amount of imperviousness for each class. Two different methods of com- puting TIA from NLCD land-cover by using the coefficient method were used. The details of these two techniques can be found in Center for Watershed Protection (1998), as implemented in the Arcview Extension 'Attila' (Ebert and Wade, 2003 and Jennings and Jarnagin, 2003).

\section{Results}

\section{Task 1-Detailed Impervious-Surface Data Compilation}

Task 1 assessed the individual contribution (percent) of roads and other classes of imperviousness to the watershed TIA. In all, six watersheds were mapped at the detailed, sub-meter resolution level and were temporally updated for five additional dates in time (to correlate with tasks 2 and 3) resulting in a total of 11 detailed GIS datasets of impervious cover. In each, six classes of impervious cover were mapped, including roads, buildings, parking lots, driveways, sidewalks, and other.

Overall, buildings led all other categories at 29.1 percent followed closely by roads at 28.3 percent. Parking lots were third at 24.6 percent. These three categories accounted for the great majority of TIA. Table 2 summarizes the area measurements for each category in acres, and table 3 summarizes the respective percentages of TIA. Figure 4 depicts graphically the cumulative percentages of each category.

\section{Task 2a-Subpixel Processing}

The availability of subpixel land-use and land-cover data is currently limited but will likely be widely available in the near future, as part of the NLCD year 2000 dataset. For this research, two separate subpixel datasets were acquired for the greater Washington, D.C., area. The first was developed by the Regional Science Applications Center (RESAC) at the University of Maryland and included 1990, 1996, and 2000 datasets. The second was developed by the USGS at the EROS Data Center for 2001 (NLCD, 2001).

The results are shown in table 4 . In the Tuscarora Creek Watershed, both the RESAC and the EDC data compiled TIA to within 10 percent of the task 1 ground-reference value. For the Difficult Run Watershed however, both the RESAC and EDC datasets significantly under-reported the TIA.

\section{Task $2 b$-Processing Using Land-Use Coefficients}

Land-use maps and coefficients were utilized on the other four watersheds in task 2 . Vector land-use maps were created and coefficients were applied. Results are shown in table 5. 
Table 1. Land-use codes and coefficients for the Chesapeake Bay Watershed (Capiella and Brown, 2001).

\begin{tabular}{|r|c|c|}
\hline \multicolumn{1}{|l|}{ Land-Use Category } & $\begin{array}{c}\text { Land-Use } \\
\text { Code }\end{array}$ & $\begin{array}{c}\text { Impervious } \\
\text { Cover Coefficients }\end{array}$ \\
\hline Open U rban land & 10 & 0.086 \\
\hline Residential -2 acre lot & 11 & 0.106 \\
\hline Residential -1 acre lot & 12 & 0.143 \\
\hline Residential -0.5 acre lot & 13 & 0.212 \\
\hline Residential -0.25 acre lot & 14 & 0.278 \\
\hline Residential $-0.125(1 / 8)$ acre lot & 15 & 0.326 \\
\hline Townhome Residential & 16 & 0.409 \\
\hline Multifamily Residential & 17 & 0.444 \\
\hline Agriculture & 20 & 0.019 \\
\hline Institutional & 30 & 0.344 \\
\hline Churches & 31 & 0.399 \\
\hline Schools & 32 & 0.303 \\
\hline Municipal & 33 & 0.354 \\
\hline Golf Courses & 34 & 0.05 \\
\hline Cemeteries & 35 & 0.083 \\
\hline Parks & 36 & 0.125 \\
\hline Light Industrial & 40 & 0.534 \\
\hline Commercial & 50 & 0.722 \\
\hline & & \\
\hline & & \\
\hline
\end{tabular}

\section{Task 3-Calculation of Impervious-Surface Area From Regional/National Synoptic Land-Cover Data Sources}

Task 3 of this process involved generating an estimate of TIA from land-cover data typically generated from satellite remote sensing data. Land-cover data, like land-use data, is a thematic representation of surface phenomenon but is based on the environmental cover or spectral-reflectance properties of the surface instead of an anthropogenic based utilization of land. In general terms, land-cover is generally less detailed than the type of land-use data used in task 2 and is generally mapped on a raster-based GIS model derived from the satellite imagery. It offers the advantage of a national, thematically consistent and regularly updated dataset from which many other spatial relationships, such as impervious surfaces, can be derived on a consistent, national basis.

Two methods were utilized to calculate TIA from NLCD data. Both methods were derived from the literature and both do essentially the same thing, which is to multiply a derived coefficient times the pixel area for that land-cover class. The difference lie in the methods used to determine the coefficients from the NLCD land-cover data. The method used by CWP uses a simple average, whereas the Jennings and Jarnagin (2003) method uses three sets of coefficients based on the level of development in the watershed. The two different methods are described in CWP (1998), as implemented in the ATTilA, Arcview extension (Ebert and Wade, 2003; and Jennings and Jarnagin, 2003). The results for both methods are summarized in table 6 .

\section{Analysis and Discussion}

\section{Task 1-Detailed Impervious-Surface Data Compilation}

The high-resolution compilation of impervious surfaces revealed the component features that make up functional

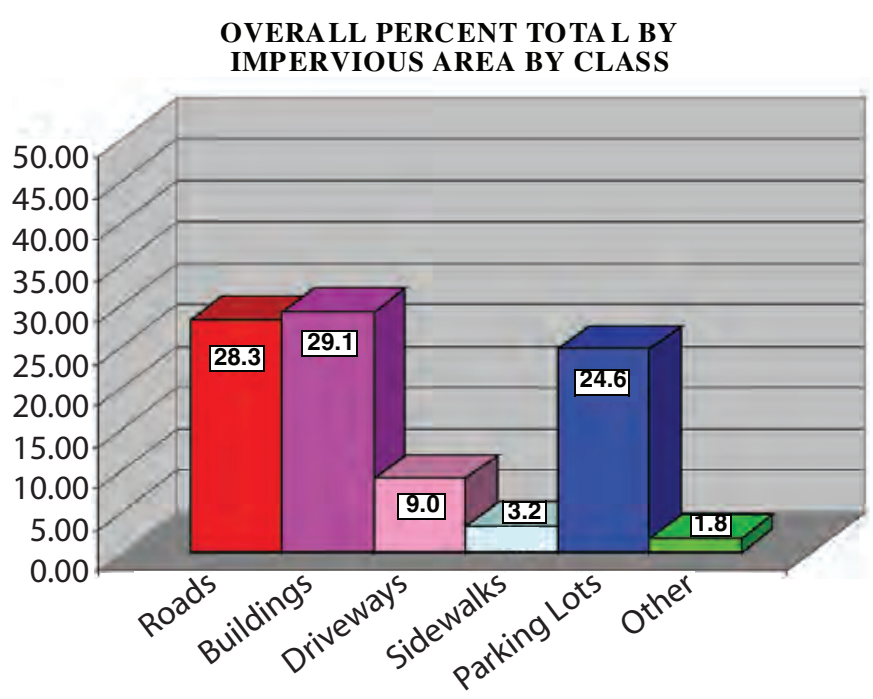

Figure 4. The percent of total impervious area as calculated from 11 separate mappings of 6 watersheds. Buildings, roads, and parking lots account for the majority of total impervious area. 
Table 2. The impervious-surface area measurements for all watersheds/dates used in this study.

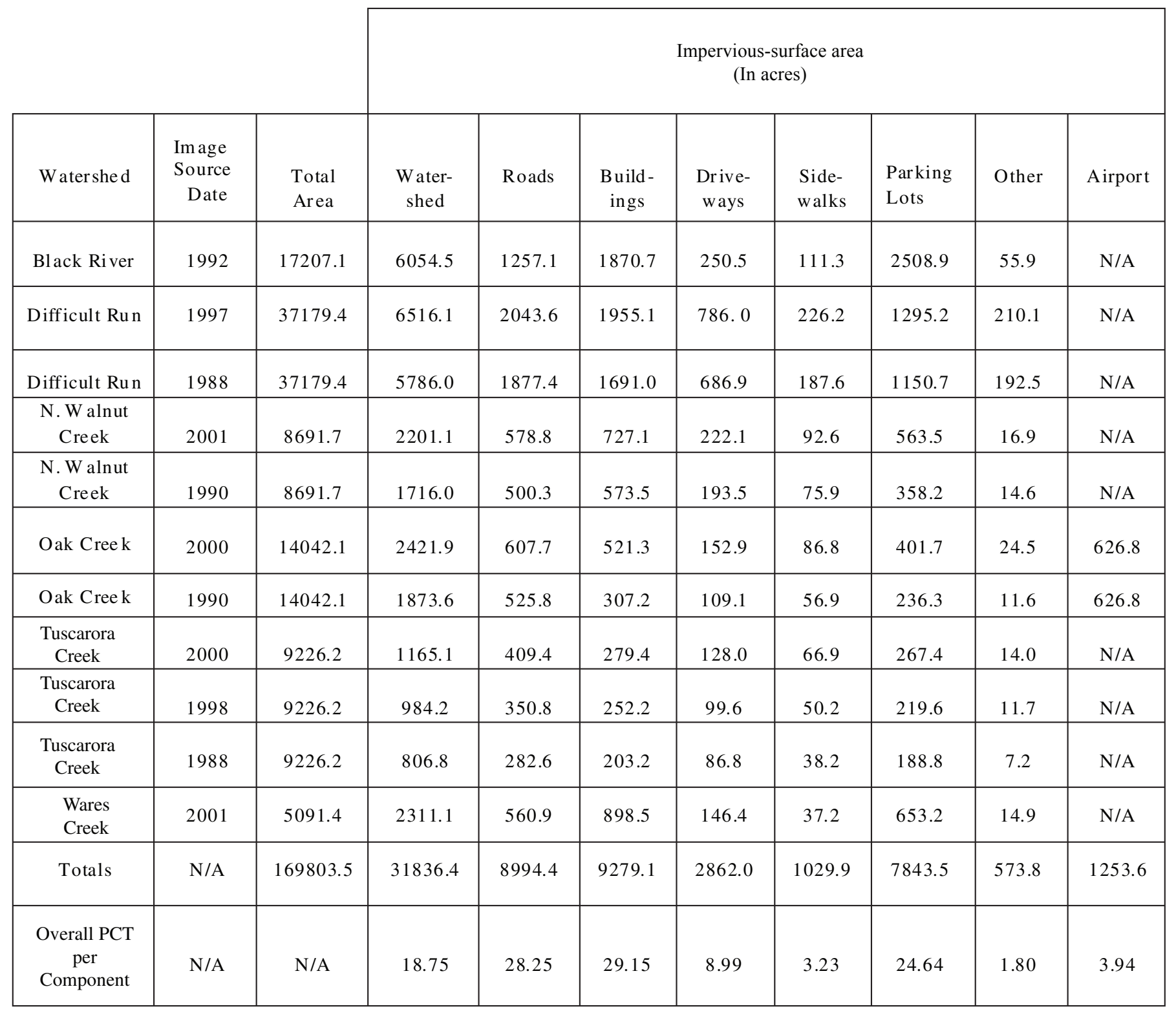

impervious-surface area. Roads, often getting the bulk of the "blame" for impervious area, are only one of the 3 major components of TIA that also include buildings and parking lots. The contribution of road impervious area (RIA) to overall TIA ranged from a low of 20.8 percent in 1992 for the Black River Watershed to a high of 35.6 percent in the 1998 Tuscarora Creek Watershed. Driveways, often unaccounted for in impervious-surface research, made up an average of 9 percent of the total impervious-surface area. Further, this data shows that even very minor classes of impervious cover are important. Very few studies on impervious-surface area take into account sidewalks, patios and tennis courts. Yet we can clearly see that in this study, these are responsible for 5 percent of TIA.
In five datasets, in the two watersheds in the suburban Washington, D.C., area, roads were the leading class of impervious cover. In the Oak Creek Watershed, the large airport/Air Force base was the dominant feature in both years of analysis. In the highly industrialized Black River Watershed, the parking lots were the leading class of imperviousness (41.4 percent). In Wares Creek, Florida, and North Walnut Creek, Iowa, buildings were the largest class of impervious cover, as well as the leading IS component overall.

Further, the relationship of RIA to TIA appears to correlate with the level of development of the watershed. Figure 5 shows the linear relationship between RIA and TIA. Recognizing TIA as a general indicator of the level of 
Table 3. Percent (PCT) contribution of each component to the total impervious area for each watershed per year.

\begin{tabular}{|c|c|c|c|c|c|c|c|c|c|c|}
\hline \multirow[b]{2}{*}{ Watershed } & \multirow[b]{2}{*}{$\begin{array}{l}\text { Image } \\
\text { Source } \\
\text { Date }\end{array}$} & \multicolumn{9}{|c|}{ Watershed and Component Impervious Surface Percentages } \\
\hline & & Watershed & Road & Bldg & $\begin{array}{c}\text { Drive-way } \\
\text { (DW) }\end{array}$ & $\begin{array}{c}\text { Side-walk } \\
\text { (SW) }\end{array}$ & $\begin{array}{l}\text { Parking } \\
\text { Lots }\end{array}$ & Other & Airport & $\begin{array}{l}\text { DW, SW, } \\
\text { and Other } \\
\text { Combined }\end{array}$ \\
\hline $\begin{array}{l}\text { Black } \\
\text { River }\end{array}$ & 1992 & 35.19 & 20.76 & 30.90 & 4.14 & 1.84 & 41.44 & 0.92 & & 6.9 \\
\hline $\begin{array}{l}\text { Difficult } \\
\text { Run }\end{array}$ & 1997 & 17.53 & 31.36 & 30.00 & 12.06 & 3.47 & 19.88 & 3.22 & & 18.75 \\
\hline $\begin{array}{l}\text { Difficult } \\
\text { Run }\end{array}$ & 1988 & 15.56 & 32.45 & 29.22 & 11.87 & 3.24 & 19.89 & 3.33 & & 18.44 \\
\hline $\begin{array}{l}\text { N. Walnut } \\
\text { Creek }\end{array}$ & 2001 & 25.32 & 26.30 & 33.03 & 10.09 & 4.21 & 25.60 & 0.77 & & 15.07 \\
\hline $\begin{array}{l}\text { N. Walnut } \\
\text { Creek }\end{array}$ & 1990 & 19.74 & 29.16 & 33.42 & 11.27 & 4.42 & 20.87 & 0.85 & & 16.54 \\
\hline Oak Creek & 2000 & 17.25 & 25.09 & 21.52 & 6.31 & 3.58 & 16.59 & 1.01 & 25.88 & 10.9 \\
\hline Oak Creek & 1990 & 13.34 & 28.06 & 16.40 & 5.82 & 3.04 & 12.61 & 0.62 & 33.46 & 9.48 \\
\hline $\begin{array}{c}\text { Tuscarora } \\
\text { Creek }\end{array}$ & 2000 & 12.63 & 35.13 & 23.98 & 10.99 & 5.74 & 22.95 & 1.20 & & 17.93 \\
\hline $\begin{array}{l}\text { Tuscarora } \\
\text { Creek }\end{array}$ & 1998 & 10.67 & 35.64 & 25.63 & 10.12 & 5.10 & 22.31 & 1.19 & & 16.41 \\
\hline $\begin{array}{c}\text { Tuscarora } \\
\text { Creek }\end{array}$ & 1988 & 8.74 & 35.03 & 25.19 & 10.76 & 4.74 & 23.40 & 0.89 & & 16.39 \\
\hline $\begin{array}{l}\text { Wares } \\
\text { Creek }\end{array}$ & 2001 & 45.39 & 24.27 & 38.88 & 6.34 & 1.61 & 28.26 & 0.64 & & 8.59 \\
\hline $\begin{array}{c}\text { Overall } \\
\text { PCT per } \\
\text { Component }\end{array}$ & N/A & 18.75 & 28.25 & 29.15 & 8.99 & 3.23 & 24.64 & 1.80 & 3.94 & 14.0 \\
\hline
\end{tabular}

\section{ROAD CONTRIBUTION CHANGE AS WATERSHED URBANIZATION INCREASES}

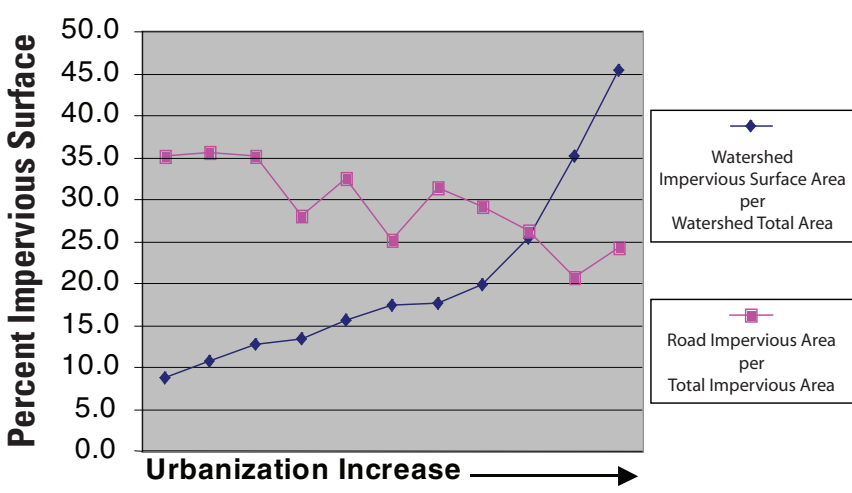

Figure 5. The relationship between road impervious area to watershed impervious area. As the watershed becomes more developed (that is, increases in the percentage of impervious area), the contribution of roads to the total impervious area declines. human development in a watershed, we can see that at lower percentages and TIA, RIA is around 35 percent. But as the watershed becomes more and more developed, the contribution of roads consistently declines, showing that there a potential issue in understanding the age and life-cycle of developed areas.

\section{Task 2-Subpixel and Land-Use Coefficient Processing}

The subpixel image processing produced mixed results. Although both methods provided good estimates of TIA in Tuscarora Creek, both methods significantly underestimated TIA in Difficult Run. This may be due to the extensive tree cover and older-large lot development in some parts of this watershed.

The Land-use coefficient method produced results generally within 10 percent of task 1 value for TIA. 
Table 4. Subpixel image-processing results.

[TIA, total impervious area]

\begin{tabular}{|c|c|c|c|c|c|c|}
\hline Watershed & $\begin{array}{c}\text { Task 1 } \\
\text { Reference } \\
\text { Data Image } \\
\text { Source Date } \\
\text { Subpixel Data } \\
\text { Source / Date } \\
\text { Reference } \\
\text { Data } \\
\text { TIA }\end{array}$ & $\begin{array}{c}\text { Task 2a } \\
\text { Subpixel } \\
\text { TIA }\end{array}$ & $\begin{array}{c}\text { Difference } \\
\text { Betwe en } \\
\text { Task 1 and } \\
\text { Task 2a } \\
\text { TIA }\end{array}$ & $\begin{array}{c}\text { Percent } \\
\text { Agreement } \\
\text { with } \\
\text { Reference }\end{array}$ \\
\hline $\begin{array}{c}\text { Tuscarora } \\
\text { Creek }\end{array}$ & 2000 & RESAC / 2000 & 1165.1 & 1132.6 & 32.5 & 97.2 \\
\hline $\begin{array}{c}\text { Tuscarora } \\
\text { Creek }\end{array}$ & 1998 & RESAC / 1996 & 984.2 & 922.2 & 61.9 & 93.7 \\
\hline $\begin{array}{c}\text { Tuscarora } \\
\text { Creek }\end{array}$ & 1988 & RESAC / 1990 & 806.8 & 835.1 & -28.3 & 96.5 \\
\hline $\begin{array}{c}\text { Difficult Run } \\
\text { Tuscarora } \\
\text { Creek }\end{array}$ & 1997 & RESAC / 1996 & 6516.1 & 3403.6 & 3112.5 & 52.2 \\
\hline $\begin{array}{c}\text { Difficult } \\
\text { Run }\end{array}$ & 1997 & EDC / 2000 & 6516.1 & 3866.5 & 2649.6 & 90.1 \\
\hline
\end{tabular}

Table 5. Land-use coefficients (Capiella and Brown, 2001) results.

[TIA, total impervious area]

\begin{tabular}{|c|c|c|c|c|c|}
\hline Watershed & $\begin{array}{c}\text { Image } \\
\text { Source } \\
\text { Date }\end{array}$ & $\begin{array}{c}\text { Task 1 } \\
\text { Reference } \\
\text { Data TIA }\end{array}$ & $\begin{array}{c}\text { Task 2b } \\
\text { Land-Use } \\
\text { Coefficients } \\
\text { TIA }\end{array}$ & $\begin{array}{c}\text { Difference Btwn. } \\
\text { Reference and } \\
\text { Land-Use } \\
\text { Coefficients }\end{array}$ & $\begin{array}{c}\text { Percent } \\
\text { Agreement } \\
\text { w/Reference } \\
\text { Data }\end{array}$ \\
\hline $\begin{array}{c}\text { Black } \\
\text { River }\end{array}$ & 1992 & 6054.45 & 5866.37 & 188.08 & 96.89 \\
\hline $\begin{array}{c}\text { North } \\
\text { Walnut } \\
\text { Creek }\end{array}$ & 2001 & 2201.13 & 2045.37 & 55.76 & 92.92 \\
\hline $\begin{array}{c}\text { Oak Creek } \\
\text { Wares }\end{array}$ & 2000 & 421.87 & 2585.84 & 163.97 & 93.23 \\
\hline Creek & 2001 & 2311.09 & 2062.19 & 248.90 & 89.23 \\
\hline
\end{tabular}

Table 6. Comparison of total impervious area percentage calculations from NLCD92 data (in acres) (Center for Watershed Protection, 1998; and Jennings and Jarnagin, 2003).

[TIA, total impervious area; IA, impervious area; PCT, percent; DIFF, difference; AGR, agriculture]

\begin{tabular}{|c|c|c|c|c|c|c|c|c|c|c|c|c|}
\hline \multirow[b]{2}{*}{ Watershed } & \multirow[b]{2}{*}{$\begin{array}{c}\text { Image } \\
\text { Source } \\
\text { Date }\end{array}$} & \multirow[b]{2}{*}{$\begin{array}{l}\text { Total } \\
\text { Area }\end{array}$} & \multicolumn{2}{|c|}{$\begin{array}{c}\text { Task } \\
\text { Reference } \\
\text { Data }\end{array}$} & \multicolumn{4}{|c|}{$\begin{array}{c}\text { Center for Watershed Protection } \\
\text { Method }\end{array}$} & \multicolumn{4}{|c|}{ Jennings and Jamagin Method } \\
\hline & & & TIA & $\begin{array}{l}\text { PCT } \\
\text { TIA }\end{array}$ & TIA & $\begin{array}{l}\text { PCT } \\
\text { IA }\end{array}$ & $\begin{array}{c}\text { DIFF } \\
\text { Between } \\
\text { Reference } \\
\text { Data }\end{array}$ & $\begin{array}{l}\text { PCT } \\
\text { AGR }\end{array}$ & TIA & $\begin{array}{l}\text { PCT } \\
\text { IA }\end{array}$ & $\begin{array}{c}\text { DIFF } \\
\text { Between } \\
\text { Reference } \\
\text { Data }\end{array}$ & $\begin{array}{l}\text { PCT } \\
\text { AGR }\end{array}$ \\
\hline $\begin{array}{l}\text { Black } \\
\text { River }\end{array}$ & 1992 & 17207.1 & 6054.5 & 35.2 & 2735.0 & 45.2 & 10.0 & 90.0 & 6016.4 & 35.0 & -0.2 & 99.8 \\
\hline $\begin{array}{l}\text { Difficult } \\
\text { Run }\end{array}$ & 1988 & 37179.4 & 5786.0 & 15.6 & 955.9 & 16.5 & 1.0 & 99.0 & 5072.0 & 13.6 & -1.9 & 98.1 \\
\hline $\begin{array}{l}\text { N. Walnut } \\
\text { Creek }\end{array}$ & 1990 & 8691.7 & 1716.0 & 19.7 & 463.0 & 27.0 & 7.2 & 92.8 & 2310.8 & 26.6 & 6.8 & 93.2 \\
\hline $\begin{array}{l}\text { Oak } \\
\text { Creek }\end{array}$ & 1990 & 14042.1 & 1873.7 & 13.3 & 222.0 & 11.9 & -1.5 & 98.5 & 1052.2 & 7.5 & -5.8 & 94.2 \\
\hline $\begin{array}{l}\text { Tuscarora } \\
\text { Creek }\end{array}$ & 1988 & 9226.17 & 806.8 & 8.7 & 71.6 & 8.9 & 0.1 & 99.9 & 531.3 & 5.8 & -3.0 & 97.0 \\
\hline $\begin{array}{l}\text { Wares } \\
\text { Creek }\end{array}$ & 2001 & 5091.4 & 2311.1 & 45.4 & 1198.8 & 51.9 & 6.5 & 93.5 & 2073.5 & 40.7 & -4.7 & 95.3 \\
\hline
\end{tabular}




\section{Task 3-Calculation of Impervious-Surface Area From Regional/National Synoptic Land- Cover Data Sources}

The two land-cover coefficients methods resulted in some interesting patterns. The CWP method over-estimated TIA in 5 of 6 cases. The Jennings and Jarnagin method under-estimated TIA in 5 of 6 cases. Each method calculated TIA very accurately in one watershed. In general, the CWP method tends to overestimate, whereas the Jennings and Jarnagin method tends to under-estimate. One of the main drawbacks of any NLCD-based method will be sensitivity to misclassification of the urban-class pixels in the dataset.

\section{Conclusions}

This study documented the component composition of impervious area in six selected watersheds. Although roads, buildings, and parking lots, make up the majority of impervious area, driveways, sidewalks, and other areas still make up a significant 14 percent of TIA and should not be ignored in calculating TIA. We also found that four of the common methods of computing impervious area show significant variability when measured against high-resolution ground reference information. Overall, the four methods tested generally produced an estimate of TIA within 10 percent of the ground-reference information. Figure 6 shows a simple

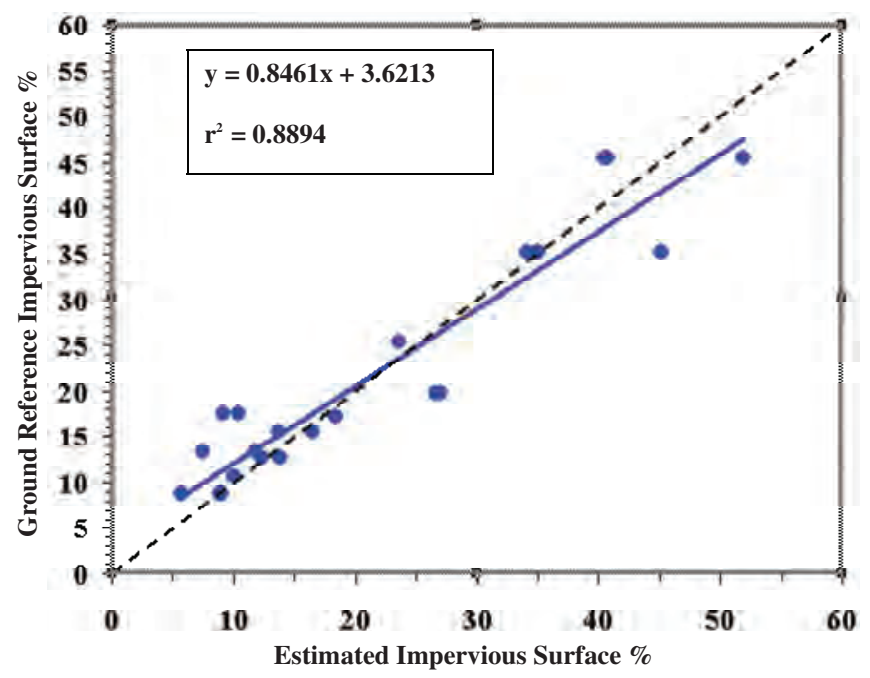

Figure 6. A regression of the estimated impervious-surface percentage against the ground-reference impervious-surface percentage. There were 24 observations. The ground-reference impervious surfaces data was derived by detailed digitizing from high-spatial-resolution imagery. The estimated impervious-surface percentage was derived from four common methods of estimating impervious-surface area. regression of the derived versus reference impervious area values for all 4 methods tested. There were 24 independent observations and an $\mathrm{r}^{2}$ value of 0.89 . Unfortunately 10 percent variability in the accuracy of this statistic is nontrivial when 25 percent impervious area is the absolute upper end of a stream's ability to support aquatic life. It is clear that there exists a need for further research in this area.

Additional high spatial resolution imagery research is needed in the area of impervious surfaces to:

(1) Quantify the component makeup of impervious surfaces, especially with respect to regional or morphological characteristics of the watershed, and

(2) Refine other commonly used estimation methods to known and quantifiable levels of accuracy and variability.

\section{Acknowledgment}

The United States Environmental Protection Agency through its Office of Research and Development partially funded and collaborated in the research described here under Interagency Agreement DW14939389-01-0 to the United States Geological Survey.

\section{References}

Anderson, D.G., 1968, Effects of urban development on floods in northern Virginia: U.S. Geological Survey Water Supply Paper 2001-C, 22 p.

Anderson, J.R., Hardy, E.E., Roach, J.T., and Witmer, R.E., 1976, A land use and land cover classification system or use with remote sensor data: U.S. Geological Survey Professional Paper 964, 28 p.

Arnold, C.L., and Gibbons, C.J., 1996, Impervious surface coverage: Journal of the American Planning Association, v. 62 , no. 2, p. $243-258$.

Bannerman, R.T., Owens, D.W., Dodds, R.B., and Hornewer, N.J., 1993, Sources of pollutants in Wisconsin storm water: Water Science and Technology, v. 28, p. 241-259.

Booth, D.B., 1990, Stream channel incision following drainage-basin urbanization: Water Resources Bulletin 26, no. 3, p. 407-417.

Booth, D.B., and Reinfelt, L.E., 1993, Consequences of urbanization on aquatic systems-measured effects, degradation thresholds and corrective strategies in Proceedings Watershed 93 Conference, Alexandria, Virginia, U.S. Environmental Protection Agency, p. 545550.

Burton, T.M., Turner, R.R., and Harriss, R.C., 1977, Suspended and dissolved solids exports from three north Florida watersheds in contrasting land use: Washington D.C., Smithsonian Institution, Watershed Research in Eastern 
North America, Correll, D.L (ed.), p. 323-342.

Capiella, K., and Brown, K., 2001, Impervious cover and land use in the Chesapeake Bay watershed: Center for Watershed Protection Report, Ellicott City, Maryland, 54 p.

Crowther, R.A., and Hynes, H.B.N., 1977, The effect of road deicing salts on the drift of stream benthos: Environmental Pollution, v. 14, p. 113-126.

Center for Watershed Protection, 2003, Impacts of impervious cover on aquatic systems: Watershed Protection Research Monograph No. 1., Center for Watershed Protection, Ellicott City, Maryland, $142 \mathrm{p}$.

Center for Watershed Protection, 1998, Rapid watershed planning handbook: A comprehensive guide for managing urban watersheds: Center for Watershed Protection, Ellicot City, Maryland, $257 \mathrm{p}$.

Ebert, D.W., and Wade, T.G., 2003, Analytical tools interface for landscape assessments (ATtILA) users guide: Version 3.03 Beta, Office of Research and Development, U.S.

Environmental Protection Agency, Las Vegas, Nevada. 23 p.

Elvidge, C.D., Milesi, C., Dietz, J.B., Tuttle B.T., Sutton, P.C., Nemani, R., and Vogelmann, J.E., 2004, U.S. constructed area approaches the size of Ohio: EOS, v. 85, no. 24, p. 233240.

Galli, J., 1991, Thermal impacts associated with urbanization and stormwater management best management practices: Metropolitan Washington Council of Governments, Maryland Department of Environment, Washington D.C., $188 \mathrm{p}$.

General Accounting Office, 2001, Water quality: Better data and evaluation of urban runoff programs needed to assess effectiveness: Washington, D.C., Report GAO-01-679, 63 p.

Hammer, T.R., 1972, Stream channel enlargement due to urbanization: Water Resources Research, v. 8, no. 6, p. 1530-1540.

Hollis, G.E., 1975, The effects of urbanization on floods of different recurrence intervals: Water Resources Research, v. 11, p. 431-435.

Huang C., and Townshend, J.R.G., 2003, A stepwise regression tree for nonlinear approximation: Application to estimating sub-pixel and cover: International Journal of Remote Sensing, v. 24, no. 1, p. 75-90.

Jennings, D.B., and Jarnagin, S.T., 2003, A modeling approach for estimating watershed impervious surface area from national landcover data 92: Photogrammetric Engineering and Remote Sensing.

Ji, M., and Jensen, J.R., 1999, Effectiveness of subpixel analysis in detecting and quantifying urban imperviousness from Landsat Thematic Mapper imagery: Journal of Geocarto International, v. 14, no. 4, p. 33-41.

Kienegger, E.H., 1992, Assessment of a wastewater service charge by integrating aerial photography and GIS: Photogrammetric Engineering and Remote Sensing, v. 58, no., 11 p. 1601-1606.

Klein, R.D., 1979, Urbanization and stream water quality impairment: Water Resources Bulletin v. 15, no., 4, p. 948963.
Leopold, L.B., 1968, Hydrology for urban land planning - a guidebook on the hydrologic effects of urban land use: U.S. Geological Survey Circular 554, Reston, VA, 18 p.

May, C.W., Horner, R.R., Karr, J. R., Mar, B.W., and Welch E.B., 1997, Effects of urbanization on small streams in the Puget Sound Lowland Ecoregion: Watershed Protection Techniques, v. 2, no. 4, p.483-493.

Monday, H.M., Urban, J.S., Mulawa, D., and Benkelman, C.A., 1994, City of Irving utilizes high resolution multispectral imagery for NPDES compliance: Photogrammetric Engineering and Remote Sensing, v. 60, no. 4, p. 411-416.

National Land Cover Dataset 2001, About the MRLC Program, What is the NLCD 2001?: [accessed July 6, 2004., http://www.mrlc.gov/mrlc2k_about.asp].

Plunk, D.E., 1989, Use of satellite imagery to assess impervious cover and nonpoint pollutant loadings in an urban watershed: Texas Christian University, Fort Worth, Texas, M.S. Thesis, $61 \mathrm{p}$.

Ridd, M.K., 1995, Exploring a V-I-S (vegetation-impervious surface-soil) model for urban ecosystems analysis through remote sensing: Comparative anatomy for cities: International Journal of Remote Sensing, v. 16, no.12, p. 2165-2185.

Schueler, T.R., 1994, The importance of imperviousness: Watershed Protection Techniques, v. 1, no. 3, p. 100-111.

Slonecker, E.T., Jennings, D.B., and Garofalo, D., 2001, Remote sensing of impervious surfaces: A review: Remote Sensing Reviews, v. 20, no. 3, p. 227-255.

Tilley, J.S., and Slonecker, E.T., 2005, Quantifying the components of impervious surfaces: U.S. Geological Survey Open-File Report, Draft, 87 p.

Todd, D.A., 1989, Impact of land use and nonpoint source loads on lake quality: Journal of Environmental Engineering, v. 115, no. 3, p. 633-649.

U.S. Environmental Protection Agency, 2001, The quality of our nation's water, 1992: United States Environmental Protection Agency, EPA-841-S-94-002, Washington, D.C., USEPA, Office of Water, $38 \mathrm{p}$.

U.S. Environmental Protection Agency, 2003a, Draft report on the environment at http://www.epa.gov/indicators/roe/, accessed April 25, 2004.

U.S. Environmental Protection Agency, 2003b, Draft Report on the environment technical document at http://www.epa. gov/indicators/roe/html/tsd/index.htm, accessed April 25, 2004.

Vogelmann, J.E., Howard, S.M., Yang, L., Larson, C.R., Wylie, B.K., Van Driel, N., 2001, Completion of the 1990s national land cover data set for the conterminous United States from Landsat Thematic Mapper data and ancillary data sources: Photogrammetric Engineering and Remote Sensing, v. 67, no. 6, p. 650-652.

Ward, D., Phinn, S.R., and Murry, A.T., 2000, Monitoring growth in rapidly urbanizing areas using remotely sensed data: Professional Geographer, v. 52, no. 3, p. 371-386. Whipple W., Jr., and Hunter, J.V., 1979, Petroleum 
hydrocarbons in urban runoff: Water Resources Bulletin 15 v. 4, p. 96-1105.

Wolman, M.G., and Schick, A.P., 1967, Effects of construction on fluvial sediment, urban and suburban areas of Maryland: Water Resources Research, v. 3, no.2, p. 451-464.
Yang, L., Huang, C., Homer, C.G., Wylie, B.K., and Coan, M.J., 2003, An approach for mapping large area impervious surfaces: Synergistic use of Landsat 7 ETM+ and high spatial resolution imagery: Canadian Journal of Remote Sensing, v. 29, no. 2, p. 230-240. 
An Assessment of Impervious-Surface Measurement Methods 


\title{
Comparing Impervious-Cover Densities on the Basis of Land-Use Types Between Sister Cities on the United States/Mexico Border
}

\author{
By Jean Parcher ${ }^{1}$
}

\section{Introduction}

As the world's population moves from a rural to a more urban environment (14 percent urban in 1900, almost 50 percent urban in 1990), man's impact on the hydrologic cycle becomes more pronounced (Douglas, 1994). The hydrologic impacts of urban growth include increased surface runoff, higher flood peaks, shorter runoff lag time, declined base flows, and impaired water quality (Savini and Kammerer, 1961; Shaw, 1988; Harbor, 1994; Arnold and Gibbons, 1996; Leopold, 1997). Increased impervious-cover due to urbanization impedes through-flow infiltration rates, escalates the probability of flooding, and accelerates the transport of contaminants into both ground and surface water flows (Leopold, 1968; McCutcheon and others, 1992; Bhaduri and others, 2000). Rapid urban growth during the $20^{\text {th }}$ century has shifted much of the world's population from rural farms to integrated population centers. Reliable methods are needed both to monitor current anthropogenic modifications to landscapes related to urban growth and to assess their hydrologic effects on the natural environment. Remotely sensed satellite data provide the capacity to analyze the relationship of these land-use and land-cover changes in a timely manner at both the regional and local level by depicting landscape data at various spatial and temporal scales (Ridd, 1995).

Few hydrologic studies have compared Mexican and American urban morphologies and their effects on surface runoff and flood management. This research examined the differences in urban morphology of cities in developed and developing countries by comparing the density of imperviouscover for different urban land-uses classes within the sister cities of Brownsville, Texas, and Matamoros, Tamaulipas, Mexico. The selection of an area spanning the U.S./Mexican border provides an opportunity to examine the differences in first and third world urbanization, while holding constant similar physical environments such as topography, vegetation, soils, and climate characteristics.

Cities in developing countries tend to be overcrowded, densely concentrated in structure, and characterized by a pro-

${ }^{1}$ U.S. Geological Survey, 8027 Exchange Dr., Austin, TX 78754. liferation of substandard housing located in marginal areas, increasing their vulnerability to natural disasters (Chardon, 2000; Lopez and others, 2001). In contrast, cities in the United States tend to sprawl in leapfrog, low-density developments (Johnson, 2001). The spatial diffusion of urban sprawl contributes to inefficient use of land resources for human mobility, larger amount of ecosystem modifications, greater dispersal of pollution, increased storm-water runoff and greater flood risks (Forman, 1995; Johnson, 2001; Yeh and Li, 2001). The shape of urban areas, their density, and their growth process significantly affect key hydrologic processes (Forman, 1995).

Surface runoff parameters used in hydrologic modeling applications are typically estimated from the density of impervious-cover and hydrologic soil properties in a watershed. Common values for these parameters are based on curve numbers developed by the U.S. Department of Agriculture, Natural Resource Conservation Service (NRCS) ${ }^{2}$ (Maidment, 1993; Haan and others, 1994). Parameters used to calculate curve-number values include hydrologic drainage properties of the soil group (retention), land-use or land-cover type (initial abstraction), and average percent of impervious-cover (abstraction). Impervious-cover estimates are calculated from each urban land-use based on national estimates.

Various methods have been used to estimate percentages of impervious-cover in a watershed basin. Since most impervious-cover is characteristic of human environments, one method is to map population densities derived from U.S. Census data to estimate impervious-cover for the temporal time period of census data collection (Stankowski, 1972; Bird, 2002b). Combining multiple datasets, such as population density from block-level census data, National Land-cover Data classes for commercial, manufacturing, and mining, and major U.S. highway road networks provided greater accuracy (Bird 2002a). Remotely sensed methods include classifying the fundamental physical features in urban areas that can be derived from imagery, based on the conceptual vegetation, impervious-cover, and soil (V-I-S) model for ecosystem analysis simplicity (Ridd, 1995, Hung, 2002). The simplicity of the triangle based V-I-S model facilitates quantifying the changes to

\footnotetext{
${ }^{2}$ The U.S. Department of Agriculture, Natural Resources Conservation Service was formally called the Soil Conservation Service. Curve numbers are defined in the Soil Conservation Service publication TR-55.
} 
surface materials and their relationship to urban morphology due to urban growth (Ward, 2000). Yet, classification of impervious surfaces with medium-resolution imagery rarely isolates pure pixel response due to the linear patterns of many impervious features. For the National Land-Cover Dataset (NLCD) 2002, Yang (2003) mapped subpixel percent imperviousness of the medium-resolution Landsat imagery by developing a regression- tree algorithm from manually classifying data using high-resolution imagery over a sample area. The rule based classifier was applied to the entire study area to classify subpixel imperviousness per 30 meter pixel.

In rapidly growing areas, such as near the U.S./Mexico border, urban growth rates quickly increase the amount of impervious-cover, demanding more frequent updates and(or) current sources of geospatial data. Satellite imagery, with repeat cycles from daily to monthly, provide a timely data source to derive impervious-cover estimates to aid city flood mitigation and infrastructure planning. In Brownsville and Matamoros, infrequent but intense tropical storms and hurricanes cause major water damage from severe ponding in the flat topography and from overbank runoff in the agricultural canals and natural drainage areas.

The main objective of this study was to test NRCS curve number $(\mathrm{CN})$ assumptions of percent impervious surface and in doing so develop improved estimates of imperviouscover for urban land-use types for cities in both a developed country (United States) and a developing country (Mexico). This research compares the impervious features in the different urban environments using land-use and land-cover data collected from medium-resolution Landsat $7 \mathrm{ETM}+$ satellite imagery and impervious surface data collected from high-resolution Quickbird 2 imagery for the U.S./Mexico Border sister cities of Brownsville and Matamoros. For each city, the density of impervious-cover by land-use type was quantified and compared to the conventional infiltration parameters used for hydrologic modeling. Results can be used for flood planning in developed and developing countries. The comparison of NRCS curve numbers with impervious-cover data provides an insight into the degree of correlation between the typical urban structure of both first and third world cities.

\section{Study Area}

The Brownsville/Matamoros sister city metropolitan area is located in the lower Rio Grande Valley near the terminus of the Rio Grande River which separates Cameron County, Texas from Tamaulipas, Mexico. The landscape is characterized by a wide deltaic floodplain, interspersed with abandoned river channel meanders. The historical meandering pattern of the Rio Grande in its delta caused alternating patterns of erosion and deposition leaving abandoned channel remnants called "resacas" in Brownsville and "meanderos" in Matamoros (Brown and others, 1980: White and others, 1986). As a wetland, resacas or meanderos play an important role in collecting and storing local flood runoff (Federal Emergency Manage- ment Agency, 1999). On the U.S. side of the border, Brownsville, has left many resacas in their natural form to provide multiple benefits, such as collection and storage of local storm runoff, conveyance channels for Rio Grande waters, irrigation and drinking water sources, wildlife habitat, and recreational attractions. In contrast, the rapid urban growth experienced by Matamoros has resulted in paving over all but two of their natural resacas (Mendoza, 2001). Therefore, flood control in Matamoros is limited to agricultural and sewage canals that lack proper maintenance for effective surface runoff.

During the past 30 years, the population of Matamoros tripled, while the population of Brownsville doubled (Instituto Nacional de Estadística, Geografía, e Informática, 2001; U.S. Census Bureau, 2001). The two cities exhibit major differences in their population density, complexity of road networks, and utility infrastructure. These three variables are interrelated. As public spending increases to construct efficient road networks and expand water, sewer, and electrical infrastructure, it becomes easier for the population to decentralize. A complex network of roads in Brownsville provides an easy commute between residences and businesses. In contrast, basic infrastructure in Matamoros is concentrated near the older, most central part of the city due to a lack of public spending. Thus, it is more convenient for higher income residents to remain centralized and reduces incentives for lower density urban growth and sprawl. Differences in land-use and urban-spatial patterns for the two cities are highly related to the availability of efficient transportation networks and funding for basic infrastructure (Alacron, 2000).

These differences in urban patterns and surface hydrologic flows result in more serious flood problems for Matamoros than for Brownsville. Since the construction of the Falcon and Amistad dams upstream from these sister cities, the Rio Grande River that separates them is no longer the primary flood hazard. Infrequent but intense tropical storms and hurricanes are more likely to cause major water damage from severe ponding in the flat topography and from overbank runoff in the agricultural canals and natural drainage areas. Unchecked urban sprawl, rapid growth, and inadequate landuse planning combine to increase the human vulnerability to flood hazards.

\section{Methods}

\section{LULC Classification Procedures}

To derive the general-purpose land-use and land-cover, supervised classification was performed on the Landsat 7 ETM+ scene using the National Land-cover Classification (NLCD) schema. The NLCD schema is a national land-use and land-cover (LULC) standard that also contains estimates for impervious-cover for each urban land-use class. The geometrically corrected Landsat 7 ETM+ scene was subsetted into a 141 square kilometer Matamoros urban area and a 310 square kilometer Brownsville urban area to reduce spectral 
confusion between training data signatures when applying classification procedures to both urban and rural areas. For the classification step, the two cities were separated because the residential patterns were distinct between Matamoros and Brownsville.

The Landsat 7 ETM+ scene was classified into fifteen LULC classes using the maximum likelihood supervised classification method. On the basis of field work and photo interpretation, 21 separate training classes were collected for the U.S. urban area and 20 training classes for the Mexican urban area, using the Rio Grande/Rio Bravo as the International Border. To compensate for similar spectral response patterns between certain classes, probability thresholds for inclusion into each class were set. After the classification was run, manual editing was performed to modify large misclassified areas that had similar spectral responses and needed ancillary information to determine the correct land-use class. To reduce the spectral output, a post classification clumping process was run on selected classes using a three by three pixel window.

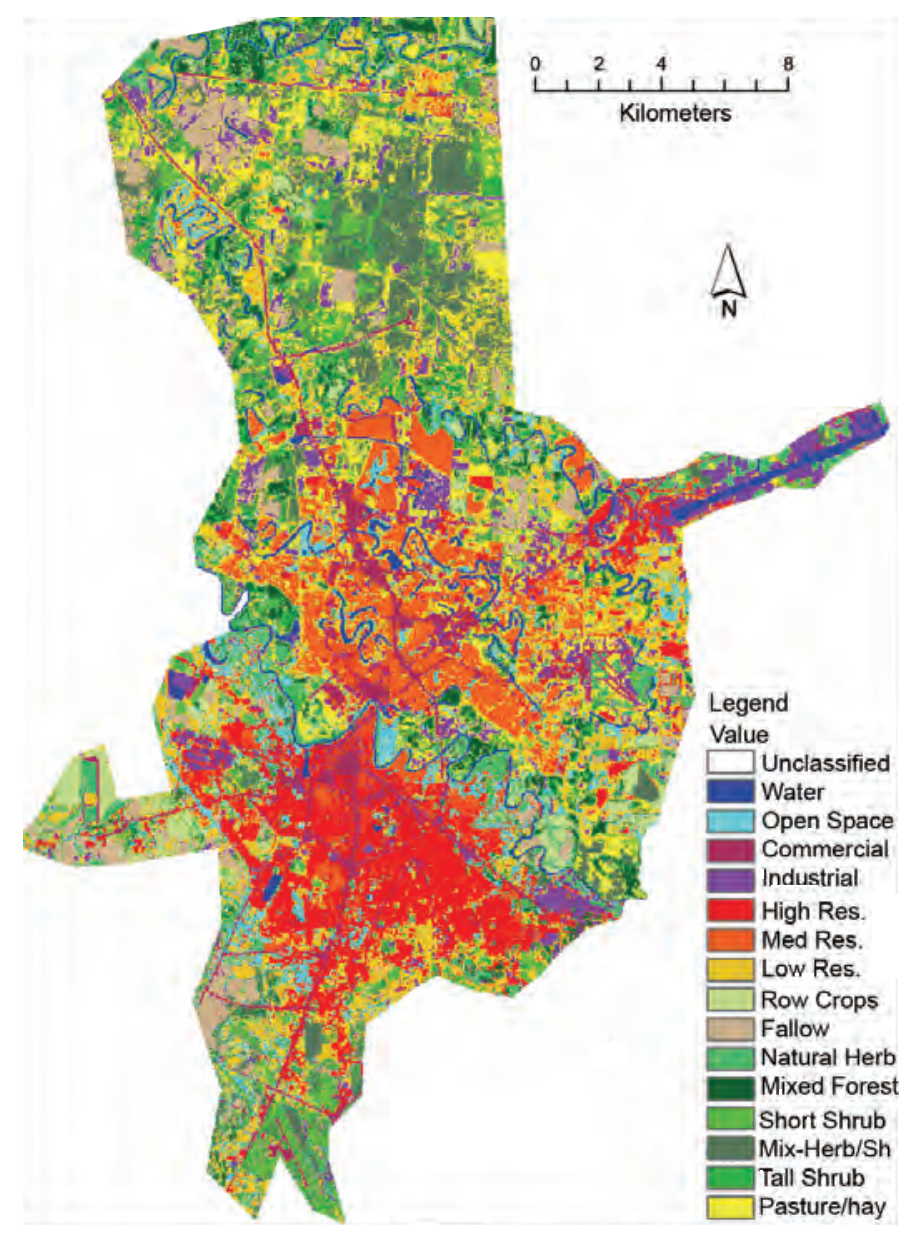

Figure 1. Land-use and land-cover classification results for Brownsville and Matamoros urban areas. High Res., high density residential; Med Res., medium density residential; Low Res., low density residential; Sh, shrub.
Finally the classes were combined into the final classification scheme, with both the Brownsville and Matamoros merged into one classification image (fig. 1). The overall classification accuracy was 78.11 percent derived from an accuracy assessment of 466 randomly selected points referenced from two higher resolution images, SPOT 5 and Digital Globe Quickbird imagery.

\section{Impervious-Cover Classification Procedures}

The impervious surface classification was extracted from a high-resolution Digital Globe Quickbird-2 satellite image date April 29, 2002, using the vegetation, impervious-cover, and soil V-I-S model derived by Ridd, 1995. The image was subsetted into distinct Brownsville and Matamoros urban areas, with separate training data defined for each country. Because impervious-cover was the significant feature to map, impervious-cover training classes consisted of light and dark paved roads, various types of roofs, cars, and trucks. The vegetation and soils training classes were aggregated according to their light and dark spectral responses.

A limiting factor in the supervised classification was the small number of bands of data (4), all clustered in the visible and near infrared spectral areas, which made it difficult to distinguish between similar spectral responses of different features. Water features were masked off using ancillary vector and polygon data because they were difficult to classify due to sun glint and growths of hydrilla and hyacinth in the river. To provide more spectral response information at a high-resolution, LIDAR (light detection and ranging) intensity data collected from a January 2003 LIDAR survey for the Brownsville area was resampled from 1 meter to 2.4 meters and merged with the Quickbird imagery to perform the supervised classification. This LIDAR intensity data greatly reduced confusion between fallow areas and dark roofs, and dirt roads and white roofs. Unfortunately, the LIDAR data did not cover Matamoros. The Matamoros impervious classification required extensive hand editing to correct for the confusion between fallow and impervious roads, fallow and dark roofs, and dirt roads and white roofs. Finally, both the Brownsville and Matamoros results were merged together into one classification. Overall classification accuracy resulted in 93.3 percent for Brownsville and 89.7 percent for Matamoros, using a randomly selected sample of 325 points referenced by the panchromatic Quickbird image.

\section{Calculating Impervious-cover for Each LULC Class}

Calculating the percentage of impervious surfaces per land-use class in each country was achieved by spatially intersecting the impervious classification layer with each of the 
LULC classes. Using a raster calculator process, the percent of impervious pixels was obtained by dividing the number of impervious pixels by the total number of pixels from that LULC class. Data were collected separately for each city.

\section{Results}

The final results are examined in several ways. First a comparison of percent impervious surfaces and impervious aggregated with bare soil between the two cities, and then a comparison with the NRCS CN and NLCD impervious surface estimates.

The final results demonstrate a higher percentage of impervious surfaces for commercial, low-density residential, and open space in Brownsville than Matamoros (table 1). For these two cities, impervious-cover estimates are very similar for high- density residential. Matamoros has higher rates of impervious-cover for industrial and medium-density residential and exhibits comparatively very high amounts of bare soil or dirt roads for all classes. For medium- and low-density residential and open space, the amount of bare soil or dirt roads in Matamoros almost equals or exceeds the amount of impervi-

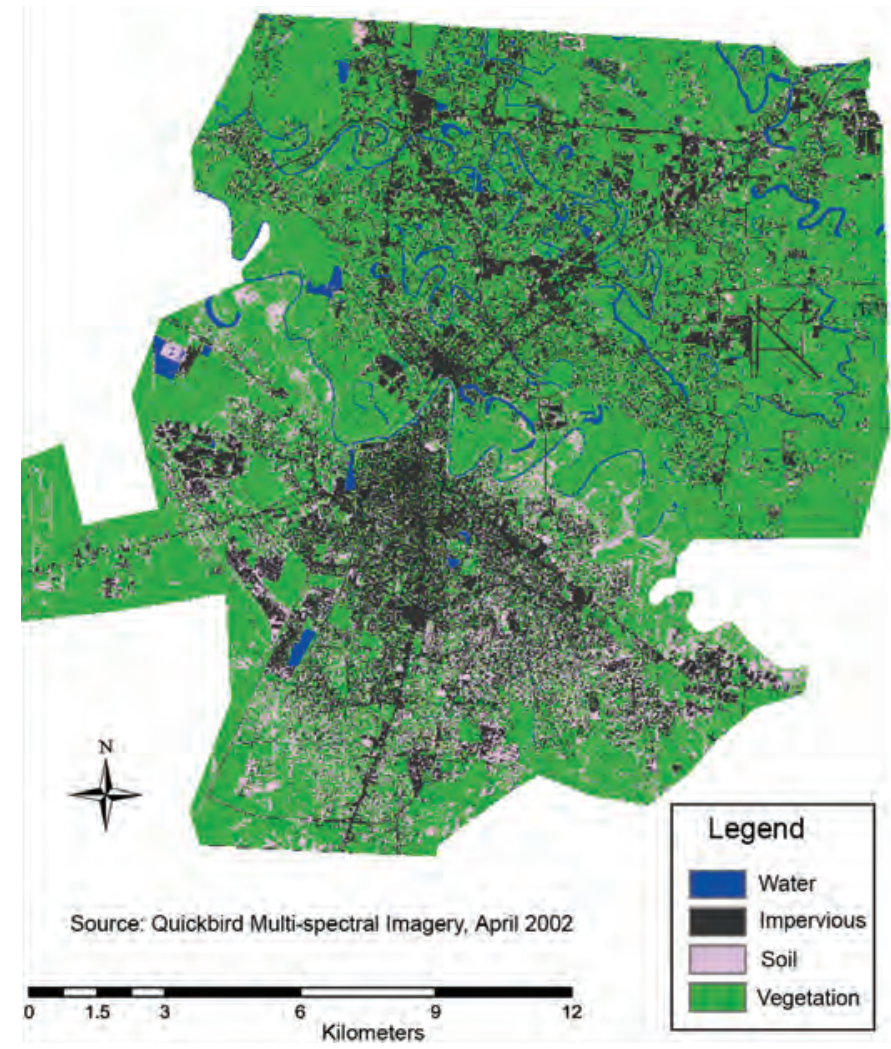

Figure 2. Vegetation, impervious-cover, and soil classification results for Brownsville and Matamoros.
Table 1. Comparison between urban land-use types in Brownsville and Matamoros and their surface components.

\begin{tabular}{|c|c|c|c|}
\hline Brownsville & \multicolumn{2}{|c|}{ Impervious Soil } & Vegetation \\
\hline Commercial & $74 \%$ & $4.65 \%$ & $19.03 \%$ \\
\hline Industrial & $37.90 \%$ & $10.10 \%$ & $45.65 \%$ \\
\hline High Density & $46.05 \%$ & $9.22 \%$ & $44.03 \%$ \\
\hline Medium Density & $28.70 \%$ & $7.18 \%$ & $63 \%$ \\
\hline Low Density & $15.94 \%$ & $6.15 \%$ & $76.40 \%$ \\
\hline Open Space & $5.30 \%$ & $1.89 \%$ & $90.80 \%$ \\
\hline Matamoros & \multicolumn{2}{|c|}{ Impervious Soil } & Vegetation \\
\hline Commercial & $63.04 \%$ & $12.98 \%$ & $23.50 \%$ \\
\hline Industrial & $40.31 \%$ & $25.35 \%$ & $32.07 \%$ \\
\hline High Density & $45.89 \%$ & $25.71 \%$ & $28.32 \%$ \\
\hline Medium Density & $29.98 \%$ & $28.28 \%$ & $41.55 \%$ \\
\hline Low Density & $8.60 \%$ & $18.41 \%$ & $72.87 \%$ \\
\hline Open Space & $4.22 \%$ & $26 \%$ & $69.51 \%$ \\
\hline
\end{tabular}

ous surfaces. This result may be an outcome of city planning in Matamoros, where streets are paved only when all residents along that street block contribute an equal amount to match the city funds to pave the street.

The high percentage of bare soils in Matamoros requires further analysis of their effects on the urban structure. Normally, urban areas with a high composition of dirt surfaces are undergoing transition to a different land-use category (Ridd, 1995). Field observations in Brownsville supported this theory. During fieldwork in Matamoros, evidence showed that many urban streets were not paved due to a lack of infrastructure funding. The compacted soil on these unpaved urban streets resulted in muddy quagmires after precipitation, due to their extremely poor drainage. Compacted bare soils have very low infiltration rates, which could result in runoff rates near precipitation rates (Haan and others, 1994). For Matamoros, aggregating this variable into the impervious surface cover may be justified for hydrologic applications.

For the commercial land-use class, the density of impervious surfaces in Brownsville is higher (74 percent) than Matamoros (63 percent), yet, when impervious and bare soil classes are aggregated, the totals are similar at 78 percent for Brownsville and 76 percent for Matamoros. In Brownsville there are several nuclei of commercial areas that include Sunrise Valley shopping mall and strip malls with large parking areas. The commercial areas in Matamoros are principally concentrated near the central business district, with older, narrow streets.

For the industrial class, the density of impervious-cover was much lower than the NRCS curve number and NLCD estimates. Matamoros was slightly higher at 40 percent, but when aggregated with bare soil, the density at 68 percent still did not reach the NLCD estimate of 72 percent. The LULC classification for industry is very broad and does not distinguish between types of industry, such as a manufacturing plant versus a software development company, yet the landscapes around the two types of industry are very distinct. 
For Brownsville, the low 38 percent density of impervious surfaces show the changing landscape of industrial areas from a 1950s style manufacturing plant to a mid-1990s style computer-manufacturing campus with athletic fields and landscaped areas. In Mexico, the lower impervious values may reflect the amount of unpaved roads and parking areas.

As expected the residential urban classes in Brownsville and Matamoros demonstrated decreased amounts of impervious surfaces as the density of housing decreased. The majority of residential areas in Matamoros were classified as high density with an average of 46 percent impervious-cover. When bare soil surfaces were aggregated with impervious-cover to reach 78 percent in Matamoros, this value exceeded the NRCS $\mathrm{CN}$ for high-density residential. In Matamoros, high-density residential is located in both the newer and older areas. The large amount of bare soils in the newer areas may be due to areas in transition, whereas in the established neighborhoods the bare soil is due to lack of infrastructure. In contrast, Brownsville's high-density residential, including apartment buildings, exhibited almost equal amounts of vegetation (44 percent) and impervious surfaces (46 percent). The use of Quickbird imagery taken during the leaf on season may have skewed the density of impervious surfaces due to tree canopies obscuring pavement in urban areas.

The majority of residential areas in Brownsville were classified as medium density areas, reflecting a suburban landscape. In Brownsville, the percentage of vegetation for this class was high at 69 percent whereas impervious surfaces were only 29 percent. In Matamoros, a large amount of medium density residential areas are located in the older, wealthier por- tions of the city, near the river and central business district. The biophysical landscape for this class was broken down to 30 percent impervious, 42 percent vegetation, and 28 percent dirt surfaces exhibiting wider transportation infrastructure than the high-density residential.

Next, the results for the two cities are compared with the average amount of impervious-cover for similar classes from the NRCS curve number tables and the NLCD. For the NRCS curve number table, the medium-density residential impervious percentage was averaged out from the middle ranges of land lot sizes. The NLCD impervious levels are based on high-density (including commercial, industrial, and residential) and medium and low density residential areas. Therefore, impervious-cover percentages were roughly estimated for the residential land-use classes for the NLCD for comparison purposes. Figure 3 shows the relationships between percentages of impervious levels:

As a final comparison (fig. 4) examines impervious features aggregated with bare soils with the percentage of impervious features for the LULC classification schemes. This method of comparison significantly changes the density of impervious surfaces for Matamoros. When bare-soil density is added to impervious density, Matamoros exhibits a greater density of impervious surfaces than Brownville in all classes except commercial. This aggregation greatly modifies the comparison with the NLCD and NRCS impervious estimates. Now Matamoros exceeds the NLCD and NRCS CN estimates for all classes except commercial and industrial. Brownsville exhibits similar results as Matamoros, except does not exceed the NRCS CN for high density residential.

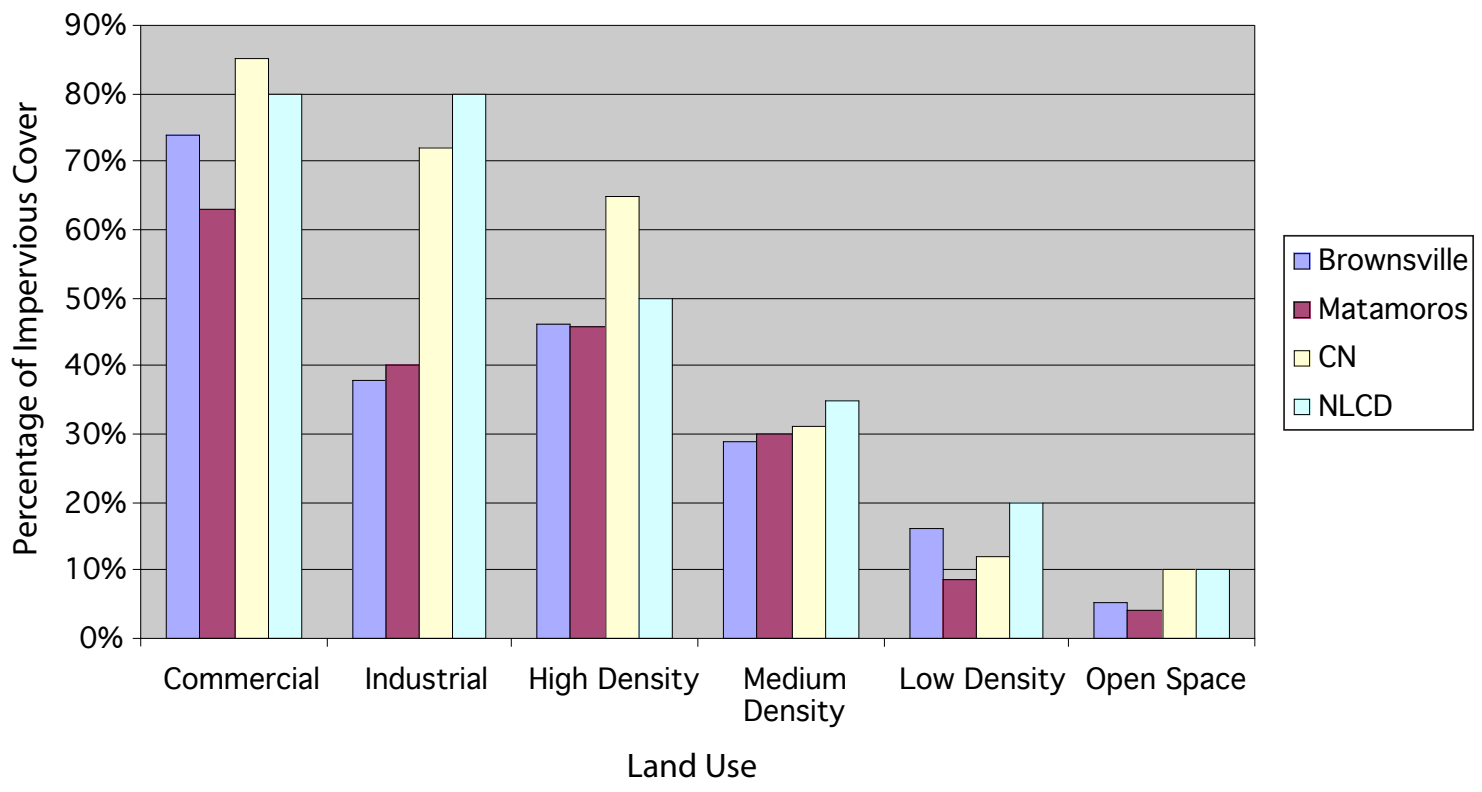

Figure 3. Comparison of impervious surfaces in Brownsville and Matamoros with Natural Resource Conservation Service curve number (CN) and National Land-Cover Dataset (NLCD) impervious-cover estimates. 


\section{Discussion}

The differences in urban structure between Mexican and American cities may require different scales of satellite imagery for similar classification schemas (Parcher, 2003). Due to the dense urban form and smaller spatial patterns in Matamoros, medium-resolution 30-meter pixel satellite imagery may not be able to distinguish the same level of hierarchical LULC features as sufficiently as it would in Brownsville. The selection of separate training data for each country attempted to compensate for some of these distinctions. Variations in predominate types of residential areas between the two countries, with high- density most prevalent in Matamoros and mediumdensity in Brownsville, reflect the unique spatial patterns between the two cities.

The variations in the physical composition of urban features between the two cities was reflected in the vegetation, impervious, and bare-soil classification results. For hydrologic modeling applications, the reliability of aggregating bare soil with impervious surface data would depend on the soil type of the dirt areas, their compaction, and relative moisture. If the dirt areas are well compacted, and the hydrological soil type is of poor drainage, then these areas may be very similar to impervious features. In developing countries with large unpaved urban areas, the V-I-S classification model provides critical biophysical data needed for both hydrologic models and urban ecosystem analysis. In more affluent countries with enforced zoning laws, estimates of impervious-cover, vegetation, and bare-soils from land-use and land-cover data may be sufficient for urban hydrology models.

\section{References}

Alarcón Cantu, Eduardo, 2000, Estructura urbana en ciudades fronterizas - Nuevo Laredo-Laredo, Reynosa-McAllen, Matamoros-Brownsville: El Colegio de la Frontera Norte. $231 \mathrm{p}$.

Arnold, C.L., Gibbons, C. J, 1996, Impervious surface coverage-The emergence of a key environmental indicator: Journal of the American Planning Association, v. 62 , no. 2, p. 243-258.

Bhaduri, Budhendra, Harbor, John, Engle, Bernie, and Grove, Matt, 2000, Assessing watershed scale, long term hydrologic impacts of land-use change using a GPS-NPS model: Environmental Management, v. 26, no. 6, p. 643-658.

Bird, S.L., Exum, L.R., Alberty, S.W., Perkins, Christine, 2002a, Estimating impervious-cover from regionally available data: EPA peer reviewed publication.

Bird, S.L. Exum, L.R., Alberty, S.W., Perkins, Christine, 2002b, Screening to identify and prevent urban storm water problems - estimating impervious area accurately and inexpensively: EPA peer reviewed publication.

Brown, L.F., Brewton, J.L., Evans, T.J., McGowen, J.H., White, W.A., Groat, C.G, Fisher, W.F., 1980, Environmental geologic atlas of the Texas coastal zone-BrownsvilleHarlingen Area: Bureau of Economic Geology, University of Texas at Austin. 140 p.

Chardon, Anne-Catherine, 1999, A geographic approach of the global vulnerability in urban area-Case of Manizales, Colombian Andes: GeoJournal, v. 49, p. 197-212.

Douglas, Ian, 1994, Human settlements, in Changes in land-

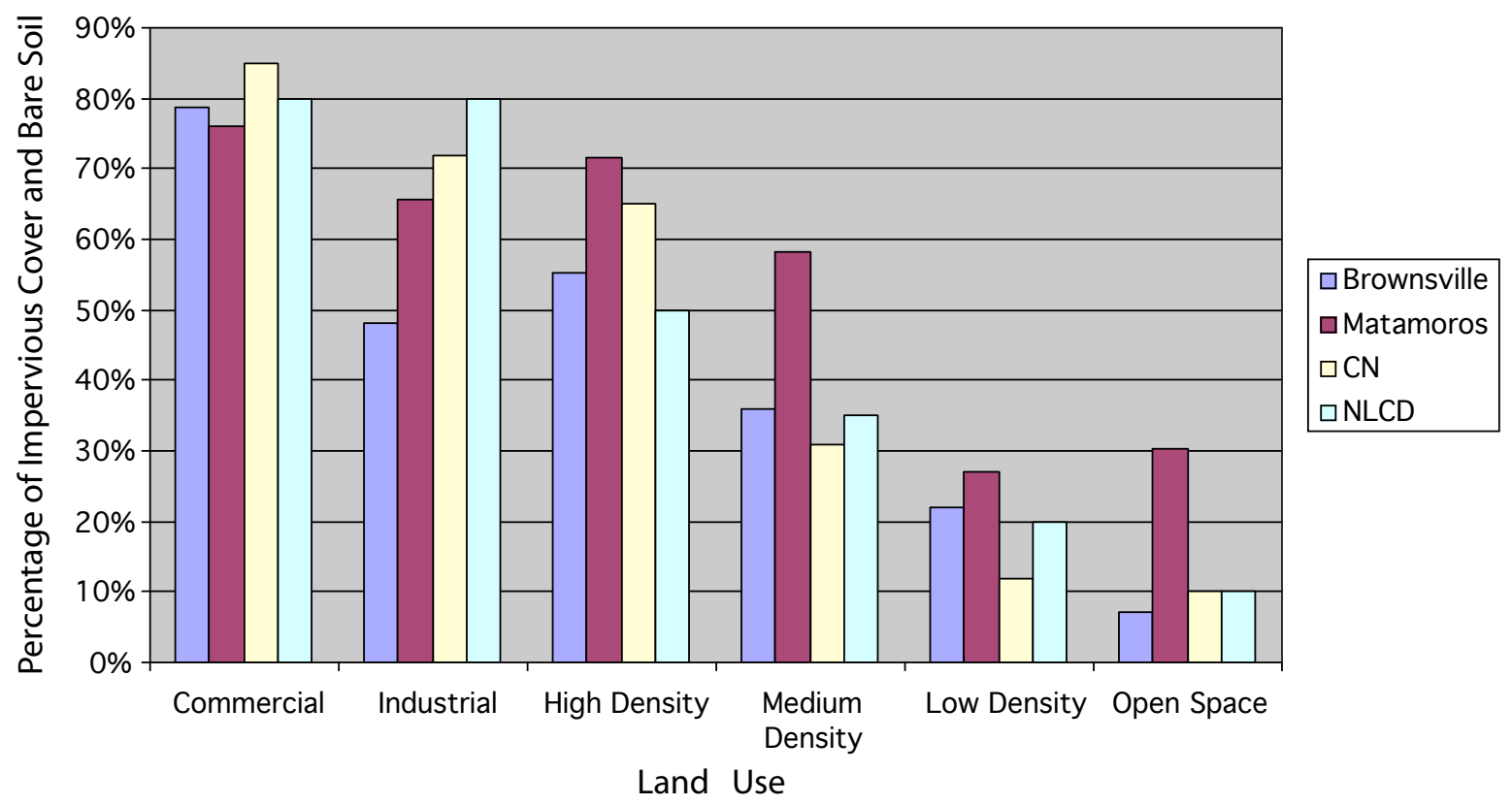

Figure 4. Comparison of impervious-cover aggregated with bare soil for Brownsville and Matamoros with Natural Resource Conservation Service curve number (CN) and National Land-Cover Dataset (NLCD) estimates. 
use and land-cover-A global perspective: Press Syndicate of the University of Cambridge, p. 149-169.

Federal Emergency Management Agency (FEMA), 1999, Flood insurance study - Cameron County, Texas, Unincorporated Areas.

Forman, R.T., 1995, Land mosaics, the ecology of landscapes and regions: Cambridge University Press, N.Y., N.Y., 605 p.

Haan, C.T., Barfield, B. J., Hayes, J.C. 1994, Design hydrology and sedimentology for small catchments: Academic Press, 581p.

Harbor, J.M., 1994, A practical method for estimating the impact of landuse change on surface runoff, groundwater recharge and wetland hydrology: Journal of the American Planning Association. v. 60, no. 1, p. 95-104.

Hung, Ming-Chih, 2002, Urban land-cover analysis from satellite images: Pecora15/Land Satellite Information IV/ ISPRS Commission I/FIEOS 2002 Conference Proceedings.

Instituto Nacional de Estadística Geografía e Informática (INEGI), 2001, Sistema de Información Municipal de Bases de Datos: Instituto Nacional de Estadística Geografía e Informática, México, D.F. [http://www.inegi.gob.mx/ estadistica/espanol/sociodem/fsociodemografia.html].

Johnson, M.P., 2001, Environmental impacts of urban sprawl - a survey of the literature and proposed research agenda: Environment and Urban Planning A, v. 33, p. 717735.

Leopold, L.B., 1968, Hydrology for urban land planning-A guidebook for the hydrologic effects of urban land-use: U.S. Geological Survey Circular.

Leopold, L.B., 1997, Waters, rivers, and creeks: University of Science Books, 185 p.

López, Erna, Bocco, Gerardo, Mendoza, Manuel, Duhau, Emilio, 2001, predicting land-cover and land-use change in the urban fringe-A case in Morelia, Mexico: Landscape and Urban Planning, v. 55, p. 271-285.

Maidment, D.R., 1993, GIS and hydrologic modeling, in Environmental modeling with GIS: Oxford University Press, p. 147-167.

McCutcheon, S.C., Martin, J.L., Barnwell, T.O., Jr., 1992, Water quality, in Handbook of hydrology: McGraw-Hill, 1992. p. 11.1-11.73.
Mendoza, Jaime, 2001, Inundaciones en MatamorosAlgunos Factores Explicativos: Unpublished paper. El Colegio de la Frontera Norte, Dirección Regional de Matamoros.

Parcher, J.W., 2003, remote sensing methods for estimating impervious cover for hydrologic modeling applications - a case study of the Brownsville/Matamoros urban area: University of Texas, Austin, unpub. Masters thesis, p. 138.

Ridd, M.K., 1995, Exploring a V-I-S (vegetation-impervious surface-soil) model for urban ecosystem analysis through remote ssensing - Comparative anatomy for cities: International Journal of Remote Sensing, no. 16, p. 2165 2185.

Savini, John, Kammerer, J.C., 1961, Urban growth and the water regime, in Hydrologic effects of urban growth: U.S. Geological Survey Water Supply Paper 1591.

Shaw, E.M., 1998, Hydrology in practice, $2^{\text {nd }}$ Ed.: Chapman and Hall, London, 563 p.

Stankowski, S.J., 1972, Population density as an indirect indicator of urban and suburban land-surface modifications: U.S. Geological Survey Professional Paper 800-B, p. B219B224.

U.S. Bureau of Census, 2001, American fact finder: [http:// factfinder.census.gov/servlet/BasicFactsServlet].

Ward, Douglas, Phinn, S.R., Murray, A.T., 2000, Monitoring growth in rapidly urbanizing areas using remotely sensed data: Professional Geographer, v. 52. no. 3, p. 371-386.

White, W.A., Calnan, T.R., Morton, R.A., Kimble, R.S., Littleton, T.G., McGowen, J.H., Nance, H.S., Shemedes, K.E., 1986, Submerged lands of Texas, BrownsvilleHarlingen area-Sediments, Geochemistry, Benthic Macroinvertebrates, and Associated Wetlands: Bureau of Economic Geology, University of Texas, Austin, 138 p.

Yeh, Anthony Gar-On, Li Xia, 2001, Measurement and monitoring of urban sprawl in a rapidly growing region using entropy: Photogrammetric Engineering and Remote Sensing, v. 96, no. 1, p. 83-90.

Yang, L., 2003, Urban land-cover change detection through sub-pixel imperviousness mapping using remotely sensed data: Photogrammetric Engineering and Remote Sensing, v. 69, no. 9, p. 1003-1010. 



\title{
The Use of Spatial Analytical Techniques to Identify Potential Brownfields Sites
}

\author{
By Janet S. Tilley ${ }^{1}$, Robin Paul ${ }^{2}$, Terrence Slonecker ${ }^{3}$, and Ellen Walkowiak ${ }^{4}$
}

\section{Introduction}

Brownfields are abandoned, idled, or underutilized properties where expansion or redevelopment is complicated by real or perceived environmental contamination (United States Environmental Protection Agency, 2004). Most brownfields sites are located in urban, commercial or industrial areas and are often prime locations for development. Because "perceptions" of a pollution problem can be extremely difficult to identify, GIS technology offers a potentially significant tool in the inventory of potential brownfields sites. In the field assessment process, it is visually difficult to determine whether a site is contaminated or not. However, with the application of particular data in the geospatial analysis, this technology can identify sites that have a history or association with a past pollution problem that may be appropriately defined as brownfields. In addition to freeing up resources, more efficient identification and inventory of possible brownfields sites will help any community pinpoint other properties that have a potential for economic redevelopment.

This study represents geographic information systems (GIS) based spatial analysis that can provide a reasonable inventory of potential brownfields properties over a city-wide area. In cooperation with United States Environmental Protection Agency (USEPA) Region 7, Polk County, Drake University, and the City of Des Moines, Iowa, we utilized field data, maps, existing environmental information, remotely sensed data, and tax records in a GIS overlay and analysis process to identify potential brownfields redevelopment properties. The results can save funds that can be applied in the later steps of redeveloping the brownfields or in other urban revitalization processes.

\section{Background}

The Small Business Liability Relief and Brownfields Revitalization Act (Public Law 107-118, http://www.epa.

\footnotetext{
${ }^{1}$ U.S. Geological Survey, Reston, Virginia, jtilley@usgs.gov.

${ }^{2}$ U.S. Environmental Protection Agency, Des Moines, Iowa, paul.robin@ epa.gov.

${ }^{3}$ U.S. Environmental Protection Agency, Reston, Virginia, slonecker.t@epa. gov.

${ }^{4}$ City of Des Moines, Des Moines, Iowa, eawalkowiak@dmgov.org.
}

gov/brownfields/sblrbra.htm) was signed into law on January 11,2002 . It defines brownfields sites as "...real property, the expansion, redevelopment, or reuse of which may be complicated by the presence or potential presence of a hazardous substance, pollutant, or contaminant." Many once thriving industrial and commercial properties throughout the United States have been abandoned. Some are contaminated from their former uses. Uncertainties over liability issues have caused lenders, investors, and developers to ignore the redevelopment potential of these areas in favor of pristine areas, or "greenfields." The result has been blighted areas with abandoned industrial and commercial facilities that create safety and health risks for residents, precipitate disinvestments, and create areas of "urban blight."

USEPA's brownfields program is designed to empower States, communities, and other stakeholders in economic development to work together in a timely manner to assess, safely clean up, and return abandoned or underutilized properties to productive use. It provides funding in the form of grants to (1) assess brownfields sites and to test cleanup and redevelopment models; (2) fund job training pilot programs that provide training for residents of communities affected by brownfields to facilitate cleanup of brownfields sites and prepare trainees for future employment in the environmental field; (3) capitalize cleanup revolving loan-fund programs to make loans for the environmental cleanup of brownfields; and (4) for direct cleanup of eligible brownfields sites (USEPA, $2003 \mathrm{~b})$. This will assist the return of vacant/underutilized properties to productive use, helping to curb sprawl by enabling reuse of urban resources (Ellman, 1997; Gernstein, 2002).

One of the key information requirements in the successful application of a regional brownfields program is the ability to identify and inventory all potential brownfields sites in a given metropolitan area. Current methods are often expensive, time consuming, and unreliable. One example of identifying brownfields sites, applied by the City of Des Moines, was by selecting large areas in the city that were more industrialized/commercialized or located in the heart of the city then driving these selected areas and conducting windshield surveys. During these surveys such information as the following were documented: company name, presence of for sale sign, what type of business it was, and whether it appears to be abandoned or not, as well as two to three photographs (Drake, 2001). However, not only is driving a car around for 
such surveys time consuming and expensive, but this method is potentially dangerous to the individuals conducting the surveys. Another example of a process of identifying brownfields sites is the designation of targeted redevelopment areas, or "enterprise zones," as is the case with the City of Des Moines (Des Moines, 2004; USEPA, 2003a). Although this approach benefits the near-term goals of the city's redevelopment plan, properties outside of the selected area, with excellent brownfields potential, may be overlooked. An objective and repeatable method for an area-wide inventory of potential brownfields sites could be an important part of a long term brownfields-program redevelopment strategy.

\section{Research Partners}

\section{The Role of the U.S. Geological Survey}

Geographic Analysis and Monitoring (GAM) Program scientists with United States Geological Survey (USGS) conduct geographic assessments of land surface change to improve our understanding of the rates, causes, and consequences of natural events, as well as human-induced processes, that shape and change the Nation's landscape over time. Studies are conducted within a geographic context and at a range of spatial and temporal scales so that investigations provide comprehensive information needed to understand the environmental, resource, and economic consequences of landscape change. Integrating natural-resource and socio-economic information with data themes from The National Map allows GAM scientists to quantify rates, identify key driving forces, and forecast future trends of landscape change (USGS, 2005).

The GAM program addresses three fundamental scientific issues concerning changes at the Earth's land surface. Specifically, GAM strives to achieve the following:

- Understand what changes are occurring on the land surface and why;

- Understand the impacts of these land surface changes on ecosystem health, climate variability, biogeochemi cal cycles, hydrology, and human health; and to

- Understand what the best methods are to incorporate scientific findings into the decision making process.

The ultimate goal of GAM is to aid people in understanding and adapting to change, now and in the future, and in making wise land-management decisions that will enhance their quality of life.

\section{The Role of U.S. Environmental Protection Agency}

The USEPA relies on sound science to safeguard both human health and the environment (USEPA, 2004). The Office of Research and Development (ORD) is the scientific research arm of USEPA. ORD's leading-edge research helps provide the solid underpinning of science and technology for the Agency. ORD conducts research on ways to prevent pollution, protect human health, and reduce risk. The work at ORD laboratories, research centers, and offices across the country helps improve the quality of air, water, soil, and the way we use resources. Applied science at ORD builds our understanding of how to protect and enhance the relationship between humans and the ecosystems of the earth. Within ORD, the National Exposure Research Laboratory's Environmental Science Division develops methods for characterizing chemical and physical stressors, and landscape and regional assessment capabilities through the use of remote-sensing and advanced spatial-analysis techniques.

The Landscape Ecology Branch focuses on the science of Landscape Ecology as an interdisciplinary science framework that studies the relationship between spatial patterns of landscape characteristics and conditions of and risks to ecological resources, including forests, rangelands, wetlands, rivers, streams, lakes, and urban environmental settings. Part of the mission of USEPA research is to integrate our efforts with that of its science partners, such as the USGS, to help solve the nation's environmental problems. To this end, in 2001 the USEPA Environmental Sciences Division entered into a cooperative interagency agreement with the USGS in order to jointly study urban ecological issues. This report is one of the first results of that collaboration.

\section{Objectives}

There is no commonly accepted methodology to identify potential brownfields sites over a city or even smaller areas within a city. It is hypothesized that geographic analysis and technologies will offer more efficient brownfields site identification than current methods being applied. To that end, the study will examine properties that returned multiple indicators from various GIS datasets. Multiple hits on suspect sites should allow for the refinement of a set of indicators from each data layer that can be used to establish a logical set of criteria for brownfields identification. The result set will be verified against a current brownfields inventory that was compiled using a series of traditional identification methods. Additionally, the study will begin to identify and recommend certain datasets, where further research will reveal other excellent types of data for rapid brownfields site identification.

\section{Study Area}

The selected study area was the City of Des Moines, Iowa, located in the Mid-west, which is situated in the Great Plains. It was selected because of the enthusiasm of the USEPA Brownfields Coordinator, Robin Paul, and the Brownfields Showcase Community Initiative Coordinator, Ellen Walkowiak, who were 
in search of a better technique than what they were currently using to identify brownfields sites. The city is divided into three sections by the two rivers flowing through it. The Raccoon River flows from west-to-east and splits off the southern portion of the city where it connects to the Des Moines River. The Des Moines River flows from north to south and splits the northern part of the city in half. The population of the city in the year 1990 was 392,928 and 10 years later increased by 12.9 percent to 443,496 (U.S. Census Bureau, 2000) (fig. 1). This City represents an excellent choice for testing our methods, as there is significant interest and activity in brownfields redevelopment.

Brownfields Showcase Communities are distributed across the country and vary by size, resources, and community type. Along with a total of 28 other cities across the United States, the USEPA selected Des Moines to be a Brownfields Showcase Community in 2000. The designation of Showcase Community allows Des Moines to serve as a national model for brownfields redevelopment. The City of Des Moines has created an impressive coalition of public and private entities focusing its brownfields redevelopment efforts on creating residential, commercial, and recreational developments in the Riverpoint West area and industrial development in the Agrimergent Technology Park projects. Des Moines is developing an area-wide redevelopment strategy to assemble private property and has made significant progress in identifying the extent of contamination in these areas. The City has identified approximately 250 brownfields sites throughout Des Moines, located primarily in the following targeted redevelopment areas: (1) the 1,100-acre Agrimergent Technology Park, (2) the 300-acre Riverpoint West area, and (3) the City's federally designated Enterprise Community.

\section{Data and Methods}

The potential brownfields inventory process described here is a basic GIS overlay/intersection operation based on property parcels with multiple data layers, for reference, that individually and in total represent some potential for brownfields redevelopment activity. Various GIS datasets, each with a unique contribution to brownfields site potential, were acquired for the purpose of determining a geographic-based brownfields identification strategy. These layers were roads, historical topographic maps, historical aerial photographs, underground storage tank (UST) sites, CERCLIS (Superfund) records, tax assessments, buildings, schools, and property parcels. The datasets that were most critical for our analysis are discussed further below.

\section{Field Surveys}

Two separate field surveys were conducted. Students from Drake University performed the first field assessment.
The Drake students performed a "windshield survey" of potentially abandoned properties in the commercial corridors of Des Moines. They provided a database containing potential brownfields site addresses, description of the property's condition, business function, photographs, and the building and land parcel property value (Drake University, 2001). The second field survey was conducted by Federal and City staff. They concentrated on the industrial corridors of the city trying to similarly identify abandoned properties. The same data collected for the commercial sites were collected for the industrial sites. Both datasets were entered into the GIS parcel database.

\section{Aerial Photographs and Historical Topographic Maps}

Urban landscapes are dynamic, constantly changing regions. In the period of one or two decades, land use can change dramatically, often leaving no visible or obvious indication of the previous activity. Historical aerial photographs and historical topographic maps have proven to be extremely valuable in identifying past hazardous waste activity as well as in developing historical profiles of landscape characteristics. A search of commercial and government sources of aerial photographs was conducted to develop a profile of available historical photography. From this profile, aerial photographs were obtained to represent a series of decadal snapshots of the City of Des Moines. Historical aerial photographs were obtained for 1938, 1945, 1956, 1961, 1967, and 1985. Numerous maps were obtained from USGS archives, the Library of Congress, and the Iowa Historical Society (fig. 2).

Aerial photographs and maps were analyzed for any anthropogenic activity that might result in a historical pollution profile. Among these are landfills/dumps, mining areas/tailings, ponds/quarries/pits, sewage disposal sites, oil tanks, sludge pits, electrical substations, industrial activity, and buildings in disrepair or obviously abandoned. These features, interpreted from historical aerial photographs and maps were digitized onto orthophoto base maps as a separate polygon theme. All sites identified in the Des Moines study were entered by property location and number in the parcel database.

\section{Underground Storage Tanks}

Information on existing USTs was acquired from the Iowa Department of Natural Resources (2002). These tanks are buried in commercial and industrial locations and generally contain petroleum. They have the potential to leak and cause groundwater contamination. These data were correlated and entered by property location in the parcel database. 


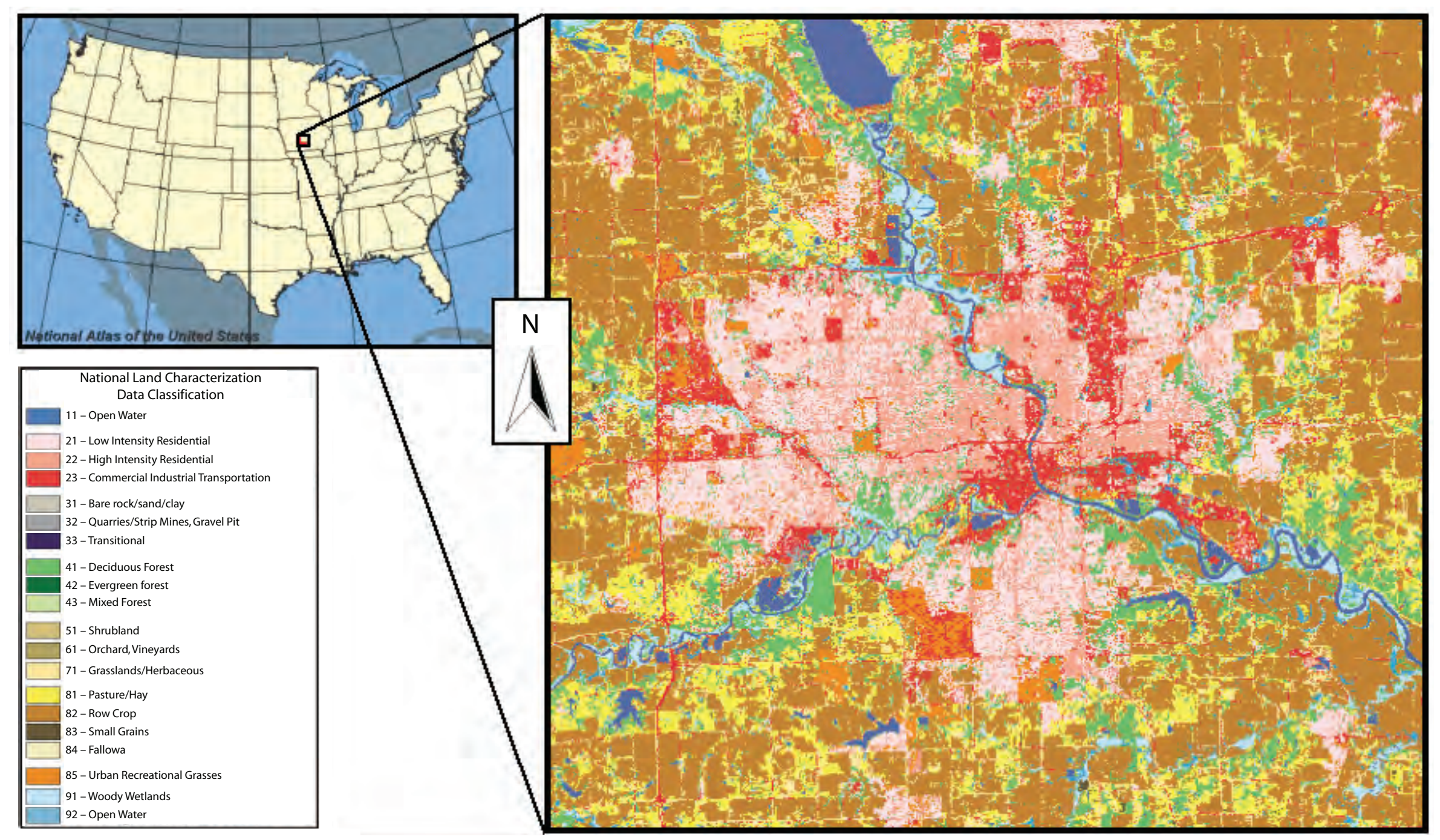

Figure 1. The Des Moines, lowa, study area, displayed using the National Land Characteristics Dataset. Pink, peach, and red-orange areas (where rivers meet and outward from that point) were built-up areas in 1992. 


\section{Comprehensive Environmental Response, Com- pensation Liability Information Systems}

Comprehensive Environmental Response, Compensation Liability Information Systems (CERCLIS) is the official Superfund hazardous waste site information system. CERCLIS contains information on potential hazardous waste sites and remedial activities across the nation, including sites that are on the National Priority List (NPL) or are being considered for the NPL. Those being considered often include sites where there is a low level of contamination or sites where emergency cleanups have been conducted. Either of these situations could contribute towards a perception of contamination as defined by the Brownfields Program. All CERCLIS identified sites in Des Moines were extracted from the database and correlated and entered by property location in the parcel database.

\section{Tax Assessor Data}

One of the most interesting and useful datasets was that containing the property values provided by the Polk County
Assessors Office (fig. 3). The data used in the study was for the 1995 and 2002 tax years and contained information on both the land and building values for all taxable commercial and industrial properties in the city. Analyses of these datasets led to several derived data layers that proved to be good indicator datasets for brownfields identification potential. The primary goal was to reveal unusual trends in the tax records that could have been indicative of abandonment or underutilization.

Five different queries were possible through the analysis. We examined two variables--land value and building value-and attempted to identify properties where these values declined rather than increased or showed unusual trends over the seven-year period.

These queries were as follows:

(1) Land value decreasing | Building value decreasing

(2) Land value decreasing | Building value unchanged

(3) Land value unchanged / Building value decreasing

(4) Land value increasing | Building value decreasing

(5) Land value decreasing | Building value increasing Each of these was extracted by a Boolean reselect operation resulting in the individual data layer.

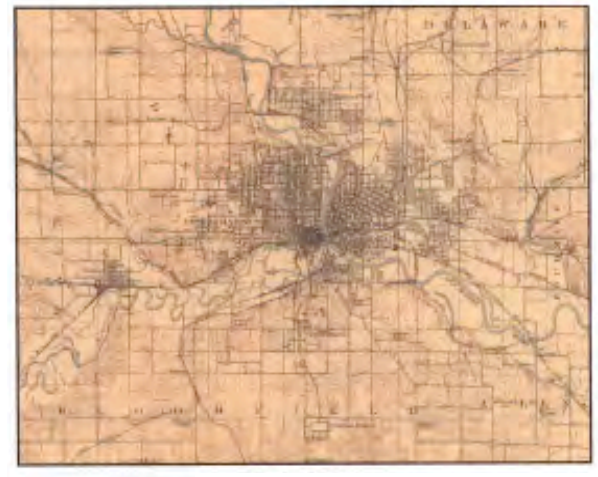

1907

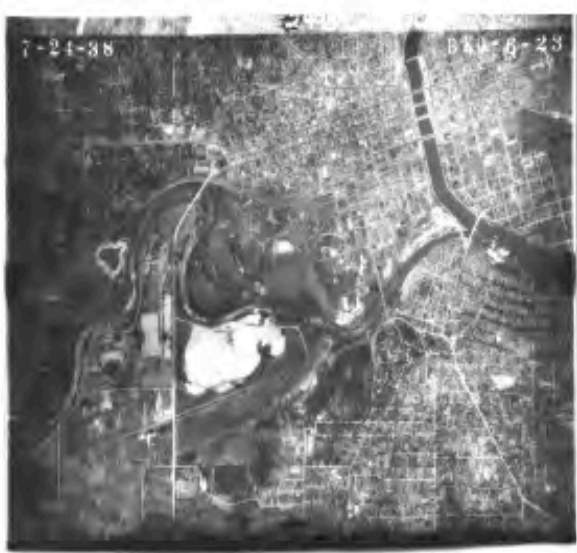

1938

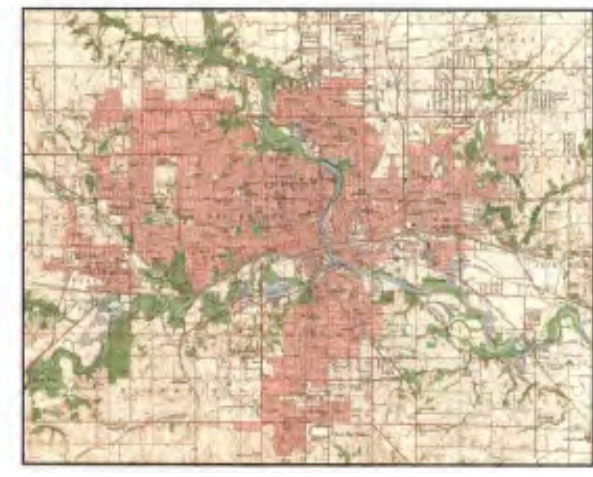

1956

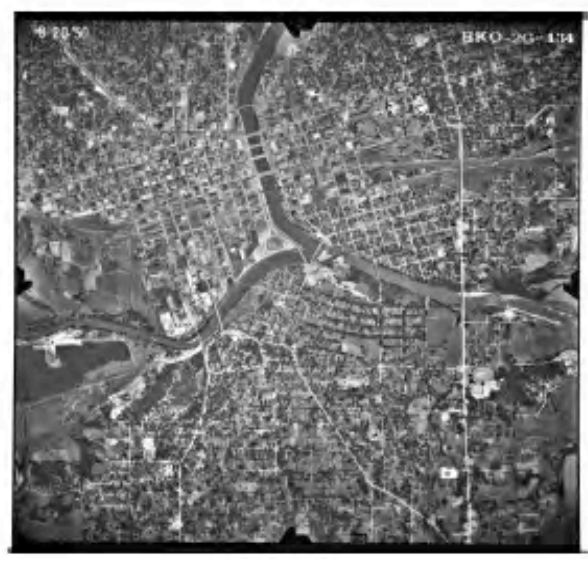

1950

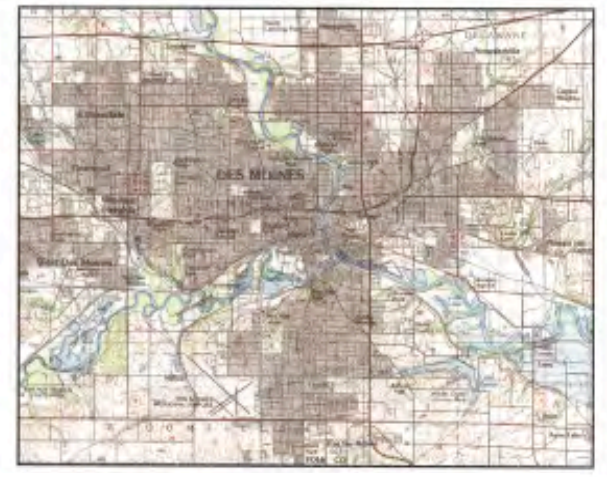

1990

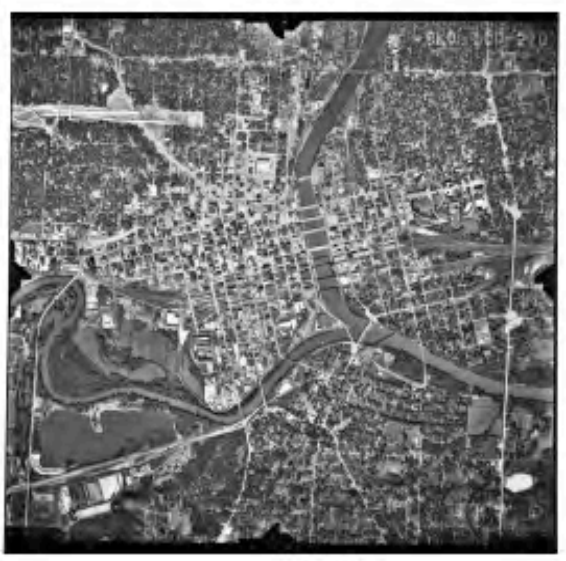

1967

Figure 2. Examples of historical maps and aerial photographs used to derive land-use patterns that could indicate potential brownfields. 


\section{Analysis and Preliminary Results}

Our initial analytical strategy involved simple overlay/intersection operations of all the datasets (fig. 4). The information from all the data layers was combined with the property parcel file obtained from the Polk County GIS Department. Information from field surveys, historical maps and aerial photographs, UST and CERLIS data were identified on a property parcel basis by creating a "flag" or specific attribute in the property table. Data layers were overlaid with the property layers and when an intersection occurred, the attribute value was calculated. For example, when an UST point fell into a specific property parcel, the "UST" attribute for that parcel was then set to 1. All of the non-taxassessors' data layers were combined with the property data and attributes were flagged. The property data, with all attributes from the above data identified, was then intersected with the data layers extracted from each of the five tax queries. When any particular property parcel contained two or more flags from any of the data layers, it was then identified as a "potential brownfields site" and extracted into a separate layer.

The results from the overlay/intersection method then were compared separately for each of the five analyses and resulted in subsets of between 29 and 250 potential brownfields sites. With this many potential sites derived from the datasets compared against the tax query results, the determination of brownfields sites knows only the spatial limits of the data extent. The tax assessor data proved to be a powerful tool in the geographic analysis of potential brownfields sites. For example, the project is demonstrating that declining tax valuations on properties in industrialized areas is a strong indicator of possible abandonment or general under utilization, and good brownfields potential.

Despite a limited ability to perform field verification and database inquiries, the initial results of this research are promising. Figure 5 shows a property with multiple hits from the different databases: tax value data, USTs, and CERCLIS; and shows the field photo of another property that was identified via GIS and verified in the field, that visually suggests it has brownfields potential.

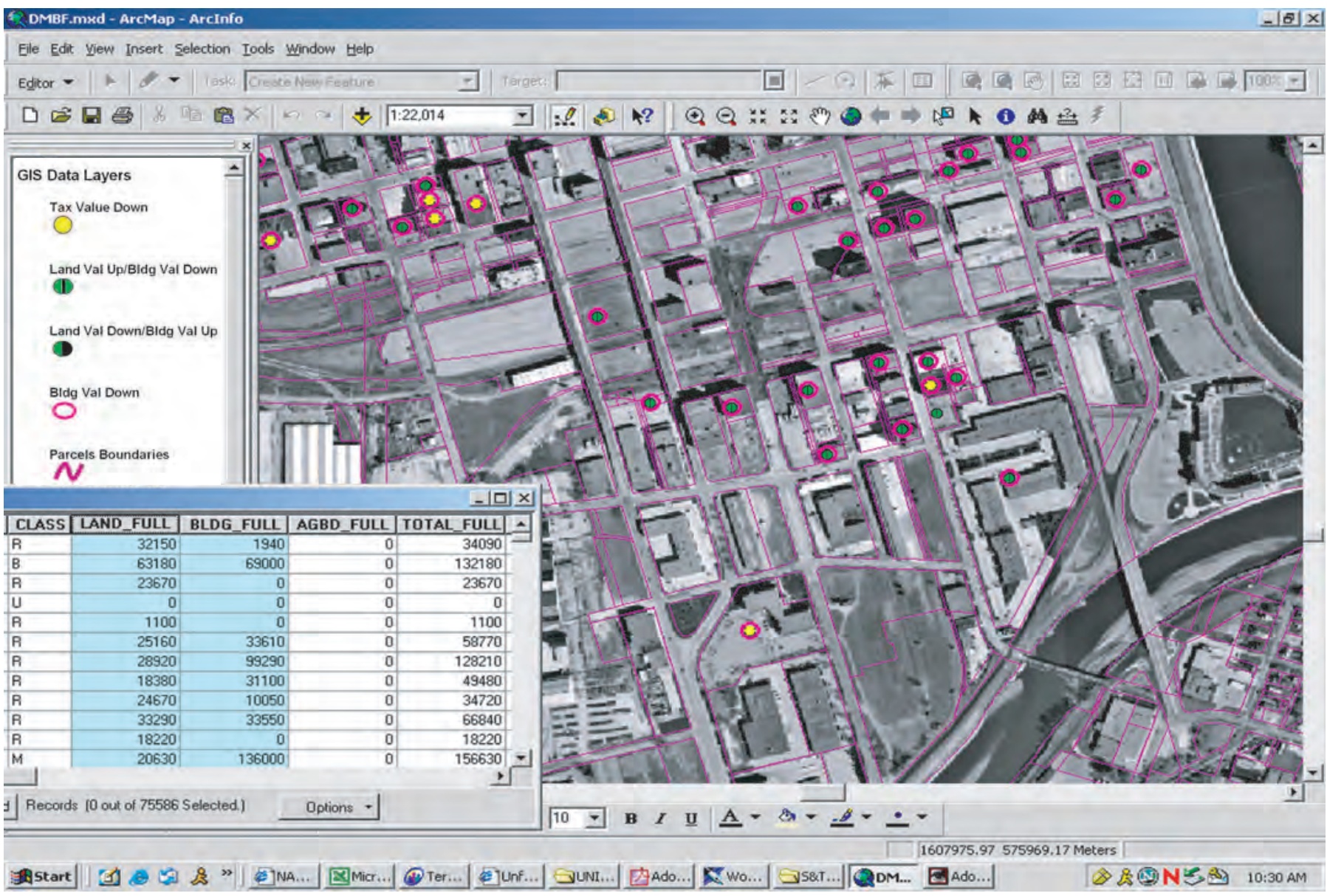

Figure 3. Tax and assessment records for a 7-year period from the Polk County Assessor's Office were invaluable in defining trends in property values possibly indicative of a brownfields profile. 

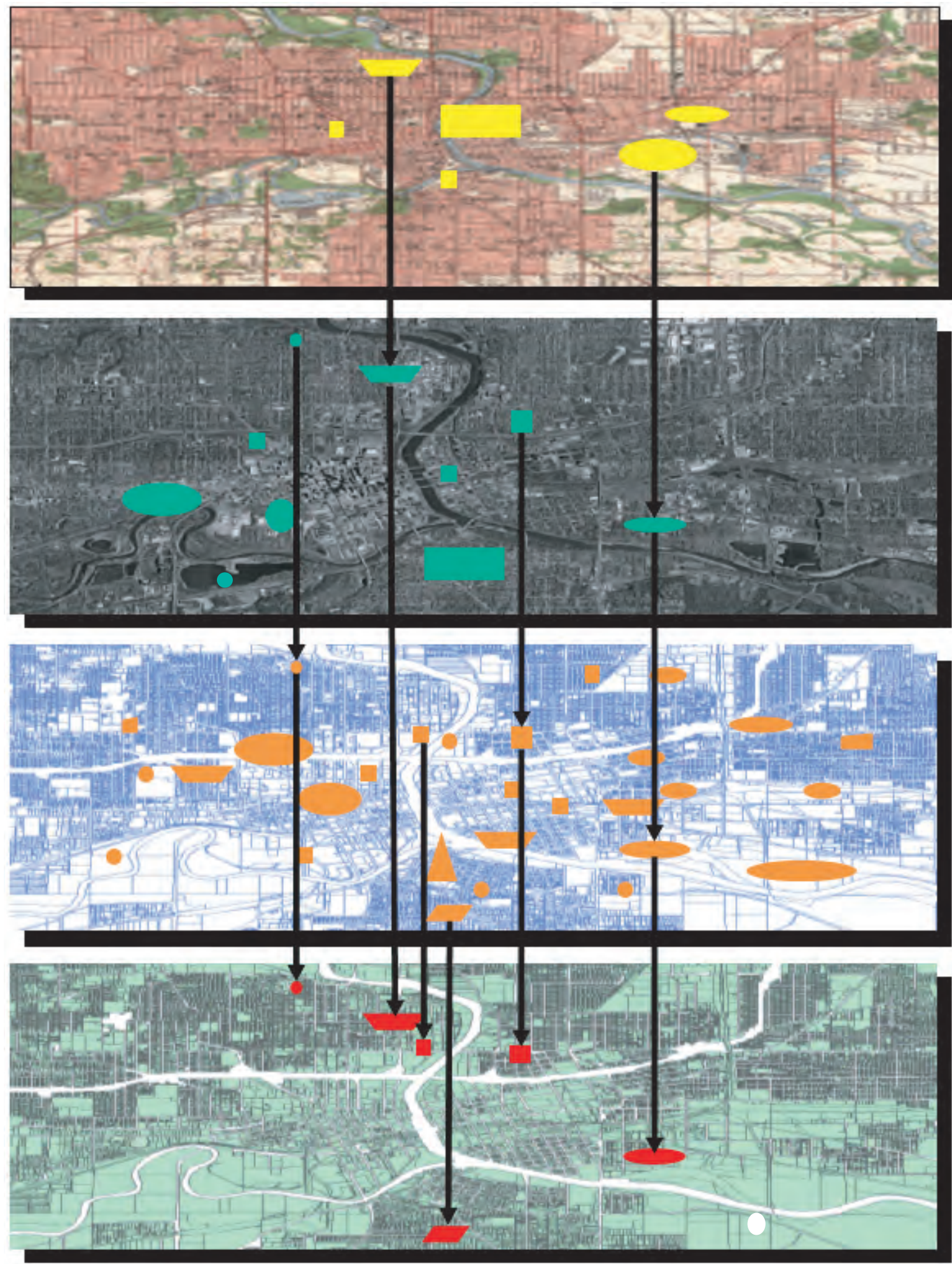

Figure 4. Example of methodology used in this study, showing various data sources except for underground storage tanks, Comprhensive Environmental Response, Compensation, and Liability Information System, and others. Each dataset offers numerous potential brownfields sites, with some sites showing up consistently from one dataset to the next. Sites present in two or more sources are referred to as "coincident" and could be brownfields. Coincident sites are put into a final potential brownfields dataset ready for field verification. In some cases, information accompanying parcel in tax-assessment data was enough to categorize it as a potential brownfields site. 


\section{Further Research}

The intent of this study was to demonstrate the potential geospatial analysis techniques have with regards to the identification of potential brownfields sites and that such analysis could be an excellent planning tool. One of the fundamental problems in this research is determining an accuracy measure against which the potential sites derived from GIS analysis could be evaluated. Since brownfields can involve perceptual distinctions, they are not easily quantified by field or analytical methods. One obvious method would be to measure GISderived properties against actual brownfields sites. However, this could take a considerable amount of time to determine overall effectiveness.

Another method that could be useful might be the use of existing brownfields sites as calibration measures for methods refinement. However, this could also be problematic because many cities, such as Des Moines, target specific city sections as redevelopment areas and encourage brownfields redevelopment in these areas. While this is a viable strategy for urban governments, it creates a bias in terms of spatial distribution. There are likely many viable commercial and industrial properties that exist outside of the redevelopment zone.

Research should be conducted to analyze the trend of both building and land values relative to previously identified brownfields sites. This information might identify market activity that is not readily observed. Market activity could include both private and public investment, and such data could be used to ascertain which brownfields sites are more viable redevelopment opportunities. Brownfields redevelopment assistance programs could then be targeted to expedite improvements in areas where the economic trend demonstrates growth, however subtle. This approach could specifically assist in serving to catalyze economic revitalization in a more strategic way.

In summary, GIS and spatial analysis of commonly available data sets appears to be a promising method for area-wide inventory of properties that have strong potential for brownfields redevelopment. Further research is needed

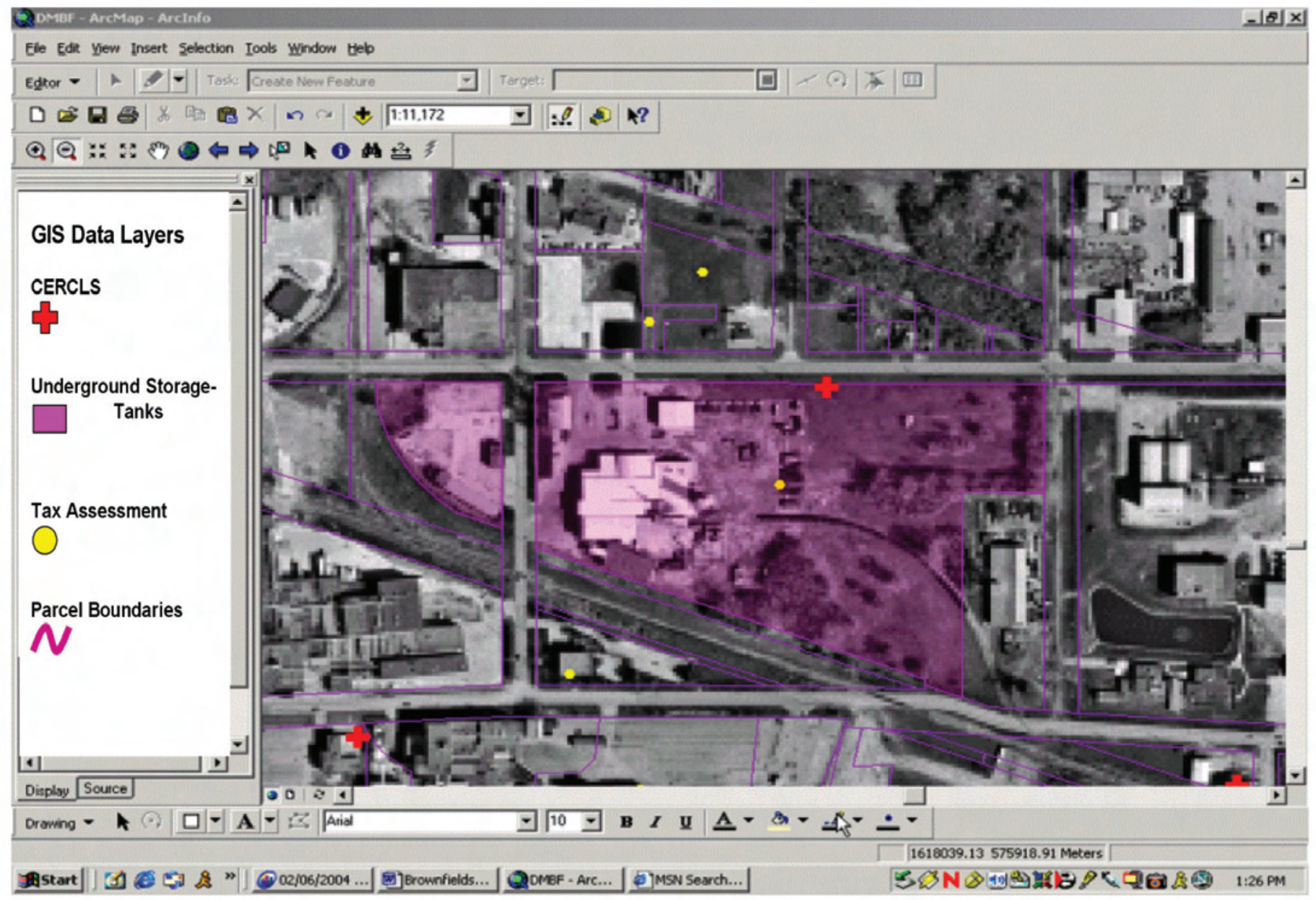

Figure 5. Screen capture showing different datasets being used in this study. Purple-tinted parcel is one that had more than one indicator from both underground storage tanks and Comprhensive Environmental Response, Compensation, and Liability Information System data. 
in the following areas: (1) development of a validation/verification method for area-wide brownfields assessment, (2) development of a statistical indicator that would measure the contribution of various different datasets and serve as a "weighting factor" of various levels of contribution to potential brownfields identification, and (3) extension of these techniques to other metropolitan areas.

\section{References}

Des Moines, 2004, City of Des Moines, Iowa, Office of Economic Development: [http://www.dmoed.org/sites/index. html, last accessed July 5, 2004].

Drake University, 2001, An inventory of potentially abandoned commercial properties in Des Moines, Iowa, in support of the USEPA Brownfields Program: Unpublished Report.

Ellman, T., 2004, Infill—The cure for sprawl?: Arizona Issue Analysis [http://www.urbanfutures.org/abstract.cfm?ID=28, last accessed July 5, 2004], last accessed July 5, 2004].

Gernstein, S., 2002, Brownfields revitalization cuts urban blight, suburban sprawl: National Policy Analysis
[http://nationalcenter.org/NPA385.html, last accessed July 5, 2004].

U.S. Census Bureau, 2004, American fact finder: [http:// factfinder.census.gov/home/saff/main.html?_lang=en, last accessed February 5, 2004].

U.S. Census Bureau, 2004, Population estimates: [http:/www. census.gov/popest/cities/, last accessed February 5, 2004].

U.S. Geological Survey, 2005, Geographic Analysis and Monitoring Program: [http://gam.usgs.gov/, last accessed July 5, 2005].

U.S. Environmental Protection Agency, 2003a, Brownfields 2003 grant fact sheet, Des Moines, Iowa: [http://www.epa. gov/swerosps/bf/03grants/desmoines.htm, last accessed July 5, 2004].

U.S. Environmental Protection Agency, 2003b, The Brownfields Program-Setting change in motion: Washington, D.C., Office of Solid Waste and Emergency Response, USEPA Report USEPA-500-F-03-248, [http://www.epa.gov/ brownfields/pubs/03brochure.pdf, last accessed July 5, 2004].

U.S. Environmental Protection Agency, 2004, Landscape Ecology Program: [http://epa.gov/nerlesd1/land-sci/intro.htm, last accessed February 5, 2004]. 



\title{
Road Densities for Urban Areas in the Conterminous United States
}

\author{
By Raymond D. Watts' ${ }^{1}$, John McCammon², Roger Compton², Carl Rich², and Tom Owens²
}

The character of an urben landscape depends, in part, on the gaps between the roads and streets of the urban area. The statistics of these gaps vary widely across the conterminous 48 states, as illustrated on figure 1 .

Regional road density patterns are unmistakable.The Northeast, the Midwest, the Pacific Northwest,and a string of cities along the Appalachian Mountains generally have low average distance toroad (high road density) and low maximum distance to road (minimal roadless area). A group of cities, primarily in the lower Mississippi River Valley, has somewhat greater mean distance to road (lower road density), but again no large roadless areas. The southern tier of States contains many cities with the lowest road densities, with an additional low-density cluster extending north along the Rocky Mountains and northwestern Great Plains.

A variety of historical and contemporary factors influences urban road density: topography, changes in utilities infrastructure, evolution of transportatation technologies, availability and cost of land, and changing cultural perceptions and legal practices of land-use managment. There is an apparent correlation between early development of cities in the East versus later development of cities in the West, and generally higher road densities (lower mean distance to road) in the East and lower road densities (higher mean distance to road) in the West.

The United States Geological Survey Geographic Analysis and Monitoring (GAM) program has developed a landscape metric called NORM-ED (National Overview Road
Metrics-Euclidean Distance). For each 30 meter square covering the conterminous United States, the value of NORM-ED is the Euclidean distance to the nearest road (DTR). Figure 1 characterizes the road density of 437 urbanized areas based on distance to road data from the NORM-ED data set. The five inset maps show the actual distance to nearest road values for five selected urban areas. The urban areas on the map of the conterminous United States are color-coded based on a combination of the mean DTR value within an urban area, and the maximum DTR value within the urban area.

The urban areas were generated using 1990 Census Tracts from the U.S. Census Bureau, and Rural-Urban Commuting Area codes (RUCA's) from the U.S. Department of Agriculture Economic Research Service (ERS). The RUCA codes classify census tracts according to whether they are part of a metropolitan-area core or areas in which certain percentages of the population commute to a metropolitan-area core (for details on RUCA codes, see http://www.ers.usda. gov/emphases/rural/data/index.htm). The urban area polygons shown on this figure were generated by merging contiguous census tracts whose RUCA codes $(1.0,1.1,4.1$, or 7.1$)$ indicate they are part of a metropolitan-area core or have greater than 30 percent of their population commuting to a metropolitan-area core.

The NORM-ED data were derived from the Dynamap/1000 street data of Geographic Data Technology; Dynamap/1000 is based on TIGER transportation files compiled by the Census Bureau for the 2000 Census.

${ }^{2}$ U.S. Geological Survey, Rocky Mountain Geographic Science Center, P.O. Box 25046, MS 516, Lakewood, CO 80225. 


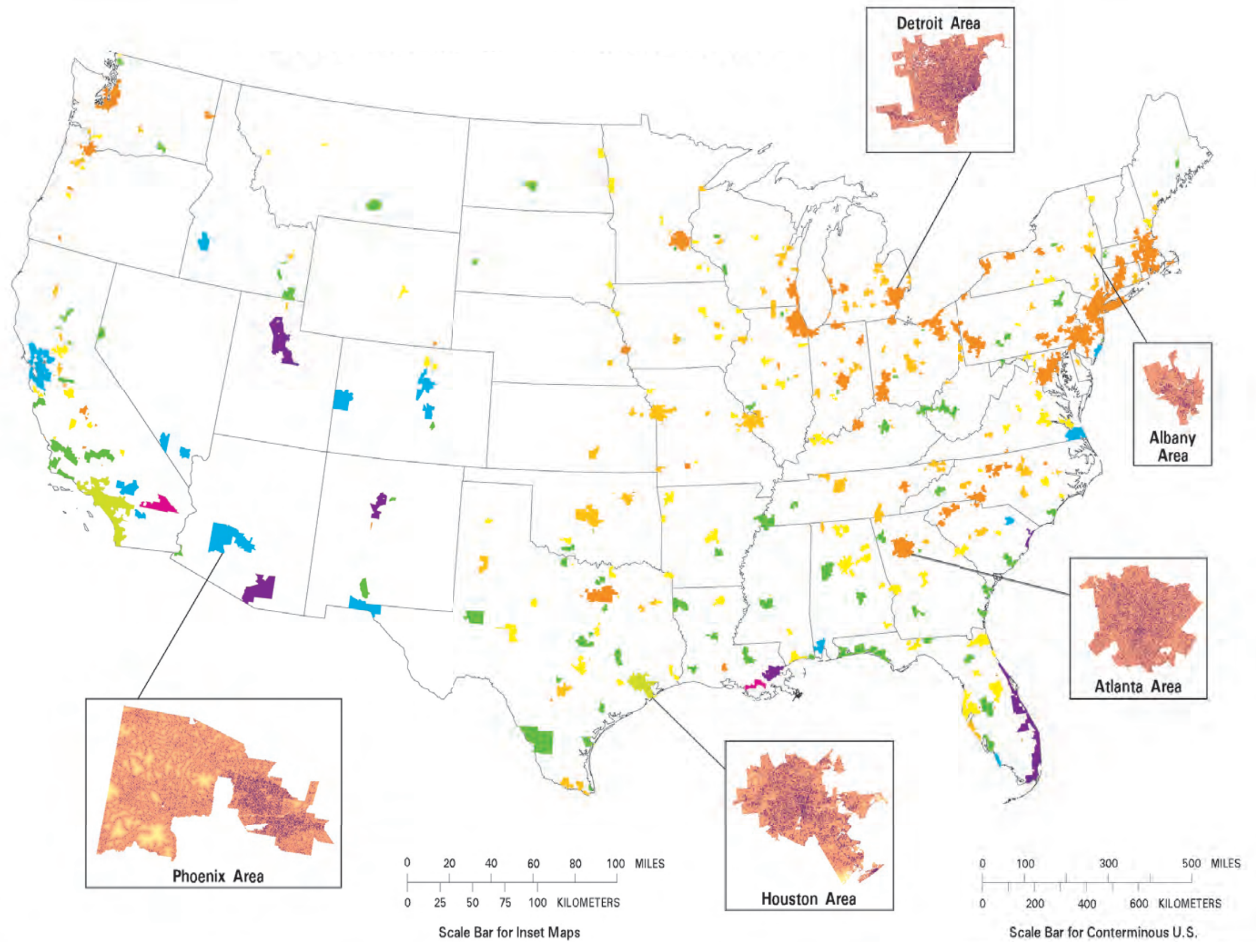

Figure 1. Map of road densities for urban areas in the conterminous United States. 


\section{Explanation for Inset Maps}

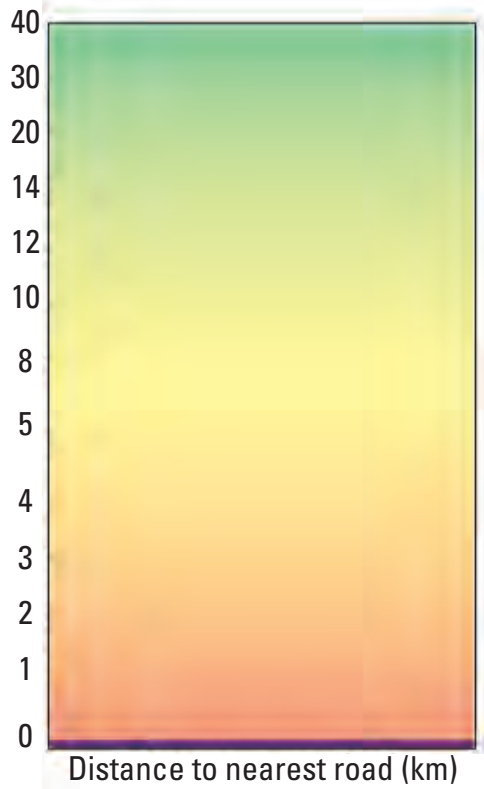

\section{Explanation for Conterminous U.S.}

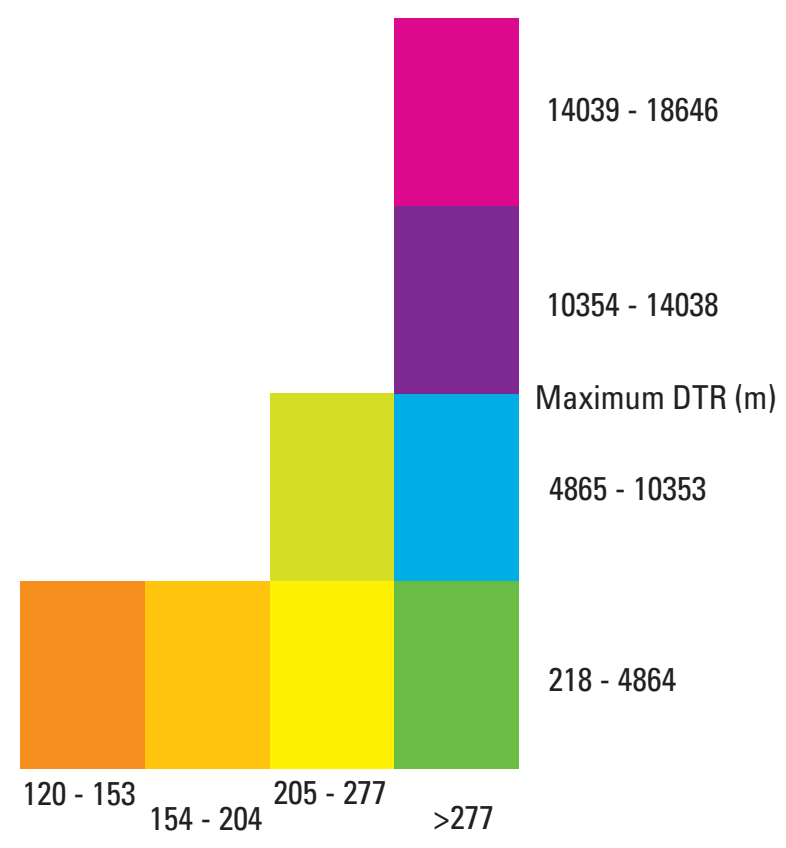

Mean distance to nearest road (DTR) (m)

Figure 1. Map of road densities for urban areas in the conterminous United States-Continued. 



\title{
Quantifying Urban Intensity in Drainage Basins for Assessing Stream Ecological Conditions ${ }^{1}$
}

\author{
By Gerard McMahon² and Thomas F. Cuffney²
}

\section{Introduction}

The deleterious effects of urbanization on water-quality are evident across the United States. In locations as geographically diverse as Washington State (Nelson, 1999), Portland, Oregon (Abrams and Prescott, 1999), the Edwards Aquifer region of Texas (Kennedy, 1999), and south Florida (Williams, 1999) urbanization is reported to adversely affect the physical (for example sedimentation), chemical (for example eutrophication), and biological (for example endangered salmonid species) characteristics of water quality. Concern about the effects of urbanization has motivated efforts to understand and manage urban development on the part of governmental organizations at the national (the Smart Growth Program of the U.S. Environmental Protection Agency (2000)), regional (Smart Growth Networks, 2000), and local (Pelley, 1999; American Planning Association, 2000) levels, as well as by research efforts such as the Baltimore Ecosystem Study, funded by the National Science Foundation (Foresman and others, 1999) and the Urban Dynamics Research Program (U.S. Geological Survey, 2000a).

As part of the National Water Quality Assessment (NAWQA) Program (U.S. Geological Survey, 2000b) an investigation is underway to determine the relation between varying intensities of drainage-basin urbanization and water quality in three contrasting environmental settings: (1) the humid Northeast (Boston, MA metropolitan area), (2) the humid Southeast (Birmingham, Ala. metropolitan area), and (3) the arid West (Salt Lake City, Utah metropolitan area). For budgetary reasons, each study has approximately 30 study drainage basins, with the basins in each study area having similar natural (for example climate, elevation, soils) characteristics and a gradient of urban development intensity.

This paper is an extract from a paper (McMahon and Cuffney, 2000) describing the activities that occurred during the planning phase of these studies. The paper covers the characterization of the anthropogenic landscape and the devel-

\footnotetext{
${ }^{1}$ Modified from Journal of the American Water Resources Association, Dec. 2000, v.36, no. 6, p. 1247-1261; used with permission.

${ }^{2}$ U.S. Geological Survey, 3916 Sunset Ridge Road, Raleigh, NC, 27607, gmcmahon@usgs.gov and tcuffney@usgs.gov.
}

opment of an urban intensity index, a measurement of the intensity of urbanization. One of the major objectives of the planning phase was to rank the population of potential study basins based on their urban intensity and choose a set of study basins with similar natural characteristics that represent a gradient of urban intensity. The urban intensity of each basin is measured using an index that integrates information about the multiple dimensions of human influence on the urban landscape at the drainage basin scale. The index, which includes information about land cover, infrastructure, population, and socioeconomic characteristics, provides an a priori ranking of potential study sites that is used to ensure that sites chosen for the investigation represent a cross-section of urban intensity. Some of the variables used in the index may also be important factors for explaining variations in water quality; this cannot be determined, however, until water quality data are collected and analyzed.

These methods were applied at three locations across the country. In order to maximize the possibility for comparing and contrasting the eventual study findings, characterization of the drainage basins used in each of the three investigations were accomplished using land cover, infrastructure, population, and socioeconomic data sets developed using similar protocols (table 1). Typically these were national data sets available in all NAWQA study areas. Superior data (for example,more recent or better resolution) may have been available for some variables in each of the study locations but were not used at the planning stage. Basin characterization and site-selection efforts associated with the Boston study are described here for illustrative purposes.

\section{An Evolving Perspective on Water-Quality}

The gradient design used in the NAWQA Program to investigate the effects of urbanization is premised on two perspectives about water quality. First, in-stream water quality is an ecological construct. Water quality is a composite of physical, chemical, and biological characteristics that vary in space and time and are influenced by natural factors and by the human activities and values (Karr, 1991; Fairweather, 1999; fig. 1). Traditional measures of water-quality have relied on 
Table 1. Potential sources of digitally mapped information for use in characterizing natural and urban landscape patterns in drainage basins.

\begin{tabular}{|c|c|c|}
\hline Landscape theme & Available maps & Scale \\
\hline \multicolumn{3}{|c|}{ Natural landscape characteristics } \\
\hline \multirow[t]{5}{*}{ Ecological regions: } & U.S. Environmental Protection & \\
\hline & Agency (USEPA) level III ecoregions & $7,000,000$ \\
\hline & USEPA level IV ecoregions & 250,000 \\
\hline & U.S. Forest Service subsections & \\
\hline & (level IV resolution) & 250,000 \\
\hline \multirow{3}{*}{$\begin{array}{l}\text { Soil drainage } \\
\text { characteristics: }\end{array}$} & U.S. Department of Agriculture & \\
\hline & State Soil Data Base (STATSGO) & \\
\hline & soil hydrologic groups & 250,000 \\
\hline Watershed boundaries: & $\begin{array}{l}\text { Developed from digital elevation models } \\
\text { (U.S. Geological Survey, 2000c) }\end{array}$ & varies \\
\hline Lithochemical zones: & $\begin{array}{l}\text { Bedrock litho-chemical zones } \\
\text { (Robinson, 1997) }\end{array}$ & $\begin{array}{l}\text { approx. } \\
250,000\end{array}$ \\
\hline \multicolumn{3}{|c|}{ Anthropogenic landscape characteristics } \\
\hline Land-cover data: & $\begin{array}{l}\text { Multi-Resolution Land Characteristics } \\
\text { (MRLC) (Loveland and Shaw, 1996) }\end{array}$ & 100,000 \\
\hline \multirow{3}{*}{$\begin{array}{l}\text { Derived from Land } \\
\text { Cover: }\end{array}$} & Impervious surface & \\
\hline & Urban Sprawl & \\
\hline & Riparian Land Cover & \\
\hline \multirow[t]{4}{*}{ Infrastructure: } & Roads & 100,000 \\
\hline & Point Source Dischargers & Point \\
\hline & USEPA Toxic Release Inventory & Point \\
\hline & Dams & Point \\
\hline \multirow{4}{*}{$\begin{array}{l}\text { Census Block Group } \\
\text { derived (examples): }\end{array}$} & Population & 100,000 \\
\hline & Housing Unit Density & 100,000 \\
\hline & Per Capital Income & 100,000 \\
\hline & Socioeconomic indices & 100,000 \\
\hline
\end{tabular}

physical and chemical characteristics as surrogate indicators for potential achievement of biological integrity — a goal of the Clean Water Act (Yoder, 1995). Because biological communities are subject to an array of physical, chemical, and biological influences, the condition of these communities reflect the integration of these influences as they occur over time and space (Yoder, 1995). Advancements in the understanding and measurement of in-stream biological communities over the past 15 years makes it possible and practical to consider water quality, and the factors that influence it, from an ecological perspective (Davis, 1995).
Second, landscape and stream characteristics within a watershed reflect not only the physical and geographic context of a watershed but the choices associated with human values and priorities. These choices are reflected in the mix of land uses in a watershed and in the diverse activities associated with even the same land uses. The character of the urban residential landscape, for example, can vary dramatically as socioeconomic factors-income, age of housing stock, levels of education - change among neighborhoods. Variations in both natural and built characteristics in a watershed affect stream flow variability (Hammer 1972, Bevin, 1986; Poff and others, 
1997; U.S. Environmental Protection Agency, 1997b), eutrophication (Mueller and Helsel, 1996; U.S. Geological Survey, 1999), the distribution of fish (Steedman, 1988; Whittier and others, 1988; Poff and Ward, 1989; Taylor and others, 1993; Poff and Allan, 1995; Angermeier and Winston, 1998), invertebrates (Corkum and Ciborowski, 1988; Corkum, 1989, 1990, 1992; Quinn and Hickey,1990; Tate and Heiny, 1995), as well as combined measures of biological, chemical, and physical water-quality measures (Cuffney and others, in press). There also is a spatio-temporal scale to these relationships - that is, water-quality responses are influenced by both regional and local factors, and they vary across space and time (Angermeier and Winston, 1998).

This conceptual framework has shaped the tasks associated with the study planning effort in two important ways. First, a drainage-basin-oriented investigation of the effects of

\title{
Physical, chemical, evolutionary, and biogeographic processes influence watershed landscape and in-stream conditions
}

\author{
Physical and Geographic Context \\ Location \\ Geological substrate \\ Climate, Elevation \\ Stream size, Gradient
}
Biological Integrity
Taxa richness
Species composition
Tolerance, Intolerance
Adaptive strategies

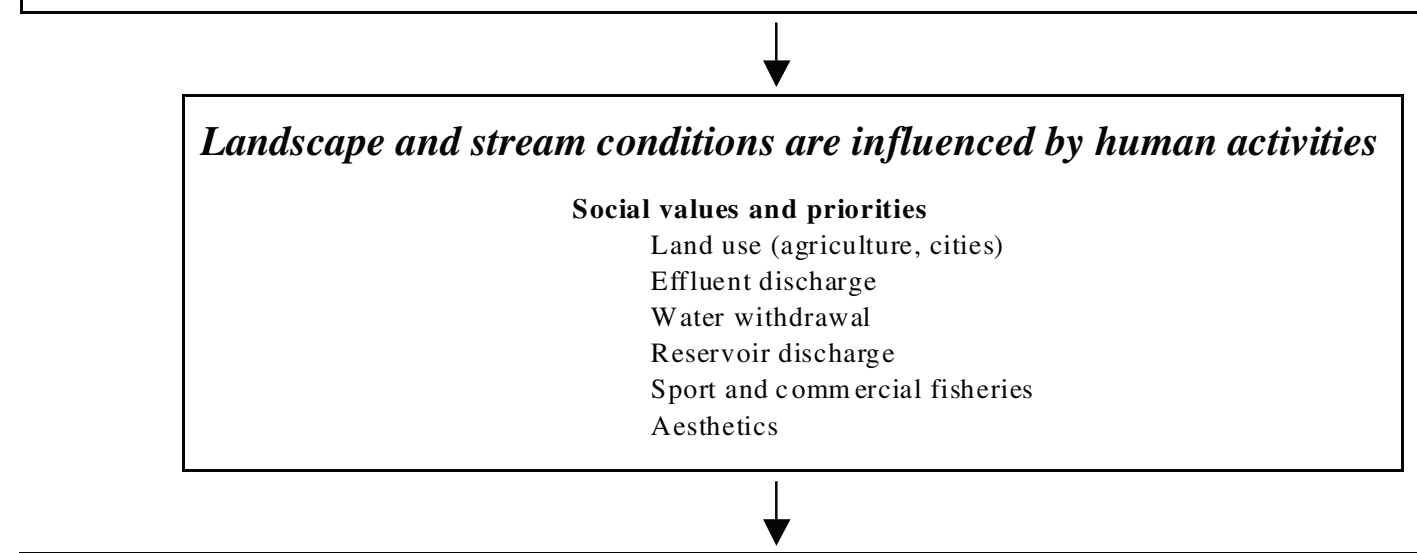

These social values and associated choices alter biogeochemical process to influence one or more in-stream characteristics

Five key environmental factors

Flow regime

Physical habitat structure

Chemical water quality

Energy sources

Biological interactions

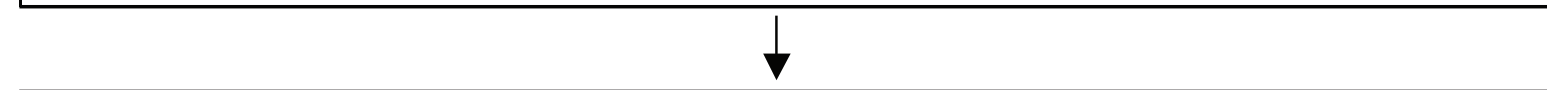

\section{Thereby altering stream health, as measured by indicators of}

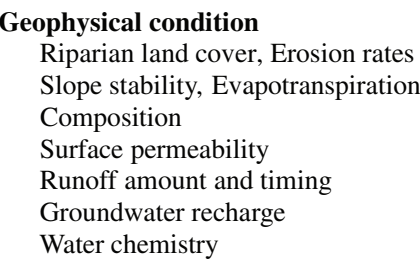

Biological conditions

Taxa richness

Taxonomic

Individual health

Ecological processes

Evolutionary processes

Figure 1. Conceptual framework of an ecological construct for in-stream water quality (after Karr and Chu, 1997). 
urbanization on water quality must control for the effects of natural factors, while allowing the degree of urbanization to vary in known ways between study basins. Large variations in the natural characteristics of study drainage basins such as drainage basin size, climate, elevation, soils, and geology will obscure the nature of any relation between urbanization and water quality. An a priori knowledge of the degree of urbanization in each candidate study basin allows the choice of a set of basins that together reflect a gradient of urbanization representative of conditions across a population of potential sites. Second, the degree of urbanization cannot adequately be described using only land-cover data, such as the amount of developed land within a drainage basin. In this study, spatial patterns in infrastructure and socioeconomic characteristics are also used to determine the degree of urbanization. Although not discussed in this paper, the response data collected at streams in each study will include nutrients, pesticides, and ions in stream water, trace elements in bed sediments, geomorphic and habitat characteristics, hydrologic stage, water temperature, alkalinity, $\mathrm{pH}$, dissolved oxygen, specific conductance, chlorophyll a, benthic algae and invertebrate communities, and fish communities.

\section{Characterizing the Anthropogenic Landscape}

Efforts to understand the functioning of urban ecosystems have emphasized the linkages in the spatial patterns and processes of both sociocultural and biophysical resources (Grove and Burch, 1997). These investigations suggest that it is impossible to understand the differentiation that occurs in the spatial pattern and processes associated with natural ecological systems without an understanding of the spatial pattern and processes of human ecological systems, including socioeconomic factors. Anthropogenic landscape characteristics used in this study to describe the population of potential gradient-study basins include (1) biophysical measures of the urban landscape, such as land cover and impervious surface (Wang and others, 1997), (2) measures of the infrastructure that supports urban development patterns (Center for Watershed Protection, 1998), and (3) socioeconomic measures describing factors such as population, housing, and income (Anson, 1991; Grove and Burch, 1997). A GIS was used to overlay thematic maps of these characteristics with drainage basin boundaries. These data were compiled in a basin characteristics spreadsheet, with a single row for each potential basin and multiple columns for the land cover, infrastructure, and socioeconomic variables, and used to develop the urban intensity index.

The primary source of land-cover/land-use information was data developed as part of the Multi-Resolution Land Characteristics (MRLC) consortium, a Federal interagency project to develop mapped land-cover data for the contiguous United States based on Landsat Thematic Mapper satellite images (Loveland and Shaw, 1996). These hierarchically orga- nized data provide both general land cover information (for example, developed versus forest) and more specific land-usetype information. For instance, land classified as developed in the general land-cover classification also has a land-use designation as either low- or high-intensity residential or commercial/industrial/transportation. MRLC data used in this study were collected in the early 1990s and processing of the data for the conterminous United States was nearly completed by the summer of 2000. Accuracy assessments have been completed for the areas within the Boston and Birmingham studies (Limin Yang, written commun., U.S. Geological Survey, July 2000). Classification errors for the developed land classes in these areas ranged between 15 and 50 percent, with better accuracies in the New England classification. Residential land areas were generally classified more accurately than commercial/industrial/transportation areas.

The MRLC land-cover data were also used to derive estimates of another important characteristic of urban intensity-impervious surface area. Several steps were followed to estimate impervious surface. A range of impervious-surface percentages associated with the detailed land-cover classes used in the MRLC classification were compiled from existing literature (Stankowski, 1972; Bedient and Huber, 1988; Arnold and Gibbons, 1996; Booth and Jackson, 1997; Center for Watershed Protection, 1998). Simple distributions (for example, uniform or triangular) were developed from these literature values and used with each MRLC land-cover type in the basin characteristics spreadsheet as multipliers in a formula that estimated impervious-surface area for all land-cover types and summed these individual estimates into a single impervious surface estimate for each potential basin. For each watershed, the spreadsheet was calculated repeatedly-1,000 iterations were used in this simulation. The software kept track of the outcomes of each iteration, created a distribution of all possible output values, and reported the mean impervious value for each watershed

Several infrastructure measures associated with anthropogenic activities were used to characterize urban intensity. These included road density, the number of point-source dischargers (U.S. Environmental Protection Agency, 1999), the number of dams (U.S. Army Corps of Engineers, 1996), and the number of Toxic Release Inventory sites (U.S. Environmental Protection Agency, 1997a; Price and Clawges, 1999).

Socioeconomic conditions shape perceptions of both the degree (for example, amount of density) and character (for example, affluence) of development within a drainage basin; they may also exert an important effect on factors that can influence water quality (Grove and Burch, 1997; Ryznar, 1998). For example, population and housing density provide a direct measure of development intensity and are likely to be correlated with impervious surface (Stankowski, 1972). Residential use of fertilizers and pesticides may vary according to the income levels of neighborhoods within a watershed, although the very limited data on the use of these chemicals in urban areas makes assessment of this intuitively appealing claim difficult. Census counts (1990 data), estimates (1997), 
Table 2. Variables used in the analysis of New England urban watershed gradient.

[Variables in bold type were correlated at a level $>=0.50$ with 1997 population density and were used in the construction of the urban intensity index. Bold italics indicate significant negative correlation. Variables marked with an asterisk are redundant with other variables listed in parentheses and were not used in index development]

\begin{tabular}{|c|c|}
\hline \multicolumn{2}{|c|}{ Land-use characteristics } \\
\hline LU21_AB & $\begin{array}{l}\text { Proportion of watershed with low intensity residential land on well- } \\
\text { drained soils }\end{array}$ \\
\hline LU21_CD & $\begin{array}{l}\text { Proportion of watershed with low intensity residential land on poor- } \\
\text { drained soils }\end{array}$ \\
\hline LU22_AB & $\begin{array}{l}\text { Proportion of watershed with high intensity residential land on well- } \\
\text { drained soils }\end{array}$ \\
\hline LU22_CD & $\begin{array}{l}\text { Proportion of watershed with high intensity residential land on poor- } \\
\text { drained soils }\end{array}$ \\
\hline LU23_AB & $\begin{array}{l}\text { Proportion of watershed with commercial/Industrial/Transportation on } \\
\text { well-drained soils }\end{array}$ \\
\hline LU23_CD & $\begin{array}{l}\text { Proportion of watershed with commercial/Industrial/Transportation on } \\
\text { poor-drained soils }\end{array}$ \\
\hline IMPERV & $\begin{array}{l}\text { Proportion of watershed with impervious land surface (not used in index } \\
\text { calculation) }\end{array}$ \\
\hline URBAN_MI & Total urban land area in watershed (square miles) \\
\hline COMRESIN & $\begin{array}{l}\text { Commercial/residential urban land index (ratio of commercial to } \\
\text { residential land cover) }\end{array}$ \\
\hline FOR_MI & Total forested land area in watershed (square miles) \\
\hline WET_MI & Total wetland area in watershed (square miles) \\
\hline MRLC_11 & Watershed area in open water (square miles) \\
\hline MRLC_12 & Watershed area in Perennial Ice/Snow (square miles) \\
\hline MRLC_21 & Watershed area in Low Intensity Residential (square miles) \\
\hline MRLC_22 & Watershed area in High Intensity Residential (square miles) \\
\hline MRLC_23 & Watershed area in Commercial/Industrial/Transportation (square miles) \\
\hline MRLC_31 & Watershed area in Bare Rock/Sand/Clay (square miles) \\
\hline MRLC_32 & Watershed area in Quarries/Strip Mines/Gravel Pits (square miles) \\
\hline MRLC_33 & Watershed area in Transitional cover (square miles) \\
\hline MRLC_41 & Watershed area in Deciduous Forest (square miles) \\
\hline$M R L C \_42$ & Watershed area in Evergreen Forest (square miles) \\
\hline$M R L C \_43$ & Watershed area in Mixed Forest (square miles) \\
\hline MRLC_51 & Watershed area in Deciduous Shrubland (square miles) \\
\hline MRLC_52 & Watershed area in Evergreen Shrubland (square miles) \\
\hline MRLC_53 & Watershed area in Mixed Shrubland (square miles) \\
\hline MRLC_61 & Watershed area in Orchards/Vineyards/Other (square miles) \\
\hline MRLC_71 & Watershed area in Grasslands/Herbaceous (square miles) \\
\hline$M R L C \_81$ & Watershed area in Pasture/Hay (square miles) \\
\hline$M R L C \_82$ & Watershed area in Row Crops (square miles) \\
\hline MRLC_83 & Watershed area in Small Grains (square miles) \\
\hline MRLC_84 & Watershed area in Fallow (square miles) \\
\hline MRLC_85 & Watershed area in Urban/Recreational Grasses (square miles) \\
\hline MRLC_91 & Watershed area in Woody Wetlands (square miles) \\
\hline MRLC_92 & Watershed area in Emergent Herbaceous Wetlands (square miles) \\
\hline BUF_AREA & $\begin{array}{l}\text { Total area (square miles) within } 240 \text { meter wide buffer }(120 \mathrm{~m} \text {. on each } \\
\text { side of stream) in watershed }\end{array}$ \\
\hline
\end{tabular}


Table 2. Variables used in the analysis of New England urban watershed gradient-Continued.

$\begin{array}{ll}\text { BUF_11 } & \text { Total area (square miles) of MRLC 11 within buffer } \\ \text { BUF_21 } & \text { Total area (square miles) of MRLC 21 within buffer } \\ \text { BUF_22 } & \text { Total area (square miles) of MRLC 22 within buffer } \\ \text { BUF_23 } & \text { Total area (square miles) of MRLC 23 within buffer } \\ \text { BUF_31 } & \text { Total area (square miles) of MRLC 31 within buffer } \\ \text { BUF_32 } & \text { Total area (square miles) of MRLC 32 within buffer } \\ \text { BUF_33 } & \text { Total area (square miles) of MRLC 33 within buffer } \\ \text { BUF_41 } & \text { Total area (square miles) of MRLC 41 within buffer } \\ \text { BUF_42 } & \text { Total area (square miles) of MRLC 42 within buffer } \\ \text { BUF_43 } & \text { Total area (square miles) of MRLC 43 within buffer } \\ \text { BUF_51 } & \text { Total area (square miles) of MRLC 51 within buffer } \\ \text { BUF_61 } & \text { Total area (square miles) of MRLC 61 within buffer } \\ \text { BUF_81 } & \text { Total area (square miles) of MRLC 81 within buffer } \\ \text { BUF_82 } & \text { Total area (square miles) of MRLC 82 within buffer } \\ \text { BUF_85 } & \text { Total area (square miles) of MRLC 85 within buffer } \\ \text { BUF_91 } & \text { Total area (square miles) of MRLC 91 within buffer } \\ \text { BUF_92 } & \text { Total area (square miles) of MRLC 92 within buffer } \\ \text { URB_BUF } & \text { Percent of watershed buffer area in urban land cover } \\ \text { FOR_BUF } & \text { Percent of watershed buffer area in forested land cover } \\ \text { WET_BUF } & \text { Percent of watershed buffer area in wetland land cover }\end{array}$

\section{Infrastructure characteristics}

ROAD_KM* road length in watershed (kilometers) (ROAD_DEN)

$\boldsymbol{R} \boldsymbol{O A D} \boldsymbol{D} \boldsymbol{D E N} \quad$ Road density in watershed [road length $(\mathrm{km}) /$ watershed area $(\mathrm{km} 2)]$

PSCOUNT Number of points source dischargers in watershed (EPA database)

DAMCOUNT Number of dams in watershed

TRICOUNT Number of Toxics Release Inventory sites in watershed

\section{Population characteristics}

AGESTR97 Age structure of population (population under 18/population over 18)

POP90* 1990 population (P97DENMI)

POP97* 1997 population (P97DENMI)

P90DENMI* 1990 population density (people/square mile of watershed area) (P97DEN)

P97DENMI 1997 population density (people/square mile of watershed area)

POP9097* Population change 1990-97 (proportion) (P97DEN)

URBSPRWL urban sprawl index [(urban land area/1997 population)*10,000]

Socioeconmic characteristics

PCINC97 1997 per capital income (dollars)

HOUSEAGE Age of residential housing stock (years)

AVGBEDRM Average number of bedrooms in residences

SEI-1

Socio-economic index 1: high levels of income and owner occupied housing; low population density

SEI-2 Socio-economic index 2: high levels of population, housing units, households, and rental units

SEI-3 Socio-economic index 3: high levels of income, population density, per capita income, rental units

SEI-4 Socio-economic index 4: high levels of length of tenure in house and occupancy rates, low per capital income and 90-97 pop change

SEI-5 Socio-economic index 5: High levels of children, persons below poverty level, houisng units on septic systems 
Table 3. New England census block group socioeconomic indices (SEI) and primary associated variables.

[Indices were derived from principal components analysis of 80 social, income, and housing characteristics associated with 1990 (counts), 1997 (estimates), and 2002 (projections) census block group data (Geolytics, 1998). Variables in these socioeconomic classes with relatively high (+) and low (-) loadings on these indices are listed. HS - high school; pop - population; yo - years old; fam - families; chil - children; HH - households; K thousands; own occ - owner occupied; HU - housing unit]

\begin{tabular}{|c|c|c|c|}
\hline & Social & Income & Housing \\
\hline SEl-1 & $\begin{array}{l}+ \text { high school grad } \\
+2 \& 3+\text { vehicle households } \\
\text { - population density } 90 \text { and } 97\end{array}$ & $\begin{array}{l}+ \text { housefold and family Income } \\
\text { - \% poverty, fam in poverty, chil<18 } \\
+97 \text { household income } \\
\text { - \% HH income less than } 15 \mathrm{~K}\end{array}$ & $\begin{array}{l}+ \text { Own occ housing units } \\
+ \text { OOHU with mortgage } \\
+ \text { average number ofbedrooms } \\
+\% \text { own occ housing units } \\
\text { - \% rental occupied housing units }\end{array}$ \\
\hline SEI-2 & $\begin{array}{l}+1990 \text { population } \\
+1 \text { vehicle households } \\
+97 \text { and } 02 \text { population } \\
+ \text { persons } 16+\end{array}$ & $\begin{array}{l}\text { + number of households } \\
+ \text { number of families }\end{array}$ & $\begin{array}{l}+ \text { number of housing units } \\
+ \text { number of occupied housing units } \\
+ \text { number of rental and \% rental units } \\
+97 \mathrm{hu} \text { - total and occupied } \\
+02 \mathrm{hu} \text { - total and occupied } \\
\text { - average number of bedrooms }\end{array}$ \\
\hline SEI-3 & $\begin{array}{l}+\% \text { Bachelors degree or higher } \\
\text { - children/1,000 women } 25-34 \text { yo } \\
+ \text { pop density } 90 \text { and } 97 \\
\text { - 90-97 \& } 90-02 \text { pop change } \\
\text { - proportion pop under } 18 \\
+\% \text { using public transportation }\end{array}$ & $\begin{array}{l}+90,97,02 \text { per capital income } \\
+\% \text { household income }>\$ 100,000\end{array}$ & $\begin{array}{l}\text { + housing unit density } \\
+ \text { age of housing unit } \\
+\% \text { housing units on public sewer } \\
\text { - \% housing units on septic } \\
+\% \text { housing units on utility gas } \\
+ \text { proportion hu occupied, } 90,97 \& 02 \\
+\% \text { rental occupied housing units }\end{array}$ \\
\hline SEI-4 & $\begin{array}{l}\text { - \% Bachelors degree or higher } \\
+\% \text { born in state of residence } \\
+ \text { proportion pop under } 18 \\
\text { - } 90-97 \& 90-02 \text { pop change }\end{array}$ & - 90 per capita income & $\begin{array}{l}+\% \text { housing units using fuel oil } \\
+ \text { length of tenure in house } \\
+ \text { proportion hu occupied, } 90,97 \& 02 \\
\text { - } \% \text { condo housing units }\end{array}$ \\
\hline SEI-5 & $\begin{array}{l}+ \text { children/1,000 women } 25-44 \text { yo } \\
\text { - } \% \text { born in state of residence } \\
+ \text { proportion pop under } 18 \\
+\% \text { females }>16 \text { unemployed }\end{array}$ & $\begin{array}{l}+ \text { household income } \\
+\% \text { persons below poverty } \\
+\% \text { poverty, fam in poverty, chil<18 } \\
+\% \text { household income }>\$ 100,000 \\
+\% \text { female headed household } \\
+ \text { proportion population under } 18\end{array}$ & $\begin{array}{l}\text { - 90-97 \& 90-02 population change } \\
+ \text { average number of bedrooms } \\
\text { - \% housing units on public sewer } \\
+\% \text { housing units on septic } \\
-90-97 \& 90-02 \text { change in \# of hu }\end{array}$ \\
\hline
\end{tabular}

and projections (2002) for population, labor, income, and housing characteristics, based on census block group areas, were used to characterize the socioeconomic aspects of the urban landscape (table 2; Geolytics, 1998). Socioeconomic indices (SEI) also were derived for each basin by using ordination of population, labor, income, and housing census variables (Anson, 1991; table 3). For the Boston study, the indices were based on 80 census variables computed over the 11,500 census block groups within the New England States. The indices contrast areas with differing combinations of social, income, housing, and labor characteristics. For example, high scores for SEI1 (which explains 23 percent of the variation between block groups in the 80 dimensional space) are associated with areas with a high number of high school graduates, relatively high household incomes, and a high level of owner occupied housing. Scores for SEI-3 are positively associated with households with very high income, small numbers of children, high percentages of college graduates, and high proportion of rental housing. 


\section{Developing an Index of Urban Intensity}

The planning phase of an urban gradient study uses an $a$ priori measure of the intensity or degree to which a basin is urbanized in order to rank potential study basins. This ranking, along with information about each basin's natural characteristics, is necessary to choose a final set of study basins that have similar natural characteristics and a desired distribution of urban intensity.

Neighborhoods within a city or communities within a single metropolitan area have distinct urban intensities that are a function of not only the amount of developed land but of differences in infrastructure, population, social, income, and housing characteristics. A multimetric approach was used in the planning phase of the gradient studies to characterize the relative urban intensity of each potential study basin. Multimetric indices are used to describe the overall condition of complex systems (Ward, 1996; Karr and Chu, 1997). Used in disciplinary settings as distinct as Wall Street (for example, index of leading economic indicators (Mitchell and Burns, 1938)) and stream ecology (for example, index of biological integrity (Yoder and Rankin, 1995)), indices combine a number of generally accepted individual condition measures of the system being assessed (for example, net business formation and new manufacturing orders for assessing economic health; amount of developed land and population density for assessing the intensity of urban development) that may be correlated but which provide distinct information about different dimensions of often complex systems. This approach allows the integration of multiple, commonly used sources of information about the urban landscape, such as urban land area, amount of impervious surface, road density, population density, and socioeconomic indices into a single measure of urban intensity (Cuffney and others, 2000; Karr and Chu, 1997).

In the Boston area study, a basin attribute table with 73 land-use, infrastructure, population, and socioeconomic variables was developed for each of the 208 potential study basins within the level-III ecoregion. Principal component analysis of the variance structure of the 73 variables across the 208 candidate basins indicated that 1997 population density was the most important characteristic in explaining the variation among the basins. The urban index was developed based on 43 landscape and socioeconomic characteristics that had an absolute Pearson correlation value of greater than or equal to 0.50 with 1997 population density (table 2).

The urban index was calculated by using a five-step procedure, with the resulting index values ranging from 0 to 100 over the set of candidate basins. An example of the calculation of the urban intensity index for one watershed using representative variables is given in table 4 and a graphical representation of the index results for the candidate New England study basins is presented in figures 2 and 3. Calculation of the index proceeds as follows:

1. Adjust raw data for basin size and measurement units (see variables in table 2):
Proportions into percentages

Areas into percent of basin area

Toxic Release Inventory, point-source dischargers, and dam counts into densities (count per unit area)

SEI $=$ SEI - minimum(SEI) to maintain absolute differences and make all values positive

Negative correlation with population $=100 \%$ - percentage

2. Transform original data so value of variables rangefrom 0-100 for candidate sites:

$$
Y=\left(X-X_{\text {min }}\right) \div\left(X_{\text {max }}-X_{\text {min }}\right)
$$

where: $X$ is the value of variable $\mathrm{X}$ for the site, $Y$ is the transformed value of variable $\mathrm{X}$ for the site,

$\mathrm{X}_{\min }$ is the minimum value of variable $\mathrm{X}$ over all sites, and

$\mathrm{X}_{\max }$ is the maximum value of variable $\mathrm{X}$ over all sites.

3. Variables that were negatively correlated with population density are adjusted so that all variables increase as population density increases:

$Y=100-Y_{\text {neg corr: }}$

4. Urban intensity is calculated as the average value of the transformed variables:

$$
U R B I=\left(\sum_{1}^{n} Y_{i}\right) / n
$$

where: $Y_{i}$ is the adjusted value of variable $i$, and $\mathrm{n}$ is the number of variables in the index.

5. Transform index URBI so the range of intensity is 0 100 for candidate sites:

$$
X_{\text {adj }}\left(X-X_{\min }\right) \div\left(X_{\max }-X_{\min }\right) * 100
$$

where: $X$ is the value of the URBI index for the site,

$X_{a d j}$ is the transformed value of the URBI index for the site,

$\mathrm{X}_{\min }$ is the minimum value of the URBI index over all sites, and

$\mathrm{X}_{\max }$ is the maximum value of the URBI index over all sites.

\section{Conclusions}

The most important lesson from implementing the methods described in this paper is that it is possible to identify and analyze the natural and anthropogenic characteristics of a population of potential-study drainage basins for a large spatial area in a relatively short period of time using straightforward GIS techniques and nationally available data sets. These techniques are scaleable, in the sense that they can be easily implemented in larger or smaller areas.

Another lesson related to the methodology of identifying and selecting basin for an urban gradient study relates to 
the importance of field reconnaissance. Basin reconnaissance was judged by project staff to be a centrally important in selecting study basin that not only made sense based on the GIS analysis but from a standpoint of large scale factors that cannot be considered by the GIS, especially related to suitability of the site for sampling activities and the local habitat features. Reconnaissance is costly in terms of staff time. The Boston study staff visited approximately 150 potential drainage basins. Approximately three weeks of time for one staff person were spent preparing for the reconnaissance effort. Three staff people took four weeks to complete these visits, and another week of one persons time were spent compiling the information into a useable format. Ideally, the timing of reconnaissance should correspond to a low-flow period; seasonally unusual wet weather conditions hampered the ability of Boston staff to visit and assess sites.

The value of the index is potentially constrained by several factors. The first is the age of the land-cover data. Sampling activities in the Birmingham study during the summer of 2000 suggest that large changes in land cover have occurred since the MRLC data were collected 8 years earlier. This is likely to be the case in any rapidly urbanizing area of the country. A significant challenge in developing an a priori urban intensity index lies in gaining access to contemporary land-cover data. This challenge is amplified if there is a need to implement these studies simultaneously in many areas across the country. The ability to compare and contrast results
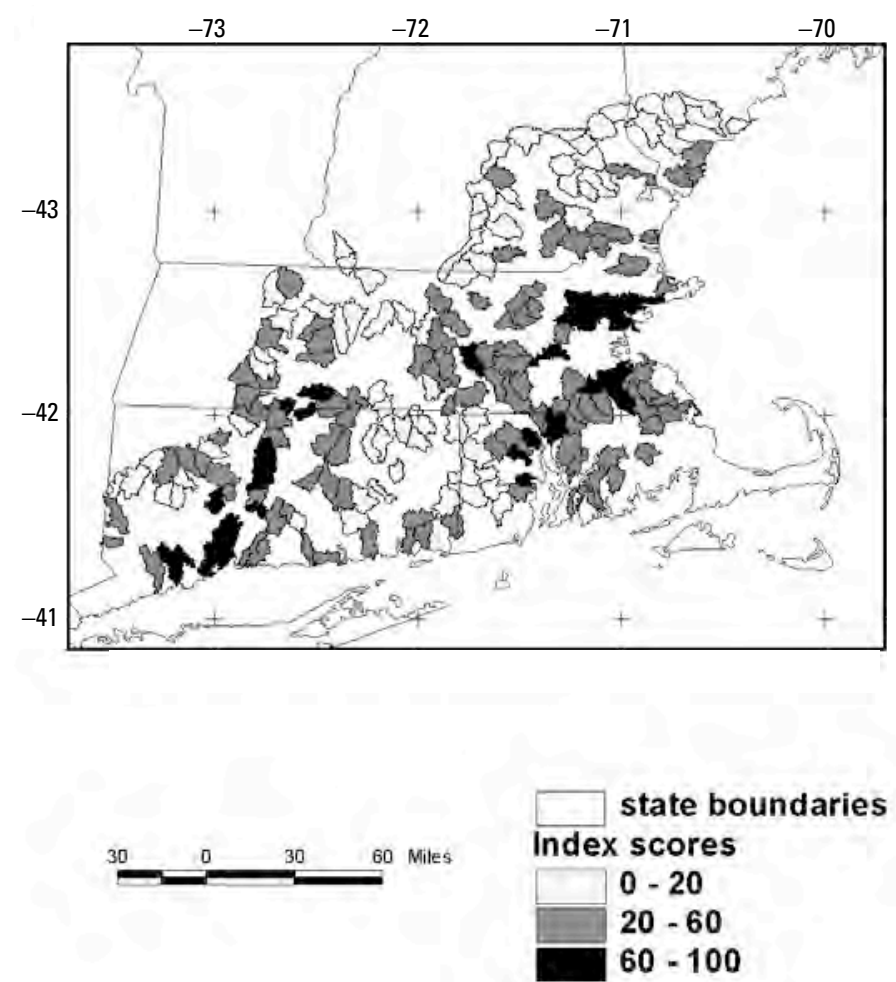

Figure 2. Urban intensity index scores for New England land-use gradient study.
Table 4. Example calculation of the urban intensity index for one watershed, using representative variable types.

\begin{tabular}{|c|c|c|c|c|c|c|}
\hline WSHED & Units & \multicolumn{2}{|c|}{ Adjustment } & Maximum & Minimum & Adjusted \\
\hline imperv $^{1}$ & 0.03 & \multicolumn{2}{|c|}{3.12} & 45.85 & 1.66 & 3.30 \\
\hline LU21_CD 1 & 0.01 & \multicolumn{2}{|l|}{0.63} & 48.38 & 0.00 & 1.31 \\
\hline LU22_CD ${ }^{1}$ & 0.00 & \multicolumn{2}{|l|}{0.00} & 11.47 & 0.00 & 0.00 \\
\hline LU23_CD ${ }^{1}$ & 0.00 & \multicolumn{2}{|l|}{0.08} & 12.76 & 0.00 & 0.66 \\
\hline urban_mi ${ }^{2}$ & 1.02 & \multicolumn{2}{|l|}{2.99} & 70.36 & 0.25 & 3.91 \\
\hline for_mi ${ }^{2}$ & 24.92 & \multicolumn{2}{|l|}{72.99} & 88.18 & 17.65 & 21.54 \\
\hline MRLLC_21 ${ }^{2}$ & 0.90 & \multicolumn{2}{|l|}{2.64} & 53.99 & 0.16 & 4.60 \\
\hline MRLC $22^{2}$ & 0.00 & \multicolumn{2}{|l|}{0.00} & 11.56 & 0.00 & 0.01 \\
\hline MRLC_2 $23^{2}$ & 0.12 & \multicolumn{2}{|l|}{0.35} & 15.02 & 0.08 & 1.77 \\
\hline MRLC_43 $43^{2}$ & 8.62 & \multicolumn{2}{|l|}{25.25} & 48.11 & 4.61 & 52.54 \\
\hline BUF_2 $\overline{1}^{2}$ & 0.12 & \multicolumn{2}{|l|}{0.36} & 11.37 & 0.00 & 3.15 \\
\hline BUF_22 ${ }^{2}$ & 0.00 & \multicolumn{2}{|l|}{0.00} & 2.57 & 0.00 & 0.00 \\
\hline BUF_232 & 0.01 & \multicolumn{2}{|l|}{0.03} & 3.99 & 0.00 & 0.79 \\
\hline URB_BUF & 2.71 & \multicolumn{2}{|l|}{2.71} & 69.15 & 0.00 & 3.91 \\
\hline FOR_BUF & 66.57 & \multicolumn{2}{|l|}{66.57} & 93.83 & 13.99 & 34.14 \\
\hline TRICOUNT $^{3}$ & 1.00 & \multicolumn{2}{|l|}{2.93} & 179.39 & 0.00 & 1.63 \\
\hline SEI_3 ${ }^{4}$ & -3.84 & \multirow{2}{*}{\multicolumn{2}{|c|}{$\frac{0.74}{4152}$}} & 8.88 & -4.69 & 8.36 \\
\hline AGESTR97 $^{1}$ & 0.42 & & & 48.57 & 22.83 & 27.39 \\
\hline ROAD-DEN & 1.68 & \multicolumn{2}{|l|}{1.68} & 9.56 & 1.14 & 6.45 \\
\hline & & & \multicolumn{3}{|c|}{ Average value of all metrics: } & 9.24 \\
\hline & & & \multirow{2}{*}{\multicolumn{3}{|c|}{ Maximum average for all sites: }} & 80.54 \\
\hline & & & & & & 4.04 \\
\hline & & & \multicolumn{3}{|c|}{ Index adjusted to $0-100$ range: } & 6.80 \\
\hline
\end{tabular}

from multiple studies relies to a great extent on the availability of explanatory and response data collected using common protocols. The need for regularly updated land-cover information in urbanizing areas, based on comparable data and classification protocols, far exceeds the availability of such data.

The urban intensity index did not include any measure or estimate of impervious surface; the impervious surface estimate for each basin was instead used to assist in site selection. Imperviousness is a particularly important indicator of urban intensity (fig. 3 ) because it can be readily measured at a variety of scales (that is, from the parcel level to the watershed) and because it has been consistently shown to affect stream hydrology and water quality (Schueler, 1994). The measurement of impervious surface for large spatial areas, whether from interpretation of large-scale aerial photography

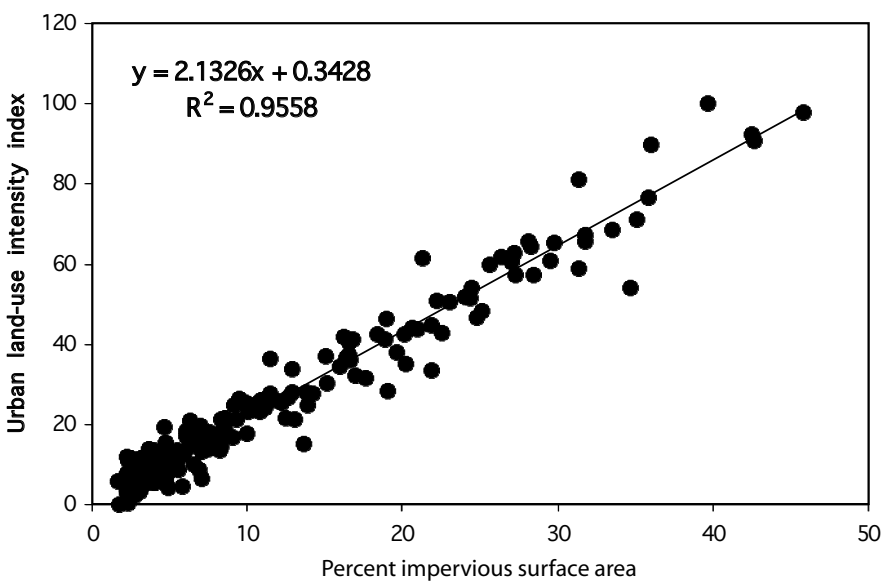

Figure 3. The relation between impervious area and the urban intensity index in the Boston study. 
or through classification of remotely sensed data, was not practical for this project. As is the case with land-cover data, the need for impervious surface data far exceed the resources typically available to generate the data, particularly to support investigations with a large spatial extent. Research is needed on techniques to measure or model impervious-surface data at the scale needed to support regional investigations of the impacts of urbanization.

The value of the urban intensity index in explaining water quality response will be uncertain until water quality data have been collected and analyzed. The index was intended primarily to be used to provide an a priori basis for ranking the relative intensity of urban development. The conceptual understanding of factors that are associated with urban intensity was purposefully inclusive and included factors not usually considered in explaining variations in water quality. An important result of the analysis stage of the urban gradient studies will be to shed light on the explanatory value of the individual variables that comprise the index.

\section{Acknowledgments}

The authors gratefully acknowledge the assistance provided by colleagues participating in the urban gradient studies-Brian Atkins, Rob Baskin, Wade Bryant, Jim Coles, Carol Couch, Elise Giddings, Steve Goodbred, Marty Gurtz, Doug Harned, John Harvill, Evelyn Hopkins, Craig Johnston, Keith Robinson, Terry Short, Steve Smith, Kidd Waddell, and Humbert Zappia.

\section{References}

Abrams, M., and C. Prescott, 1999, The Endangered Species Act enters the urban landscape - can Portland streams sustain salmon? in Sakrison, R., and Sturtevant, P., eds., Watershed management to protect declining species: American Water Resources Association Proceedings, Seattle, Washington, December 5-9, 1999, pp. 95-98.

American Planning Association, 2000, Growing smart: [http://www.planning.org/plnginfo/growsmar/gindex.html, accessed March 2, 2000].

Angermeier, P.L., and Winston, M.R., 1998, Local vs. Regional influences on local diversity in stream fish communities in Virginia: Ecology, v. 79, p. 911-927.

Anson, J., 1991, Demographic indices as social indicators: Environment and Planning, v. 23, p. 433-446.

Arnold, C.L., and Gibbons, C.J., 1996, Impervious surface coverage-The emergence of a key environmental indicator: Journal of the American Planning Association, v. 62, n. 2, p. 243-258.

Bedient, P.B, and Huber, W.C., 1988, Hydrology and floodplain analysis: Reading, MA, Addison-Wesley Publishing Company.

Bevin, K.J., 1986, Hillslope runoff processes and flow frequency characteristics, in Abrahams, A.D., ed., Hillslope processes: Boston, MA, Allen and Unwin, p. 187-202.

Booth, D.B., and Jackson, C.R., 1997, Urbanization of aquatic systems - Degradation thresholds, stormwater detection, and the limits of mitigation: Journal of the American Water Resources Association, v. 33, n. 5, p. 1077-1090.

Center for Watershed Protection, 1998, Rapid watershed planning handbook - A comprehensive guide for managing urbanizing watersheds: Ellicott City, MD.

Corkum, L.D., 1989, Patterns of benthic invertebrate assemblages in rivers of northwestern North America: Freshwater Biology, v. 21, p. 191-205.

Corkum, L.D., 1990, Intrabiome distributional patterns of lotic macroinverterate assemblages: Canadian Journal of Fisheries and Aquatic Sciences, v. 47, p. 2147-2157.

Corkum, L.D., 1992, Relationships between density of macroinvertebrates and detritus in rivers: Archiv für Hydrobiologie, v. 125, p. 149-166.

Corkum, L.D., and Ciborowski, J.J.H., 1988, Use of alternative classifications in studying broad-scale distributional patterns of lotic invertebrates: Journal of the North American Benthological Society, v. 7, p. 167-179.

Cuffney, T.F., Meador, M.R., Porter, S.D., and Gurtz, M.E., 2000, Responses of physical, chemical, and biological indicators of water quality to a gradient of agricultural land use in the Yakima River Basin, Washington: Environmental Monitoring and Assessment, v. 64. p. 259-270.

Davis, W.S., 1995, Biological assessment and criteriaBuilding on the past, in Davis, W.S., and Simon, T.P., eds., Biological assessment and criteria-Tools for water resource planning and decision making: Boca Raton, FL, Lewis Publishers, p. 15-30.

Fairweather, P.G., 1999, State of environmental indicators of "river health'-Exploring the metaphor: Freshwater Biology, v. 41. p. 211-220.

Foresman, T., Pickett, S., and Kuhlman, K., 1999, Act locally-Baltimore ecosystem study: Geo Info Systems, v. 9, n. 2, p. 25-29.

Geolytics, 1998, Census CD + maps, release 2.1: East Brunswick, NJ, Geolytics, Inc.

Grove, J.M, and Burch, W.R., Jr., 1997, A social ecology approach and applications of urban ecosystem and landscape analyses - A case study of Baltimore, Maryland: Urban Ecosystems, v. 1, p. 259-275.

Hammer, T.R., 1972, Stream channel enlargement due to urbanization: Water Resources Research, v. 8, p. 1530-1540.

Karr, J.R., 1991, Biological integrity—A long-neglected aspect of water resource management: Ecological Applications, v. 1, p. 66-84.

Karr, J.R., and Chu, E.W., 1997, Biological monitoring and assessment-Using multimetric indexes effectively: Seattle, WA, EPA 235-R97-001, p. 149 pp.

Kennedy, K., 1999, What's so special about the Edwards aquifer? in Sakrison, R., and Sturtevant, P., eds., Watershed management to protect declining species: American Water Resources Association, Seattle, Washington, December 5-9, 
1999, p. 115-118.

Loveland, T.R., and Shaw, D.M., 1996, Multi-resolution land characterization-Building collaborative partnerships, in Scott and others, eds., GAP analysis - A landscape approach to biodiversity planning: American Society for Photogrammetry and Remote Sensing, p. 83-90.

McMahon, G., and Cuffney, T.F., 2000, Quantifying urban intensity in drainage basins for assessing stream ecological conditions: Journal of the American Water Resources Association v. 36, n. 6, p. 1247-1261.

Mitchell, W.C, and Burns, E.F., 1938, Statistical indicators of cyclical revivals: New York, National Bureau of Economic Research.

Mueller, D.K., and Helsel, D.R., 1996, Nutrients in the Nation's waters - Too much of a good thing?: U.S. Geological Survey Circular 1136, 24 p.

Nelson, E., 1999, Sediment budget of a mixed-use, urbanizing watershed, in Sakrison, R.. and Sturtevant, P., eds., Watershed management to protect declining species: American Water Resources Association, Seattle, Washington, December 5-9, 1999, p. 469-472.

Pelley, J., 1999, Building smart-growth communities: Environmental Science and Technology, January 1, 1999, p. 28A-32A.

Poff, N.L., and Allan, J.D., 1995, Functional organization of stream fish assemblages in relation to hydrological variability: Ecology, v. 76, p. 606-627.

Poff, N.L., and Ward, J.V., 1989, Implications of stream flow variability and predictability for lotic community structure-A regional analyses of stream flow patterns: Canadian Journal of Fisheries and Aquatic Sciences, v. 46, p. 1805-1818.

Poff, N.L., Allan, J.D., Bain, M.B., Darr, J.R., Prestegaard, K.L., Richter, B.D., Sparks, R.E., and Stromber, J.C., 1997, The Natural Flow Regime-A paradigm for river conservation and restoration: BioScience, v. 47, n. 11, p. 769-784.

Price, C.V., and Clawges, R.M., 1999, Digital data sets describing water use, toxic chemical releases, metropolitan areas, and population density of the conterminous United States: U.S. Geological Survey Open-File Report 99-78.

Quinn, J.M., and Hickey, C.W., 1990, Characterization and classification of benthic invertebrate communities in 88 New Zealand rivers in relation to environmental factors: New Zealand Journal of Marine and Freshwater Research v. 24, p. 387-410.

Ryzner, R.M., 1998, Urban vegetation and social change-An analysis using remote sensing and census data: University of Michigan, Ph.D. Dissertation, 124 p.

Smart Growth Networks, 2000, Development that serves economy, community, and environment: [http://www. smartgrowth.org/index frameset.html, accessed March 2, 2000].

Stankowski, S.J., 1972, Population density as an indirect indicator of urban and suburban land-surface modification: U.S. Geological Survey Professional Paper 800-C, p. B219B224.
Steedman, R.J., 1988, Modifications and assessment of an index of biotic integrity to quantify stream quality in southern Ontario: Canadian Journal of Fisheries and Aquatic Sciences, v. 45, p. 492-501.

Tate, C.M., and Heiny, J.S., 1995, The ordination of benthic invertebrate communities in the South Platte River Basin in relation to environmental factors: Freshwater Biology, v. 33, p. 439-454.

Taylor, C.M., Winston, M.R., and Matthews, W.J., 1993, Fish species-environment and abundance relationships in a Great Plains river system: Ecography, v. 16, p. 16-23.

U.S. Army Corps of Engineers, 1996, Water control infrastructure, national inventory of dams, 1995-96: U.S. Federal Emergency Management Agency, CD-ROM.

U.S. Department of Agriculture, 1994, State soil geographic (STATSGO) data base data use information: U.S. Department of Agriculture-Natural Resources Conservation Service Miscellaneous Publication 1492, 36 p.

U.S. Environmental Protection Agency, 1997a, 1987-1995 Toxics release inventory: Washington, D.C., EPA 749-C-97003, CD-ROM.

U.S. Environmental Protection Agency, 1997b, Urbanization and streams - Studies of hydrologic impacts: Washington, D.C., EPA841-R-97-009.

U.S. Environmental Protection Agency, 1999, Permit compliance system homepage-U.S. Environmental Protection Agency: [http://www.epa.gov/envirofw/html/ water.html, accessed November 12, 1999].

U.S. Geological Survey, 1999, The quality of our Nation's water-Nutrients and pesticides: U.S. Geological Survey Circular 1225, $82 \mathrm{p}$.

U.S. Geological Survey, 2000a, Urban Dynamics Research Program, U.S. Geological Survey: [http://edcdgs9.cr.usgs. gov/urban, accessed March 2, 2000].

U.S. Geological Survey, 2000b, National Water-Quality Assessment Program, U.S. Geological Survey: [http://water. usgs.gov/nawqa/nawqa_home.html, accessed March 6, 2000].

U.S. Geological Survey, 2000c, National elevation dataset: [http://gisdata.usgs.gov/ned/, accessed March 1, 2000].

Wang, L., Lyons, J., Kanehl, P., and Gatti, R., 1997, Influences of watershed land use on habitat quality and biotic integrity in Wisconsin streams: Fisheries, v. 22, n. 6 , p. 6-12.

Ward, R.C., 1996, Water quality monitoring - Where's the beef?: Water Resources Bulletin v. 32, n. 4, p. 673-680.

Whittier, T.R., Hughes, R.M., and Larsen, D.P., 1988, Correspondence between ecoregions and spatial patterns in stream ecosystems: Canadian Journal of Fisheries and Aquatic Sciences v. 45, p. 1264-1278.

Williams, D., 1999, Sustainable urban and regional designThe South Dade watershed project, in Sakrison, R., and Sturtevant, P., eds., Watershed management to protect declining species: American Water Resources Association, Seattle, Washington, December 5-9, 1999, p. 457-460. Yoder, C.O, 1995, Policy issues and management applications 
of biological criteria, in Davis, W.S. and Simon, T.P., eds., Biological assessment and criteria-Tools for water resource planning and decision making: Boca Raton, FL, Lewis Publishers, p. 327-343.

Yoder, C.O., and Rankin, E.T., 1995, Biological response signatures and the area of degradation value-New tools for interpreting multimetric data, in Davis, W.S. and Simon, T.P., eds., Biological assessment and criteria-Tools for water resource planning and decision making: Boca Raton, FL, Lewis Publishers, p. 263-286. 


\title{
Analyzing Albuquerque's Landscape Evolution in the 20th and 21st Centuries
}

\author{
By David J. Hester ${ }^{1}$
}

\section{Introduction}

The Middle Rio Grande Basin (MRGB) Study was a 6-year effort (1995 to 2001) by the U.S. Geological Survey (USGS) and other agencies to improve the understanding of the hydrologic, geologic, and landscape characteristics of the MRGB in order to provide the scientific information needed for water-resources management. The Albuquerque metropolitan area located within the MRGB is faced with rapid population and economic growth and relies on the Santa Fe Group aquifer as the main source of municipal water. The New Mexico Office of the State Engineer administers the appropriation and use of New Mexico water resources and has declared the basin a "critical basin"; that is, a ground-water basin faced with rapid economic and population growth where there is less than adequate technical information regarding the available water supply (Bartolino, 2002).

To investigate how humans are altering the landscape, the USGS, as part of the MRGB study, researched the anthropogenic impacts of Albuquerque's urban growth on central New Mexico's land surface. To monitor land-use transitions, temporal land-use and land-cover data for the timeframes covering the 1930s, 1950s, 1970s, and 1990s were mapped to analyze patterns, rates, and trends in Albuquerque's landscape change.

\section{Study Area Description}

As part of the MRGB Study, USGS researched the anthropogenic impacts of Albuquerque's urban growth on central New Mexico's land surface. For the landscape change investigation, the USGS used the Albuquerque Metropolitan Statistical Area (MSA: consisting of Bernalillo, Sandoval, Torrance, and Valencia Counties) as the geographic extent for regional land-use history and socioeconomic analysis. This area includes twenty-eight 1:24,000-scale (24K) quadrangles for temporal land-use trend analysis and sixteen $24 \mathrm{~K}$ quadrangles centered on Albuquerque's urban core as the study area for predictive landscape change modeling (fig. 1).

${ }^{1}$ U.S. Geological Survey, Rocky Mountain Geographic Science Center, Fort Collins, CO 80526, (303) 202-4318, dhester@usgs.gov.

\section{Socioeconomic Setting}

As of 1990, the Albuquerque MSA accounted for about 40 percent $(590,000)$ of New Mexico's residents. From 1900 to 1990, the population of New Mexico increased from 195,000 inhabitants to 1,515,000 (U.S. Bureau of the Census, 1995). The Albuquerque MSA contributed approximately 40 percent $(550,000)$ to New Mexico's population growth during this time.

Historically the employment sectors that drove urban growth and landscape change in the Albuquerque region were transportation (the Atchison, Topeka, and Santa Fe Railroad), education (University of New Mexico), healthcare (U.S. Veterans Administration hospital), and military/Federal (Kirtland Air Force Base and Sandia National Laboratories). These same employment sectors in 1995 accounted for about 45 percent of employers in the Albuquerque region and the Albuquerque MSA employed 325,000 or about 50 percent of New Mexico's workforce (Middle Rio Grande Council of Governments, 1997a).

The location and geographic extent of Albuquerque's urbanized areas on the landscape is influenced by land-surface property rights such as land ownership. Public and NativeAmerican land ownership, such as Cibola National Forest, Petroglyph National Monument, Isleta Pueblo, Sandia Pueblo, and Santa Ana Pueblo create land areas within the Albuquerque metropolitan area that are exempt from future urbanization. Approximately 60 percent $(2,304,000$ acres $)$ of the Albuquerque MSA is excluded from future urban growth due to land ownership (Middle Rio Grande Council of Governments, 1999).

\section{Physical Environment Setting}

Located in central New Mexico along the Rio Grande, the Albuquerque urban area at an elevation of approximately 5,300 feet is the highest metropolitan region in the United States (Albuquerque Economic Development Team, 2004). Albuquerque's physiographic setting is comprised of mountain, mesa, and river valley landforms. Starting in the Rio Grande Inner Valley and traveling east of central Albuquerque in Bernallilo County we cross alluvial fans on the East Mesa bounded by the Sandia Mountains, which rise to an elevation of almost 11,000 feet. Intersecting the Sandia Mountains to the south is Tijeras Canyon through which runs Federal 


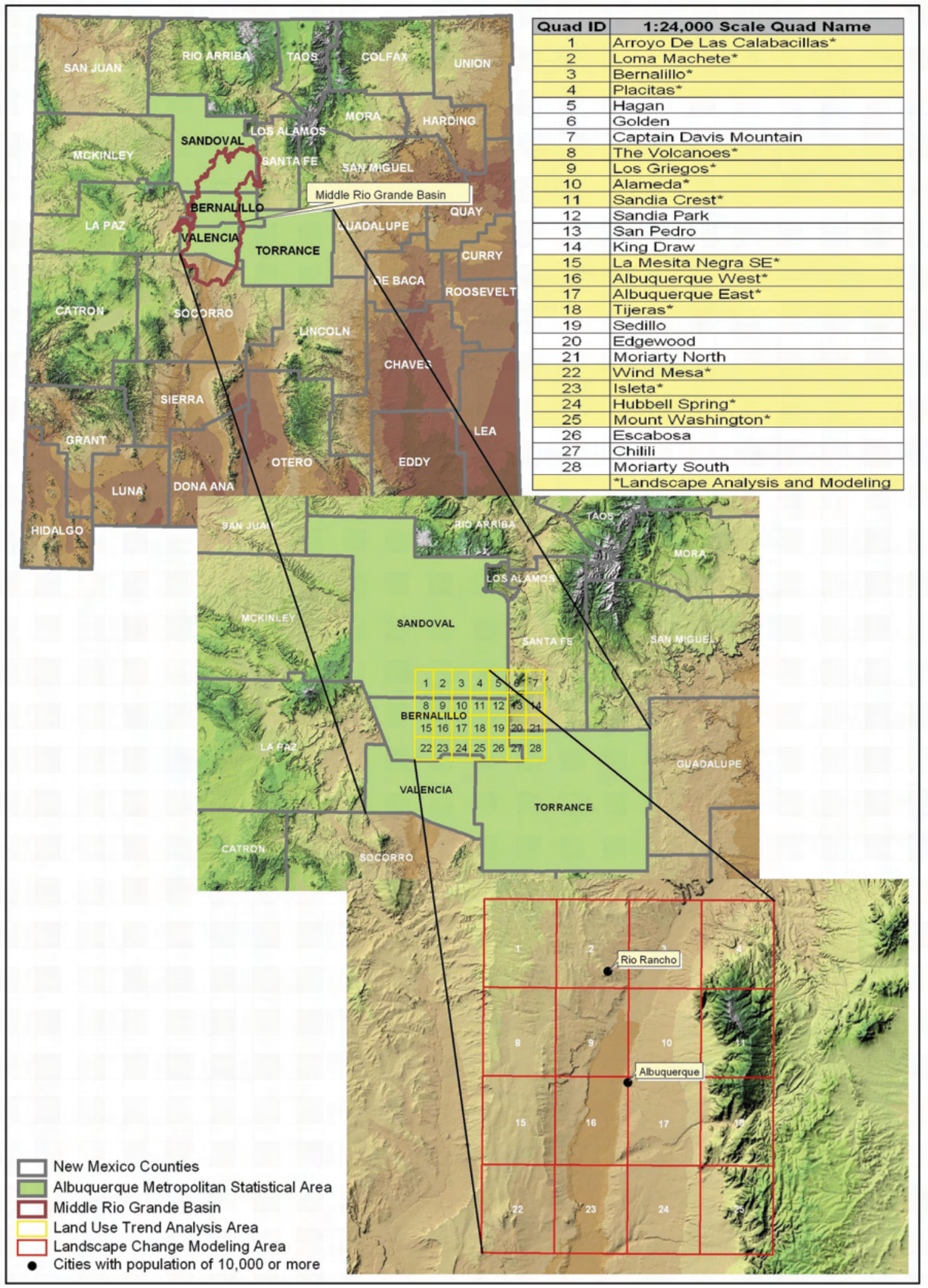

Figure 1. Study area overview map showing geographic extents for Albuquerque land-use history, landscape-change analysis, and land-use modeling research. 
Table 1. Terrain characteristics, such as percent slope, for the Albuquerque metropolitan area and 1991 developed land.

\begin{tabular}{|c|c|c|c|}
\hline Percent slope & $\begin{array}{c}\text { Total area } \\
\text { (acres) }\end{array}$ & $\begin{array}{c}1991 \\
\text { Urban land } \\
\text { (acres) }\end{array}$ & $\begin{array}{c}\text { Undeveloped } \\
\text { land (acres) }\end{array}$ \\
\hline $0-5$ & $388,233.1$ & $75,267.7$ & $188,822.2$ \\
\hline $5-10$ & $102,390.8$ & $8,342.6$ & $52,002.5$ \\
\hline $10-15$ & $31,336.4$ & 946.7 & $12,507.2$ \\
\hline $15-20$ & $19,948.8$ & 185.3 & $5,210.1$ \\
\hline $20-30$ & $33,073.3$ & 102.4 & $4,878.7$ \\
\hline $30-40$ & $19,665.7$ & 27.0 & $1,740.1$ \\
\hline $40-50$ & $12,939.7$ & 11.6 & 628.8 \\
\hline Slope $>50$ & $16,925.6$ & 7.2 & 276.0 \\
\hline
\end{tabular}

Interstate Highway 40; formerly U.S. Route 66 , and is the northern border for the Manzanita Mountains to the southeast of Albuquerque. Further south of the Manzanita Mountains is the Manzano mountain range which is primarily located within the Torrance County portion of the Albuquerque MSA. Traveling west across the high plateau mesa, we traverse back through Valencia County to the Rio Grande Inner Valley and riparian woodland area known as the Bosque. To the west of the Rio Grande floodplain and Bosque riparian corridor, the Albuquerque metropolitan area is framed on the western side by a volcanic escarpment located within Sandoval County known as the West Mesa.

Physical terrain characteristics, such as slope, can influence which portions of the land surface will typically transition from the natural landscape into urban lands. As of 1991, approximately 98 percent of Albuquerque's land-use development $(83,600$ acres) had occurred predominantly on flat land with slopes less than 10 percent (table 1). Because about 90 percent of land available for development (240,800 acres) has slopes less than 10 percent, Albuquerque's future urban growth does not appear to be constrained by steeper slopes on the land surface.

Prior to the actual settlement of Albuquerque in 1706, the Spaniards evaluated the area to determine the most suitable site for a village. The location selected for Albuquerque was based on the necessary natural resource, water, as required by Spanish law (Stier, 1998). Today, the Santa Fe Group Aquifer is the main source of municipal water for sustaining urban growth in the Albuquerque region. Because approximately 600,000 people live in the region, water shortfalls could have serious economic consequences for the State. Albuquerque's annual ground-water withdrawal from the Santa Fe Group Aquifer has increased from about 2,000 acre-feet in 1933 to about 113,000 acre-feet in 1998 (Kernodle, 1995), with more than 55 percent $(2,080,000$ acre-feet $)$ of the total withdrawal occurring between 1980 and 1998. New high-technology industries, for example Intel's Rio Rancho microchip manufacturing plant, place a high demand on existing ground-water resources. To avoid continued sole reliance on ground-water for domestic water supplies, the City of Albuquerque has acquired 48,000 acre-feet of surface water rights known as the San Juan-Chama project (Albuquerque Journal, 1999) to sustain Albuquerque's continued economic and population growth.

\section{Ecological Setting}

The Albuquerque urban area is a semiarid metropolis that is an intersection of the Great Basin and Great Plains grasslands and upper Chihuahuan Desert ecological regions (Middle Rio Grande Council of Governments, 1999). Annually, the Albuquerque metropolitan area averages approximately 9 inches precipitation, with the surrounding higher elevation mountainous areas receiving as much as 20 inches per year. Most of the total annual precipitation comes during Albuquerque's monsoon season which runs from June through September (Albuquerque Economic Development Team, 2004).

Elevation variance from approximately 5,000 feet up to almost 11,000 feet and localized differences in the amount of annual precipitation result in the Albuquerque metropolitan area being covered ecologically by six distinct vegetative zones (Rosner, 1996a). The Rio Grande Inner Valley and Bosque riparian areas fall within the river's floodplain and the Grasslands vegetative zone (less than 5,500 feet). Even though Albuquerque's urban growth through time has decreased the irrigated acreage and number of farms within the Rio Grande 
Valley, there still are fertile agricultural lands used for pasture and growing crops such as alfalfa. The riparian woodland area known as the Bosque, which is adjacent to the Rio Grande, benefits ecologically from available ground water and is dominated by native species such as cottonwood as well as invasive vegetative species such as salt cedar and Russian olive (Rosner, 1996b). Rising above 5,500 feet and the Rio Grande Inner Valley, we enter the Upper Sonoran vegetative zone that covers the terraces known as the East and West Mesas. These terraces, formed by debris flows from the Sandia Mountains as well as windblown and volcanic processes, have historically been prairie grasslands. Today, the natural vegetative cover for the East Mesa remains short grasses, such as blue and black gramma, as well as shrubs like saltbush. In comparison, the West Mesa is transitioning from short prairie grasses to vegetative cover indicative of a desert grassland ecosystem (Rosner, 1996d). Climbing into the Sandia and Manzano Mountains east and southeast of Albuquerque we encounter the montane and subalpine forest vegetative zones. These zones are the Upper Sonoran (6,100 to 7,600 feet) in the foothills, the Transition (7,600 to 8,200 feet), and Canadian (8,200 to 10,000 feet) on the mountain slopes and Hudsonian (above 10,000 feet) on the mountain peaks. Albuquerque's foothill communities on the western slope of the Sandia Mountains, as well as towns such as Cedar Crest and Sandia Park on the eastern mountain slopes, are covered by these vegetative zones. Due to higher elevation of the mountainous terrain, greater precipitation and runoff in these zones results in denser, taller vegetative cover. The aspect or direction of sunlight creates different vegetation on each side of the canyons within the Sandia and Manzano Mountains depending on whether the mountain slope has a southern or northern exposure. Vegetative species that are indicative of the Upper Sonoran, Transition, Canadian, and Hudsonian zones for a northern-facing mountain slope are pinyon pine, ponderosa pine, Gambel oak, and blue spruce (Rosner, 1996c). In contrast, a southern-facing slope in the mountains surrounding Albuquerque would typically have prickly pear cactus, Utah juniper, mountain mahogany, and white fir.

\section{Historic Urban Growth}

Analyzing the evolution of Albuquerque's landscape required developing an understanding of the regional land-use history and the historical events that helped form the city's land use patterns. For example, evaluating the "Bird's Eye View of Albuquerque" map (fig. 2) (Fitzpatrick, 1976) drawn by Augustus Koch in 1886 reveals that during the late 1880s several characteristics affected land-use patterns. These were (1) the Albuquerque Foundry (city's 2nd largest employer), (2) the Atchison, Topeka, and Santa Fe Railroad (railroad transportation improved access to the region), (3) East Mesa "sandhills," east of Walter Avenue (terrain inhibited development), (4) "new" Albuquerque's rectangular network of city streets (surveyed and platted roads shaped future urban form), and (5) the Rio Grande (water resources sustained irrigated agriculture adjacent to Old Town).

Human-induced land transformations were characterized by temporally mapping the shape and spatial extent of Albuquerque's urban form. The urban form at any given time represents the land that has been consumed by the built environment, including residential, retail, industrial, communications and utilities, transportation, and recreational facilities and institutions. Understanding Albuquerque's regional landuse history required relating the mapped temporal land-use patterns to significant social, political, and environmental events that contributed to the region's urbanized area.

Albuquerque's ability to conduct commerce was enabled with the arrival of the Atchison, Topeka, and Santa $\mathrm{Fe}$ (AT\&SF) railroad in 1880. The improved transportation allowed Albuquerque's agricultural, textile, and mining commodities to be sold in markets throughout the United States (Stier, 1998). The AT\&SF railroad also brought an influx of new residents seeking employment to the region. Road-influenced growth began to affect the landscape with the introduction of Albuquerque's first automobile in 1897. The introduction of the electric trolley in 1904 permitted access to Albuquerque's perimeter and created urban growth corridors extending outward from the established urban center (Johnson, 1981). Albuquerque's entrance into the age of air travel in 1928 enhanced urban growth as the region became New Mexico's major transportation hub. By 1935, the spatial extent of the road network had grown to about 245 miles of principal transportation routes (fig. 3), and Albuquerque's urbanized area covered approximately 4,400 acres of the land surface (table 2 and fig. 4). Developed land was predominantly east of the Rio Grande and within Bernalillo County. The majority of the urban center was concentrated in the Central Albuquerque region. Development began to expand onto the East Mesa (Near Heights), as influenced by the University of New Mexico, U.S. Veterans Administration Hospital, and Albuquerque Municipal Airport (Fitzpatrick, 1976). Locations of small urban cores such as Isleta and Bernalillo (North Valley) were found adjacent to the AT\&SF railroad. The only urban centers west of the Rio Grande were Atrisco and Los Padillas in the South Valley.

Between 1940 and 1950 Albuquerque's urban footprint doubled, and by 1951 the built environment had grown to cover approximately 15,400 acres of the land surface (table 2 and fig. 4). Driving urban growth during this period was the development of major military installations (U.S. Air Force bases) such as Kirtland, Sandia, and Manzano (Taylor, 1996) on the East Mesa. The establishment of Los Alamos Laboratory in 1943 initiated New Mexico's involvement in atomic research during World War II (WWII). The development of nuclear weapons by the Los Alamos Manhattan Project required extensive testing facilities and flight support and in 1945 the Z Division Unit was moved to Sandia Base in Albuquerque (Collins, 1996). In 1949, the Sandia Corporation was formed from the Z Division Unit to focus on development and testing of special weapons. Today, the Sandia 
National Laboratories (SNL) continues conducting research and development of energy sources as the largest tenant on Kirtland Air Force Base (AFB). During the post-WWII years, Albuquerque's urban development occurred primarily in the North Valley (Los Ranchos de Albuquerque and Los Griegos), in close proximity to Kirtland AFB and SNL on the East Mesa (Mid-Heights area), and spread west of the Rio Grande (South Valley-Armijo and Pajarito). The introduction of commercial jet aircraft in 1958 and subsequent opening of Albuquerque's new airport terminal in 1963 shifted one of the primary entry points for newly arriving residents from the railroad depot to the airport (Gerckens, 1998). Air transport provided by the Albuquerque International Sunport has assumed a similar enabling role for Albuquerque's future landscape change as did the AT\&SF railroad in the 1880s.

As part of the 1956 Federal Interstate Highway System Act implementation, the completion of Interstate 40 in 1973 and Interstate 25 in 1975 stimulated the peripheral expansion of Albuquerque's metropolitan area. The Albuquerque region continued to boom during the post-World War II years, with the highest annual rate of urban landscape change peaking at 7.19 percent during the 1960s (table 2). The Winrock and Coronado Shopping Centers were constructed then, ending downtown Albuquerque's retail dominance (Taylor, 1996) and stimulated urbanization in the East Mesa (Mid-Heights) area. Urban development in the East Mesa (Foothills) area, including the

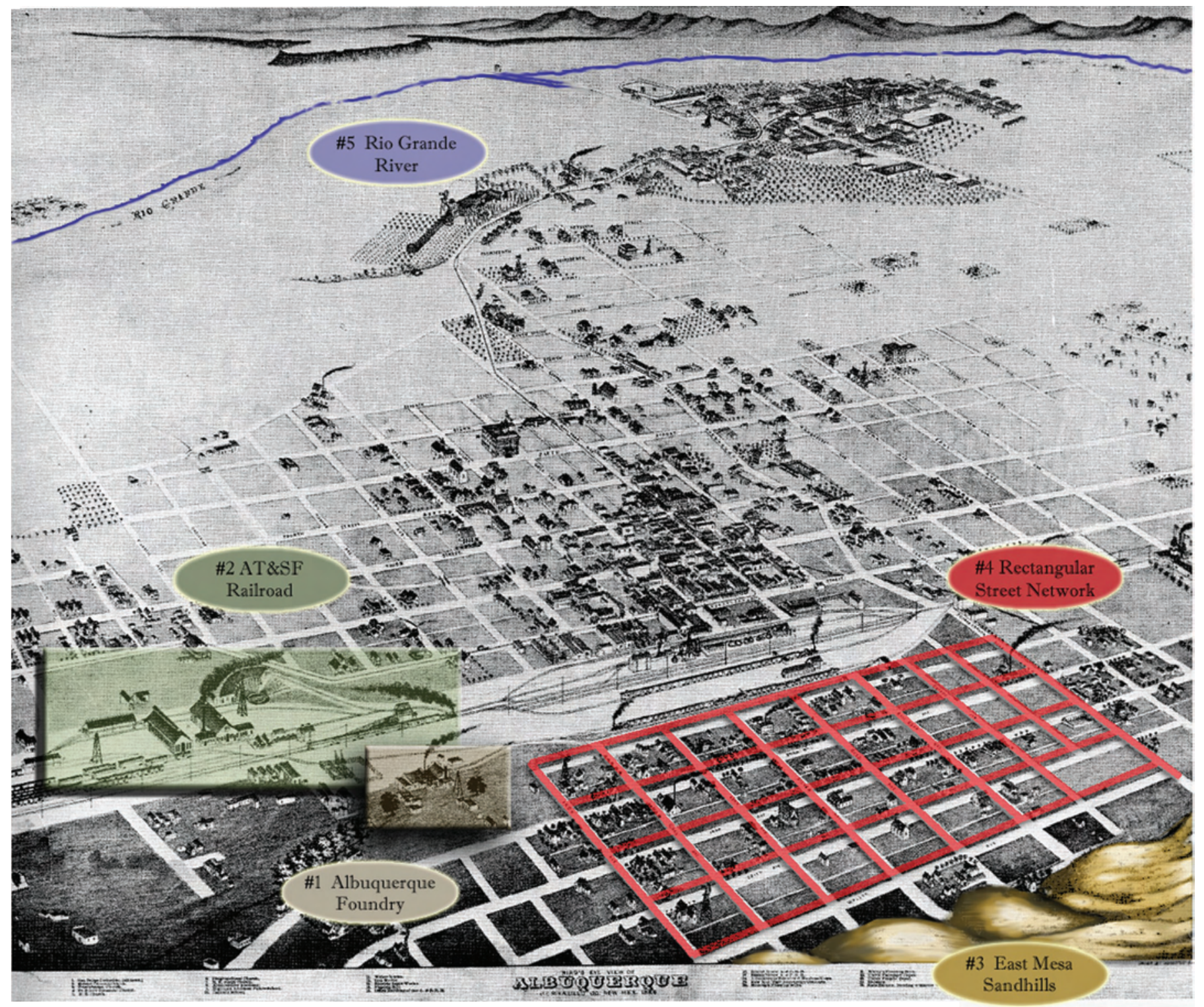

Figure 2. 1886 "Bird's Eye View of Albuquerque" drawn by Augustus Koch from Albuquerque—100 Years in Pictures (Fitzpatrick and Caplin, 1976). 
Table 2. Albuquerque Metropolitan Statistical Area (MSA) and City of Albuquerque urbanization and population growth metrics for the 20th century.

\begin{tabular}{|c|c|c|c|c|c|c|c|c|c|c|c|c|c|c|}
\hline $\begin{array}{c}\text { Years } \\
\text { Mapped }\end{array}$ & $\begin{array}{c}\begin{array}{c}\text { Urban Area } \\
\text { (acres) }\end{array} \\
\end{array}$ & $\begin{array}{c}\text { Decades } \\
\text { corresponding } \\
\text { to population } \\
\text { totals }\end{array}$ & $\begin{array}{c}\text { Urban area } \\
\text { by decade } \\
\text { (acres) }\end{array}$ & $\begin{array}{c}\text { Change in } \\
\text { urban } \\
\text { area } \\
\text { (acres) }\end{array}$ & $\begin{array}{c}\begin{array}{c}\text { Annual rate } \\
\text { of urban } \\
\text { change }\end{array} \\
\end{array}$ & $\begin{array}{c}\text { Albuquerque } \\
\text { MSA } \\
\text { population } \\
\end{array}$ & $\begin{array}{l}\text { Change in } \\
\text { population }\end{array}$ & $\begin{array}{l}\text { Annual rate } \\
\text { of } \\
\text { population } \\
\text { change }\end{array}$ & $\begin{array}{l}\text { Acres of } \\
\text { urban } \\
\text { land per } \\
\text { capita }\end{array}$ & $\begin{array}{c}\text { Number of } \\
\text { persons } \\
\text { per urban } \\
\text { acre }\end{array}$ & \begin{tabular}{|c|} 
City of \\
Albuquerque \\
population
\end{tabular} & $\begin{array}{c}\text { City of } \\
\text { Albuquerque } \\
\text { as } \\
\text { percentage } \\
\text { of MSA } \\
\text { population } \\
\end{array}$ & $\begin{array}{l}\text { City of Rio } \\
\text { Rancho } \\
\text { population }\end{array}$ & $\begin{array}{c}\text { City of Rio } \\
\text { Rancho as } \\
\text { percentage } \\
\text { of MSA } \\
\text { population }\end{array}$ \\
\hline 1935 & 4,372 & 1900 & & & & 42,525 & & & & & 7,517 & $17.68 \%$ & & \\
\hline 1951 & 15,398 & 1910 & & & & 45,505 & 2,980 & $0.68 \%$ & & & 12,000 & $26.37 \%$ & & \\
\hline 1973 & 49,746 & 1920 & & & & 52,513 & 7,008 & $1.44 \%$ & & & 15,000 & $28.56 \%$ & & \\
\hline \multirow[t]{7}{*}{1991} & 84,891 & 1930 & & & & 72,760 & 20,247 & $3.31 \%$ & & & 26,570 & $36.52 \%$ & & \\
\hline & & 1940 & 7,818 & & & 103,534 & 30,744 & $3.59 \%$ & 0.076 & 13.2 & 35,449 & $34.24 \%$ & & \\
\hline & & 1950 & 14,709 & 6,891 & $6.52 \%$ & 180,592 & 77,058 & $5.72 \%$ & 0.081 & 12.3 & 96,815 & $53.61 \%$ & & \\
\hline & & 1960 & 29,449 & 14,741 & $7.19 \%$ & 315,485 & 134,893 & $5.74 \%$ & 0.093 & 10.7 & 201,189 & $63.77 \%$ & & \\
\hline & & 1970 & 45,062 & 15,613 & $4.35 \%$ & 373,805 & 58,320 & $1.71 \%$ & 0.121 & 8.3 & 243,751 & $65.21 \%$ & & \\
\hline & & 1980 & 63,413 & 18,351 & $3.48 \%$ & 515,614 & 141,809 & $3.27 \%$ & 0.123 & 8.1 & 331,736 & $64.34 \%$ & 9,985 & $1.94 \%$ \\
\hline & & 1990 & 82,938 & 19,525 & $2.72 \%$ & 589,131 & 73,517 & $1.34 \%$ & 0.141 & 7.1 & 384,736 & $65.31 \%$ & 32,505 & $5.52 \%$ \\
\hline
\end{tabular}

1966 Sandia Peak Tramway opening, brought an increasing demand for urban city services. The completion of I-40 and I-25 improved the east-west and north-south access through the region (Stier, 1998) and increased road-influenced corridor development. The region experienced approximately 60 percent growth in primary roads between 1951 and 1973 (fig. 3), which influenced urban growth in the North Valley (Alameda and Corrales) and the South Valley (Mountainview). Interstate 40 became the eastern gateway to Albuquerque, contributing to tremendous urban growth and land development between 1951 and 1973 on the East Mesa area (North Albuquerque and Mid-Heights). During the early 1960s, urban growth northwest of Albuquerque was initiated when the American Real Estate and Petroleum (AMREP) corporation purchased the Koontz Ranch and began a nationwide land sales marketing program to develop 90,000 acres on the Northwest Mesa. AMREP sold more than 75,000 lots between 1961 and 1977 with the first homes for the Rio Rancho community west of the Rio Grande being constructed in 1963 (Ryan, 1996). By 1973, the Albuquerque region's developed land had grown to 49,700 acres

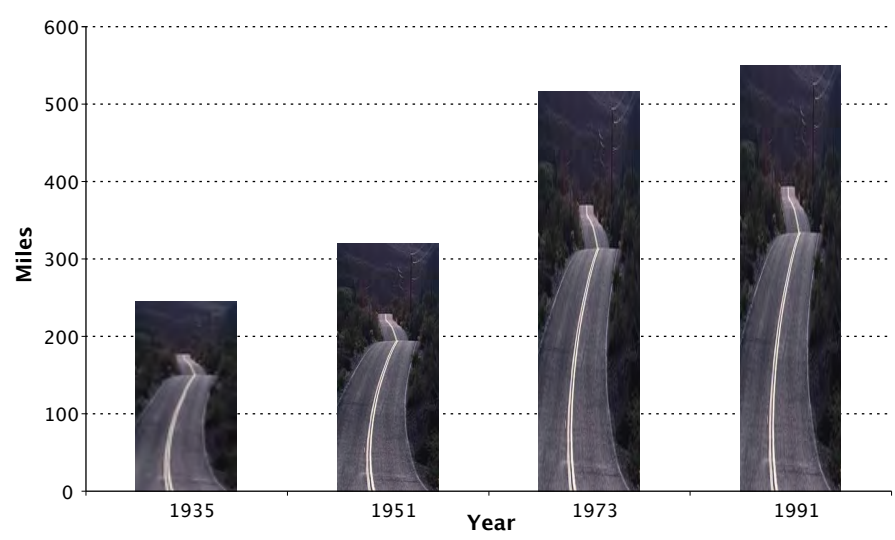

Figure 3. Primary road mileage (1935 to 1991) for the Albuquerque metropolitan area. (table 2 and fig. 4) and the Rio Rancho community was well on its way to becoming an incorporated city.

By 1991, Albuquerque's human-induced land transformations had consumed 84,900 acres of the region's landscape as urban land (table 2 and fig. 4). The dominant land-use trend was urban expansion west of the Rio Grande and along Coors Boulevard (New Mexico State Highway 45) onto the Northwest Mesa (Rio Rancho) and the Southwest Mesa. Rapid development west of the Rio Grande, that is the West Side, was due to lower land prices and close commuting proximity to Albuquerque. Rio Rancho's urban growth on the Northwest Mesa by 1995 had resulted in the fourth largest New Mexico city (Ryan, 1996). Economic growth driving West Side urbanization included the construction of Intel's Rio Rancho microchip manufacturing plant (Albuquerque Journal, 1999) and the State's largest regional shopping mall (Cottonwood). Intel selected Rio Rancho in 1980 as the site for constructing its new plant based on criteria such as the presence of intellectual capital (Sandia National Laboratories), proximity to an international airport (Sunport) and major highways (Interstate 25 and 40), a metropolitan area population greater than 500,000, local access to a major academic research institution (University of New Mexico), housing and living costs below the national average and the abundance of ground-water resources beneath Albuquerque (Starner, 2001). As urban growth expanded on the Rio Grande's west side, land-use development encroached upon the Petroglyph National Monument. A proposed 1998 Federal bill suggested withdrawing 8.5 acres from the National Monument to extend the Paseo del Norte transportation corridor through the historical area. The objective in extending Paseo del Norte is to service planned urban developments on the western edge of the monument (Robbins, 1999). Urbanization continued to spread in the North Valley (Corrales) while South Valley land-use development increased concerns regarding preservation of existing agricultural land. Albuquerque's urban footprint on the East Mesa expanded eastward with increased growth in the East Gateway area and Tijeras Canyon (Carnuel). Even though Albuquerque's metropolitan urban form exhibited in-fill development and satellite 
urban centers growing together through time to become urban cores, the long-term land-use trend from 1935 to 1991, based on the basis of a visual assessment, was greater dispersion of urban lands on the region's landscape (fig. 4).

Albuquerque's rank as New Mexico's largest city according to the 2000 Population and Housing Census is attributable to a variety of socioeconomic factors from which it benefited throughout the $20^{\text {th }}$ century. Although the city's historic urban growth was enabled by being a regional hub of the national transportation infrastructure (that is, AT\&SF Railroad, Interstate Highways 25 and 40, and Sunport International Airport), it was the diversity of its historic economic development that drove its urban expansion and distinguished it from other cities in New Mexico. The amenities of higher education and health-care systems that attracted people to Albuquerque early in the $20^{\text {th }}$ century were augmented by the lure of employment provided by significant local investment by the Federal government during the Great Depression and WWII. The post-WWII period saw the emergence of Albuquerque's manufacturing base as industries ranging from electronics to clothing began locating their operations in the area. Presently, Albuquerque's solid base of labor and intellectual capital coupled with its low business tax rates and various incentives (Albuquerque Economic Development Team, 2004) position the city to maintain its appeal to new industries and residents in the $21^{\text {st }}$ century.

\section{Regional Land-Use Trend Analysis}

The dominant land-use trend is the transition of undeveloped land to human settlements, workplaces, and urban infrastructure. To monitor regional land-use transitions, temporal land-use and land-cover (LULC) data were mapped to analyze patterns, rates, and trends in Albuquerque's landscape change.

\section{Temporal Land-Use and Land-Cover Mapping}

As part of the MRGB Study, the USGS temporally mapped LULC data for the timeframes covering the 1930s, 1950s, 1970s, and 1990s (Stier, 1999). The contemporary and historical LULC were collected for an area consisting of twenty-eight $24 \mathrm{~K}$ quadrangles covering the Albuquerque urban area (fig. 1).
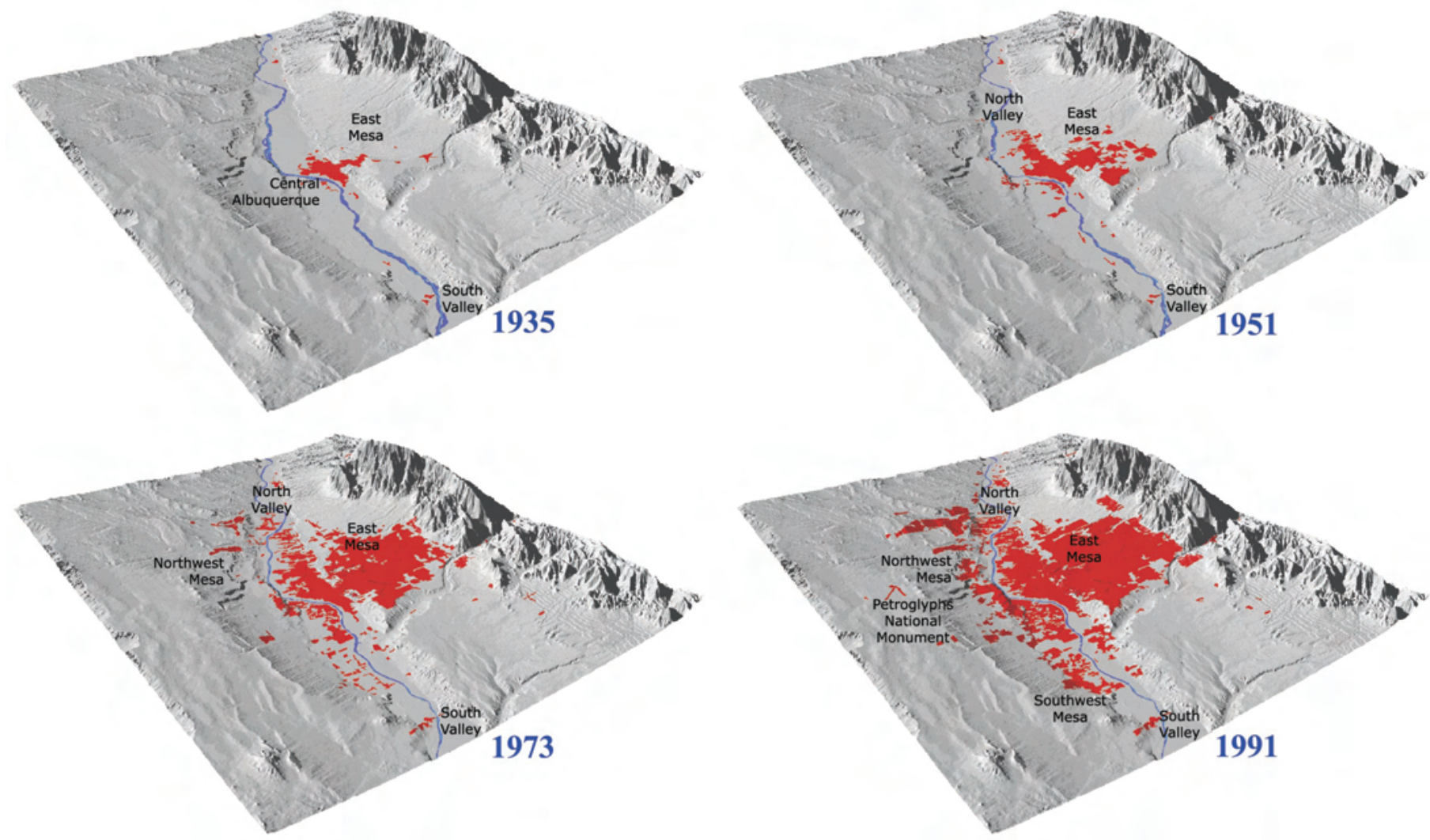

Figure 4. Three-dimensional perspective view of urban land in the vicinity of Albuquerque (1935 to 1991). Urban land is shown in red and perspective view is to the northeast. 
The first step in compiling the temporal LULC data was to acquire historical aerial photographs, USGS digital orthophoto quadrangle (DOQ) imagery, and ancillary data for collecting, interpreting, and classifying the land-surface features. As part of the MRGB Study, historical aerial photographs were acquired from the Department of Agriculture's Natural Resources Conservation Service, U.S. Forest Service, and USGS archives. For the 1930 and 1950 time periods, only black-and-white aerial photographs were available. Acquisition of ancillary source material, such as the U.S. Fish \& Wildlife Service National Wetlands Inventory data, USGS 24K topographic maps, and the Bureau of Reclamation's land-use trend analysis data, helped enhance the interpretation and classification of Albuquerque's historical LULC data.

The historical aerial photographs acquired were scanned, geo-referenced, and mosaiced using image processing software. During the geo-referencing process, a USGS 24K digital-line-graph (DLG) file was used to locate well-defined features, such as road intersections, and the DLG coordinates for each feature were transferred to the same feature on the scanned historical image. The geo-referenced portion of each photograph was clipped and mosaiced to adjacent aerial photographs in order to create a historical image covering each USGS 24K quadrangle for the Albuquerque urban area.

Temporal LULC mapping for Albuquerque used a minimum mapping unit of 2.5 acres and a minimum polygon width of 125 feet for delineating land-surface features. The interpretation of LULC categories followed a modified Anderson Level IV classification scheme developed by the USGS Rocky Mountain Geographic Science Center. Contemporary LULC features were mapped first using the 1990s DOQ as the primary data collection source. Upon completion, the 1990s LULC data set was used as the foundation for collecting the 1970s LULC data. The completed 1990s LULC data set was modified using the 1970s imagery as a reference for delineating 1970s land-use patterns. The 1950s and 1930s LULC data sets were collected using the next most recent time period as the land-surface foundation and subsequently modified using the older historical images to reflect the respective temporal land-use patterns. Using the more recent LULC data set as the foundation for collecting earlier time periods avoided the collection of unchanged LULC features. The historical LULC data compiled for each $24 \mathrm{~K}$ quadrangle was then merged into one seamless data set per vintage for subsequent land-use trend analysis.

\section{Land-Use Trends}

Albuquerque is a post-WW II American city that experienced more than half of its population growth since 1940 . Subsequently, the 1930s LULC data are considered the base land-surface condition for analyzing landscape composition and categorical land-use trends. In the 1930s, the principal LULC categories dominating the landscape were rangeland (shrubs, natural grasses, and other herbaceous vegetation) and forested areas (fig. 5 and table 3). During the early half of the $20^{\text {th }}$ century, surface water from the Rio Grande was the source of life for agrarian communities and irrigated agriculture was centered within the Inner Valley due to easy access to water. However, existing irrigation systems for agriculture were insufficient and primitive. Consequently, the Middle Rio Grande Conservancy District (MRGCD) was created during the 1920s to improve the irrigation system, drain and reclaim saturated land, and make the Inner Valley a more profitable place to farm (Hansen, 1997). The irrigation system improvement by the MRGCD is exhibited by the fact that agricultural land occupied 5.5 percent of the landscape by 1935 (table 3) and was the primary land use along the Rio Grande. Albuquerque was still the dominant urbanized area, however, communities such as Bernalillo, Placitas, and Isleta are evident as satellite urban centers in figure 5 .

Between the 1930s and 1950s, the urban land area nearly tripled to approximately 24,000 acres (table 3 ). The increase in the region's urban footprint was primarily the result of agricultural land and rangeland being converted to urban land use. Conversion of a land parcel to another land use is dependent on an area's accessibility and proximity to the transportation infrastructure. Expansion of the transportation network by approximately 30 percent resulted in urbanization extending linearly in all directions outward from Albuquerque's urban core (fig. 5). The decline in water acreage and the corresponding increase in barren land (table 3 ) are most likely a result of the 1950s drought experienced by the region.

The distance and speed that humans can commute between their residence and workplace is one of the factors influencing dispersion of land use development on the landscape. Transportation infrastructure improvements, such as Interstate 40, resulted in leapfrog development of urbanized areas during the 1970s occurring primarily east of the Sandia Mountains and Cibola National Forest (fig. 5). The spontaneous and diffusive growth of bedroom communities east of Cibola National Forest, such as Sandia Park and Cedar Crest, resulted in the first occurrence of forested land actually declining on the Middle Rio Grande landscape (table 3). Even though the agricultural land acreage decreased from the 1950s to the 1970s (table 3), there is a definite growth in agriculture north and south of Moriarty (fig. 5). Torrance County in which the community of Moriarty is located, historically had agricultural land devoted to pinto bean production until the drought of the 1950s affected the agricultural land-use management practice of dry crop land farming (Middle Rio Grande Council of Governments, 1997a). Declaration of the Estancia Underground Water Basin by the New Mexico State Engineer in 1950 (Shoemaker, 1996) led to the development of Estancia Basin ground-water resources in Torrance County and circular land-use patterns evident on the 1970s landscape surrounding Moriarty demonstrate the use of center-pivot technology for production of irrigated agricultural crops (fig. 5). The increase in water acreage (table 3) between the 1950s and 1970s is due to dredging and channelizing the Rio Grande by the U.S. Bureau of Reclamation and Army Corp of Engineers to control 
Table 3. Temporal land-use and land-cover categorical composition for the Albuquerque area from the 1930s to the 1990s.

\begin{tabular}{|c|r|r|r|r|r|r|r|r|}
\hline \multirow{2}{*}{$\begin{array}{c}\text { Anderson } \\
\text { Level I }\end{array}$} & \multicolumn{2}{|c|}{1935} & \multicolumn{2}{|c|}{1951} & \multicolumn{2}{c|}{1973} & \multicolumn{2}{c|}{1991} \\
\cline { 2 - 9 } & \multicolumn{1}{|c|}{ Acres } & Percent & \multicolumn{1}{|c|}{ Acres } & Percent & \multicolumn{1}{c|}{ Acres } & Percent & \multicolumn{1}{l|}{ Acres } & Percent \\
\hline Urban & $8,681.6$ & 0.8 & $23,722.8$ & 2.2 & $61,957.8$ & 5.7 & $122,885.1$ & 11.2 \\
\hline Agriculture & $60,105.5$ & 5.5 & $57,481.1$ & 5.3 & $53,113.5$ & 4.9 & $40,033.1$ & 3.7 \\
\hline Rangeland & $833,060.8$ & 76.2 & $820,436.4$ & 75.1 & $784,938.1$ & 71.8 & $736,384.6$ & 67.4 \\
\hline Forest & $177,066.0$ & 16.2 & $177,096.1$ & 16.2 & $173,846.9$ & 15.9 & $172,149.4$ & 15.7 \\
\hline Water & $2,871.1$ & 0.3 & $2,441.4$ & 0.2 & $4,721.9$ & 0.4 & $4,112.1$ & 0.4 \\
\hline Wetlands & $2,761.2$ & 0.3 & $3,189.1$ & 0.3 & $2,967.8$ & 0.3 & $3,267.6$ & 0.3 \\
\hline Barren & $8,263.5$ & 0.7 & $8,444.1$ & 0.7 & $11,266.9$ & 1.0 & $13,980.8$ & 1.3 \\
\hline
\end{tabular}

the river's flow and reduce Albuquerque's susceptibility to flash flooding.

By the 1990s, Albuquerque's urban footprint approximately doubled in comparison to the 1970s landscape (table 3). The continued decline in agricultural land (table 3) illustrates the shift from an extractive economy to a service-ori- ented economy. The increase in barren land from the 1970s to the 1990 s (table 3 ) is most likely not a result of climatic change, but rather land that is in a state of transition. The barren land may be either "brownfields" awaiting redevelopment or land where the natural land cover has been removed in preparation for new urban development. Emergence of Rio
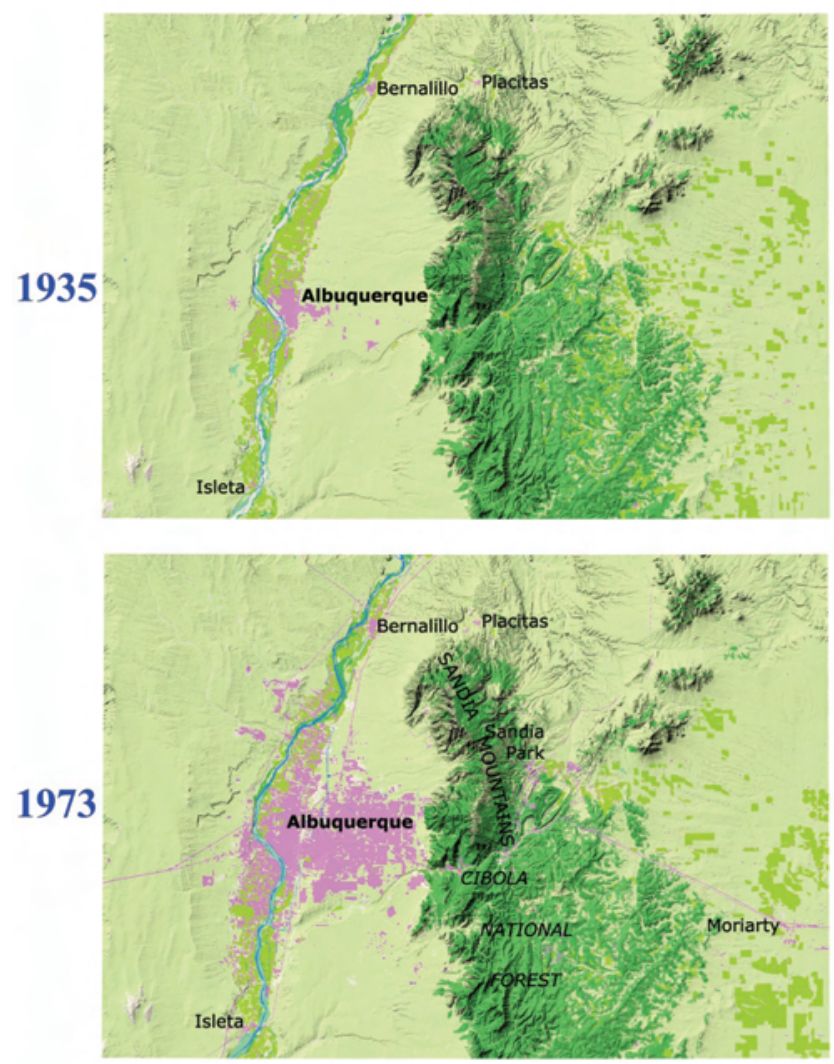
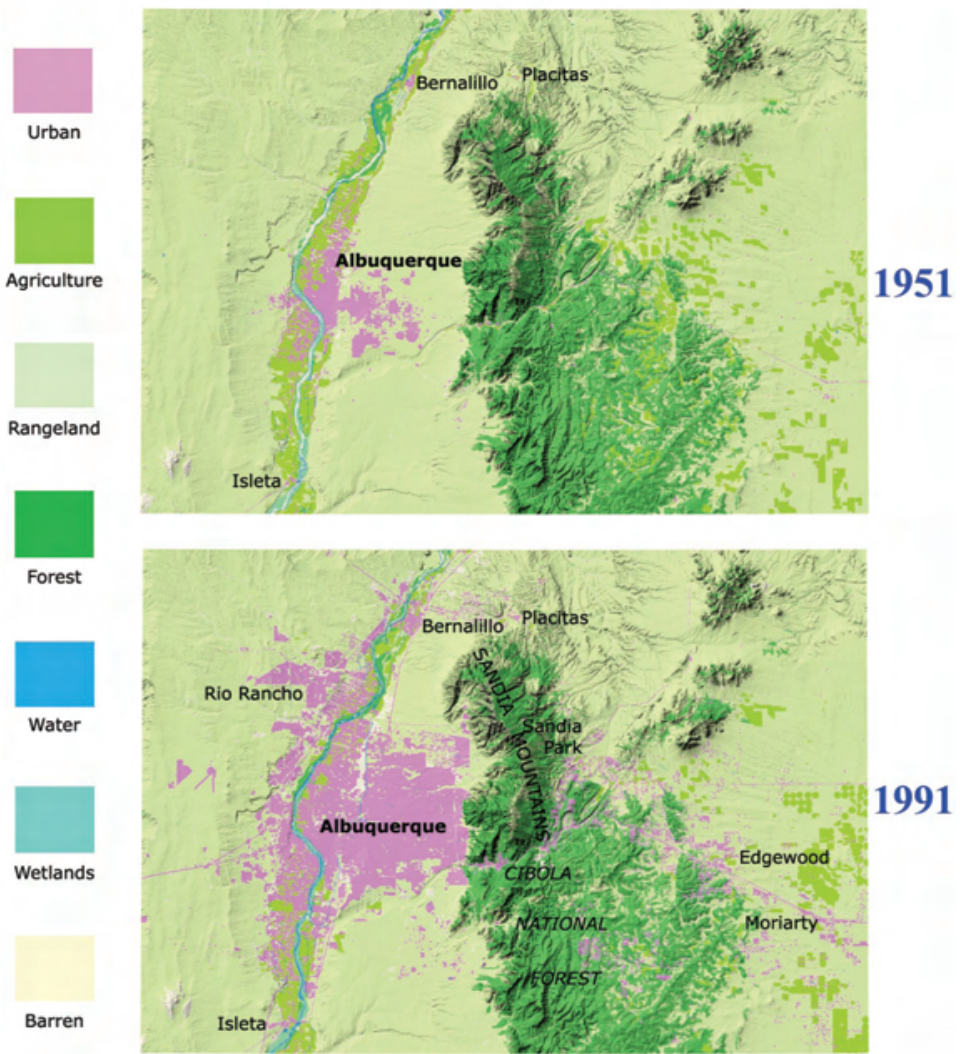

Figure 5. Temporal (1935 to 1991) 1:24,000-scale land-use and land-cover (LULC) data generalized to Anderson Level I LULC categories for the Albuquerque area. 
Rancho and the associated Intel microchip processing plant west of the Rio Grande began the westward shift of Albuquerque's population and urban growth. Transition of Rio Rancho from a smaller local community to a larger regional city is exhibited by the creation of the Double Eagle airport west of the Rio Grande (fig. 5). From 1980 to 1990, continued urban land transformations around the communities of Edgewood in southern Santa Fe County and Moriarty in Torrance County (fig. 5) contributed to Torrance County becoming the fastest-growing nonmetropolitan county in New Mexico during the 1990s. Since the 1970s, Torrance County has experienced inmigration population growth from residents who work in the Albuquerque urban area but desire the amenities of living in a rural landscape (Middle Rio Grande Council of Governments, 1997b). Communities such as Moriarty and Edgewood on Albuquerque's eastern urban fringe began to grow between the 1970s and 1990s with low-density land-use development and became part of the metropolitan area's commuting region. Because Moriarty and Edgewood are approximately 35 miles from Albuquerque on Interstate 40, the fact that 35 percent of Torrance County residents who did not work at home in 2000 had commute times between 45 to 90 minutes demonstrates the employment opportunities offered by the Albuquerque metropolitan area (New Mexico Economic Development Department, 2004).

\section{Urban Growth Rates}

Spatial statistical analysis of Albuquerque's temporal urban growth and human footprint can improve the understanding of how the land surface has transitioned through time. During the process of modeling Albuquerque's landscape change, an extract of the urbanized area from the temporal land use and land cover data is used for calibrating the University of California-Santa Barbara (UCSB) SLEUTH (Slope, Land use, Exclusions, Urban, Transportation, and Hillshade) land-use model. During model calibration, Albuquerque urban form metrics, such as number of urbanized pixels, number of urban edges, and number of clusters, are statistically calculated for each temporal period.

Figure $6 \mathrm{~A}$ represents the number of urbanized pixels, or portion of the landscape converted to urban land use. Each pixel equates to a 240 -meter cellsize resolution, or 57,600 square meters ( 14.2 acres) in area. Figure $6 \mathrm{~A}$ illustrates that the period 1973 through 1991 represented the greatest total transition to urban land (2,470 pixels), whereas the period 1935 to 1951 represented the highest percent urban growth rate (table 5) due to Albuquerque's post-WW II economic boom. From 1951 to 1973 , the conversion rate of 200.8 pixels per year to an urban use was a direct result of the densification and extension of the road network.

The interface between urban land (developed) and wildland (undeveloped land) is what is classified as "edges" or the urban fringe. For example, any pixel classified as urban land that shares at least one side with land that is undevel- oped is counted as an edge. The increasing number of pixels from 1935 to 1991 with an urban land/wildland edge is an indicator of Albuquerque's dispersed land-use development on the Middle Rio Grande landscape. Examination of Figure $6 B$ shows that from 1951 to 1973 , the greatest total number of pixels with an urban land and wildland interface occurred. This urban fringe metric correlates with the implementation of the 1956 Federal Interstate Highway Act and the construction of I-25 and I-40 during the 1951 to 1973 timeframe.

Clusters are the number of pixels classified as developed land that are spatially contiguous. For example, a single isolated urban pixel surrounded by undeveloped land would count as one cluster. Quantifying Albuquerque's landscape change using a cluster metric provides insight regarding the type of urban growth occurring on the landscape and the phase of land-use development. Initially, a single pixel can be a cluster or urban area driving landscape change. The increase in the number of clusters from 1935 to 1973 is an example of spontaneous and diffusive growth as urbanization centers expanded across the regional landscape. An increase in the number of clusters indicates new development or the transition of undeveloped land cover to an urban land use. The greatest total increase in the number of clusters (66) and the highest annual rate for cluster development during the period from 1951 to 1973 (fig. 6C), illustrate the effects of road-influenced growth and the spread of urban centers on the landscape. Since 1973, the total number, percent growth, and annual rate of urbanized area clusters have been declining. The downward trend indicates that Albuquerque's landscape is maturing as satellite urban centers grow together into urban cores along transportation corridors as the result of in-fill development.

\section{Human Migration Trends}

Analysis of Albuquerque's human migration trends allows researchers to investigate the social, economic, and political causes influencing temporal changes in the direction, distance, and migration rates in population and urbanized area centers of mass. Comparative analysis between the Albuquerque MSA historical population center and Albuquerque's temporal urbanized area center migratory paths was conducted as a technique to study the different patterns of movement between these two centers as a quantitative metric of population density loss (distribution) and urban sprawl (landscape change). According to a Brookings Institution Center on Urban and Metropolitan Policy study, Albuquerque was ranked as having the fourth largest population density loss between 1982 and 1997 for MSA's in the Census Bureau's Western Region (Fulton, 2001).

To coincide as closely as possible to the historical vintages and time periods that were used for mapping Albuquerque's urban lands, temporal population centers for the Albuquerque MSA were calculated for the 1930, 1950, 1970, and 1990 decades. A population center represents the point at which an imaginary, weightless, rigid, and flat land surface 
would balance if each individual person had an equal weight. The historical population centers for the Albuquerque MSA were calculated as the spatial mean of the four counties (Bernalillo, Sandoval, Torrance, and Valencia) comprising the MSA weighted by each county's population for the selected decades. An urban center is defined as the geographic center of all urbanized areas at which point the urban or developed land surface would balance if it were a plane with uniform weights for each urban pixel. During the process of calibrating the SLEUTH land use model for simulating Albuquerque's future

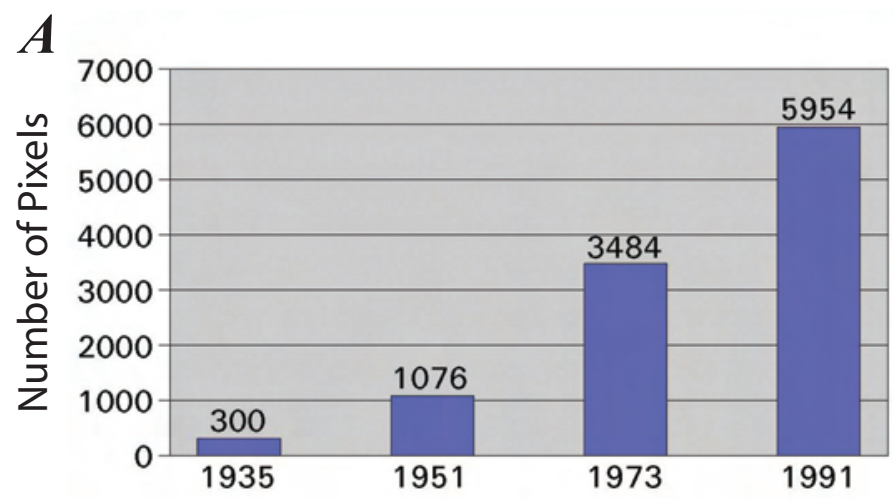

B

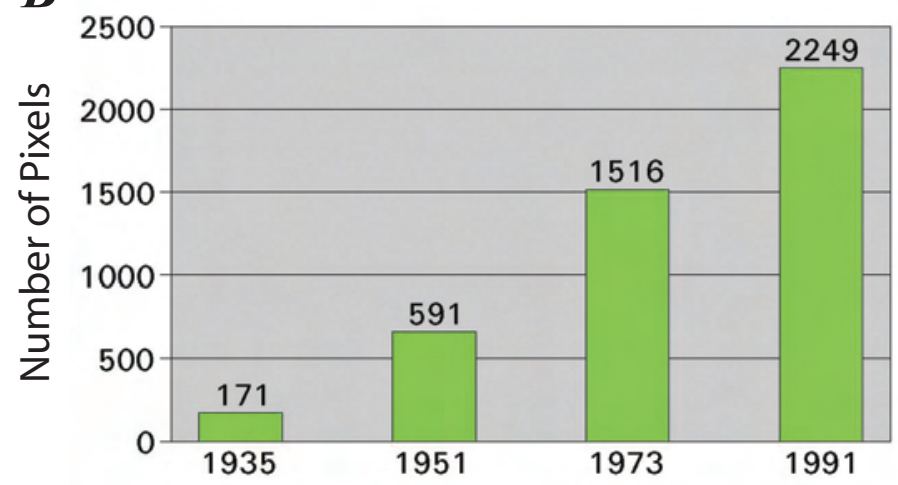

C

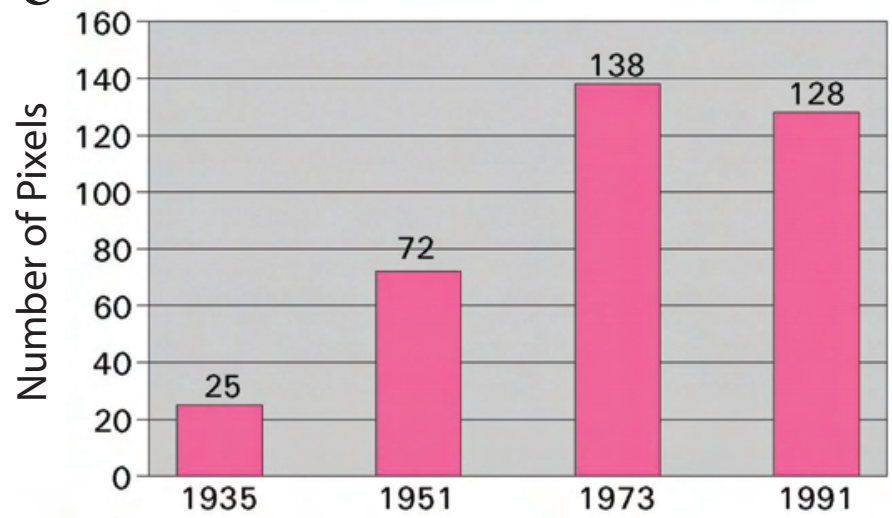

Figure 6. Urban area $(A)$, urban land/wildland edges $(B)$, and urban clusters $(C)$ metrics monitoring Albuquerque's urban landscape change from 1935 to 1991. Each pixel equates to a 240-meter cell size resolution or 57,600 square meters ( 14.2 acres). growth, an urban area center was calculated for each historical thematic urban land input. For each historical population and urban area center, migration distance, direction and annual migration rate metrics were derived (table 4).

Analysis of table 4 and annual rates of urban change and population change from table 2 illustrate that the population center shows greater sensitivity to changes in growth rates than does the urban center. Although the annual rate of urban change was consistently greater through time than the annual rate of population change (table 2), the annual MSA population-center migration rate changed more dramatically than did the urban-area-center migration rate. For instance, the MSA population center migration rate in table 4 decreased by 49 percent from 1950 to 1970 and increased 212 percent from 1970 to 1990 , whereas in comparison the urban area center migration rate respectively increased 18 percent and decreased 23 percent for these same time periods. From 1970 to 1990, the Albuquerque MSA population center migrated the farthest distance and at the fastest rate and coincides with the Albuquerque MSA experiencing the greatest change in population (table 2) during this same timeframe. In comparison, the urban area center migrated the greatest distance and at the highest annual rate from 1951 to 1973 and can be predominantly attributed to dispersed land-use development and road-influenced urban growth during this period as a result of the completion of Interstate 25 and Interstate 40 through the region.

Visualization of the population and urban area centers through time (fig. 7) is a technique that can be used to understand the relation between the temporal migratory path and historical land-use and demographic trends. From 1935 to 1973, the urban area center migrated in an eastern or southeastern direction as a result of the majority of Albuquerque's land-use development occurring primarily on the East Mesa (Mid-Heights), as well as around Kirtland Air Force Base and Sandia National Laboratories. Since the 1970s, the migration direction for Albuquerque's urban area and population cen-

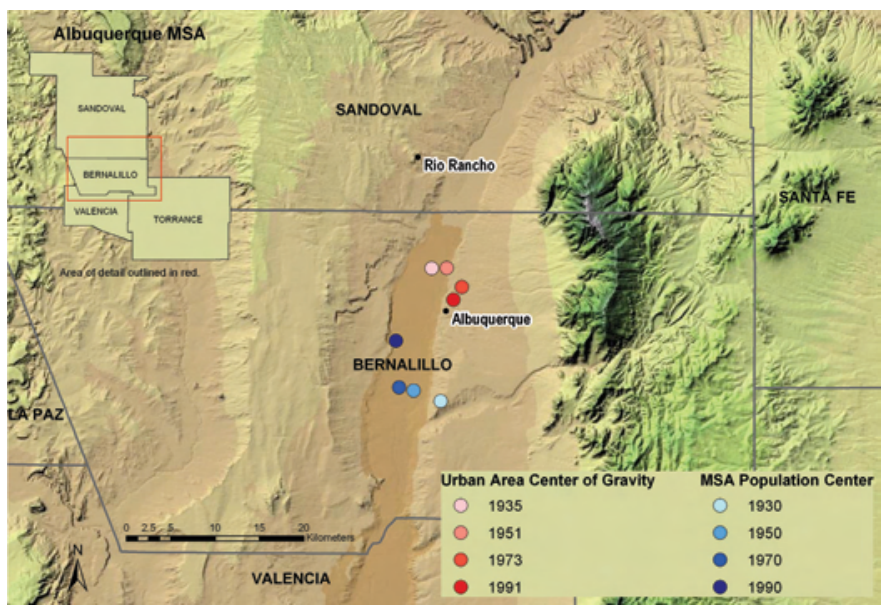

Figure 7. Visualization of Albuquerque Metropolitan Statistical Area (MSA) population center and urban area center of gravity migratory paths from the 1930s to the 1990s. 
Table 4. Albuquerque temporal urban-area mean center of gravity and Metropolitan Statistical Area (MSA) population-center migration analysis metrics.

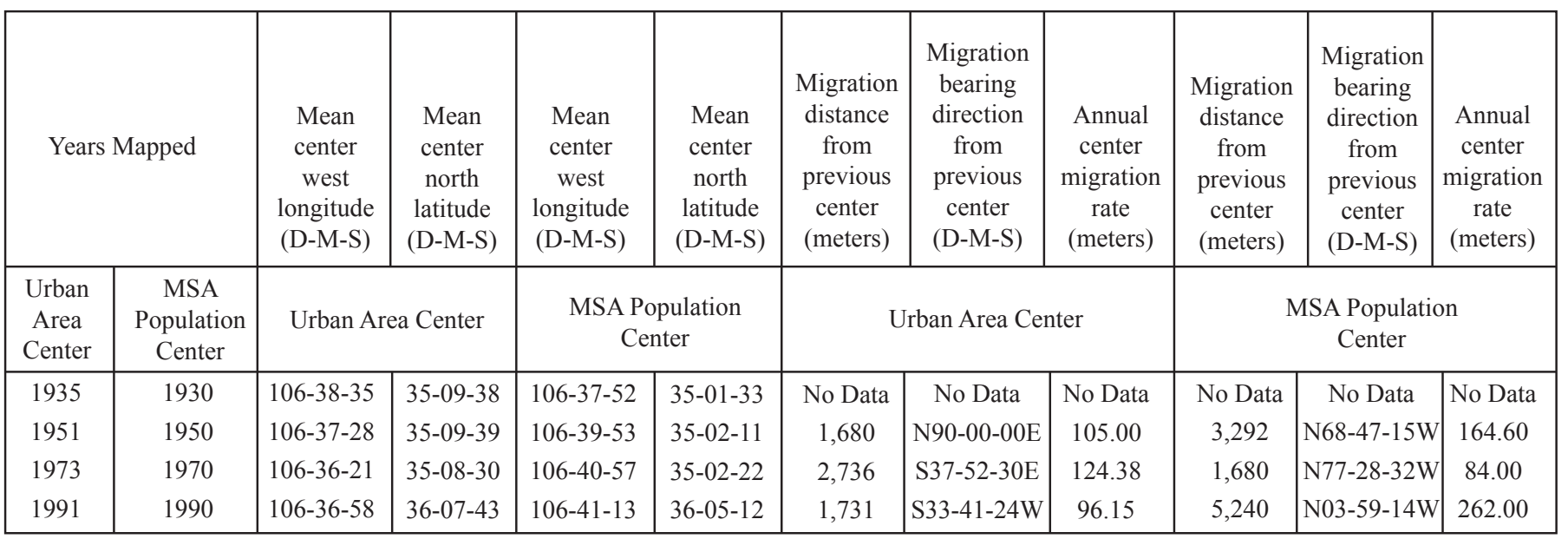

ters have been pulled westward across the Rio Grande due to lower land prices and 60 percent of the Albuquerque MSA's population growth between 1980 and 1995 occurring west of the Rio Grande (Middle Rio Grande Council of Governments, 1997a). Figure 7 illustrates that from 1970 to 1990 the population center for the Albuquerque MSA has been migrating in a northerly direction due to population growth occurring in Sandoval County (Rio Rancho). The significant northern movement of the Albuquerque MSA population center during this period is influenced by Rio Rancho's population growing to account for approximately 5 percent of the MSA total population by 1990, whereas the City of Albuquerque's population contribution to the MSA has remained constant at approximately 65 percent since the 1970s (table 2). Analysis of the county-level population data for the Albuquerque MSA from 1970 to 1990 indicates that Valencia County has been experiencing a 3 percent per year population loss since 1980, which would have created an additional northern push to the MSA population center migration.

\section{Landscape-Change Modeling}

The goal of landscape change modeling is to provide accurate scientific information such as land-use model projections to allow the formation of sound policies for guiding future urban growth. Because the Albuquerque area is surrounded by numerous boundaries with Federal and Pueblo lands, and because the availability of water may ultimately be limited, decisions on urban growth only can be improved by a firm foundation of scientific knowledge. Temporal urban retrospective and LULC databases not only provide the scientific foundation for analyzing how urbanization has affected the landscape but also are used to calibrate and simulate landscape change by modeling future land-use development patterns (USGS, 1999).
Albuquerque's future landscape change was simulated using the SLEUTH land-use model (USGS, 2001). The SLEUTH model incorporates four types of urban growthspontaneous, diffusive, organic, and road-influenced, which are regulated by growth-control coefficients. The growth rate of an urban area is the summation of all four types of growth for each model year. If the growth rate is unusually high or low, the growth-control coefficients are altered by the model's self-modification growth constants, that is boom and bust multipliers. Self modification of the SLEUTH model's growthcontrol coefficients is essential to simulate the typical S-curve growth rate of urban expansion (USGS, 2001). Generating a landscape prediction using the SLEUTH model does not take into consideration factors such as socioeconomic projections for population, employment, or housing. Therefore, the SLEUTH model only can predict the probability of an area becoming urbanized based on land-use trends (for example, existing urban areas) and landscape characteristics (for example, transportation infrastructure, slope, and areas excluded from land-use development).

\section{Model Calibration}

To predict future urbanization patterns in the Albuquerque area, the SLEUTH model was calibrated using historical urbanized areas, a historical transportation network, lands that restricted urban development and land-surface slope. The urban land-use footprint of 1935 was used as the urbanization seed for model calibration. An initial set of model parameters (growth control coefficients) were used to calibrate the behavior of the model from 1935 through 1991. Collected observations of Albuquerque's urbanized areas from 1951, 1973, and 1991 were used as control years for self modification of the model's calibration parameters depending on whether the region's historical annual urban growth rate for 
Table 5. Albuquerque's urban growth, 1935-2050; figures for 2050 are projections.

\begin{tabular}{|c|c|c|c|}
\hline Year & $\begin{array}{c}\text { Urban area } \\
\text { (acres) }\end{array}$ & $\begin{array}{c}\text { Percent growth, } \\
\text { cumulative from } \\
1935\end{array}$ & $\begin{array}{c}\text { Percent growth } \\
\text { from } \\
\text { previous period }\end{array}$ \\
\hline 1935 & $4,372.2$ & No data & No data \\
\hline 1951 & $15,397.9$ & 252 & 252 \\
\hline 1973 & $49,746.1$ & 1,038 & 223 \\
\hline 1991 & $84,890.5$ & 1,842 & 71 \\
\hline 2050 & $124,608.5$ & 2,750 & 47 \\
\hline
\end{tabular}

each model year was classified as no growth, slow growth, or normal growth. In addition, urbanization "boom or bust" multipliers were applied during Monte Carlo simulations to adjust the SLEUTH model calibration parameters if the region was experiencing rapid urban growth or urban decay. During the model calibration, statistical metrics were calculated to obtain the best fit solution of the growth control coefficients between Albuquerque's observed and predicted urbanization patterns.

\section{Model Prediction}

Once calibrated, the SLEUTH land-use model can be used stochastically to forecast land-use development (Clarke, 2002). The contemporary thematic inputs for urban lands, transportation, and lands excluded from development can be modified to take into consideration future planned urban developments, transportation infrastructure improvements, and open-space acquisitions to simulate land-use development scenarios for planning purposes. However, one limitation of the SLEUTH model's predictive capability for simulating landscape change is that the model does not incorporate future events that are entirely random drivers facilitating urban growth.

For the Albuquerque area, SLEUTH model simulations were run to predict the urbanized area in 2050 (fig. 8). This 50 -year projection was chosen to correspond with the FOCUS 2050 Regional Land Use Plan (Middle Rio Grande Council of Governments, 2000). Using a "best-fit" model calibration composite score, a combination of model parameters was used to simulate land-use patterns covering the timeframe between 1991 and 2050. Figure 8 illustrates the land surface for the Albuquerque area that has a 100 percent probability of becoming urbanized by the year 2050. Planned urban developments, such as Mesa del Sol on the Southeast Mesa, were not included as urbanized areas for the landscape change modeling, because the contemporary landscape (1991) did not have any existing population base for the planned community. Because the land on which Mesa del Sol will be developed was not excluded from the urban growth process, urbanization actually did occur in that area, however, development did not occur for each model run (100-percent probability) during SLEUTH execution. Subsequently, only those lands that became urbanized for every SLEUTH model run (100-percent probability) were retained as the 2050 land-use prediction or human footprint for the Albuquerque metropolitan area.

\section{Conclusions}

The long-term land-use trend for the Middle Rio Grande landscape is that Albuquerque's developed land or human environment is replacing the natural environment. Decline and displacement of agricultural land has increased concerns for preserving agrarian land-management practices and lifestyles for future generations. Continued land-use development and expansion of urban land has resulted in the decrease of land conducive to ground-water recharge. The conversion of agricultural, range, and forested lands into urbanized areas, which are predominantly impermeable, is resulting in more efficient drainage systems that increase urban runoff, decrease the amount of water available for replenishing the aquifer on which Albuquerque depends for its municipal water supply, and increase the area's susceptibility to flooding.

Even though Albuquerque's historical urban growth has occurred on both vacant land within developed areas (in-fill development) and on the fringe of previously developed areas (new development), the long-term land-use trend was greater dispersed development leading to an increase in the human footprint or size of Albuquerque's urbanized area (table 5). Assuming that redevelopment did not contribute to the total urban area, from 1940 to 1990 the amount of urban land in the Albuquerque area consumed per person approximately doubled (fig. 9).

Albuquerque's economy ranked $22^{\text {nd }}$ highest of 316 MSAs nationwide in 1999 (Middle Rio Grande Council of Governments, 1999), and population projections from approximately 713,000 in 2000 to 1,536,000 in 2050 (Middle Rio Grande Council of Governments, 2000) are indicators of economic and population growth driving potential $21^{\text {st }}$ century landscape change. The existence of Rio Rancho's Intel microchip manufacturing facility and continued expansion of tourism 


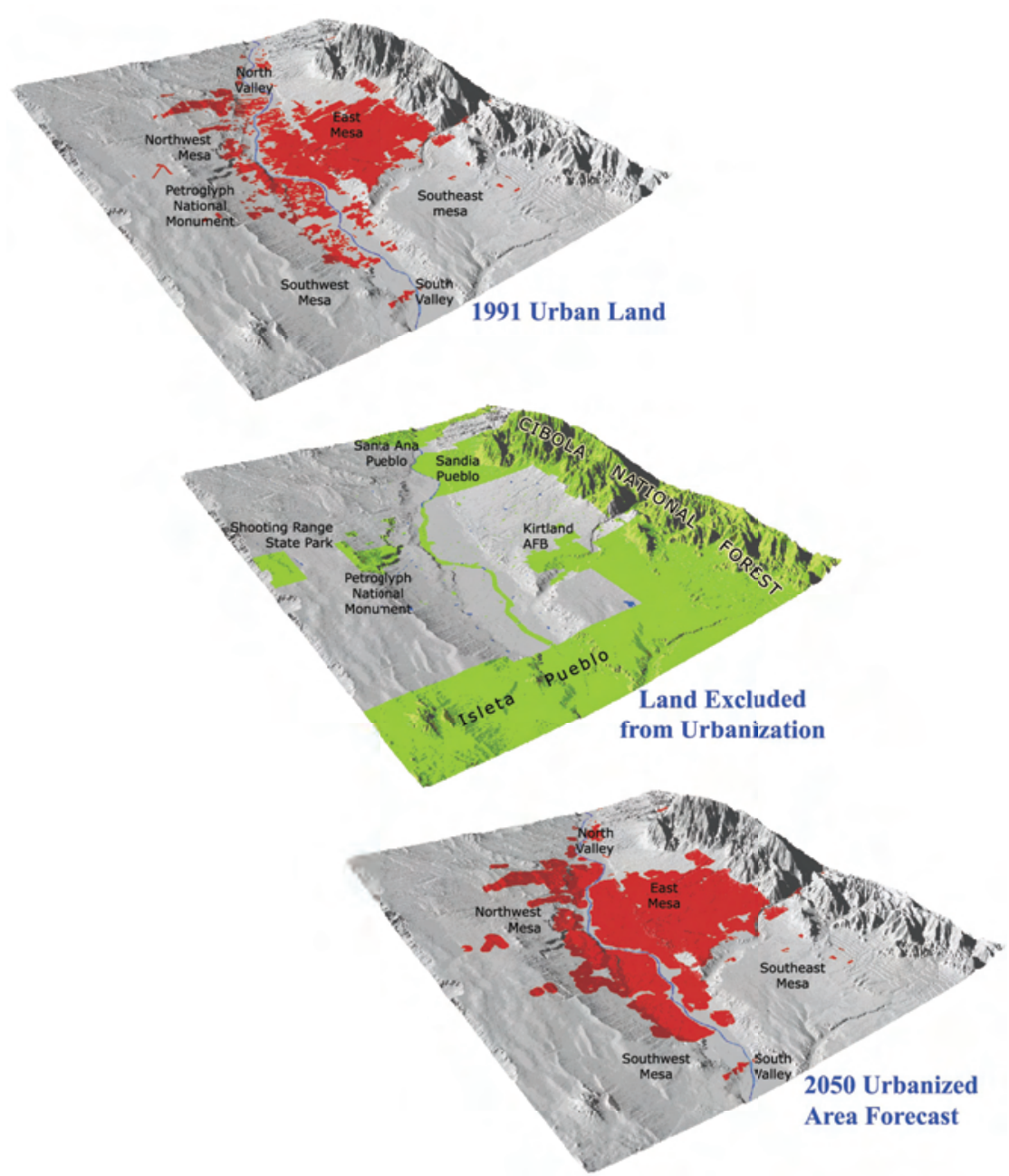

Figure 8. Contemporary urban land and land exempt from urbanization (as of about 1991) and simulated 2050 urbanized area for the Albuquerque vicinity. The 2050 urban land shown in red was predicted using the SLEUTH land-use model. Perspective view is to the northeast.

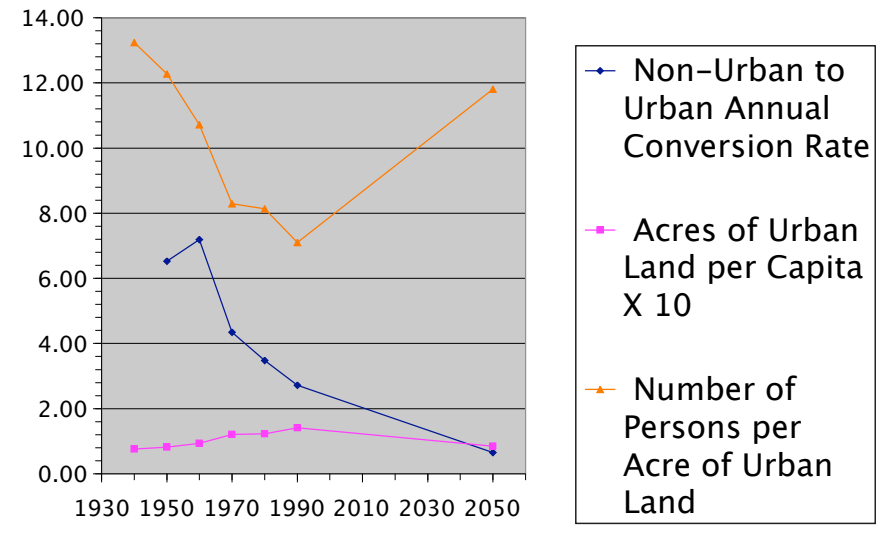

Figure 9. Metrics analyzing Albuquerque's landscape change from 1940 to 2050 - annual rate (percent) of non-urban to urban land conversion, acres of urban land per capita, and number of persons per acre of urban land. Figures for 2050 are projections. 
through Native American gaming casinos, golf courses, and resort hotels, as well as the International Balloon Fiesta, may continue to stimulate Albuquerque's future urban growth. If land-use development in the Albuquerque area continues until 2050, the SLEUTH land-use model forecasts that approximately 125,000 acres of the Middle Rio Grande landscape will be urbanized (table 5), with a population density of 11.8 persons per urban acre (fig. 9). The land-use trend from the contemporary (1991) to the simulated (2050) landscape, as illustrated by the downward trend in "acres of urban land per capita" (fig. 9), indicates a major shift in historical land-use development patterns as the Albuquerque landscape matures and evolves into a more compact urban form through infill development occurring on the East Mesa and existing urban centers on the Northwest and Southwest Mesas growing together into a contiguous urban core.

\section{Note on Metrics}

Metrics quantifying historical urban landscape change for figures 3, 6 and 9 and tables 1,2, 4 and 5 were calculated for the sixteen $24 \mathrm{~K}$ quadrangle area centered on Albuquerque's urban core. This is the same study area that was used for the predictive landscape change modeling. Table 3 temporal landuse and land-cover categorical composition was computed for the twenty-eight $24 \mathrm{~K}$ quadrangle study area.

\section{Acknowledgments}

The Middle Rio Grande Council of Governments of New Mexico contributed FOCUS 2050 Regional Plan information that fostered Albuquerque landscape-change research. In addition, this publication would not have been possible without the USGS research assistance provided by Kathy Casey, Mark Feller, Maria McCormick, Steve Methven, Ben Sherrouse, Mike Stier, and Stewart Wright.

\section{References}

Albuquerque Economic Development Team, 2004, Albuquerque Metropolitan Statistical Area location profile 2004: Albuquerque, New Mexico, Albuquerque Economic Development Incorporated [http://www.abq.org/pdfs/ 2004WebBLP.pdf; accessed September 9, 2004].

Albuquerque Journal, 1999, New Mexico at the Millennium, special section to the Sunday, September 19, 1999 edition: Albuquerque, New Mexico, Albuquerque Journal, 84 p.

Bartolino, J.R., Cole, J.C., and Hester, D.J., 2002, Groundwater resources of the Middle Rio Grande Basin: U.S.

Geological Survey Fact Sheet FS-088-02, 6 p.

Clarke, Keith C., 2002, Land-use modeling using SLEUTH, Proceedings of the Advanced Training Workshop on Land Use and Land Cover Change Study, Taiwan, December
9-20, 2002: National Central University/National Taiwan University/START, p. 525-573.

Collins, Mary Kay, and Gritton, Paul, 1996, Albuquerque's environmental story, Section II-Albuquerque's built environment, Part 3-A sense of place (A Community Called Kirtland): Albuquerque, New Mexico, City of Albuquerque [http://www.cabq.gov/aes/s2krt.html; accessed September 1, 2004].

Fitzpatrick, George, and Caplin, Harvey, 1976, Albuquerque100 years in pictures: Albuquerque, New Mexico, Modern Press.

Fulton, William, Pendall, Rolf, Nguyen, Mai, and Harrison, Alicia, 2001, Who sprawls most? How growth patterns differ across the U.S.: Washington D.C., The Brookings Institution Center on Urban and Metropolitan Policy, 23 p.

Gerckens, Laurence, 1998, Ten events that shaped the 20th century American city: Burlington, Vermont, Planning Commissioners Journal, Issue No. 30, Spring 1998, p. 1220.

Hansen, Steve, and Gorbach, Chris, 1997, Middle Rio Grande Water Assessment Final Report: Albuquerque, New Mexico, U.S. Bureau of Reclamation, Albuquerque Area Office.

Johnson, Byron, and Dauner, Robert, 1981, Early Albuquerque - a photographic history-1870-1918: Albuquerque, New Mexico, The Albuquerque Journal and The Albuquerque Museum.

Kernodle, J.M., McAda, D.P., and Thorn, C.R., 1995, Simulation of ground-water flow in the Albuquerque Basin, central New Mexico, 1901-1994, with projections to 2020: U.S. Geological Survey Water-Resources Investigations Report 94-4251, figure 41, p 75.

Middle Rio Grande Council of Governments, 1997a, Draft FOCUS 2050 snapshot — existing conditions, significant trends, and projections in the Middle Rio Grande Region: Albuquerque, New Mexico, Middle Rio Grande Council of Governments.

Middle Rio Grande Council of Governments, 1997b, 2020 Socioeconomic forecasts for data analysis subzones in state planning and development district 3: Albuquerque, New Mexico, Middle Rio Grande Council of Governments, Transportation Report (TR-125), 69 p.

Middle Rio Grande Council of Governments, 1999, Draft FOCUS 2050 regional plan: Albuquerque, New Mexico, Middle Rio Grande Council of Governments.

Middle Rio Grande Council of Governments, 2000, FOCUS 2050 regional plan: Albuquerque, New Mexico, Middle Rio Grande Council of Governments, State Planning Report (SPR-278), $61 \mathrm{p}$.

New Mexico Economic Development Department, 2004, New Mexico Communities-Moriarty: Santa Fe, New Mexico, New Mexico Economic Development Department [http:// www.edd.state.nm.us/RESEARCH/PRoFILES/cities.html; accessed September 15, 2004].

Robbins, Cathy, 1999, Monumental chaos: Paonia, Colorado, High Country News, vol. 31, no. 20.

Rosner, Hy, and Rosner, Joan, 1996a, Albuquerque's 
environmental story, Section I-Albuquerque's natural environment, Ecological profiles of Albuquerque's open space (Mountain Uplands): Albuquerque, New Mexico, City of Albuquerque [http://www.cabq.gov/aes/s1mntup. html; accessed October 4, 2004].

Rosner, Hy, and Rosner, Joan, 1996b, Albuquerque's environmental story, Section I-Albuquerque's natural environment, Fitting the pieces together: Albuquerque, New Mexico, City of Albuquerque [http://www.cabq.gov/ aes/s1pieces.html; accessed October 4, 2004].

Rosner, Hy, and Rosner, Joan, 1996c, Albuquerque's environmental story, Section IV-The home, school, and neighborhood as mini-environments, Part I-The natural environment (A Mountain School): Albuquerque, New Mexico, City of Albuquerque [http://www.cabq.gov/aes/ s4p1mtn.html; accessed October 5, 2004].

Rosner, Hy, and Rosner, Joan, 1996d, Albuquerque's environmental story, Section IV-The home, school, and neighborhood as mini-environments, Part I-The natural environment (A West Mesa School): Albuquerque, New Mexico, City of Albuquerque [http://www.cabq.gov/aes/ s4p1wm.html; accessed October 4, 2004].

Ryan, Michael J., and Ryan, Genie, 1996, Albuquerque's environmental story, Section II-Albuquerque's built environment, Part 3-A sense of place (Rio Rancho-City of Vision): Albuquerque, New Mexico, City of Albuquerque [http://www.cabq.gov/aes/s2rr.html; accessed July 26, 2004].

Shoemaker, John, and Associates, 1996, Regional water plan estancia underground water basin: Albuquerque, New Mexico, John Shoemaker and Associates, Inc.

Starner, Ron, 2001, Intel outside - competition, history lesson force chip maker to build fab plants at fast pace:
Site Selection Online Magazine, May 2001 [http://www. siteselection.com/issues/2001/may/p300/; accessed August 31, 2004].

Stier, M.P., 1998, Albuquerque - a historical perspective, in Slate, J.L., ed., U.S. Geological Survey Middle Rio Grande Basin Study - Proceedings of the Second Annual Workshop, Albuquerque, New Mexico, February 10-11, 1998: U.S. Geological Survey Open-File Report 98-337, p. 29-30.

Stier, M.P., 1999, Temporal land use and land cover mapping, in Bartolino, J.R., ed., U.S. Geological Survey Middle Rio Grande Basin Study_-Proceedings of the Third Annual Workshop, Albuquerque, New Mexico, February 24-25, 1999: U.S. Geological Survey Open-File Report 99-203, p. 18-21.

Taylor, Phyllis, 1996, Albuquerque's environmental story, Section II-Albuquerque's built environment, Part 3-A sense of place (Mid-Heights): Albuquerque, New Mexico, City of Albuquerque [http://www.cabq.gov/aes/s2midht.html; accessed July 26, 2004].

U.S. Bureau of the Census Population Division, 1995, County population census counts 1900-1990: Washington, D.C., U.S. Bureau of the Census [http://www.census.gov/ population/cencounts/nm190090.txt; accessed August 13, 2003].

U.S. Geological Survey, 1999, Analyzing land use change in urban environments: U.S. Geological Survey, Fact Sheet FS-188-99, 4 p.

U.S. Geological Survey, University of California at Santa Barbara, and Environmental Protection Agency, 2001, Project Gigalopolis - urban and land cover modeling: Santa Barbara, California, University of California at Santa Barbara [http://www.ncgia.ucsb.edu/projects/gig; accessed August 25, 2003]. 


\title{
Change to Urban, Agricultural, and Forested Land in Central and Southern Maryland From 1850-1990
}

\author{
By Janis L. Taylor ${ }^{1}$ and William Acevedo ${ }^{2}$
}

\section{Introduction}

European colonization of North America began in the seventeenth century and many of the landscape changes that have occurred since that time are the result of human activities such as agricultural production and urbanization. On the west coast of the Chesapeake Bay, landscape changes in central and southern Maryland have been dramatic over the past 300 years due to a long history of intensive agriculture followed by high population-growth rates. Today, this area includes parts of the Baltimore-Towson and WashingtonArlington-Alexandria metropolitan statistical areas - two of the Nation's largest metropolitan statistical areas. Over the years, as populations increased, human-induced changes to the landscape in this region have resulted in serious consequences to natural resources such as waterways and native species (Chesapeake Bay Program 2002). There are currently numerous efforts underway to restore the bay's natural resources. Most of the restoration strategies are developed from a scientific understanding of both the landscape change and the associated environmental consequences of human activities.

Landscape change is the result of both natural and human-induced alterations to land cover. Natural forces that shape the landscape include climate, hydrology, and geology. Landslides, hurricanes, and flooding are the result of natural forces. Human-induced forces that shape the landscape include building towns and cities, planting and harvesting crops, and logging forests. As human populations grow, human activities continue to increase in frequency and the rate and extent of land-cover change also increases. Negative consequences of land-cover change include erosion, declining water quality and quantity, species endangerment, and loss of native vegetation.

Studying land-cover and associated land-use change is viewed as a means to understand and possibly reduce the negative impacts of human-induced change. Studying and analyzing the links between the physical changes to the landscape and the social influences associated with those changes

\footnotetext{
${ }^{1}$ SAIC TSSC, work performed under U.S. Geological Survey contract 03CRN001 at U.S. Geological Survey, Center for Earth Resources Observation and Science, Sioux Falls, SD 57198.

${ }^{2}$ U.S. Geological Survey, Center for Earth Observations and Science, Sioux Falls, SD 57198.
}

can help land managers to understand and plan for future land-use change.

The goal of this paper is to demonstrate how urban land-cover changes between 1850 and 1992 were associated with changes in agricultural and forested land in central and southern Maryland. This is achieved through a spatial and temporal reconstruction of three land-cover types (urban, agricultural, and forested land). The changes to the three land-cover types are illustrated and associated with historical events. This work builds upon an earlier U.S. Geological Survey (USGS) study that mapped the urban and transportation changes in the Baltimore/Washington, D.C. region between 1790 and 1990 (Acevedo and others, 1996; Crawford-Tilley and others, 1996; Clarke and others, 1996). The temporal urban data from this earlier work provided the baseline for land use and land cover change in this study.

\section{Study Area Description}

By 1861, all of the land in southern and central Maryland was divided into seven counties, Anne Arundel, Calvert, Charles, Howard, Montgomery, Prince George's, and Saint Mary's. This study focuses on the land-use and land-cover changes in these seven counties. This portion of southern and central Maryland is also divided into two distinct physiographic regions, the Coastal Plain and the Piedmont. The division between the Coastal Plain and the Piedmont is the Fall Line. The Fall Line is the zone on the landscape in which the rivers fall due to a change in elevation resulting from a change in geology. Montgomery and Howard counties are mostly in the Piedmont region with the Fall Line running through the eastern portions of these two counties. The other counties, Prince George's, Anne Arundel, Charles, Calvert, and St. Mary's lie mostly in the Coastal Plain (fig. 1).

These seven counties are located on the western shore of the Chesapeake Bay. The Chesapeake Bay is the largest estuary in the United States. It extends nearly 200 miles north to south and is 30 miles wide at the mouth. More than 100 rivers and tributaries flow into the bay, sending fresh water to mix with the salty Atlantic Ocean currents. Flowing in and around the seven counties are the Patuxent, Potomoc, and Patapsco Rivers. The Patuxent and Potomoc are two of the nine largest rivers that flow into the Chesapeake Bay. 


\section{Methods}

The temporal land-use and land-cover (LULC) data sets for this region of southern and central Maryland were developed using remote sensing and geographic information systems (GIS) technology. Information from a variety of sources, both modern and historical, were integrated to create LULC data for six time periods $1992,1982,1972,1953,1900$, and 1850 .
The land-use and land-cover categories of urban, agricultural, and forested land were mapped. For all time-periods, the extent and location of urban land came from a previous study, the Baltimore-Washington Regional Collaboratory (Acevedo and others, 1996; Crawford-Tilley and others, 1996; Clarke and others, 1996). The Baltimore-Washington Collaboratory data were derived from a wide variety of information sources ranging in scale and resolution including historical maps, USGS topographic maps, aerial photographs, USGS Digital Line Graphs

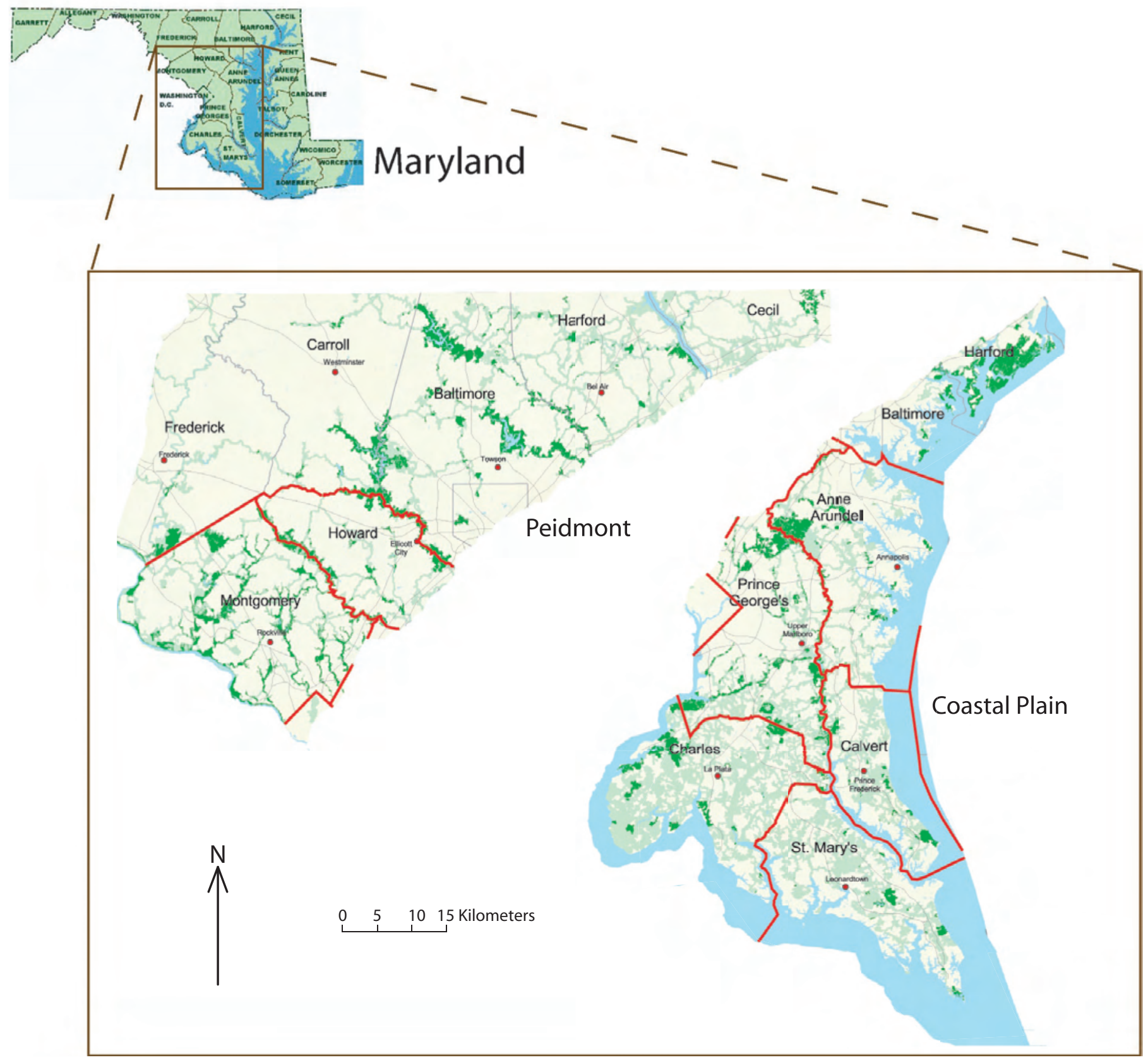

Figure 1. The seven southern and central Maryland counties in the study area. The Fall Line delineates the physiographic regions of the Coastal Plain and the Piedmont and it runs across the southeastern boundaries of Montgomery and Howard Counties. The Potomac River borders the counties on the western side. The Patuxent River forms the border between counties, running north to south, with three counties on the west shore and four counties on the east shore. 
(DLG) of hydrography and transportation routes, USGS Geographic Information and Analysis System (GIRAS) Land-use and Land-cover (LULC) data, Landsat Multispectral Scanner (MSS) satellite data, and Landsat Thematic Mapper (TM) data. In the Baltimore-Washington Regional Collaboratory study, urban extent was characterized based on the source, either by color tint on historical maps, road density on DLGs, or spectral reflectance in the satellite data used. Similar methods were used to map urban extent in a study of the San Francisco-Sacramento region (Acevedo and Bell, 1994; Kirtland and others, 1994; Bell and others, 1995).

In this study of southern and central Maryland the landuse and land-cover categories of agricultural and forested land for the six time periods were compiled from a wide variety of information sources using methods similar to compilation methods used in the Baltimore-Washington and San FranciscoSacramento studies. For the time periods 1850, 1900, and 1950 statistical information from the Census of Agriculture (U.S. Census) was used to model the location of agricultural land. Historical topographic maps yielded the locations of forested lands for 1950 . Remotely sensed data and national land-cover data sets were used to develop both the agricultural land cover and the forested land cover for the contemporary time periods (the 1970s, 80s and 90s).

The 1992 dataset of agricultural and forested land came directly from the USGS National Land-cover Dataset (NLCD) (Vogelmann and others, 1998). The NLCD land-cover categories for agricultural and forested land were aggregated to level 1 classes in the Anderson classification system (Anderson and others, 1976). The 1982 dataset for agricultural and forested land was derived from the National Oceanic and Atmospheric Administration's Coastal and Shoreline Change Analysis Program (C-CAP) (NOAA 1995) data. The 1972 dataset for agricultural and forested land was derived from the USGS Land-use Land-cover (LULC) Geographic Information Retrieval and Analysis System (GIRAS) (Fegeas and others, 1983; Loelkes 1977) data. For all three time-periods, corresponding Landsat multispectral imagery was used to verify proper classification. For the 1992 and the 1982 data, Landsat Themattic Mapper (TM) images were used. For the 1972 data, a Landsat Multispectral Scanner (MSS) image was used. Classification crosswalks were established to mitigate differences between the data sources. In some cases, differences between the land-cover data sets were resolved through additional interpretation and adjustment of the previously mapped pixels.

Land-cover data representing agriculture for the historical time periods 1950,1900 , and 1850 , were determined using digital elevation data, agricultural statistics, and GIS modeling techniques. Statistical data from the Census of Agriculture (U.S. Census Bureau 1995) was essential to the spatial reconstruction. The location of the land dedicated to farming for these historical time periods were determined by a spatial allocation model that used image processing software. The model identified areas most likely to have been in agriculture using a simple allocation table defined by a predetermined set of rules. The rules included spatial information about location of urban lands, location of water, topographic, and geologic features, including slope and soil quality, along with acreage information from the Census of Agriculture.

The spatial extent of forested land for the 1950 time period was interpreted directly from topographic maps. The green tint on the topographic map offered a reasonable representation of forest cover for that time period. The spatial extent of forested land for the 1900 and 1850 time periods was not determined through analytical methods. Land that was not determined to be urban, water, wetland, or agriculture was considered forested in both time periods. More information about the development of this time series of urban, agricultural, and forested land can be found on the USGS web site http://landcover.usgs.gov/urban/ cbay/ag/intro.asp.

\section{Regional Land-Use History}

\section{Land-Use and Land-Cover Changes: Before 1850}

Prior to European colonization, the landscape surrounding the Chesapeake Bay consisted of a large amount of forested land (American Forests, 1999; Grumet, 2000). Native Americans lived in this forested landscape and all around the Chesapeake Bay for thousands of years before the European colonists arrived in the seventeenth century (Grumet, 2000; Virta, 1991). These early inhabitants were hunters and gatherers and slowly evolved into farmers raising beans, squash, tobacco, and corn (Mountford, 1999). English Captain John Smith's 1608 exploration of the Patuxent River encouraged future colonization of the region by Europeans. Early colonists inhabited the land on the western shore of the Chesapeake Bay and along the Patuxent, Potomoc, and the Patapsco Rivers.

Colonists came from England, Scotland, Wales, Ireland, and France. To the colonists that were able to pay for their voyage, generous grants of land were offered. Those who could not pay their way spent several years working as indentured servants (Grumet, 2000). What brought many of the colonists to Maryland was the promise of land and freedom. Ironically, Africans also became a large part of the growing population, brought here to work as slaves.

The soil and climate of southern and central Maryland made agriculture the way of life for many colonists. Colonial agriculture was primitive but exceedingly profitable. Soon after colonists became established, they found tobacco to be the highest paying crop per acre, due to high demand for it in Europe (Middleton 1994). Even small farmers could support their families by planting tobacco. Family farms grew into plantations as tobacco production developed into a prosperous agricultural economy throughout southern and central Maryland (Virta, 1991).

Agriculturally induced soil erosion increased in the late 1700 s, after use of the plow became widespread throughout the Chesapeake Bay Region and the field rotation system was discarded in favor of crop rotation and increased use of fertil- 


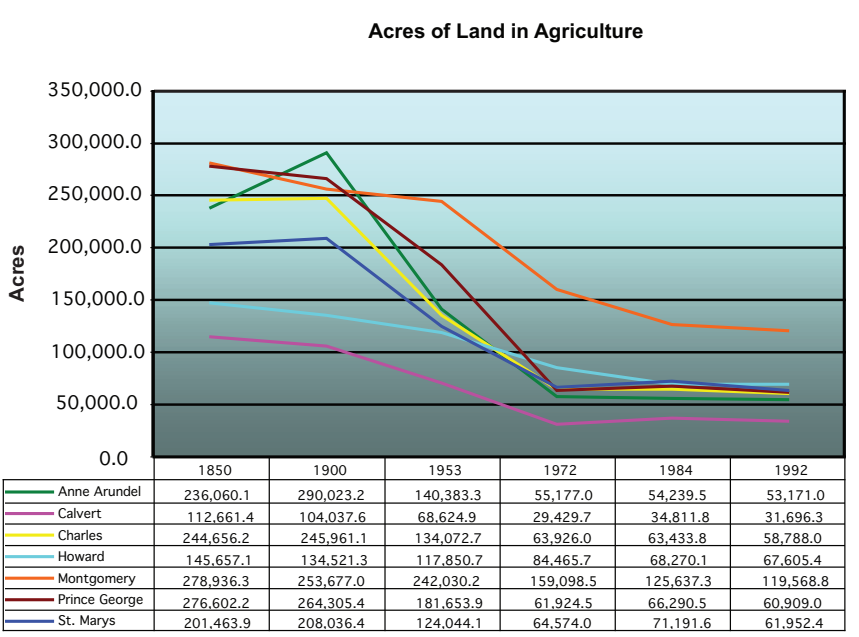

Figure 2. Graph and table of changes in the number of acres of land in agriculture for six time periods. It includes values for each county and totals for the seven-county region.

izers. Increased soil erosion in the late 1700 s caused increased build up of sedimentation in many of the tobacco ports along the rivers, leading to their demise and depopulation.

\section{Land-Use and Land-Cover Changes: 1850 to 1900}

During this 50-year time period all three land cover types increased in acreage with respective decreases in water, wetlands, and bare soil. Agriculture was the dominant land use and tobacco was the dominant crop. Land continued to be cleared or filled to create new agricultural land. Land in agriculture increased by 4,500 acres between 1850 and 1900 from 1.49 million acres to 1.5 million acres (fig. 2). The spa-

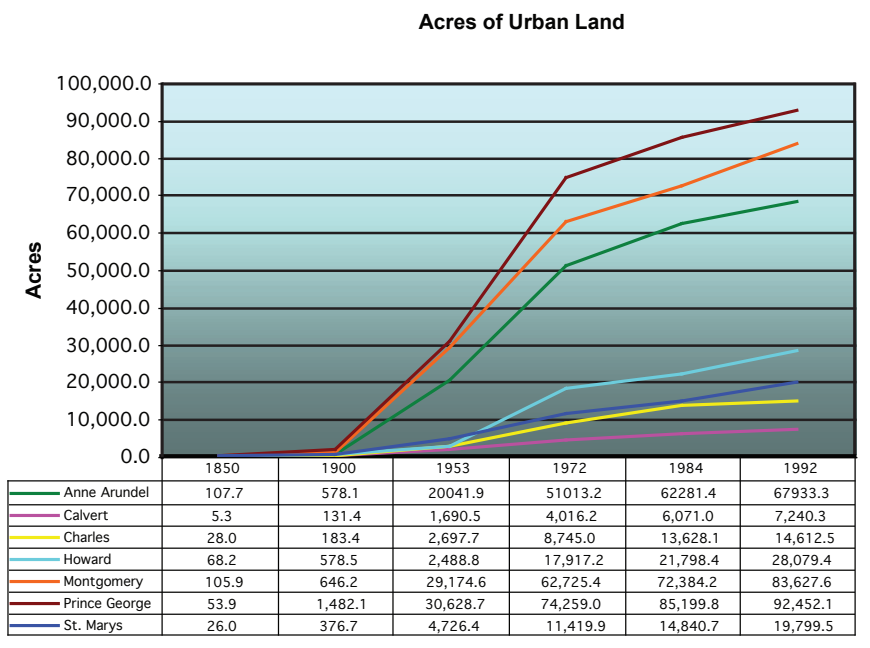

Figure 3. Graph and table of changes in the number of acres of urban land, for the six time periods. It includes values for each county and totals for the seven-county region.

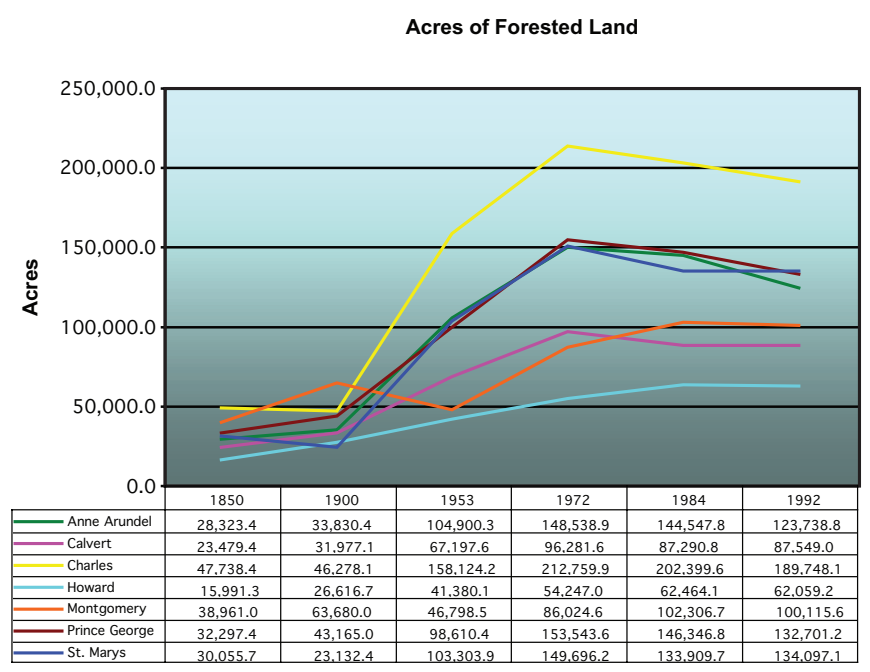

Figure 4. Graph and table of changes in the number of acres of forested land for the six time periods. It includes values for each county and totals for the seven-county region.

tial extent of urban land grew from only 500 acres in 1850 to 4,000 acres in 1900 (fig. 3). This relatively small amount of land that became urban was found mainly around Baltimore and Washington, D.C.

Forested land increased by 50,000 acres, mainly due to agricultural lands that had been exhausted and left fallow. Just prior to this time period, the amount of forested land had reached an all time low throughout the seven county region due to clearing of forests for agriculture, urban settlement, harvesting for wood products, and for fuel to fire furnaces (fig. 4). Even though coal replaced wood as fuel for the furnaces,

Population Change

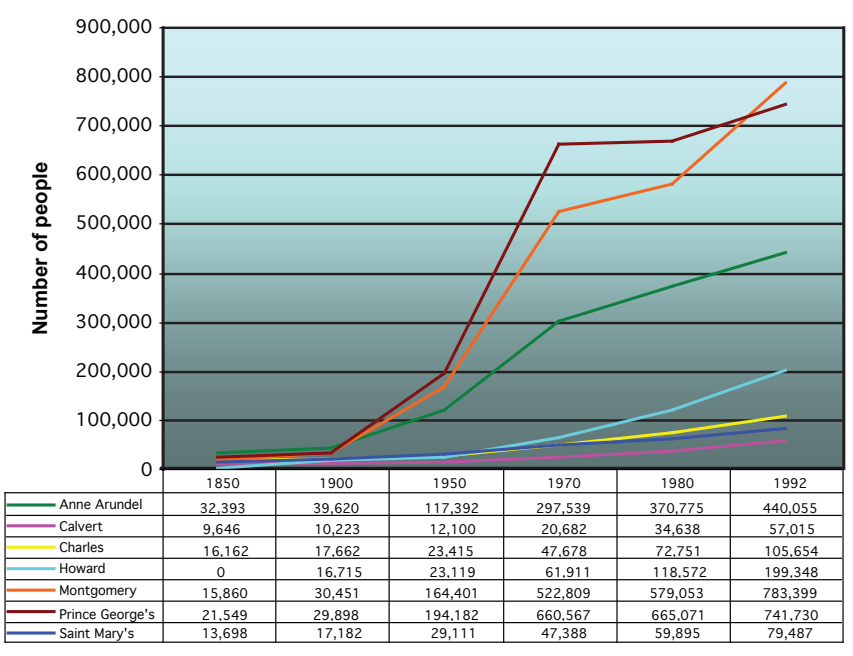

Figure 5. Population change over time in all seven counties. Population statistics for each county from the Census Bureau (U.S. Census Bureau, 1995; University of Virginia Geospatial and Statistical Data Center, 2004). 
factories, and foundries as early as 1860 , this conversion did not stop the consumption of forested land.

The corresponding population change during this time was slow but steady growth, increasing from a population of about 110,000 in 1850 to a population of more than 160,000 in 1900 (fig. 5). The growing population in southern and central Maryland slowly shifted from scattered farms on the waterways, to river-towns in the Coastal Plain, to Fall Line towns in the Piedmont, and finally to the urban centers of Baltimore and Washington, D.C.

The growing population was made up of a large number of Africans and indentured servants, because up until 1865 farmers relied on slave labor for the cultivation of tobacco. In some areas, such as the rich tobacco plantation neighborhoods near Upper Marlboro, in Prince George's County, the population consisted of 60 to 70 percent slaves (Virta, 1991).

Tobacco production continued to dominate the agricultural industry even though the tobacco market went through a series of depressions. It was the highest paying crop per acre (Calvert County Living, 2003b) in the region. After slaves were freed, a big change was seen as larger plantations broke into smaller land holdings for more efficient farming without slave labor. For example, between the end of the Civil War and the turn of the century, the number of farms in Prince George's County doubled, while the average farm size decreased dramatically (Virta, 1991). In Calvert County, many of the large plantations disappeared altogether and the economy shifted to commercial fishing, boat building, and fish processing (Calvert County Living, 2003a).

During this 50-year time period, agricultural practices intensified. Intensive tillage methods improved production in the short term, however they destroyed soil retention in the long term, resulting in increased erosion. Massive soil erosion due to agricultural practices and the clearing of forests directly effected surrounding waterways (Friends of Jug Bay, 1999; Grumet, 2000; Mountford, 1999). Rivers became choked with sediments, water quality declined, and fisheries were lost. Many water-based transportation routes used for shipping goods and moving people throughout the region were lost.

As agricultural activities increased and agricultural practices intensified, fertile soils became nutrient deficient and the quality and quantity of the harvests declined. Farmers began to rely more and more on fertilizers such as bird guano, lime, marl, river mud, gypsum, manure, ashes, and fish and vegetable matter to revitalize the depleted soil (Grumet, 2000). As the available rich soils of the Coastal Plain were completely exhausted, the low rolling landscapes and fertile valleys in the Piedmont became the replacement. As soils became increasingly depleted, new land continued to be opened up to agriculture.

Improvements to local and regional transportation routes stimulated other economic development throughout southern and central Maryland. The Washington branch of the Baltimore and Ohio Railroad (B\&O) provided a link between the towns in the Coastal Plain and the urban centers of Baltimore and Washington, D.C. Railroad access encouraged other industries, such as truck farming, associated food processing plants, and recreational centers, to grow in this region, toward the end of this 50 -year period.

Agricultural production shifted from primarily tobacco to corn, wheat, hay, and fruit. Market gardens supplied fresh fruit and vegetables to the growing populations in urban areas in and around Baltimore and Washington, D.C. Canning and fertilizer plants that supported the truck farming industry opened in northern Anne Arundel County. Initially, Baltimore and Washington, D.C. were the primary markets for local farmers. As transportation systems improved and diversified, local products such as peas, beans, strawberries and cantaloupes from the region became available across the eastern seaboard (Anne Arundel County, 2003).

\section{Land-Use Changes: 1900 to 1950}

Dramatic land-use and land-cover changes continued across southern and central Maryland during the first half of the twentieth century (fig. 6). Agriculture remained the dominant land use; however, the amount of land in agriculture decreased steadily from 1.5 million acres in 1900 to only 1.0 million acres in 1950. During this time, forested land increased by 350,000 acres (fig. 4) from 269,000 acres in 1900 to 620,000 acres in 1950 . Active reforestation efforts were underway, in addition to forests that were reemerging on abandoned agricultural fields. Forest advocates encouraged landowners to replant and protect forests in an effort to improve water quality (Grumet, 2000; Mountford, 1999).

The spatial extent of urban land increased by more than 87,000 acres from close to 4,000 acres in 1900 to more than 90,000 acres in 1950 (fig. 3 ). The corresponding population change in these seven Maryland counties during this time period began to pick up speed. The population of more than 160,000 in 1900 tripled to 560,000 people in this half century (fig. 5). A large portion of the population along the Patuxent

Land Use Change: 1850 - 1992

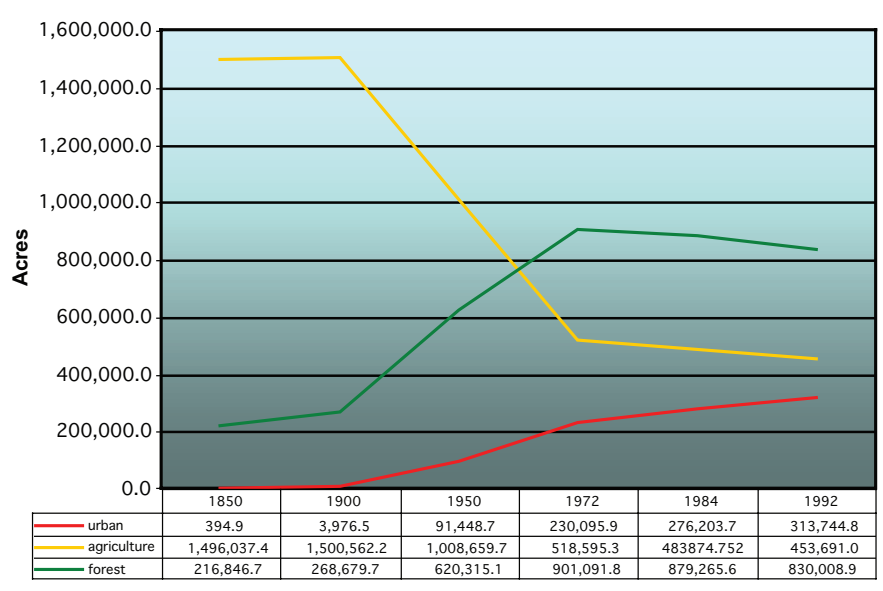

Figure 6. Graph and table of land-use change for each of the land covers - urban, agricultural, and forested land -in the study area. 
River in southern and central Maryland was now located in and around Baltimore and Washington, D.C. urban centers. The land along the Patuxent River in southern Maryland was largely rural in the 1900 to 1950 time period.

During the 1930s and 1940s, wartime mobilization generated jobs and housing in and around Baltimore and Washington, D.C. These jobs drew in people at a record pace. Many of the individuals drawn to the region for the war effort remained in the area after the war was over, working in peacetime production industries (Grumet, 2000). Suburbs of the large cities were growing out into the surrounding counties. All along the borders of Baltimore and Washington, D.C., towns were built as bedroom communities to the larger metropolitan area. Suburbanization also encompassed previously existing towns that had their own economies, like the mill towns of Laurel, Savage, and Ellicott City or the market towns of Rockville and Reisterstown. During this time, the percentage of the population that earned their livelihood through agriculture was in decline (Virta, 1991).

\section{Land-Use Changes: 1950 to 1970}

During this 20-year time period the population and urban extent grew considerably (figs. 3 and 5). There was a 138,000 acre increase in the spatial extent of the urban footprint. The population more than tripled in both Montgomery and Prince George's Counties to 522,00 and 660,000 respectively. In Anne Arundel County, population more than doubled to 297,000. The spatial extent of urban land in these three counties more than doubled (fig. 3). Jobs in and around Baltimore and Washington, D.C., continued to draw people at a record pace.

The amount of land in agriculture continued to decline from just more than 1 million acres in 1950 to just 518,000 in 1970. Forested land continued to increase from 620,000 acres in 1950 to more than 901,000 acres in 1970. Even with less agricultural land, the use of chemical fertilizers and pesticides increased six-fold (Environment and Energy Study Institute, 2001). This quickly took its toll on regional water quality. Waterways previously polluted with sediments now flowed with vast amounts of nitrogen, phosphorus, and synthetic chemicals found in fertilizers and pesticides that were washing off farm fields. Comprehensive reforestation efforts were established as a means to improve water quality.

\section{Land-Use Changes: 1970 to 1990}

The amount of land in agriculture continued to decrease, losing almost 65,000 acres in this 20 -year time period (fig. 2). At the same time, however, the amount of urban land increased from 230,000 acres in 1970 to more than 313,000 acres. Much of the urban growth occurred in Montgomery, Prince George's, and Anne Arundel Counties along the Potomac and Patapsco rivers. Urbanization along the Patuxent River in St. Mary's and Calvert Counties occurred late in the 20th century. This increase in urban land came at the expense of forested land that was no longer on the increase and in some counties was in decline (fig. 4). Throughout the seven counties, forested land decreased from a high of 901,000 acres to 830,000 acres.

Locally, as well as nationally, there was heightened concern for the quality of water. Nationally, the Federal Clean Water Act was passed early in the 1970s, regulating the flow of chemicals and other pollutants into bodies of water. Water-quality issues continued to plague the counties in southern and central Maryland. For example, pollution from chemicals, waste, and erosion began to cause significant decline in water clarity and quality in the Patuxent River. In 1977, the Tri-County Council for Southern Maryland (TCCSMD) coordinated a campaign to reduce the flow of nutrients into the river from point and non-point sources in the seven counties along the river (Tri-County Council for Southern Maryland, 2002). The use of chemical fertilizer finally began to taper off in the 1980s.

In 1983, the Chesapeake Bay Agreement was signed into action and through this agreement the Chesapeake Bay Program began a regionally coordinated effort to reverse the declining natural resources of the bay. In a separate effort, the Patuxent River Policy Plan was established to protect the river and its watershed by restoring surface and ground-water quality, habitat, and quality of life along the river and its tributaries (Patuxent River Commission, 2000). The original Patuxent River Policy Plan was adopted in 1984. Amendments for the plan have been considered every 5 years as new information and ideas are developed. Because agriculture was considered an important part of the Southern Maryland economy, TCCSMD organized the Southern Maryland Agricultural Commission to support and encourage local agriculture in 1988. The 1990s also brought more nutrient-management programs and riparian-forest protection (Alliance for the Chesapeake Bay, 1996).

\section{Conclusion}

Landscape changes that have occurred in Anne Arundel, Calvert, Charles, Howard, Montgomery, Prince George's, and Saint Mary's Counties in southern and central Maryland over the past 300 years are mainly the result of human activities. Agriculture, logging, and urban expansion have each played a role in shaping the evolving landscape. Prior to European colonization, forests covered the landscape like a blanket from the Atlantic to the Mississippi River (American Forests, 1999). In the seven counties of southern and central Maryland a similar forest pattern existed. After European colonization, the blanket of forest began to unravel as agricultural land uses took over and population in the region began to increase.

Between 1850 and 1900, the decrease of forested land mirrored the increase in agricultural land. Colonists cleared forests to create agricultural fields, as well as urban areas. Forests were cut to export wood and wood products to Europe, as well as to provide fuel for homes and industry. By 1850, there 
were only 216,000 acres of forested land in the seven counties. In 1972, forests covered more than 900,000 acres. After this high point, forested land began to decrease again and was at 830,000 acres in 1992 (fig. 7) (American Forests, 1999).

Over the years, agriculture, specifically tobacco production, played a large role in shaping the landscape. When colonists first settled the land of southern and central Maryland, the physical condition of the land was a key factor in the location of agricultural land. The land that was cultivated first included areas with good soil quality with a moderate slope, areas not inundated with water, and areas that had good access to waterways for transportation. However, modernization of agricultural methods and improved transportation routes made all the lands within the region susceptible to cultivation. In 1900 , there were more than 1.5 million acres of agricultural land throughout these seven counties. The counties with the greatest amount of agricultural land at this time included Anne Arundel, Prince George's, and Montgomery. By 1992, the amount of land in agriculture for all seven counties was only 454,000 acres (fig. 8).
At the end of the twentieth century, the three counties with the largest population and greatest amount of urbanized land were Montgomery, Prince George's, and Anne Arundel. In Montgomery County, the largest of the seven counties in size and population, the urban footprint grew from 646 acres in 1900 to more than 83,000 acres in 1990. In 1990, Prince George's County had the largest urban extent with more than 92,000 acres of urban land (fig. 9).

The other four counties, Howard, Charles, Calvert, and St. Mary's, had much smaller populations and resulting urban extent. The urban extent of Howard County in 1992 was just more than 28,000 acres with a population of almost 200,000. In 1992, the urban footprint of Charles was only 14,612 acres with a population of 105,000 , making it one of the more rural counties. Saint Mary's, the second smallest county, had less then 20,000 acres of urban land in 1992 with a population of 79,487 . Calvert, the smallest of the seven counties, had 7,240 acres of urban land with a population of 57,000 in 1992.

During the 1990s, agriculture continued to be the major land use, while forested land remained second. However,

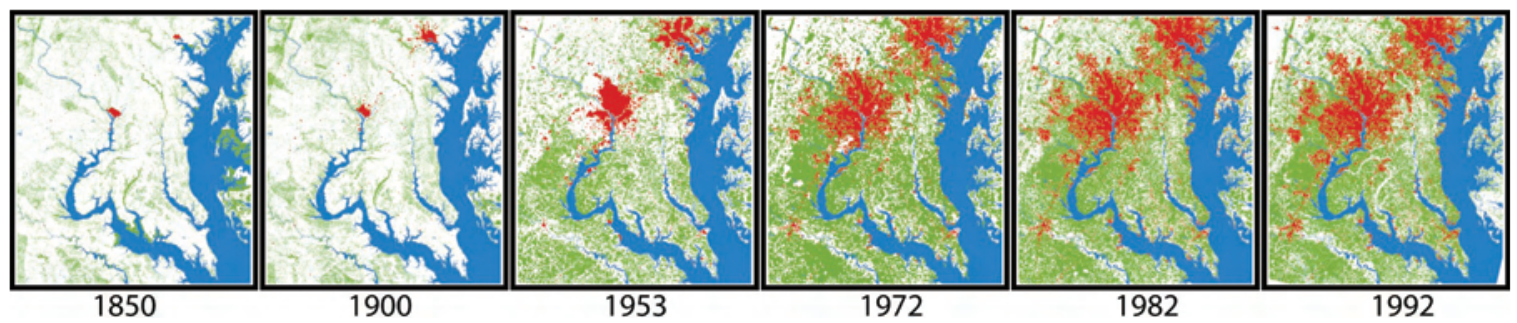

Figure 7. Spatial time series of changes in forested land in the study area. The green tint identifies the location of forested land.

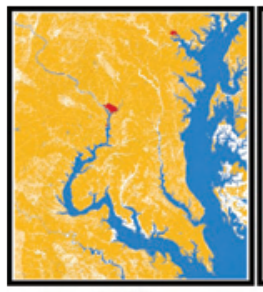

1850

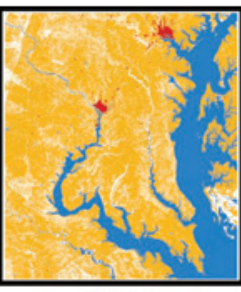

1900

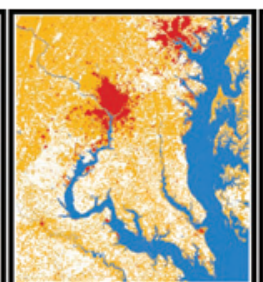

1953

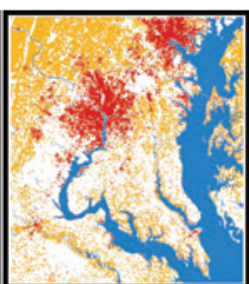

1972

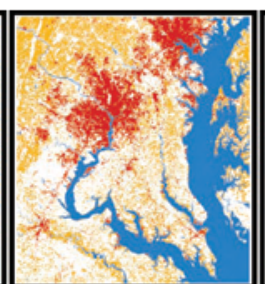

1982

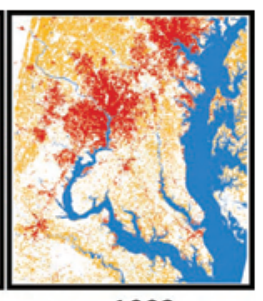

1992

Figure 8. Spatial time series of changes in agriculture land in the study area. The gold tint identifies the location of agricultural land.

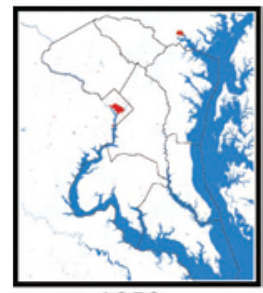

1850

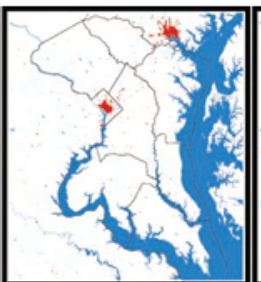

1900

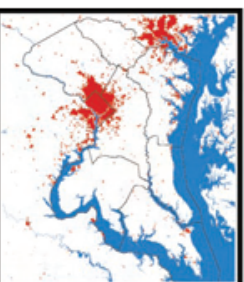

1953

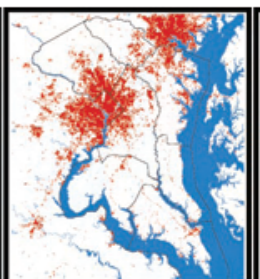

1972

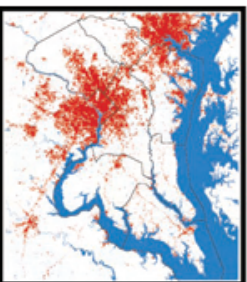

1982

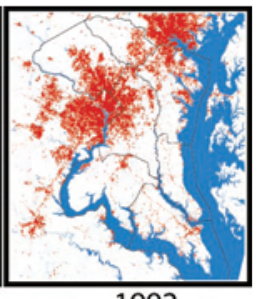

1992

Figure 9. Spatial time series of changes in urban land in the study area. The red tint identifies the location of urban land. 
spreading subdivisions and other urban uses continued to whittle away the landscape. Of the seven counties, the four counties in the Coastal Plain remained more rural, primarily due to their distance from the large urban centers of Baltimore and Washington, D.C. Within this region, local and regional zoning along with conservation easements, maintain agriculture as an important part of the southern Maryland economy. However, agricultural trends in the region have changed as farmers shift away from the 300-year-old tradition of tobacco production. In 2000, the State of Maryland instituted a voluntary tobacco buy-out program to transition farmers out of tobacco production (Tri-County Council for Southern Maryland, 2002).

\section{References}

Acevedo, W., and Bell, C., 1994, Time series animation of historical urban growth for the San Francisco Bay region: Association of American Geographers abstracts, 90th Annual Meeting. San Francisco, CA, p. 2.

Acevedo, W., Foresman, T., Buchanan, J.T., 1996, Origins and philosophy of building a temporal database to examine human transformation processes: Proceedings ASPRS/ ACSM Annual Convention and Exhibition, Baltimore, MD.

Alliance for the Chesapeake Bay, 1996, Riparian Forest Buffers: [http://www.acb-online.org/pubs/projects/ deliverables-148-2-2003.pdf; accessed Sept. 3, 2003].

American Forests, 1999, Regional ecosystem analysis Chesapeake Bay region and the Baltimore-Washington corridor - Calculating the value of nature: [http://www. americanforests.org/downloads/rea/AF_Chesapeake.pdf; accessed Sept. 25, 2003].

Anderson, J.R., Hardy, E.E., Roach, J.T., and Witmer, R.E., 1976, A land use and land cover classification system for use with remote sensor data: U.S. Geological Survey Professional Paper 964, 28 p.

Anne Arundel County, Maryland, 2003, History-Seventeenth century through the present: Citizens Information Center [http://www.co.anne-arundel.md.us/AboutAACo/history. cfm; accessed January 26, 2003].

Bell, C., Acevedo, W., and Buchanan, J.T., 1995, Dynamic mapping of urban regions - Growth of the San FranciscoSacramento Region: Proceedings for Urban and Regional Information Systems Association, San Antonio, TX, p. 723734.

Calvert County Living, 2003a :From a history of Calvert County Maryland, by Charles Francis Stein, 1976 [http:// calvert-county.com/history.htm; accessed Sept. 3, 2003].

Calvert County Living, 2003b, Tobacco: [http://calvert-county. com/tobacco.htm; accessed Sept. 3, 2003].

Chesapeake Bay Program, 2002, Chesapeake Bay ProgramAn overview of its history, structure, accomplishments, and goals: [http://www.acb-online.org/pubs/projects/ deliverables-146-4-2003.pdf; accessed Nov. 15, 2003].

Clark, S., Starr, J., Foresman, T.W., Prince, W., and Acevedo,
W., 1996, Development of the temporal transportation database for the analysis of urban development in the Baltimore-Washington region: Proceedings ASPRS/ACSM Annual Convention and Exhibition, Baltimore, MD, April 22-24, Vol. III, p. 77-88.

Crawford, J.S., Acevedo, W., Foresman, T.W., and Prince, W., 1996, Developing a temporal database of urban development for the Baltimore-Washington region: Proceedings ASPRS/ ACSM Annual Convention and Exhibition, Baltimore, MD, April 22-24, Vol. III, p. 101-110.

Environment and Energy Study Institute, 2001, Water Symposium - Water pollution in urban and rural settings: [http://www.eesi.org/briefings/publications/03.23.01water. pdf; accessed Feb. 7, 2003].

Fegeas, R.G., Claire, R.W., Guptill, S.C., Anderson, K.E., and Hallam, C.A., 1983, Land use and land cover digital data: U.S. Geological Survey Circular 895-E, 21 p.

Friends of Jug Bay, 1999, Jug Bay wetlands sanctuaryHistory: [http://www.jugbay.org/jugbay/history.html; accessed Feb. 7, 2003].

Grumet, Robert S., 2000, Bay Plain and Peidmont—A landscape history of the Chesapeake heartland from 1.3 billion years ago to 2000; National Park Service Chesapeake Bay Heritage Context Project: [http://www. chesapeakebay.net/pubs/gateways/plainandpiedmont/; accessed Sept. 2, 2003].

Kirkland, D., Gaydos, L., Clarke, K., DeCola, L., Acevedo, W., and Bell, C., 1994, An analysis of human-induced land transformation in the San Francisco Bay-Sacramento area: World Resource Review, v. 6, no. 2, p. 206-217.

Loelkes, G.L., 1977, Specifications for land use and land cover and associated maps: U.S. Geological Survey Open File Report 77-555, 103 p.

Middleton, Arthur Pierce, 1994, Tobacco Coast-A Maritime history of Chesapeake Bay in the Colonial Era: Baltimore, MD, Johns Hopkins University Press.

Mountford, Kent, 1999, A sapsule history of the Chesapeake Bay: Chesapeake Bay Program Office [http://www. chesapeakebay.net/hist1.htm; accessed Dec. 5, 2003].

National Oceanic Atmospheric Administration (NOAA), 1995, Coastal Change Analysis Program (C-CAP) - Guidance for regional implementation: NOAA Technical Report NMFS 123, Department of Commerce April 1995, [http://www.csc. noaa.gov/crs/lca/proto2.html; accessed Aug. 25, 2003].

Patuxent River Commission, 2000, Patuxent Policy Plan: Maryland Department of Planning [http://www.op.state. md.us/info/patuxplan.htm; accessed October 20, 2003].

Tri-County Council for Southern Maryland, 2002, Southern Maryland regional strategy-Action plan for agriculture, Tobacco Crop Conversion Program, ten-year strategic plan and five-year action strategies-2002-2012: [http://www. tccsmd.org/web/ag/agstrategy.html; accessed Dec. 5, 2003]. University of Virginia Geospatial and Statistical Data Center, 2004, U.S. Census Bureau population figures - 1790-1960: United States Historical Census Data Browser, [http://fisher. lib.virginia.edu/census/; accessed Nov. 1998]. 
U.S. Census Bureau, 1995, Maryland population of counties by decennial census - 1900 to 1990 , compiled and edited by Forstall, Richard L.: Population Division Washington, D.C. [http://www.census.gov/population/cencounts/md190090. txt; accessed Nov. 1998].

Virta, Alan, 1991, Prince George's County-Over 300 years of history-A county with rich history: Prince George's
County History Prince George's County Historical Society web page [http://www.pghistory.org/PG/PG300/history. html; accessed Sept. 3, 2003].

Vogelmann, J., Sohl, T., and Howard, S., 1998, Regional characterization of land cover using multiple sources of data: Photogrammetric Engineering and Remote Sensing, v. 64, no. 1, p. 45-57. 



\title{
Regional Landscape Change in Northern Colorado Front Range
}

\author{
By Carol S. Mladinich ${ }^{1}$
}

Introduction

Forty percent of future urban growth in the United States is expected in the eight Rocky Mountain West (Arizona, Colorado, Idaho, Montana, New Mexico, Nevada, Utah, and Wyoming) States. Over the past 150 years, cultivation, heavy livestock grazing, mining, and urban/suburban development have modified the northern Colorado Front Range. This region is becoming more urban as it becomes the center of growth in the Rocky Mountain West.

A commonly held perception sees urban development as occupying all the Nation's open spaces. In reality, only a small fraction of the land in the United States has been developed; one third of the land is not available for development because it is Federal land. Urban development often occurs in areas valued for other uses, including prime agricultural land, natural resource development such as mining for minerals or aggregate, and physical environment amenities such as wildlife habitats and scenic environments (Shumway and Otterstrom, 2001; Rasker, 1993, 1994; Power, 1996). As populations move and grow in a region, there is an overall shift in land use from open spaces (forests and grasslands) and agriculture to more urban and residential uses, each with their own environmental and economic implications. A more pressing issue is the multiple demands for the land and the need to understand and convey the temporal evolution of regional landscape change by human populations. Over the past 150 years cultivation, heavy livestock grazing, mining, and urban/ suburban development have modified the northern Colorado Front Range.

The northern Colorado Front Range urban corridor between Denver and Fort Collins is an example of a region whose natural resources and environment have been greatly modified by human modifications. The region has evolved through a series of economic booms and busts related to beaver furs, gold and silver, cattle, coal, oil and gas, agriculture, manufacturing, and now perhaps its most precious commodity, the "Colorado landscape," as typified by its beauty and natural environment. The value of the Colorado landscape was recognized early in the state's formative years but was far

\footnotetext{
${ }^{1}$ U.S. Geological Survey, Rocky Mountain Geographic Science Center, P.O. Box 25046, MS 516, Lakewood, CO 80225, 303-202-4313, csmladinich@ usgs.gov.
}

overshadowed by the extraction and exploitation of its mineral resources. Today, it is this landscape value that draws people to Colorado and in particular the Front Range urban corridor every year (Governor's Commission on Saving Open Spaces, Farms and Ranches, 2000).

Landscape studies are integral to any assessment of human-induced impacts on the environment. These studies look at arrangements of environmental elements and incorporate humans and their activities. Historical perspectives of urbanization give insight into the development and growth of urban ecosystems that assess the degree of man's influence as it affects both the biotic and physical environment. The loss of natural land covers may result in the loss of native species and habitats, increasing threats to ground water and coastal water quality, as well as a loss of open space and view sheds. To understand and possibly reduce negative impacts of landscape change, urban growth modeling can be used to simulate future shifts and patterns on the landscape.

Population growth is a driving factor for landscape change (Matheny and Wear, 2000; Hobbs and others, 1997; Shumway and Otterstrom, 2001; Vias, 1999). As population transforms the landscape, increased demands are placed on natural resources. Forty percent of the future growth in the Nation is expected to occur in the eight Rocky Mountain West (West) States of Colorado, Utah, Wyoming, New Mexico, Idaho, Montana, Arizona, and Nevada (as defined by the U.S. Department of Commerce, Rasker 1994; Clark, 2000; Vias, 1999). These states are now more urban (86 percent) than the Mid-Atlantic region (75 percent). Population growth is intensifying around existing urban centers, such as Phoenix, Denver, and Salt Lake City. The seven counties of the northern Colorado Front Range-Adams, Arapahoe, Boulder, Denver, Jefferson, Larimer, and Weld - have long been a leading area of urban growth and development in Colorado. The City and County of Broomfield was officially created in 2000, after the time-period used for this study. This region is already home to 80 percent of Colorado's population (Clark, 2000). The State's population grew by more than 30 percent, from 3,294,394 to 4,301,261 from 1990 to 2000, and the Front Range accounted for more than 61 percent of that growth. In the past, worries about population growth had never been an issue, there was plenty of land, and growth was encouraged and sought after. From 1990 to 1995, Colorado alone had ten of the fifty fastest growing counties with Douglas County (south of Denver) being one of the fastest growing counties in the country. Ft. Collins' (north of the Denver) population took almost 100 years to reach 50,000 , but took only 20 years to double to 
100,000 . It is estimated that it will only take another 20 years to double that again to 200,000 (Cornelius, 1999).

The landscape assessment of the Northern Colorado Front Range described in this paper was completed in 2001 as part of a 5-year U.S. Geological Survey (USGS) study to develop methods for assessing infrastructure resources and to characterize the location, distribution, and quality of the infrastructure resources along the Northern Colorado Front Range urban corridor between Denver and Fort Collins (USGS Front Range Infrastructure Resources Project, 2002).

\section{Study Area Description}

The seven counties of the Northern Front Range, including all or portions of Adams, Arapahoe, Boulder, Denver,
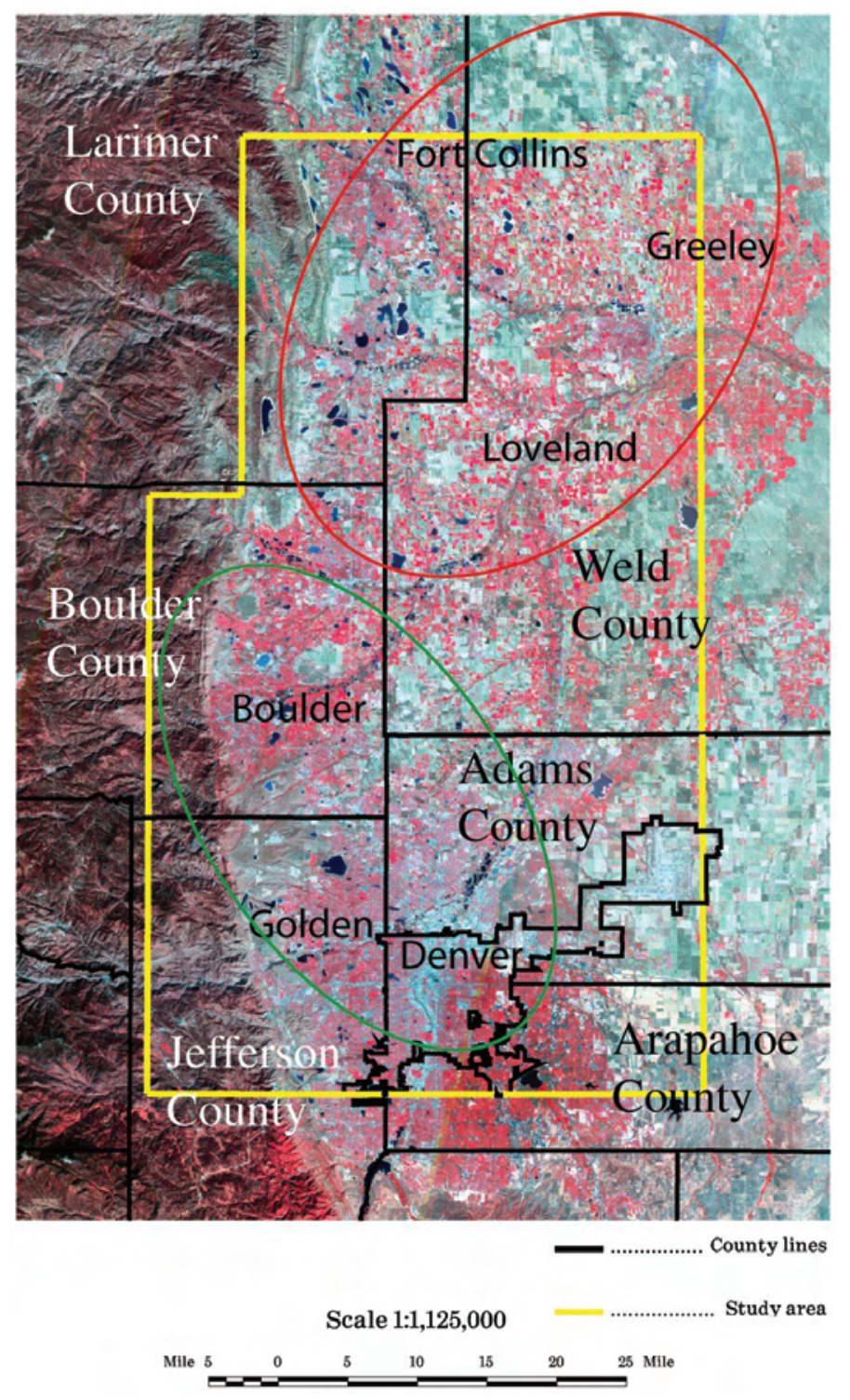

Figure 1. Map of the northern Colorado Front Range study area. The urban core is circled in green and the northern agricultural area is circled in red.
Jefferson, Larimer, and Weld Counties, have long been a leading area of urban growth and development in Colorado. This urban corridor area was selected by the USGS Front Range Infrastructure Resources (FRIR) project because of its abundance of natural resources-aggregate, coal, oil and gas, and ground water - that are all needed to support growing urban regions yet are put at risk for development by these same urban areas (USGS Front Range Infrastructure Resources Project, 2002). The northern Front Range has been comprised of two distinct yet intricately linked regions since the region's early development in the 1850's as described by Wyckoff (1999). The regions include the Denver metropolitan area of Denver, Golden, and Boulder and the northern agricultural area, north of the urban core, in the Fort Collins, Loveland, and Greeley area. The urban core developed as the financial and manufacturing core for the mining coming from the mountains to the west and the agricultural area to the north provided the food stuffs needed by the urban area and western mining. I will use these same regional distinctions to provide the historical perspective of the spatial patterns of land use change in this area that marks the western limits of the High Plains and the eastern most range of the Rocky Mountains. The region is roughly 2,500 square miles in area and is a mixture of open rolling country and stream valleys that gradually rise westward to the Front Range foothills and the higher ranges of the Rocky Mountains (fig. 1).

The Front Range's semiarid climate plays an important role in the development of the region. Precipitation averages only 15 inches per year. The amount of precipitation can vary greatly from year to year and drought is an ever-present possibility. The climate is characterized by wide difference in temperature between summer and winter and is subject to sudden and extreme changes on a daily basis. The presence and availability of water (or lack of water) continues to play a major role in the urban development along the Front Range. During Zebulon Pike's exploration of the Southwest in 1806, he declared the region to be the "Great American Desert, never to be settled." Pike recalled that the deserts were like those of Africa and that there were "tracts of many leagues where the wind had thrown up the sand in all the fanciful form of the ocean's rolling wave; and on which not a speck of vegetable matter existed" (U.S. National Park Service, 2003).

The average elevation of the region is 6,800 feet above sea level. Steeply dipping sedimentary rocks mark the boundary between the Rocky Mountains and the High Plains. The major streams in the region flow northeasterly to the South Platte River. The major tributaries to the South Platte River, including Clear and Boulder Creeks and the St. Vrain, Big Thompson, and Cache la Poudre Rivers, originate at an elevation of nearly 14,000 feet in the Front Range, west of the study area near the Continental Divide. The most fertile soils in Colorado are found in the irrigated alluvial soils of the river valleys that cross the plains. Prior to European settlement, the High Plains region was almost treeless, except for certain areas that contained peach leaf willow and cottonwood trees. Natural grasslands once covered most of Colorado's plains but 
are now limited to those areas that are not cultivated. Buffalo grass and blue grama are the most common native grasses and large areas of bare ground are common and natural. Examples of the native grasslands are preserved in the Pawnee National Grasslands, northeast of Greeley, Colorado (Veblen and Lorenz, 1991).

\section{Regional Land-Use History}

The Front Range is a prime example of a region that has been shaped by its proximity to natural resources and agriculture that typifies the West. This region is also an example of the paradigm shift that began after WWII, described by Shumway and Otterstrom as the change of the Old West to the New West. The economy is no longer based on the exploitation of raw mineral resources and agriculture but rather the exploitation of the natural environment, the place, and the servicebased economies that thrive on it (Rasker, 1993; Power, 1996; Rudzitis, 1999; McGranahan, 1999; Nelson, 1999).

After the discovery of gold and silver in the late $1850 \mathrm{~s}$, this region has continued to be the financial and economic Gateway for not only the rest of Colorado but also the entire West. The Front Range area landscape was transformed by a boom and bust export-based economy that began with the fur trade and progressed through the extraction of various mineral resources, such as gold, silver, uranium, molybdenum, coal, and oil and gas (Bird, 1993; Kendall, 2002). The Front Range grew and flourished as a support base, providing commerce, agriculture, transportation, and communication to supply the various industries that were key drivers to landscape change. Today, the ambiance of the "Colorado landscape," the natural environment, and its amenities now draw high technology and other service-based industries to the region. Using Wyckoff's designation, the Front Range area can be subdivided into two zones - an urban core zone and an agricultural zone to describe the land use history of the region. The urban core is concentrated in a triangle made up of the cities of Denver, Boulder, and Golden. The agricultural zone is north of this urban core (1999).

\section{Early European History to 1900}

Prior to the 1850 s, the Front Range was largely unsettled by of European descent, with the exception of the fur trading and military outposts of Fort Lupton, Jackson, Vasquez, and St. Vrain along the South Platte River. The westward migration was to the California gold fields and travel was either north along the Oregon Trail or south along the Santa Fe Trail. The discovery of gold in 1858 was the principle driving factor that transformed the Front Range area from a landscape characterized by native grasses, labeled in the East as the Great American Desert (United States National Park Service), into booming settlements and thriving agricultural lands. It is estimated that as many as 100,000 people came to Colorado as "59ers."
As the gateway to the West, transportation has been the key enabler shaping the region's landscape. Simple foot trails were transformed to more substantial trails and roads as their use intensified with the discovery of gold after 1858 . The railroad, which originally bypassed the Front Range, arrived after business owners and politicians financed the linking of Denver north to Cheyenne and east to Kansas City. Multiple railroad lines soon connected the mining regions in Gilpin, Clear Creek, and Boulder Counties to the growing urban centers of Golden, Denver, and Boulder and the agricultural communities to the north.

The three towns of Denver, Boulder, and Golden, making up the urban core, developed their own individual traits and marks on the landscape. Denver, a rugged outpost in 1860 , was by 1900 , one of the 25 largest cities in the Nation. Now the state capitol, Denver was beginning to see the boom and bust trends that are still present today. It maintained its gateway status for the rest of the State by continuing to provide a steady transportation infrastructure, a reliable water supply, and a regional trade center. Boulder was transformed from a collection of miners' cabins to the home of the University of Colorado and an economically diverse urban center. Golden, because of its unique foothill setting at the base of the Rockies and its nearness to mineral resources, became home to the Colorado School of Mines and many different types of manufacturing. As Denver grew, an extensive streetcar network enabled the development of residential suburbs outside of the city. This allowed people to move into the country where the land was cheaper and where they could still be connected to their jobs and other amenities of the city center. Yesteryear this was a modern marvel; today this is commonly referred to as urban sprawl.

Even in the early years, the region's scenic physical environment attracted people to the area. The rise in tourism helped shape the economy, with the development of dude ranches and hotels in the scenic foothills and nearby Rocky Mountains. By 1940, tourism was the third-largest source of income in the State after agriculture and manufacturing (Williamson, 1999). In the late 1800s, the reported fresh clean air also became a mecca for those Easterners suffering from respiratory ailments. It is estimated that one third of the population in the region were either present or former victims of respiratory ailments. More people came to the region for the "climate cure" than for gold and silver (Bird, 1993). Many hospitals and sanatoriums opened and flourished in the region. The National Jewish Medical and Research Center, founded in 1899 as a hospital for tuberculosis (TB) patients, is still today the only facility in the world dedicated exclusively to respiratory, immune, and allergic disorders. This migration included a large number of wealthy business owners resulting in a buildup of many new and service related industries.

The agricultural zone produced crops of an amount that was not typical of a semiarid region. The agricultural development was made possible with the creation of a vast network of ditches and reservoirs transforming the grasslands into productive farmlands and thriving agricultural towns. The inten- 
sive agriculture was also made possible by the fertility of the piedmont soils, the availability of water, and the proximity to local markets in the urban core and mining districts. The agricultural zone had regional centers in Fort Collins, Loveland, and Greeley. Though agriculture was established in the region by the 1860 s, the output was small until the establishment of several agricultural colonies and rail lines in the late 1870s.

Water became and remains the lifeblood for the entire region, acting as not only an enabler but also constrainer of landscape change. The West's prior appropriation water doctrine was codified for the first time as competing farmers and then the courts determined water claims (Wyckoff, 1999). The new water laws gave preference to the "first user in time"; this resulted in agriculture having preference over manufacturing. Interbasin projects or the transferring of water from one basin to another and the protection of forestland to protect the watersheds for agricultural purposes was also pioneered in the region.

In just fifty years, the landscape of the region had dramatically changed from the rest of the Arid West. By 1900, more than 1 million acres and 90 percent of the agricultural land were irrigated along the Front Range. The yield and intensity of the irrigated operations, the high price of the farmland, and the nearby commercial markets kept the farm sizes small in comparison to the rest of the High Plains to the east and the rest of Colorado. The resulting landscape had farmhouses closer together and had produced a very lush developed landscape that was different from many other regions in the arid West. The transportation infrastructure also changed the landscape. Unlike most of the rural West, multiple rail lines and heavily used roads connected the region to markets in Cheyenne, Denver, and nearby mining districts (Wyckoff, 1999).

\section{0 to 1940}

After the turn of the century, farming and ranching dominated the region's economy. The introduction of sugar beets on the eastern slope had a very large impact on the agricultural economy, giving rise to facilities to process the raw materials into food products. The network of railroads also helped provide easy access for the ranchers to bring their cattle and sheep to market. The Denver stockyards became one of the Nation's largest with most of the largest brand-name packers of the time period having plants along with many smaller local operators. The period following World War I and leading up to the 1930's depression saw the region's chief economic industries of agriculture and mining becoming stagnate and in decline.

Transportation continued as a key enabler during the automobile age that increased the demand for more roads, enabling city-dwellers to spread out even further on the landscape. The extent of paved roads increased from 1,200 miles in 1914 to more than 8,500 miles by the mid-1920s. The transportation infrastructure also grew with the start of the commercial airline industry and the opening of Denver Municipal Airport in 1929. Denver became the region's key aviation point in the western United States, because of its large size, good weather, and strategic location.

The Federal Government's New Deal Program began a dramatic transformation on the landscape by adding to the region's basic infrastructure that included roads, agriculture, and municipal water works, telephone and electrical lines, public buildings, dams and reservoirs, and parks. This building effort stabilized the economies of many urban and rural communities. A larger presence for the Federal Government, as reflected in the growth of number of government offices, also began in the region. The region would soon grow to have the second largest concentration of Federal agencies outside of Washington D.C. This governmental presence would help soften the impact of economic downturns caused not only by the Great Depression and Dust Bowl, but continue through future economic downturns.

Water was now recognized as a potential constraining factor to any kind of development and in particular to agriculture. It was becoming a large regional issue not only for the Front Range but also for the rest of Colorado and West. State and the Federal governments were forced to develop strategies to insure water availability. Agreements were made to secure the legal basis for long term water supply in Colorado and other western states. New transmountain water diversion projects brought water from the Western Slope to the Front Range. The Big Thompson Project, the largest effort during this time, was started in 1930 and completed in 1954. This project demonstrated the lengths that western agriculturists would go to get a steady supply of water to maintain and (or) increase their productivity.

\section{0 to Present}

The population growth in Colorado slowed between WWI and WWII to only 10 percent. By 1940, over half of Colorado's population lived in cities, mainly along the Front Range. In terms of the landscape, the urban West was setting the stage for what was to become the dominant urban feature after WWII, with population growth as the driving force behind landscape change (Vias, 1999, Shumway and Otterstrom, 2001). The growing populations were characterized by the growth of decentralized populations in suburbs, the formation of multicentered nodes of commercial activity, and the institutionalization of commuting. It was during these years that the combined population of the seven county area grew to include more than 50 percent of the population of the entire State (Colorado Dept. of Local Affairs, 2002) (fig. 2). Denver dominated not only the Front Range but also the surrounding Mountain West and western High Plains. The city was in the middle of the Colorado Mineral Belt and large agricultural areas. It became the regional trade center of industry and finance for the interior West. Development in the Front Range urban centers paralleled southern California, but rather than the key centers growing larger with annexations, the surrounding smaller cities grew larger and became more integrated with 
Denver. Smaller farm communities declined as the improved roads made travel to larger; more diversified service centers easier (Colorado Dept. of Local Affairs, 2002). Agricultural mechanization enabled large-scale farm operations resulting in fewer farm laborers and larger, fewer farms.

During WWII, agricultural production was at its highest and Colorado military installations greatly expanded. The war brought many people to the Denver area; afterwards many decided to make Denver home, and new developments continued. After WWII, Denver became the business and financial center of the Intermountain West. The region had shifted from a heavy reliance on mining and agriculture to a more diversified economy with a strong emphasis on the presence of the Federal Government and high-technology and space/telecommunication industries. The biomedical sector became an important high-tech sector; built on the historical migration of people to the area with TB and other respiratory ailments and the resulting pioneering medical advances. Today, the Denver/ Boulder area is a leader in genetic research and home to one of largest concentrations of biotechnology firms in the Nation (Williamson, 1999).

Suburbs were spreading to the north, west (though constrained somewhat by the mountains), and east of Denver, enabled by the construction of several highways in the 1950s. The three major highways were Interstate 25, running north/ south through Denver, Interstate 70 running east/west through Denver, and the Boulder Turnpike connecting Boulder and Denver. In the mid- to late- 1970s and early 1980s, a booming oil and gas industry helped foster another large influx of out-of-state residents into the seven county area. After an economic slowdown in the mid-1980s, urban population growth again sped up, this time fueled by the influx of many high-tech companies and a very strong state economy that attracted many skilled workers. Once more the region has become the crossroads for another type of transportation, in the form of satellite communication and imagery.

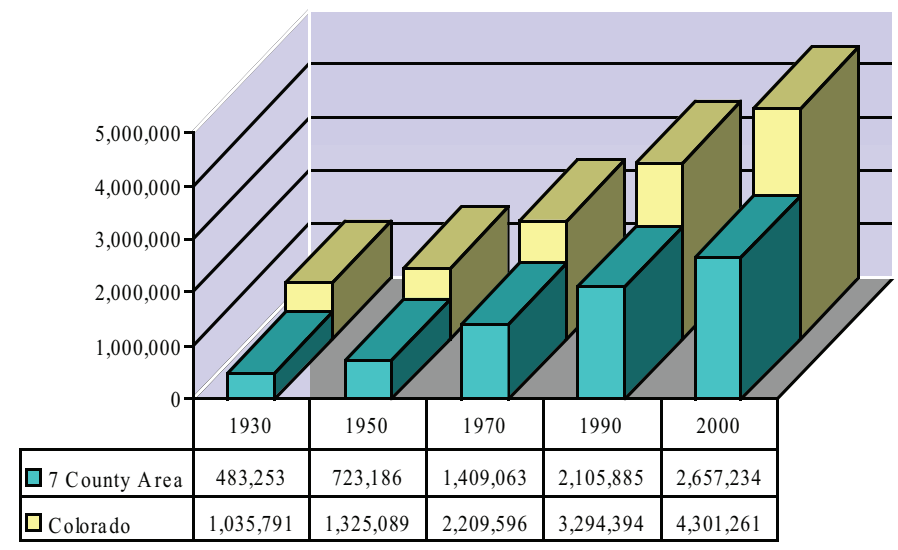

Figure 2. A comparison of the population of the seven-county northern Colorado Front Range region and the entire State of Colorado from 1930 to 2000.

\section{Methodology}

This study selected four time-periods, the mid to late 1930s (1937), the mid to late 1950s (1957), the mid to late 1970s (1977), and the mid to late 1990s (1997), to represent the major growth periods in the region (fig. 3). In the late 1930s were just beginning to recover from the Dust Bowl and Great Depression. The post-WWII patterns, represented by 1957 , found along the Front Range were indicative of the great shifts taking place throughout the country's population and economic activity (Power, 1996). This significant growth along the Front Range set a pattern that continues today. The late 1990s saw a diversification in Colorado's economy, which no longer relied on one or two major industries; it was a time for growth after the economic stagnation of the 1980s.

Aerial photography, obtained from the U.S. Department of Agriculture (USDA) and the USGS, from these time-periods were scanned, rectified, and interpreted into land use and land cover (LULC) classes using a modified Anderson classification. For more details on the methodology and classification system see the metadata file for each time period (USGS, 2001a,b,c,d). The LULC vector polygons were manually collected using an ESRI Arc Info Workstation with the imagery as a backdrop. A minimum mapping unit of 2.5 acres was used. Work was begun with the 1997 imagery and then the interpreters worked backwards through each time-period. Stereo pairs (two overlapping photos that can be viewed with stereoscopic glasses) were used when possible to help identify features. There was a team of two to three operators working on the project, so consistency in interpretation was emphasized over individual conclusion. When there were disagreements, the group was to come to a consensus and then hold to that interpretation. A rigorous accuracy assessment of the temporal LULC data was not possible but a validation of the collection was performed to ensure consistency in the interpretation of the LULC classes for each time period. Unfortunately, the imagery was not coregistered which is crucial when doing temporal studies. The slight misregistration between the images made collection that much harder because the interpreter had to manually shift the polygons to make it match the new image he or she was working on. The change detection program used in this study required raster data. The polygons were rasterized to a 50-meter cell size. The cell size was selected to be compatible with other modeling and analysis on going in the project.

There are many methods of change detection techniques that were summarized in Lu and others (2004), that include image differencing, image ratioing, tasseled cap, and post classification comparison. This project selected to use the thematic change approach to change detection provided by the Erdas ArcView Image v.3.2 Analysis Extension software module. This module creates a new output image documenting every combination of each pixel change from the first image to the second image. For example, if the pixel in the first image (1937) was water, class 1, changed in the second image (1957) to natural vegetation, class 6 , a new class would be generated in the output image, in this case class 15 , representing 
the combined change from class 1 to class 6 . The Thematic Change module also generates a summarization of areas based on either input theme or the output theme in acres, hectares, or square miles. Combining the three change images (1937 to 1957, 1957 to 1977, and 1977 to 1997), interactions between the time-periods can be shown. This ability made it very easy to take this output into a spreadsheet to analyze the data further and generate charts and graphs (ERDAS, Inc., 1998). One of the advantages of this type of change detection when using four time-periods or three time changes is the ability to track
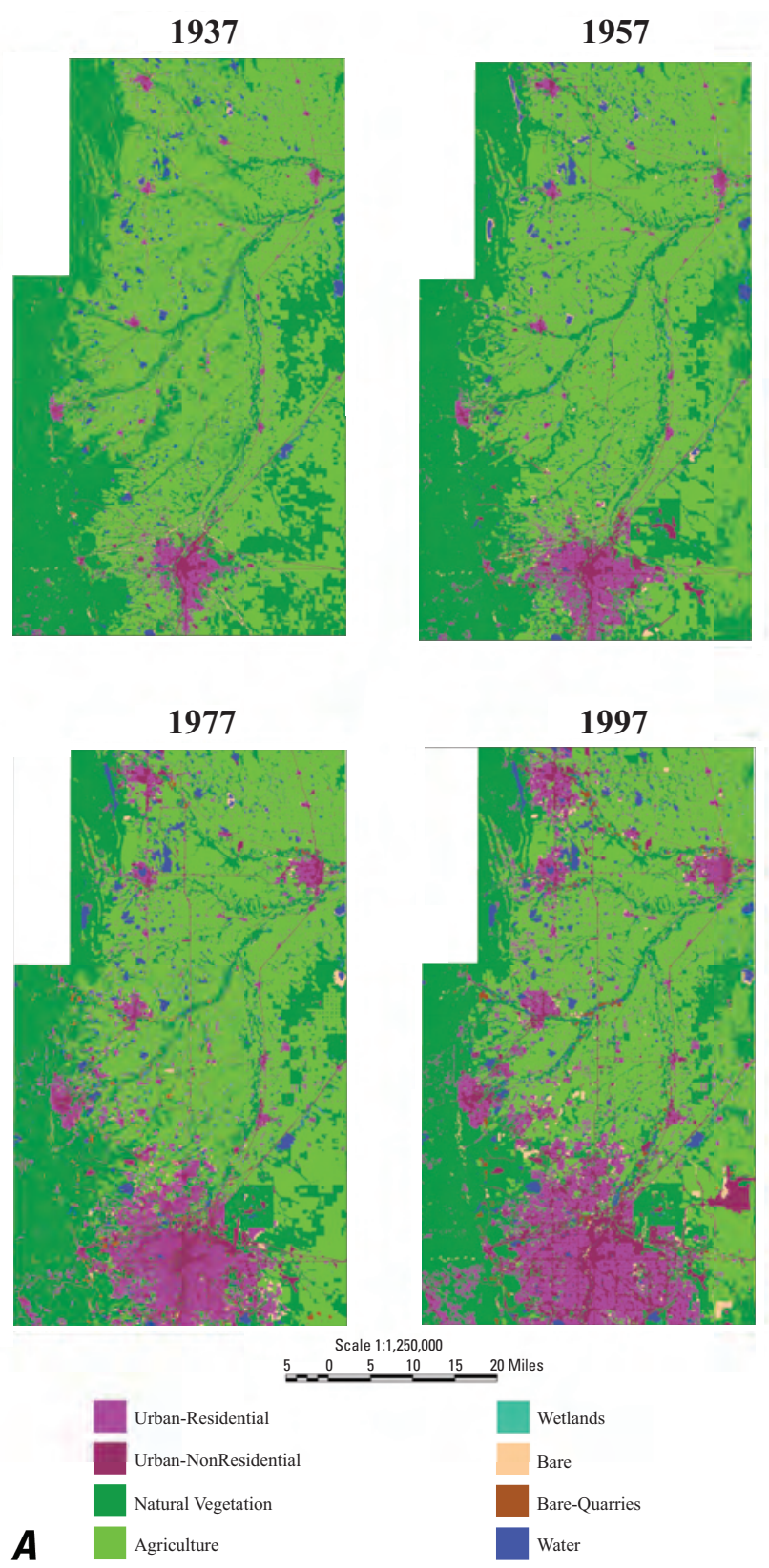

Figure 3. A, Temporal (1937 to 1997) views of landscape cover for the northern Colorado Front Range using Modified-Anderson categories. $B$, Chart showing the distribution of the four major land-cover classes in the northern Colorado Front Range from 1937 to 1997. Natural Vegetation includes the forest, shrub, grassland, and wetland land-cover classes. how pixels or regions have changed. Has a region stayed the same over the 60-year period of the study, how has it changed, or how many times has it changed?

Some strange class transitions were found in the residential and nonresidential classes. Although they accounted for only small percentages, it was unusual to see urban classes switch to either another urban class in the early years and especially to see the switch to the natural vegetation and agricultural classes (table 1). It would be expected to see classes such as natural vegetation and agriculture change to residential or nonresidential but not the other way around. When one encounters figures such as these, it shows that one cannot rely on numeric data alone. One must return to the spatial distribution of the data and ask questions, such as are these anomalies happening in just one area during all time periods or are all the anomalies uniformly distributed? Other questions may be raised by the data itself. We know the imagery was not coregistered, so are we seeing misregistration errors. We also know there was no accuracy assessment done on the data, which we admit would be difficult to achieve with the dates of the imagery, so misclassification could be a cause of the errors. A 50-meter cell size was used for the change detection algorithm. Perhaps a smaller cell size might have provided better results, but these values were relatively small and uniform and could be account for by any of the above suggestions and demonstrate the spatial relationships have an important role in analyzing the landscape.

\section{Land-Surface Analysis}

Four time-periods were used to analyze not only the rates of landscape change over time but also to understand

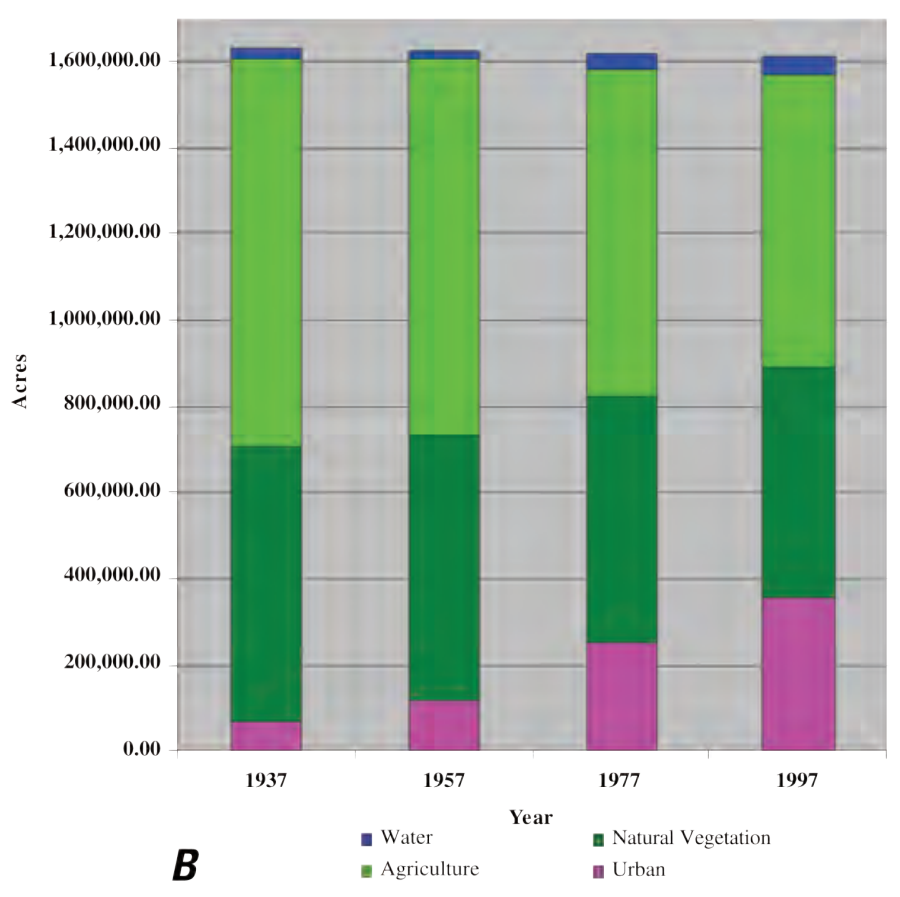


Table 1. Acres of residential and nonresidential land-use and land-cover (LULC) classes and the largest amount of acreage lost for each time-period as compared to amount of acreage lost from natural-vegetation and agriculture LULC classes to residential and nonresidential LULC classes.

\begin{tabular}{|c|c|c|c|c|c|c|}
\hline \multirow[t]{2}{*}{ LULC Class } & \multicolumn{2}{|c|}{$1937-1957$} & \multicolumn{2}{|c|}{ 1957-1977 } & \multicolumn{2}{|c|}{$1977-1997$} \\
\hline & Acres & Percent & Acres & Percent & Acres & Percent \\
\hline Total Residential & $47,148.97$ & $100 \%$ & $76,709.53$ & $100 \%$ & $159,860.64$ & $100 \%$ \\
\hline Residential to & & & & & & \\
\hline Nonresidential & $1,908.27$ & $4.05 \%$ & $5,470.30$ & $7.13 \%$ & $2,117.08$ & $1.32 \%$ \\
\hline Residential to & & & & & & \\
\hline Natural Veg etation & $1,608.66$ & $3.41 \%$ & $2,577.31$ & $3.36 \%$ & $2,572.99$ & $1.161 \%$ \\
\hline Residential to & & & & & & \\
\hline Agriculture & $2,865.80$ & $6.08 \%$ & $3,706.58$ & $4.83 \%$ & $2,918.93$ & $1.83 \%$ \\
\hline Total Nonresidential & $27,319.39$ & $100 \%$ & 43717.84 & $100 \%$ & $97,059.28$ & $100 \%$ \\
\hline Nonresidential to & & & & & & \\
\hline Residential & $1,391.20$ & $5.09 \%$ & $1,051.43$ & $2.24 \%$ & 835.22 & $0.86 \%$ \\
\hline Nonresidential to & & & & & & \\
\hline Natural Vegetation & $1,033.52$ & $3.78 \%$ & $3,101.79$ & $7.10 \%$ & $3,279.09$ & $3.38 \%$ \\
\hline Nonresidential to & & & & & & \\
\hline Agriculture & $2,397.54$ & $8.78 \%$ & $1,052.67$ & $2.41 \%$ & 753.05 & $2.41 \%$ \\
\hline $\begin{array}{l}\text { Natural Vegetation } \\
\text { - no change }\end{array}$ & $503,013.00$ & $79.73 \%$ & $470,916.00$ & $77.12 \%$ & $454,466.00$ & $81.12 \%$ \\
\hline $\begin{array}{l}\text { Natural Vegetation } \\
\text { to Residential }\end{array}$ & $11,297.00$ & $1.79 \%$ & $32,157.70$ & $5.27 \%$ & $28,168.80$ & $5.03 \%$ \\
\hline $\begin{array}{l}\text { Natural Vegetation } \\
\text { to Nonresidential }\end{array}$ & $7,891.31$ & $2.57 \%$ & $22,896.80$ & $6.93 \%$ & $19,063.60$ & $4.20 \%$ \\
\hline $\begin{array}{l}\text { Agriculture - no } \\
\text { change }\end{array}$ & $766,834.00$ & $85.07 \%$ & $692,112.00$ & $79.46 \%$ & $631,805.00$ & $89.90 \%$ \\
\hline $\begin{array}{l}\text { Agriculture to } \\
\text { Residential }\end{array}$ & $23,202.60$ & $2.57 \%$ & $60,382.70$ & $6.93 \%$ & $31,976.10$ & $4.20 \%$ \\
\hline $\begin{array}{l}\text { Agriculture to } \\
\text { Nonresidential }\end{array}$ & $10,975.80$ & $1.22 \%$ & $28,564.10$ & $3.28 \%$ & $23,277.30$ & $3.05 \%$ \\
\hline
\end{tabular}

the dynamics that caused the changes (Marceau and others, 2001). By combining the three change images (1937 to 1957, 1957 to 1977 , and 1977 to 1997), interactions between the time-periods can be shown. The resulting map shown in figure 4 highlights those areas with one LULC class change in light yellow, those areas that changed twice in bright yellow, and those areas that did not change in the standard land cover class colors. Table 2 demonstrates how six random pixels changed in each time period starting in 1937 and tracks those pixels through 1997.

The areas closer to the cities demonstrated two transitions during the three time-change periods, with the exception of the area slightly north east of Denver that is now the location of Denver International Airport. The 1937 LULC data corre- spond to the relatively stable landscape conditions that had not significantly changed since the turn of the century. The 1957 LULC data correspond to the initial growth resulting primarily from wartime and immediate post wartime activities. The 1977 LULC data represent the beginning of the transition from an extractive natural resource- and agricultural-based economy to the high-tech service-based economy driven by the "Colo-

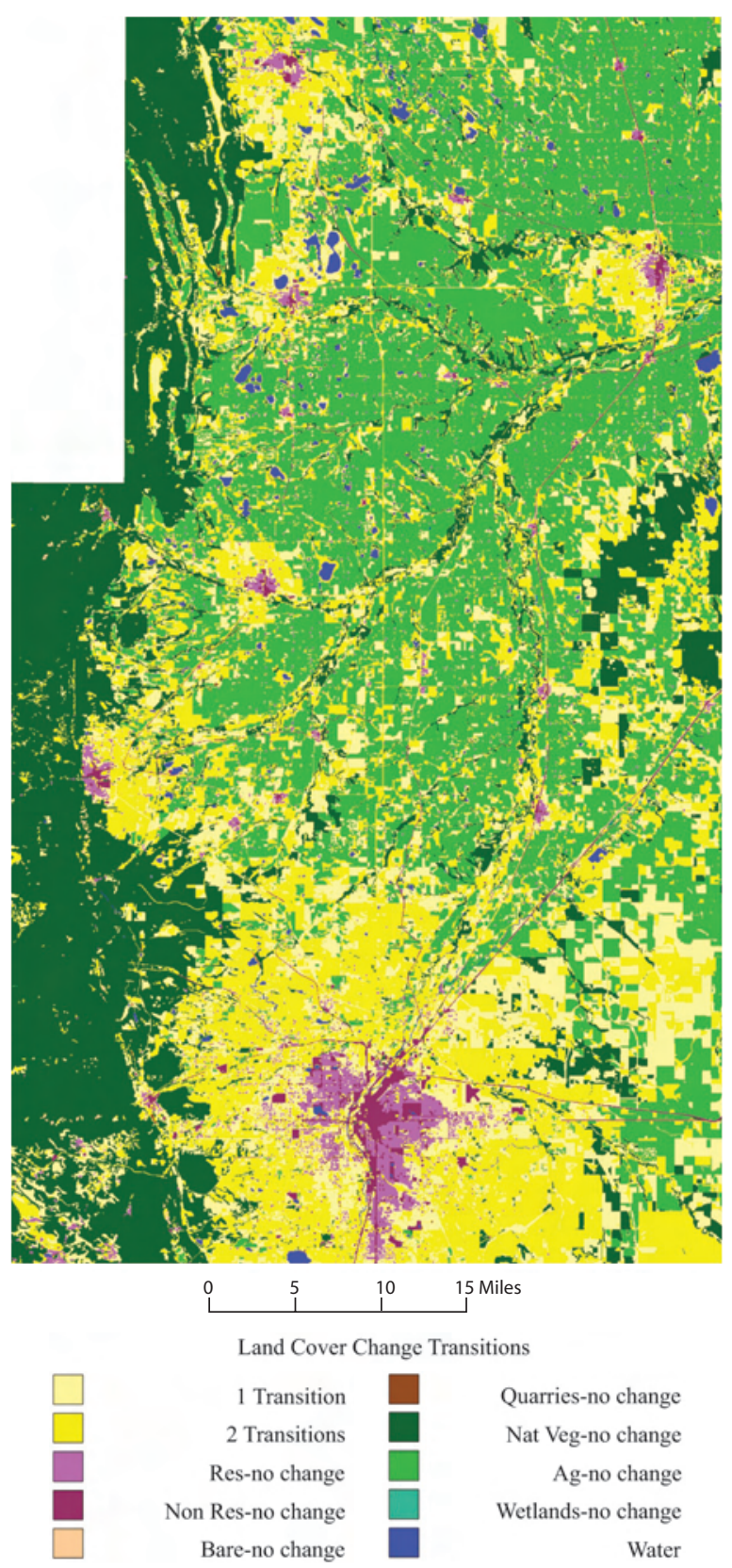

Figure 4. This image shows those areas of the northern Colorado Front Range that have undergone either one or two transitions in the three time change periods (1937-1957, 1957-1977, and 19771997). Transitions are shown in shades of yellow. The areas that have not changed remain in their representative colors shown in the legend, essentially representing the 1937 time period. Res, residential; Nat, natural vegetation; Ag, agriculture. 
Table 2. Demonstration of how six random pixel land-use and landcover (LULC) class values for the northern Colorado Front Range have changed through time and how many changes, if any, the pixels made over time.

\begin{tabular}{|c|c|c|c|c|c|c|}
\hline Year & \multicolumn{5}{|c|}{ Pixel LULC Class Values } \\
\hline & No Change & 1 Change & \multicolumn{3}{|c|}{ 2 Changes } & 3 Changes \\
\hline 1937 & 7 & 6 & 1 & 7 & 7 & 7 \\
\hline 1957 & 7 & 6 & 6 & 7 & 7 & 6 \\
\hline 1977 & 7 & 3 & 1 & 6 & 4 & 7 \\
\hline 1997 & 7 & 3 & 1 & 3 & 2 & 3 \\
\hline
\end{tabular}

Class 1 - Water Class 2-Residential Class 3-Non Residential

Class 4-Bare Class 5-Quarries Class 6-Natural Vegetation

Class 7 - Agriculture Class 8 -Wetland

rado landscape." The last time-period used in this study correlates to the huge boom in high-tech service-based economy that resulted after the last extractive resource (the oil and gas/ energy) economic bust that took place in the early 1980s. As shown in table 2, pixels either do not change their land class value or change their land class values over time. When computing the total number of acres in a class, acres either remain static or are subtracted or added to the land class value. This is demonstrated in table 3.

By the 1930s, the predominant LULC categories were agriculture (55 percent of the landscape) and natural vegetation (39 percent of the landscape). Urban lands only occupied 4.5 percent of the landscape (fig. 5). As the largest city in the region, Denver is the most significant feature on the landscape. Boulder, Fort Collins, and Greeley established themselves as the largest satellite cities in the region (refer back to fig. 4). Surrounding Denver and the larger urban centers are predominantly small, farming and ranching rural communities.

The post-WWII boom was reflected in the significant growth of the suburbs around Denver. Growing urban populations increased the demand to convert forest, grass, and agricultural land to residential, commercial, and industrial uses. The amount of urban land grew by 61 percent to approximately 120,500 acres. The farm and ranch lands in and close to the suburbs continued to change to residential, commercial, and industrial land uses over time (fig. 6).

This transition was enabled by the growing transportation infrastructure demanded by an automobile-centered society and cheaper land prices. The road network expanded by 123 percent with the construction of major highways (Primary routes/Class 1) and residential streets in the new subdivisions (Roads/Class 3) (fig. 7). The majority of the converted urban land radiated out from Denver to the west, south, and east. Urban development north of Denver, in spite of the presence of Interstate 70, an east to west bounding highway north of downtown Denver, was slow due to the traditional manufacturing/industrial emphasis of the area that included the railroad
Table 3. Comparison of total acreage, acreage gained, and acreage lost for each time change period (1937-1957, 1957-1977, 1977-1997).

[The acreage lost is from each change period and class, the acreage gained is from the other land-use and land-cover (LULC) classes from each change period.]

\begin{tabular}{|l|c|c|c|}
\hline \multicolumn{1}{|c|}{ LULC Class } & $\mathbf{1 9 3 7 - 1 9 5 7}$ & $\mathbf{1 9 5 7 - 1 9 7 7}$ & $\mathbf{1 9 7 7 - 1 9 9 7}$ \\
& Acres & Acres & Acres \\
\hline Residential Total & 47148.97 & 76709.53 & 159860.64 \\
\hline Residential Gained & 76641.59 & 159601.69 & 219216.64 \\
\hline Residential Lost & -6516.17 & -11992.03 & -8034.64 \\
\hline Nonresidential Total & 27319.39 & 43717.84 & 97059.28 \\
\hline Nonresidential Gained & 43612.28 & 96718.84 & 138501.34 \\
\hline Nonresidential Lost & -4945.19 & -5611.14 & -5949.68 \\
\hline Bare Total & 6162.19 & 10424.14 & 15586.17 \\
\hline Bare Gained & 8290.38 & 14034.97 & 19734.46 \\
\hline Bare Lost & -3825.81 & -8915.56 & -12740.13 \\
\hline Quarries Total & 1444.95 & 3288.97 & 6912.77 \\
\hline Quarries Gained & 3288.97 & 6841.11 & 8735.79 \\
\hline Quarries Lost & -817.30 & -2189.97 & -4504.73 \\
\hline $\begin{array}{l}\text { Natural Vegetation } \\
\text { Total }\end{array}$ & 630886.32 & 610625.12 & 560271.00 \\
\hline $\begin{array}{l}\text { Natural Vegetation } \\
\text { Gained }\end{array}$ & 607159.93 & 559250.05 & 526640.59 \\
\hline Natural Vegetation Lost & -127873.32 & -139709.12 & -105805.00 \\
\hline Agriculture Total & 901411.97 & 871012.02 & 762109.30 \\
\hline Agriculture Gained & 870549.72 & 761750.66 & 681111.14 \\
\hline Agriculture Lost & -134577.97 & -178900.02 & -130304.30 \\
\hline Wetland Total & 5546.91 & 4714.77 & 5845.89 \\
\hline Wetlands Gained & 2314.76 & 3586.73 & 1897.16 \\
\hline Wetlands Lost & -3261.18 & -2710.13 & -2934.99 \\
\hline Water & & 22778.79 & 36242.92 \\
\hline Water Gained & & & -4253.92 \\
\hline
\end{tabular}

yards, the Denver Stockyards, Stapleton International Airport, and the Rocky Mountain Arsenal. The growth of individual towns closest to Denver on the west was constrained because of their proximity to the mountains. To the east, the presence of Lowry Air Force, Fitzsimons Army, and Buckley Air National Guard bases enabled Aurora to expand, converting large tracts of grass and ranch lands to subdivisions and associated services. Individual towns merged to form a continuous Denver metropolitan mass. 


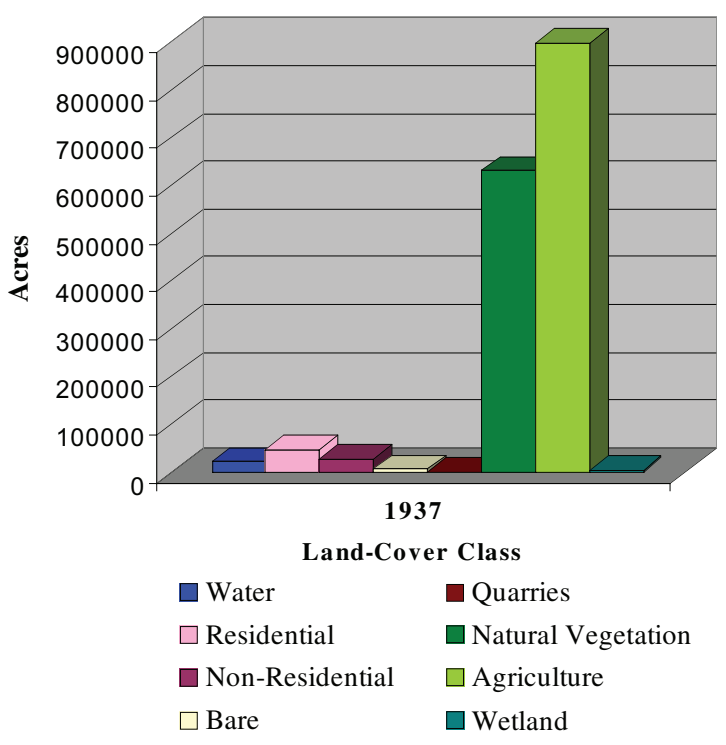

Figure 5. This chart shows the distribution of the landuse and land-cover classes for the northern Colorado Front Range in 1937. It is quite evident that agriculture and natural vegetation (used for grazing) were still the major classes.

In the $1970 \mathrm{~s}$, the amount of urban land more than doubled to 104,008 ha $(257,000$ acres $)$. The land continued to change from agricultural (loss of 6.6 percent) and grass (loss of 3.3 percent) lands to urban land uses (fig. 8). To the north, the towns of Boulder, Fort Collins, Greeley, Longmont, and Love-

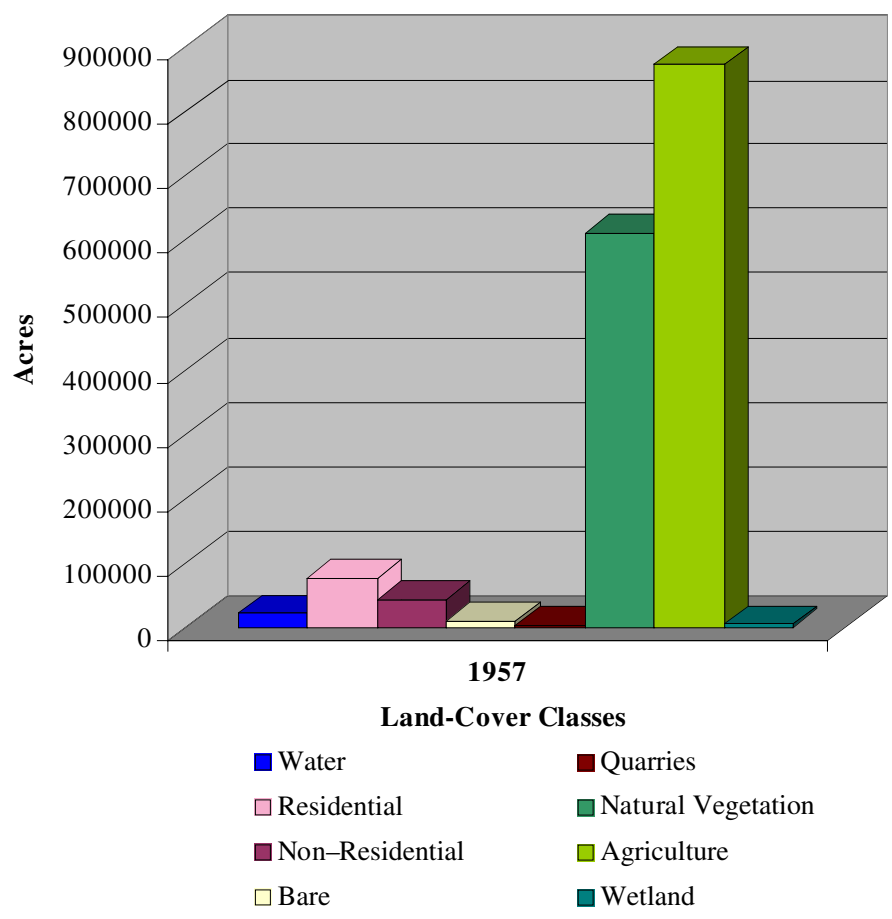

Figure 6. This chart shows the distribution of the land-use and landcover classes for the northern Colorado Front Range in 1957. It is quite evident that agriculture and natural vegetation (used for grazing) were still the major classes.

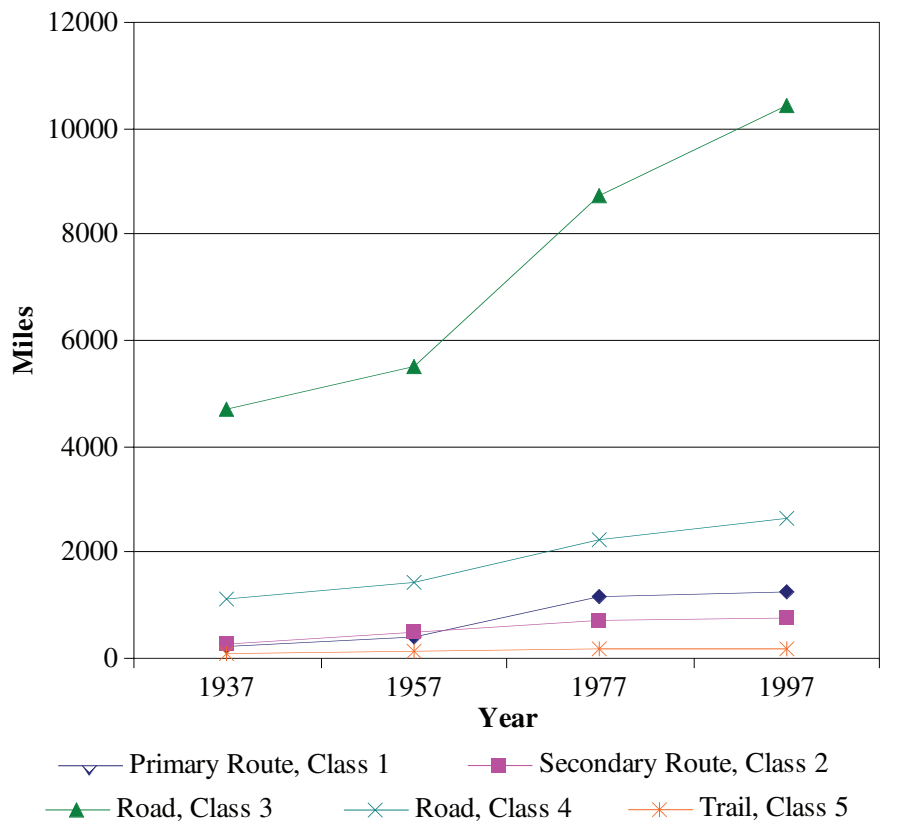

Figure 7. The total road mileage by road class for the northern Colorado Front Range for each time period studied (1937-57, 1957-77, 1977-97). The road class in green (road, class 3 ) represents residential and other similar size streets.

land were expanding, the results of the improved transportation networks and the arrival of high-technology industries. The area around Boulder is unique in the Front Range. Boulder enacted growth control measures in the 1970s that slowed

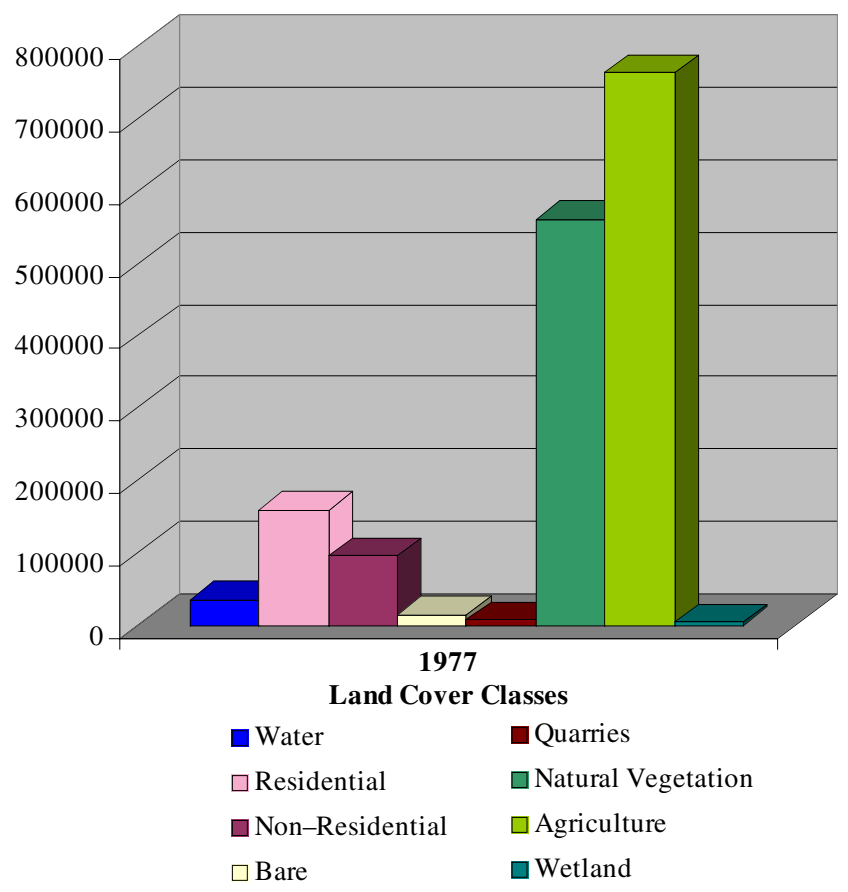

Figure 8. Chart showing the distribution of the land-use and land-cover classes for the northern Colorado Front Range in 1977. It is quite evident that agriculture and natural vegetation (used for grazing) were still the major classes, but the urban class areas are beginning to show an increase. 
down the rate of growth, while the bordering towns of Lafayette and Louisville began to grow (fig. 9A). The slowdown in the traditional agricultural- and mining-based economies was reflected in the trend of static population growth in the rural towns, such as Berthoud, Erie, Frederick, and Timnath. By 1977, the metropolitan area started to expand northward, due to the decline and replacement of the traditional manufacturing and agricultural base. The populations of these towns show a slow rise in the 1980 s with dramatic increases by 2000 . The population increases are due to the rise of service-base industries, cheaper land values, and small-town atmospheres of safety and low living costs (fig. 9B) (Clark, 2000, Kendall, 2002).
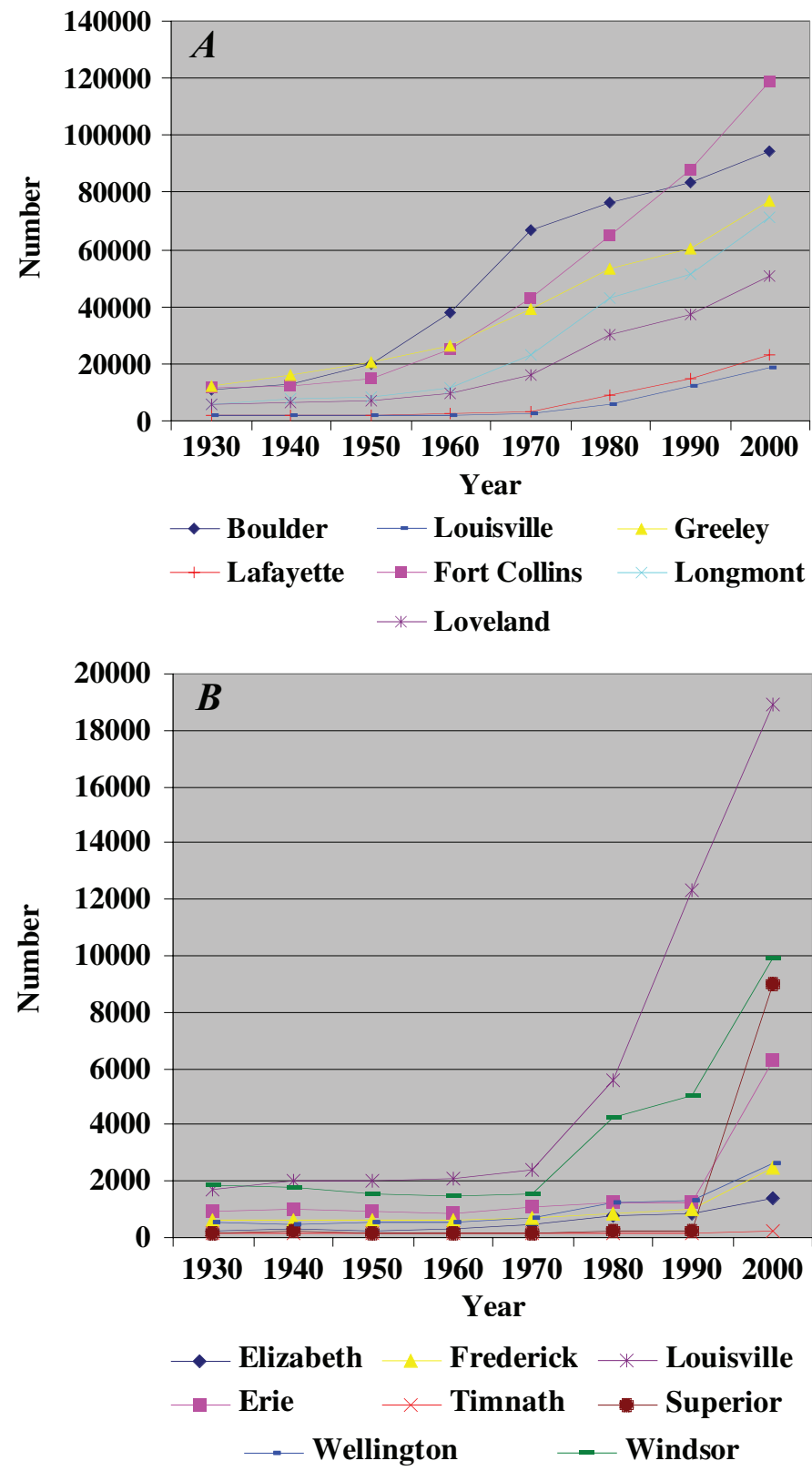

Figure 9. $A$, Graph showing the nonmetropolitan Denver area cities populations, 1930-2000. B, Graph showing selected rural town populations in the northern Colorado Front Range from 1930-2000.
Urban development to the southwest and south of Denver also started in the 1980s, though hampered by a lack of major highways. Cheaper land prices were becoming a major enabling factor of urban growth. As the northward migration began, the smaller communities of Brighton and Fort Lupton, to the northeast between Denver and Greeley, were seeing some growth. This pattern is an example of the leapfrog effect that takes place along transportation corridors.

There are environmental and social implications for the change of highly valued "open spaces" to urban development (Governor's Commission on Saving Open Spaces, 2000. Theobald and Hobbs 2002. Theobald and Hobbs, 2000. Cornelius, 1999). These open spaces include areas of natural vegetation (forests, grasslands, and wetlands) and agricultural lands that offer rich habitats for many different species as well as the amenities valued by the people. Though few in acreage when compared with the entire study area, wetlands are a good example of the effect that other land covers had on open spaces over the study time-period. The overall acreage total has remained relatively stable but the distribution on the landscape has changed (fig. 10A). In addition, there are other transformations resulting from urban growth with environmental implications (Matheny and Wear, 2000). An example of a consequence of urban growth in the semiarid Front Range region is demonstrated by the growing trend of changing wetland LULC class and associated with the wetlands is the increase in area in the water and quarry LULC classes. Though only comprising a small percentage of the overall landscape, each of these features together portrays a land demanding the raw resources required to support urban growth (especially in semiarid to arid regions) — raw building materials (aggregate) and water (fig. 10B).

Of the original 5,500 acres of wetlands mapped in 1937, approximately 41 percent (2286 acres) of the area has remained wetlands while the other 59 percent (3,261 acres) has changed to other LULC classes in 1957 (primarily natural vegetation, agriculture, and water). At the same time, wetlands gained approximately 42 percent $(2,315$ acres) of the area from other LULC classes, primarily from natural vegetation, agriculture, and water (fig. 10C). In the later years, 1977 on, a possible reason for this change is the legal requirement under section 401 of the Clean Water Act to replace wetlands that had been converted to other uses. Between 1937 and 1997 , approximately 17,000 acres of land were converted to water, almost doubling the amount of acres in that class. The movement of the aggregate industry and subsequent reservoir development can be tracked with the temporal data. The large numbers of these reservoirs are the result of a lack of other quarry reclamation efforts and now meet the demand for water by agriculture and the urban centers (Arbogast, 2001). Other larger reservoirs such as Chatfield, Cherry Creek, and Bear Creek Reservoirs were built for flood control along the South Platte River Valley or as part of western slope diversion projects (Horsetooth Reservoir) for irrigation, drinking water, and hydropower generation. The largest land-cover contributors to this transition were natural vegetation, agriculture, and bare 

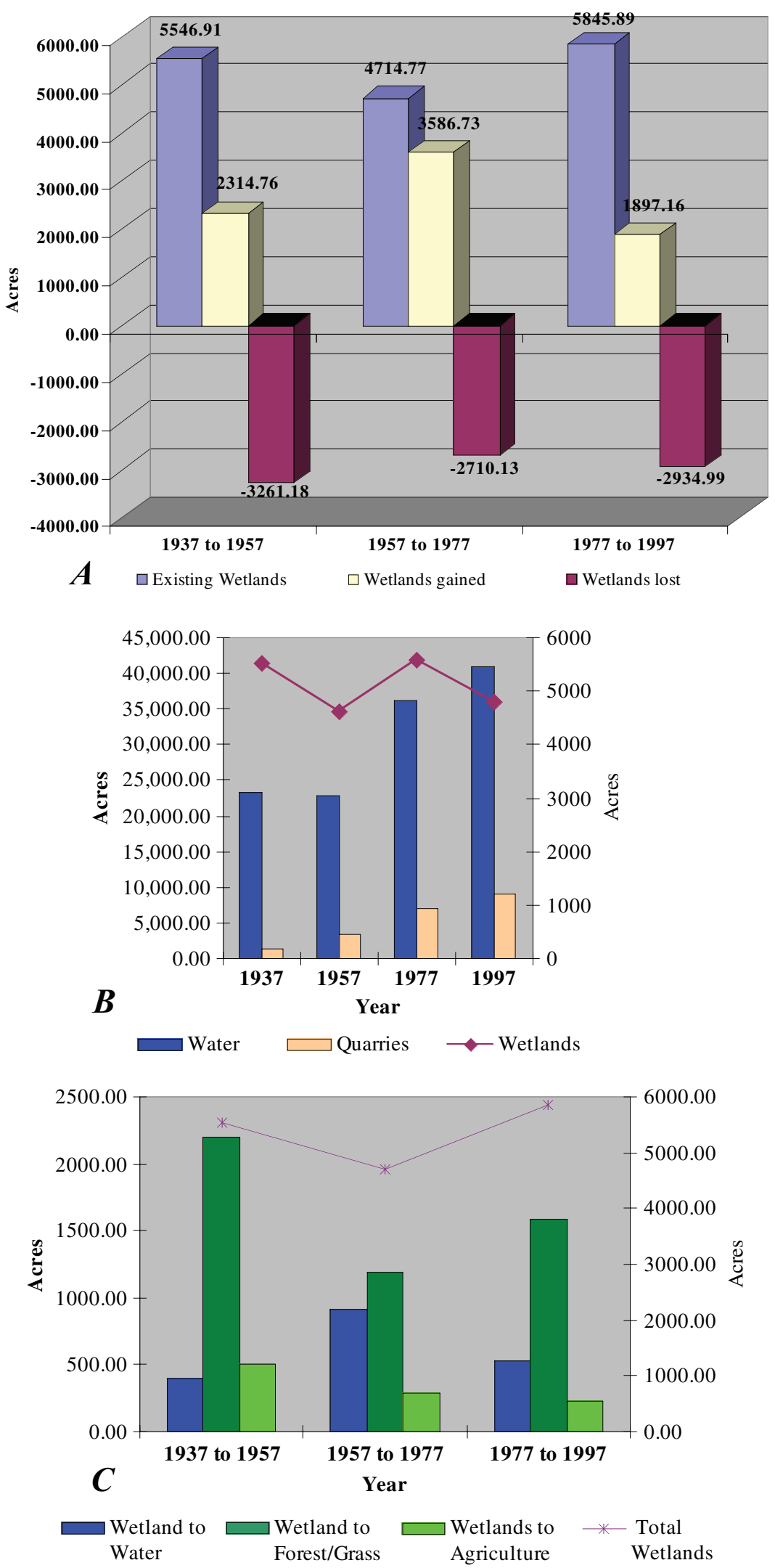

Figure 10. $A$, Chart showing total existing acres of wetlands, acres lost to other land covers, and acres gained from other land-use covers for the three time periods studied for the northern Colorado Front Range. $B$, Comparison of transitions of wetlands, water, and quarry land-cover classes because of urban growth. $C$, Comparisons of key land-cover conversions of wetland cover class. 
classes. Besides the urban LULC class, the water and bare classes were the only classes in the region to actually increase in size rather then decrease. This trend contributes to the trend of the region more and more urban.

The 1990s typified the changing social and economic drivers behind the contemporary landscape dominating the landscape on urban fringes. While the landscape patterns are easy to characterize (fig. 11), integrating socioeconomic data, such as land ownership behavior, transportation-related characteristics, and population dynamics, will be of most value to planners and land managers as they deal with the multiple demands placed on the landscape. In the case of the Front Range, the Colorado lifestyle and emphasis on open spaces and high-tech industries are the principal enablers behind the changing landscape.

This combination of the physical and human environment demonstrates the need to integrate both the socioeconomic and environmental data with the spatiotemporal description of the landscape. The region has moved from an economy reliant on natural resources (extractive minerals and agriculture) to an economy strongly influenced by the high tech and other service-based industries (Bird, 1993. Kendall, 2002). Today, these industries are not driven by the proximity to a natural resource or transportation hub but rather the proximity to the amenities that will entice and retain employees, such as those found along the Front Range and the West (Shumway and Otterstrom, 2001, McGranahan, 1999, Nelson, 1999, Rudzitis, 1999, Vias, 1999).

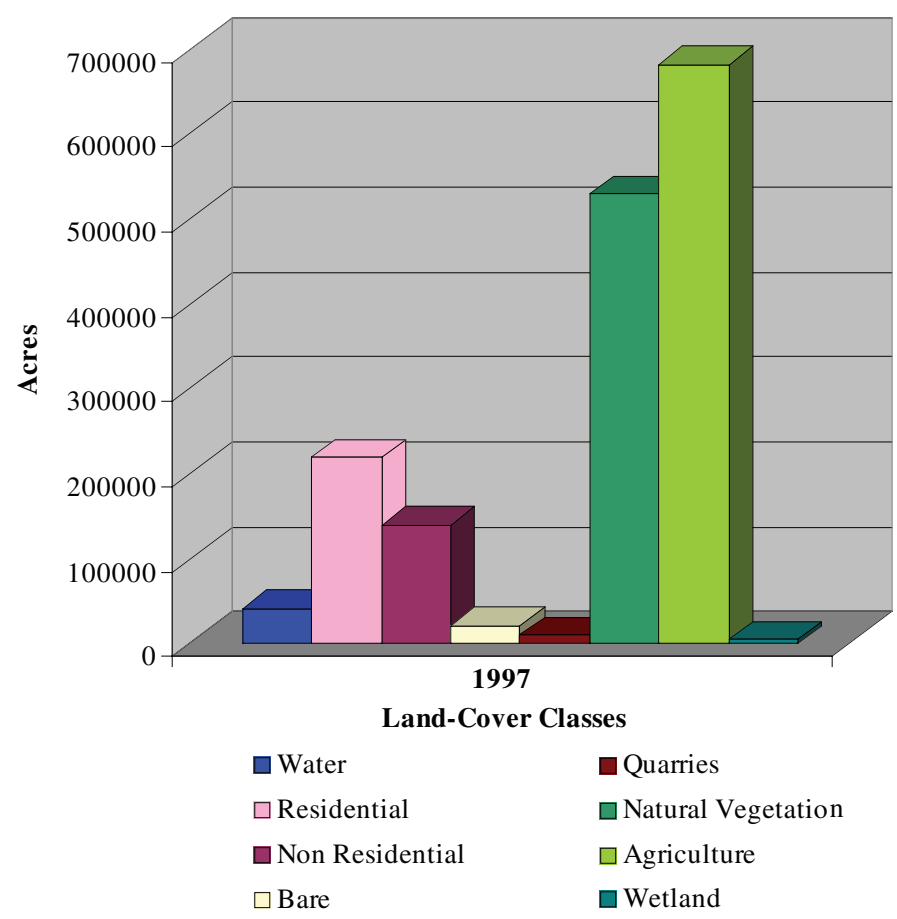

Figure 11. Chart showing the distribution of the land-use and land-cover classes for the northern Colorado Front Range in 1997. Agriculture and natural vegetation are still the major land classes, but those acreages are falling and the urban and water classes acreages continue to grow.
An interesting characteristic of the urban growth in the region can be seen in the migration patterns exhibited on the landscape. The desire to be in or close to open space has become a driving factor for the current and future landscape transformations. James Weskott, Colorado State demographer, has suggested in a Denver Post study, that employment considerations and Western attitudes have combined to produce the growth patterns (Olinger, 1999). People from out of state tend to locate in established areas where jobs are more plentiful, creating a demand for housing and driving up housing costs. As these areas become denser and housing more unaffordable, many current Colorado residents move out into the edge suburbs and into the countryside where the housing costs are typically lower. As more out-of-state people move in, current residents move out and the amount of urban acres grows.

Another growing migration trend that became apparent in the late 1970s and has greatly increased in the 1990s is the move to the mountains. Bountiful land on the plains has kept urban growth concentrated in lands under 10 percent slopes. Once again, the growing desire to be closer to nature and in open space is resulting in a move into the mountain foothills west of the urban centers. The mountain communities west of Denver and Boulder are all experiencing growth. Areas of summer homes have given way to year-round dwellers. The mountains constrained urban development in the past, but no more, today they act as a driving factor for attracting people (fig. 12).

\section{Conclusions}

The landscape of the United States is constantly changing. The rates, causes, types, impacts, and extents of change

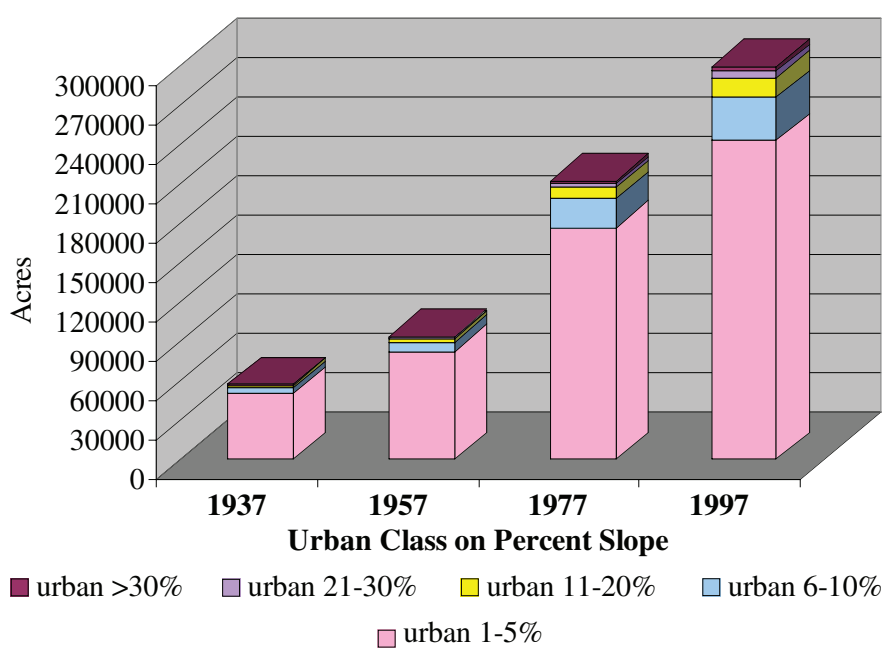

Figure 12. Chart combining the area of urban land cover with percentage of slope shows the movement of people into the mountains to the west in the northern Colorado Front Range. The trend of mainly summer homes in the 1930s and 1950s was changing into year-round residences starting in the 1970s and continuing through the present. 
vary from place to place. Local changes in land use can have a ripple effect throughout a larger region. Expanding urban areas are placing multiple and often competing demands on the land. Understanding and analyzing the rates, trends and drivers behind landscape change are essential to help answer fundamental questions asked by not only scientists but also planners and land-management decisionmakers. Change detection, the understanding of both the time and space, remains at the heart of many of these questions (Marceau and others, 2001). Temporal, geospatial databases coupled with socioeconomic data in models can provide an understanding to the dynamics occurring through time that causes landscape change. By understanding the dynamics of landscape change, urban and regional planners, policymakers, and Earth scientists can effectively measure trends in urban expansion, analyze patterns of water pollution and sedimentation, understand the impacts of development on ecosystems, or develop predictive modeling techniques to better simulate the effects of future urban growth. The analysis of the changing landscape of the Front Range will not only help local and regional decisionmakers but may also be used to simulate the future landscape of the West. The dynamics that shaped the Front Range have already been put into motion and could herald similar changes in regions in the West that are just beginning to experience growth.

Improved decisionmaking can be aided by understanding not only the rates and trends of landscape change but also the causes behind the change and the consequences of land-development decisions. Forty percent of the future growth in the United States is expected in the eight Rocky Mountain West states. The Denver metropolitan area is expected to experience the bulk of this population growth (Clark, 2000). This study begins to look at the rates, trends, and general causal factors that shape the Colorado Front Range landscape. A better understanding and integration of quantitative socioeconomic influences is needed. This study has shown that human actions, such as population change, are the primary cause in landscape change along the Front Range.

Growing populations will continue to see the transition from agricultural, grass, and forest lands to a more human dominated landscape. The cycle of people wanting to live on the urban fringe continues to shape the urban landscape. As the region grows, there is an outmigration of those who feel crowded and this in turn causes urban growth to occur at the urban fringe. The checkerboard development pattern and subsequent fragmentation of farm and ranch land are soon filled in with other homes and the desired amenities of the urban environment. Low-density ranchette developments become the new suburban town, and what were isolated farm communities expand and join to become part of the growing metropolitan area. The northern Colorado Front Range is becoming more urban as the region is becoming the center of growth in the Rocky Mountain West.

This study sets the stage for further development into techniques and metrics for assessing landscape change (Mladinich and others, 2003). Future urban growth simulations can be derived and assessments made with the integration of socioeconomic and environmental information in a spatiotemporal context. This understanding can help planners and land managers make informed decisions regarding the balancing of the multiple demands being placed on the landscape and natural resources. Scientists may also have a better understanding of the effects of such issues as climate change and air and water quality.

\section{Acknowledgments}

Stacy Welding, Orkand Corp., Stewart Wright and Rick Poss, Rocky Mountain Geographic Science Center, and Chad Owens, USGS Volunteer for Science, University of Colorado, Boulder.

\section{References}

Arbogast, B., Knepper, D.H., Jr., Melick, R.A., and Hickman, J., 2001, Reading, remembering, and reshaping the past-Clear Creek, Colorado, in Kuula-Väisänen, P., and Uusinkoa, R., eds., Proceedings, Aggregate 2001Environment and Economy, Helsinki, Finland, August 6-10, 2001: Tampere University of Technology, Laboratory of Engineering Geology, Publication No. 51, v. 2, p. 371-376.

Bird, M., 1993, The economic development of Colorado in historical perspective: Golden, Colo., Independence Institute, June 4, 1993, Issue Paper 17-93, 13 p.

Clark, T.A., 2000, Auguring the Future of Rural Communities in the New West-Patterns and Prospects of Nonmetropolitan Industrial Change in Fast-growing Areas of the Non-metropolitan Mountain West, 2000, Proceedings: Association Collegiate Schools of Planning, Atlanta, Georgia. p. 1-34.

Colorado Dept. of Local Affairs-Demography Section, 2002, Historical census population for counties and municipalities 1870-2000: Denver, Colo., Colorado Dept. of Local Affairs [http://dola.colorado.gov/demog/history/allhist.cfm; accessed May 15, 2003)].

Cornelius, C., 1999, Growth an inescapable topic: Denver, Colo. The Denver Post, July 19, 1999. p. D-12.

ERDAS, Inc., 1998, Working with ArcView Image Analysis Extension, Atlanta, p. 9-1 to 9-10.

Governor's Commission on Saving Open Spaces, Farms, and Ranches, 2000, Colorado's legacy to its children: [http:// www.state.co.us/issues/open_space8.pdf; accessed October 20, 2003)].

Hobbs, N.T., Theobald, D.M., Zack, J.A. Bearly, T.L., Riebsame, W.E. and Shenk, T., 1997, Forecasting Impacts of Land Use Change on Wildlife Habitat - Collaborative Development of an Interactive GIS for Conservation Planning: Natural Resource Ecology Laboratory, Colorado State University [http://ndis.nrel.colostate.edu/scop/ 
SCoPwww.html; accessed November 2, 1999)].

Kendall, W.D., 2002, A brief economic history of Colorado:

Denver, Colo., Center for Business and Economic

Forecasting, Inc., $23 \mathrm{p}$.

Lu, D., Mausel, P., Brondízio, E., and Moran, E., 2004, Change detection techniques: International Journal of

Remote Sensing, v. 25, no. 12, p. 2365-2407.

Marceau, D.J., Guindon, L., Bruel, M. and Marois, C., 2001, Building temporal topology in a GIS database to study the land-use changes in a rural-urban environment: The Professional Geographer, v. 53, no. 4, p. 492-502.

Matheny, R.W., and Wear, D., 2000, Logistic regression techniques applied to pixilated land use change modeling, in 2000 Urban and Regional Information Systems Association Annual Conference Proceedings: Orlando, Fla. 12 p.

McGranahan, D.A., 1999, Natural amenities drive rural population change: Food and Rural Economics Division, Economic Research Service, United States Department of Agriculture, Agricultural Economic Report 781.

Mladinich, C.S., Welding, S.L., and Owens, C.C., 2003, Systems-approach to Landscape Analysis and ModelingThe Northern Colorado Front Range Example: Poster and paper presented to the $99^{\text {th }}$ Annual Association of American Geographers Conference, 5-9 March, 2003, New Orleans, Louisiana.

Nelson, P.B., 1999, Quality of life, nontraditional income, and economic growth-New development opportunities for the rural west: Rural Development Perspectives. v.14, no. 2, p. 32-37.

Olinger, D, 1999, Growth in the '90s: Denver, Colo., The Denver Post. February 7, 1999, p. A-1, 20-22.

Power, T.M., 1996, Lost Landscapes and failed economiesThe search for a value of place: Washington, D.C., Island Press, 304 p.

Rasker, R., 1993, Rural development, conservation, and public policy in the Greater Yellowstone Ecosystem: Society and Natural Resources, v. 6, p. 106-126.

Rasker, R., 1994, A new look at old vistas-The economic role of environmental quality in Western public lands: University of Colorado Law Review, v. 65, no. 2, p. 369399.

Rudzitis, G., 1999, Amenities increasingly draw people to the rural West: Rural Development Perspectives, v. 14, no. 2, p. 9-13.

Shumway, J.M., and Otterstrom, S.M., 2001, Spatial patterns of migration and income change in the Mountain WestThe dominance of service-based, amenity-rich counties: The Professional Geographer, v. 53, no. 4, p. 492-502.

Theobald, D.M., and Hobbs, N.T., 2002, A framework for evaluating land use planning alternatives - Protecting biodiversity on private land: Conservation Ecology, v. 6, no.1, p. 5. [http://www.consecol.org/vol6/iss1/art5].

Theobald, D., and Hobbs, N.T., 2000, A Comparison of Databases for Modeling Rural Land Use Change: Banff, Alberta, Canada, 4th International Conference on Integrating GIS and Environmental Modeling (GIS/EM4) Problems, Prospects and Research Needs, September 2-8, 2000.

U.S. Geological Survey, 2001a, High-Resolution Land Use and Land Cover 1937/1938 Front Range Infrastructure Resources Project Demonstration Area, Rocky Mountain Mapping Center, Lakewood, Colo: [http://rockyweb. cr.usgs.gov/frontrange/NMD/data/lu30.html (metadata) and http://rockyweb.cr.usgs.gov/frontrange/NMD/data/lu30.e00 (data)].

U.S. Geological Survey, 2001b, High-Resolution Land Use and Land Cover 1953-1958 Front Range Infrastructure Resources Project Demonstration Area, Rocky Mountain Mapping Center, Lakewood, Colo: [http://rockyweb.cr.usgs. gov/frontrange/NMD/data/lu50.html (metadata) and http:// rockyweb.cr.usgs.gov/frontrange/NMD/data/lu50.e00 (data)].

U.S. Geological Survey, 2001c, High-Resolution Land Use and Land Cover 1977/1978 Front Range Infrastructure Resources Project Demonstration Area, Rocky Mountain Mapping Center, Lakewood, Colo: [http://rockyweb. cr.usgs.gov/frontrange/NMD/data/lu70.html (metadata) and http://rockyweb.cr.usgs.gov/frontrange/NMD/data/lu70.e00 (data)].

U.S. Geological Survey, 2001d, High-Resolution Land Use and Land Cover 1996/1997 Front Range Infrastructure Resources Project Demonstration Area, Rocky Mountain Mapping Center, Lakewood, Colo: [http://rockyweb.cr.usgs. gov/frontrange/NMD/data/lu90.html (metadata) and http:// rockyweb.cr.usgs.gov/frontrange/NMD/data/lu90.e00 (data)].

U.S. Geological Survey Front Range Infrastructure Resources Project, 2002, Planning for the Conservation and Development of Infrastructure Resources in Urban AreasColorado Front Range Urban Corridor: U.S. Geological Survey Circular 1219.

United States National Park Service, 2004, Zebulon PikeHard-Luck Explorer or Successful Spy?: [http://www.nps. gov/jeff/LewisClark2/Circa1804/WestwardExpansion/ EarlyExplorers/ZebulonPike.htm\#top; accessed February 8, 2004].

Veblen, T.T., and Lorenz, D.C., 1991, The Colorado Front Range; a century of ecological change: Salt Lake City, Utah, University of Utah Press, 186 p.

Vias, A.C., 1999, Jobs follow people in the rural Rocky Mountain West: Rural Development Perspectives, v. 14, no. 2, p. 14-23.

Williamson, R., 1999, 10 events that helped make Denver business what it is today: Denver, Colo., Rocky Mountain News, October 31, 1999, p. $1 \mathrm{G}$.

Wyckoff, W., 1999, Creating Colorado_-The making of a western American landscape, 1860-1940: New Haven, Conn., Yale University Press, 336 p. 


\title{
A 30-Year Study of Urban Dynamics for the Municipality of Anchorage, Alaska, 1970-2000
}

\author{
By Carl J. Markon ${ }^{1}$
}

\section{Introduction}

For most urban areas, development of local economies is driven by a number of factors, including (1) transportation networks to and from other urban, non-urban (natural lands), or industrial areas, (2) population increases (both in terms of local birth rates and influx from other areas), and (3) the amount of available land for development. In northern, more boreal or remote communities, however, development is often driven by boom and bust economic cycles, such as gold discovery (Yukon and Nome gold rush), mining of rare elements or metals (diamonds near Yellowknife, Northwest Territories, Canada), or fossil fuels (oil discovery at Prudhoe Bay, Alaska). To a lesser extent, albeit becoming more important, the easy access to areas for recreation or tourism (Denali National Park) is also significant. In many of the larger metropolitan areas, urban expansion is currently facilitated by easily accessible land, that is, relatively level forested, agricultural, or arid areas (for example Chicago, Phoenix, and Los Angeles). The ultimate result of urbanization is the loss of natural vegetation, open space, and agricultural lands (Wear and others 1998), a decline in wetlands and available wildlife habitat, encroachment of recreational areas, a decline in ground water availability and surface water quality (Booth and Jackson, 1997; Ourso, 2001), and additional impacts on human health and psychological well being (Horowitz, 2002). With increased urban expansion to the park and forest boundaries, wildlifehuman interactions are becoming increasingly common, most often to the detriment of the wildlife.

The Municipality of Anchorage is a northern latitude urban area that has experienced a number of boom and bust cycles, each serving to provide periods of growth and quiescence. Its political extent covers approximately $4,370 \mathrm{~km}^{2}$ of land; however, its border includes areas of water to the west and south $\left(684 \mathrm{~km}^{2}\right)$, and rugged mountains to the east (fig. 1). Although Anchorage issurrounded by vast areas of undeveloped land, the Alaska Department of Natural Resources, Division of Parks Recreation, Bureau of Land Management (BLM), and the U.S. Forest Service administer the vast majority of these lands within the municipal boundary to the east, and the presence of two military bases further limit the usable

${ }^{1}$ U.S. Geological Survey, Alaska Science Center, 4230 University Drive, Anchorage, AK 99508-4664, email: markon@usgs.gov. space for growth and development. Expansion of the municipality, therefore, is beginning to reach a critical stage were development will become more restricted in some areas (that is, small lot size and more dense housing) and expanding into other areas that are less conducive to building (on steeper slopes or in areas that have a further commuting distance).

To document the expansion of the Municipality of Anchorage from its core urban area (areas prone to greatest development) to less developed surrounding lands (areas of steeper terrain at the edges of recreational and multi-use lands) and speculate on the future of this northern boreal urban area, a study to document the recent historical development and subsequent expansion of the urban environment was made, spanning 30 years. This was accomplished by mapping increases in urban sprawl over the Municipality using aerial photography and satellite data at roughly 10 -year intervals from the early 1970 s to 2000 . From this data, a composite record can be made about the effects urban sprawl had on the local ecosystem and what future effects may result if the current growth trends continue in the area.

\section{Historical Background}

The initiation of Anchorage as a hub of urban activity began in 1915 when President Woodrow Wilson authorized funds for the construction of the Alaska Railroad. The engineering headquarters were set up at the mouth of Ship Creek, creating an ocean- accessible locus for construction-related activities. By the late 1920's, the population reached 2,700, and by 1940 it had nearly doubled with most activities occurring along the creek and on the southern bluff. With the United States pending involvement in World War II, the population of Anchorage saw growth resulting primarily from the arrival of military personnel and an increase in the civilian population for construction activities on the newly activated Elmendorf and Fort Richardson bases. The influx of defense dollars continued into the $1950 \mathrm{~s}$, and with it, the population, increasing fivefold to more than 30,000.

By the start of the 1960s, Anchorage was experiencing a steady increase in population that continued into the $1970 \mathrm{~s}$ (fig. 2; Municipality of Anchorage, 2000) due to a Cold War military build up and the presence of an over-the-pole refueling airport (Anchorage International Airport). In the early 1970s, the speculation of oil development created jobs and the immigration of people, especially those associated 
with the development of the Prudhoe Bay oil fields and the Trans-Alaska Oil Pipeline. Anchorage, being the largest metropolitan area in the State, and the center of both railroad, airline, and shipping facilities, saw a steady and sometimes dramatic increase in population, office space, and housing. At about the same time, a major influx of government personnel occurred because of the Alaska National Interest Lands Conservation Act, when vast areas of land were turned over for management by different Federal land management agencies. This precipitated an increase in Federal employees into the state, followed by a commercial and residential building boom to house them. Between 1973 and 1977, new housing units (single family, duplex, and multifamily) authorized for construction increased by more than 2,800 units (Municipality of Anchorage, 1989). This did not last long, however, as a slight economic slowdown followed the completion of the Trans-Alaska Pipeline in 1976.

During the 1980s, the economy picked up again because of a number of infrastructure development activities that arose from a relatively dramatic increase in statewide funds due to

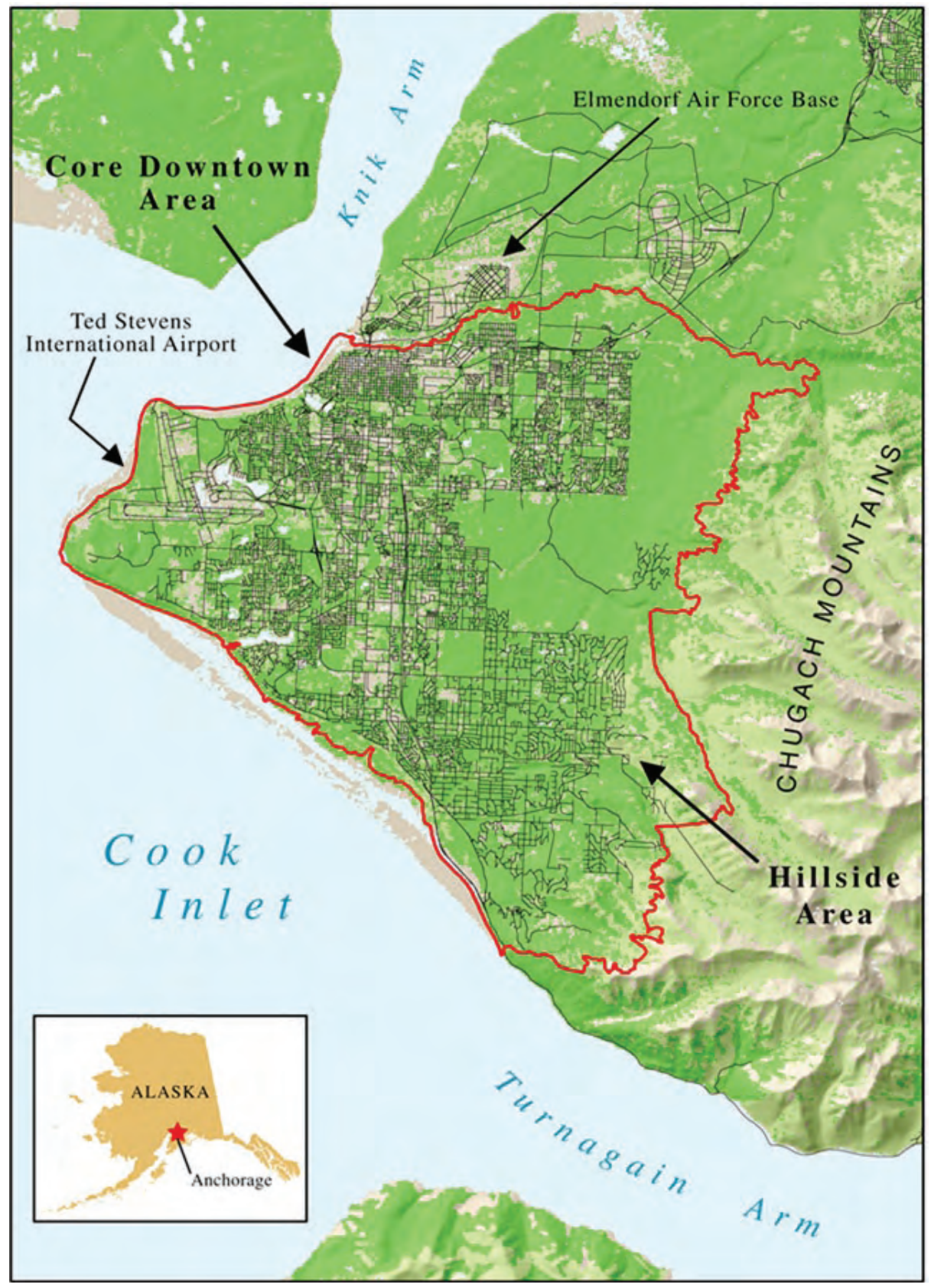

Figure 1. Location and extent of the Municipality of Anchorage study area (red outline). 
taxes on the new export oil commodity. During this time, the Municipality of Anchorage initiated its Project 80's program, a multiyear period that resulted in a new convention center, performing arts complex, and a sports arena. In addition, the prospects of new grain exports (barely), the construction of a coal loading dock in Seward, 90 miles south of Anchorage, and new oil field developments on the Arctic Coastal Plain fueled urban expansion throughout the city. Between 1980 and 1987, nearly a billion dollars worth of capital projects were initiated or completed in Anchorage. These events created another brief economic boom in 1983 that increased the number of commercial businesses in the city and the authorization of over 9,000 new housing starts (Municipality of Anchorage, 1989). As the major construction projects came to an end and oil prices dropped, the economy started to collapse by 1987, resulting in a slight efflux of people from the area.

This was also reflected in the number of new housing starts, as indicated by the number of approved permits for new houses, ultimately falling to a low of 208 by 1988 .

Toward the end of the 1980s, a local economic recession resulting from declining oil prices and the end of major infrastructure construction brought a significant slowdown to both commercial and residential development. During this time, many businesses went defunct and numerous parcels cleared for development remained barren or were revegetated by shrubs, although a small amount of urban development did occur, resulting in a four percent increase in urban sprawl.

The depressed economy remained in effect until the end of the 1980s when the economy slowly returned and new development (primarily residential) increased.

From the late 1980s and into the 1990s, the economy slowly began to grow, with tourism becoming a multimillion dollar industry. By the mid-1990s, the economy had started to stabilize. The core job producers, oil, coal, timber, and the Federal Government, continued to employ the bulk of the work force. Tourism continued to be a multimillion dollar industry, and many of the "Big Box" stores (Fred Meyer,
Wal-Mart, Costco, Kmart) became prevalent in Anchorage and Fairbanks. During the 1990s and early 2000 period, the number of landscape patches (areas of distinct, identifiable land use types) increased (fig. 3), primarily by the spread of new neighborhoods along the hillside in southeast Anchorage, the construction of new schools and other institutions, and the clearing of land for development. Today, Anchorage is the largest municipality in Alaska with a population of a little under 260,000 (2000 Census); it is still the center for commerce in the State, and is on the verge of another population increase due to a stable economy, prospects of new oil and gas discoveries, and a new gas pipeline. With these developments, increasing demands for space for housing and commercial enterprises will probably also occur.

\section{Geographical Scope}

Developable land for urban expansion in Anchorage is primarily limited to what is commonly called the Greater Anchorage Bowl Area. It is delimited on the north by two military bases, with the demarcation line being Ship Creek that provides a substantial source of drinking water upstream and an urban salmon fishery; in the past it was also used for hydroelectrical power. Two large bodies of water, Cook Inlet and Turnagain Arm, demarcate the west and southern extent, and the eastern boundary roughly follows the tree line (approximately $850 \mathrm{~m}$ ) along the west range of the Chugach Mountains (fig. 1). The area can be roughly demarcated into two general geographic regions. The larger, western portion consists of level undulating outwash plains interspersed with lakes, poorly drained peatlands and low hills. The dominant soils are well drained, sandy and gravely deposits of glacial outwash and drift. These areas have provided the municipality with a rich source of construction-grade gravel material, and still do to a limited extent today. Soils in the area provide few or moderate limitations for residential or commercial buildings (Rieger and

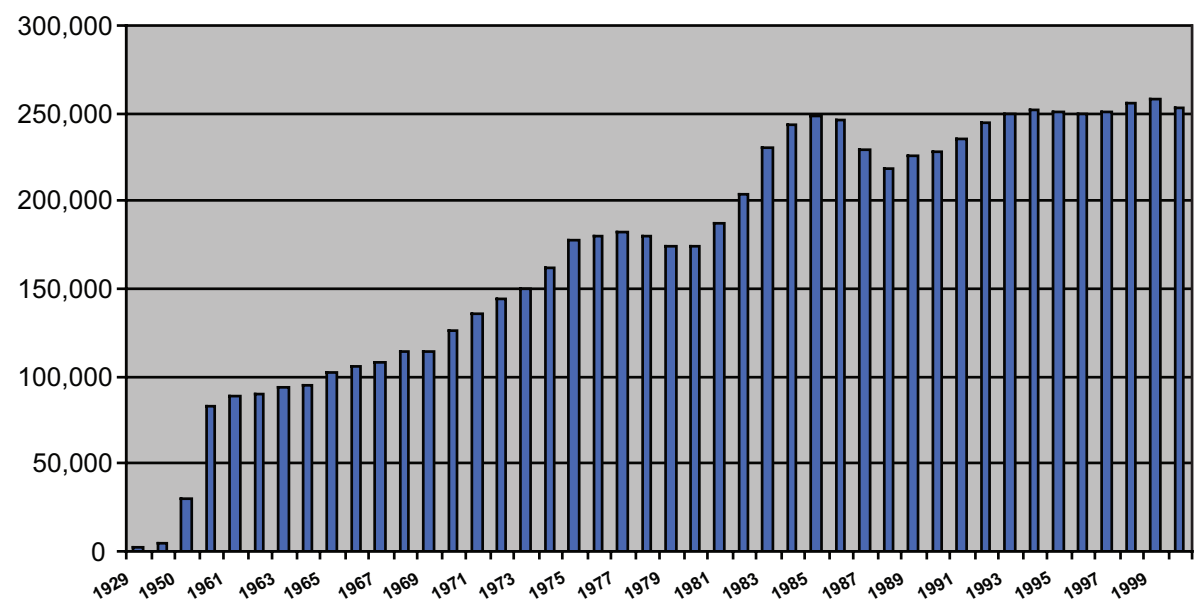

Figure 2. Population of Anchorage, Alaska, 1929-1999. 
others, 1979; Moore, 2001) and are vegetated primarily with paper birch and white spruce. Large areas of poorly drained, shrub and Sphagnum-dominated peatlands occur in the west central portion of the lowlands, and shrub and black sprucedominated peatlands occur along some stream floodplains and in scattered pockets between moraines. Although originally considered substandard for housing or business construction, some of these areas have been drained, filled, and in the case of single and multiple unit housing, placed on pilings 20 or more meters deep.

On the eastern side of the area, elevation contours begin as loess bluffs roughly 20 to $30 \mathrm{~m}$ above Cook Inlet and gradually increase in elevation inland to $150 \mathrm{~m}$ above sea level. The eastern (smaller portion) of the study area is dominated by silty loess over gravely to stony glacial drift on moderate to steep foothills of the Chugach Mountains (Moore, 2001). Most of these slopes have slight or moderate limitations for construction and are generally good for residential buildings. The Bureau of Land Management and the Department of Defense manage a large portion of this area, providing relatively undisturbed areas for recreation. Houses in this area usually have high market value because of their somewhat rural nature and scenic views of the Alaska Range to the west, and Mount McKinley and the Talkeetna Mountains to the north. Paper birch, aspen, and white spruce, or mixtures of each, dominate these areas.

The foothills region begins at about $150 \mathrm{~m}$ elevation in the north and at water's edge in the south, rising to about $300 \mathrm{~m}$ elevation before the more rugged mountainous terrain begins. Paper birch and white spruce dominate the lower to mid-slopes, gradually giving way to open white spruce mixed with alder. On the upper and steeper slopes, alder and low shrubs predominate. In this area, Chugach State Park and Chugach National Forest dominate the land holdings, and little development occurs here except in small inholdings. During the mid to late 1990's, a spruce bark beetle epidemic infected the spruce, resulting in a large loss of spruce stumpage and

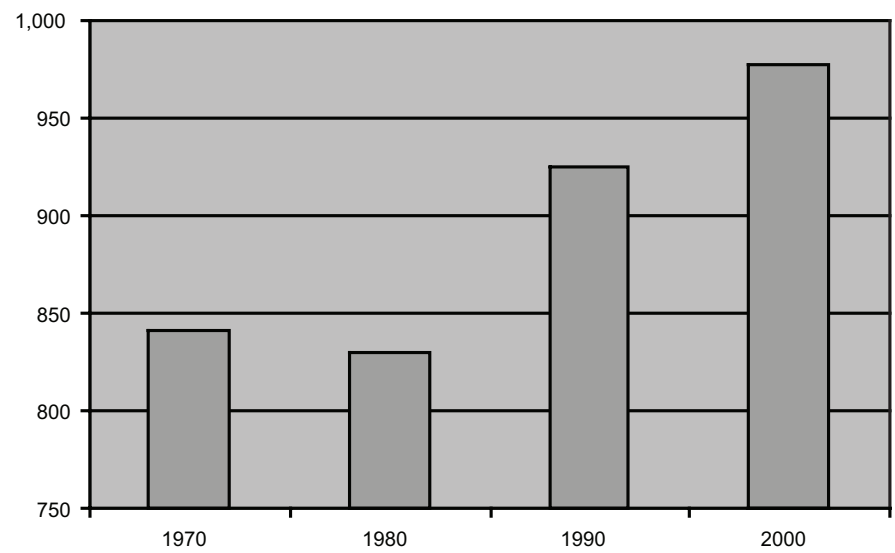

Figure 3. Number of landscape patches (areas of distinct, identifiable land-use types) mapped in the Anchorage study area for each of the temporal periods).
Table 1. Land-use/land-cover classes used to map the Municipality of Anchorage.

\begin{tabular}{ll}
\hline Residential & Urban Barren \\
Commercial & Natural Barren \\
Urban Vegetation & Lake/Pond \\
Natural Vegetation (forest and shrub) & Wetlands \\
\hline
\end{tabular}

making the area a substantial fire hazard, so much so that the Municipality of Anchorage developed a special fire Web site, indicating the importance of urban development along the hillside areas of the Municipality.

\section{Methods}

\section{Land-Use Patterns and Trends}

Land-use/land-cover (LULC) types were mapped using a general classification scheme (table 1), similar to level one of Anderson and others (1972). The LULC scheme used was slightly different from the Anderson scheme in that it is nonhierarchical, but would easily fit into the Anderson hierarchy.

\section{Image-Data Interpretation}

Aerial photography and satellite imagery used to analyze urbanization in the Municipality of Anchorage roughly represented the decadal periods 1970, 1980, 1990, and 2000 (table 2). The temporal intervals used are based primarily on the availability of historical photography and satellite imagery, but also on major developmental periods for the area, availability of census data, and temporal time frames used in other national environmental studies (for example, National Water Quality Assessment [NAWQA] program). The aerial photographs were acquired from the U.S. Geological Survey (USGS), Earth Science Information Center; the satellite image (false-color infrared IKONOS) was acquired from Space Imaging. LULC features were delineated and identified on the aerial photos using standard stereo photo-interpretation techniques using a minimum spatial mapping unit of 5 hectares for polygonal features (except for ponds at 2.5 hectares) and a 50-m width for linear corridors (for example, major roads). The delineated features for each period were digitized and georeferenced as a composite to baseline USGS 1:63,360-scale topographic series maps (circa 1960-1974). Each data layer for each year was superimposed on each other and manually checked on a display screen to ensure common boundaries matched for each temporal period. Data layers for the 2000 period were produced by heads-up digitizing, using the satellite image and 1990 polygon data as a backcoverage. Any changes from 1990 to 2000 were then identified and delineated. 
Table 2. Photography and satellite imagery used for mapping the temporal urban development and associated landscape of Anchorage, Alaska (scale is nominal for most data sets).

\begin{tabular}{|c|c|c|c|c|}
\hline Date & $\begin{array}{c}\text { Nominal } \\
\text { Reference } \\
\text { Date }\end{array}$ & Nominal Scale & Data Type & Format \\
\hline 2000 & 2000 & $1: 20,000$ & Satellite & Color Infrared \\
\hline $1988 / 1990$ & 1990 & $1: 40,000$ & Photo & Black and White \\
\hline 1984 & 1980 & $1: 60,000$ & Photo & Color Infrared \\
\hline $1972 / 1973$ & 1970 & $1: 60,000$ & Photo & Black \& White \\
\hline
\end{tabular}

Although numerous site visits were made throughout the study area to assess the type and extent of development throughout the Anchorage bowl in 2002, no formal accuracy assessment was produced.

The resulting database was then used to analyze changes in LULC activities through time, taking note of the patterns, locations, and trends. This was accomplished by summarizing the type and amount (size) of changes between each LULC over any given polygon and in the number of patches (individual polygons) of each of the LULC classes (Elkie and others, 1999).

\section{Results and Discussion}

The time period of most noteworthy change in urban development occurred between the early 1970 s and mid1980s, with less dramatic changes thereafter (fig.e 4). In 1970 , approximately 7,356 ha of the 31,117 ha study area was mapped as urban developed, increasing to 12,263 ha by the mid-1980s. Most residential development occurred between 1970 and 1980 in the forested areas (1,654 ha; fig. 1) with 600 ha being converted from a low-density type to a higher density type, the bulk of which occurred directly east and south of the core downtown area. Residential areas outside the core downtown area were relatively sparse in the early 1970's, with an average patch size of 22 ha and occurring primarily in forested areas and shrub and graminoid communities along the lower to upper hillsides in the southeast portion of the city (fig. 1). Between 1980 and 1990, relatively little new development occurred in this area. Those areas that were developed, however, occurred predominantly as extensions of existing sites in forested sites. By 2000, development had again increased, extending over the hillside areas, at times in more remote forest and shrub land areas.

The development of commercial sites increased dramatically between 1970 and 2000. Most development occurred in the downtown area to the north on previously denuded sites through the conversion of forest and wetland areas for airport development to the west and within a north-south oriented "commercial corridor" that occupied the center portion of the municipality between two main transportation arteries.

To support the development of commercial, institutional, and residential areas in Anchorage, large quantities of fill were needed. Most of this material was extracted from within the municipality from a few sites that were intensely quarried over the years. In 1970, approximately 373 ha were identified as being used for the extraction of sand and gravel. Between 1970 and 1980, 227 ha of newly excavated area were mapped, with more than one-half (168 ha) coming from natural vegetated sites (forest, and shrub/graminoid-dominated areas). From 1980 to 1990,73 ha were newly excavated, coming from previous commercial and urban barren sites, but by 2000 little new excavation was performed (about $16 \mathrm{ha}$ ), coming primarily from forested sites.

One of the more interesting classes that showed change throughout the 30-year period was that of urban barren. This type was used for those areas that were barren due to the activities of man and normally involved areas such as recently stripped ground as preparation for construction, temporary storage of equipment and supplies, and those areas that had been recently cleared of vegetation on speculation of development; it also included areas that were cleared because of the demolition of buildings. Of the urban barren mapped in the 1970 data, the majority was used primarily for residential (129 ha) and commercial (112 ha) development. From 1970 to 1980 there was a dramatic increase in land clearing (about a 22 percent increase); however, only about one-third was used for housing or commercial development and the majority of the land (44 percent) reverted back to a vegetated state by 1990. The reduction in area was probably due to a recession that occurred in the mid 1980s, and areas that were cleared for anticipated construction were never developed. Of the 177 ha mapped as urban barren in 1990, about 99 ha were new (that is, not previously mapped as urban barren), occurring over areas of previous commercial activity, forest and shrub land, and wetlands. Approximately 5 ha were mapped as previously being institutional, occupied by an old native hospital and a small (less than 5 ha) high-density residential area, both of which were demolished (the native hospital site was ultimately reseeded and the residential site became a cemetery). By 2000, additional land cleared for development occurred primarily on forestlands, wetlands, and areas previously mapped as urban barren in 1990.

Lakes and ponds remained relatively stable throughout the entire period although a fare amount of wetlands were lost to drainage ditches and development. Ponds in the area 
increased by 19 percent between 1970 and 1980, primarily due to the accumulation of melt water in gravel pits, with a subsequent loss of ponds between 1980 and 1990 due to the filling/conversion of the gravel pits for other uses (predominantly commercial development) and expansion of the Ted Stevens Anchorage International Airport and associated complex.

More than half of the wetlands mapped in 1970 were identified as a different LULC class in 1980. The largest loss was due to the construction of residential housing and commercial development, and from 1980 through to 2000 an additional 84 ha were lost to road construction. Throughout the mapping period, approximately 180 ha of wetlands remained as wetlands but changed in type and form. In 1970, shrubby wetlands were dominant, with many small areas of graminoid and strang/moore. With the draining of wetlands that began in the late 1970's and continued through 2000, some of the graminoid wetlands became shrubby wetlands, and the strang/moore type had all but disappeared. Strang/moore wetlands were present in a large wetland system located in a northwest/southeast-oriented swath from north of the Ted Stevens Anchorage International Airport to south of Campbell Lake. In some areas of intense draining, many of the remaining shrubby wetlands became forested wetlands (primarily codominates of spruce and shrubs).

\section{Trends}

Like most urban areas, Anchorage has recently experienced a steady increase in growth, both in terms of urban
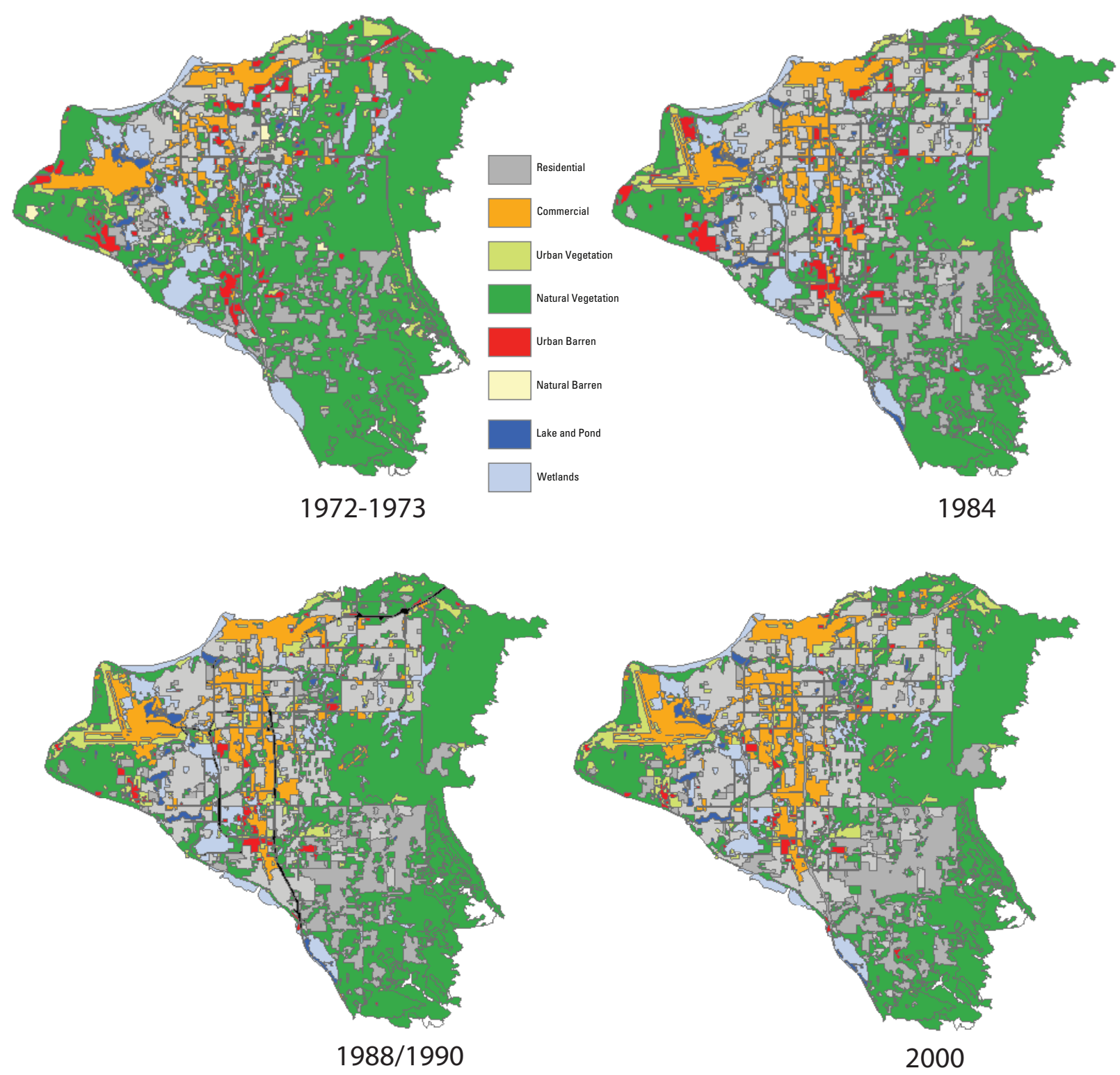

Figure 4. Land-use/land-cover map of Anchorage, Alaska, for the four temporal periods: 1970 (1972-1973), 1980 (1984), 1990 (1988/1990), and 2000. 
development and population. Population growth has increased in a linear manner since 1950 at about 4,400 people per year (fig. $5 A$ ), with a slight increase to 5,600 people between 2000 and 2020 (Municipality of Anchorage, 2001). Urban sprawl is also increasing but is approaching a limit imposed by the shrinking amount of usable land, and thus urban growth in the area is beginning to level off (fig. $5 B$ ), with most new singlefamily homes being built in communities 10 to 50 miles north of the Greater Anchorage Bowl (Eagle River, Chugiak, Matanuska-Susitna Borough; Municipality of Anchorage, 2001). With Anchorage being surrounded on three sides by water (Cook Inlet), and on the east by the Chugach Mountains, the amount of readily available land is reducing and is approaching it limits to urban growth. A 1998 study (Municipality of Anchorage, 2001) indicated that there were 6,100 ha of land available for development, but only 4,700 ha were deemed suitable or marginal for use. This could change however, if some of the lands currently being used as State parkland, natural areas, or military lands are opened up for development; however, prospects of parkland and military land being opened to new development are slim. The parkland is administered by the State of Alaska and occurs primarily in rugged mountainous terrain that is unsuitable for development. The military land may be made available in the distant future, but an exten-
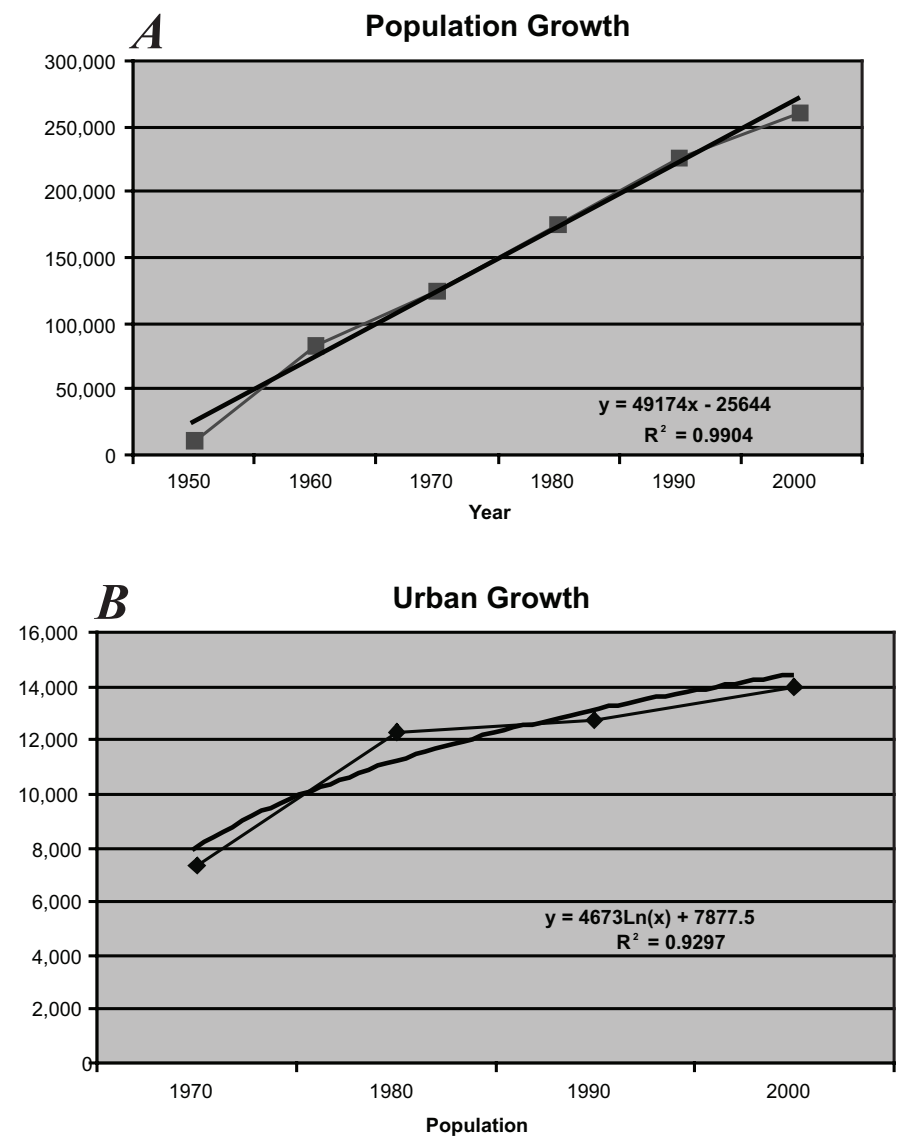

Figure 5. (A) Population growth (1950-2000) and $(B)$ urban growth (1970-2000) for Anchorage, Alaska. sive and thorough search for unexploded ordinances would have to be conducted first. The only large natural area within the study area that may become available for development is a large tract of mostly undeveloped land called the Campbell Creek Track. This area is currently administered by BLM for recreational and educational use and not available for development except for multiple-use trails (for example, walking, running, biking, horseback riding, and sled-dog mushing).

\section{Conclusions}

This project provides one of the first historical overviews of land-use/land-cover changes for the Greater Anchorage Bowl area. Results from this study indicate that the process of urban development closely followed the boom and bust of economic conditions until the late 1980s, after which most development proceeded at a slower pace as the local economy gradually became more stable, relying less on short term, high impact events. In other studies of urban growth (Bell and others, 1995; Crawford and others, 1996; Pijanowski and others, 2002) it was noted that existing transportation corridors have a profound effect on where urban growth occurs (Buchanan and Acevedo, 1996), although Paquette and Domon (2001) found other landscape contexts such as woodlots and panoramic views to be equally important in southern Quebec, Canada. For the Anchorage area, urban growth appeared to be more influenced by the availability of nearly level land near the city center, then expanding to other areas that provided views of the Alaska Range and less developed woodlots. Between the early 1970s and mid-1980s, most urban development occurred in vacant areas and open space alongside existing development in the areas of low topographic relief close to and encircled by the major transportation network. Beginning in the late 1980s, development started to expand into the southeast portion of the Anchorage Bowl along the predominantly undeveloped and more rugged hillside, requiring a totally new network of roads and utilities. It is not clear, however, if this was due to the desirability of having panoramic views, a "leapfrog" effect where developers skip over properties to obtain land at a lower price (Heim, 2001), the recent availability of land from existing homesteads, or a combination of one or more of these events. As urban growth continues in the Greater Anchorage Bowl area, the amount of commercial lands will continue to decrease as suitable land decreases (generally flat and close to major transportation corridors) and the need for residential property increases. Because requirements for residential property are less stringent, there is still a sizable area that can be developed in the southeast portion of the municipality, although these lands are also limited to some extent by State park, military, and other public land boundaries.

The urbanization of this enclosed area also contributes to local hydrologic problems. The increase in impermeable structures and surfaces (buildings, paved lots, and roads), channeling of watercourses, and draining and filling of wet- 
lands has promoted a number of environmental problems. Runoff from impermeable surfaces has increased the potential of hazardous substances being washed into the water system and elevated bacteria in streams (Frenzel and Couvillion, 2002). Increased runoff and the loss of wetlands reduce water percolation into the ground, thereby lessening the natural purification process of water to surface and subsurface water supplies. The channeling of small streams reduces the amount of habitat for fish and water birds and allows increased flows of runoff into nearby Cook Inlet.

The data used for this study were obtained, in part, to correlate as closely as possible to a ten-year interval that is used with the NAWQA program based on the even decade (for example, 1970, 1980, 1990, 2000). Intervals such as this, however, may not be appropriate for studying urban change through time (Marceau and others, 2001), being more dependent on the area that is being observed and the social and economic events that have or are about to take place. For example, the authorization of new housing units from 19731999 for Anchorage (fig. 6), indicate that land development was more abundant during the subdecadal periods and were minimally captured by the 1980 s data. On the basis of this information, a more appropriate time interval to study urban dynamics in the Anchorage area would be on the order of 5 years. This would better correspond to some major economic events that happened in Alaska, such as the 1964 earthquake, an oil lease sale in 1969, oil pipeline construction from 197477 , an economic depression in 1979-80, an oil price boom from 1981-1984, and subsequent recession in the late 1980s. Dramatic economic swings have not occurred in Anchorage recently, and are reflected in the amount of change during the last 10 years (fig. 4). This may change, however, during the next decade with the possibility of oil development in the Arctic National Wildlife Refuge and National Petroleum Reserve-Alaska, and the construction of a natural gas pipeline from Alaska to the conterminous United States; these events may again trigger increased economic development in the area. The prospects of continuing this study into the future is made somewhat easier by the IKONOS and Digital Globe high resolution satellites in orbit that can readily supply highresolution imagery on a repeatable interval, thereby allowing the quick updating of the current maps to track developments in a more timely manner.

\section{Acknowledgments}

This work originally produced for the USGS, by Raytheon STX Corp. staff, Contract Number 1434-CR-N97-CN40274, with funding support by the USGS, Alaska Geographic Science Office and Water Resources Office.

\section{References}

Bell, C., Acevedo, W., and Buchanan, J.T., 1995, Dynamic mapping of urban regions - Growth of the San Francisco/ Sacramento region: URISA Annual Convention, San Antonio, Texas., p. 723-734.

Booth, D.B., and Jackson, C.R., 1997, Urbanization of aquatic systems - degradation thresholds, storm water detection,

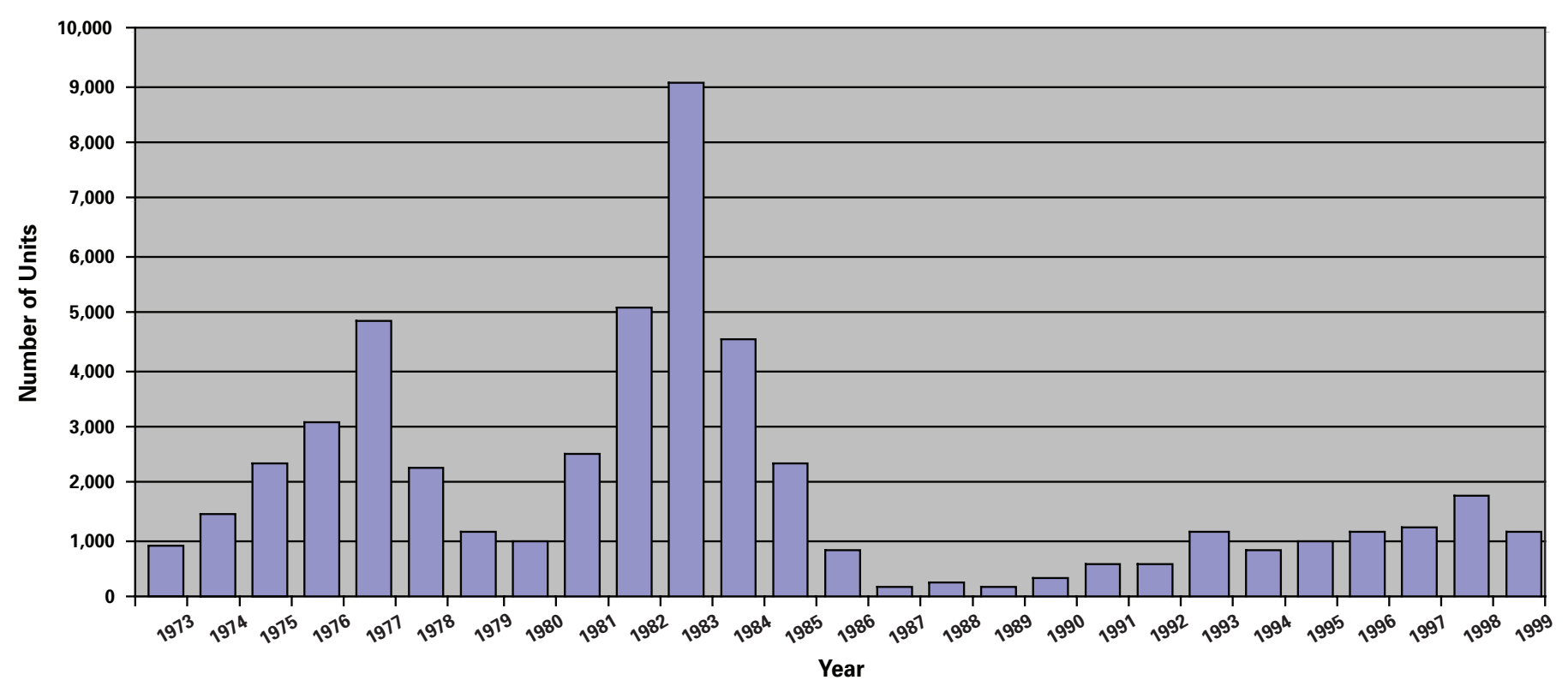

Figure 6. New housing units authorized for construction in Anchorage, Alaska, from 1973 to1999 (Municipality of Anchorage, 2000). 
and the limits of mitigation: Journal of the American Water Resources Association, v. 33, no. 5, p. 1077-1090.

Buchanan, J.T., and Acevedo, W., 1996, Studying urban sprawl using a temporal database: Geo Info Systems, v. 6, p. 42-47.

Crawford, J.S., Acevedo, W., Foresman, T.W., and Prince, W., 1996, Developing a temporal database of urban development for the Baltimore-Washington region: Proceedings 1996, ASPRS/ASCM Annual Convention, Baltimore, Md, p, 101-110.

Elkie, P.R., Rempel, R., and Carr, A., 1999, Patch analyst user's manual (TM-002): Ontario Ministry of Natural Resources, Northwest Science and Technology, Thunder Bay, Ontario, 16 p.

Frenzel, S.A., and Couvillion, C.S., 2002, Fecal-indicator bacteria in streams along a gradient of residential development: Journal of the American Water Resources Association, v. 38, p. 265-273.

Heim, C.E., 2001, Leapfrogging, urban sprawl, and growth management: American Journal of Economics and Sociology, v. 60 , no. 1, p. 245-283.

Horowitz, S., 2002, The adverse effects of urban sprawl: Alternative and complementary Therapies, v. 8, no. 5, p. 273-277.

Marceau, D.J., Guindon, L., Bruel, M., and Marois, C., 2001, Building temporal topology in a GIS database to study the land-use changes in a rural-urban environment: The Professional Geographer, v. 53, p. 546-558.

Rieger, S., Schoephorster, D.B., and Furbush, C.E., 1979,
Exploratory soil survey of Alaska: Soil Conservation Service, Washington, D.C.

Moore, D., 2001: Soil survey of Anchorage area, Alaska: Natural Resources Conservation Service, Palmer, Alaska, 308 p.

Municipality of Anchorage, 1989, Anchorage indicators: Economic Development and Planning Department, Anchorage, Alaska.

Municipality of Anchorage, 2000, Housing and construction indicators: Community planning and Development Department, Anchorage, Alaska.

Municipality of Anchorage, 2001, Anchorage 2020 Anchorage Bowl Comprehensive Plan: Anchorage, Alaska, $122 \mathrm{p}$.

Ourso, R.T., 2001, Effects of urbanization on benthic macro invertebrate communities in streams, Anchorage, Alaska: U.S. Geological Survey, Water-Resources Investigations Report 01-4278, 38 p.

Paquette, S., and Domon, G., 2001, Trends in rural landscape development and sociodemographic recomposition in southern Quebec (Canada): Landscape and Urban Planning, v. 55, n. 4, p. 215-238.

Pijanowski, B.C., Brown, D., Shellito, B., and Manick, G., 2002, Using neural networks and GIS to forecast land use changes - A land transformation model: Computers Environment and Urban Systems, v. 26, p. 553-575.

Wear, D.N., Turner, M.G., and Naiman, R.J., 1998, Land cover along an urban-rural gradient: implications for water quality: Ecological Applications, v. 8, no. 3, p. 619-630. 



\title{
The Effects of Urbanization on Discharge and Suspended- Sediment Concentrations in a Southern California River
}

\author{
By Jonathan A. Warrick' and Kevin M. Orzech ${ }^{1}$
}

\section{Introduction}

The purpose of this paper is to explore the effects of urbanization on the hydrologic systems of the southern California region with a primary focus on the largest and longest monitored river, the Santa Ana. Urbanization in the United States occurred rapidly in the 20th century, particularly along the East and West Coasts (Beach, 2002). Exceptionally high rates of urbanization occurred in southern California (fig. 1), where the population grew from $\sim 250,000$ to almost 20 million between 1900 and 2000 (U.S. Census Bureau, 2003). Much of this population growth has resulted in the building of single-family home communities, creating widespread, sprawling suburbanization over much of the coastal and inland lowlands (Gumprecht, 1999).

As the southern California landscape has changed, the rivers of this region (fig. $1 A$ ) have also been fundamentally altered. Most rivers have been dammed for flood control and (or) water supply ( $\sim 54$ percent of the coastal southern California watershed area is dammed; Willis and Griggs, 2003), whereas many of the urban rivers have been channelized to prevent channel avulsion and increase flood discharge capacity. Damming is estimated to have caused $\sim 40$ percent reduction in sand and gravel discharge to the southern California beaches, which may be influencing coastal erosion patterns (Willis and Griggs, 2003). Population growth has also put an increasing demand on ground water that has led to a reversal of subsurface pressure gradients and intrusion of ocean water into aquifers (Edwards and Evans, 2002). This problem has promoted the diversion of surface water and treated municipal wastewater into the ground-water aquifers of the region.

In southern California the predominant land-use alteration during the past 50 years was from cultivated land to urban (State of California Dept. of Water, 1993). Urbanization increases impervious surfaces, which in turn are known to increase runoff rates during precipitation (Leopold, 1968). Generally, runoff rates over paved areas are about two to ten times larger than non-paved surfaces, such as

${ }^{1}$ Coastal and Marine Geology Program, U.S. Geological Survey, 345 Middlefield Rd., MS 999, Menlo Park, CA 94025-3591. cultivated ground or grassland, with the variability associated with variables such as slope, infiltration rates, interception, and soil type (Haan and others, 1994).

Below, analyses of the time history of river discharge for southern California rivers show that substantial increases in runoff have occurred in the urbanized rivers and that the increases coincided with the history of development. Expanding upon this work, we detail hydrologic and sedimentological impacts of urbanization in southern California's largest river basin, the Santa Ana. These analyses reveal that peak floods and annual average discharges have increased over the past 40 years concurrent with a dramatic ten-fold decrease in river suspended sediment rating curves.

\section{Southern California Rivers}

Southern California rivers have highly pulsed discharge (dominantly occurring during frontal precipitation events of the winter) and are highly variable annually, largely due to El Niño climatic forcing (Brownlie and Taylor, 1981; Inman and Jenkins, 1999; Warrick and Milliman, 2003). River discharge in southern California responds differently during dry and wet years. Discharge during years of low precipitation is generally very low to negligible due to the high infiltration capacity of the dry soils. During years with high precipitation the earthen ground can become saturated promoting exceptional runoff rates and volumes.

Increases in total annual discharge were observed in many southern California rivers during the past century (fig. 2). For large watersheds (Santa Ana and Los Angeles Rivers shown in figs. $2 A$ and $B$ ), average annual discharge (here normalized by precipitation) show the effects of major dams, which trap water for municipal uses and thus reduce river discharge. Since this period of dam construction, however, increases in discharge are observed in both the Santa Ana and Los Angeles Rivers. In the smaller creeks (Trabuco and San Diego Creeks shown in figs. $2 C$ and $D$ ), discharge increases over the past 50 years appear to be more dramatic than for the large rivers. This is largely due to the lack of damming and flow regulation in these watersheds. All of the observed discharge increases (for both large and small rivers) can be accounted for during winter stormflow (as shown for the Santa Ana River below) and have occurred during periods of rapid urbanization. 

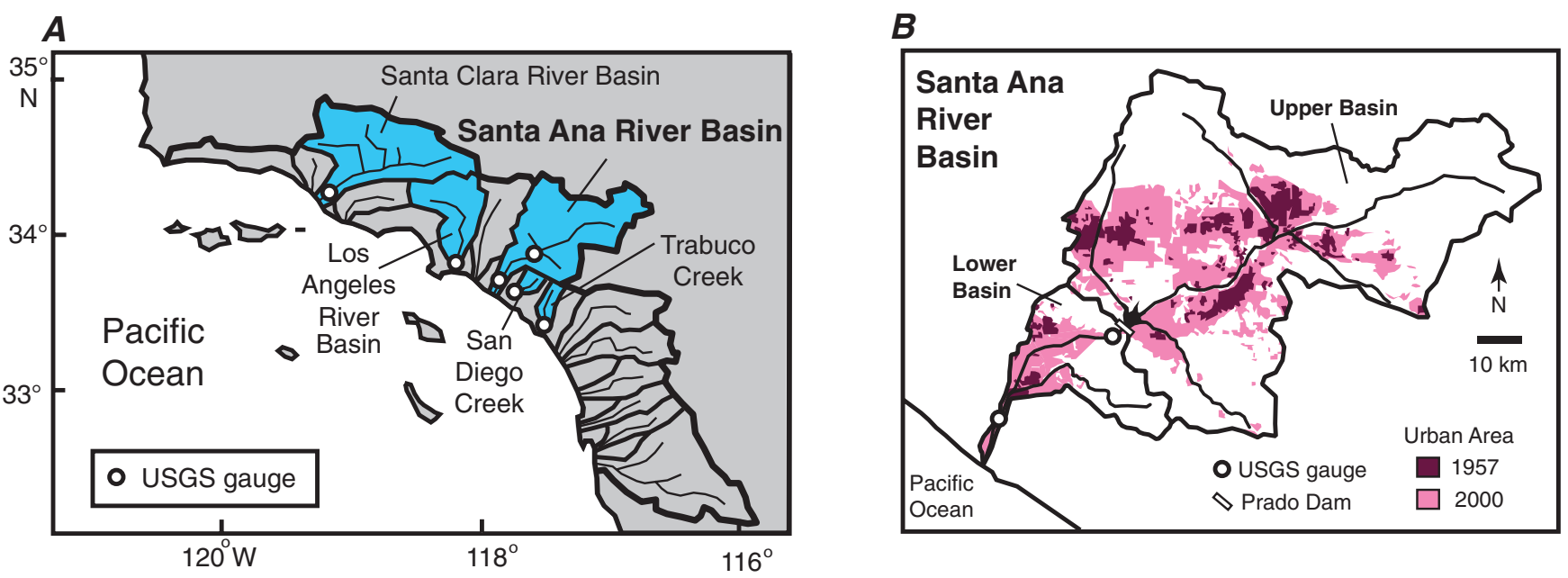

Figure 1. $A$, The southern California watersheds; watersheds identified in the text are highlighted in blue. $B$, The Santa Ana River watershed with extent of urban land cover during 1957 and 2000. Land-cover information digitized from California Department of Water Resources (1957, 1964 and 2000).

\section{Santa Ana River}

The Santa Ana River (fig. $1 B$ ) is the conduit for the largest watershed in southern California $\left(4,381 \mathrm{~km}^{2}\right)$ and drains portions of the San Gabriel, San Bernardino, and Santa Ana
Mountains. [The San Jacinto tributary of the Santa Ana watershed rarely discharges into the Santa Ana River (Brownlie and Taylor, 1981) and is therefore not considered here in computations of land-use and drainage areas.] A majority of the watershed $\left(3,911 \mathrm{~km}^{2}\right.$ or 89.3 percent) is upstream of Prado Dam,

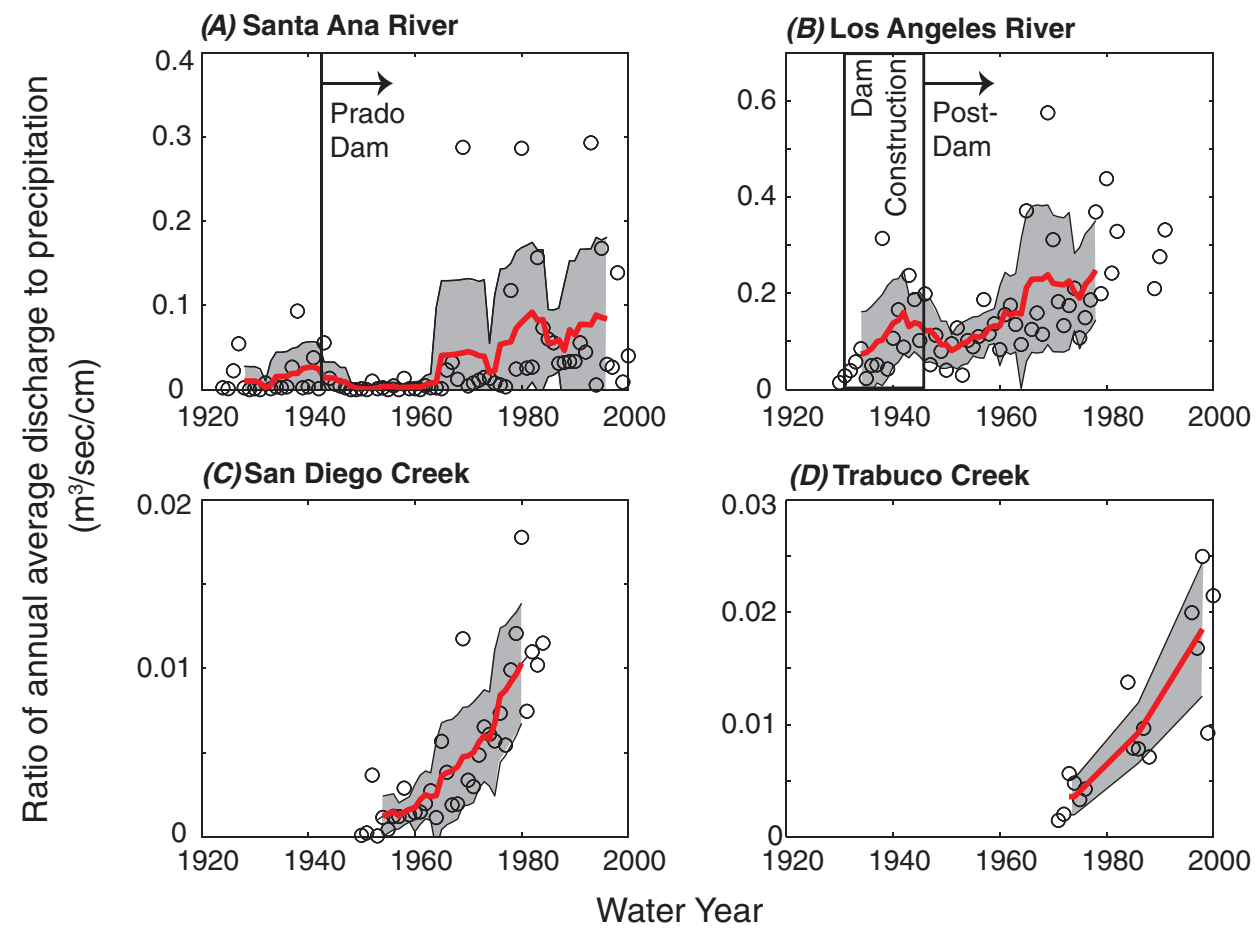

Figure 2. The time history of the relationship between river discharge and precipitation for southern California rivers showing increases in discharge with respect to precipitation. River discharge data obtained from the following U.S. Geological Survey (USGS) stream gauges: $A$, Santa Ana River at Santa Ana (USGS 11078000); $B$, Los Angeles River at Long Beach (USGS 11103000); $C$, San Diego Creek at Culver Drive near Irvine (USGS 11048500); $D$, Arroyo Trabuco at San Juan Capistrano (USGS 11047300). All records have been normalized by the annual precipitation measured at Santa Ana, California. Solid lines show 10-year means, shadings are one standard deviation about the means. 
which was built in 1941 to retain winter stormflow for subsequent ground-water recharge in infiltration basins downstream of the dam and to provide flood control for the lower watershed. For the purpose of this paper, the "upper basin" is defined as the drainage upstream of Prado Dam, whereas the "lower basin" is below the dam (fig. 1B).

Time evolution of Santa Ana River water and sediment discharges were evaluated using discharge and suspended sediment data from two of the long-standing United States Geological Survey (USGS) gauges in the watershed: USGS 11074500 (Santa Ana River below Prado Dam) and USGS 11078000 (Santa Ana River at Santa Ana; fig. 1B). These sites represent discharge immediately downstream of the dam (upper basin) and just upstream of the river mouth (combined upper and lower basins), respectively. These data represent some of the longest and most complete discharge and sediment-sampling records for southern California rivers.

\section{Water Discharge}

To help evaluate how discharge has changed during the 20th century, figure 3 summarizes annual precipitation and discharge information from the Santa Ana River along with corresponding urbanization and population statistics. The most dramatic rise in urbanization and population occurred in the later part of the 20th century (figs. $3 A$ and $B$ ). Urban areas increased from $\sim 4$ percent in 1942 to $\sim 35$ percent in 2000 , with the most prominent growth occurring in the 1960s and 1970s. The human population in the region of the Santa Ana River has grown at an average rate of 60 percent per decade during the 20th century (fig. 3B).

Annual peak discharges at the lower gauging station (fig. 3D) have increased dramatically since the building of Prado Dam (1941) and especially since 1967, the period for which USGS suspended sediment sampling record exists. The 7year running median annual peak discharges (plotted in fig. 3D) increased by a factor of 4 between 1967 and 1998. These increases were greatest for the driest years, however, as dry-year peaks (years with precipitation less than the lower quartile of $231 \mathrm{~mm}$ ) increased by more than 6 times during the sampling period.

Total annual discharge from the river (fig. $3 E$ ) is related to precipitation (fig. 3C), although the discharge response to rain has increased dramatically over the period of record. For example, since Prado Dam was built, 12 of the 15 (80 percent) highest discharge years were recorded after 1977, even though only 8 of the 15 (53 percent) highest precipitation years were recorded during this period. Increases in total discharge were again greater for dry years than for the wet years of 1967-2001. Total annual discharge increased by a factor of 5 for the driest 9 years during 1967-2001, compared to doubling of total annual flow for the 9 wettest years.

These increases in discharge volume were not associated with runoff during the dry summer and fall, but instead occurred during winter storms. Discharge-duration relationships (fig. 3F)

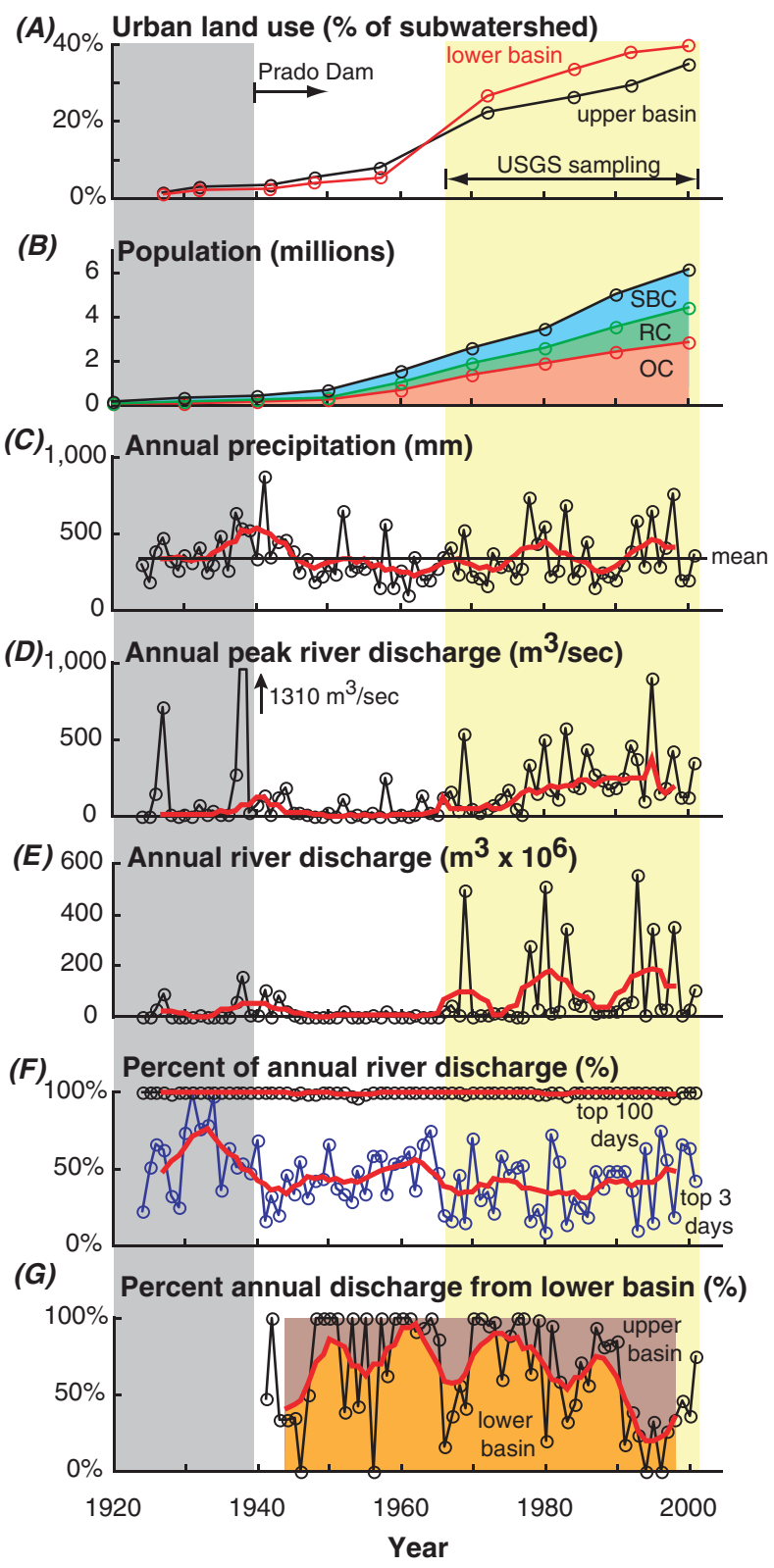

Figure 3. Temporal trends in the Santa Ana River characteristics. Grey shade represents the period before Prado Dam (pre-1940), whereas the yellow shade represents the period of U.S. Geological Survey (USGS) suspended-sediment sampling (1967-2001). Thick red lines represent 7-year weighted means for $C, E, F$, and $G$ and 7-year median for $D$. A, Land use in the Santa Ana River watershed from California Department of Water Resources (1957, 1964, 1993 and 2000). B, Population of counties with land in the Santa Ana drainage (San Bernardino (SBC), Riverside (RC) and Orange (OC) Counties) from U.S. Census (2003; note that portions of the populations live outside of the watershed). C, Annual precipitation at Santa Ana from California Department of Water Resources. $D$ and $E$, Annual Santa Ana River discharge and peak flow rate at the lower stream gauge (USGS 11078000). F, Annual flow duration relationship for the Santa Ana River at Santa Ana. $G$, Percent of annual discharge derived from the lower basin as measured at Santa Ana station (see text for computational methods). 
show that since the building of Prado Dam, the top three days of runoff contributed on average slightly less than 50 percent of the annual discharge. This three-day percentage is inversely related to annual precipitation, largely due to an increase in the total number of storms during wet years. The top 100 days of discharge (roughly the winter months each year) almost always contribute 100 percent of the total discharge. Thus, baseflow and urban runoff during the dry months contribute very little to the total annual discharge from the river.

The primary region of runoff generation has changed, however, coming less from the lower basin (downstream of the dam) and more from the upper basin (upstream of the dam). A mass balance of water from the upper and lower basins was created with average daily discharge from the two USGS gauges and diversions and infiltration between the gauges for groundwater recharge (always less than or equal to $15 \mathrm{~m}^{3} / \mathrm{s}$; Izbicki and others, 1998). The mass balance reveals that for most years since Prado Dam was built, the majority of discharge at the Santa Ana River mouth was generated in the lower portion of the watershed (even though it only represents 10.7 percent of the total watershed area; fig. $3 G$ ). This is not unexpected because Prado reservoir was designed to store most of the upper watershed runoff except during wet winters when flows are released at rates in excess of the groundwater recharge capacity (Brownlie and Taylor, 1981). However, the upper basin provided a greater proportion of the total discharge with time due to higher upper basin runoff and therefore more frequent and larger dam releases. More frequent and larger releases from the dam are also due to a slight decrease in reservoir storage capacity from the accumulation of river sediment. Storage capacity measurements in 1941 and 1975 showed a decrease in reservoir volume of 11 percent (from 275 to 244 million $\mathrm{m}^{3}$ ) due to sediment accumulation (Brownlie and Taylor, 1981). Projecting this number forward, the reservoir would have lost about 25 percent of its storage capacity in 2001 due to sedimentation. However, this storage loss will be more than accounted for in dam expansion plans of the U.S. Army Corps of Engineers to be completed in 2008.

In summary, large increases are observed in peak and total discharge of the Santa Ana River, an important source of which is stormflow generated in the upper basin and released from Prado Dam during high flow events. Below we look at the implications of these changes on suspended sediment discharge.

\section{Suspended-Sediment Discharge}

Suspended sediment concentration records at the two gauging stations (fig. 1B) are available from 1967 to 2001. The data from each site differ greatly. For example, suspended sediment concentrations immediately downstream of the dam (mean $=480 \pm 290 \mathrm{mg} / \mathrm{l}$, median $=130 \mathrm{mg} / \mathrm{l}, \mathrm{n}=$ 454) are about an order of magnitude less than concentrations near the mouth $($ mean $=3200 \pm 5800 \mathrm{mg} / 1$, median $=$ $1150 \mathrm{mg} / \mathrm{l}, \mathrm{n}=206$ ). The suspended sediment concentra- tions immediately below the dam do not correlate with river discharge (power law, $\mathrm{R}^{2}=0.07$ ), and do not show temporal trends over the period of record (1967-2001). The concentrations near the mouth, on the contrary, were positively correlated with discharge (power law, $\mathrm{R}^{2}=0.53$ ), and exhibited decreasing trends with time (fig. 4). Thus, much of the scatter in the complete lower gauge suspended sediment data can be attributed to consistent decreases in suspended sediment concentrations per unit flow. Average concentrations at this site decreased by 10 to 20 times for equivalent discharge rates during the sampling record (1967-2001; fig. 4). These decreases are significant for all discharge values using nonparametric, Kendall-tau techniques of Dinehart (1997). Further, the 5- to 7-year intervals chosen in figure 4 enable the incorporation of short term climactic variations within each of the five periods, which makes the comparisons relatively free of bias due to climactic shifts.

Order of magnitude drops in the sediment concentration-discharge relationships, such as observed at the lower Santa Ana River site (fig. 4), typically coincide with decreasing river sediment load due to reduction in sediment supply (Van Sickle and Beschta, 1983; Reid and Dunne, 1996; Dinehart, 1997). However, this is not the case with the Santa Ana. To test whether the sediment loads have declined, cumulative sediment loads from the Santa Ana were compared with cumulative loads from the Santa Clara River (USGS 11114000) for the period 1967-2001. This comparison is useful because the Santa Clara River does not have time-varying suspended sediment concentrations (Brownlie and Taylor, 1981; Warrick, 2002). Using the five time-dependent rating curves for the Santa Ana River (fitted power functions shown in fig. 4), cumulative sediment discharge does not show a decreasing trend with time when compared to the Santa Clara River (fig. 5). In fact, since the 1969 water year the Santa Ana River suspended sediment discharge reveals a slight increase with respect to the Santa Clara River, which is counter to the rating curve implications described above.

Thus, the strong decreases in suspended sediment concentrations per unit flow in the Santa Ana River are not associated with decreases in sediment loads. It is important to note that suspended sand loads do not decrease with time using the same methods and rating curves of suspended sand $(>63 \mu \mathrm{m})$ concentrations, which similarly drop 10 to 20 times over the period of record.

\section{Discussion and Conclusion}

Data presented here suggest that southern California river discharges have increased in conjunction with urbanization. As shown for the Santa Ana River, increases in discharge were inversely related to the event magnitude (that is, greatest for low magnitude events and least for high magnitude events), which has long been known to be a characteristic of urbanizing basins (for example, Hollis, 1975). Further, discharge to the river mouth is overwhelmingly from winter stormflow, 
whereas summer discharge is negligible. Lastly, with time, stormflow at the mouth has originated more and more from the upper basin due to storm releases from Prado Dam.

We hypothesize that the increases in discharge (fig. 3) have caused the decreases in the suspended sediment rating curve (fig. 4) largely through dilution. This "dilution hypothesis" suggests that the additional sources of stormflow did not include considerable amounts of suspended sediment or erode sediment within the river channel. Additional stormflow from the upper basin does have comparatively low concentrations of suspended sediment due to settling behind Prado Dam (data summarized above). For example, if the average suspended sediment concentrations from the upper gauging station and the time varying rating curves are used to estimate sediment flux past each USGS station, only $\sim 7$ percent of the suspended flux past the lower station can be accounted for from the upper station. Thus, the majority of river suspended-sediment discharged at the mouth originates from the lower basin (Brownlie and Taylor, 1981), and additional discharge from the upper basin would serve to dilute suspended sediment generated from erosion in the lower basin.

The dilution hypothesis, if true, should also be consistent with sediment production patterns in the lower basin. Sediment production within the lower basin can generally be attributed to erosion in the uplands, lowlands and river channel. Below we focus on sediment production in each of these three regions to evaluate whether changes may have occurred over time and influenced the sediment rating curve results presented above.

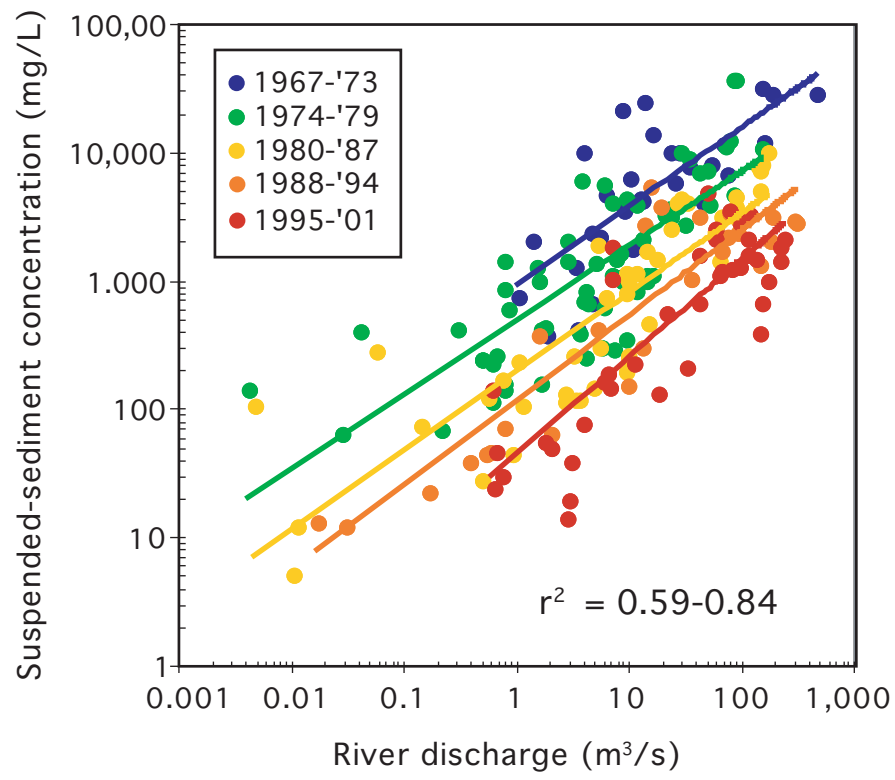

Figure 4. Suspended-sediment concentration relationships for the Santa Ana River at Santa Ana (USGS 11078000). Data have been binned into consecutive 5- to 7-year periods (the length of periods were not uniform so that high and low discharges could be included in each) to show temporal trends using power law rating curves $\left(r^{2}=\right.$ $0.59,0.64,0.75,0.84$ and 0.70 , respectively).
Sediment production rates in the uplands have likely remained relatively steady during the period of USGS sampling, since these areas have remained undeveloped (and largely in state and county park hands). The uplands have, however, been subject to periodic wildfire, which is known to increase landscape erosion in southern California (for example, Taylor, 1981; Rice, 1982; Florsheim and others, 1997). These post-fire erosion responses are known to last for a period of approximately 2 to 4 years (Florsheim and others, 1997). The recent history of fire in the uplands of the lower Santa Ana River basin is shown in figure 6. The large Paseo Grande fire of 1967 ended a nearly two-decade period without large wildfires and occurred at the beginning of the USGS suspended sediment sampling. Another period of wildfire occurs in the late 1970s and early 1980s and includes the Owl and Gypsum fires. The history of fire in the Santa Ana River Basin would suggest that sediment production would peak following the 1967, 1980, and 1982 events and, perhaps, be lower during the period between these fires and during the most recent period. However, these patterns are not observed in either the suspended sediment concentration or sediment discharge data (figs. 4 and 5). In fact, sediment production during the lowfire 1990s appears to be equal or higher with respect to the Santa Clara River than during periods of fire. Thus, although sediment production in the lower watershed has likely been

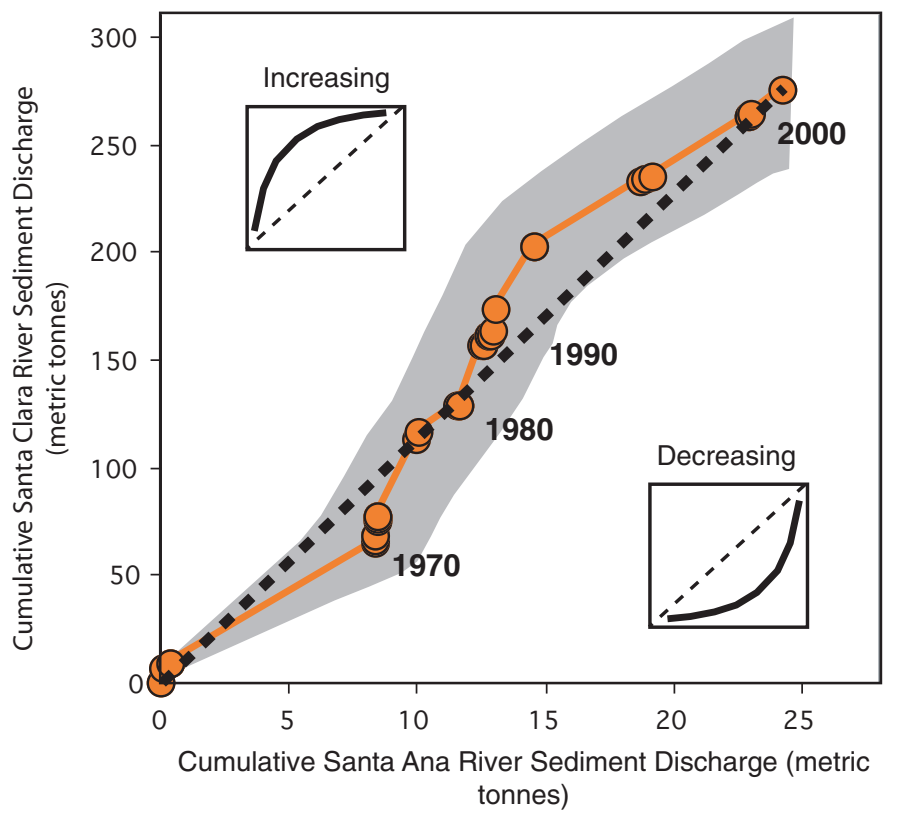

Figure 5. Cumulative sediment loads for the Santa Ana River (USGS 11078000) and Santa Clara River (USGS 11140000) during 1965-2000. Dashed line represents a constant relationship in sediment loads; gray shade is the accumulated standard error of the cumulative loads. Inserts show the patterns for increasing and decreasing loads from the Santa Ana River. Santa Ana River loads calculated with daily discharge records and time-dependent power law rating curves shown in figure 4. Santa Clara River sediment loads calculated with daily discharge records and a stationary rating curve (data tabulated in Warrick, 2002). 
influenced by fire in the uplands, wildfire does not appear to be the dominant control in the total flux out of this watershed or to have caused the order of magnitude changes in suspended sediment concentrations.

Sediment production in the lowlands has likely changed dramatically, largely due to the widespread land-use changes from agriculture to urban (fig. $1 B$ ). It is not clear how these land use changes affected sediment loads, since many have shown that sediment production is complex during and following urbanization (Ebisemiju, 1989; Booth, 1990; Nelson and Booth, 2002). For example, paving over the adjacent San Diego Creek (fig. 1A) imparted increases in sediment fluxes, due to tributary channel degradation (Trimble, 1997). Once urbanized, increased rates of runoff eroded these natural, small channels at rates that surpassed denudation from the former agricultural lands (Trimble, 1997). However, it is not clear whether these results are applicable to the Santa Ana River, largely because rates and styles of development (especially tributary channelization) have been different. Thus, without a detailed sediment budget of the lower Santa Ana River Basin lowlands (for which limited data exist), we cannot determine how steady lowland erosion has been. Since the overall flux of sediment from the Santa Ana River with respect to other regional rivers has remained relatively steady (fig. 5), we will assume that either the lowland contributions to the sediment budget have remained somewhat steady or that they are substantially lower than contributions from the steep uplands.

Finally, some sediment has been available for erosion in the mainstem channel. The channel is not a dominant source of suspended sediment, however, since bank stabilization has largely limited this potential source. The channel bed, where it is natural, has experienced and is projected to experience sig-

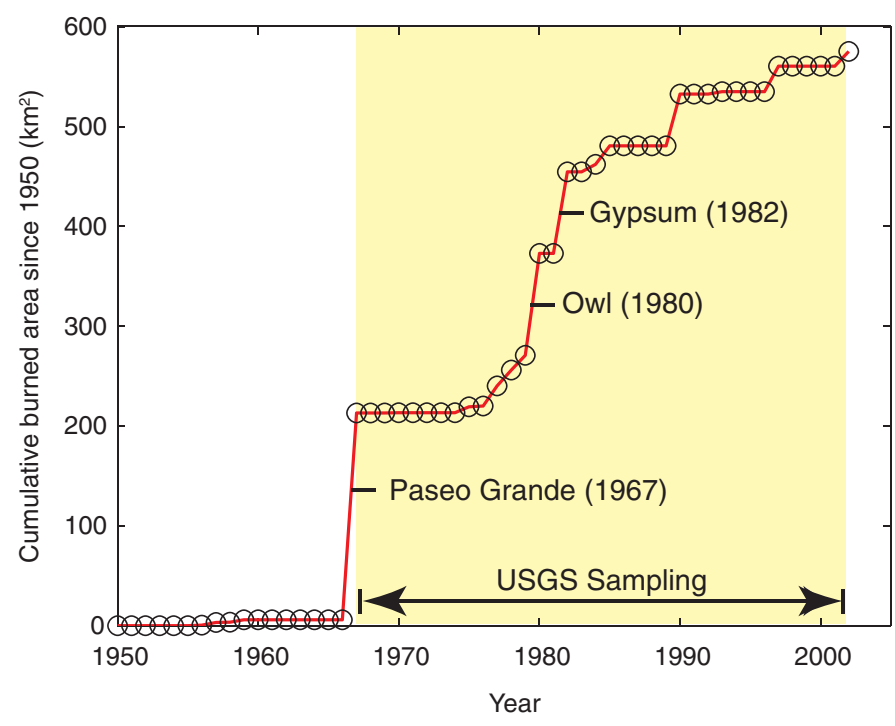

Figure 6. Cumulative area of wildfire in the lower Santa Ana River basin during 1950-2002. Some regions of the basin have burned repetitively during the period of record. Data from California Department of Forestry and Fire Protection (2004). nificant degradation (Brownlie and Taylor, 1981; Nelson, 1982; Chang, 2003). However, little of this material is represented in the suspended sediment, because on average 96 percent $( \pm 9$ percent) and 88 percent ( \pm 16 percent) of the suspended sediment mass is finer than the bed material $\mathrm{D}_{50}(0.45 \mathrm{~mm})$ and $\mathrm{D}_{15}(0.25 \mathrm{~mm})$, respectively. Further, the size distributions of the bed and suspended sediment have not changed with time, which do not suggest that the decreasing sediment rating curves are due to coarsening of the bed (for example, Rubin and Topping, 2001). Lastly, the rates of channel degradation $(\sim 0.12 \mathrm{Mt} / \mathrm{yr}$; Chang, 2003) are less than 15 percent of the average suspended-sediment budget of the lower basin. Thus, the relatively steady suspended-sediment flux from the Santa Ana River with respect to other regional rivers during a 30+ year period of urbanization (fig. 5) can be attributed to steady sediment production in the uplands, altered, but perhaps steady production in the lowlands, and limited production in the mainstem channel.

Because we have focused only on suspended-sediment discharge up to this point, the relationship between our suspended-sediment results and bedload sediment transport in the Santa Ana River deserves comment. Unfortunately, bedload is generally not measured in southern California rivers. Many have tried to understand bedload transport in the region; however, because it is likely an important source of sand to the southern California beaches. Brownlie and Taylor (1981) used a "modified Einstein" technique for a limited number of basins and calculated average bedload to suspended load ratios of 5 to 14 percent. Using more recent results of similar techniques, Inman and Jenkins (1999) assumed that bedload was $\sim 10$ percent and $\sim 15$ percent of total sediment load for large $\left(>500 \mathrm{~km}^{2}\right)$ and small $(<500$ $\mathrm{km}^{2}$ ) southern California rivers, respectively. Due to a general lack of data, Willis and Griggs (2003) assumed that 10 percent of the total sediment load was bedload for their inventory of sand and gravel for coastal California rivers. Thus, researchers have generally agreed that roughly a tenth of the total sediment transport from southern California rivers is due to bedload. For the Santa Ana River, increases in peak and total discharge, along with dilution of suspended sediment, should increase the importance of bedload transport. However, due to the lack of data, this has not been quantified. Lastly, due to the importance of this information for littoral sand budgets, we strongly encourage more attention and investigation into these topics.

One important ramification of the altered river discharge conditions we report here is the dispersal and fate of this material in the coastal ocean. First, the higher rates of river discharge will increase the total and peak momentum of river water entering the ocean during runoff events, forcing river plumes of water and sediment farther offshore (for example, Warrick and others, 2004). Second, river water that is heavily laden with sediment ( $>40 \mathrm{~g} / \mathrm{L}$ ) will exhibit negative buoyancy (that is, hyperpycnal plumes) once it is expelled into coastal waters (Mulder and Syvitski, 1995; Warrick and Milliman, 2003) and form gravity driven turbidity currents of 
sediment along the seabed. Due to the changes in sediment concentrations with time, the Santa Ana River was much more likely to exhibit hyperpycnal behavior $(>40 \mathrm{~g} / \mathrm{L})$ in the 1960s and 70s than in the 1980s and 90s (fig. 4; also see instantaneous data from 1969 in Warrick and Milliman, 2003, with concentrations in excess of $150 \mathrm{~g} / \mathrm{L}$ ). Because sediment concentrations were diluted by runoff from landscape urbanization, it follows that land-use change may be responsible for altering the dispersal mechanisms and fate of sediment on the Continental Shelf offshore and along the coast.

In conclusion, maintaining and expanding the long-term data collection networks in watersheds is essential for understanding the long-term trends and impacts of urbanization on the river and coastal regions. As shown here, these long-term records clearly detail the time history of urban impacts on river discharge in southern California. Unfortunately, other southern California basins do not have long sediment sampling records such as those for the Santa Ana River so the applicability of our sedimentological results cannot be shown at this time. Continued monitoring is needed to further characterize the hydrologic and sedimentological impacts of the widespread urbanization of the southern California lowlands.

\section{Acknowledgments}

Reviews provided by Jerad Bales and Doug Johnson greatly improved this paper. We are also grateful to David Rubin, Noah Snyder, Jodi Harney, and Eric Grossman for insightful discussions early in our investigations. G.I. Bergquist at California Department of Water Resoucres supplied land-use data and Lori Hibbeler, Beth Feingold, and Florence Wong assisted with data management and interpretation. Jonathan Warrick was funded by a USGS Mendenhall Postdoctoral Fellowship.

\section{References}

Beach, D., 2002, Coastal sprawl-The effects of urban design on coastal ecosystems in the United States: Arlington, Va., Pew Ocean Commissions, $40 \mathrm{p}$.

Booth D.B., 1990, Stream-channel incision following drainage-basin urbanization: Water Resources Bulletin, v. 26, n. 3, p. 407-417.

Brownlie, W.R., and Taylor, B.D., 1981, Sediment management for Southern California Mountains, coastal plains and shoreline; Part C, Coastal sediment delivery by major rivers in southern California: Pasadena, California, California Institute of Technology, Environmental Quality Laboratory Report No. 17-C, 314 p.

California Department of Water Resources (DWR), 1957, 1957 Land use survey quadrangle maps for Anaheim, Santiago Peak, El Toro and Orange quadrangles: Glendale, Calif.

California Department of Water Resources (DWR), 1964,
1964 Land use survey quadrangle maps for Yorba Linda, Prado Dam, Black Star Canyon, and Corona South quadrangles: Glendale, Calif.

California Department of Water Resources (DWR), 1993, 1993 Survey report of land use in the Upper Santa Ana River drainage area: Glendale, Calif.

California Department of Water Resources (DWR), 2000, Web directory of shape files for land use in 2000: accessed August 2003 [ftp://ftp.consrv.ca.gov/pub/dlrp/fmmp/2000/ ESRI_ArcShape/].

California Department of Forestry and Fire Protection (FRAP), 2004, Fire perimeters map: accessed July 2004 [http://frap.cdf.ca.gov/projects/fire_data/fire_perimeters/]. Chang H.H., 2003, Appendix E - Santa Ana scour study, in Orange County Sanitation District (OCSD) and Santa Ana Watershed Project Authority (SAWPA), Santa Ana River interceptor expanded alternatives study: Prepared by Brown and Caldwell.

Dinehart, R.L., 1997, Sediment transport at gaging stations near Mount St. Helens, Washington, 1980-90: U.S. Geological Survey Professional Paper 1573.

Ebisemiju, F.S., 1989, The response of headwater stream channels to urbanization in the humid tropics: Hydrological Processes, v. 3, p. 237-252.

Edwards, B.D., and Evans, K.R., 2002, Saltwater intrusion in Los Angeles area coastal aquifers-The marine connection: U.S. Geological Survey Fact Sheet 030-02.

Florsheim, J.L., Keller, E.A., Best, D.W, 1991, Fluvial sediment transport in response to moderate storm flows following chaparral wildfire, Ventura County, southern California: Geological Society of America Bulletin, v. 103, n. 4, p. 504-511.

Gumprecht, B., 1999, The Los Angeles River-Its life, death, and possible rebirth: Baltimore, Md., Johns Hopkins University Press, $369 \mathrm{p}$.

Haan, C., Barfield, B.J., and Hayes, J.C., 1994. Design Hydrology and sedimentology for Small Catchments: San Diego, Calif., Academic Press, p. 84-85.

Hollis, G.E., 1975, The effect of urbanization on floods of different recurrence interval: Water Resources Research. v. 11, n. 3, p. 431-435.

Inman, D.L. and Jenkins, S.A., 1999, Climate change and the episodicity of sediment flux of small California Rivers: Journal of Geology, v.107, n. 3, p. 251-270.

Izbicki, J.A., Mendez, G.O., and Burton, C.A., 2000, Stormflow chemistry in the Santa Ana River below Prado Dam and at the diversion downstream from Imperial Highway, southern California, 1995-98: U.S. Geological Survey, Water Resources Investigation Report 00-4127.

Leopold, L.B., 1968, Hydrology for urban land planning- a guidebook on the hydrologic effects of urban land use: U.S. Geological Survey Circular 554, 18 p.

Mulder, T., and Syvitski, J.P.M., 1995, Turbidity currents generated at river mouths during exceptional discharges to the world oceans: Journal of Geology, v. 103, p. 285-299.

Nelson, C.R., 1982, The Santa Ana River in Orange County, 
California - A case history in sediment transport, in National Research Council and California Institute of Technology, 1980, Storms, floods, and debris flows in southern California and Arizona 1978 and 1980: Proceedings of symposium, September 17-18, 1980.

Nelson, E.J, Booth, D.B., 2002, Sediment sources in an urbanizing, mixed land-use watershed: Journal of Hydrology, v. 264, n. 1-4, p. 51-68.

Reid, L.M, and Dunne, T., 1996, Rapid Evaluation of sediment budgets: Reiskirchen, Germany, Catena Verlag, 167 pp.

Rice, R.M., 1982, Sedimentation in the chaparral - how do you handle unusual events?, in Swanson FJ, Janda RJ, Dunne T, and Swanston D.N., (eds.), Sediment budgets and routing in forested drainage basins: Pacific Northwest Forest and Range Experiment Station, General Technical Report PNW-141.

Taylor, B.D., 1981, Sediment management for Southern California mountains, coastal plains and shoreline; Part B, Inland sediment movements by natural processes: California Institute of Technology, Pasadena, Environmental Quality Laboratory Report No. 17-B.

Trimble, S.W., 1997, Contribution of stream channel erosion to sediment yield from an urbanizing watershed: Science. v.
278, p.1442-1444.

U.S. Census Bureau, 2003, U.S. Census Bureau population data: accessed June 26, 2003 [http://www.census.gov].

Van Sickle, J., and Beschta, R.L., 1983, Supply-based models of sediment transport in streams: Water Resources Research. v. 19, n. 3, p. 768-778.

Warrick, J.A., 2002, Short-term (1997-2000) and long-term (1928-2000) observations of river water and sediment discharge to the Santa Barbara Channel: Santa Barbara, Calif., University of California at Santa Barbara, Ph.D. dissertation, $337 \mathrm{p}$.

Warrick, J.A., and Milliman, J.D., 2003, Hyperpycnal sediment discharge from semiarid southern California rivers-Implications for coastal sediment budgets: Geology, v. 31, p. 781-784.

Warrick, J.A., Mertes, L.A.K., Washburn, L., and Siegel, D.A, 2004, Dispersal forcing of southern California river plumes, based on field and remote sensing observations: GeoMarine Letters, v. 24, n. 1, p. 46-52.

Willis, C.M., and Griggs, G.B., 2003, Reductions in fluvial sediment discharge by coastal dams in California and implications for beach sustainability: Journal of Geology, v. 111, p. 167-182. 


\title{
Changes in Anthropogenic Impervious Surfaces, Precipitation, and Daily Streamflow Discharge-A Historical Perspective in a Mid-Atlantic Subwatershed'
}

\author{
By David B. Jennings ${ }^{2}$ and S. Taylor Jarnagin ${ }^{3}$
}

\section{Introduction}

Environmental protection of water quality is evolving from the detection of end-of-pipe sources of water pollution, such as sewage and industrial waste, towards a watershed management approach based primarily upon detection of non-point-source (NPS) pollution (USEPA, 1994). In generally urbanized watersheds, NPS pollution is related to human habitation and the subsequent build-up of anthropogenic impervious surfaces on the landscape. In this study, these features specifically include roads, rooftops, parking lots, driveways, and sidewalks. The amount of impervious surface in a watershed is a landscape indicator integrating a number of concurrent interactions that influence a watershed's hydrology (Schueler, 1994). The direct hydrologic effect of impervious surfaces occurs as a change in the magnitude and variability of velocity and volume of surface flow. Within landscapes under the influence of impervious surfaces, precipitation that would normally be part of natural infiltration instead falls on and flows over impervious surfaces. The runoff is then channeled and released via storm sewers directly into the receiving stream. This alteration of the natural hydrologic process reduces runoff lag time, increases the peak rate of streamflow discharge, increases the resulting number of bankfull/subbankfull values and brings about subsequent increases in the scouring and incision of the stream channel (Leopold, 1973; Booth, 1990). In this way, the channeled runoff from anthropogenic impervious surfaces influences the morphological structure of the stream and thereby alters the in-stream and riparian ecology.

The impact of impervious surfaces on hydraulic change and stream stability has been discussed in Hammer (1972), Leopold (1973), Booth (1990), and Henshaw and Booth (2000). Klein (1979) and Galli (1991) related increases in impervious surfaces to increases in stream temperature. Jones and Clark (1987) and Kennen (1999) discussed the lack of

\footnotetext{
${ }^{1}$ Originally published in Landscape Ecology, 2002, v. 17, no. 5, p. 471-489. ${ }^{2}$ U.S. Environmental Protection Agency, 12201 Sunrise Valley Dr., Reston, VA. 20192, jennings.david@epa.gov.

${ }^{3}$ U.S. Environmental Protection Agency, USGS National Center, MS 555, 12201 Sunrise Valley Dr., Reston, VA 20192, jarnagin.taylor@epa.gov.
}

benthic diversity associated with urban environments. Studies by Limburg and Schmidt (1990), Weaver and Garman (1994), May and others (1997) and Wang and others (2001) related changes in fish communities to increases in urbanization. Anderson (1968), Hollis (1975), and Rose and Peters (2001) discussed the impacts of urbanization and impervious surfaces on streamflow, whereas Biggs (1995) and Poff and Allen (1995) specifically related disturbance from streamflow variability to significant changes in aquatic habitat structure. Schueler (1994) observed that imperviousness of a watershed is the primary gauge of urban stream ecosystem health and hypothesized that a threshold for urban stream stability and habitat quality exists at approximately 10 percent to 20 percent watershed impervious surface area. While the biological effects of altered hydrologic regime have been quantified, few empirical studies have attempted to discriminate and relate the relative historical impacts of precipitation and landscape change on streamflow rate at the daily temporal scale. In addition, although continuous hydrologic modeling efforts such as Dinicola (1989), James (1994), and Leitch and Harbor (1999) are numerous, there have been no empirical studies that specifically utilized daily precipitation as an input for determining changes in long-term streamflow response. In light of current climate change investigations (Karl and Riebsame, 1989; Karl and others, 1995; Karl and Knight, 1998), historical precipitation data is necessary for discrimination of long-term causes of streamflow rate change in urbanized basins.

In their review investigation into the uses of remote sensing for the detection of impervious surfaces, Slonecker and others (2001) reported on such uses as aerial photography, satellite multi-spectral imagery, and airborne multi-spectral imagery to map impervious surfaces. In general, they found that most uses of remote sensing have emphasized general land use mapping and single-date conditions as inputs into hydrologic models or tax assessment structures. Of note are Hammer (1972), Graf (1975), and Moscript and Montgomery (1997). These studies employ historical approaches but rely upon secondary geo-spatial sources and/or generalized land cover mapping to determine the area and extent of impervious surfaces. Concerning historical landscape change and streamflow investigations, there has been little scientific effort placed on the accuracy, resolution, and consistency of explicit impervious surface area calculation across time.

In this study, we related the impact of anthropogenic impervious surfaces upon daily streamflow discharge, inde- 
pendent of precipitation variables, over a 51-year period (October 1947 through September 1998) in the upper Accotink Creek subwatershed of Fairfax, Virginia. Six dates of rectified aerial photography were utilized to map historical changes in total impervious surface area (TIA). Impervious surface area data were then compared with coincident mean daily streamflow discharge data and daily precipitation records to determine historical trends between impervious surface growth and changes in the amount and pattern of mean daily streamflow discharge.

\section{Study Area}

The area of interest for this study is the upper Accotink Creek subwatershed. This sub-watershed is bisected from the larger Accotink Creek watershed at the pour point location of the Virginia Department of Environmental Quality (VDEQ) Stream Gage 01654000, Accotink Creek, near Annandale, Virginia. (fig. 1). Located $15 \mathrm{~km}$ west of Washington D.C., within Fairfax County, Virginia, Accotink Creek flows in a generally southeasterly direction from its source in Fairfax City and empties directly into the Potomac River at Gunston Cove. The upper Accotink Creek subwatershed drains $61 \mathrm{~km}^{2}$ with a stream length from headwater to gauging station of 18 $\mathrm{km}$ and an average slope of $3.6 \mathrm{~m} \mathrm{~km}^{-1}$ (Anderson, 1968). The basin lies in the Piedmont region of Northern Virginia and has a geologic composition of crystalline rock and saprolite with an overburden primarily of clay and silt (Froelich and Zennone, 1985). The instantaneous peak discharge for stream gage 01654000 was initially set by VDEQ as $11.34 \mathrm{~m}^{3} \mathrm{~s}^{-1}$ in 1947 , and modified to $22.67 \mathrm{~m}^{3} \mathrm{~s}^{-1}$ in 1961 and to $39.67 \mathrm{~m}^{3} \mathrm{~s}^{-1}$ in 1966. The changes in the reporting of instantaneous peak discharge are related to the consistent increases in bankfull discharge as observed by the stream gage (fig. 2). This is further borne out by the historical increases in the mean frequency per year (6.0 to 20.6) and mean streamflow rate per year $\left(23.16 \mathrm{~m}^{3}\right.$ $\mathrm{s}^{-1}$ to $\left.27.40 \mathrm{~m}^{3} \mathrm{~s}^{-1}\right)$ of instantaneous discharge values $\geq 11.34$ $\mathrm{m}^{3} \mathrm{~s}^{-1}$ observed between the first and last decade of record for the gage.

\section{Methods}

\section{Calculation of Impervious Surface Area}

This study makes use of hardcopy film and digital rectified historical aerial photographs to map impervious surfaces from six dates ranging from 1949 to 1994 (table 1). U.S.Geological Survey (USGS) digital orthophoto quarter quads (DOQQ, USGS, 1996) derived from 1994 National Aerial Photography Program (NAPP) data (Light, 1993) were utilized as a base to rectify all historical aerial photographs not commercially available in digital rectified format (years 1979 and earlier). The unrectified historical photographs were scanned and converted to digital format at $1 \mathrm{~m}^{2}$ pixel resolu-

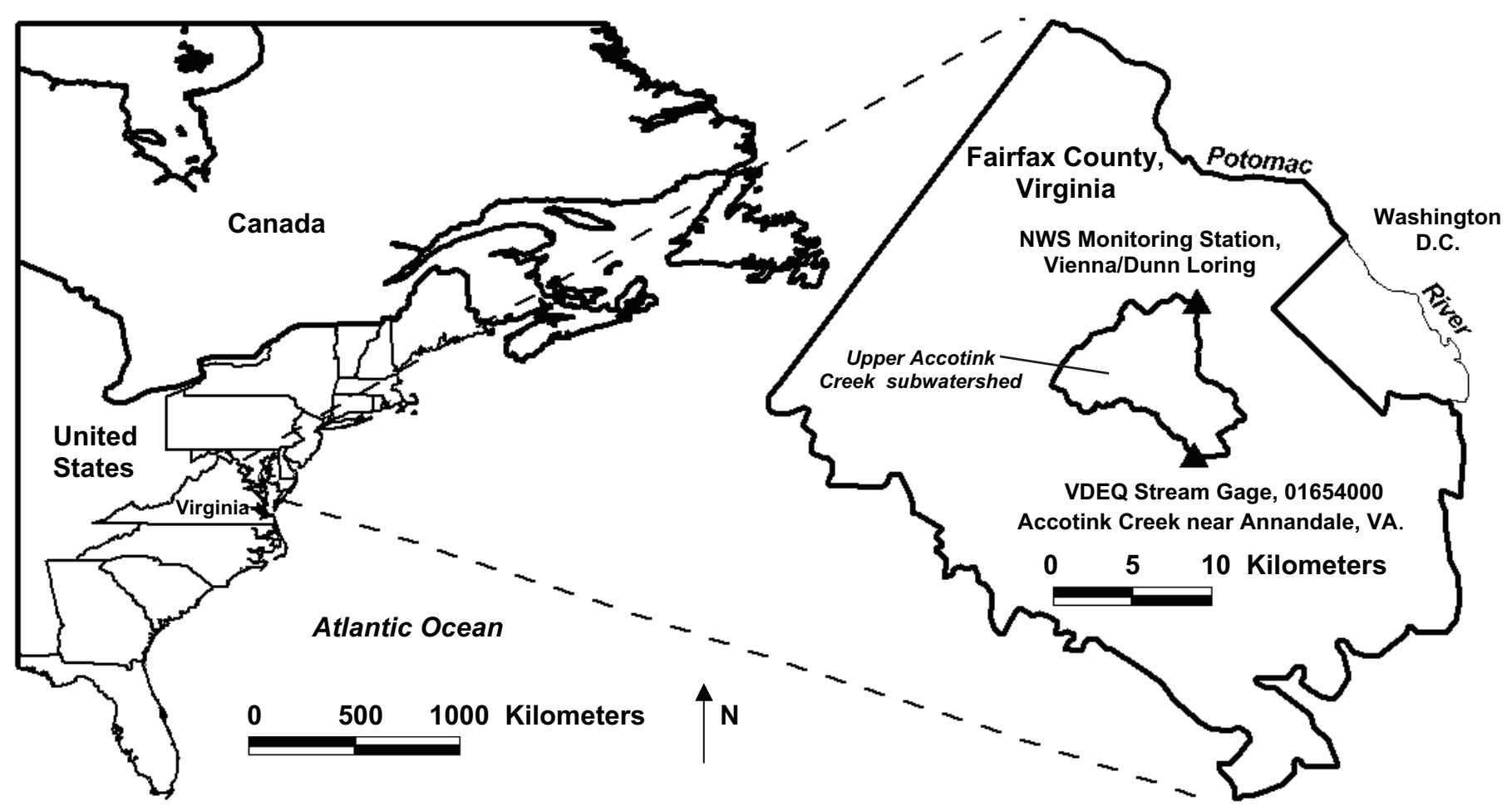

Figure 1. Location of the upper Accotink Creek subwatershed study area. 
Table 1. Aerial photographic data for the upper Accotink Creek subwatershed.

[USGS, U.S. Geological Survey; ASCS, Agricultural Soil Conservation Service; VDOT, Virginia Department of Transportation; *, also acquired in USGS DO00 format]

\begin{tabular}{cccc}
\hline Date & Photo Scale & Film Type & Source \\
\hline $3 / 94^{*}$ & $1: 40,000$ & Color InfraRed & USGS \\
$4 / 88^{*}$ & $1: 40,000$ & Color InfraRed & USGS \\
$10 / 79$ & $1: 40,000$ & Black and white & ASCS \\
$4 / 71$ & $1: 24,000$ & Black and white & VDOT \\
$4 / 63$ & $1: 24,000$ & Black and white & USGS \\
$4 / 49$ & $1: 24,000$ & Black and white & USGS \\
\hline
\end{tabular}

tion. These data were subsequently rectified to the 1994 orthoimagery utilizing image-to-image registration techniques and second order polynomial transformation algorithms (Jensen, 1996). The use of rectified digital imagery allowed impervious surfaces to be compiled in a digital mapping environment. This enabled the compiled impervious surface data to have "real world" areal extent that could be concisely tabulated as TIA.

Impervious surface areas were analyzed and compiled through the composite means of analog stereoscopic visual analysis and "heads-up" digital collection procedures. Impervious surface boundaries were delineated using standard photographic interpretation techniques as put forth in Jensen (1983) and Haack (1997)). The five categories chosen for compilation (roads, parking lots, sidewalks, rooftops, and driveways) were representative of the predominant anthropogenic cover types in the basin. The minimum mapping unit set for this project was 1 pixel or $1 \mathrm{~m}^{2}$. This resolution corresponds to the spatial resolution necessary to discern and compile sidewalks, the smallest spatial unit of the five impervious surface categories. Where features were not clearly discernable on the photograph and the scanned image, they were not compiled. Photographic resolution (Table 1) limited our ability to discriminate the degree of compaction of soil in order to determine infiltration and runoff capability. Based on the compacted nature of bare soil transportation networks ("dirt roads"), a decision rule was employed to compile bare soil areas related to road features only. If a "dirt road" pattern could be distinguished then it was compiled as an impervious surface.

The map compilation of the various impervious surface components was broken down into two categories: (1) direct compilation (fig. 3) in which a unique area feature was mapped with a unique polygon, thus allowing an individual area assessment for each unique polygon; and (2) indirect compilation (fig. 4) in which sampling procedures were introduced to assign probable area assessments to point features. Direct compilation methods were utilized for the analysis and mapping of roads, parking lots, sidewalks, multifamily rooftops as well as commercial rooftops and institutional rooftops (schools, churches, hospitals). Indirect compilation of

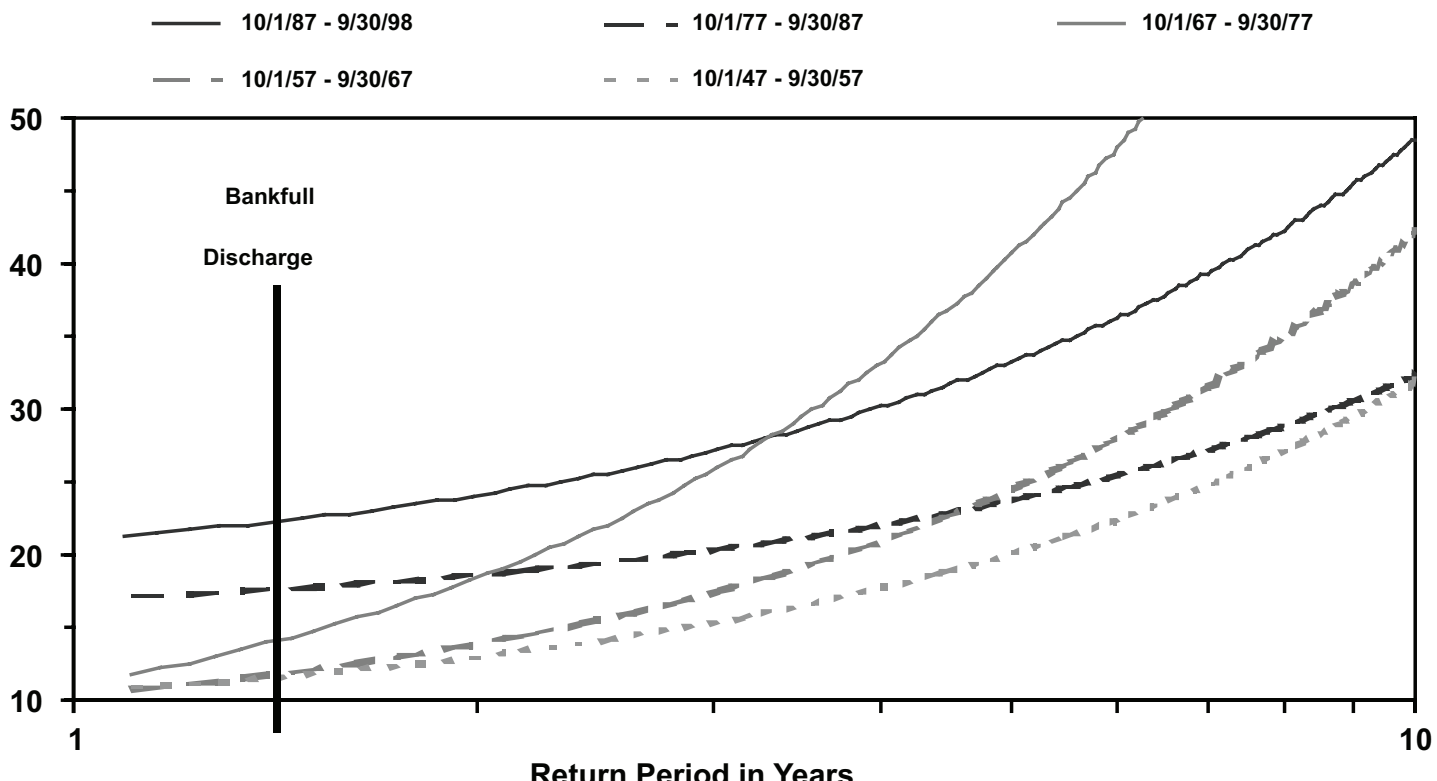

Figure 2. Bankfull discharge per decade for the upper Accotink Creek subwatershed using yearly peak mean daily streamflow data. Return Period derived as per Leopold (1968). 


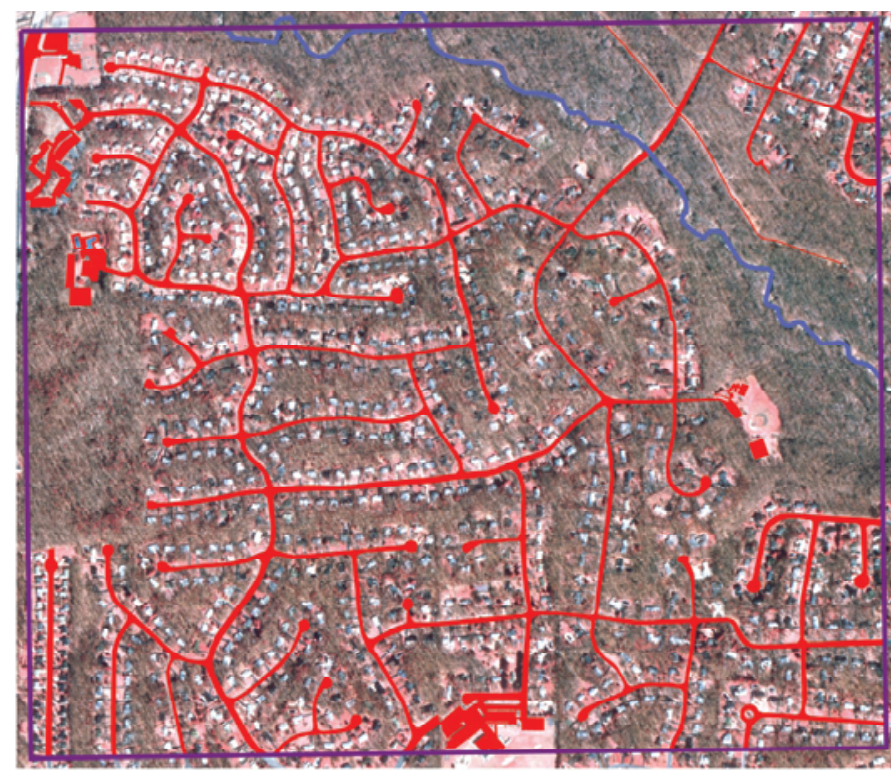

Figure 3. Direct impervious-surface compilation method. Delineated roads, parking lots, and commercial/institutional rooftop areas are mapped in red. Accotink Creek is mapped in blue.

single-family detached rooftops employed a sampling strategy based on the number of residential parcels/rooftops contained within $2 \mathrm{~km}^{2}$ grid areas. For each given grid, a point theme denoting the total number of single-family dwellings was created. Area assessments were then derived for a sample set of 5 percent of these single-family dwellings for each respective grid. Rooftops, driveways, and walkways from the singlefamily parcel sample set were delineated with polygons, and a resultant sampled mean for the impervious surface area per parcel was derived. The sample set mean was then multiplied by the number of total rooftops, per respective grid, such that impervious surface area related to single family houses could be calculated. Derived impervious surface area data from the two approaches (direct and indirect) were combined and a TIA for the watershed was calculated. The TIA was then divided by the total watershed area to compute an impervious surface percentage for each separate year of imagery. No efforts were made to distinguish between the TIA and the Effective Impervious Area (EIA) as defined in Alley and Veenhuis (1983).

\section{Precipitation/Streamflow Data}

Historical mean daily streamflow data from the VDEQ stream gage 0165400, Accotink Creek near Annandale, VA (USGS, 2001), were obtained for the water-year period of 1948 through 1998. Water year is defined as October $1^{\text {st }}$ of the previous year through September $30^{\text {th }}$ of the current year that is water year $1950=10 / 1 / 49-9 / 30 / 50$ ). Historical daily precipitation records coincident with the streamflow records were acquired from the National Weather Service (NWS) monitoring station Vienna/Dunn Loring (NCDC, 1998). The NWS station is located approximately 10 kilometers north of the VDEQ streamflow gage (fig. 1) and provided the best historical estimate of overall precipitation amount and distribution in the upper Accotink Creek basin. The streamflow dataset was 100 percent complete while the precipitation dataset was missing 434 total records - primarily from the first two years of data. No attempt was made to interpolate values for the missing precipitation records.

Coincident daily precipitation/streamflow data pairs were formed from the individual data sets and grouped into categories based on measurable daily precipitation cutoff values at (1) $>0 \mathrm{~mm},(2) \geq 6.0 \mathrm{~mm}$, and (3) $\geq 35.0 \mathrm{~mm}$. The

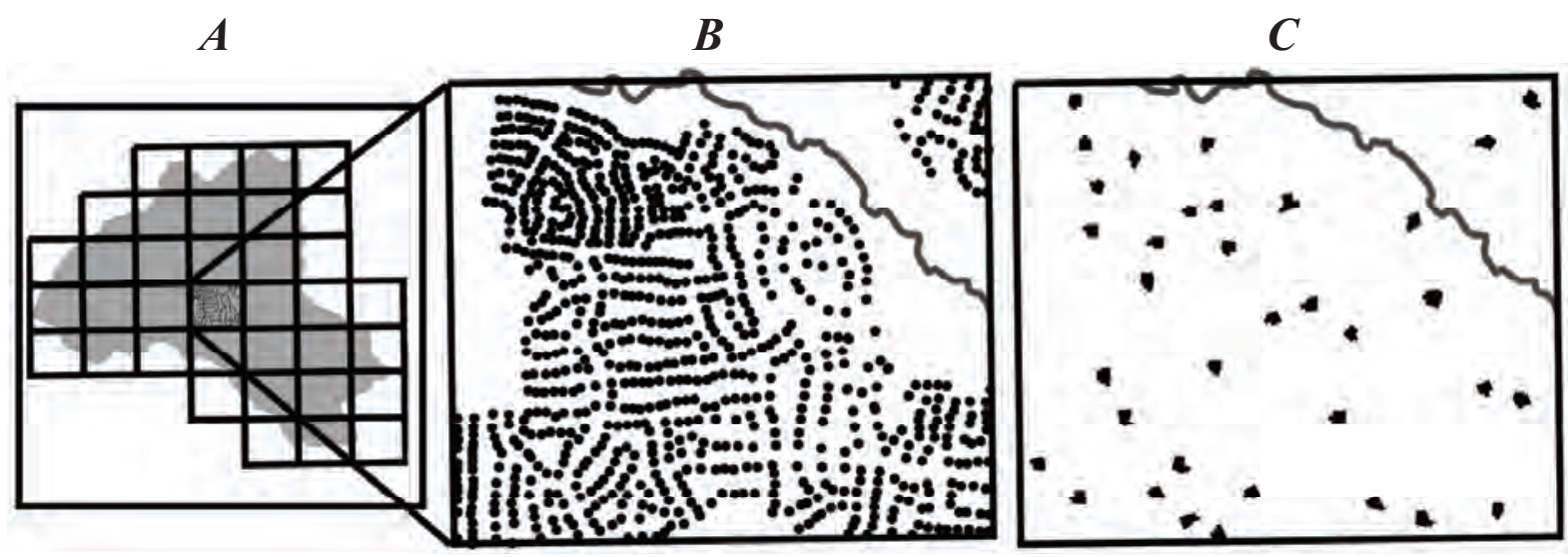

Figure 4. Indirect compilation based on $(A) 2 \mathrm{~km}^{2}$ sampling grid network overlaid on the basin (the stippled area in the center of the sampling grid is the identical $2 \mathrm{~km}^{2}$ area referenced in figure 3 above); $(B)$ the compiled point theme representative of parcel/rooftops; (C) an area sample displaying 5 percent of the parcel/rooftop point theme compiled as polygons from rooftop, driveway, and walkway impervious-surface features associated with each parcel. The mean of the polygonal areas then became the mean area for all residential rooftops in that particular grid. 
precipitation cutoff \# $>0.0 \mathrm{~mm}$ included all daily occurrences of measurable precipitation and allowed the general relationship of precipitation and streamflow to be explored. The precipitation cutoff $\# \geq 6.0 \mathrm{~mm}$ included approximately 45 percent of the data pairs with measurable precipitation ( $6.0 \mathrm{~mm}$ was viewed as a "normal" precipitation occurrence). The precipitation cutoff $\# \geq 35.0 \mathrm{~mm}$ included approximately 5 percent of the data pairs with measurable precipitation ( $35.0 \mathrm{~mm}$ was viewed as "extreme" precipitation occurrence).

The precipitation/streamflow data pairs were further binned into temporal categories as: (1) 10-year bins to examine the overall historical precipitation/streamflow discharge trend; and (2) 3-year bins, around each date of photographic coverage, to examine the relationship of a specific percent impervious surface area on streamflow discharge. Due to missing precipitation data and a single "decade" that consisted of more than 10 years (10/1/87-9/30/98), we used a sample year (365 days) and sample decade (3,650 days) to standardize the number of data pairs per year for 10 -year and 3-year bins.

\section{Streamflow Frequency Pattern}

We grouped the counts of mean daily streamflow discharge rates ranging in volume from $0.25 \mathrm{~m}^{3} \mathrm{~s}^{-1}$ to $14.0 \mathrm{~m}^{3} \mathrm{~s}^{-1}$ into 10-year bins to develop a frequency analysis that would characterize historical variability in given levels of streamflow discharge.

\section{Calculation of a Streamflow Response Value}

For the streamflow-precipitation data pairs related to the precipitation cutoff groupings of $\geq 6 \mathrm{~mm}$ and $\geq 35 \mathrm{~mm}$, a daily streamflow response value (per meter of precipitation) was produced. The streamflow response $\left(\mathrm{m}^{3} \mathrm{~s}^{-1} \mathrm{~m}^{-1}\right)$ metric is the product: [mean daily streamflow $\left(\mathrm{m}^{3} \mathrm{~s}^{-1}\right) /$ daily precipitation (in meters)]. "Streamflow response" provided a unifying term for the data pair whereby historical changes in streamflow response to per unit of precipitation could be tracked and reported over time.

The streamflow response value is similar to a daily runoff coefficient (RC) in that the variables of streamflow and precipitation are utilized to derive a runoff ratio. The terms of area and time are constants in this study, so that the relative change in the daily relationship of the streamflow response value and the $\mathrm{RC}$ are identical. With respect to change over time in single watershed studies, there is no difference between the streamflow response value and the RC. However, we feel that as a metric, streamflow response provided a more intuitive stream ecology relationship than the $\mathrm{RC}$ and better captured the changing magnitude of streamflow as an ecological disturbance event.

\section{Historical Precipitation Pattern}

As part of the data pair approach, precipitation data was tested for differences in frequency and amount per 10-year and 3 -year bins for the categories $>0 \mathrm{~mm}, \geq 6 \mathrm{~mm}$, and $\geq 35 \mathrm{~mm}$.

Additionally, we tested for changes in historical precipitation pattern that could influence historical streamflow discharge patterns. Precipitation data for the categories $>0 \mathrm{~mm}$ and $\geq 6 \mathrm{~mm}$ were grouped into 10-year bins based on occurrences of 1-day, 2-day, 3-day, and $>3$-day precipitation duration by decade. The categories $>0 \mathrm{~mm}$ and $\geq 6 \mathrm{~mm}$ were also grouped into 10-year bins based on the seasonal categories of winter, spring, summer and fall to test for changes in seasonal patterns. The "continuous daily precipitation duration" and "daily precipitation by season" groupings were tested for changes in the frequency and mean amount of daily precipitation per decade.

\section{Statistical Analysis}

Normality of data was tested utilizing KolmogorovSmirnov One Sample Tests using a Normal $(0.00,1.00)$ distribution and 2-tail Lilliefors probabilities. All statistical tests were run with SAS (Science Analysis System) 7.0 and SYSTAT 9.0 on a Windows NT platform.

\section{Results}

Both the streamflow and precipitation data were not normally distributed and this condition was not correctable using data transformations. Therefore, we used the nonparametric Kruskal-Wallis One-Way Analysis of Variance for the tests of differences in amount of the streamflow and precipitation variables. One-Way Crosstabs using Pearson chi-square were used to test for differences in the frequency of variable values.

\section{Mapping of Impervious Surfaces}

Figure 5 is a set of image mosaics, produced from rectified digital photographs, overlaid with compiled impervious street networks and commercial/institutional areas. These images reveal the changing nature of the landscape in the basin over the study period. The percentage of impervious cover in the basin grew from approximately 3 percent in 1949 to 33 percent in 1994. Root Mean Square (RMS) error for the image-toimage registration was $<2.5$ pixels for each coverage, while post-rectification check points showed that registration errors were in the 2 to 4 pixel range. Individual map accuracy assessments were achieved via simple random sampling procedures as set forth by Congalton and Green (1999). Total map accuracy for the six impervious surface maps ranged from 97 percent in 1949 to 91 percent in 1994 (table 2). 
Table 2. Registration error, percent impervious-surface area, and total map accuracy assessment per photographic coverage for the upper Accotink Creek subwatershed.

[Registration error is based on the mean of four post-rectification check points per coverage]

\begin{tabular}{ccccc}
\hline $\begin{array}{c}\text { Year of } \\
\text { Imagery }\end{array}$ & $\begin{array}{c}\text { Registration Error } \\
\text { (in Pixel Units) }\end{array}$ & $\begin{array}{c}\text { Approximate } \\
\text { TIA \% }\end{array}$ & $\begin{array}{c}\text { Total Map } \\
\text { Accuracy \% }\end{array}$ \\
\hline 1949 & $\mathrm{X}=2.1$ & $\mathrm{Y}=3.4$ & 3 & 97 \\
1963 & $\mathrm{X}=1.1 \quad \mathrm{Y}=2.7$ & 13 & 95 \\
1971 & $\mathrm{X}=2.9 \quad \mathrm{Y}=2.9$ & 21 & 96 \\
1979 & $\mathrm{X}=1.9 \quad \mathrm{Y}=1.5$ & 27 & 93 \\
1988 & $\mathrm{~N} / \mathrm{A}$ & 33 & 92 \\
1994 & $\mathrm{~N} / \mathrm{A}$ & 33 & 91 \\
\hline
\end{tabular}
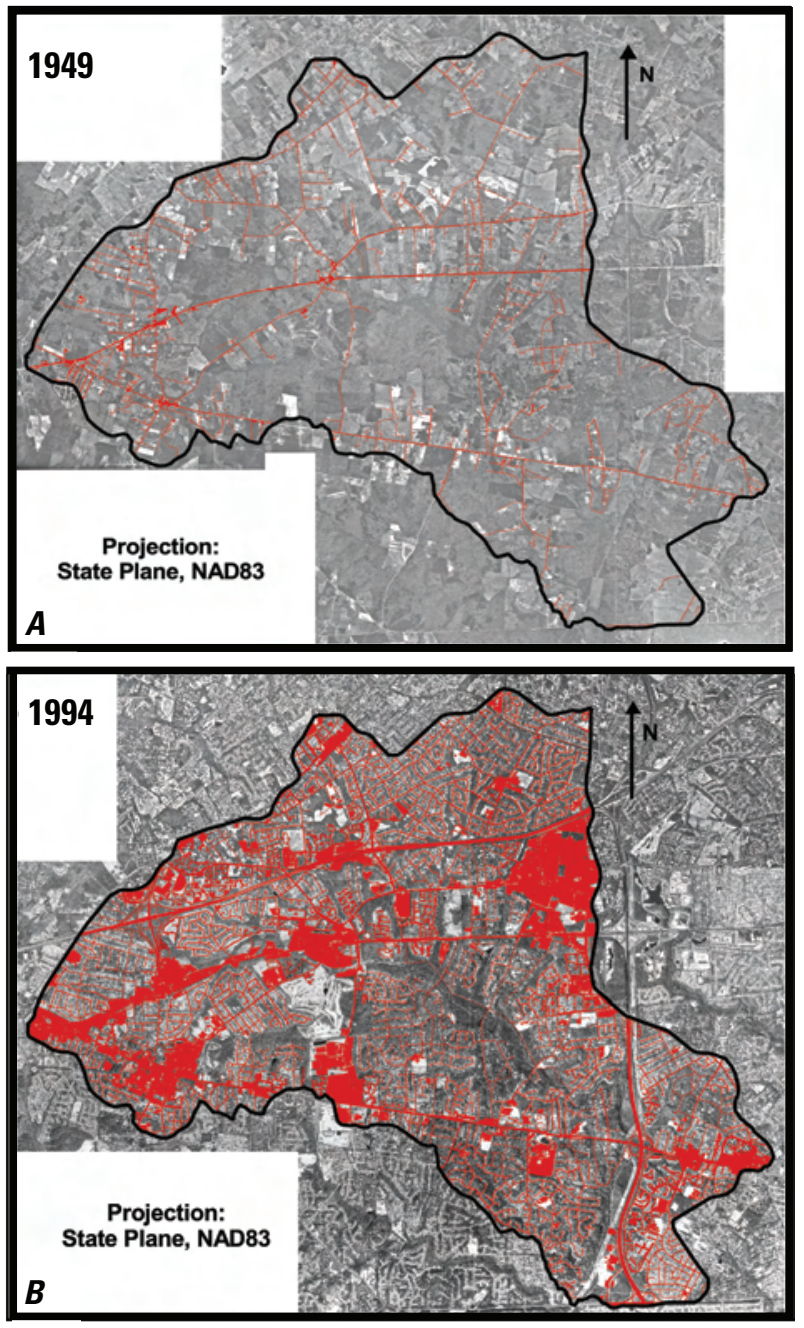

Figure 5. Upper Accotink Creek subwatershed image mosaics for (A) 1949 and (B) 1994 where roads and commercial/institutional areas are mapped in red. Anthropogenic impervious-surface area has increased from 3 percent in 1949 to 33 percent in 1994.

\section{Ten-Year Bins (General Streamflow and Pre- cipitation Trends)}

Figure 6 is a graph of the regression lines from the scatterplots of the streamflow-precipitation data pairs related to precipitation values $>0 \mathrm{~mm}$, grouped in 10 -year bins. The graph represents a general historical characterization of streamflow-precipitation relationship. A rising slope over time is observed indicating an increasingly direct relationship between precipitation and runoff. The data appear to form two distinct groupings of slopes over time, with the precipitation/ streamflow response curves for the first two decades showing a lower streamflow response to increasing precipitation than the last three decades.

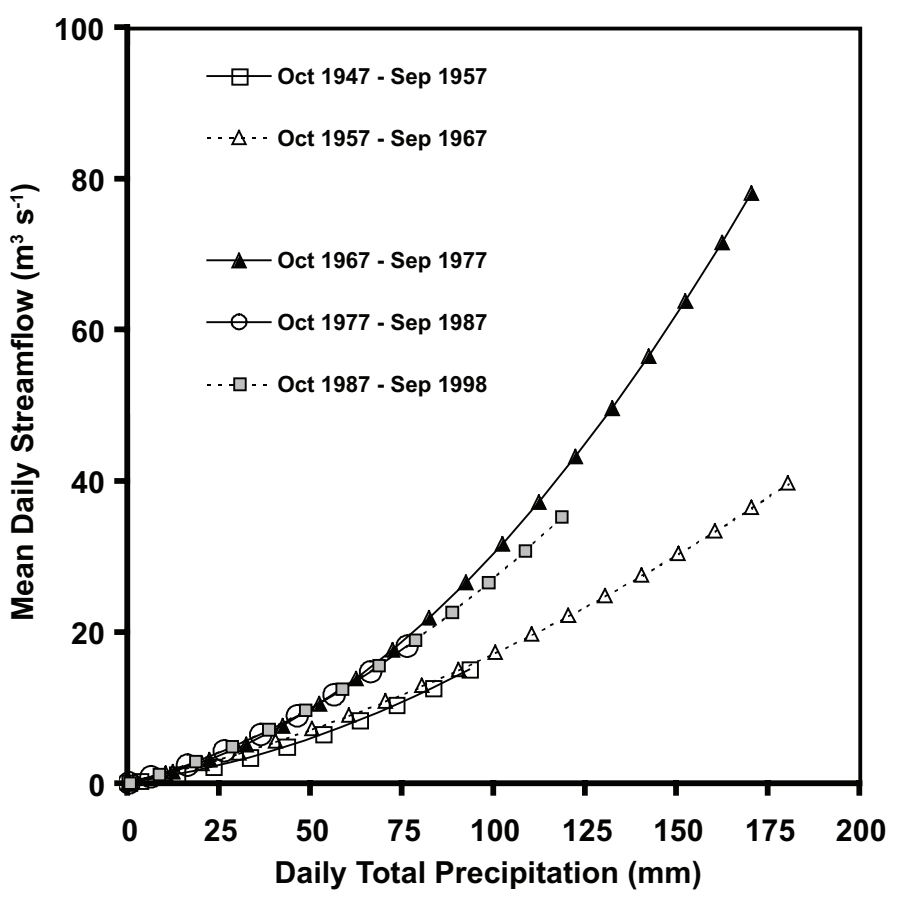

Figure 6. Streamflow versus precipitation for days of measurable precipitation (1947-1998) for the upper Accotink Creek subwatershed. A decade-by-decade series of regressions illustrating the general historical curvilinear relationships of daily precipitation and streamflow. Figure includes all streamflow-precipitation data pairs where precipitation values $>0, N=5865$. The regression lines for the first two decades follow a similar path, whereas the curves for the last three decades form a second group.

Regression equations and sample $\mathrm{n}$ per decade:

$1^{\text {st }}$ decade $(10 / 47-9 / 57): y=0.001 x^{2}+0.0678 x+0.3595, R^{2}=0.4609, n=1051$; $2^{\text {nd }}$ decade $(10 / 57-9 / 67): y=0.0005 x^{2}+0.1259 x+0.1366, R^{2}=0.5429, n=$ 1076;

$3^{\text {rd }}$ decade $(10 / 67-9 / 77): y=0.0022 x^{2}+0.0811 x+0.4803, R^{2}=0.7139, n=$ 1159;

$4^{\text {th }}$ decade $(10 / 77-9 / 87): y=0.0013 x^{2}+0.1372 x+0.1425, R^{2}=0.5406, n=$ 1199;

$5^{\text {th }}$ decade $(10 / 87-9 / 98): y=0.0014 x^{2}+0.1297 x+0.4052, R^{2}=0.4849, n=$ 1380. 
Table 3. Differences in streamflow frequencies by decade for the upper Accotink Creek subwatershed.

[The darker middle column denotes historical mean $\left(0.8 \mathrm{~m}^{3} \mathrm{~s}^{-1}\right)$. Significant differences were found among decades at $\alpha=0.05$ for all mean daily stream-flow occurrence cutoff levels. One-way cross-tabs $\left(\chi^{2}\right)$ statistical tests used were for the number of values per sample decade, results reported as (test statistic value, df, p-value)]

\begin{tabular}{|c|c|c|c|c|c|c|}
\hline Decades & $\begin{array}{c}\text { Number of } \\
\text { days with mean } \\
\text { daily stream } \\
\text { flow } \\
\geq 0.25 \mathrm{~m}^{3} \mathrm{~s}^{-1} \\
\text { per sample } \\
\text { decade }\end{array}$ & $\begin{array}{c}\text { Number of } \\
\text { days with mean } \\
\text { daily stream } \\
\text { flow } \\
\geq 0.5 \mathrm{~m}^{3} \mathrm{~s}^{-1} \text { per } \\
\text { sample decade }\end{array}$ & $\begin{array}{c}\text { Number of } \\
\text { days with mean } \\
\text { daily stream } \\
\text { flow } \\
\geq 0.8 \mathrm{~m}^{3} \mathrm{~s}^{-1} \text { per } \\
\text { sample decade }\end{array}$ & $\begin{array}{c}\text { Number of } \\
\text { days with mean } \\
\text { daily stream } \\
\text { flow } \\
\geq 1.5 \mathrm{~m}^{3} \mathrm{~s}^{-1} \text { per } \\
\text { sample decade }\end{array}$ & $\begin{array}{c}\text { Number of } \\
\text { days with mean } \\
\text { daily stream } \\
\text { flow } \\
\geq 9.0 \mathrm{~m}^{3} \mathrm{~s}^{-1} \text { per } \\
\text { sample decade }\end{array}$ & $\begin{array}{c}\text { Number of } \\
\text { days with mean } \\
\text { daily stream } \\
\text { flow } \\
\geq 14.0 \mathrm{~m}^{3} \mathrm{~s}^{-1} \\
\text { per sample } \\
\text { decade } \\
\end{array}$ \\
\hline $\begin{array}{c}10 / 1 / 47 \text { - } \\
9 / 30 / 57\end{array}$ & 2450.0 & 1525.7 & 816.3 & 281.8 & 22.0 & 6.0 \\
\hline $\begin{array}{l}10 / 1 / 57 \text { - } \\
9 / 30 / 67\end{array}$ & 2360.7 & 1265.3 & 722.6 & 305.8 & 23.0 & 13.0 \\
\hline $\begin{array}{l}\text { 10/1/67 - } \\
\text { 9/30/77 }\end{array}$ & 2691.8 & 1397.9 & 738.4 & 360.7 & 46.0 & 19.0 \\
\hline $\begin{array}{c}10 / 1 / 77 \text { - } \\
9 / 30 / 87\end{array}$ & 2102.8 & 1125.4 & 684.6 & 362.8 & 38.0 & 19.0 \\
\hline $\begin{array}{c}10 / 1 / 87- \\
9 / 30 / 98\end{array}$ & 2204.7 & 1143.7 & 672.2 & 447.8 & 49.1 & 25.4 \\
\hline Results & $\begin{array}{c}(90.051,4 \\
<0.001)\end{array}$ & $\begin{array}{c}(88.231,4, \\
<0.001)\end{array}$ & $\begin{array}{c}(17.81,4, \\
0.001)\end{array}$ & $\begin{array}{c}(46.74,4 \\
<0.001)\end{array}$ & $\begin{array}{c}(17.94,4 \\
0.001)\end{array}$ & $\begin{array}{c}(13.04,4, \\
0.011)\end{array}$ \\
\hline
\end{tabular}

Table 3 is a set of historical streamflow discharge frequencies, in 10-year bins, ranging in volume from $0.25 \mathrm{~m}^{3} \mathrm{~s}^{-1}$ to 14.0 $\mathrm{m}^{3} \mathrm{~s}^{-1}$. The table reflects streamflow data only and does not refer to coincident precipitation values. The frequency of flows for the three cutoff values above the historical mean $\left(0.80 \mathrm{~m}^{3} \mathrm{~s}^{-1}\right)$ have significantly increased over time, while the frequency of flows for the three cutoff values at or below the mean have significantly decreased over time. Figure 7 compares the streamflow response value and precipitation for precipitation values $\geq$ $6.0 \mathrm{~mm}$ by 10 -year bin. Two trends emerge from the data: (1) mean precipitation volume shows no significant variation over time, whereas (2) the streamflow response value shows a significant change over the same period.

Table 4 is a compilation of 10-year bin statistics of precipitation and streamflow for data pairs associated with the daily precipitation cutoff values of $\geq 6.0 \mathrm{~mm}$ (fig. 7) and $\geq 35.0$ $\mathrm{mm}$. There was no significant difference among bins for the frequency of precipitation occurrences or in the mean amounts of precipitation per value at either cutoff value. There was a significant difference among decades found for the streamflow response value at both cutoff values.

\section{Three-Year Bins (Impervious Surface and Streamflow Relationship)}

Figure 8 compares the streamflow response value and precipitation for precipitation values $\geq 6.0 \mathrm{~mm}$ by 3 -year bins centered on aerial photography acquisition dates. As in figure 7,

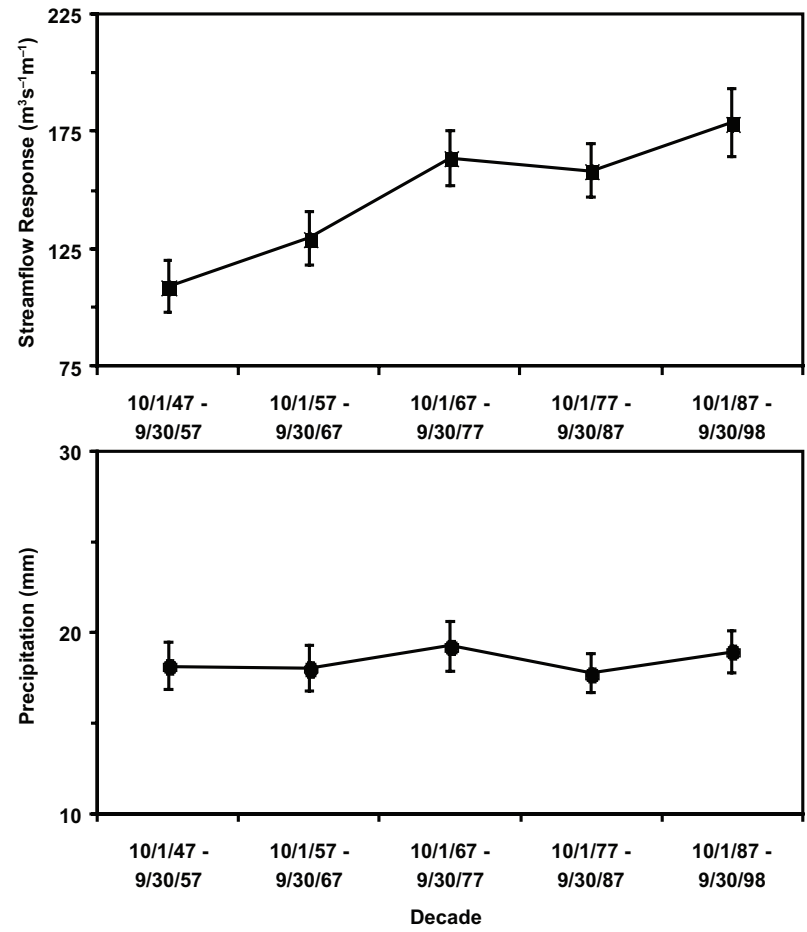

Figure 7. Comparison of decade averages of daily precipitation (mm) and daily streamflow response value $\left(\mathrm{m}^{3} \mathrm{~s}^{-1} \mathrm{~m}^{-1}\right)$ for the upper Accotink Creek subwatershed. Daily streamflow response values were calculated for days where daily precipitation value $\geq 6.0 \mathrm{~mm}$. Error bars show the \pm 95 percent confidence interval for the means. $\mathrm{N}=$ 2,681 streamflow-precipitation pairs. Data related to Hurricane Agnes (June 21-22, 1972) were excluded from the analysis as outliers. 
Table 4. Statistics for October 1947 through September 1998 precipitation and stream-flow response value for the upper Accotink Creek subwatershed.

[The data are binned by decade. $*=$ significant difference found among decades at $\alpha=0.05$. Statistical tests used for number of values = one-way cross-tabs $\left(\chi^{2}\right)$, tests for amounts = Kruskal-Wallis one-way analysis of variance, results reported as (test statistic value, df, $\mathrm{p}$-value). $\mathrm{N}=2,681$ stream-flow-precipitation pairs for precipitation values $\geq 6.0 \mathrm{~mm}, \mathrm{~N}=259$ stream-flow-precipitation pairs for precipitation values $\geq 35.0 \mathrm{~mm}$. Data related to Hurricane Agnes (June 21-22, 1972) were excluded from the analysis as outliers]

\begin{tabular}{|c|c|c|c|c|c|c|}
\hline Decades & $\begin{array}{c}\text { Number of } \\
\text { daily } \\
\text { precipitation } \\
\text { values } \geq 6 \\
\text { mm per } \\
\text { sample year }\end{array}$ & $\begin{array}{c}\text { Mean } \\
\text { precipitation } \\
\text { amount } \\
(\mathrm{mm}) \text { per } \\
\text { value } \geq 6 \\
\text { mm } \pm 95 \% \\
\text { C.I. }\end{array}$ & $\begin{array}{c}\text { Stream-flow } \\
\text { response } \\
\left(\mathrm{m}^{3} \mathrm{~s}^{-1} \mathrm{~m}^{-1}\right) \\
\text { per } \\
\text { precipitation } \\
\text { value } \geq 6 \\
\mathrm{~mm} \\
\pm 95 \% \text { C.I. } \\
*\end{array}$ & $\begin{array}{c}\text { Number of } \\
\text { daily } \\
\text { precipitation } \\
\text { values } \geq \mathbf{3 5} \\
\text { mm per } \\
\text { sample year }\end{array}$ & $\begin{array}{c}\text { Mean } \\
\text { precipitation } \\
\text { amount } \\
(\mathrm{mm}) \text { per } \\
\text { value } \\
\geq 35 \mathrm{~mm} \\
\pm \mathbf{9 5 \%} \text { C.I. }\end{array}$ & $\begin{array}{c}\text { Stream-flow } \\
\text { response } \\
\left(\mathrm{m}^{3} \mathrm{~s}^{-1} \mathrm{~m}^{-1}\right) \\
\text { per } \\
\text { precipitation } \\
\text { value } \geq 35 \\
\mathbf{m m} \\
\pm 95 \% \text { C.I. } \\
*\end{array}$ \\
\hline $\begin{array}{c}10 / 1 / 47- \\
9 / 30 / 57\end{array}$ & 54.7 & $18.1 \pm 1.3$ & $108.9 \pm 10.9$ & 5.3 & $53.7 \pm 5.3$ & $119.5 \pm 28.3$ \\
\hline $\begin{array}{c}10 / 1 / 57- \\
9 / 30 / 67\end{array}$ & 49.9 & $18.0 \pm 1.3$ & $129.6 \pm 11.3$ & 4.9 & $50.6 \pm 6.7$ & $172.3 \pm 34.0$ \\
\hline $\begin{array}{c}\text { 10/1/67 - } \\
9 / 30 / 77\end{array}$ & 53.6 & $18.8 \pm 1.3$ & $161.8 \pm 11.8$ & 5.8 & $51.7 \pm 5.0$ & $191.7 \pm 27.3$ \\
\hline $\begin{array}{c}10 / 1 / 77- \\
9 / 30 / 87\end{array}$ & 56.2 & $17.7 \pm 1.0$ & $158.3 \pm 11.2$ & 4.6 & $49.2 \pm 3.6$ & $224.1 \pm 39.3$ \\
\hline $\begin{array}{c}10 / 1 / 87- \\
9 / 30 / 98\end{array}$ & 54.6 & $18.9 \pm 1.1$ & $178.4 \pm 14.5$ & 5.4 & $51.5 \pm 4.9$ & $223.1 \pm 38.5$ \\
\hline Results & $\begin{array}{c}(0.42,4 \\
0.981)\end{array}$ & $\begin{array}{c}4.08,4, \\
0.395)\end{array}$ & $\begin{array}{c}(176.07,4, \\
<0.001)\end{array}$ & $\begin{array}{c}(0.16,4, \\
0.997)\end{array}$ & $\begin{array}{c}(1.53,4, \\
0.821)\end{array}$ & $\begin{array}{c}(24.17,4 \\
<0.001)\end{array}$ \\
\hline
\end{tabular}

two trends emerge from the data: (1) mean precipitation volume show no significant variation over time, whereas (2) the streamflow response value shows a significant difference over the same period. The transition in streamflow, previously observed in figures 7 and 8 is now generally present between the 3 percent to 21 percent impervious surface levels (years 1949, 1963 and 1971 respectively). Impervious surface percent for the years 1988 and 1994 were both mapped at 33 percent. Pair-wise testing revealed no significant difference in their respective streamflow response values; therefore, these years were combined into a single category.

Table 5 is a compilation of 3-year bin statistics of precipitation and streamflow for data pairs associated with the daily precipitation cutoff values of $\geq 6.0 \mathrm{~mm}$ (fig. 8) and $\geq 35.0 \mathrm{~mm}$. There was no significant difference among bins for the frequency of precipitation occurrences or in the mean amounts of precipitation per value at either cutoff value. There was a significant difference among decades found for the streamflow response value at the cutoff value $\geq 6.0 \mathrm{~mm}$ but not at the cutoff value $\geq 35.0 \mathrm{~mm}$.

\section{Precipitation Frequency, Magnitude, and Pattern}

No statistically significant differences were found in the amounts or frequency of the daily precipitation data, per 10 -year bins, associated with the cutoff values of \# $>0 \mathrm{~mm}$
(Kuskal-Wallis test statistic $=3.24, \mathrm{df}=4, \mathrm{p}=0.518 ; \chi^{2}=$ $1.45, \mathrm{df}=4, \mathrm{p}=0.835), \geq 6 \mathrm{~mm}$ (statistics in table 4 ) and $\geq$ $35 \mathrm{~mm}$ (statistics in table 4).

The pattern of daily precipitation $\geq 6 \mathrm{~mm}$ revealed a statistically significant increase for the frequency of precipitation occurrences $>3$-days in duration $\left(\chi^{2}=27.47, \mathrm{df}=12, \mathrm{p}\right.$ $=0.007$ ) by 10 -year bin. We tested the frequency of $>3$-day duration occurrences and found that for the first 4 decades, when the predominant increase in streamflow response value occurred, no significant change in the frequency of $>3$-day occurrences was observed $\left(\chi^{2}=5.09, \mathrm{df}=6, \mathrm{p}=0.532\right)$. It is not until we include the final decade of the $>3$-day duration data that a significant difference in frequency is observed. The frequency of all other duration periods related to the cutoff values $>0 \mathrm{~mm}$ and $\geq 6 \mathrm{~mm}$ were not statistically significant.

We did factor analysis of streamflow and related precipitation duration values. These results showed that streamflow significantly increased with an increase in the duration of precipitation (four levels: one-day, two-day, three-day, and $\geq$ three-day; ANOVA F-Ratio $=35.05, \mathrm{df}=12, \mathrm{p}<$ $0.001)$ and the decade of occurrence (ANOVA F-Ratio $=$ $15.95, \mathrm{df}=12, \mathrm{p}<0.001)$. However, the interaction of streamflow to precipitation duration among 10-year bins was not significantly different (ANOVA F-Ratio $=1.05, \mathrm{df}=12$, $\mathrm{p}=0.402$ ). This means that the increase in streamflow with 
Table 5. Statistics for precipitation and standardized stream-flow per percentage of impervious surface found over time in the upper Accotink Creek subwatershed.

[Three-year bins centered on the aerial photography acquisition dates group the data. $*=$ a significant difference found among decades at $\alpha=$ 0.05 . Statistical tests used for number of values $=$ one-way crosstabs $\left(\chi^{2}\right)$, tests for amounts $=$ Kruskal-Wallis one-way analysis of variance, results reported as (test statistic value, df, p-value). $\mathrm{N}=990$ streamflow-precipitation pairs for precipitation values $\geq 6.0 \mathrm{~mm}, 85$ streamflow-precipitation pairs for precipitation values $\geq 35.0 \mathrm{~mm}$. Data related to Hurricane Agnes (June 21-22, 1972) were excluded from the analysis as outliers]

\begin{tabular}{|c|c|c|c|c|c|c|}
\hline $\begin{array}{l}\text { Impervious } \\
\text { surface \% } \\
\text { related to } \\
3 \text {-year bin }\end{array}$ & $\begin{array}{c}\text { Number of } \\
\text { daily } \\
\text { precipitation } \\
\text { values } \geq 6 \\
\text { mm per year }\end{array}$ & $\begin{array}{c}\text { Mean } \\
\text { precipitation } \\
\text { amount }(\mathrm{mm}) \\
\text { per value } \\
\geq 6 \mathrm{~mm} \\
\pm 95 \% \text { C.I. }\end{array}$ & $\begin{array}{c}\text { Stream-flow } \\
\text { response value } \\
\left(\mathrm{m}^{3} \mathrm{~s}^{-1} \mathrm{~m}^{-1}\right) \text { per } \\
\text { precipitation } \\
\text { value } \\
\geq 6 \mathrm{~mm} \\
\pm 95 \% \text { C.I. } \\
*\end{array}$ & $\begin{array}{c}\text { Number of } \\
\text { daily } \\
\text { precipitation } \\
\text { values } \geq 35 \\
\text { mm per year }\end{array}$ & $\begin{array}{c}\text { Mean } \\
\text { precipitation } \\
\text { amount }(\mathrm{mm}) \\
\text { per value } \\
\geq 35 \mathrm{~mm} \\
\pm 95 \% \text { C.I. }\end{array}$ & $\begin{array}{c}\text { Stream-flow } \\
\text { response value } \\
\left(\mathrm{m}^{3} \mathrm{~s}^{-1} \mathrm{~m}^{-1}\right) \text { per } \\
\text { precipitation } \\
\text { value } \\
\geq 35 \mathrm{~mm} \\
\pm 95 \% \text { C.I. }\end{array}$ \\
\hline 3 & 62.2 & $17.0 \pm 2.0$ & $113.4 \pm 15.4$ & 5.5 & $51.2 \pm 7.9$ & $130.3 \pm 41.1$ \\
\hline 13 & 49.3 & $17.8 \pm 2.0$ & $139.2 \pm 21.5$ & 4.3 & $49.3 \pm 6.0$ & $162.3 \pm 42.9$ \\
\hline 21 & 56.3 & $17.8 \pm 2.0$ & $168.4 \pm 20.1$ & 5.0 & $52.0 \pm 6.8$ & $205.2 \pm 63.6$ \\
\hline 27 & 60.6 & $18.1 \pm 1.9$ & $181.9 \pm 25.5$ & 4.6 & $52.5 \pm 4.9$ & $238.1 \pm 62.5$ \\
\hline 33 & 53.7 & $18.1 \pm 1.4$ & $167.1 \pm 12.7$ & 4.6 & $48.3 \pm 6.2$ & $227.2 \pm 53.4$ \\
\hline Results & $\begin{array}{c}(1.93,4, \\
0.748)\end{array}$ & $\begin{array}{c}4.18,4 \\
0.383)\end{array}$ & $\begin{array}{c}(54.51,4, \\
>0.001)\end{array}$ & $\begin{array}{c}(0.51,4 \\
0.973)\end{array}$ & $\begin{array}{c}(5.00,4 \\
0.292)\end{array}$ & $\begin{array}{c}(8.38,4 \\
0.079)\end{array}$ \\
\hline
\end{tabular}
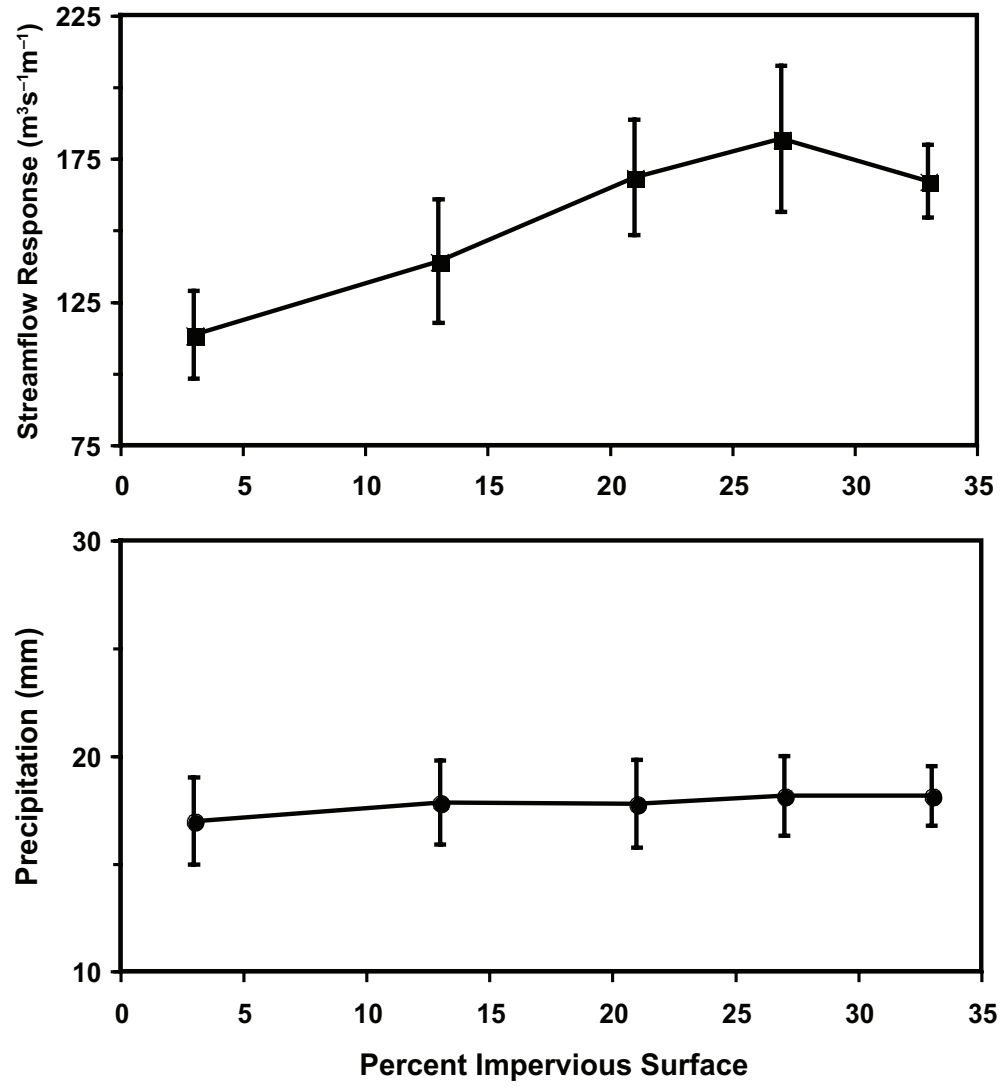

Figure 8. Comparison of averages of daily precipitation $(\mathrm{mm})$ and daily stream-flow response value $\left(\mathrm{m}^{3} \mathrm{~s}^{-1}\right.$ $\mathrm{m}^{-1}$ ) for the percentages of impervious surface found over time in the upper Accotink Creek subwatershed. The 3-year bin periods are centered on the acquisition date years of aerial photography used to determine the percentage of impervious surface. Daily stream-flow response values were calculated for days where total precipitation $\geq 6.0 \mathrm{~mm}$. Error bars show the \pm 95 percent confidence interval for the means. $N=990$ stream-flowprecipitation pairs. Data related to Hurricane Agnes (June 21-22, 1972) were excluded from the analysis as outliers. 
increasing duration of precipitation was the same across decades.

The pattern of daily precipitation $\geq 6 \mathrm{~mm}$ also showed a statistically significant change in the mean amount of 3-day precipitation duration occurrences (Kruskal-Wallis test statistic $=10.65, \mathrm{df}=4, \mathrm{p}=0.031$ ) by 10 -year bin. This, however, is due to a declining trend in $>3$-day duration amounts. A declining precipitation amount trend should have no positive impact on an increasing streamflow trend. The amounts of all other duration periods related to the cutoff values $>0 \mathrm{~mm}$ and $\geq 6$ $\mathrm{mm}$ were not statistically significant.

We observed no significant change in seasonal data, by 10 -year bin, in mean amount or frequency related to the daily precipitation cutoff values of $>0 \mathrm{~mm}$ and $\geq 6 \mathrm{~mm}$.

\section{Discussion}

We feel that historical climate data analysis is a required component for any analysis of change in historical streamflow discharge rates, particularly at the daily temporal scale where changes in streamflow pattern would have the greatest observable impact on stream ecology. Climate change research by Karl (1998) reported historical precipitation increases for the frequency of days with precipitation as well as the frequency of extreme precipitation values $(50 \mathrm{~mm})$ across the United States. We did not find this result for the precipitation station in our study area. Our results suggest that the historical frequency, magnitude, and temporal pattern of precipitation values at multiple cutoff levels were generally unchanged for the period of the study. Where we did observe a statistically significant change in pattern (frequency of precipitation values $>3$-days in duration, amount of precipitation per 3-day duration value), we found no concurrent increases in historical streamflow response.

It is understood that wet and dry climate patterns may have short-term impacts upon streamflow rate; however, we found no long-term precipitation trend that would alter streamflow discharge over time.

Three historical trends emerge from our data: (1) mean precipitation volume and the frequency of precipitation show no significant variation (2) both the daily streamflow response per unit precipitation and the daily streamflow frequency pattern show significant change, and (3) the landscape trend is characterized by increasing impervious surface area. These results suggest that hydrologic changes in daily streamflow have occurred due to landscape changes, specifically, the buildup of impervious surfaces. From the historical trend, several possible inter-relationships and transitions emerge related to landscape pattern and streamflow discharge.

We found a statistically significant shift in mean daily streamflow rate in the 10 -year bins associated with daily precipitation values $\geq 6.0 \mathrm{~mm}$ and $\geq 35.0 \mathrm{~mm}$ and in the 3 -year bins associated with daily precipitation values $\geq 6.0 \mathrm{~mm}$. The streamflow response trend for the 3-year bins associated with precipitation values $\geq 35.0 \mathrm{~mm}$, while not statistically significant, showed consistent increases over the study period. The lack of statistical significance for the trend in the 3-year bin data is due to fewer observations than the 10-year bin data.

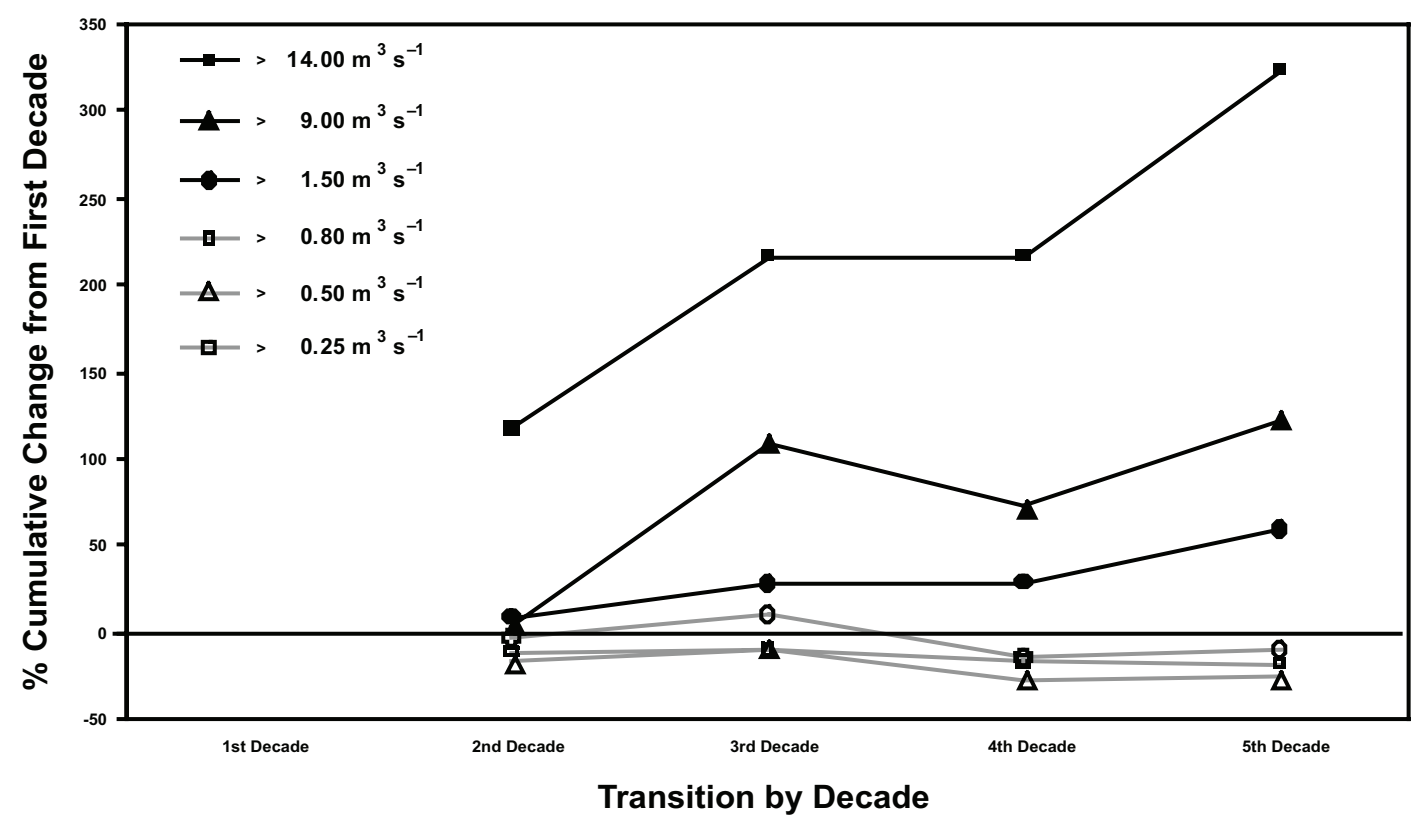

Figure 9. Historical streamflow frequency patterns for the upper Accotink Creek subwatershed as derived from data in table 3. Categories defined as the daily streamflow $\left(\mathrm{m}^{3} \mathrm{~s}^{-1}\right)$ above a given level. Change is reported per flow category as cumulative percent change in the frequency of streamflow occurrences from the first decade. The historical daily mean streamflow for the upper Accotink Creek is $0.8 \mathrm{~m}^{3} \mathrm{~s}^{-1}$. 
Our results imply that the amount of precipitation required to produce a given level of streamflow has decreased over time. The amount of precipitation necessary to produce a streamflow of $12 \mathrm{~m}^{3} \mathrm{~s}^{-1}$ (bankfull discharge for the first decade, fig. 2) dropped from approximately 80 $\mathrm{mm}$ in the first decade to approximately $55 \mathrm{~mm}$ in the final decade (fig. 6). An increase in the frequency of large flows is a consequence (table 3). The increase in frequency of larger discharge streamflows over time implies a change in the stream's disturbance regime related to the volumes. We found that it was four times more likely to record a mean daily streamflow $\geq 14.0 \mathrm{~m}^{3} \mathrm{~s}^{-1}$ in the last decade of our study than in the first. The altered flow regime is further illustrated by figure 9 (derived from table 3 ) where percent cumulative changes in specific streamflow cutoff levels reflect the historical change in streamflow pattern. Henshaw and Booth (2000) observed that increasing urbanization was related to decreases in the frequency of flows above the mean. A similar pattern is noted here, where a decreasing frequency of daily flows above the historical mean $\left(0.8 \mathrm{~m}^{3} \mathrm{~s}^{-1}\right)$ is observed. Further, observations show an increase in hydrologic variability at all given streamflow frequency ranges during the study period. The impact is most pronounced at higher volumes but is also evident at low flow levels. The hydrologic alteration of lower flow volumes agrees with Rose and Peters (2001) where a transition to shorter recession periods was related to urbanizing basins. This altered flow regime is indicative of an increasingly "flashy" streamflow prone to short-term high flows and a quick recession back to base flow. The changing stream ecology impacts the benthic and aquatic habitat as: (1) larger and more frequent pulse events in the form of peak discharges well above the historical mean and (2) less frequent sustained flows at or below the historical mean.

As illustrated in figure 6, the data appear to form two groupings of slopes over time - suggesting a shift in the streamflow discharge pattern during the study period. Under "normal" precipitation conditions, the level at which significant change in historical mean daily streamflow response first occurred was between 13 percent and 21 percent impervious surface area (Mann-Whitney $\mathrm{U}$ test statistic $=$ 10028.50, $\mathrm{df}=1, \mathrm{p}=0.002)$ for the 3 -year bins, and between the 1st and 2nd decades (Mann-Whitney $\mathrm{U}$ test statistic $=$ 107649.00, $\mathrm{df}=1, \mathrm{p}=0.002$ ) for the 10 -year bins. The 13 percent impervious surface category and the 1 st decade category appear to be transitional zones, above which permanent alteration of streamflow discharge is observed. A more precise relationship of impervious surface area and streamflow response might be obtained if the study were expanded to include photographic coverage between 1963 and 1971. However, we can generally state that a change in mean daily streamflow response in this basin occurred in the

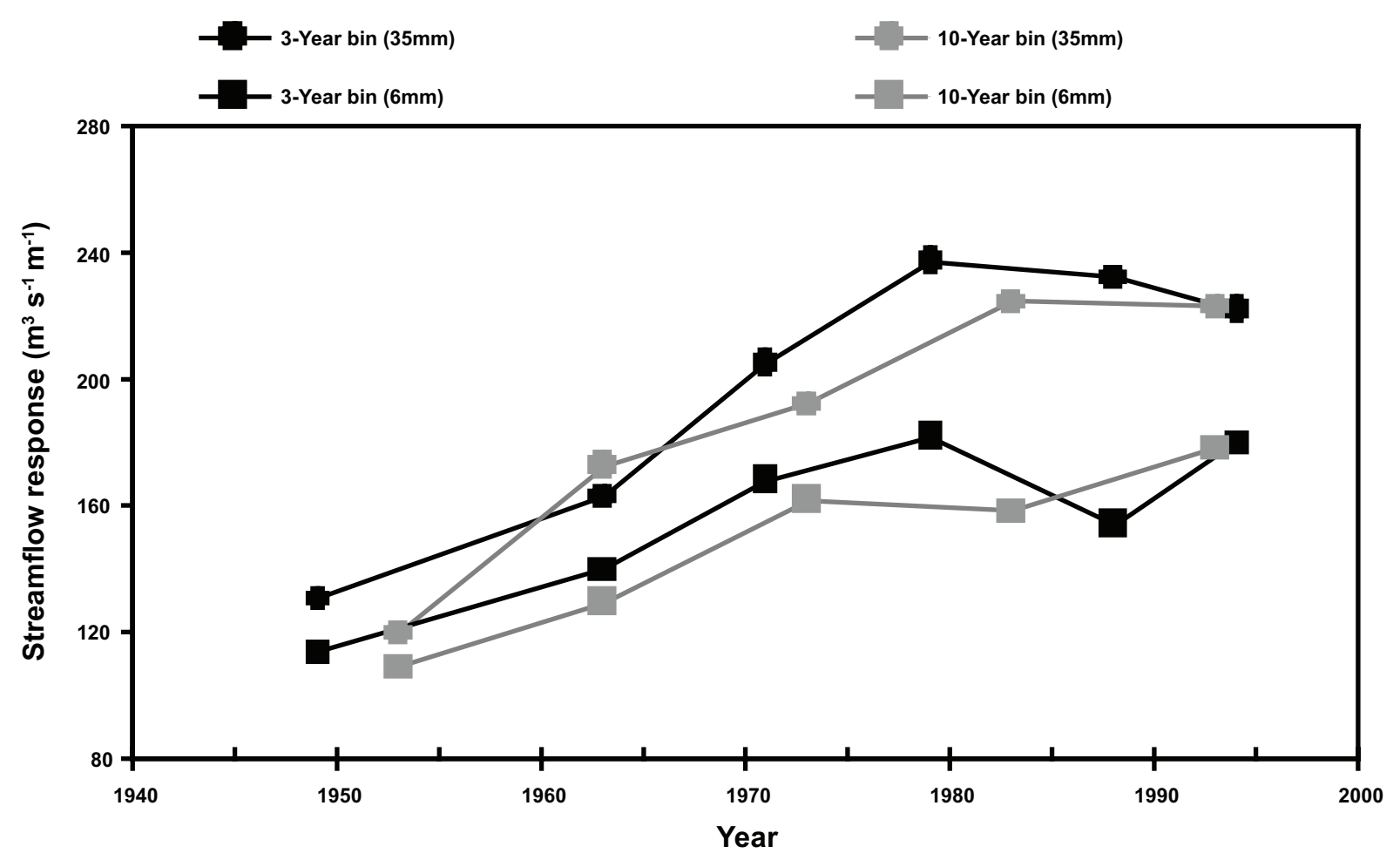

Figure 10. Trends of streamflow response value $\left(\mathrm{m}^{3} \mathrm{~s}^{-1} \mathrm{~m}^{-1}\right)$ for the upper Accotink Creek subwatershed at 3-year and 10-year bins associated with precipitation cutoff values $\geq 6 \mathrm{~mm}$ and $\geq 35 \mathrm{~mm}$. Data points for 10-year category are plotted at approximate mid-decade $(1953,1963,1973,1983,1993)$. Data points for the 3-year category are plotted per photo year. 
mid-1960s time-period. This trend is observed at all precipitation cutoff values used in our investigation: $>0 \mathrm{~mm}$ (fig. 6), $\geq 6.0 \mathrm{~mm}$ (fig. 7, fig. 8) and $\geq 35.0 \mathrm{~mm}$ (tables 4 and 5). In addition, during the period of rapid impervious surface growth (1949-1979), there is a corresponding rise in daily streamflow response. In the subsequent period (1980-1994), slower impervious surface growth corresponds to a slower rise in streamflow response. It is also possible that this later period was influenced by detention basins that were widely introduced into Fairfax County in the mid-to-late-1970s (A. Rayyan, personal commun., 2000).

Ecological studies such as Klein (1979), Limburg and Schmidt (1990), Weaver and Garmen (1994) and Wang and others (2001) utilized land-use/land-cover information to derive an impervious component and found that significant ecosystem change occurred at approximately 10 percent to15 percent impervious surface area. The results presented here (significant hydrological change between 13 percent and 21 percent impervious surface area) agree with these investigations. However, the reasons for agreement are unknown. As speculated in Wang and others (2000), it is possible that instream changes in species composition noted in urban studies are primarily due to changes in the variability of frequency and magnitude of streamflow disturbance brought about by impervious surfaces. However, the connection between the change in stream disturbance regime and changes in stream species composition is not supported by this investigation or by the current science. While the literature is abundant with investigations that have related impervious surface and stream biota there have been few investigations that specifically relate the historical relationship of impervious surface area, streamflow and stream biota (Moscript and Montgomery, 1997) and none that specifically address this issue at the daily temporal scale. We did not have a long-term biota data set from which to assess this issue and suspect that, with few exceptions, consistent longterm stream sampling data in urban environments (coincident with stream gages) are rare. An issue for future research would be capturing and analyzing fine temporal-scale, long-term stream data (streamflow and biota) along with explicit impervious surface data to determine specific linkages between changes in historical hydrologic pattern and in-stream biological communities in urbanizing watersheds. The production of stream-flow pattern metrics based on the de-construction of historical daily streamflow variability in urbanizing basins, as simply illustrated in figure 9 , might be a step towards determining the exact mechanisms by which impervious surfaces and hydrologic change impact stream biota.

Ecological change due to hydrological disturbance has specifically been addressed in Biggs (1995) and Poff and Allen (1995). These studies, while not specifically addressing an impervious surface issue, reveal the biological impacts related to altered flow regimes and changing hydrologic pattern. Cairns (1995) discussed the concept of ecological elasticity and urban runoff and concluded that "The effects of closely spaced pulses of urban runoff, which do not permit full recovery to occur, undoubtedly have a cumulative impact ... but the cumulative impact of multiple, closely spaced pulses is not well understood."

Figure 10 illustrates the general agreement on streamflow response value between the 3 -year and 10-year bins. We assumed that high variance associated with the 3-year windows (wet-year/dry-year impacts and smaller sample sizes) would necessitate a decade bin analysis to accurately characterize an overall streamflow trend. However, the agreement between the differing temporal resolutions suggests the 3year window has been minimally influenced by wet-year/dryyear precipitation phenomena and accurately characterizes the landscape, precipitation, and runoff relationship. This agreement between the two temporal scales allowed us a higher level of confidence in the relationship of impervious surface percent and streamflow response.

Manual analysis and compilation proved to be a highly accurate method for the mapping of impervious surfaces. However, there were three areas subject to interpretation confusion. Sidewalks were not always compiled due to a lack of clearly definable edges. This was due primarily to the spatial resolution of the scanned imagery. Pixel size $\left(1 \mathrm{~m}^{2}\right)$ was based on USGS DOQQ standards, which provided a standard mapping methodology across all years of coverage. In many areas however, the resolution precluded discrimination of smaller features such as sidewalks that often are imaged at sub-pixel resolutions. Open compacted soils related to construction zones were possibly mis-classified due to the inability of aerial photography to determine a measure of imperviousness for these soil areas. Single-family rooftops were subject to confusion due to the density of canopy cover over portions of the residential areas. In numerous cases, the density of woody overgrowth precluded clearly delineating impervious polygon boundaries at the parcel level. Due to the number of rooftops increasing over time, this source of confusion could possibly lead to an increasing amount of error in the TIA per photographic coverage over time.

\section{Conclusion}

Using an empirical approach, we have attempted to characterize the long-term impact of impervious surface growth on mean daily streamflow discharge. Results show that, over the study time period, daily streamflow response values coinciding with "normal" and "extreme" precipitation occurrences have increased approximately 50 percent and 100 percent respectively, while the percent of anthropogenic impervious surface area has increased 10 -fold. Results suggest that a statistically significant change $(\mathrm{p}<0.05)$ in streamflow response occurred between the 13 percent (1963) and 21 percent (1971) impervious surface levels for the 3-year bins and between the 1st (1948-1957) and 2nd (1958-1967) decades for the 10-year bins. Results also indicate that a statistically significant $(\mathrm{p}<0.05)$ disturbance in 
the frequency of mean daily streamflow levels has occurred between the flow range of $\geq 0.25 \mathrm{~m}^{3} \mathrm{~s}^{-1}$ and $\geq 14 \mathrm{~m}^{3} \mathrm{~s}^{-1}$. This particular alteration of the physical ecology is suggestive of an urbanizing basin prone to "flashy" flows that bring about an increased variability in streamflow at the daily temporal scale.

Anthropogenic impervious surface, as a landscape variable, is not the only driver of changes in streamflow response in urbanizing basins. More research is necessary to determine the historical relationship that streamflow has with other individual landscape variables such as forest patches, grasslands and agricultural areas, riparian area as well as the effects of integrated landscape pattern. In addition, in historical investigations, there is a need to further define historical precipitation patterns and their possible impacts on streamflow rate. However, there is historical evidence, in the upper Accotink Creek subwatershed, to suggest that anthropogenic impervious surface growth is an indicator of statistically significant response in streamflow discharge.

The methodologies utilized in this investigation offer a means to discern the historical relationship between landscape, precipitation, and streamflow. Utilizing these to formulate historical integrated assessments can be a research mechanism for determining the relative health of evolving stream eco-systems. However, in order to implement this method over larger landscape areas, a more efficient method of accurately measuring impervious surfaces is required. To that end, the mapping portions of this investigation will be used to study the classification accuracy of coarser resolution remote sensing data such as LANDSAT MSS and TM data, and such evolving image classification methods as data fusion and sub-pixel analysis. As noted by Booth and Jackson (1997), the lack of consistent methodology for determining impervious surface area as well as the lack of reporting of how the parameter was generated inhibits a thorough scientific comparison of results. A common mapping framework for impervious surfaces needs to be established before the myriad integrated impacts of this ecological indicator can be fully understood.

\section{Acknowledgments}

We specially thank Maliha Nash for her advice regarding the statistical relationship of precipitation and streamflow. We also thank Chad Cross, Dan Henry, K. Bruce Jones, Mary Lacerte-Benger, E. Terrence Slonecker, and Peter Stokely, for their assistance in this effort. The efforts and recommendations of two anonymous reviewers are greatly appreciated.

The views expressed here are those of the individual authors and do not necessarily reflect the views and policies of the U.S. Environmental Protection Agency (EPA). The manuscript was prepared by scientists in the USEPA's Office of Research and Development (ORD) and has been administratively reviewed and approved for publication.

\section{References}

Alley, M.A., and Veenhuis, J.E., 1983, Effective impervious area in urban runoff modeling: Journal of Hydrological Engineering, ASCE, v. 109, p. 313-319.

Anderson D.G., 1968, Effects of Urban Development on Floods in Northern Virginia: U.S. Geological Survey Water Supply Paper 2001-C, 22 p.

Biggs, B.J., 1995, The contribution of flood disturbance, catchment geology and land use to the habitat template of periphyton in stream ecosystems: Freshwater Biology, v. 33, p. 419-438.

Booth, D.B., 1990, Stream channel incision following drainage-basin urbanization: Water Resources Bulletin, v. 26, p. 407-417.

Booth, D.B., and Jackson, C.R., 1997, Urbanization of aquatic systems - degradation thresholds, storm-water detection, and the limits of mitigation: Journal of the American Water Resources Association, v. 33, p. 1077-1091.

Cairns J., 1995, Urban runoff in an integrated landscape context, in Herricks, Edwin E., ed., Stormwater runoff and receiving systems - Impact, monitoring, and assessment: Boca Raton, Fla., Lewis Publishers, 480 p.

Congalton, R.G., and Green, K., 1999, Assessing the Accuracy of remotely sensed data principles and practices: Boca Raton, Fla., Lewis Publishers, 137 p.

Dinicola, R.S., 1989, Characterization and simulation of rainfall-runoff relations for headwater basins in western King and Snowhomish Counties, Washington State: U.S. Geological Survey Water Resources Investigation Report 89-4052, 52 p.

Froelich, A.J., and Zennone, C., 1985, Maps showing geologic terrain, drainage basins, overburden, and low flow of streams in Fairfax County and vicinity, Virginia: U.S. Geological Survey Miscellaneous Investigation Series Map I-1534.

Galli, J., 1991, Thermal impacts associated with urbanization and stormwater management best practices: Washington, D.C., Metropolitan Washington Council of Governments and Maryland Department of Environment, $188 \mathrm{p}$.

Graf, W.L., 1975, The Impact of sub-urbanization on fluvial geomorphology: Water Resources Research, v. 11, p.690692.

Haack, B.N., 1997, Urban analysis and planning, in Philipson, Warren, ed., Manual of photographic interpretation: Bethesda, Md., American Society of Photogrammetry and Remote Sensing, 689 p.

Hammer, T.R., 1972, Stream channel enlargement due to urbanization: Water Resources Research, v. 8, p. 15301540 .

Henshaw, P., and Booth, D., 2000, Natural restabilzation of stream channels in urban watersheds: Journal of the American Water Resources Association, v. 36, p. 12191236.

Hollis, G., 1975, The effect of urbanization on floods of 
different recurrence interval: Water Resources Research, v. 11, p. 431-435.

James, W., 1994, Channel and habitat change downstream of urbanization, in Herricks, Edwin E., ed., Stormwater runoff and receiving systems - Impact, monitoring, and assessment: Boca Raton, Fla., Lewis Publishers, 480 p.

Jensen, J.R. 1983. Urban and suburban land use analysis, ch. 30 of Robert Colwell, E.D., Manual of Remote Sensing: Bethesda, Md., American Society of Photogrammetry and Remote Sensing, 2440 p.

Jensen, J.R., 1996. Introductory Digital Image Processing: Upper Saddle River, NJ, Prentice Hall, 318 p.

Jones, R.C., and Clark, C.C., 1987, Impact of watershed urbanization on stream insect Communities: Water Resources Bulletin, v. 23, p. 1047-1055.

Karl, T.R., and Riebsame, W.E., 1989, The impact of decadal fluctuations in mean precipitation and temperature on runoff-A sensitivity study over the United States: Climatic Change, v. 15, p. 423-477.

Karl, T.R., Knight, R.W., and Plummer, N., 1995, Trends in high-frequency climate variability in the twentieth century: Nature, v. 377, p. 217-220.

Karl, T.R., and Knight, R.W., 1998, Secular trends of precipitation amount, frequency and intensity in the United States: Bulletin of the American Meteorological Society, v. 79, p. 231-241.

Kennan, J.G., 1999, Relation of macro-invertebrate community impairment to catchment characteristics in New Jersey streams: Journal of the American Water Resources Association, v. 35, p. 939-955.

Klein, R.D., 1979, Urbanization and stream water quality impairment: Water Resources Bulletin, v. 15, p. 948-1963.

Leitch, C., and J. Harbor, 1999, Impacts of land use change on freshwater runoff into the near-coastal zone, Holetown Watershed, Barbados - Comparisons of long-term to singlestorm effects: Journal of Soil and Water Conservation, no. 54, p. 584-592.

Leopold, L.B., 1968, Hydrology for urban land planning-A guidebook on the hydrologic effects of urban land use: U.S. Geological Survey Circular 554, 18 p.

Leopold, L.B, 1973, River channel change with time-An example: Geological Society of America Bulletin, v. 84, p. 1845-1860.

Light, D.L., 1993, The National Aerial Photography Program as a Geographic Information System resource: Photogrammetric Engineering and Remote Sensing, v. 59, p. 61-65.
Limburg, K.E., and Schmidt, R.E., 1990, Patterns of fish spawning in Hudson River tributaries-Response to an urban gradient: Ecology, v. 71, p. 1238-1245.

May, C.W., Horner, R.R., Karr, J.R., Mar, B.W., Welch, E.B., 1997, Effects of urbanization on small streams in the Puget Sound lowland ecoregion: Watershed Protection Techniques, v. 2, p. 483-493.

Moscript, A.L., and Montgomery, D.R., 1997, Urbanization, flood frequency, and salmon abundance in Pugent Sound lowland streams: Journal of American Water Resources Association, v. 33, p. 1289-1297.

National Climatic Data Center (NCDC), 1998, Cooperative summary of the day: TD3200.

Poff, N.L. and Allen, J.D., 1995, Functional organization of stream fish assemblages in relation to hydrological variability: Ecology, v.76, p. 606-627.

Rose, S, and Peters, N., 2001, Effects of urbanization on streamflow in the Atlanta area (Georgia, USA) - A comparative hydrological approach: Hydrological Processes, v. 15, p. 1441-1457.

Schueler, T., 1994, The importance of imperviousness: Watershed Protection Techniques, v. 1, p. 100-111.

Slonecker, E., Jennings, D., and Garofalo, D., 2001, Remote sensing of impervious surfaces-A review: Remote Sensing Reviews, v. 20, p. 227-255.

U.S. Environmental Protection Agency (USEPA), 1994, The quality of our Nation's water-1992, EPA/841/S/94/002: Washington, D.C.

U.S. Geological Survey (USGS), 1996, National mapping program standards, digital orthophoto standards Web site: [http://rockyweb.cr.usgs.gov/nmpstds/doqstds.html].

U.S. Geological Survey (USGS), 2001, Water resources of the United States; Accotink Creek near Annandale, Virginia (01654000) Web site: [http://nwis.waterdata.usgs.gov/va/ nwis/discharge].

Wang, L., Lyons, J., Kanehl, P., Bannerman R., and Emmons, E., 2000, Watershed urbanization and changes in fish communities in southeastern Wisconsin streams: Journal of American Water Resources Association, v. 36, p. 1173-1189.

Wang, L., Lyons, J., Kanehl, P., and Bannerman, R., 2001, Impacts of urbanization on stream habitat and fish across multiple scales: Environmental Management, v. 28, p. 255266.

Weaver, L.A., and Garman, G.C., 1994, Urbanization of a watershed and historical changes in a stream fish assemblage: Transactions of the American Fisheries Society, v. 123 , p. $162-172$. 


\title{
Urban Growth and Seagrass Distribution Trends in Tampa Bay, Florida
}

\author{
By Mike Crane ${ }^{1}$ and George Xian ${ }^{2}$
}

\section{Introduction}

The watershed of Tampa Bay covers approximately $5,700 \mathrm{~km}^{2}$ and encompasses most of Pinellas, Hillsborough, and Manatee Counties and portions of Pasco, Polk, and Sarasota Counties. Four major sources of surface waterthe Hillsborough, Alafia, Little Manatee, and Manatee Rivers-flow into the bay. The largest municipalities within the watershed are Tampa, St. Petersburg, Clearwater and Bradenton. Tampa Bay is situated on the Gulf coast of westcentral Florida with an areal extent of approximately 1,030 $\mathrm{km}^{2}$, making it one of the largest open-water estuaries in the southeastern United States.

Seagrasses are one of the most important components of the Tampa Bay's ecosystem and are found in the shallow waters along its shoreline. They play an important role in reducing coastal erosion by binding sediments and moderating the impacts of waves and strong currents (Johansson and Greening, 2000; Lewis and others, 1982). In addition, seagrasses provide valuable habitat for a variety of economically and ecologically important marine species including shrimp, bay scallop, spotted sea trout, red drum, a variety of turtles, and manatee for foraging, shelter, and protection from predators within these dense underwater pastures (Avery, 1991; Johansson and Greening, 2000; Kurz and others, 2000; Phillips, 1960; Stowers and others, 2002). Compared to bare sand bottom areas of the bay, seagrass beds harbor 50 percent more fish and invertebrates (Stoner, 1980; Lewis and others, 1982; Livingston, 1982).

\section{Seagrass Declines}

To thrive, seagrasses require sunlight and clear water (Boler and others, 1991; Dixon, 2000). Because of these requirements, seagrasses are usually found in shallow water, however, they can grow at depths of $32 \mathrm{~m}$ and have been found in clear water at $68 \mathrm{~m}$. Seagrasses also prefer to live in shallow coastal waters where there is shelter (such as sand bars) from winds, wave action, and strong currents that could create turbulent muddy water (Phillips, 1962). Because

${ }^{1}$ U.S. Geological Survey, EROS, Sioux Falls, SD 57198.

${ }^{2}$ SAIC Contractor to U.S. Geological Survey, EROS, Sioux Falls, SD 57198. of their sensitivity to water clarity and nutrient loading, seagrasses function as a key indicator of estuarine health in Tampa Bay (Johansson and Greening, 2000).

Seagrass meadows in Tampa Bay have declined noticeably since settlement of the region began at the end of the $19^{\text {th }}$ century (Avery, 2000; Johansson, 2002; Lewis, 2002). When human settlement commenced in the late 1870's, seagrasses extended as vast aquatic meadows along the shore of the bay, as shown in figure 1, and are believed to have covered on the order of 31,000 ha (Lewis and others, 1982). Following World War II, urban growth increased significantly while seagrasses declined in areal extent from approximately 16,500 ha in 1950 to their smallest coverage of about 8,700 ha in 1982 (Lewis and others, 1991). These declines are attributed to a variety of human-induced disturbances that include destruction of habitat (Stowers and others, 2002; Zarbock, 1991), decreased water clarity (Boler and others, 1991), and declining water quality (Carlson and others, 2002).

\section{Urban Growth}

Tampa Bay is one of the fastest growing metropolitan areas in the country. From 1940 to 1999 urban land area increased approximately six fold. Until the late 1970s, the estuary was characterized by decades of neglect, alteration of the shoreline by industrial and residential development, and discharge of barely treated wastewater directly into the bay (Johansson and Lewis, 1992; Johansson, 1991; Greening, 2002). Pollution and deteriorated water quality and clarity, together with damage from dredging operations and scarring by boat propellers, seriously affected the extent and vigor of seagrasses in the bay. Hillsborough Bay, for example, had the poorest water quality in Tampa Bay and eutrophic conditions had become evident by the 1960s (Johansson and Greening, 2000; Lewis and others, 1998; Lewis and others, 1982). Discharges into Hillsborough Bay from fertilizer industries near the perimeter and from the City of Tampa's primary wastewater treatment plant were the main pollutant sources (Johansson, 1991). Little wonder that seagrass extent decreased about 50 percent from 1940 to 1982 (fig. 2). It wasn't until 1979 that the state legislated that all sewage treatment plants discharging into the bay were required to meet strict treatment standards (Johansson and Greening, 2000). 


\section{Nutrient Loading}

Nutrients such as nitrogen and phosphorus are introduced into the estuary by urban stormwater, agricultural runoff, leachate from septic tanks, sewage treatment plants, and atmospheric deposition from powerplants and cars. Specific sources included the Alafia River and the fertilizer industry within its basin, the City of Tampa's wastewater plant at Hookers Point, the U.S. Phosphoric Products Company, and the Nitram Chemical Company (Johansson, 1991).
Before a mandated reduction in discharges began, it was estimated that the Alafia River and the chemical companies supplied 63 percent of the total nitrogen and 94 percent of the total phosphorus entering the bay (Johansson and Lewis, 1992). The Hookers Point facility discharged 40 percent of the total nitrogen and less than 5 percent of total phosphorus (Johansson and Lewis, 1992). Excessive levels of these nutrients stimulate the growth of algae in the bay. As algae grow, they block sunlight needed by the submerged aquatic vegetation of the bay. Thus, algal blooms contribute to declines
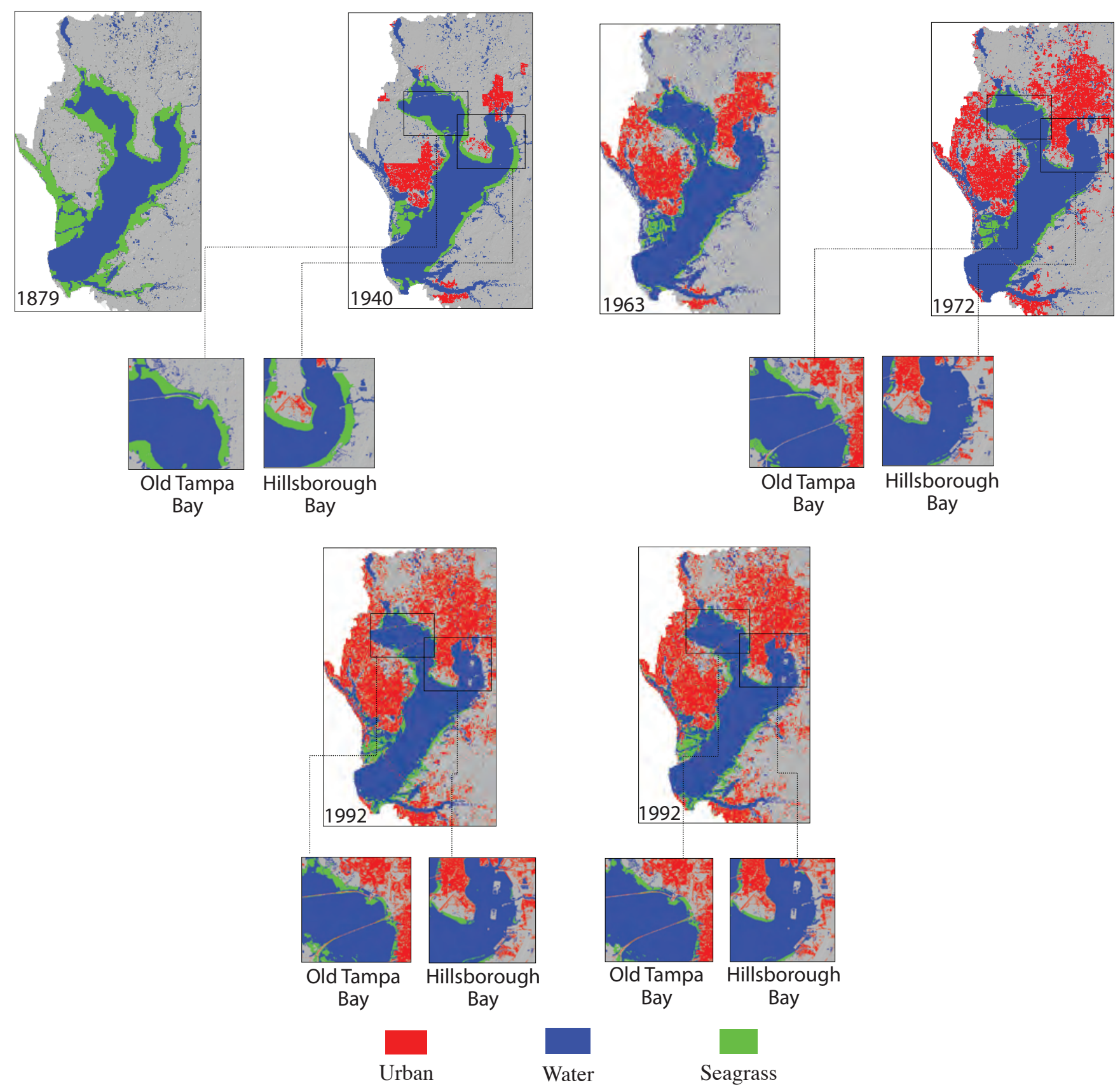

Figure 1. This sequence of maps depicts increases in urban development and changes in seagrass distribution in Tampa Bay from 1879 to 1999. 
in seagrass beds. Figure 3 depicts the correlation between urban sprawl and decline in seagrasses from 1940 to 1982. The increase in seagrasses between 1982 to 1998 (fig. 2) is associated with a significant reduction in nitrogen loading to Tampa Bay through better treatment of discharge from domestic and industrial point-sources. A concurrent reduction of agriculture and commercial/industrial water use in the Tampa Bay watershed led to a further decrease in nutrient loading and helped seagrasses recover after the early 1980's (Xian and Crane, 2003).

\section{Conclusions}

Eutrophication, dredging, and urban sprawl are primary factors in declines of the extent of seagrasses in Tampa Bay. The process of urbanization continues to characterize the Tampa Bay region and threatens to negatively impact seagrasses distributed around its margins. Efforts to improve water quality and benthic habitats started in the 1970s and, as a result of advanced wastewater treatment, succeeded in reversing the degradation trend. By 1996 seagrasses had been restored to about 11,000 ha (Johansson and Greening, 2000). Recently the trend appears to have reversed, and once again seagrass extent is declining (Tomasko, 2002). Further studies are needed to better understand urban development and its impact on the seagrasses of Tampa Bay, as well as development of a long-term mitigation strategy that provides for the sustainability of this valuable aquatic resource.

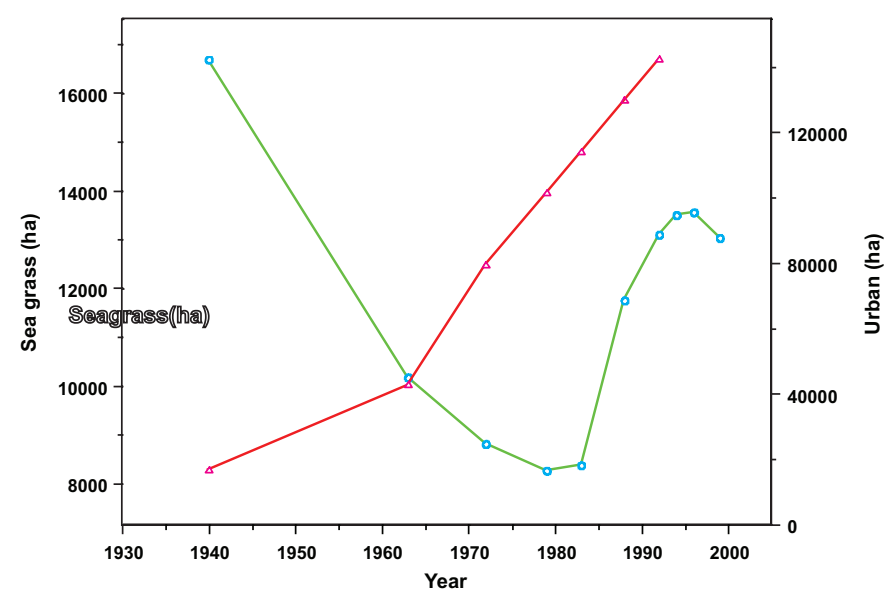

Figure 2. This graph compares urban growth and seagrass variation in Tampa Bay. The red line represents urban growth and shows a steady increase from about 20,000 ha in 1940 to more than 140,000 ha in 1990. During the same period, the green line shows a decline in seagrasses from more than 16,000 ha to a low of 8,700 ha in 1982 , then recovering dramatically to more than 13,000 ha. Since 1998 , seagrasses have exhibited further decline.

\section{References}

Avery, W., 2000, Monitoring submerged aquatic vegetation in Hillsborough Bay, Florida, in Bortone, S.A., Seagrasses: CRC Press, p. 137-145.

Avery, W.M., 1991, Status of naturally occurring and introduced Halodule wrightii in Hillsborough Bay: Proceedings, Tampa Bay Area Scientific Information Symposium 2, Tampa Bay, Fla., p. 177-187.

Boler, R.N., Malloy, R.C., and Lesnett, E.M., 1991, Surface water quality monitoring by the Environmental Protection Commission of Hillsborough County: Proceedings, Tampa Bay Area Scientific Information Symposium 2, Tampa, Fla., p. 111-135.

Carlson, P.R., Yarbro, L.A., Peterson, B.J., Ketron, A., Arnold, H., Madley, K.A., 2002, The influence of sediment sulfide on the structure of south Florida seagrass communities: Proceedings, Seagrass Management-It's Not Just Nutrients!, St. Petersburg, Fla., p. 215-227.

Dixon, L.K., 2000, Establishing light requirements for the seagrass Thalassia testudinum-An example from Tampa Bay, Florida, in Bortone, S.A., Seagrasses: CRC Press, p. 9-31.

Fletcher, D., 1991, Changes in climate, sea level, and Tampa Bay: Proceedings, Tampa Bay Area Scientific Information Symposium 2, Tampa Fla., p. 101-104.

Greening, H., 2002, Implementing the Tampa Bay seagrass restoration management strategy: Proceedings, Seagrass Management-It's Not Just Nutrients!, St. Petersburg, Fla., p. 29-37.

Johansson, J.O.R., 2002, Historical overview of Tampa Bay water quality and seagrass-Issues and trends: Proceedings,

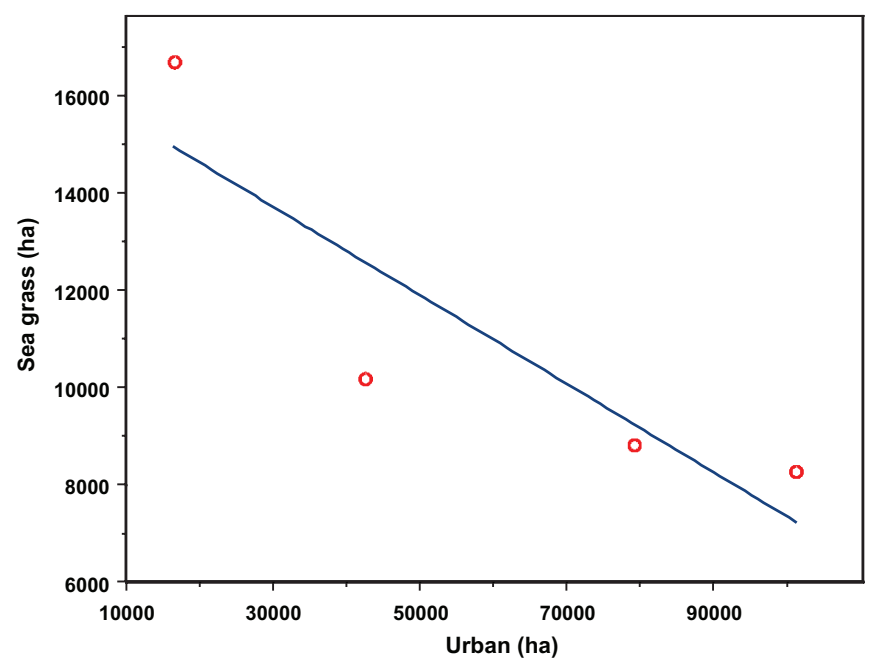

Figure 3. This poly-fit plot shows the strong relationship between the extent of urban area and seagrasses in Tampa Bay from 1940 to 1979 . 
Seagrass Management-It's Not Just Nutrients!, St. Petersburg, Fla., p. 1-10.

Johansson, J.O.R., and Greening, H., 2000, Seagrass restoration in Tampa Bay: A resource-based approach to estuarine management, in Bortone. S.A., Seagrasses: CRC Press, p. 279-293.

Johansson, J.O.R., and Lewis, R., 1992, Recent improvements of water quality and biological indicators in Hillsborough Bay, a highly impacted subdivision of Tampa Bay, Florida, USA: Amsterdam, Elsevier Science Publishers B.V., Science of the Total Environment, Supplement 2, p. 11991215.

Johansson, J.O.R., 1991, Long-term trends of nitrogen loading, water quality and biological indications in Hillsborough Bay, Florida: Proceedings, Tampa Bay Area Scientific Information Symposium 2, Tampa, Fla., p. 157-176.

Kurz, R.C., Tomasko, D.A., Burdick, D., Ries, T.F., Patterson, K., and Finck, R., 2000, Recent trends in seagrass distributions in southwest Florida coastal waters, in Bortone, S.A., Seagrasses: CRC Press, p. 157-166.

Lewis, R., 2002, The potential importance of the longshore bar system to the persistence and restoration of Tampa Bay seagrass meadows: Proceedings, Seagrass ManagementIt's Not Just Nutrients!, St. Petersburg, Fla., p. 177-183.

Lewis, R., Clark, P., Fehrings, W.F., Greening, H.S., Johansson, R.O., and Paul, R.T., 1998, The rehabilitation of the Tampa Bay estuary, Florida, USA, as an example of successful integrated coastal management: Marine Pollution Bulletin, v. 37, n. 8-12, p. 468-473.

Lewis, R., Haddad, K., and Johansson, J.O.R., 1991, Recent areal expansion of seagrass meadows in Tampa Bay, Florida - Real bay improvement or drought-induced?: Proceedings, Tampa Bay Area Scientific Information Symposium 2, Tampa, Fla., p. 189-192.

Lewis, R.R., Durako, M.J., Moffler, M.D., Phillips, R.C., 1985, Seagrass meadows of Tampa Bay-A review:
Minneapolis, Minn., Burgess Publishing Co., Proceedings, Tampa Bay Area Scientific Information Symposium, p. 210246.

Livingston, R., 1982, Trophic organization of fishes in a coastal seagrass system: Marine Ecology_Progress Series, v. 7, p. 1-12.

Phillips, R., 1962, Distribution of seagrasses in Tampa Bay, Florida: Florida State Board of Conservation Special Scientific Report No. 6, p. 1-12.

Phillips, R., 1960, Observations on the ecology and distribution of the Florida seagrasses: Professional Papers Series, Number Two, Florida Marine Laboratory, St. Petersburg, Fla., p. 1-72.

Stoner, A., 1980, The role of seagrass biomass in the organization of benthic macrofaunal assemblages: Bulletin of Marine Science, v. 30, n. 3, p. 537-551.

Stowers, J.F., Fehrmann, E., and Squires, A., 2002, Seagrass scarring in Tampa Bay-Impact analysis and management options: Proceedings, Seagrass Management_-It's Not Just Nutrients!, St. Petersburg, Fla., p. 47-54.

Tomasko, D., 2002, Status and trends of seagrass coverage in Tampa Bay, with reference to other southwest Florida estuaries: Proceedings, Seagrass Management_-It's Not Just Nutrients!, St. Petersburg, Fla., p. 11-20.

Weisberg, R.H., and Williams, R.G., 1991, Initial findings on the circulation of Tampa Bay: Proceedings, Tampa Bay Area Scientific Information Symposium 2, Tampa, Fla., p. 49-66.

Xian, G., and Crane, M., 2003, Impact of urban development on seagrass in Tampa Bay: Proceedings, 19th National Environmental Monitoring Conference, Arlington, Virginia, No. 23.

Zarbock, H.W., 1991, Past, present and future freshwater inflow to Tampa Bay-Effects of a changing watershed: Proceedings, Tampa Bay Area Scientific Information Symposium 2, Tampa, Fla., p. 23-33. 


\title{
An Overview of Stressors and Ecological Impacts Associated With Regional and Global Patterns of Population, Land-Use, and Land-Cover Change
}

\author{
By S. Taylor Jarnagin ${ }^{1}$
}

\section{Introduction}

Meyer (1995) describes land use as "the way in which, and the purposes for which, human beings employ the land and its resources: for example, farming, mining, or lumbering" and land cover as "the physical state of the land surface: as in cropland, mountains, or forests." The definition of the term land cover has broadened in recent usage to include human structures such as buildings or pavement (impervious surfaces) and other aspects of the natural environment, such as soil type, biodiversity, and surface and groundwater (Meyer, 1995). As human population and activities have increased over time, changes in land-use and land-cover change due to human activities have become major factors in changes in ecological processes at local to global scales (Groom and Schumaker, 1993; Houghton, 1994; Imhoff, 1994; Ojima and others, 1994).

R.T. Paine $(1966,1969)$ described a "keystone predator" as one controlling species diversity by selective predation upon a competitive dominant. This definition was expanded to that of a "keystone species" (Naiman, 1986), not necessarily a predator, where a species alters the ecosystem by modifying large areas of habitat to make it more suitable for their occupation thereby altering the community structure without having direct trophic effects on other species (that is, a beaver altering a stream community by dam building). "Keystone species" have been even more broadly defined (Power and others, 1996) as those having large effects on community structure or ecosystem function (that is, high overall importance) relative to abundance (that is, high community importance) and who perform roles not performed by other species or processes (Kotliar, 2000). Using the broader definitions, human beings act as a keystone species - a species that regulates ecosystem structure and function. Human activates alter not only their own environment but also act directly and indirectly to structure the ecosystem for all other organisms. Some authors argue that the impact of humans has become so great on a global

${ }^{1}$ Research Ecologist, U.S. EPA Landscape Ecology Branch, Environmental Photographic Interpretation Center (EPIC), 2D115 USGS National Center, MS 555, 12201 Sunrise Valley Drive, Reston, VA 20192-0002, jarnagin.taylor@epa.gov. scale that the current geological epoch should be renamed the "anthropocene" (Crutzen and Stoermer, 2000; Crutzen, 2002).

Recently, human activities have increased to a level where they dominate the Earth's global ecosystem. Between one-third and one-half of the land surface of the planet Earth has been transformed by human activity (Vitousek and others, 1997) with approximately 40 percent of the Earth's terrestrial vegetated surface impaired in its ability to furnish benefits due to human activity (Daily, 1995). Humans appropriate more than 30 percent of terrestrial net primary production (Vitousek and others, 1986; Rojstaczer and others, 2001) and human use accounts for 25 percent of the world's total evapotranspiration and 50 percent of the accessible runoff supply of fresh water (Postel and others, 1996).

The consequences of land-use and land-cover change at a global scale are not easily measured and quantified but have impacts on global processes such as climate change (Houghton and others, 1999; Hurtt, and others, 2002), resource depletion (Peskin, 1990; Daily, 1997), nutrient and hydrologic cycling (Nobre and others, 1991; Rasmussen and others, 1998), biodiversity (Wilson, 2002), and, ultimately, the carrying capacity of the Earth for human populations (Cohen, 1995a). At a regional scale, the impacts of agriculture, deforestation, and development on regional climate have been greater than global changes in $\mathrm{CO}_{2}$ up to the current time (Couzin, 1999; Caspersen, and others, 2000; Schimel, and others, 2000). In the United States, urbanization alone may be responsible for half of the observed decrease in temperature range over the last half-century in the 48 conterminous States (Kalnay and Cai, 2003). Except for the potentially catastrophic effects of global climate change, for terrestrial ecosystems, future global biodiversity is most dependent upon changes in human population and land-use (Sala and others, 2000; Wilson, 2002).

This report will not attempt to examine in detail the specific consequence of each potential change in land-use and land-cover at a global scale. Rather, it will concentrate on the ecological impacts of land-use and land-cover change (LULCC), linking LULCC to specific environmental changes, drivers of LULCC and their resulting stressors and ecological impacts, and regional and global patterns of change. 


\section{Ecological Impacts of Land-Use and Land-Cover Change}

Human-induced land-use and land-cover change produces both direct and indirect effects across spatial and temporal scales. Some effects are transitory in nature and others, such as regional desertification, may produce changes in hydrology that result in the loss of biotic potential (Schlesinger and others, 1990; UNEP, 1992) and are essentially irreversible on any time scale relevant to human societies (Glantz and Orlovsky, 1983; von Hardenberg and others, 2001). Humaninduced species extinctions are also irreversible and are occurring at unprecedented rates as are the human-induced landscape changes to which those extinctions have been linked (Melillo and others 1985; Skole and Tucker 1993; Sisk and others, 1994; Pimm and others, 1995).

At the spatial scale of the watershed, landscape and landuse patterns, along with hydrology and climatology, play a critical role in determining sediment and pollutant loading to aquatic ecosystems. Understanding the impact of land-use and land-cover change is critically important as the environmental protection of water quality evolves from the detection of endof-pipe sources of water pollution, such as sewage and industrial waste, towards a watershed management approach based primarily upon detection of non-point-source (NPS) pollution and Total Maximum Daily Load (TMDL) science (USEPA, 1994; USEPA, 2002).

Direct and immediate effects of human-induced landuse and land-cover change result from the conversion of land cover from a "natural," undisturbed state to one meeting human needs, such as housing, agriculture, and forestry. Direct effects on habitat (conversion, loss, simplification, and fragmentation) lead to increased erosion from altered surfaces and changes in surface and ground-water hydrology, peak flow and flood frequency, nutrient cycling, and solar radiation and thermal balance (Peterjohn and Correll, 1984; Saunders and others, 1991; Franklin, 1992; Inman, 1995; Inman, 2000).

Indirect effects of land-use and land-cover change are seen in ecosystem consequences, such as changes in ecosystem function; shift in species composition; increased spread of invasive species and infectious diseases; loss of biodiversity; increased levels of sediments, metals, and pesticides in surface and ground water; increased air pollution; and increased temperature of surface water and air (Woodley and others, 1993; Daily, 1997; Daily and others, 1997; Wilcove and others, 1998; Binder and others, 1999; Harvell and others, 1999; Barnes and others, 2000; Doyle and others, 2001; Jones and others, 2001a; Harvell and others, 2002).

Local-scale habitat loss and fragmentation breaks up species metapopulations at a regional scale (Verboom and others, 1991) and results in species extinctions and loss of biodiversity (Lubchenco and others, 1991; Kattan and others, 1994; Koopowitz and others, 1994; Noss and Cooperrider, 1994; Short and Turner, 1994; Knick and Rotenberry, 1995). At the regional to continental spatial scale, habitat loss, fragmenta- tion, and simplification are the most important causes for the loss of biodiversity (Turner 1989; Turner and others 1991; Saunders and others 1991; Noss and others 1995).

Some research has indicated that reduced connectivity (increased habitat fragmentation) can have beneficial effects. Habitat fragmentation can be beneficial to a species if it reduces the spread of disease either by reducing intraspecific contact or by reducing the degree of interspecific disease transmission (Hale and others, 2001). Increasing habitat fragmentation could theoretically limit human disease transmission by reducing the contact between disease vectors and human populations or even by fragmentation reaching the "extinction threshold" (Lande, 1987) of a vector. An extinction of a disease vector metapopulation due to habitat fragmentation could produce a result indistinguishable from reaching an epidemiological eradication threshold through immunization (Bascompte and Rodríguez-Trelles, 1998). However, these theoretical positive human health aspects of reduced biodiversity and increased fragmentation are countered by empirical studies that show that increasing species diversity and reduced habitat fragmentation reduces the spread of Lyme disease (Allan and others, 2003; Ostfeld and Keesing, 2000).

Quantifying these changes at a global scale is a difficult task. One approach uses ecological economics. Recently, attempts have been made to assess the financial value of goods and services delivered by intact, natural ecosystems at a global scale (Costanza and others, 1997; Costanza, 1998; Daily, and others, 2000; Balmford and others, 2002). Although the amounts estimated are open to debate, the values estimated for ecosystem services ( $\$ 33$ trillion) are on the same order of magnitude as estimated for global gross domestic product (GDP, $\$ 18$ trillion). These efforts have prompted criticism that has focused on the difficulties of valuing ecosystem goods and services (Toman, 1998; Turner, 1998; Nunes and van den Bergh, 2001). For example, some authors argue that urban sprawl reduces biodiversity (Wilson, 1986; Pope, 1999; Wilson, 2002), and others argue that economically important species, specifically white tail deer, have improved habitats due to sprawl (Dunn, 1999).

Human-induced land-use and land-cover change can act to increase the economic value of the land changed and do not necessarily imply a degradation of the land (Meyer, 1995). Although the use of ecological economics provides a means to try to quantify land-use and land-cover change at a global scale, it is likely the concept is more useful as a means to organize discussion than a method of direct quantification.

Another approach to quantifying land-cover changes at a global scale is to try to map generalized land classes and quantify changes over time. This is a daunting task for largescale areal assessments. Studies that clearly relate generalized land-use and land-cover change at a synoptic or national scale to specific degradation of ecosystem values are few and sometimes contradictory (Turner and others, 1993). This may be in part due to a shifting of ecological consequences at the global scale. For example, the percentage of forested land has increased in the conterminous United States during the past 
100 years, while the population, standard of living, and overall consumption of wood products has increased over that same period (Sisk, 1998). This may be due in part to increased globalization in resource extraction (for example, the increased utilization of wood products harvested outside the conterminous United States in the example of increased forest landcover). The "exportation" of human-induced landscape change by more developed to less-developed countries has long been a problem for modelers of sustainable development (Arrow and others, 1995). Global consequences of local preservation of resources need to be considered in sustainable development models.

Another difficulty in correlation studies is caused by the use of a small number of nonspecific land-use/land-cover classes during classification. A closed canopy, old growth forest is quite different biotically and functionally than a recently harvested tract of land managed for timber harvesting. However, both areas might wind up classified as "forest" in a continental scale analysis utilizing a limited number of classes. Another confounding variable is the cyclical spatial and temporal nature of land-use change. Whereas the overall percentage of a given land-cover type in a watershed may remain relatively constant over time, there may still be an environmentally significant portion of land-cover conversions among classes during the period of consideration for example, between "barren" and "forested" (Mehaffey and others, 1999; Mehaffey and others, 2001). Although global-scale associations between generalized land-cover and land-use change and global-scale changes in ecosystem functioning may be weak, at local and regional scales there are many studies that link the conversion of land-cover to direct human use and occupation (urbanization) to degradation of environmental quality and ecosystem function (Klein, 1979; Schueler, 1994; Barnes and others, 2000; Doyle and others, 2001, Capiella and Brown, 2001).

\section{Urbanization, Impervious Surfaces, and Aquatic Systems-Linking Land-Use and Land-Cover Change to Specific Environmental Change}

Urbanization produces changes in land-use and landcover that are measurable and quantifiable from local to continental and global scales using techniques ranging from field survey to satellite imagery (Elvidge and others 1997a; Elvidge and others 1997b; Sutton and others, 1997; Imhoff and others, 1998). Anthropogenic impervious surfaces include roads, rooftops, parking lots, driveways, and sidewalks and are direct, quantifiable results of the urbanization transformation of the natural land-cover. The impacts of urbanization that have been linked to impervious surfaces include changes in air quality; habitat loss and fragmentation; and changes in water quality (Schueler, 1994; Arnold and Gibbons, 1996; Benfield and others, 1999; Barnes and others, 2000). Because of the way that aquatic ecosystems act to focus and reflect land-use and land-cover changes within their watersheds, studies of aquatic systems have provided some of the best evidence quantitatively linking specific and measurable land-cover and landuse change (particularly impervious surfaces) to specific and measurable changes in ecosystem function and water quality (Jones and others, 1997; Jones and others, 2000; Jennings and Jarnagin, 2002).

At the spatial scale of the watershed, quantifiable changes in land-cover can be linked to specific responses in environmental variables. For example, the amount of impervious surface in a watershed is a landscape indicator integrating a number of concurrent interactions that influence a watershed's hydrology (Schueler, 1994). Increases in the amount of impervious surfaces in a watershed have been related to changes in the way in which streamflow responds to precipitation (Jennings and Jarnagin, 2002) and the frequency of disturbance events. Changes in impervious surfaces result in measurable changes in stream hydraulics and stream bank stability (Hammer, 1972; Leopold, 1973; Booth, 1990; Henshaw and Booth, 2000). Klein (1979) and Galli (1991) related increases in impervious surfaces to increases in stream temperature. Jones and Clark (1987) and Kennen (1999) discussed the lack of benthic diversity associated with urban environments. Studies by Limburg and Schmidt (1990), Weaver and Garman (1994), May and others (1997), and Wang and others (2001) related changes in fish communities to increases in urbanization. Anderson (1968), Hollis (1975), and Rose and Peters (2001) discussed the impacts of urbanization and impervious surfaces on streamflow, whereas Biggs (1995) and Poff and Allen (1995) specifically related disturbance from streamflow variability to significant changes in aquatic habitat structure. Schueler (1994) observed that imperviousness of a watershed is the primary gauge of urban stream ecosystem health and hypothesized that a threshold for urban stream stability and habitat quality exists at approximately 10 percent to 20 percent watershed impervious surface area. Elvidge and others (2004) estimated that the total surface area of the lower 48 States covered by impervious surfaces was approximately 112,610 $\mathrm{km}^{2}$, an area nearly the size of the state of Ohio or nearly 1.4 percent of the surface of the area of the lower 28 States.

\section{Drivers of Land-Use and Land-Cover Change}

Ecological footprint-A useful organizing construct in understanding land-use and land-cover change is the "ecological footprint." Simply stated, the ecological footprint is a quantified measure of the affect a given population or activity has on the environment (Wackernagel and Rees, 1996). One of the earliest descriptions of an ecological footprint is the $\mathrm{I}=\mathrm{P} *[\mathrm{~F}(\mathrm{P})]$ relation, rewritten to $\mathrm{I}=\mathrm{PAT}[\mathrm{Impact}=$ Population

* Affluence * Technology] (Commoner, 1971; Ehrlich and 
Holdren, 1971; Commoner, 1972; Holdren and Ehrlich, 1974; Ehrlich and Ehrlich, 1990). There have been several computations of ecological footprints that try to estimate values at national and global scales (for example, see Wackernagel and others, 1999). These efforts have been criticized for many of the same reasons as the attempts to value ecosystem services, including difficulties in valuing services, accounting for trade, and dealing with multiple spatial scales (van den Bergh and Verbruggen, 1999; van Kooten and Bulte, 2000). Even if the specific values computed from ecological footprint computations are controversial, a main benefit derived from the concept of the ecological footprints is their use to direct discussion of environmental stressors and their impacts (Ehrlich and Ehrlich, 1990). Rewriting the ecological footprint equation as $\mathrm{EI}=\mathrm{P} *(\mathrm{C} / \mathrm{E})$, [Environmental Impact $=$ Population * (Consumption/Efficiency)] helps to illustrate simply the functional drivers to land-use and land-cover change and the fact that there are magnifiers and modifiers to human population that affect environmental impact.

Population, consumption, and efficiency-The most obvious and largest driver to changes in land-use and land-cover is the growth in human population. There is a minimum requirement for each person for space, food, water, air, and the landuses associated with those requirements. More people require more resources and either a greater conversion of natural landcover to human-altered land-cover or a more intensive use of existing human-altered land-cover. This per capita driver to changes in land-use is magnified by lifestyle factors (that is, increased consumption offset by increases in efficiencies).

When Malthus first published "An Essay on the Principle of Population" in 1798, there were approximately one billion humans on the planet Earth. It took another 125 years to add another billion (1925), 35 years to add the next billion (1960), 15 years to add the next billion (1975), 11 years to add the next billion (1986), and 13 years to add the next billion (a total of six billion in 1999) (Cohen, 1995b; UNFPA, 1999). Given the difficulties of estimating current populations (Cohen, 1995b), much less how many people the Earth can support (Cohen, 1995a), future estimates of global population change are uncertain. The best current probabilistic estimates of future global human population predict a peak in the range of eight to ten billion within the next century, with nine billion as the best estimate (Smil, 1999; UN, 1999a; Keilman, 2001; Lutz and others, 2001).

Future changes in the consumption and efficiency factors of the global population will have major impacts on the ultimate resource requirements, pressures placed on global resources, and the resultant changes in land-use and landcover to be expected. These changes can act to either increase or reduce the ecological pressure of the population. For example, in 1800 , each of the one billion humans required approximately 20,000 square meters of agricultural land to obtain a year's supply of food, whereas in 1999 it only took 2,000 square meters of agricultural land to supply each human with food (Evans, 1998). Although this increase in efficiency has acted to reduce the potential total agricultural land-use require- ment (the pattern of land-use), this has happened only because of advances in agricultural techniques such as pesticide use and biological pest control, plant breeding, and genetics (Trewavas, 2002) and massive inputs of human-fixed nitrogen fertilizer that now roughly equal the entire natural global nitrogen-fixation amount (Vitousek and others, 1997). This change in the process of land-use has resulted in increased nutrient cycling, contamination of surface and ground water, and excessive fertilization of aquatic ecosystems resulting in eutrophication of coastal and estuarine ecosystems (Smil, 1997). Similarly, Cohen (1995a) notes that although human population roughly quadrupled from 1860 to 1995 , each human's use of energy increased roughly 20 times, resulting in a 100 times increase in total global energy consumption (and concurrent land-use impacts due to energy extraction, mining activity, pollution, transportation, and energy production.). The intensity of human activity per unit of land-use may have ecological impacts that are just as important, or more important, as the land-use itself.

Urbanization-Along with the rapidly expanding human population, changes in the pattern of human habitation have had major consequences for land-use and land-cover changes in the past several centuries. While the global population roughly tripled from 1900 to 2000 , the number of people living in urban areas increased by a more than tenfold (WRI, 1996). Nearly half the world's population now lives in urban areas and virtually all of the population growth expected during 2000 to 2030 will be concentrated in the urban areas of the world (UN, 1999b; UNEP, 2002). By 2050, 65 percent of the total population is expected to be urban (UN, 2001). Urbanization increases with development-about 84 percent of the population in developed areas of the world is expected to be living in urban areas by 2030 (UN, 1999b; UNFPA, 1999). About 60 percent of the current global population lives within $100 \mathrm{~km}$ of the coastline and this proportion is expected to increase (WRI, 1996). More than half of the U.S. population lives in the coastal zone and more than half of the projected increase in population expected over the next 15 years will occur in that zone, which only covers 17 percent of the land area of the 48 conterminous U.S. States (Beach, 2002).

For much of human history, urban centers have tended to be regional aggregations consisting of a densely populated core surrounded by a less populated region from which the urban core drew resources. Megacity complexes now cover large areas of territory - they have grown large enough to alter regional weather (Shepherd and others, 2002). The urban megacity acts to concentrate the products of land-cover change from a wide, even global, area. Long-distance transport of agricultural and resource extraction products from the conversion of grassland to agriculture and forest to timber harvest are processed by the concentrations of population and the waste products discharged in the air and watersheds of those urban concentrations. This has particular significance for coastal ecosystems.

Land-use conversion has also tended to concentrate on the most productive land. For most of the last 9,000 years of 
human history, population growth has been dependent upon the conversion of natural systems to agricultural production and has been concentrated in areas with the most productive soils where sources of freshwater were available (Kates and others, 1990). Using satellite-derived imagery, Imhoff and others (1997) estimated that urban areas accounted for 2.7 percent of the surface area of the 48 conterminous States, an area approximately equal to the state of Minnesota or one-half the size of California. They also determined that the growth of urban areas was concentrated on the better agricultural soils. In addition to the recent concentration of population in coastal urban areas, recent changes in the pattern of urban development have acted to magnify the impact of urbanization and the amount of land-cover converted to urban use. Collectively, these changes have come to be called "urban sprawl" (Benfield and others, 1999).

Regional patterns of change (suburbanization/urban sprawl) - There has been a major shift in the pattern of urban land-use in the United States over the past two centuries. The population of the United States has grown increasingly urban in distribution since colonial times. The increase in urban population has accelerated in the past 100 years, while the number of Americans living in rural areas has remained fairly constant (fig. 1). Using the 1990 U.S. Census Bureau definition of urban, suburban, and rural, the U.S. Council on Environmental Quality (USCEQ, 1997) tabulated the U.S. population over the past 50 years of growth and migration. Their result shows that from 1950 to 1996, the urban population increased by 63 percent, the rural population decreased by 19 percent, and the greatest relative change occurred in the suburban population, an increase of 274 percent. Their analysis calculated a 1950 to 1996 urban:suburban:rural population proportion shift as $33: 23: 44$ to $30: 50: 20$ while the total population increased from 150.7 to 265.3 million (fig. 2).

Since 1950, the U.S. Census Bureau has issued several revisions in their definition of metropolitan areas that have complicated historical trend analyses (Meyers and Simon, 1994; Imhoff and others, 1998; U.S. Bureau of the Census, 1998). Considering how difficult it is to precisely define an "urban area," it is perhaps not surprising that many definitions of "urban sprawl" exist and that different conclusions can be reached depending on the definition used (Hess, 2001; personal commun.). In general, when an urban area is adding urbanized land at a rate faster than it is adding population, it is experiencing sprawl. A good metric to quantify urban/suburban sprawl is the "per household land consumption" (PHLC), which is calculated by dividing the total area of developed land by the number of households in that area takes into account both residential and nonresidential uses (EPA, 2000). Using this metric over the period 1965-1990, the per household land consumption rate for the study area (Montgomery County, Pennsylvania) increased from 0.80 acres of developed land per household in 1965 to 1.14 acres per household in 1990.

Another metric of increased sprawl is the increase in miles driven per capita. Wallis and others (2001) found that between 1983 and 1997, Broward County's population grew by 38 percent and the number of licensed drivers increased by 31 percent. However, the number of miles driven on county freeways increased by 177 percent, more than four times the rate of population increase and five times the increase in the number of drivers. Nationwide, from 1960 to 1995 , the population of the United States increased by 48

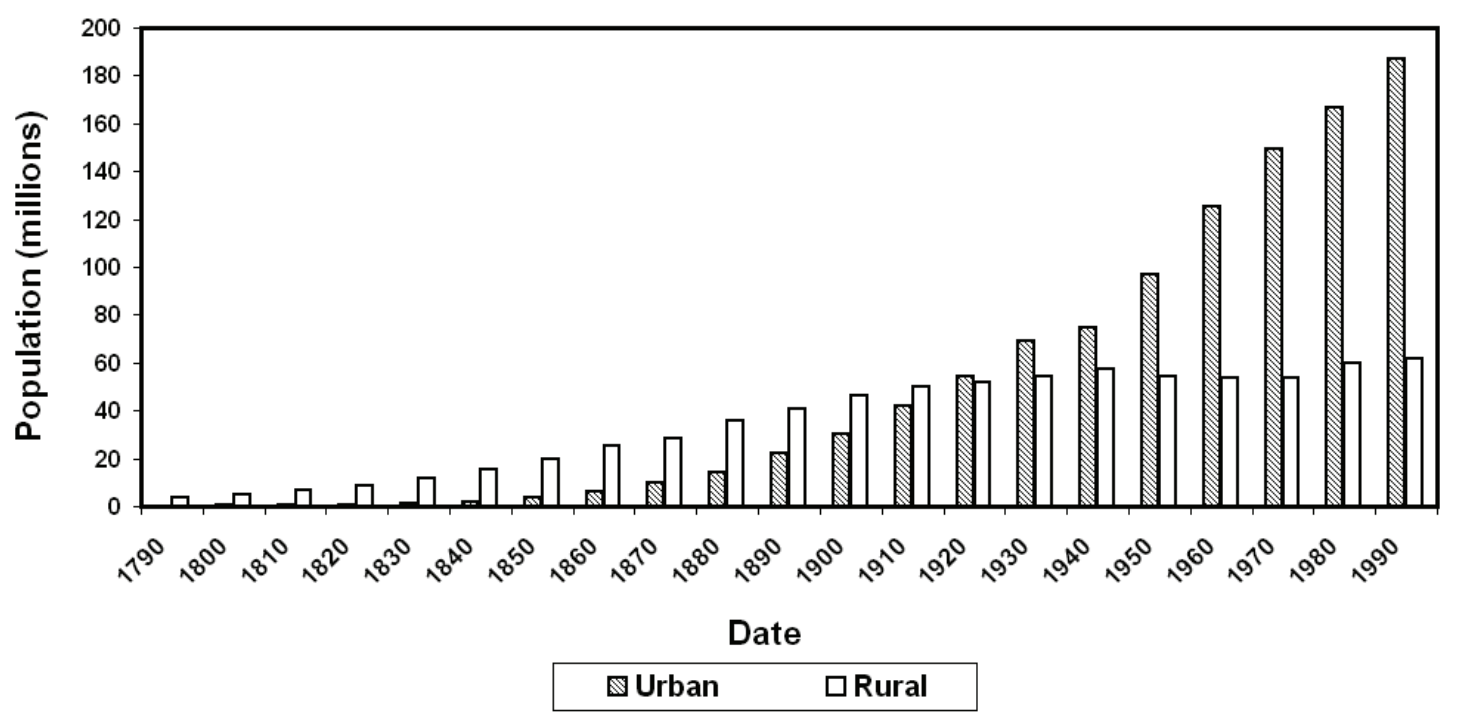

Figure 1. U.S. population in urban and rural areas, 1790-1990. Data from U.S. Department of Commerce, Bureau of the Census, table 4, available on the Web at http://www.census.gov/population/censusdata/table-4.pdf. 


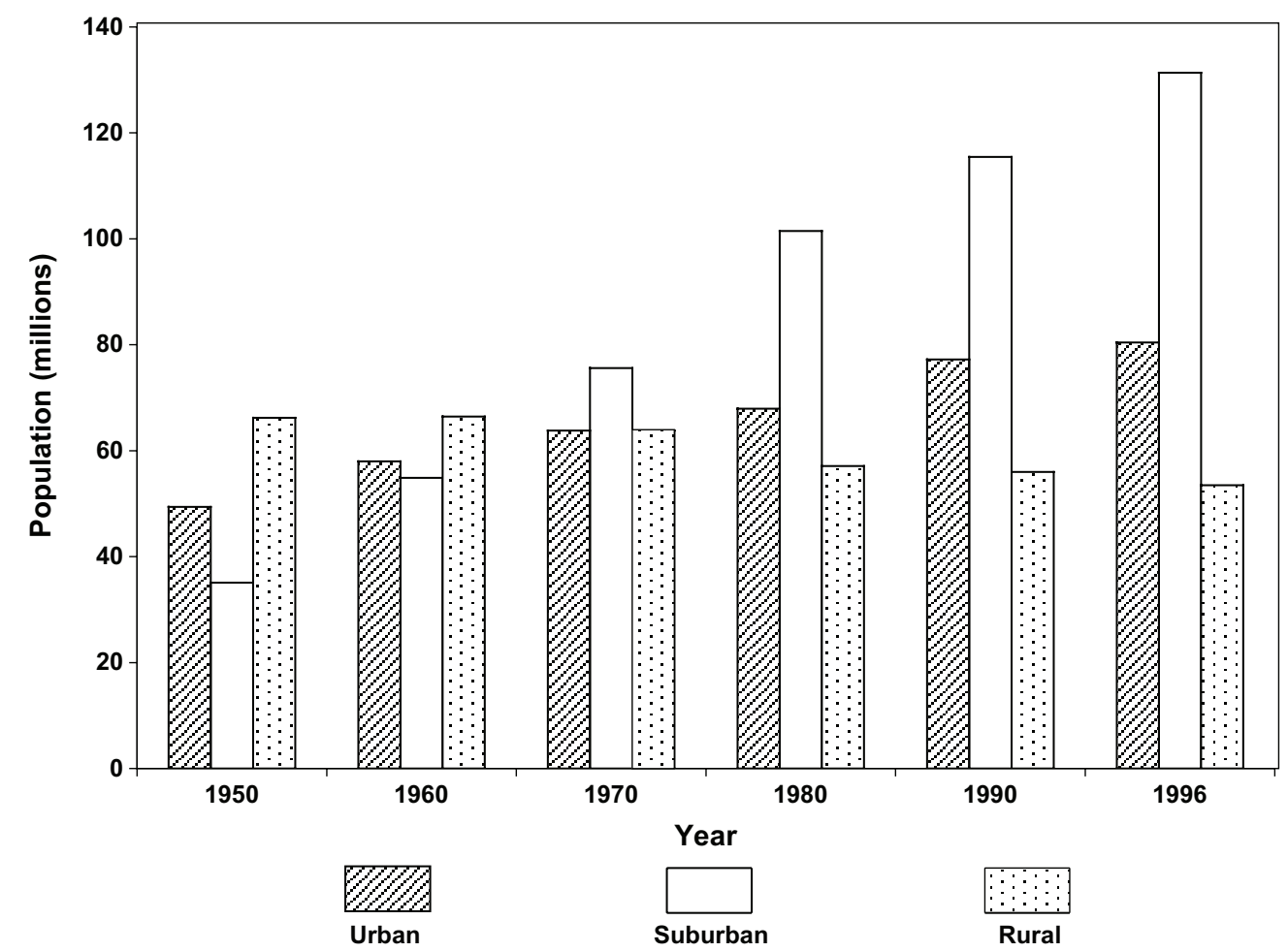

Figure 2. U.S. population in urban, suburban, and rural areas, 1950-1996. Data from U.S. Council on Environmental Quality, The 1997 Annual Report of the Council on Environmental Quality, Part III Environmental Data and Trends, table 1.4, available on the Web at http://ceq.eh.doe.gov/nepa/reports/1997/ tables.pdf. Urban refers to population inside central cities of metropolitan areas (MAs). Suburban refers to MA population in suburbs outside central cities. Rural refers to nonmetropolitan population. MAs are defined for each population census.

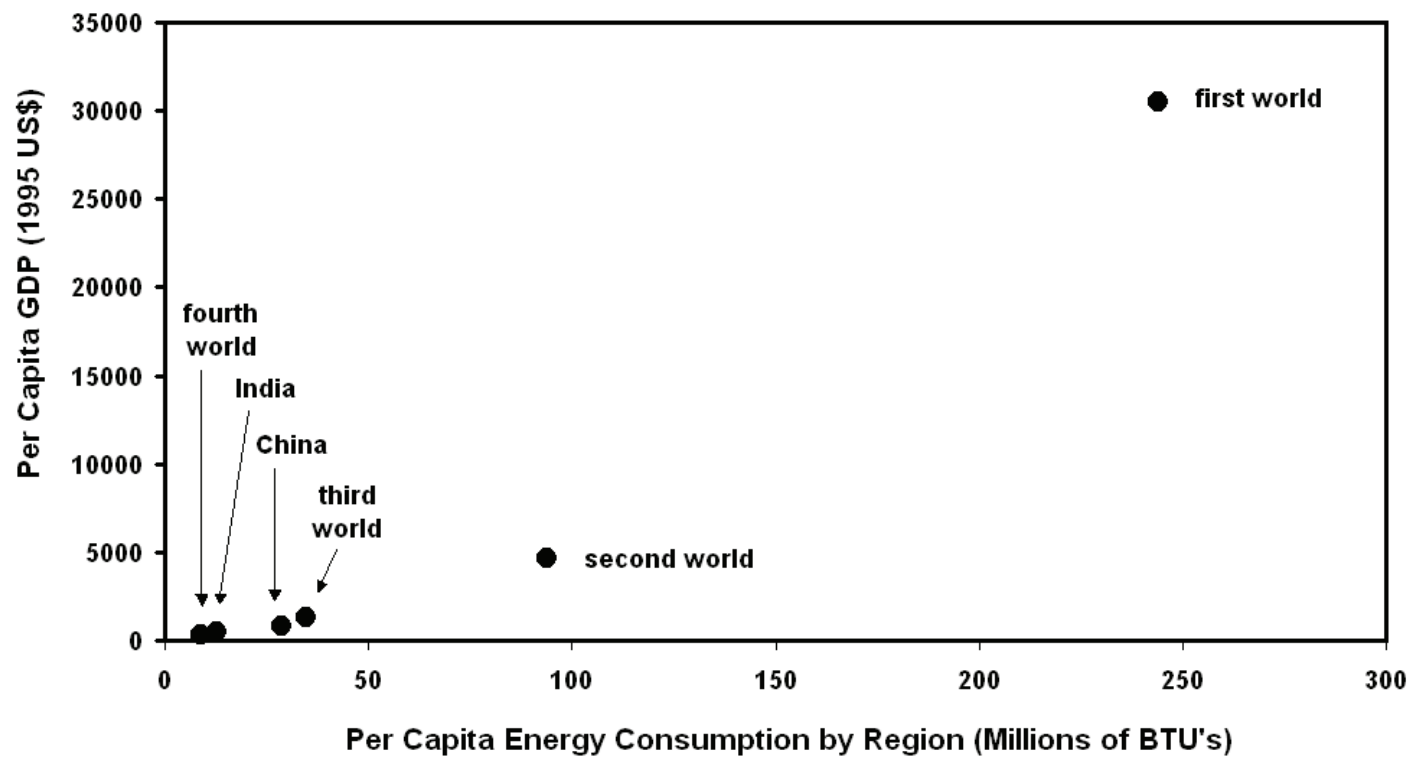

Figure 3. Per capita energy consumption versus per capita gross domestic product (GDP) by wealth grouping. Data from U.S. Department of Energy, Energy Information Administration, Washington, D.C. GDP dollar estimates for all countries are derived from purchasing power parity (PPP) calculations rather than from conversions at official currency exchange rates, normalized to 1995 U.S. dollars. Most of the GDP estimates are based on extrapolation of PPP numbers published by the U.N. International Comparison Program (UNICP) and by Professors Robert Summers and Alan Heston of the University of Pennsylvania and their colleagues. 
Table 1. Current world population in roughly equal size groups sorted by natural breaks in affluence.

[For this exercise, "affluence" is defined as the per capita gross domestic product (GDP) and is considered roughly proportional to "standard of living"]

\begin{tabular}{|ccc|}
\hline Category & $\begin{array}{c}\text { Affluence } \\
\text { (per capita } \text { GDP in 1995 U.S. } \\
\text { dollars) }\end{array}$ & $\begin{array}{c}\text { Population } \\
\text { (millions) }\end{array}$ \\
\hline \hline First world & GDP $>\$ 15,000$ & 872.1 \\
Second world & $\$ 13,000>$ GDP $>\$ 2,400$ & 950.1 \\
Third world & $\$ 2,399>$ GDP $>\$ 740$ & 904.1 \\
Fourth world & GDP $<\$ 710$ & 859.2 \\
India & GDP $=\$ 464$ & 1002.1 \\
China & GDP $=\$ 818$ & 1273.0 \\
\hline
\end{tabular}

percent while the number of miles driven per capita by that population ("vehicle miles traveled" or "VMT" per capita) increased by 132 percent (USBTS, 1998). The increasing per capita space utilized and mobility of the population acts as a multiplier on the population increase to magnify the human impact and the land-use conversion required to meet human needs.

Urban sprawl and associated land-uses have been cited as primary drivers of declines in environmental conditions in the United States (Flather and others, 1998) and other areas of the world (Houghton, 1994). Fulton and others (2001) found that the trend towards sprawl was widespread in the United States and that from 1982 to 1997 about 25 million acres of land was converted to "urban" from some other land-cover class. Nationally, forested land-cover is being maintained or increased while agricultural land is being lost (Sorenson and others, 1997; Sisk, 1998). Using satellite imagery and GIS in a regional scale analysis, Jones and others, (2001b) grouped land-cover in the mid-Atlantic region into six classes. They found that from the early 1970 's to the early 1990's, out of the six land-cover classes, the urban land-cover class increased the most and agriculture land-cover decreased the most while forests, water, and barren land experienced small increases and emergent wetlands had very small decreases.

\section{Global Economics and Prospects for Land-Use and Land-Cover Change}

Except for the potentially catastrophic effects of global climate change at a global scale over the next century, the future human impact on land-use and land-cover change will be determined by three factors: (1) the additional three billion people who will be added to the human population-pri- marily in the less developed nations (UNPD, 2001), (2) the standard of living achieved by the nine billion inhabitants of the planet (consumption), and (3) the efficiency of the global population's conversion of the Earth's landscape to meet human needs. The traditional development path for the most highly developed countries today has been to achieve a higher standard of living through a higher expenditure of energy and a more intensive use and extensive conversion of land-cover to human use. If we group the current world population in roughly equal size groups sorted by natural breaks in affluence (table 1, with "affluence" defined as the per capita Gross Domestic Product (GDP) — roughly proportional to "standard of living") and plot those groups versus the per capita energy consumption (roughly proportional to environmental impact) for these groups, we can visually see the gap that separates the most developed nations from the rest of the world (fig. 3). How the human population of approximately nine billion people impacts global land-use and land-cover change patterns in the next century will be determined by the degree to which the seven billion people represented in the lower left corner of the graph improve their standard of living without mirroring today's consumption pattern of the two billion people who will be living in the most developed nations.

\section{References}

Allan, B.F., Keesing, F., and Ostfeld, R.S., 2003, Effect of forest fragmentation on Lyme disease risk: Conservation Biology, v. 17, n. 1, p. 267-272.

Anderson, D.G., 1968, Effects of urban development on floods in Northern Virginia: U.S. Geological Survey Water Supply Paper 2001-C, 22 p.

Arnold, Jr., C.L. and Gibbons, C.J., 1996, Impervious surface coverage - The emergence of a key environmental indicator: Journal of the American Planning Association, v. 62, n. 2, p. 243-258.

Arrow, K., Bolin, B., Costanza, R., Dasgupta, P., Folke, C., Holling, C.S., Jansson, B.O., Levin, S., Maler, K.G., Perrings, C., and Pimental, D., 1995, Economic growth, carrying capacity, and the environment: Science, v. 268, n. 5210, p. 520-521.

Balmford, A., Bruner, A., Cooper, P., Costanza, R., Farber, S., Green, R.E., Jenkins, M., Jefferiss, P., Jessamy, V., Madden, J., Munro, K., Myers, N., Naeem, S., Paavola, J., Rayment, M., Rosendo, S., Roughgarden, J., Trumper, K., and Turner, R.K., 2002, Economic reasons for conserving wild nature: Science, v. 297, n. 5583, p. 950-953.

Barnes, K.B., Morgan III, J.M., and Roberge, M.C., 2000, Impervious surfaces and the quality of natural and built environments: A white paper prepared for the project "Chesapeake Bay From Space" [http://www. chesapeakebayfromspace.net].

Bascompte, J., and Rodríguez-Trelles, F., 1998, Eradication thresholds in epidemiology, conservation biology and 
genetics: Journal of Theoretical Biology, v. 192, p. 415418.

Beach, D., 2002, Coastal sprawl-The effects of urban design on aquatic ecosystems in the United States: Arlington, VA: Pew Oceans Commission [http://www.pewoceans.org/ reports/water_pollution_sprawl.pdf].

Benfield, F.K., Raimi, M., and Chen, D., 1999, Once there were greenfields - How urban sprawl is undermining America's environment, economy and social fabric: The Natural Resources Defense Council, Washington DC.

Biggs, B.J.F., 1995, The contribution of flood disturbance, catchment geology and land-use to the habitat template of periphyton in stream ecosystems: Freshwater Biology, v. 33, n. 3, p. 419-438.

Binder, S., Levitt, A.M., Sacks, J.J., and Hughes, J.M. 1999, Emerging infectious diseases-Public health issues for the 21st Century: Science, v. 284, n. 5418, p. 1311-1313.

Booth, D.B., 1990, Stream channel incision following drainage-basin urbanization: Water Resources Bulletin, v. 26, n. 3, p. 407-417.

Capiella, K., and Brown, K., 2001, Impervious Cover and Land-use in the Chesapeake Bay Watershed: Center for Watershed Protection (CWP) Report prepared for U.S. EPA Chesapeake Bay Program, Land Growth and Stewardship Subcommittee, Ellicott City, MD, CWP.

Caspersen, J.P., Pacala, S.W., Jenkins, J.C., Hurtt, G.C., Moorcroft, P.R., and Birdsey, R.A., 2000, Contributions of land-use history to carbon accumulation in U.S. forests: Science, v. 290, n. 5494, p. 1148-1151.

Cohen, J.E., 1995a, Population growth and Earth's human carrying capacity: Science, v. 269, n. 5222, p. 341-346.

Cohen, J.E., 1995b, How many people can the Earth support?: New York, NY, W. W. Norton, 532 p.

Commoner, B., 1971, "The closing circle: nature, man, and technology." in Cahn, M.A., and O'Brien, R., eds., Thinking About The Environment: Armonk, NY, M.E. Sharpe, Inc., p. 161-166.

Commoner, B., 1972, The environmental cost of economic growth in Population, Resources and the Environment: Government Printing Office, Washington, D.C., p. 339-63.

Costanza, R., dArge, R., deGroot, R., Farber, S., Grasso, M., Hannon, B., Limburg, K., Naeem, S., O’Neill, R.V., Paruelo, J., Raskin, R.G., Sutton, P., and van den Belt, M., 1997, The value of the world's ecosystem services and natural capital: Nature, v. 387, n. 6630, p. 253-260.

Costanza, R., 1998, The value of ecosystem services: Ecological Economics, v. 25, n. 1, p. 1-2.

Couzin, J., 1999, Landscape changes make regional climate run hot and cold: Science, v. 283, n. 5400, p. 317-319.

Crutzen, P.J. and Stoermer, E.F., 2000, The 'anthropocene': IGBP Newsletter v. 41, p. 17-18 (Royal Swedish Academy of Sciences, Stockholm, 2000).

Crutzen, P.J., 2002, Geology of mankind: Nature, v. 415, n. 6867, p. 23.

Daily, G.C., 1995, Restoring value to the world's degraded lands: Science, v. 269, n. 5222, p. 350-354.
Daily, G.C., ed., 1997, Nature's services-Societal dependence on natural ecosystems: Washington, DC, Island Press.

Daily, G.C., Alexander, S., Ehrlich, P.R., Goulder, L., Lubchenco, J., Matson, P.A., Mooney, H.A., Postel, S., Schneider, S.H., Tilman, D., and Woodwell, G.M., 1997, Ecosystem services - Benefits supplied to human societies by natural ecosystems: Issues in Ecology, v. 2, p. 1-16.

Daily, G.C., Söderqvist, T., Aniyar, S., Arrow, K., Dasgupta, P., Ehrlich, P.R., Folke, C., Jansson, A., Jansson, B.O., Kautsky, N., Levin, S., Lubchenco, J., Mäler, K.G., Simpson, D., Starrett, D., Tilman, D., and Walker, B., 2000, The value of nature and the nature of value: Science, v. 289, n. 5478 , p. 395-396.

Doyle, K., Kostyack, J., McNitt, B., Sugameli, G., Whitaker, C., Whitcomb-Blaylock, K., Byrd, J., and Stull, G., 2001, Paving paradise-Sprawl's impact on wildlife and wild places in California: A Smart Growth and Wildlife Campaign California White Paper, National Wildlife Federation, Washington, D.C. [http://nwf.org/smartgrowth].

Dunn, J.R., 1999, Wildlife in the suburbs: Political Economy Research Center Reports, v. 17, n. 4, p. 3-5.

Ehrlich, P.R. and Ehrlich, A.H., 1990, The population explosion: New York, NY, Simon and Schuster.

Ehrlich, P.R. and Holdren, J.P., 1971, Impact of population growth: Science, v. 171, n. 3977, p. 1212-1217.

Elvidge, C.D., Baugh, K.E., Kihn, E.A., Kroehl, H.W., and Davis, E.R., and Davis, C. 1997a, Relation between satellite observed visible - near infrared emissions, population, and energy consumption: International Journal of Remote Sensing, v. 18, n. 6, p. 1373-1379.

Elvidge, C.D., Baugh, K.E., Kihn, E.A., Kroehl, H.W., and Davis, E.R., 1997b, Mapping city lights with nighttime data from the DMSP operational linescan system: Photogrammetric Engineering \& Remote Sensing, v. 63, n. 6, p. 727-34.

Environmental Protection Agency (EPA), 2000, Green communities, where are we going?, Socio-economic tools - Sprawl: [http:/www.epa.gov/region03/greenkit/ 2sprawl/htm].

Evans, L. T. 1998. Feeding the ten billion; plants and population growth. Cambridge University Press, New York, NY. 247 pp.

Flather, C.H., Knowles, M.S., and Kendall, I.A., 1998, Threatened and endangered species geographycharacteristics of hot spots in the conterminous United States: BioScience, v. 48, n. 5, p. 365-376.

Franklin, J.F., 1992, Scientific basis for new perspectives in forests and streams, in Naiman, R.J., ed., Watershed Management: New York, NY, Springer-Verlag, p. 25-72.

Fulton, W., Pendall, R., Nguyen, M., and Harrison, A., 2001, Who sprawls most? How growth patterns differ across the U.S.: Brookings Institution Center on Urban and Metropolitan Policy, Washington, D.C., 24 p.

Galli, J., 1991, Thermal impacts associated with urbanization and stormwater management best management practices: 
Metropolitan Washington Council of Governments and Maryland Department of Environment, Washington, DC. Glantz, M.H. and Orlovsky, N.S., 1983, Desertification-A review of the concept: Desertification Control Bulletin, v. 9, p. 15-22.

Groom, M.J. and Schumaker, N., 1993, Evaluating landscape change - patterns of worldwide deforestation and local fragmentation, in Kareiva, P.M., Kingsolver, J.G., and Huey, R.B., eds., Biotic interactions and Global Change: Sunderland, MA, Sinauer, p. 24-44.

Hale, M.L., Lurz, P.W.W., Shirley, M.D.F., Rushton, S., Fuller, R.M., and Wolff, K., 2001, Impact of landscape management on the genetic structure of red squirrel populations: Science, v. 293, n. 5538, p. 2246-2248.

Hammer, T.R., 1972, Stream channel enlargement due to urbanization: Water Resources Research, v. 8, n. 6, p. 1530-1540.

Harvell, C.D., Kim, K., Burkholder, J.M., Colwell, R.R., Epstein, P.R., Grimes, D.J., Hofmann, E.E., Lipp, E.K., Osterhaus, M.E., Overstreet, R.M., Porter, J.W., Smith, G.W., and Vasta, G.R., 1999, Emerging marine diseasesClimate links and anthropogenic factors: Science, v. 285, n. 5433, p. 1505-1510.

Harvell, C.D., Mitchell, C.E., Ward, J.R., Altizer, S., Dobson, A.P., Ostfeld, R.S., and Samuel, M.D., 2002, Climate warming and disease risks for terrestrial and marine biota: Science, v. 296, n. 5576, p. 2158-2162.

Henshaw, P., and Booth, D., 2000, Natural restabilzation of stream channels in urban watersheds: Journal of the American Water Resources Association, v. 36, n. 6, p. 12191236.

Hess, G., 2001, Measuring suburban sprawl: Oral presentation at the IALE 2001 International Association for Landscape Ecology Annual Meeting, Tempe, AZ.

Holdren, J.P. and Ehrlich, P.R., 1974, Human population and the global environment: American Scientist, v. 62, n. 3, p. 282-292.

Hollis, G., 1975, The effect of urbanization on floods of different recurrence interval: Water Resources Research, v. 11, n. 3, p. 431-435.

Houghton, R.A., 1994, The worldwide extent of land-use change: BioScience, v. 44, n. 5, p. 305-313.

Houghton, R.A., Hackler, J.L., and Lawrence, K.T., 1999, The U.S. carbon budget - Contributions from land-use change: Science, v. 285, n. 5427, p. 574-578.

Hurtt, G.C., Pacala, S.W., Moorcroft, P.R., Caspersen, J., Shevliakova, E., Houghton, R.A., and Moore, B., 2002, Projecting the future of the US carbon sink: Proceedings of the National Academy of Sciences, U.S.A., v. 99, n. 3, p. 1389-1394.

Imhoff, M.L., 1994, Mapping human impacts on the global biosphere: Bioscience, v. 44, n. 9, p. 598.

Imhoff, M.L., Lawrence, W.T., Elvidge, C.D., Paul, T., Levine, E., Prevalsky, M.V., and Brown, V., 1997, Using nighttime DMSP/OLS images of city lights to estimate the impact of urban land-use on soil resources in the United States:
Remote Sensing of Environment, v. 59, n. 1, p. 105-117. Imhoff, M.L., Lawrence, W.T., Stutzer, D., and Elvidge, C., 1998, Assessing the impact of urban sprawl on soil resources in the United States using nighttime "City Lights" satellite images and digital soils maps, in Sisk, T.D., ed., Perspectives on the land-use history of North America-a context for understanding our changing environment: U.S. Geological Survey, Biological Resources Division, Biological Science Report USGS/BRD/BSR-1998-0003 (Revised September 1999), p. 13-22, 104 p.

Inman, E.J., 1995, Flood-frequency relations for urban streams in Georgia-1994 update: U.S. Geological Survey Water Resources Investigations Report 95-4017, 27 p.

Inman, E.J., 2000, Lagtime relations for urban streams in Georgia: U.S. Geological Survey Water Resources Investigations Report 00-4049, 12 p.

Jennings, D.B. and Jarnagin, S.T., 2002, Changes in anthropogenic impervious surfaces, precipitation and daily stream flow-A historical perspective in a mid-Atlantic subwatershed: Landscape Ecology, v. 17, n. 5, p. 471-489.

Jones, K.B., Riitters, K.H., Wickham, J.D., Tankersley, R.D., O’Neill, R.V., Chaloud, D.J., Smith, E.R., and Neale, A.C., 1997, An ecological assessment of the United States MidAtlantic Region-A landscape atlas: Washington, D.C., EPA/600/R-97/130.

Jones, K. B., Heggem, D.T., Wade, T.G., Neale, A.C., Ebert, D.W., Nash, M.S., Mehaffey, M.H., Hermann, K.A., Selle, A.R., Augustine, S., Goodman, I.A., Pedersen, J., Bolgrien, D., Viger, J.M., Chiang, D., Lin, C.J., Zhong, Y., Baker, J., and Van Remortel, R.D., 2000, Assessing landscape conditions relative to water resources in the western United States-A strategic approach: Environmental Monitoring and Assessment, v. 64, p. 227-245.

Jones, K.B., Neale, A.C., Nash, M.S., Van Remortel, R.D., Wickham, J.D., Riitters, K.H., and O’Neill, R.V., 2001a, Predicting nutrient and sediment loadings to streams from landscape metrics - a multiple watershed study from the United States Mid-Atlantic Region: Landscape Ecology, v. 16, n. 4, p. 301-312.

Jones, K.B., Neale, A.C., Wade, T.G., Wickham, J.D., Cross, C.L., Edmonds, C.M., Loveland, T.J., Nash, M.S., and Riitters, K.H., 2001b, The consequences of landscape change on ecological resources-An assessment of the United States Mid-Atlantic Region, 1973-1993: Ecosystem Health, v. 7, n. 4, p. 229-242.

Jones, R.C. and Clark, C.C., 1987, Impact of watershed urbanization on stream insect communities: Water Resources Bulletin, v. 23, n. 6, p. 1047-1055.

Kalnay, E. and Cai, M., 2003, Impact of urbanization and land-use change on climate: Nature, v. 423, n. 6939, p. 528531.

Kates, R.W., Turner II, B.L., and Clark, W.C., 1990, in Turner II, B.L., Clark, W.C., Kates, R.W., Richards, J.F., Mathews, J.T., and Meyers, W.B., eds., 1990, The Earth as transformed by human action: Cambridge, UK, Cambridge University Press, p. 1-17 
Kattan, G.H., Alvarez-Lopez, H., and Gerald, M., 1994, Forest fragmentation and bird extinctions-San Antonio eighty years later: Conservation Biology, v. 8, n. 1, p. 138-46.

Keilman, N., 2001, Demography-Uncertain population forecasts: Nature, v. 412, n. 6846, p. 490-491.

Kennen, J.G., 1999, Relation of macro-invertebrate community impairment to catchment characteristics in New Jersey streams: Journal of the American Water Resources Association, v. 35, n. 4, p. 939-955.

Klein, R.D., 1979, Urbanization and stream water quality impairment: Water Resources Bulletin, v. 15, n. 4, p. 9481963.

Knick, S.T., and Rotenberry, J.T., 1995, Landscape characteristics of fragmented shrub steppe habitats and breeding passerine birds: Conservation Biology, v. 9, n. 5, p. 1059-1071.

Koopowitz, H., Thornhill, A.D., and Andersen, M., 1994, A general stochastic model for the prediction of biodiversity losses based on habitat conversion: Conservation Biology, v. 8 , n. 2 , p. $425-38$.

Kotliar, N.B., 2000, Application of the new keystonespecies concept to prairie dogs-How well does it work?: Conservation Biology, v. 14, n. 6, p. 1715-1721.

Lande, R., 1987, Extinction thresholds in demographic models of territorial populations: The American Naturalist, v. 130, n. 4, p. 624-635.

Leopold, L.B., 1968, Hydrology for urban land planning-A guidebook on the hydrologic effects of urban land-use: U.S. Geological Survey Circular 554, 18 p.

Limburg, K.E. and Schmidt, R.E., 1990, Patterns of fish spawning in Hudson River tributaries - response to an urban gradient: Ecology, v. 71, n. 4, p. 1238-1245.

Lutz, W., Sanderson, W., and Scherbov, S., 2001, The end of world population growth: Nature, v. 412, n. 6846, p. 543545.

May, C.W., Horner, R.R., Karr, J.R., Mar, B.W., and Welch, E.B., 1997, Effects of urbanization on small streams in the Puget Sound lowland ecoregion: Watershed Protection Techniques, v. 2, n. 4, p. 483-493.

Mehaffey, M.H., Wade, T.G., Nash, M.S., and Edmonds, C.M., 1999, A landscape analysis of New York City's water supply (1973-1998): EPA/600/R-99/102.

Mehaffey, M.H., Nash, M.S., Wade, T.G., Edmonds, C.M., Ebert, D.W., Jones, K.B., and Rager, A., 2001, New York City's water supply_A 25 year landscape analysis of the Catskill/Delaware watersheds: United States Environmental Protection Agency Report. EPA/600/R-01/075.

Melillo, J.M., Palm, C.A., Houghton, R.A., Woodwell, G.M., and Myers, N., 1985, A comparison of two recent estimates of disturbance in tropical forests: Environmental Conservation, v. 12, n. 1, p. 37-40.

Meyer, W.B., 1995, Past and present land-use and land-cover in the USA: Consequences v. 1, n. 1, p. 25-33.

Meyers, N., and Simon, J., 1994, Scarcity or abundance- - a debate on the environment: New York, N.Y., Norton, 254 p. Nobre, C A., Sellers, P.J., and Shukla, J., 1991, Amazonian deforestation and regional climate change: Journal of Climate, v. 4, n. 10, p. 957-988.

Noss, R.F., and Cooperrider, A.Y., 1994, Saving nature's legacy - protecting and restoring biodiversity: Washington, D.C., Island Press.

Noss, R.F., LaRoe, E.T., and Scott, J.M., 1995, Endangered ecosystems of the United States - a preliminary assessment of loss and degradation: U.S. National Biological Survey Report 28, Washington, DC.

Nunes, P.A.L.D. and van den Bergh, J.C.J.M., 2001, Economic valuation of biodiversity - sense or nonsense?: Ecological Economics, v. 39, n. 2, p. 203-222.

Ojima, D.S., Galvin, K.A., and Turner II, B.L., 1994, The global impact of land-use change: BioScience, v. 44, n. 5, p. 300-304.

Ostfeld, R.S. and Keesing, F., 2000, Biodiversity and disease risk - the case of Lyme disease: Conservation Biology, v. 14, n. 3, p. 722-728.

Paine, R.T., 1966, Food web complexity and species diversity: American Naturalist, v. 100, p. 65-75.

Paine, R.T., 1969, A note on trophic complexity and species diversity: American Naturalist, v. 103, p. 91-93.

Peskin, H.M., 1990, Accounting for natural resource depletion and degradation in developing countries: World Bank, Washington, D.C., Environment Department Working Paper $13,39 \mathrm{p}$.

Peterjohn, W.T. and Correl, D.L., 1984, Nutrient dynamics in an agricultural watershed-observations on the role of a riparian forest: Ecology, v. 65, n. 5, p. 1466-1475.

Pimm, S.L., Russell, G.J., Gittleman, J.L., and Brooks, T.M., 1995, The future of biodiversity: Science, v. 269, n. 5222, p. 347-350.

Poff, N.L. and Allen, J.D., 1995, Functional organization of stream fish assemblages in relation to hydrological variability: Ecology, v. 76, n. 2, p. 606-627.

Pope, C., 1999, Americans are saying no to sprawl: Political Economy Research Center Reports, v. 17, n. 1, p. 5-7.

Postel, S.L., Daily, G.C., and Ehrlich, P.R., 1996, Human appropriation of renewable fresh water: Science, v. 271, n. 5250, p. 785-788.

Power, M.E., Tilman, D., Estes, J.A., Menge, B.A., Bond, W.J., Mills, L.S., Daily, G., Castilla, J.C., Lubchenco, J., and Paine, R.T., 1996, Challenges in the quest for keystones: BioScience, v. 46, n. 8, p. 609-620.

Rasmussen, P.E., Goulding, K.W.T., Brown, J.R., Grace, P.R., Janzen, H.H., and Körschens, M., 1998, Long-term agroecosystem experiments-Assessing agricultural sustainability and global change: Science, v. 282, n. 5390, p. 893-896.

Rojstaczer, S., Sterling, S.M., and Moore, N.J., 2001, Human appropriation of photosynthesis products: Science, v. 294, n. 5551, p. 2549-2552.

Rose, S., and Peters, N., 2001, Effects of urbanization on streamflow in the Atlanta area (Georgia, USA) - a comparative hydrological approach: Hydrological Processes, v. 15, n. 8, p. 1441-1457. 
Sala, O.E., Chapin III, F.S., Armesto, J.J., Berlow, E., Bloomfield, J., Dirzo, R., Huber-Sanwald, E., Huenneke, L.F., Jackson, R.B., Kinzig, A., Leemans, R., Lodge, D.M., Mooney, H.A., Oesterheld, M., Poff, N.L., Sykes, M.T., Walker, B.H., Walker, M., and Wall, D.H., 2000, Global biodiversity scenarios for the year 2100: Science, v. 287, n. 5459, p. 1770-1774.

Saunders, D.A., Hobbs, R.J., and Margules, C.R., 1991, Biological consequences of ecosystem fragmentation: a review: Conservation Biology, v. 5, n. 1, p. 18-32.

Schimel, D., Melillo, J., Tian, H., McGuire, A.D., Kicklighter, D., Kittel, T., Rosenbloom, N., Running, S., Thornton, P., Ojima, D., Parton, W., Kelly, R., Sykes, M., Neilson, R., and Rizzo, B., 2000, Contribution of increasing CO2 and climate to carbon storage by ecosystems in the United States: Science, v. 287, n. 5460, p. 2004-2006.

Schlesinger, W.H., Reynolds, J.F., Cunningham, G.L., Huenneke, L.F., Jarrell, W.M., Virginia, R.A., and. Whitford, W.G., 1990, Biological feedbacks in global desertification: Science, v. 247, n. 4946. p. 1043-1048.

Schueler, T.R., 1994, The importance of imperviousness: Watershed Protection Techniques. v. 1, n. 3, p. 100-111.

Shepherd, J.M., Pierce, H., and Negri, A.J., 2002, Rainfall modification by major urban areas-Observations from spaceborne rain radar on the TRMM satellite: Journal of Applied Meteorology, v. 4, n. 7, p. 689-701.

Short, J., and Turner, B., 1994, A test of the vegetation mosaic hypothesis - a hypothesis to explain the decline and extinction of Australian mammals: Conservation Biology, v. 8, n. 2, p. 439-49.

Sisk, T.D., Launer, A.E., Switky, K.R., and Ehrlich, P.R., 1994, Identifying extinction threats - Global analyses of the distribution of biodiversity and the expansion of the human enterprise: Bioscience, v. 44, n. 9, p. 592-605.

Sisk, T.D., 1998, Toward a Land-use History of North America, in Sisk, T.D., ed. Perspectives on the land-use history of North America - a context for understanding our changing environment: U.S. Geological Survey, Biological Resources Division, Biological Science Report USGS/BRD/ BSR-1998-0003 (Revised September 1999), 104 p.

Skole, D. and Tucker, C., 1993, Tropical deforestation and habitat fragmentation in the Amazon - Satellite data from 1978 to 1988: Science, v. 260, n. 5116, p. 1905-1909.

Smil, V., 1997, Global population and the nitrogen cycle: Scientific American, v. 277, n. 1, p. 76-81.

Smil, V., 1999, How many billions to go?: Nature, v. 401, n. 6752 , p. 429.

Sorenson, A.A., Green, R.P., and Russ, K., 1997, Farming on the edge: DeKalb, IL, American Farmland Trust.

Sutton, P., Roberts, D., Elvidge, C., and Meij, H., 1997, A comparison of nighttime satellite imagery and population density for the continental United States: Photogrammetric Engineering \& Remote Sensing, v. 63, n. 11, p. 1303-1313.

Toman, M., 1998, Why not to calculate the value of the world's ecosystem services and natural capital: Ecological Economics, v. 25, n. 1, p. 57-60.
Trewavas, A., 2002, Malthus foiled again and again: Nature, v. 418, n. 6898, p. 668-670.

Turner, M.G., 1989, Landscape ecology - the effect of pattern on process: Annual Reviews of Ecological Systems, v. 20, p. 171-97.

Turner, S. J., O’Neill, R.V., Conley, W., Conley, M.R., and Humphries, H.C. 1991. Pattern and scale: statistics for landscape ecology. In: Turner, M.G., and Gardner, R.H. (eds.) Quantitative Methods in Landscape Ecology, pp. 1749. Springer-Verlag, NY.

Turner, B.L., Moss, R.H., and Skole, D.L., eds., 1993, Relating land-use and global land-cover change-A proposal for an IGBP-HDP core project: Report from the IGBP-HDP Working Group on Land-Use/Land-Cover Change, Joint publication of the International GeosphereBiosphere Programme (Report No. 24) and the Human Dimensions of Global Environmental Change Programme (Report No. 5), Stockholm, Royal Swedish Academy of Sciences.

Turner, R.K., Adger, W.N., and Brouwer, R., 1998, Ecosystem services value, research needs, and policy relevance-a commentary: Ecological Economics, v. 25, n. 1, p. 61-65.

United Nations (UN), 1999a, Long-range population projections_-Based on the 1998 revision: United Nations, New York, NY.

United Nations (UN), 1999b, World urbanization prospectsThe 1999 revision: Population Division, Department of Economic and Social Affairs, United Nations, New York, NY.

United Nations Environmental Programme (UNEP), 1992, World atlas of desertification: London, Eng., Edward Arnold.

United Nations Environment Programme (UNEP), 2002, Global Environment Outlook 3-Past, present and future perspectives: London, and Sterling, VA., Earthscan Publications Ltd.

United Nations Population Fund (UNFPA), 1999, The state of world population 1999-6 billion-A time for choices: New York, NY, UNFPA.

United Nations Population Division (UNPD), 2001, World population prospects-The 2000 revision: New York, NY, UNPD.

U.S. Bureau of the Census, 1998, Historical national population estimates: Washington, D.C.

U.S. Bureau of Transportation Statistics (USBTS), 1998, Vehicle miles traveled (VMT) per capita, 1960-1995, table 4-12: U.S. Department of Transportation, National Transportation Statistics 1988, Washington, D.C.

U.S. Council on Environmental Quality (USCEQ), 1997, The 1997 annual report of the Council on Environmental Quality, Part III-Environmental data and trends, table 1.4: [http:/ceq.eh.doe.gov/nepa/reports/1997/tables.pdf].

U.S. Environmental Protection Agency (USEPA), 1994, The quality of our Nation's water-1992: U.S. Environmental Protection Agency, Office of Water, Washington D.C., EPA/841/S/94/002. 
U.S. Environmental Protection Agency (USEPA), 2002, The twenty needs report-How research can improve the TMDL program: U.S. Environmental Protection Agency, Office of Water, Washington D.C., EPA841-B-02-002, 43 p.

van den Bergh, J.C.J.M., and Verbruggen, H., 1999, An evaluation of the 'ecological footprint' - reply to Wackernagel and Ferguson: Ecological Economics, v. 31, n. 3, p. 319-322.

van Kooten, G.C., and Bulte, E.H., 2000, The ecological footprint-Useful science or politics?: Ecological Economics, v. 32, n. 3, p. 385-89.

Verboom, J., Schotman, A., Opdam, P., and Metz, J.A.J., 1991, European nuthatch metapopulations in a fragmented agricultural landscape: Oikos, v. 61, p. 149-56.

Vitousek, P.M., Ehrlich, P.R., Ehrlich, A.H., and Matson, P.A., 1986, Human appropriation of the products of photosynthesis: BioScience, v. 36, n. 6, p. 368-373.

Vitousek, P.M., Aber, J.D., Howarth, R.H., Likens, G.E., Matson, P.A., Schindler, D.W., Schlesinger, W.H., and Tilman, D.G., 1997, Human alteration of the global nitrogen cycle: Sources and consequences: Ecological Applications, v. 7, n. 3, p. 737-750.

Vitousek, P.M., Mooney, H.A., Lubchenco, J., and Melillo, J.M., 1997, Human domination of Earth's ecosystems: Science, v. 277, n. 5325, p. 494-499.

von Hardenberg, J., Meron, E., Shachak, M., and Zarmi, Y., 2001, Diversity of vegetation patterns and desertification: Physical Review Letters v. 87, n. 19, p. 198101-1 - 1981014.

Wackernagel M. and Rees, W., 1996, Our ecological footprint: Gabriola Island, B.C., New Society Publishers.

Wackernagel, M., Onisto, L., Bello, P., Linares, A.C., Falfán,
I.S.L., García, J.M., Guerrero, A.I.S., and Guerrero, M.G.S., 1999, National natural capital accounting with the ecological footprint concept: Ecological Economics, v. 29,n. 3, p. 375-390.

Wallis, A.D., Aguelles, E., Lampe, D. and Meehan, M., 2001, Imaging the region: south Florida by indicators and public opinions: Florida Atlantic University/ Florida International University Joint Center for Urban and Environmental Problems. Miami, Florida. Accessed 20 Dec. 2001, [http:// www.jc.fau.edu/3publications/imagingtheregion.pdf].

Wang, L., Lyons, J., Kanehl, P., and Bannerman, R., 2001, Impacts of urbanization on stream habitat and fish across multiple scales: Environmental Management v. 28, n. 2, p. 255-266.

Weaver, L.A. and Garman, G.C., 1994, Urbanization of a watershed and historical changes in a stream fish assemblage: Transactions of the American Fisheries Society, v. 123, n. 2, p. 162-172.

Wilcove, D.S., Rothstein, D., Dubow, J., Phillips, A., and Losos, E., 1998, Quantifying threats to imperiled species in the United States: BioScience, v. 48, n. 8, p. 607-615.

Wilson, E.O., 1986, The current state of biological diversity in Wilson, E.O., ed., Biodiversity: Washington, DC, National Academy Press, p. 3-18.

Wilson, E.O., 2002, The future of life: New York, NY, Alfred A. Knopf, 229 p.

Woodley, S.J., Kay, J., and Francis, G., 1993, Ecological integrity and the management of ecosystems: Ottawa, Canada, St Lucie Press.

World Resources Institute (WRI), 1996, World resources 1996-97-A guide to the global environment - The urban environment. Oxford, UK, Oxford University Press, 400 p. 


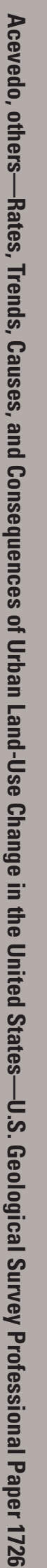

ISBN $\quad 1-411-31046-2$ 